
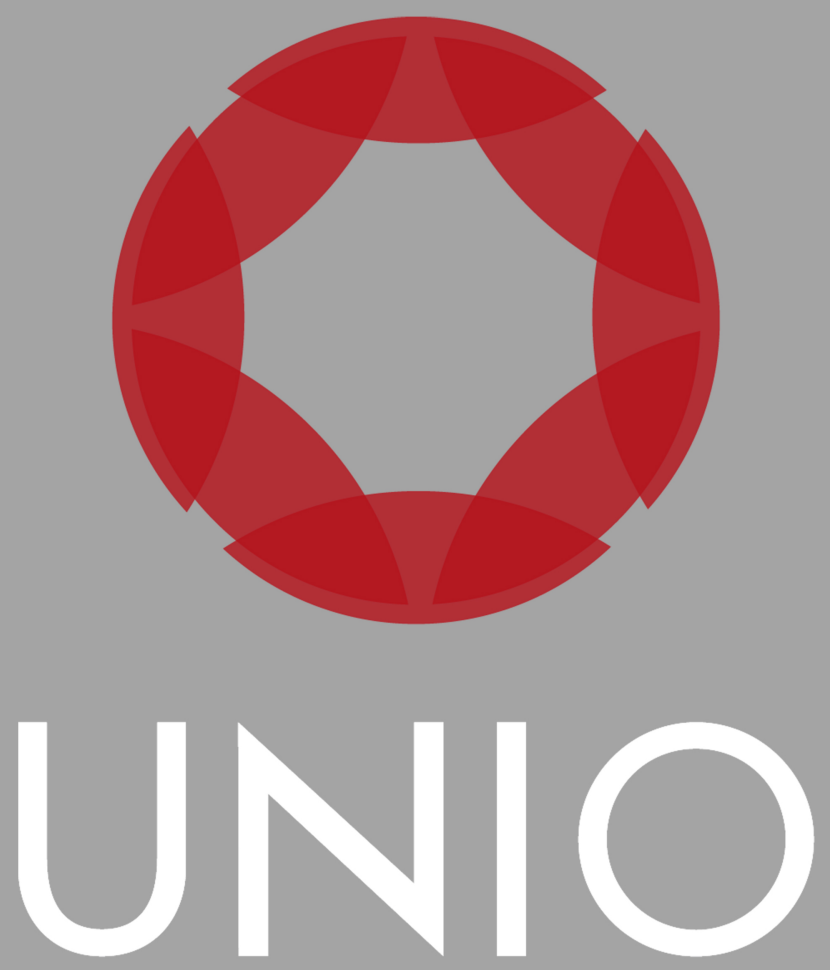

E-book

Volume I

Workshops CEDU 2016

Coordenação científica

Alessandra Silveira 



\section{UNIO E-book Volume I}

\section{Workshops CEDU 2016}

Coordenação científica de Alessandra Silveira

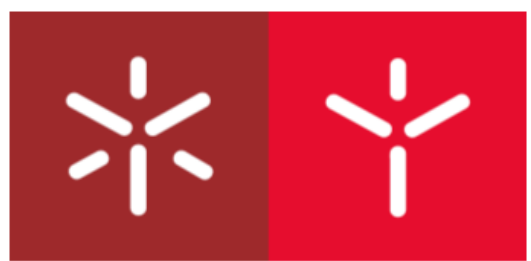

Universidade do Minho

Escola de Direito

Centro de Estudos em Direito da União Europeia 


\title{
UNIO E-book Volume I - Workshops CEDU 2016
}

\section{Coordenação científica:}

Alessandra Silveira

\begin{abstract}
Autores:
Alessandra Silveira|Ana Filipa Afonseca|Ana Margarida Pereira|Fátima Pacheco|Flávia Noversa Loureiro|Gemma Pérez Souto|Guilherme Estima Giacobbo|Isa António|Isabel Espín Alba|Isabel Lirola Delgado|Joana Covelo de Abreu|José Ricardo Sousa |Natacha Ribeiro|Paulo Márcio Cruz|Pedro Madeira Froufe |Ricardo Hermany|Rogério Gesta Leal|Sophie Perez Fernandes|Zenildo Bodnar

\section{Edição:}

Centro de Estudos em Direito da União Europeia

Escola de Direito da Universidade do Minho

http://www.cedu.direito.uminho.pt | cedu@direito.uminho.pt

\section{Coordenação técnica:}

Rita de Sousa Costa

Tiago Sérgio Cabral
\end{abstract}

Este trabalho é financiado por Fundos Nacionais através da FCT - Fundação para a Ciência e Tecnologia no âmbito do projeto UID/DIR/4199/2016.

\section{ISBN:}

978-989-99766-3-4

Braga, abril de 2017
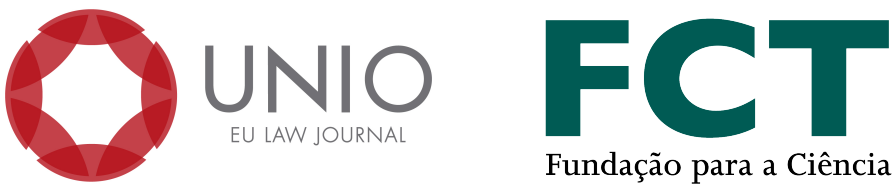


\section{Índice}

Apresentação

9

Os atributos de uma cidadania administrativa na Carta dos Direitos Fundamentais da

União Europeia

- Sophie Perez Fernandes

A cidadania europeia e a tutela dos direitos fundamentais na União - breve análise dos avanços e retrocessos na jurisprudência do TJUE

- Francielle Vieira Oliveira

Tempo, vínculos e direitos: quando circular e permanecer não tende a ser o estatuto fundamental dos nacionais dos Estados-Membros

- Fátima Pacheco

A cidadania municipal a partir da Carta Europeia de Autonomia Local e do princípio da subsidiariedade

- Ricardo Hermany/Guilherme Estima Giacobbo

A tramitação prejudicial acelerada e urgente como resposta às exigências de celeridade

e proteção jurisdicional efetiva no contencioso da União

- Natacha Ribeiro.

Qual a contribuição do direito penal contemporâneo em face da responsabilidade das pessoas jurídicas por atos de corrupção?

- Rogério Gesta Leal

A recuperação de ativos na política de prevenção e repressão da criminalidade económicofinanceira: linhas essenciais do modelo português no atual quadro de cooperação internacional - Flávia Noversa Loureiro

La búsqueda de la homogeneidad en las atribuciones de los Miembros Nacionales de Eurojust y su papel en la lucha contra la delincuencia transnacional: ¿misión cumplida?

- Gemma Pérez Souto 
La agenda "Mujeres, pazy seguridad" como una política internacional de criminalización de la violencia sexual en los conflictos armados: la contribución de la Unión Europea

- Isabel Lirola Delgado

Las nuevas formas de creatividad literaria digital y los límites del derecho de autor: especial referencia a las fanfiction

- Isabel Espin Alba.

Estatuto e competências da Entidade Reguladora da Saúde - em especial em matéria de defesa da concorrência

- Isa António

As competências reguladoras e decisórias europeias e nacionais no negócio TAP - reflexões

- José Ricardo Sousa.

O Regulamento n. ${ }^{\circ}$ 655/2014 que estabelece um procedimento de decisão europeia de arresto de contas: direitos à ação e de defesa em tensão reflexiva no contexto de uma integração judiciária em matéria civil - uma precoce antevisão

- Joana Covelo Abreu

O private enforcement em matéria de antitrust e o regime de clemência: uma nota sobre a articulação possível

- Ana Margarida Pereira.

A nova diretiva sobre proteção do segredo comercial: contributo para um sistema coordenado do mercado interno

- Ana Filipa Afonseca

O insustentável peso democrático do populismo: deambulações em torno da União

Europeia, de olhos postos em Donald Trump

- Pedro Madeira Froufe.

A "commonlização" do direito positivo, o ativismo judicial e a crise do Estado

- Paulo Márcio Cruz/Zenildo Bodnar

Brexit e o princípio federativo da lealdade europeia: considerações sobre o artigo $50 .^{\circ}$ do Tratado da União Europeia

- Alessandra Silveira 




\section{Apresentação}

Sempre que um investigador senior visita o Centro de Estudos em Direito da União Europeia (CEDU) da Universidade do Minho, a Direção do Centro promove a sua interação com os investigadores que trabalham áreas afins, sobretudo com os mais jovens, organizando workshops com os convidados. Esta prática resulta do compromisso do CEDU com a Fundação para a Ciência e a Tecnologia (FCT), pretendendo-se algo intimista, com cerca de 10-15 investigadores em interação, numa troca de experiências e perspetivas a partir de uma temática proposta pelo convidado. Para além da intervenção principal do investigador convidado, todos os intervenientes podem apresentar temas que estejam a investigar e submeter as suas inquietações e resultados ao escrutínio dos Colegas.

Os contributos agora publicados resultam do debate de ideias encetado no âmbito dos workshops do CEDU realizados em 2016. Os temas desenvolvidos pelos investigadores neste exercício interativo foram amplamente influenciados pelos inputs que receberam através de UNIO - EU Law Journal e do blog que lhe é associado UNIO The official blog - thinking \& debating Europe. Por esta razão, a Direção do CEDU decidiu publicar os textos em formato e-book com a chancela da referida revista e disponibiliza-lo nas diversas plataformas digitais disponíveis na Escola de Direito da Universidade do Minho.

O primeiro workshop decorreu no dia 5 de fevereiro e ocupou-se das temáticas da "Cidadania e tutela jurisdicional", tendo como convidada a Professora Caterina Baruffi, da Università degli Studi di Verona (Itália).

O segundo workshop aconteceu no dia 17 de março e abordou questões relacionadas com "Políticas públicas e criminalidade", tendo como convidado o Professor Rogério Leal, da Universidade de Santa Cruz do Sul (Rio Grande do Sul, 
Brasil), além do Chefe do Gabinete da Senhora Ministra da Administração Interna, Senhor Procurador Jorge Costa.

O terceiro workshop aconteceu no dia 17 de maio e versou sobre "Relações de mercado e direitos fundamentais", tendo como convidada a Professora Isabel Espín, da Universidade de Santiago de Compostela (Espanha), além do Professor Ricardo Hermany da Universidade de Santa Cruz do Sul (Rio Grande do Sul, Brasil).

O quarto workshop foi a 15 de julho e versou sobre o tema "Mercado interno, concorrência e regulação", tendo como convidada a Professora Ana Tobío, da Universidade de Vigo (Espanha), além das Professoras Isabel Lirola e Isabel Espín, ambas da Universidade de Santiago de Compostela (Espanha).

$\mathrm{O}$ quinto e último workshop, intitulado "Integração jurídico-constitucional e comunidade política europeia", decorreu no dia 6 de dezembro, tendo como convidados os Professores Paulo Cruz, da Universidade do Vale do Itajaí (Santa Catarina, Brasil), Teresa Freixes, da Universidade Autónoma de Barcelona (Espanha) e Nuno Piçarra, da Universidade Nova de Lisboa.

Os textos agora publicados foram agrupados, tanto quanto possível, seguindo o roteiro das discussões entabuladas durante os workshops, sendo certo que alguns textos beneficiaram da participação do seu Autor em mais de um workshop. Nem de propósito, os workshops começaram por abordar a temática da cidadania europeia enquanto cidadania de direitos e terminaram por perspetivar a comunidade política que almejamos construir - retornando, de certa forma, ao ponto inicial. O último texto desta publicação, relativo ao art. $50 .^{\circ}$ do TUE e a possibilidade de retirada de um Estado-Membro da União Europeia, encerra o percurso dialógico que convidamos o interlocutor a trilhar com a ideia de que, num sistema federativo como aquele que nos ocupa, até mesmo a secessão é orientada pelo imperativo de lealdade ao conjunto e suas implicações. 




\title{
Os atributos de uma cidadania administrativa na Carta dos Direitos Fundamentais da União Europeia
}

\author{
Sophie Perez Fernandes*
}

RESUMO: Tendo por referência o catálogo de direitos de cidadania plasmado na CDFUE, e, em especial, a tríade formada pelo direito a uma boa administração, pelo direito de acesso aos documentos das instituições, dos órgãos e dos organismos da União e pelo direito de petição ao Provedor de Justiça Europeu, o presente texto tem em vista explorar o sentido de uma cidadania administrativa em construção na ordem jurídica da União. Em relação a este catálogo de direitos, a CDFUE não se limita, com efeito, a conferir-lhes o estatuto de direitos fundamentais, mas também, ao integrá-los no seu Título $V$, permite a sua qualificaşão como direitos de cidadania no contexto da União, neles se identificando, então, alguns dos atributos de uma cidadania administrativa europeia. A presente análise tem o propósito de procurar atribuir um sentido a esta sistematização, quer para os diversos direitos considerados, quer para a cidadania da União em geral.

PALAVRAS-CHAVE: cidadania da União - cidadania administrativa - direitos fundamentais - boa administração.

ABSTRACT: With reference to the catalog of citizenship rights set out in the CFREU, and in particular the triad consisting of the right to good administration, the right of access to documents of the institutions, bodies, offices and agencies of the Union, and the right to refer to the European Ombudsman, the purpose of this text is to explore the meaning of administrative citizenship under construction within the EU's legal order. With regard to this catalog of rights, the CFREU does not confine itself to conferring on them the status of fundamental rights, but also, by inscribing them in its Title V, allows them to be qualified as citizenship rights in the context of the EU, thereby identifying some of the attributes of an European administrative citizenship. The purpose of the present analysis is to try to give meaning to this systematization, both for the various rights considered and for EU citizenship in general.

KEYWORDS: EU citizenship - administrative citizenship - fundamental rights - good administration.

\footnotetext{
* Professora da Escola de Direito da Universidade do Minho. Membro Doutorado do Centro de Estudos em Direito da União Europeia (CEDU) da Universidade do Minho.
} 


\section{Ponto de ordem}

Por ocasião dos diversos encontros promovidos pelo Centro de Estudos em Direito da União Europeia (CEDU) ao longo do ano de 2016, tivemos especial oportunidade de oferecer para debate temáticas atinentes à promoção de uma boa administração no sistema jurídico europeu. O objetivo foi o de apresentar para discussão uma apreciação crítica da consagração de um direito a uma boa administração no art. 41. ${ }^{\circ}$ da Carta dos Direitos Fundamentais da União Europeia (CDFUE). Agora, aquando da publicação dos textos resultantes de tão profícuos encontros, aproveitamos o ensejo para trazer à colação o conceito de cidadania administrativa com o qual aquele se encontra inextricavelmente ligado.

Esta opção permite-nos aprofundar aquela primeira análise pela consideração de outros direitos que igualmente integram o estatuto jurídico do cidadão-pessoa perante as autoridades que exercem o poder público na União Europeia. Tratar-se-á, especialmente, dos direitos de acesso aos documentos das instituições, dos órgãos e dos organismos da União (art. 42. ${ }^{\circ}$ CDFUE) e de petição ao Provedor de Justiça Europeu (art. 43. ${ }^{\circ}$ CDFUE). Em relação ao universo de direitos considerados, a CDFUE não se limita a conferir-lhes o estatuto de direitos fundamentais como tal protegidos pela ordem jurídica da União, mas também, ao integrá-los no seu Título V, permite a sua qualificação como direitos de cidadania no contexto da União, neles se identificando, então, alguns dos atributos de uma cidadania administrativa europeia. Assim, embora tendo presente que as disposições da CDFUE apenas são aplicáveis por efeito da aplicação de (outras) disposições do direito da União ${ }^{1}$, continuaremos a ter

\footnotetext{
${ }^{1}$ Cfr. art. 51. ${ }^{\circ}$, n. ${ }^{\circ}$ 1, CDFUE. Sobre a jurisprudência inaugurada no acórdão TJUE de 26 de fevereiro de 2013, Fransson, Processo C-617/10, EU:C:2013:105, considerandos 17-23 e 29, a propósito desta disposição, cfr., entre outros, Angela Ward, "Article 51", e Koen Lenaerts e José Antonio GutiérrezFons, "The Place of the Charter in the EU Constitutional Edifice", in The EU Charter of Fundamental Rights. A Commentary, ed. Steve Peers et al. (Oxford: Hart Publishing, 2014), 1413-1454 e 1566-1568, respetivamente; Daniel Sarmiento, "Who's afraid of the Charter? The Court of Justice, national courts and the new framework of fundamental rights protection in Europe", Common Market Law Review, 50 (2013): 1267-1304; e, entre nós, Alessandra Silveira, "Cidadania Europeia e Direitos Fundamentais", in Direito da União Europeia - Elementos de Direito e Políticas da União, coords. Alessandra Silveira, Mariana Canotilho e Pedro Madeira Froufe (Coimbra: Almedina, 2016), 51-67.
} 
como quadro de referência o catálogo de direitos de cidadania plasmado na CDFUE com o propósito de procurar atribuir um sentido àquela sistematização, quer para os diversos direitos considerados, quer para a cidadania da União em geral.

Antes, contudo, de avançar com a análise proposta, não podemos deixar passar a oportunidade de agradecer os convites para participar daqueles encontros e de contribuir para a presente publicação. A simplicidade dos primeiros não engana, apenas corresponde à elevação dos contributos apresentados, das ideias debatidas, das reflexões partilhadas - corresponde às palavras de Victor Hugo: "la simplicité est grandeur'. E, assim, simplesmente, porque proporcionam igual oportunidade para diferentes interlocutores exporem as suas inquietações em busca, não necessariamente de pistas de solução ou rumos de investigação, mas de companhia no, por vezes, solitário caminho da investigação científica que só se faz caminhando...

\section{A cidadania da União enquanto cidadania de direitos - a emergência de um núcleo comum de direitos como expressão do sentido da cidadania da União}

Ao conceito de cidadania subjaz a ideia de filiação de um indivíduo a determinada comunidade ancorada em valores de igualdade, pertença e identidade coletiva, filiação que, no plano jurídico-político, se traduz num vínculo entre o indivíduo e a comunidade ao qual estão associados direitos e deveres específicos. A cidadania da União não escapa a esta concetualização de base, sendo também ela a expressão de um vínculo específico que une os cidadãos da União à própria União. Nos termos dos Tratados, a cidadania da União implica para os cidadãos da União o gozo dos direitos e o respeito pelos deveres previstos nos Tratados [art. 20. ${ }^{\circ}$, n. ${ }^{\circ}$ 2, do Tratado sobre o Funcionamento da União Europeia (TFUE)]. Se bem que não especifiquem os deveres dos cidadãos da União ${ }^{2}$, os Tratados oferecem um

\footnotetext{
${ }^{2}$ Ausência "reveladora de uma certa fraqueza dos laços de ligação entre o cidadão e a União" para Ana Maria Guerra Martins, Manual de Direito da União Europeia (Coimbra: Almedina, 2014), 236. No seu relatório de 2008 relativo à aplicação da Diretiva (CE) 2004/38 do Parlamento Europeu e do Conselho, de 29 de abril de 2004, relativa ao direito à livre circulação e residência dos cidadãos da União e dos membros das suas
} 
catálogo (não exaustivo) de direitos associados à cidadania da União ${ }^{3}$. A cidadania da União afirma-se primacialmente, por isso, enquanto "cidadania de direitos" 4 , ou seja, ser cidadão da União significa, antes de tudo, ser titular de direitos protegidos pela ordem jurídica da União.

Se até a institucionalização/constitucionalização da cidadania da União o vínculo que se estabelecia, por via do reconhecimento de direitos, entre os nacionais dos Estados-Membros e a União servia os propósitos da integração por via do mercado, a inscrição das disposições relativas à cidadania da União no corpo dos Tratados reconfigura este vínculo: continuando a assentar essencialmente no reconhecimento de direitos, o vínculo passa a estabelecer-se entre a União e os "seus cidadãos" ${ }^{5}$ sendo direcionado para os propósitos de uma integração para além do mercado ${ }^{6}$. Pelas palavras do Advogado-Geral Francis Jacobs, a cidadania da União "foi largamente inspirada pela preocupação de aproximar a União dos seus cidadãos e de exprimir

famílias no território dos Estados-Membros, que altera o Regulamento (CEE) n. ${ }^{\circ}$ 1612/68 e que revoga as Diretivas 64/221/CEE, 68/360/CEE, 72/194/CEE, 73/148/CEE, 75/34/CEE, 75/35/CE, 90/364/CE, 90/365/CEE e 93/96/CE, JO L 158 de 30.04.2004, pp. 77-123, a Comissão sublinha, no contexto do Capítulo VI relativo às restrições aos direitos de entrada e residência por razões de ordem pública, segurança pública ou saúde pública, que "[a]queles que beneficiam do direito de livre circulação devem assumir obrigações perante o seu Estado-Membro de acolbimento, sendo a primeira o respeito da sua legislação" - cfr. Comissão Europeia, Relatório ao Parlamento Europeu e ao Conselho sobre a aplicação da Diretiva (CE) 2004/38 relativa ao direito de livre circulação e residência dos cidadãos da União e dos membros das suas famílias no território dos Estados-Membros, de 10.12.2008, COM(2008) 840 final, p. 8. A obrigação de respeitar a legislação do Estado-Membro de acolhimento não se impõe, contudo, por força do direito da União (contrariamente ao que sucede com os direitos associados à cidadania da União), mas sim por força do direito do Estado-Membro de acolhimento, de modo que a afirmação são é suficiente para superar aquela ausência.

${ }^{3}$ Cfr. arts. $20 .^{\circ}$ a $24 .^{\circ}$ TFUE, especialmente o elenco não taxativo constante do art. $20 .^{\circ}$, n. ${ }^{\circ}$ 2, TFUE.

${ }^{4}$ Neste sentido, cfr. Alessandra Silveira, "Cidadania e Jusfundamentalidade na União Europeia - do argumento de James Madison à jurisprudência Ruiz Zambrano", in Estudos em Homenagem ao Prof. Doutor José Joaquim Gomes Canotilho, Volume III - Direitos e Interconstitucionalidade: entre Dignidade e Cosmopolitismo, org. Fernando Alves Correia, Jónatas E. M. Marchado e João Carlos Loureiro (Coimbra: Coimbra Editora, 2012), 941.

${ }^{5}$ Como se pode ler hoje em várias disposições do Tratado da União Europeia (TUE), nomeadamente os arts. 3..$^{\circ}$ (objetivos da União), 9. (princípio da igualdade) e 13. (quadro institucional).

${ }^{6}$ Neste sentido, cfr. Ferdinand Wollenschläger, "A New Fundamental Freedom beyond Market Integration: Union Citizenship and its Dynamics for Shifting the Economic Paradigm of European Integration", European Law Journal 17, 1, (2011): 1-34, doi: 10.1111/j.1468-0386.2010.00536.x. 
a sua natureza como algo de diverso de uma união puramente económica" ${ }^{7 / 8}$. Ao associar os cidadãos da União ao processo de integração sem passar por caminhos trilhados por apenas alguns deles - os cidadãos dinâmicos e economicamente ativos, agentes de um mercado interno assente nas liberdades de circulação -, a cidadania da União visa neles forjar um sentimento de identificação com a União e, assim, promover a construção de uma comunidade política europeia ${ }^{9}$. A ideia subjacente à cidadania da União é, regressando a Francis Jacobs, permitir aos cidadãos da União afirmarem "civis europeus sum"10.

A primeira dificuldade para a emergência de tal sentimento de pertença e de identidade advém, porventura, de o texto dos Tratados fazer do estatuto de cidadão da União um "estatuto de aquisição heterónoma" - um estatuto que pressupõe e deriva da nacionalidade de um Estado-Membro ${ }^{11}$. São assim os Estados-Membros que, mediante os mecanismos da nacionalidade, "recorta $[m]$ a cidadania" da União ${ }^{12}$. O estatuto de cidadão da União tem, pois, natureza derivada e acresce, por "sobreposição"13

\footnotetext{
${ }^{7}$ Conclusões do Advogado-Geral Francis Jacobs de 19 de março de 1998, Bickel e Franz, Processo C-274/96, EU:C:1998:115, considerando 23.

${ }^{8}$ A construção do mercado comum desde o início almejou transcender o caráter puramente económico do processo de integração, afirmando-o igualmente enquanto projeto político. É a ideia motora patente na Declaração Schuman de 9 de maio de 1951, desde o seu primeiro esboço - cfr. Jean Monnet, Mémoires (Paris: Fayard, 1976), 349-350. Sobre o "recurso ao método da integração económica" como "instrumento fundamental do projeto - eminentemente político - de integração europeia", cfr. Pedro Madeira Froufe e José Caramelo Gomes, "Mercado Interno e Concorrência", Direito da União Europeia - Elementos de Direito e Políticas da União, coords. Alessandra Silveira, Mariana Canotilho e Pedro Madeira Froufe (Coimbra: Almedina, 2016), 449-461.

${ }^{9} \mathrm{O}$ objetivo foi assumido expressamente pela Comissão Europeia: "A cidadania da União é simultaneamente fonte de legitimação do processo de integração europeia, devido ao reforço da participação dos cidadãos, e um elemento fundamental para a criação de um sentimento de pertença dos cidadãos à União Europeia, de uma verdadeira identidade europeia" - Comissão Europeia, Terceiro Relatório sobre a cidadania da União, de 07.09.2001, $\operatorname{COM}(2001) 506$ final, p. 7.

${ }^{10}$ Conclusões do Advogado-Geral Francis Jacobs de 9 de dezembro de 1992, Konstantinidis, Processo C-168/91, EU:C:1992:504, considerando 46.

${ }^{11}$ Nos termos dos arts. 9. ${ }^{\circ}$ TUE e $20 .^{\circ}$, n. ${ }^{\circ}$ 1, TFUE, é cidadão da União qualquer pessoa que tenha a nacionalidade de um Estado-Membro, estatuto que acresce à cidadania nacional sem a substituir.

12 José Joaquim Gomes Canotilho, "Brancosos" e Interconstitucionalidade. Itinerários dos discursos sobre a historicidade constitucional (Coimbra: Almedina, 2006) 241.

${ }^{13}$ Assim, entre outros, Martins, Manual de Direito da União Europeia, 226; e José Narciso da Cunha Rodrigues, "Artigo 45. - Liberdade de circulação e permanência", in Carta dos Direitos Fundamentais da União Europeia Comentada, coords. Alessandra Silveira e Mariana Canotilho (Coimbra: Almedina, 2013), 524.
} 
ou "acumulação"14, ao estatuto de nacional de um Estado-Membro. Mas aí reside o paradoxo ou, nas palavras de Miguel Poiares Maduro, o "milagre da cidadania da União" "15: ao mesmo tempo que reforça os laços que unem os indivíduos aos respetivos Estados-Membros de nacionalidade, na medida que os cidadãos da União filiam-se nesta através daqueles, também destes os emancipa uma vez que os cidadãos da União são cidadãos para além dos respetivos Estados-Membros de nacionalidade. A cidadania da União une ao abrigo de um estatuto comum ${ }^{16}$ todos os nacionais dos Estados-Membros num vínculo que transcende a nacionalidade de cada um deles e, assim, reconfigura a noção de pertença a uma comunidade, tornando-a mais aberta e flexível ${ }^{17}$ : os nacionais dos distintos Estados-Membros integram, compõem, incluem-se numa comunidade política europeia ampla em emergência, o que lhes permite desprenderem-se da respetiva comunidade de origem e livremente optar por viver e participar numa comunidade que não aquela que lhes confere a nacionalidade em condições tendencialmente idênticas às dos nacionais dessa comunidade ${ }^{18}$.

Contudo, a mais-valia da cidadania da União não reside tanto nas respostas oferecidas às questões relativas ao acesso ao estatuto de cidadão da União e à pertença a uma comunidade política em emergência, mas no conjunto de direitos que lhe estão

\footnotetext{
${ }^{14}$ Paulo Rangel, "Artigo 39. - Direito de eleger e de ser eleito nas eleições para o Parlamento Europeu”, in Carta dos Direitos Fundamentais da União Europeia Comentada, coords. Alessandra Silveira e Mariana Canotilho (Coimbra: Almedina, 2013), 471.

${ }^{15}$ Conclusões do Advogado-Geral Miguel Poiares Maduro de 30 de setembro de 2009, Rottmann, Processo C-135/08, EU:C:2009:588, considerando 23.

${ }^{16}$ É nestes termos que, no Preâmbulo do TUE, os Estados-Membros se referem à cidadania da União - enquanto "cidadania comum aos nacionais dos seus países" (parágrafo 10).

${ }^{17}$ A ideia de pertença a uma determinada comunidade formatada pelo modelo da cidadania nacional contradiz, aliás, a dinâmica própria do processo de integração. Como explica Francis Jacobs, "[o] conceito de 'circular e permanecer livremente no território dos Estados-Membros' não assenta na hipótese de uma única deslocação de um Estado-Membro para outro, seguida da integração neste último. A intenção é antes permitir a livre, e possivelmente repetida ou mesmo contínua, circulação, no seio de um único 'espaço de liberdade, de segurança e de justiça', no qual são garantidas tanto a diversidade cultural como a proibição da discriminação." - Conclusões do Advogado-Geral Francis Jacobs de 22 de maio de 2003, Garcia Avello, Processo C-148/02, EU:C:2003:311, considerando 72.

${ }^{18}$ Entre nós, cfr. Miguel Poiares Maduro, A Constituição Plural. Constitucionalismo e União Europeia (Cascais: Principia, 2006), 272: “(...) já não somos 'prisioneiros' da nossa comunidade política original e podemos optar entre várias comunidades políticas. Enquanto continuamos a beneficiar da nossa comunidade política nacional de origem, entramos num novo contrato social que nos confere o direito (ainda limitado) de viver e participar em diferentes comunidades politicas nacionais pertencentes ao espaço europeu.".
} 
associados. Em virtude da cidadania da União, os Estados-Membros deixaram de ser a única entidade por referência à qual se perspetiva a cidadania e se exercem direitos de cidadania. O modo derivado de aquisição do estatuto de cidadão da União não afeta a autonomia da cidadania da União enquanto fonte de direitos: da cidadania da União emergem direitos protegidos pelo direito da União cuja titularidade não depende (do direito) dos Estados-Membros e que, como se verá infra, sequer estão reservados aos nacionais dos Estados-Membros, ou seja, aos cidadãos da União; os EstadosMembros devem, para além disso, assegurar que o exercício dos direitos associados à cidadania da União opere, nas respetivas ordens jurídicas, em conformidade com o direito da União. É, assim, enquanto fonte de direitos que a cidadania da União se revela como "estatuto de conteúdo autónomo".

No texto dos Tratados, especialmente no art. 20. ${ }^{\circ}$, n. ${ }^{\circ}$ 2, TFUE, mas também na CDFUE com "o mesmo valor jurídico" $"$ do que aqueles, a cidadania da União é configurada como fonte de direitos duplamente direcionados: a cidadania da União não se projeta apenas enquanto i) vínculo entre o cidadão da União e a própria União, mas também enquanto ii) vínculo entre o cidadão da União e todos os Estados-Membros da União, incluindo o(s) Estado(s)-Membro(s) da nacionalidade do cidadão da União. À cidadania da União estão associados direitos suscetíveis de serem exercidos junto dos vários componentes do sistema plural, multinível ou compósito da União, incluindo, pois, as autoridades dos Estados-Membros, direitos aos quais está transversalmente associado o princípio da igualdade e, em particular, o "imperativo de igualdade dos nacionais dos distintos Estados-Membros"20 enquanto atributo essencial da cidadania da União ${ }^{21}$.

Dentro do primeiro grupo de direitos i), encontram-se o direito de acesso aos documentos das instituições, dos órgãos e dos organismos da União ${ }^{22}$, o direito de participar nas eleições para o Parlamento Europeu ${ }^{23}$, o direito de petição junto desta

\footnotetext{
${ }^{19}$ Art. 6. ${ }^{\circ}$ TUE.

${ }^{20}$ Silveira, "Cidadania e Jusfundamentalidade na União Europeia", 949.

${ }^{21}$ Cfr. arts. 9. ${ }^{\circ}$ TUE e $18 .^{\circ}$ TFUE, bem como arts. $20 .^{\circ}$ e $21 .^{\circ}$ CDFUE.

${ }^{22}$ Cfr. art. $15^{\circ}{ }^{\circ}$, n. 3 , TFUE.

${ }^{23}$ Cfr. art. $14 .^{\circ}$, n. ${ }^{\circ}$, TUE.
} 
instituição ${ }^{24}$, o direito de apresentar queixas ao Provedor de Justiça Europeu ${ }^{25}$ e o direito de interagir na língua oficial da União escolhida ${ }^{26}$, elenco ao qual o Tratado de Lisboa acrescentou o direito de iniciativa legislativa ${ }^{27}$ e permitiu, como veremos, adicionar o direito a uma boa administração ${ }^{28}$. Dentro do segundo grupo ii), encontram-se o direito de livre circulação e residência ${ }^{29}$, o direito de participar nas eleições para o Parlamento Europeu e nas eleições municipais no Estado-Membro de residência ${ }^{30}$ e o direito à proteção diplomática e consular ${ }^{31}$. A cidadania da União não é somente fonte dos direitos previstos nos Tratados - o elenco dos direitos consagrados no art. $20 .^{\circ}$, n. $^{\circ}$ 2, TFUE sequer é taxativo ${ }^{32}-$, mas também em outras fontes do direito da União, como instrumentos de direito derivado ${ }^{33}$ ou a própria jurisprudência do Tribunal de Justiça ${ }^{34}$.

Desta forma, a afirmação reiterada nesta jurisprudência pela qual "o estatuto de cidadão da União tende a ser o estatuto fundamental dos nacionais dos Estados-Membros" 35

\footnotetext{
${ }^{24}$ Cfr. arts. $20 .^{\circ}$, n. $^{\circ} 2$, d) $, 24 .^{\circ}, 2^{\circ}$ parágrafo, e $227 .^{\circ}$ TFUE.

${ }^{25}$ Cfr. arts. $200^{\circ}$, n. $^{\circ} 2$, d) $, 24 .^{\circ}, 3^{\circ}$ parágrafo, e $228 .^{\circ}$ TFUE.

${ }^{26}$ Cfr. art. $20 .^{\circ}$, n. $^{\circ} 2$, d), TFUE.

${ }^{27} \mathrm{Cfr}$. art. $11 .^{\circ}$, n. $^{\circ} 4$, TUE e art. $24 .^{\circ}, 1^{\circ}$ parágrafo, TFUE.

${ }^{28}$ Cfr. art. $41 .^{\circ}$ CDFUE.

${ }^{29} \mathrm{Cfr}$. arts. $20 .^{\circ}$, n. $^{\circ} 2$, a), e $21 .^{\circ}$ TFUE.

${ }^{30}$ Cfr. arts. $20 .^{\circ}$, n. $^{\circ} 2$, b), e $22 .^{\circ}$ TFUE.

${ }^{31}$ Cfr. arts. $20 .^{\circ}$, n. $\left.^{\circ} 2, \mathrm{c}\right)$, e $23{ }^{\circ}$ TFUE.

${ }^{32}$ Para além de o art. $25 .^{\circ}, 2^{\circ}$ parágrafo, TFUE prever (procedimentalmente) a possibilidade de "aprofundar os direitos enumerados no n. 2 do artigo 20. ."

${ }^{33}$ Com especial destaque para os direitos decorrentes da Diretiva 2004/38 relativa ao direito à livre circulação e residência dos cidadãos da União e dos membros das suas famílias no território dos Estados-Membros.

${ }^{34}$ Neste sentido, cfr. Jo Shaw, Law of the European Union (3 $3^{\text {a }}$ ed., New York: Palgrave Macmillian, 2000), 381. Da jurisprudência do Tribunal de Justiça destaca-se especialmente o direito de os cidadãos da União não serem privados, de jure ou de facto, por efeito de medidas adotadas pelas autoridades do respetivo Estado-Membro de nacionalidade, do gozo efetivo do essencial dos direitos conferidos pelo seu estatuto de cidadão da União (para já) concretizado (com sucesso) enquanto direito a não perder o estatuto de cidadão da União sem que a proporcionalidade da decisão nacional que tenha esse efeito seja examinada à luz do direito da União e o direito a não ser forçado a deixar o território da União - como resulta, respetivamente, dos acórdãos TJUE de 2 de março de 2010, Rottmann, Processo C-135/08, EU:C:2010:104, considerandos 42 e 55, e de 8 de março de 2011, Zambrano, Processo C-34/09, EU:C:2011:124, considerandos 42-44.

${ }^{35}$ Pela primeira vez vertida no acórdão TJUE de 20 de setembro de 2001, Grzelccyyk, Processo C-184/99, EU:C:2001:458, considerando 31.
} 
deve ser compreendida à luz da "cidadania de direitos" que lhe subjaz, traduzindo a ideia de que a cidadania da União não é "concha vazia"36 mas aspira/"tende a" ser a principal fonte de direitos dos cidadãos da União ${ }^{37}$. Uma vez que a cidadania da União potencia o exercício desses direitos num contexto mais alargado e em condições de tendencial igualdade, o cidadão da União vê alargado o seu leque de oportunidades (políticas, económicas, sociais, culturais) para além dos confins da(s) sua(s) respetiva(s) nacionalidade(s). O declínio da soberania do Estado é, no contexto da cidadania da União, acompanhado do reforço da soberania do indivíduo ${ }^{38}$ por via do reconhecimento e do exercício de direitos de cidadania.

Confirmando o quanto a cidadania da União se emancipa enquanto "conceito jurídico e político autónomo relativamente ao de nacionalidade" 39 e que, contrariamente ao que o Estado-Nação habituou, cidadania e nacionalidade não caminham tanto "lado a lado" mas exercem funções distintas, a leitura das disposições de direito primário relativas ao elenco dos direitos associados à cidadania da União mencionado supra revela que a titularidade do estatuto de cidadão da União e a titularidade dos direitos de cidadania da União não coincidem totalmente: alguns direitos associados à cidadania da União são titulados, nos termos do direito da União e independentemente do direito dos Estados-Membros, por quem não é nacional de nenhum deles e, assim, não goza do estatuto de cidadão da União. Pese embora dela derivar a titularidade do estatuto de

\footnotetext{
${ }^{36}$ Conclusões do Advogado-Geral Michel Wathelet de 14 de abril de 2016, NA, Processo C-115/15, EU:C:2016:259, considerando 11.

${ }^{37}$ Cfr., neste sentido, Dimitry Kochenov, “Rounding up the Circle: The Mutation of Member States' Nationalities Under Pressure from EU Citizenship", EUI Working Papers - Robert Schuman Centre For Advanced Studies, 23 (2010): 25, acesso em 01/02/2017, disponível em: http://hdl.handle.net/1814/13634; e Jo Shaw, "Citizenship: Contrasting Dynamics at the Interface of Integration and Constitutionalism", EUI Working Papers, Robert Schuman Centre For Advanced Studies, 60 (2010): 1-3, acesso em 01/02/2017, disponível em: http://hdl.handle.net/1814/14396.

38 A propósito, cfr. o debate doutrinário sintetizado por Dimitry Kochenov, "The essence of EU Citizenship emerging from the last ten years of academic debate: Beyond the cherry blossoms and the moon?", International and Comparative Law Quaterly, 62, 1 (2013): 129-131, doi: 10.1017/ S0020589312000589.

${ }^{39}$ Cfr. Conclusões Rottmann..., considerando 23, onde Miguel Poiares Maduro retoma Joseph Weiler, The Constitution of Europe (Cambridge: University Press, 1999), 344.

${ }^{40}$ Ou "voltam a separar-se" também de acordo com Martins, Manual de Direito da União Europeia, 221-222.
} 
cidadão da União, a nacionalidade de um Estado-Membro não é condição sine qua non da titularidade de alguns dos direitos associados à cidadania da União.

Com efeito, o direito da União reconhece alguns direitos associados à cidadania da União a quem ostenta outro tipo de ligação à União que não a nacionalidade de um Estado-Membro ou, por outras palavras, a quem ostenta outro tipo de ligação à União que não o estatuto de cidadão da União. Alguns direitos de cidadania da União são, desta forma, reconhecidos a não cidadãos da União por direito próprio, não se tratando de direitos derivados do reconhecimento de outros direitos a cidadãos da União ${ }^{41}$. Assim sucede com alguns dos direitos de cidadania da União afetos às relações entre os indivíduos e a União e, em particular, aqueles que infra se destacarão enquanto atributos de uma cidadania administrativa europeia: os direitos de acesso aos documentos das instituições, dos órgãos e dos organismos da União e de petição ao Parlamento Europeu e ao Provedor de Justiça Europeu são igualmente reconhecidos às pessoas, singulares ou coletivas, que residam ou tenham a sua sede num EstadoMembro ${ }^{42}$; o direito a uma boa administração é, por sua vez, reconhecido a todas as pessoas $^{43}$.

Uma vez que o estatuto de cidadão da União se encontra reservado aos nacionais dos Estados-Membros, a cidadania da União também participa do atributo típico da cidadania (nacional) - a definição do "nós" (quem é cidadão da União) por exclusão do "outro" (quem não é cidadão da União) ${ }^{44}$. A propósito da definição do "nós", sublinha Alessandra Silveira que a cidadania da União é "originária e essencialmente uma cidadania inclusiva" ${ }^{45}$, uma vez que respeita a cidadãos que, por definição, não partilham da mesma nacionalidade. Ora, do ponto de vista do seu conteúdo, dos direitos que

\footnotetext{
${ }^{41}$ Para uma análise crítica destes direitos, cfr. Dimitry Kochenov, "Ius tractum of many faces: European Citizenship and the difficult relationship between status and rights", Columbia Journal of European Law, 15, 2 (2009): 225-234.

${ }^{42}$ Cfr. arts. $15 .^{\circ}$, n. ${ }^{\circ} 3,227 .^{\circ}$ e $228 .^{\circ}, 1^{\circ}$ parágrafo, TFUE, bem como os "correspondentes" arts. $42 .^{\circ}$, 43. ${ }^{\circ}$ e $44 .^{\circ} \mathrm{CDFUE}$.

${ }^{43}$ Cfr. art. $41 .^{\circ} \mathrm{CDFUE}$.

${ }^{44}$ Também referindo-se às duas facetas, "includente" e "excludente", da cidadania da União, Martins, Manual de Direito da União Europeia, 242 (itálico da Autora).

${ }^{45}$ Silveira, "Cidadania e Jusfundamentalidade na União Europeia", 949.
} 
lhe estão associados, a cidadania da União revela-se inclusiva mesmo para quem não participa do estatuto. Se é da igualdade, da igualdade no exercício de direitos, que emerge um corpo de cidadãos de um conjunto aleatório de indivíduos ${ }^{46}$, então nem só cidadãos da União, pelo menos no que toca a alguns direitos de cidadania, integrarão aquele corpo.

\section{Em busca de um estatuto de cidadania administrativa na União - os indícios trazidos pela CDFUE}

Esta parcial bifurcação entre o âmbito pessoal (titularidade do estatuto) e o âmbito material (titularidade dos direitos) da cidadania da União refletiu-se, necessariamente, nas disposições consagradas no capítulo da CDFUE respeitante à "Cidadania". A individualização de um capítulo dedicado aos "direitos dos cidadãos da União" estava inscrito no mandato de Colónia de 199947. Guy Braibant dá conta das dificuldades que esta categoria acarretava: i) parecia contrária ao princípio fundamental da universalidade dos direitos fundamentais; ii) o seu alcance seria reduzido, na medida em que apenas os direitos de participação política nas eleições para o Parlamento Europeu e nas eleições municipais (bem como o direito à proteção diplomática e consular) estão reservados aos cidadãos da União; e iii) os demais direitos aplicar-se-iam igualmente aos residentes no território da União (independentemente da sua nacionalidade, de um Estado-Membro ou de um país terceiro) ou mesmo a qualquer pessoa ${ }^{48}$.

É assim que, no Título V da CDFUE, a "Cidadania" é contemplada como valor ${ }^{49}$

\footnotetext{
${ }^{46}$ Assim, Kochenov, "Ius tractum of many faces", 173: "The emphasis on equality is particularly important in the citizenship context. Equality contributes to forging a body of citizens out of a random collective of individuals. By virtue of simply being a citizen, any individual can expect to be regarded as being as valuable a member of the community as any other individual possessing the same status. In practice this means that the laws apply to all the citizens equally and no action on the part of the citizen is required in order to be entitled to treatment equal with others".

${ }^{47}$ Cfr. Conselho Europeu, Conclusões da Presidência do Conselho Europeu de Colónia de 3 e 4 de junho de 1999, Anexo IV: Decisão do Conselho Europeu sobre a elaboração de uma Carta dos Direitos Fundamentais da União Europeia.

${ }^{48}$ Cfr. Guy Braibant, La Charte des droits fondamentaux de l'Union européenne (Éditions du Seuil, 2001), 38-40. ${ }^{49}$ A CDFUE preferiu intitular os seus respetivos capítulos através de um único termo que expressasse,
} 
identitário da União e não somente como instituto reservado apenas aos nacionais dos Estados-Membros. Os arts. 39. ${ }^{\circ}$ a 46. ${ }^{\circ}$ CDFUE acolhem, no essencial, os direitos que os Tratados, especialmente a Parte II do TFUE (arts. $18 .^{\circ}$ a $25 .^{\circ}$ ), associam ao estatuto de cidadão da União, mas não reproduzem fielmente as disposições correspondentes. É também imediatamente percetível que a CDFUE altera em parte a ordem seguida pelos Tratados, nomeadamente no art. $20 .^{\circ}$, n. $^{\circ}$ 2, TFUE, no arranjo sequencial dos direitos consagrados. Se, por exemplo, no TFUE é o direito à livre circulação e residência que assume a dianteira ${ }^{50}$, na CDFUE são os direitos de participação política. Os direitos reconhecidos aos cidadãos da União nas suas relações com a União, que no TFUE são referidos conjuntamente e por último ${ }^{51}$, merecem consagração individualizada na $\mathrm{CDFUE}^{52}$. Sem que daí se deva depreender a existência, seja nos Tratados, seja na CDFUE, de uma qualquer hierarquia entre os direitos em causa, ou que essa hierarquia tenha sido alterada com o reconhecimento de força jurídica vinculativa à CDFUE, estas alterações sugerem, contudo, que a CDFUE reflete, de certa forma, uma compreensão mais atualista do sentido último da cidadania da União - o maior envolvimento das pessoas com o projeto de integração europeia em si, para além do exercício de direitos de circulação e do paradigma do mercado interno e, também, para além da própria titularidade do estatuto de cidadão da União.

Esta leitura é particularmente proporcionada pelo núcleo de direitos consagrados no Título V da CDFUE que constituem a base para a construção de um conceito de

\footnotetext{
não apenas um conjunto de direitos, mas verdadeiros valores - cfr. Guy Braibant, La Charte des droits fondamentaux de l'Union européenne, 39. No mesmo sentido, cfr. Maria Luísa Duarte, União Europeia e Direitos Fundamentais - no espaço da internormatividade (Lisboa: Associação Académica da Faculdade de Direito da Universidade de Lisboa, 2006), 137.

${ }^{50} \mathrm{~A}$ ordem seguida na listagem dos direitos associados à cidadania da União no TFUE mantém-se inalterada desde o Tratado de Maastricht. Esta ordem, que coloca o direito à livre circulação e residência em primeiro lugar, não só demonstra a importância deste direito no quadro da cidadania da União, mas também preserva um certo sentido de continuidade pré e pós-Maastricht - cfr., neste sentido, Kochenov, "Ius tractum of many faces", 196.

${ }^{51}$ Cfr. arts. $20 .^{\circ}$, n. ${ }^{\circ}$ 2, d) e $24 .^{\circ}$ TFUE, o qual remete para os arts. $227 .^{\circ}$ e $228 .^{\circ}$ TFUE.

${ }^{52} \mathrm{Cfr}$. arts. $41 .^{\circ}$, n. $^{\circ} 4,43 .^{\circ}$ e $44 .^{\circ}$ CDFUE. Contrariamente ao TFUE, a CDFUE não acolheu a iniciativa de cidadania, de resto também não elencada no art. $20 .^{\circ}$, n. ${ }^{\circ} 2$, d), TFUE, mas consagrada no art. $11 .^{\circ}$, n. ${ }^{\circ} 4$, TUE e no art. $24 .^{\circ}, 1^{\circ}$ parágrafo, TFUE. Em contrapartida, adicionou o direito de acesso aos documentos das instituições, dos órgãos e dos organismos da União plasmado no art. $15 .^{\circ}$, n. ${ }^{\circ} 3$, TFUE.
} 
cidadania administrativa da União: o direito a uma boa administração (art. 41. ${ }^{\circ}$ CDFUE), o direito de acesso aos documentos das instituições, dos órgãos e dos organismos da União (art. 42. ${ }^{\circ}$ CDFUE) e o direito de petição ao Provedor de Justiça Europeu (art. 43. $\left.{ }^{\circ} \mathrm{CDFUE}\right)^{53} /{ }^{54}$. O conceito de "cidadania administrativa" pretende traduzir o estado atual de evolução do lugar do indivíduo, da pessoa, face ao exercício do poder público, que penosamente passou de súbdito (a utente e) a cidadão ${ }^{55}$. Com ele pretende traduzirse a crescente consideração da pessoa enquanto sujeito que participa ativamente do exercício do poder público, por oposição à sua conceção como mero objeto passivo - como "sujeito num processo comunicativo e não objeto de decisões autoritárias unilaterais dos poderes públicos" ${ }^{56}$. Assim é porque as demandas democráticas reconfiguram o papel da autoridade e do indivíduo: as relações entre as autoridades incumbidas do exercício do poder público e as pessoas afetadas por ele não podem mais conceber-se exclusivamente como relações de domínio porque, num sistema democrático, são as pessoas o verdadeiro dominus do poder público e da Administração ${ }^{57}$.

A CDFUE, enquanto manifesto dos valores da União, não podia senão refletir este estádio evolutivo. Ora, a simples leitura das disposições supra destacadas permite desde logo concluir que a cidadania administrativa da União se distingue da "cidadania da União clássica em razão da definição extensiva dos seus titulares" "58. Com

\footnotetext{
${ }^{53}$ Assim, Jacques Ziller, «Droit à une bonne administration», Jurisclasseur Libertés, 1040 (2007), parágrafo 72 (tradução livre); no mesmo sentido, Braibant, La Charte des droits fondamentaux de l'Union européenne, 212.

${ }^{54}$ Não será aqui considerado o direito de queixa à Comissão uma vez que o mesmo continua sem previsão nos Tratados, apenas estando contemplado no regulamento interno da instituição - cfr. Regulamento Interno da Comissão [C(2000) 3614], JO L 308 de 08.12.2000, pp. 26-34, em especial o art. 6. ${ }^{\circ}$ do Código de Boa Conduta Administrativa para o pessoal da Comissão Europeia nas suas relações com o público anexo ao regulamento.

${ }^{55}$ Neste sentido, cfr. Émilie Chevalier, Bonne administration et Union européenne (Bruxelles: Bruylant, 2014), 401.

${ }^{56}$ José Joaquim Gomes Canotilho e Vital Moreira, Constituição da República Portuguesa Anotada. Volume II, (4 $4^{a}$ edição revista, Coimbra: Coimbra Editora, 2010), 820, que se referem, em anotação ao art. 268. ${ }^{\circ}$ CRP, ao "estatuto de cidadania administrativa dos particulares" (destaque dos Autores).

${ }^{57}$ Em particular, sobre as relações entre boa administração e democracia, e a propósito da consagração de um direito a uma boa administração no art. 41. ${ }^{\circ}$ CDFUE, cfr. Jaime Rodríguez-Arana, "El derecho fundamental a la buena administración de instituciones públicas y el Derecho Administrativo", in El derecho a una buena administración y la ética pública, coords. Carmen Maria Ávila Rodríguez e Francisco Gutierrez Rodríguez (Valência: Tirant lo Blanch, 2011), 77-105.

${ }^{58}$ Chevalier, Bonne administration et Union européenne, 396 (tradução livre).
} 
efeito, e à semelhança das respetivas disposições correspondentes do TFUE ${ }^{59}$, o direito de acesso aos documentos e o direito de apresentar petições ao Provedor de Justiça Europeu são reconhecidos a "[q]ualquer cidadão da União, bem como qualquer pessoa singular ou coletiva com residência ou sede social num Estado-Membro". A consagração dos direitos de acesso aos documentos ${ }^{60}$ e de petição ${ }^{61}$ evidencia a adesão da União a um "modelo de atuação pautado pela abertura e pela transparência" e exprime um compromisso assumido quanto ao modo de funcionamento das suas instituições e dos seus órgãos e organismos, que se pretende "democrático, próximo dos cidadãos, participado e permanentemente sujeito ao seu escrutinio." ${ }_{22}$ A consagração de tais direitos visa, pois, assegurar uma relação de abertura, transparência e proximidade entre as instituições, os órgãos e os organismos da União e quem tenha um vínculo estreito para com a própria União em razão da sua residência no respetivo território. Está em causa assegurar o "maior respeito possivel" pelo princípio da abertura ${ }^{63}$, fomentar formas de democracia participativa no seio da estrutura institucional da União ${ }^{64}$ e, em último termo, consolidar a legitimação democrática da União. É a razão pela qual a titularidade de tais direitos de participação cidadã se estende a qualquer pessoa

\footnotetext{
${ }^{59}$ Cfr. arts. $15 .^{\circ}$, n. $^{\circ} 3,228 .^{\circ}$ e $227 .^{\circ}$ TFUE, respetivamente.

${ }^{60}$ No direito derivado, cfr. Regulamento (CE) n. ${ }^{\circ}$ 1049/2001 do Parlamento Europeu e do Conselho, de 30 de maio de 2001, relativo ao acesso do público aos documentos do Parlamento Europeu, do Conselho e da Comissão, JO L 145 de 31.05.2001, pp. 43-48.

${ }^{61}$ No direito derivado, cfr. Decisão 94/262/CECA, CE, Euratom do Parlamento Europeu, de 9 de março de 1994, relativa ao estatuto e às condições gerais de exercício das funções de Provedor de Justiça Europeu, JO L 113 de 04.05.1994, pp. 15-18, por último alterada pela Decisão 2008/587/CE, Euratom do Parlamento Europeu, de 18 de junho de 2008, JO L 189 de 17.07.2008, pp. 25-27.

${ }^{62}$ Assim se expressa Catarina Gouveia Alves no que toca ao direito de acesso aos documentos cfr. Catarina Gouveia Alves, "Artigo 42. - Direito de acesso aos documentos", in Carta dos Direitos Fundamentais da União Europeia Comentada, coords. Alessandra Silveira e Mariana Canotilho (Coimbra: Almedina, 2013), 490.

${ }^{63} \mathrm{Cfr}$. art. $15 .^{\circ}$, n. $^{\circ} 1$, TFUE. A primeira referência ao princípio da abertura é logo feita no $2^{\circ}$ parágrafo do art. 1. ${ }^{\circ}$ TUE, sendo o princípio retomado, no contexto específico da função administrativa da União, no "mantra" de uma "administração europeia aberta, eficaz e independente" plasmado no art. 298. ${ }^{\circ}$, n. 1 , TFUE. ${ }^{64}$ Cfr., neste sentido, art. $10 .^{\circ}$, n. ${ }^{\circ} 3$, TUE, nos termos do qual " [t] odos os cidadãos têm o direito de participar na vida democrática da União. As decisões são tomadas de forma tão aberta e tão próxima dos cidadãos quanto possivel.". O elenco das formas de participação na vida democrática da União foi reforçado com a introdução, pelo Tratado de Lisboa, da iniciativa de cidadania - cfr. art. $11 .^{\circ}$, n. $^{\circ}$ 4, TUE e art. $24 .^{\circ}, 1^{\circ}$ parágrafo, TFUE e, no direito derivado, (UE) n. ${ }^{\circ} 211 / 2011$ do Parlamento Europeu e do Conselho, de 16 de fevereiro de 2011, sobre a iniciativa de cidadania, JO L 65 de 11.03.2011, pp. 1-22.
} 
singular ou coletiva com residência ou sede num Estado-Membro, pois a aplicação do direito da União não afeta apenas os nacionais dos Estados-Membros.

$\mathrm{O}$ art. 41. ${ }^{\circ}$ CDFUE, por sua vez, ao reconhecer as diferentes dimensões do direito a uma boa administração que consagra a "todas as pessoas", aprofunda a dissociação entre o âmbito pessoal da cidadania da União (os nacionais dos EstadosMembros) e o respetivo âmbito material (os direitos que lhe estão associados). Trata-se, aliás, do mais alargado âmbito subjetivo ativo de aplicação dos direitos consagrados no Título V da CDFUE, abrangendo "todas as pessoas, físicas e coletivas [...], que, independentemente da sua nacionalidade, residência e sede social, e por qualquer motivo ou circunstância, estabeleçam uma relação com a Administração" ${ }^{55}$ ou sejam afetados pela sua atuação. A nacionalidade, a residência ou o simples trânsito no território da União não importam para a delimitação do círculo de beneficiários do direito a uma boa administração consagrado no art. 41. ${ }^{\circ}$ CDFUE - tão só, mas significativamente, a condição de pessoa (jurídica) importa.

O alargado âmbito subjetivo ativo de aplicação do preceito não deixa de levantar problemas quando confrontado com as disposições dos arts. 42. ${ }^{\circ}$ e $43 .^{\circ}$ CDFUE. Assim, por exemplo, uma pessoa, singular ou coletiva, que não resida nem se encontre sediada em nenhum Estado-Membro, mas que, por qualquer motivo, se relaciona com alguma instituição ou algum órgão ou organismo da União, poderá exigir do mesmo o respeito por qualquer uma das dimensões do direito a uma boa administração de que é titular nos termos do art. 41. ${ }^{\circ}$ CDFUE, mas não o poderá fazer i) de forma informada, pois está-lhe vedado o acesso aos documentos da instituição, do órgão ou do organismo da União em causa, nem poderá ii) apresentar uma petição ao Provedor de Justiça Europeu ${ }^{66}$, mesmo que a atuação da instituição, do órgão ou do organismo da União em causa configure um caso de má administração ${ }^{67} /{ }^{68}$. O acesso

\footnotetext{
${ }^{65}$ Cláudia Viana, "Artigo 41. - Direito a uma boa administração", in Carta dos Direitos Fundamentais da União Europeia Comentada, coords. Alessandra Silveira e Mariana Canotilho (Coimbra: Almedina, 2013), 483.

${ }^{66} \mathrm{Nem}$ ao Parlamento Europeu, muito embora a questão se integre num domínio de atividade da União e lhe diga diretamente respeito (art. art. 227. ${ }^{\circ}$ TFUE).

${ }^{67}$ Cfr. arts. $228{ }^{\circ}$ TFUE e $43 .{ }^{\circ}$ CDFUE.

${ }^{68}$ Admitindo que o TJUE possa optar por uma interpretação mais ampla dos preceitos da CDFUE e do
} 
aos documentos por pessoas, singulares ou coletivas, que não sejam cidadãos da União, nem tenham a sua residência ou sede num Estado-Membro, apenas encontra acolhimento no direito derivado e depende de decisão da instituição, do órgão ou do organismo da União ao qual o pedido de acesso tenha sido dirigido ${ }^{69 / 70}$.

Mas o real problema de delimitação colocado pelas disposições em análise não é esse. Todas partilham o mesmo âmbito de aplicação limitado à atuação das instituições, dos órgãos e dos organismos da União: os atributos de uma cidadania administrativa da União destacados encontram-se configurados como direitos de proteção dos indivíduos face ao exercício do poder público pelo nível da União de atuação, com exclusão do principal aparato responsável pela aplicação do direito da União - os Estados-Membros. Assim, contrariamente às petições dirigidas ao Parlamento Europeu - que podem reportar-se à atuação das autoridades dos EstadosMembros, desde que a questão "se integre nos domínios de atividade da União" e "diga diretamente respeito" ao peticionário (art. 227. 'TFUE) ${ }^{71}$-, as queixas/petições dirigidas

TFUE relativos aos direitos de acesso aos documentos e de apresentar petições ao Provedor de Justiça Europeu à luz do amplo círculo de beneficiários do direito a uma boa administração consagrado no art. 41. ${ }^{\circ}$ CDFUE, Jesús Ángel Fuentanaja Pastor, "El avance del derecho a la buena administración en el Tratado de Lisboa", Revista de Derecho de la Unión Europea, 19 (2010): 51.

${ }^{69}$ Com efeito, se os cidadãos da União e todas as pessoas singulares ou coletivas que residam ou se encontrem sediadas em algum Estado-Membro "têm direito de acesso aos documentos", as instituições, os órgãos ou os organismos da União "podem conceder acesso aos documentos" a qualquer pessoa singular ou coletiva que não resida ou não se encontre sediada num Estado-Membro - cfr. art. 2. ${ }^{\circ}$, n. ${ }^{\text {os }} 1$ e 2 , do Regulamento n. ${ }^{\circ}$ 1049/2001 (itálico nosso).

${ }^{70}$ Por sua vez, a possibilidade para pessoas, singulares ou coletivas, que não sejam cidadãos da União nem tenham a sua residência ou sede num Estado-Membro apresentarem petições ao Provedor de Justiça Europeu não está contemplada no respetivo Estatuto. Pelo contrário, a possibilidade de pessoas, singulares ou coletivas, que não sejam cidadãos da União nem tenham a sua residência ou sede num Estado-Membro apresentarem petições ao Parlamento Europeu encontra acolhimento no Regimento do Parlamento Europeu [8a legislatura, setembro de 2015, disponível em www.europarl.europa.eu], mas depende da apreciação pelo Comité das Petições do Parlamento Europeu quanto à oportunidade da petição apresentada. Nos termos do art. $215 .^{\circ}$, n. ${ }^{\circ} 13$, do referido regimento, as petições apresentadas ao Parlamento Europeu por "pessoas singulares ou coletivas que não sejam cidadãos da União Europeia nem tenham a sua residência ou sede social num Estado-Membro" são incluídas e classificadas em lista separada, sendo apreciadas se considerado "oportuno" pela Comissão das Petições.

${ }^{71}$ Também é possível apresentar uma denúncia junto da Comissão Europeia relativa a uma medida (legislativa, regulamentar ou administrativa) ou uma prática imputável a um Estado-Membro considerada contrária a uma disposição ou a um princípio do direito da União - cfr., a propósito, Comissão Europeia, Comunicação "Inobservância do direito comunitário por um Estado-Membro: formulário-tipo para 
ao Provedor de Justiça Europeu apenas podem respeitar a "casos de má administração na atuação das instituições, órgãos ou organismos da União" (arts. 228. 'TFUE e 43. ' CDFUE). Da mesma forma, o direito de acesso aos documentos apenas respeita aos "documentos das instituições, órgãos e organismos da União" (arts. 15. ${ }^{\circ}$, n. ${ }^{\circ}$ 3, TFUE e 42. ${ }^{\circ}$ CDFUE), muito embora o direito da União também se preocupe (leia-se, aplica-se) com o acesso aos documentos dos Estados-Membros porque detidos pela União ${ }^{72}$ ou em razão do domínio setorial em causa $^{73}$. O mesmo sucede em relação às diferentes dimensões do direito a uma boa administração acolhidas no art. 41. ${ }^{\circ}$ CDFUE: muito embora o seu âmbito de aplicação se limite também à atuação das instituições, dos órgãos e dos organismos da União, interpretação literal que tem vindo a encontrar amplo suporte na jurisprudência do Tribunal de Justiça ${ }^{74}$, as diferentes concretizações

as denúncias a apresentar à Comissão Europeia”, JO C 119 de 30.04.1999, 5-7; Comissão Europeia, Comunicação ao Parlamento Europeu e ao Provedor de Justiça Europeu relativa às relações com o autor da denúncia em matéria de infrações ao direito comunitário, JO C 166 de 12.07.2002, 3-6; e Comissão Europeia, Comunicação ao Conselho e ao Parlamento Europeu "Atualização da gestão das relações com o autor da denúncia em matéria de aplicação do direito da União", de 02.04.2012, COM(2012) 154 final.

${ }^{72}$ Assim dispõem os n. ${ }^{\circ} 4$ e 5 do art. 4. ${ }^{\circ}$ do Regulamento n. ${ }^{\circ}$ 1049/2011: "4. No que diz respeito a documentos de terceiros, a instituição consultará os terceiros em causa tendo em vista avaliar se qualquer das excepções previstas nos no. 1 ou 2 é aplicável, a menos que seja claro se o documento deve ou não ser divulgado. 5. Qualquer EstadoMembro pode solicitar à instituição que esta não divulgue um documento emanado desse Estado-Membro sem o seu prévio acordo." A propósito do transcrito art. 4. ${ }^{\circ}$, n. ${ }^{\circ}$ 5, cfr. acórdão TJ de 18 de dezembro de 2007, Suécia contra Comissão, Processo C-64/05 P, EU:C:2007:802, e, na doutrina, Ami Barav, "Opacité et transparence ou le droit d'empêcher. La jurisprudence en matière d'accés aux documents provenant des États Membres détenus par les institutions communautaires ", Chemins d'Europe, Mélanges en l'honneur de Jean Paul Jacqué (Paris: Dalloz, 2010), 34-50.

${ }^{73}$ Cfr., por exemplo, a Diretiva (CE) 2003/4 do Parlamento Europeu e do Conselho, de 28 de janeiro de 2003, relativa ao acesso do público às informações sobre ambiente e que revoga a Diretiva (CEE) 90/313 do Conselho, JO L 41 de 14.02.2003, pp. 26-31.

${ }^{74}$ Apenas em uma ocasião o Tribunal de Justiça considerou o art. 41. ${ }^{\circ}$ CDFUE aplicável no quadro de um procedimento administrativo interno. Afirmando que o "Direito a uma boa administraşão" consagrado no art. 41. ${ }^{\circ}$ CDFUE "reflete um princípio geral do direito da União", o Tribunal de Justiça retirou a seguinte consequência no acórdão de 8 de maio de 2014, H. N., Processo C-604/12, EU:C:2014:302, considerandos 49 e 50: "uma vez que, no processo principal, um Estado-Membro aplica o direito da União, as exigências que decorrem do direito a uma boa administração, designadamente o direito que assiste a qualquer pessoa de ver os seus processos serem tratados com imparcialidade num prazo razoável, aplicam-se no quadro de um processo de concessão da proteção subsidiária, (...), conduz̨ido pela autoridade nacional competente." Embora em termos menos claros, a mesma orientação fora seguida no acórdão TJUE de 22 de novembro de 2012, M. M., Processo C-277/11, EU:C:2012:744, considerandos 81-84 e 89. Contudo, o Tribunal de Justiça tem vindo a seguir orientação oposta na jurisprudência que seguiu, afirmando que "resulta claramente da letra 
do direito a uma boa administração consagradas no preceito vinculam igualmente as autoridades administrativas dos Estados-Membros quando atuam como administração funcionalmente europeia enquanto componentes do princípio geral da boa administração jurisprudencialmente construído ${ }^{75}$.

Assim, apenas por via do direito derivado da União ou com base numa leitura cuidada da jurisprudência do Tribunal de Justiça é que certos atributos de uma cidadania administrativa da União revelam-se como participando plenamente da natureza compósita e multinível da cidadania da União ${ }^{76}$. Outra das "menos-valias" apontada à cidadania administrativa da União prende-se com o facto de descurar a dimensão coletiva ínsita ao processo de democratização administrativa, assentando essencialmente na lógica de uma relação administrativa individual ${ }^{77}$. Nesse sentido, resulta, por exemplo, do teor do art. 41. ${ }^{\circ}$ CDFUE relativo ao direito a uma boa administração que o mesmo visa primacialmente os procedimentos de tomada de

do artigo 41. ${ }^{\circ}$ da Carta que este não se dirige aos Estados-Membros mas unicamente às instituições, órgãos e organismos da União", de modo que os particulares não podem dele retirar direitos oponíveis aos Estados-Membros, mesmo quando estes atuam no âmbito de aplicação do direito da União - cfr. acórdãos TJUE de 17 de julho de 2014, YS, Processos apensos C-141/12 e C-372/12, EU:C:2014:2081, considerando 67; de 5 de novembro de 2014, Mukarubega, Processo C-166/13, EU:C:2014:2336, considerando 44; de 11 de dezembro de 2014, Khaled Boudjlida, Processo C-249/13, EU:C:2014:2431, considerandos 32 e 33; e de 17 de dezembro de 2015, WML, Processo C-419/14, EU:C:2015:832, considerando 83.

75 A título de exemplo, cfr. acórdãos $H$. N., considerandos 52 e 56 (a respeito da exigência de imparcialidade e do conceito de "prazo razoável"); de 18 de dezembro de 2008, Sopropé, Processo C-349/07, EU:C:2008:746, considerandos 36-38 (quanto ao direito de ser ouvido); de 14 de junho de 2011, Pfleiderer, Processo C-360/09, EU:C:2011:389, considerandos 23-32 (quanto ao acesso aos documentos); de 15 de outubro de 1987, Heylens, Processo 222/86, EU:C:1987:442, considerando 15 (sobre a obrigação de fundamentação, acórdão mencionados nas Anotações ao art. 41. ${ }^{\circ} \mathrm{CDFUE}$ ); de 5 de março de 1996, Brasserie du Pếcheur, Processos apensos C-46/93 e C-48/93, EU:C:1996:79, considerandos 29 e 40-47 (a respeito do direito à reparação emergente da responsabilidade dos EstadosMembros fundada em violação do direito da União). Ainda que o direito de interagir na língua oficial da União escolhida não se imponha, enquanto tal, aos Estados-Membros, na medida em que dele decorre uma obrigação de clareza e transparência (na leitura de Miriam Aziz, "Mainstreaming the Duty of Clarity and Transparency as part of Good Administrative Practice in the EU", European Law Journal, 10, 3, 282-295), esta vincula igualmente os Estados-Membros quando atuam no âmbito de aplicação do direito da União - neste sentido, cfr. acórdão TJUE de 21 de junho de 1988, Comissão contra República Italiana, Processo 257/86, EU:C:1988:324, considerando 12.

${ }^{76}$ Assim a caracteriza amplamente a doutrina, mas também a própria Comissão Europeia, Terceiro Relatório sobre a cidadania da União, 7-8.

${ }^{77}$ Nesse sentido, cfr. Chevalier, Bonne administration et Union européenne, 408. 
decisões individuais, o que viria a ser confirmado pelo Tribunal de Justiça ${ }^{78}$. Assim, muito embora reforçados, os atributos de uma cidadania administrativa da União ainda se encontram em emergência no direito da União, em geral, e na CDFUE, em particular.

\section{Conclusão}

Uma cidadania administrativa assente na participação dos indivíduos nos procedimentos públicos de tomada de decisão, em vias de comunicação com as autoridades incumbidas do exercício do poder público, o que demanda abertura e transparência da sua parte, e em mecanismos de controlo sobre a sua atuação, parece estar a desenhar-se no quadro jurídico-institucional da União. No seu Livro Branco sobre Governança Europeia de 2001, a Comissão Europeia fez dos princípios da abertura, da participação, da responsabilização, da eficácia e da coerência os pilares da boa governança na União ${ }^{79}$. As disposições dos arts. 41. ${ }^{\circ}$ a 43. ${ }^{\circ}$ CDFUE acolhem, sob a forma de direitos fundamentais, mecanismos tendentes a concretizar estes princípios. Os direitos aí contemplados, num instrumento superiormente posicionado no sistema normativo da União dotado de força jurídica vinculativa imediata junto dos poderes públicos, têm a potencialidade de contribuir especialmente para a "qualidade do exercício do poder a nível europeu" "80: a CDFUE reforça a proteção daqueles direitos ao incrementar a sua visibilidade (e acessibilidade) junto dos principais interessados - as pessoas titulares

\footnotetext{
${ }^{78}$ Cfr. acórdão TJUE de 17 de março de 2011, AJD Tuna, Processo C-221/09, EU:C:2011:153, considerando 49: "O artigo 41. ' da Carta, (...), prevê, nomeadamente, o direito de qualquer pessoa a ser ouvida antes de ser tomada contra si qualquer medida individual que a afecte desfavoravelmente. Daqui resulta que esta disposição não visa os processos de elaboração de actos de alcance geral". Mais uma vez, tal não implica que o "princípio" da boa administração não seja aplicável a tais procedimentos - cfr., por exemplo, acórdão TJUE de 12 de julho de 2005, Nutri-Link, Processos apensos C-154/04 e C-155/04, EU:C:2005:449, considerandos 72 e 82 (relativamente ao procedimento de alteração do conteúdo das listas de substâncias autorizadas para utilização no fabrico de suplementos alimentares).

${ }^{79}$ Comissão Europeia, Comunicação "Governança Europeia - Um Livro Branco", de 25.07.2001, COM(2001) 428 final, JO C 287 de 12.10.2001, 1-29.

${ }^{80}$ Comissão Europeia, Comunicação “Governança Europeia - Um Livro Branco”, 5.
} 
dos direitos fundamentais consagrados, colocados "no cerne" da ação da União ${ }^{81}$.

Se a cidadania administrativa em emergência na União já permite aprofundar a natureza inclusiva da cidadania da União enquanto cidadania de direitos, pois no seu seio a diferença entre os cidadãos da União e os não cidadãos da União, entre o "nós" e os "outros", é fluída ou mesmo inexistente, o principal desafio que enfrenta, contudo, ainda é o de assimilar a natureza integrada do sistema administrativo da União - para, assim, servir de quadro operativo para o exercício de direitos nas relações entre as pessoas e a autoridade administrativa da União considerada no seu todo ${ }^{82}$. Algumas propostas nesse sentido são equacionáveis, do alargamento do âmbito de aplicação do art. 41. ${ }^{\circ}$ CDFUE para a atuação das autoridades administrativas dos EstadosMembros quando atuam no âmbito de aplicação do direito da União - orientação que tem sido defendido por alguma doutrina ${ }^{83}$ e alguns Advogados-Gerais ${ }^{84}$-, até à adoção ao abrigo do art. 298. 'TFUE de uma regulamentação do procedimento administrativo da União igualmente aplicável aos procedimentos administrativos

\footnotetext{
${ }^{81} \mathrm{Cfr}$. $2^{\circ}, 4^{\circ}$ e $5^{\circ}$ parágrafos do Preâmbulo da CDFUE.

82 Tal como definida, por exemplo, por Jacques Ziller, "L'autorité administrative dans l'Union européenne", in L'autorité de l'Union européenne, dir. Loïc Azoulai e Laurence Burgorgue-Larsen (Bruxelas: Bruylant, 2006), 122: "La notion d'autorité administrative de l'Union peut être définie à mon sens comme l'exercice d'une fonction d'application de la législation et des politiques de l'Union européenne, par les institutions pertinentes de l'Union et de ses Etats membres, dans le respect de principes communs, dont l'application est garantie par les mécanismes de contrôles prévus tant pour les institutions de l'Union que pour celles de ses Etats membres.".

${ }^{83}$ Cfr., entre outros, Diana-Urania Galetta, "Le champ d'application de l'article 41 de la Charte des droits fontamentaux de l'Union européenne sur le droit à une bonne administration, à propôs des arrêts Cicala et M.", Revue trimestrielle de droit européen, 1 (2013), 77-85; e Isaac Martín Delgado, "La Carta ante las Administraciones Nacionales: Hacia la europeización de los derechos fundamentales", in Eva Nieto Garrido e Isaac Martín Delgado, Derecho Administrativo Europeo en el Tratado de Lisboa, (Madrid/ Barcelona/Buenos Aires: Marcial Pons, 2010), 118-132.

${ }^{84}$ Cfr., entre outros, as Conclusões do Advogado-Geral Melchior Wathelet de 25 de junho de 2014, Mukarubega, Processo C-166/13, EU:C:2014:2031, considerando 56, e de 25 de junho de 2014, Khaled Boudjlida, Processo C-249/13, EU:C:2014:2032, considerando 47; e as Conclusões do Advogado-Geral Paolo Mengozzi de 12 de fevereiro de 2015, CO Sociedad de Gestión y Participación SA, Processo C-18/14, EU:C:2015:95, nota 48, e de 13 de janeiro de 2016, Bensada Benallal, Processo C-161/15, EU:C:2016:3, considerando 38-34. Nas suas Conclusões de 16 de setembro de 2015, WML, Processo C-419/14, EU:C:2015:606, considerandos 136-138, Melchior Wathelet identifica a divergência entre o precedente fixado no acórdão $H$. N. e a jurisprudência que lhe se lhe seguiu, minimizando o seu impacto uma vez que, não sendo o art. 41. ${ }^{\circ} \mathrm{CDFUE}$ aplicável no quadro de procedimentos conduzidos pelas autoridades dos Estados-Membros, "isso não impede que o Tribunal de Justiça esclareça o órgão jurisdicional de reenvio sobre a interpretação e a apreciação do princípio geral em causa."
} 
internos de aplicação do direito da União e aos procedimentos administrativos complexos $^{85}$. $\mathrm{Na}$ mesma senda, têm sido formuladas propostas na doutrina tendentes a superar as dificuldades do controlo jurisdicional exercido sobre os atos praticados no decurso de procedimentos administrativos $\operatorname{complexos}^{86} \mathrm{e}$, aquando da redação do malogrado Tratado que estabelece uma Constituição para a Europa, Jacob Söderman, então Provedor de Justiça Europeu, havia sugerido que este órgão passasse a receber também "petições respeitantes a casos de má administração na aplicação do direito comunitário por parte de organismos públicos de um Estado-Membro" ${ }^{87}$.

\footnotetext{
${ }^{85}$ Assim propõe, com base na conjugação das disposições dos arts. 298. ${ }^{\circ}$ TFUE e $41 .^{\circ}$ CDFUE, Isaac Martín Delgado "Hacia una norma europea de procedimiento administrativo", in Eva Nieto Garrido e Isaac Martín Delgado, Derecho Administrativo Europeo en el Tratado de Lisboa, (Madrid/Barcelona/Buenos Aires: Marcial Pons, 2010), 169-181. Também a equipa que compõe a Research Network on EU Administrative Law (ReNUAL) apresenta uma proposta de código de procedimento administrativo da União que assenta numa definição assimétrica do respetivo âmbito de aplicação. Se bem que o código proposto apenas se aplique à adoção de normas administrativas, decisões e contratos pelas instituições e pelos órgãos e organismos da União, e não se estende, por regra, às autoridades administrativas dos Estados-Membros, a proposta contempla, contudo, certas disposições que, "por definição", não podem deixar de aplicarse às administrações públicas dos Estados-Membros - trata-se das disposições relativas à assistência mútua entre autoridades administrativas e à gestão administrativa de informação - cfr. AA.VV., Código ReNUAL de procedimiento administrativo de la Unión Europea, dir. Oriol Mir et al. (Madrid: Instituto Nacional de Administración Pública), 2015, acesso em 01/02/2017, disponível em http://reneual.eu/).

${ }^{86}$ Dificuldades resultantes do descompasso existente entre o sistema de tutela jurisdicional efetiva previsto pelo direito da União (tal como resulta desenhado pelo art. 19. ${ }^{\circ}$, n. ${ }^{\circ}$ 1, TUE) e a institucionalização de procedimentos administrativos compostos: a repartição de competências entre o TJUE e os órgãos jurisdicionais nacionais não oferece soluções suficientes para a fiscalização da legalidade, a imputação de responsabilidades e a proteção dos direitos dos particulares face a procedimentos de tomada de decisões complexos porque assentes em fórmulas de estreita e interdependente cooperação vertical (União/ Estados-Membros) e/ou horizontal (entre Estados-Membros). As propostas passam, nomeadamente, pela previsão de mecanismos de reenvio prejudicial descendente (do TJUE para os órgãos jurisdicionais nacionais) e horizontal (entre órgãos jurisdicionais nacionais), pela atribuição de competência ao TJUE para a fiscalização de atos administrativos nacionais adotados em aplicação do direito da União (e não em resultado da aplicação do direito nacional) no quadro de procedimentos administrativos complexos que terminem pela adoção de um ato jurídico da União, ou ainda pela revisão do conceito de ato impugnável ao abrigo do art. 263. ${ }^{\circ}$ TFUE - cfr. Herwig C. H. Hofmann, "Composite decision making procedures in EU administrative law", e Herwig C. H. Hofmann e Alexander H. Türk, "Legal challenges in EU administrative law by the move to an integrated administration", in Legal Challenges in EU Administrative Law. Towards an Integrated Administration, ed. Herwig C. H. Hofmann e Alexander H. Türk (Cheltenham: Edward Elgar, 2009), 157-165 e 367-375, respetivamente.

${ }^{87}$ Cfr. Jacob Söderman, Propostas de alteração aos Tratados, Contributo recebido pela Convenção Europeia, CONV 221/02, Bruxelas, 26 de julho de 2002. Da proposta resultaria não só que a queixa seria dirigida ao próprio Provedor de Justiça Europeu caso nenhum provedor ou entidade responsável
} 
Em comum, estas propostas procuram atender à dinâmica multinível sob a qual assenta o sistema de aplicação administrativa do direito da União, sistema que articula, de forma interdependente, estruturas de informação, atuação e decisão da União e dos Estados-Membros na prossecução de objetivos e interesses comuns e que se pretende, ainda assim, coeso e integrado porque movido pela ideia de uma União de Direito. Partilham, ainda, a especial mais-valia de procurarem tirar partido das potencialidades já existentes no sistema jurídico-institucional da União. Contribuiriam, porventura, para o fortalecimento de um sentimento de identificação com a União pois, mesmo em relação à atuação das autoridades dos Estados-Membros, a União se mostraria (ainda) mais próxima dos cidadãos que, não sendo necessariamente nacionais dos Estados-Membros, com ela teceram um vínculo tido por relevante pela própria ordem jurídica da União em vários domínios e para diversos efeitos.

pelo tratamento de petições num Estado-Membro fosse competente para a apreciação do assunto, mas também, na prática, que o direito de queixa junto dos provedores de justiça nacionais, ou outra entidade independente, encontraria fundamento numa norma de direito da União... A proposta não foi retida para o Tratado que estabelece uma Constituição para a Europa, nem no Tratado de Lisboa que se lhe seguiu. 


\title{
A cidadania europeia e a tutela dos direitos fundamentais na União - breve análise dos avanços e retrocessos na jurisprudência do TJUE
}

\author{
Francielle Vieira Oliveira*
}

RESUMO: Este trabalho faz uma breve análise do estatuto de cidadania europeia e dos direitos que lhe estão associados, tendo por referência a jurisprudência do TJUE. Em um primeiro momento, verificamos que o TJUE desenvolveu uma interpretação extensiva dos direitos de cidadania europeia, tendo, no entanto, mais recentemente, passado a tomar uma posição mais restritiva quanto a esses direitos, tal como ilustram os acórdãos McCartby e Dano. A discriminação dos cidadãos inativos e estáticos, que aparentemente parecia ter sido resolvida respetivamente nos acórdãos Martinez. Sala, Carpenter e Zambrano, continua todavia a ser uma ameaça à essência genuína de uma "cidadania de direitos". Para que haja o desenvolvimento de uma cidadania inclusiva, concluimos pela necessidade de um aprofundamento das componentes federativas do sistema de integração europeu, que compreende a uma ampliação das competências da União em matérias como, por exemplo, a segurança social.

PALAV RAS-CHAVE: cidadania da União-direitos fundamentais-jurisprudência do TJUE - cidadão estático/ dinâmico e ativo/inativo - discriminação inversa.

ABSTR ACT: This paper briefly examines the status of EU citizenship and the rights associated with it, having the case law of the CJEU as a reference for our study. Firstly, we see that the CJEU has developed a broad interpretation related to the rights of the EU citizenship, but more recently it has been taking a more restrictive position regarding to those rights, as it can be illustrated in McCartby and Dano case law respectively. Whilst discrimination against inactive and static citizens appeared to be settled in case law such as Martinez. Sala, Carpenter and Zambrano, it nevertheless remains a threat to the genuine essence of a "citizenship of rights". In order to bave the development of an inclusive citizenship, we conclude stating that it is necessary to deepen the federative components of the European integration system by extending the Union's competences in matters such as e.g. social security.

KEYWORDS: EU citizenship - fundamental rights - CJEU case law - static vs. migrant and active vs. inactive citizens - reverse discrimination.

\footnotetext{
* Doutoranda em Ciências Jurídicas Públicas na Universidade do Minho, com bolsa atribuída pela Coordenação de Aperfeiçoamento de Pessoal de Nível Superior - CAPES/Brasil.
} 


\section{Introdução}

O Tratado de Maastricht introduziu na ordem jurídica europeia a figura do cidadão da União, que por sua vez foi inspirada no Projeto Spinelli (de 1984) e no Relatório "A Europa dos Cidadãos" (apresentado em 1975 pelo ministro belga Leo Tindemans, na sequência da Cimeira de Copenhaga em 1973). Mais tarde, a Comissão Europeia propôs que o ano de 2013 fosse designado o "Ano Europen dos Cidadãos". Hoje, decorridos vinte e três anos desde a sua instituição, o que é que (ordinariamente) se sabe sobre o estatuto de cidadania europeia e dos direitos que the estão associados?

O último Eurobarómetro, realizado em outubro de 2015, revela que 87\% das pessoas entrevistadas, nos vinte e oito Estados-Membros, conhecem o termo "cidadão da União", porém apenas $42 \%$ reconhecem que estão bem informadas sobre os seus direitos enquanto cidadãos da União e somente $26 \%$ dizem saber o que fazer quando seus direitos como cidadão da União não são respeitados ${ }^{1}$. Com base nesses números, podemos afirmar que a cidadania europeia, embora seja amplamente conhecida, carece ainda de uma melhor divulgação e clarificação quanto aos direitos correspondentes ao seu estatuto.

Mas, se, por um lado, o desconhecimento e as dúvidas relativamente aos direitos associados ao estatuto de cidadania europeia têm sido dominantes entre as massas, por outro lado, os especialistas também têm-se defrontado com algumas dificuldades e incertezas, principalmente em razão da jurisprudência oscilante do TJUE sobre a matéria, conforme pretendemos demonstrar ao longo deste trabalho. Iniciaremos por discorrer brevemente sobre o propósito de criação da cidadania da União no processo de integração europeia e, de seguida, passaremos a analisar alguns casos do TJUE no intuito de saber, por fim, quais direitos estão relacionados ao estatuto de cidadania europeia.

\footnotetext{
1“Cidadania da União Europeia, Flash Eurobarómetro 430”, Comissão Europeia, consultado em fevereiro 01, 2017, http://www.igfse.pt/upload/docs/2016/FlashEurobarometro430_CidadaniadaUE.pdf.
} 


\section{Da cidadania da União}

Uma das principais ideias subjacentes à criação da cidadania europeia residiu na importante tarefa de salvar a União Europeia (antes Comunidade Europeia) de perecer num "vą̧io ético". A construção de uma integração económica europeia em prol apenas do mercado interno seria não apenas indefensável, mas sobretudo errada. Afinal, a União Europeia surgiu de um projeto muito mais ambicioso do que simplesmente um desejo de integrar os mercados dos Estados-Membros, ou seja, a União Europeia foi sempre mais do que um "mport-export de clementinas"3.

Há que se considerar, todavia, que à partida a cidadania seria um exclusivo dos Estados-nações ${ }^{4}$. Não obstante não ser um Estado, nem possuir um povo, a União Europeia mesmo assim ousou em readaptar o conceito de cidadania no seio de sua organização político-económica. Focando-se desde então nos cidadãos, a União Europeia estabeleceu com eles uma ligação vertical (ainda que indireta ${ }^{5}$ ), oferecendo uma «alternativa ao entendimento clássico das relações interestaduais, no sentido do movimento de "diplomacia" para "democracia" ".

Isso se revelou em sintonia com o objetivo que já se contemplava desde os Tratados de Roma, designadamente de se "criar uma união cada vez mais estreita entre os povos europeus", que pode ser traduzido "na vontade inequivoca de aprofundar as vertentes política e constitucional da integração, superando a visão estritamente económica anteriormente transcrita no Tratado de Paris"' . Logo, a concessão de direitos especiais aos cidadãos dos

\footnotetext{
${ }^{2}$ Andrew Williams, The Ethos of Europe - Values, Law and Justice in the EU (Cambridge: Cambridge University Press, 2009).

${ }^{3}$ Cfr. Dimitry Kochenov, “The Citizenship Paradigm”, Law Research Paper Series 8 (2013): 4.

${ }^{4}$ Cfr. Paulo Vila Maior, “A cidadania da União Europeia: algo mais que retórica?”, Revista Antropológicas 11 (2009): 104.

5 "Indireta porque a cidadania da União está condicionada à nacionalidade de um Estado-Membro da União Europeia. Questionou-se e questiona-se ainda hoje se terá sido esta a melhor opção, ou se por acaso não se deveria ter, ao invés, individualizado um critério específico que ligasse diretamente o indivíduo à União Europeia". Dulce Lopes, "A Cidadania da União Europeia e a importância de ser europeu”, Debater a Europa - Periódico do CIEDA e do CEI20 7 (julho/dezembro 2012).

${ }^{6}$ Allot Philip, "The European Community is not the true European Community", The Yale Law Journal 100, 8 (1991): 2485-2500.

${ }^{7}$ Cfr. Paulo Castro Rangel, "Comentário ao artigo 39.", in Carta dos Direitos Fundamentais da União
} 
Estados-Membros da União Europeia alinhava-se perfeitamente a esse propósito. Daí que o Tratado de Maastricht elencou um rol de direitos, nomeadamente direitos de livre circulação e direitos políticos.

Relativamente aos direitos políticos, em especial os direitos de participação política (eleger e ser eleito), pese embora não correspondessem a uma novidade no cenário normativo da União - uma vez que já haviam sido introduzidos anteriormente pelo Ato de 1976 -, ainda assim podemos afirmar que o contributo do Tratado de Maastricht foi no sentido de os elevar à condição de direitos constitucionalmente estabelecidos. Desta forma, os direitos políticos resultantes do estatuto de cidadania europeia passavam a promover os ideais constitucionais de representação e de participação.

A partir de então, qualquer cidadão que circulasse e exercesse suas liberdades económicas fora do Estado-Membro de sua nacionalidade poderia eleger e ser eleito nas eleições municipais do Estado-Membro de residência, bem como nas eleições para o Parlamento Europeu ${ }^{8}$, nas mesmas condições que os nacionais do Estado de acolhimento; os cidadãos da União também passaram a ter o direito de petição junto do Parlamento Europeu; o direito de apresentação de queixa junto do Provedor de Justiça Europeu; e o direito de proteção diplomática pela embaixada de um EstadoMembro em Estados terceiros?.

Além do mais, com o Tratado de Lisboa, foi introduzido no atual art. $11 .^{\circ}$ do TUE o direito de iniciativa de cidadania $^{10}$, a partir do qual os cidadãos europeus passaram a poder pedir à Comissão que proponha iniciativas legislativas desde que recolham um milhão de assinaturas, de pelo menos sete Estados-Membros, e que a

\footnotetext{
Europeia Comentada, coords. Alessandra Silveira e Mariana Canotilho (Coimbra: Almedina, 2013), 369.

${ }^{8}$ Sobre o sistema de exercício de direito de voto e de elegibilidade nas eleições para o Parlamento Europeu dos cidadãos da União residentes num Estado-Membro de que não tenham nacionalidade, veja-se a Diretiva (CE) 93/109, de 6 de novembro de 1993.

${ }^{9} \mathrm{O}$ rol destes direitos encontra-se resguardado no atual art. 20. ${ }^{\circ}$ do TFUE.

${ }^{10}$ Sobre os procedimentos e as condições para a apresentação de uma iniciativa de cidadania, veja-se o Regulamento (UE) 211/2011 do Parlamento Europeu e do Conselho de 16 de fevereiro de 2011, que entrou em vigor 20 dias depois da sua publicação, mas só passou a ser aplicável a partir de 1 de abril de 2012.
} 
proposta seja em matéria da competência da União Europeia ${ }^{11}$. Trata-se de um novo direito democrático à participação no formato da cidadania europeia, permitindo um espaço de autonomia cívica e de cooperação entre os cidadãos dos EstadosMembros $^{12}$.

Quanto aos direitos de livre circulação, foi concedido através do estatuto de cidadania europeia um conjunto de direitos (civis e sociais) ao nacional de um EstadoMembro que estivesse a exercer liberdades económicas noutro Estado-Membro. A Parte II do Tratado de Maastricht salvaguardava assim os direitos dos cidadãos migrantes e trabalhadores, de modo a colocá-los em situação de igualdade em relação aos nacionais do Estado-Membro de acolhimento ${ }^{13}$. O princípio de livre circulação estava desta forma intrinsecamente ligado ao princípio da não-discriminação.

Importa frisar que todos os nacionais de um Estado-Membro são cidadãos da União ${ }^{14}$ e, nesta medida, são também sujeitos de direitos que decorrem do ordenamento jurídico europeu ${ }^{15}$ - cujo rol foi inclusivamente ampliado com a entrada em vigor do Tratado de Lisboa, que conferiu efeito jurídico-vinculativo à Carta dos Direitos Fundamentais da União Europeia (CDFUE). Contudo, ao atribuir direitos decorrentes do estatuto de cidadão europeu apenas àqueles indivíduos que exerciam as suas liberdades económicas e/ou de circulação, criou-se uma ideia de exclusão inconciliável com a teoria dos direitos fundamentais, que por princípio é inclusiva e universalizante ${ }^{16}$. Desde então o reconhecimento da cidadania europeia levantou a questão de saber quem realmente poderia gozar de tal estatuto e quais direitos teriam ${ }^{17}$.

\footnotetext{
11 Sobre as iniciativas de cidadania apresentadas à Comissão, veja-se: "Iniciativa de Cidadania Europeia: Registo Oficial”, acesso em março 6, 2017, http://ec.europa.eu/citizens-initiative/public/ welcome?lg=pt.

${ }^{12}$ Cfr. Jürgen Habermas, Um ensaio sobre a Constitnição da Europa (Lisboa: Edições 70, 2012), 35 e 80.

${ }^{13} \mathrm{Cfr}$ arts. $8 .^{\circ} \mathrm{B}, 8 .^{\circ} \mathrm{C}, 8^{\circ} \mathrm{D}, 8^{\circ} \mathrm{E}$ do Tratado de Maastricht, atuais arts. $22 .^{\circ}, 23^{\circ}$ e $24^{\circ}$ do TUE.

${ }^{14}$ Cfr. o art. 9. ${ }^{\circ}$ do TUE e o art. $20 .^{\circ}$ do TFUE.

15 "Assim a nacionalidade funciona como um vínculo legal e a cidadania como um conjunto de direitos que a nacionalidade dá acesso". Lopes, "A Cidadania da União Europeia e a importância de ser europeu”, 60.

${ }^{16}$ Cfr. Maria Rosa Oliveira Tching, "O papel dos tribunais na construção do padrão de jusfundamentalidade da União Europeia e do estatuto de cidadania europeia” (Master's diss., Escola de Direito da Universidade do Minho, 2012), 73-74.

${ }^{17}$ Cfr. Damian Chalmers et al., European Union Law Text and materials (Cambridge: Cambridge University Press, 2006), 561-562.
} 


\section{Da jurisprudência do TJUE}

De acordo com a jurisprudência do TJUE, desde Van Gend \& Loos ${ }^{18}$ - muito antes da instituição do estatuto de cidadania europeia -, já havia o entendimento no sentido de que os Tratados concedem aos nacionais dos Estados-Membros direitos suscetíveis de integrarem as suas esferas jurídicas e de serem por eles invocados em tribunal ${ }^{19}$. Nesta esteira, o TJUE desenvolveu em suas primeiras decisões pós-Maastricht uma interpretação ampliada dos direitos decorrentes do estatuto de cidadania europeia, de modo a não reduzi-la a uma cidadania de mercado (market citizenship) ${ }^{20}$.

Nesta senda podemos destacar o caso Martínez Sala ${ }^{21}$, no qual o TJUE separou o estatuto de cidadania (e os direitos e liberdades que lhe estão associados) do exercício de atividades económicas. Estava em causa saber se um cidadão europeu, previamente autorizado a residir na Alemanha, teria direito ao subsídio para criação dos filhos, previsto na legislação alemã, independentemente da posse de um título de residência válido, nas mesmas condições que os nacionais daquele mesmo Estado.

O TJUE pronunciou-se no sentido de que Martínez Sala incluía-se no domínio de aplicação ratione personae e ratione materiae das disposições do Tratado consagradas à cidadania europeia. Isto é, o fato de Martínez Sala ser uma cidadã da União (ratione personae) que havia exercido sua liberdade de circulação num outro Estado-Membro, tendo ali estabelecido residência (ratione materiae), foi motivo suficiente para torná-la elegível para receber o referido subsídio, logo equiparando sua situação no âmbito do princípio da igualdade de tratamento independentemente da nacionalidade ${ }^{22}$.

Nota-se, além do mais, que o TJUE adaptou sua jurisprudência de modo a não

\footnotetext{
${ }^{18}$ Acórdão Van Gend \& Loos, 5 de fevereiro de 1963, Processo 26/62, EU:C:1963:1, p. 210-211, no qual o TJUE instituiu o princípio do efeito direto.

${ }^{19}$ Cfr. Alessandra Silveira, "Interconstitucionalidade: normas constitucionais em rede e integração europeia na sociedade mundial", in Interconstitucionalidade e interdisciplinariedade: desafios, âmbitos e niveis de interação no mundo global, coords. Alexandre Walmott Borges e Saulo de Oliveira Pinto Coelho (Uberlândia: LAECC, 2015), 37.

${ }^{20}$ Niamh Nic Shuibhne, "The Resilience of EU Market Citizenship", Common Market Law Review 47 (2010): 1597-1628.

${ }^{21}$ Acórdão Martinez Sala, 12 de maio de 1998, Processo C-85/96, ECLI:EU:C:1998:217.

${ }^{22}$ Acórdão Martinez Sala..., considerando 65.
} 
permitir uma discriminação entre os economicamente ativos e os inativos. $\mathrm{O}$ acesso não discriminatório a um subsídio para a criação dos filhos - normalmente concedido a trabalhadores migrantes - estendeu-se a um cidadão da União migrante, mas naquele momento não trabalhador. Nesta medida esta decisão mostrou-se inovadora ao desvincular a noção de cidadania europeia arraigada à lógica do mercado interno.

O caso Carpenter ${ }^{23}$, por sua vez, revelou-se num outro passo importante dado pela jurisprudência do TJUE, pois enfraqueceu os requisitos tanto económicos quanto transfronteiriços para que um cidadão da União pudesse vir a beneficiar-se dos direitos previstos nos Tratados.

Estava em causa a interpretação do art. 49..$^{\circ}$ do TCE (atual art. 56. ${ }^{\circ}$ do TUE) e da Diretiva (CEE) 73/148 do Conselho, de 21 de maio de 1973, no sentido de saber se estas disposições conferiam a um nacional de um Estado terceiro (no caso, M. Carpenter, cidadã de nacionalidade filipina) o direito de residência com o seu cônjuge (P. Carpenter, cidadão do Reino Unido) no Estado-Membro de origem deste, quando este se encontrava estabelecido nesse Estado-Membro e prestava serviços a pessoas estabelecidas noutros Estados-Membros.

Em sede de reenvio prejudicial, o TJUE considerou que a Diretiva 73/148 não poderia ser aplicada ao caso, pois não regula o direito de permanência dos membros da família de um prestador de serviços no seu Estado-Membro de origem. Entretanto entendeu que a situação de P. Carpenter, descrita no processo, enquadrava-se no âmbito de aplicação do então art. 49. ${ }^{\circ}$ do TCE, restando de consequência garantido o seu direito à livre prestação de serviços, designadamente através da venda de espaços publicitários em revistas médicas e científicas a anunciantes estabelecidos noutros Estados-Membros.

Uma vez que a situação de P. Carpenter enquadrava-se no âmbito de aplicação de uma das normas de direito da União, o TJUE entendeu que esta seria a conexão hábil através da qual se poderia invocar direitos fundamentais como princípios gerais de direito da União (hoje protegidos pela CDFUE). Neste contexto, o TJUE declarou que a separação dos cônjuges Carpenter constituía uma ingerência no exercício por

$\overline{{ }^{23} \text { Acórdão Carpenter, } 11}$ de julho de 2002, Processo C-60/00, EU:C:2002:434. 
P. Carpenter do direito ao respeito da sua vida familiar, prejudicando, portanto, as condições do exercício de suas liberdades fundamentais. Com efeito, estas liberdades não poderiam produzir a plenitude dos seus efeitos se P. Carpenter fosse dissuadido de as exercer em virtude de obstáculos colocados pelo seu país de origem à entrada e à permanência do seu cônjuge ${ }^{24}$.

O TJUE demostrou nesta jurisprudência que, embora os membros da família Carperter não fossem trabalhadores migrantes, ainda assim poderiam gozar do direito à proteção da vida familiar ${ }^{25}$. Logo, tornou-se evidente que o exercício dos direitos decorrentes do estatuto de cidadania europeia não se limitava ao âmbito do princípio da livre circulação.

$\mathrm{Na}$ sequência, designadamente no acórdão Zambrano ${ }^{26}$, o TJUE determinou a extensão dos direitos do estatuto de cidadania europeia a indivíduos que nunca exerceram o seu direito de circulação, ou seja, que nunca saíram do Estado-Membro onde nasceram.

Neste caso, somos apresentados à situação de Ruiz Zambrano e de sua mulher, nacionais de um Estado terceiro (ambos cidadãos colombianos), que entraram na Bélgica munidos de um visto emitido pelas autoridades belgas em Bogotá, com o objetivo de aí conseguirem asilo. No entanto, foram-lhes negados respetivamente os seus sucessivos pedidos de asilo, residência e autorização para o trabalho. Acontece que, no decorrer deste período de permanência na Bélgica, o casal teve dois filhos, que adquiriram a nacionalidade belga por força do princípio do ius solis - sendo, consequentemente, cidadãos europeus.

Havendo dúvidas quanto à aplicação e interpretação do direito da União neste caso em concreto, o órgão jurisdicional de reenvio (Tribunal du Travail de Bruxelles) suscitou a questão de saber, em suma, se as disposições do Tratado sobre a cidadania da União deveriam ser interpretadas no sentido de que conferem ao ascendente, nacional de um Estado terceiro, que tem a seu cargo menores de tenra idade,

\footnotetext{
${ }^{24}$ Acórdão Carpenter..., considerando 39.

${ }^{25}$ Cfr. Eleanor Spaventa, “Striving for equality: who 'deserves' to be a Union citizen?”, in Scritti in onore di Giuseppe Tesauro (Napoli: Editoriale Scientifica, 2014), 2452.

${ }^{26}$ Acórdão Zambrano, 8 de março de 2011, Processo C-34/09, EU:C:2011:124.
} 
cidadãos da União, um direito de permanência no Estado-Membro de que estes têm a nacionalidade e em que residem, bem como a dispensa de autorização de trabalho nesse Estado-Membro.

Os governos que apresentaram observações ao TJUE e a Comissão Europeia alegaram tratar-se de uma questão puramente interna, na medida em que os filhos nascidos em Bélgica nunca haviam saído daquele Estado-Membro ${ }^{27}$. Neste mesmo sentido o TJUE considerou que a Diretiva (CE) 2004/38 do Parlamento Europeu e do Conselho, de 29 de abril de 2004 não tinha aplicação ao caso, pois abrangia apenas os cidadãos da União "que se desloquem ou residam num Estado-Membro que não aquele de que são nacionais, bem como aos membros das suas famílias" 28 .

Seguindo, no entanto, as considerações da Advogada-Geral Eleanor Sharpston - onde havia defendido que "seria no mínimo paradoxal que um cidadão da União pudesse invocar os direitos fundamentais consagrados no direito da União enquanto trabalhador, ou quando o direito nacional é abrangido pelo âmbito de aplicação do Tratado, ou quando invoca o direito derivado da União (como uma diretiva), mas não o pudesse fazer quando se limita a permanecer nesse Estado-Membro" ${ }^{29}$-, o TJUE relembrou, em consonância com a jurisprudência Grzelcyk ${ }^{30}$, Baumbast ${ }^{31}$, Garcia Avello ${ }^{32}$, Zhu e Chen ${ }^{33}$, e Rottmann ${ }^{34}$, que o art. 20. ${ }^{\circ}$, n. ${ }^{\circ} 1$, do TFUE confere a qualquer pessoa que tenha a nacionalidade de um Estado-Membro o estatuto de cidadão da União, o qual obsta a medidas nacionais que tenham o efeito de privar os cidadãos do gozo efetivo do essencial dos direitos conferidos por esse seu estatuto ${ }^{35}$.

Assim sendo, o TJUE reconheceu que a recusa de permanência do progenitor, nacional de um Estado terceiro, no Estado-Membro de que são nacionais e onde

\footnotetext{
${ }^{27}$ Acórdão Zambrano..., considerando 37.

${ }^{28}$ Acórdão Zambrano..., considerando 39.

${ }^{29}$ Conclusões da Advogada-Geral Eleanor Sharpston em Zambrano, 30 de setembro de 2010., Zambrano, Processo C-34/09, considerando 38.

${ }^{30}$ Acórdão Grzelcyk, 20 de setembro de 2001, Processo C-184/99, EU:C:2001:458.

31 Acórdão Baumbast, 17 de setembro de 2002, Processo C-413/99, EU:C:2002:493.

${ }^{32}$ Acórdão Garcia Avello, 2 de outubro de 2003, Processo C-148/02, EU:C:2003:539.

33 Acórdão Zhu e Chen, 19 de outubro de 2004, Processo C-200/02, EU:C:2004:639.

${ }^{34}$ Acórdão Rottmann, 2 de março de 2010, Processo C-135/08, EU:C:2010:104

${ }^{35}$ Acórdão Zambrano..., considerando 42.
} 
residem os seus filhos de tenra idade e que estão a seu cargo, tem a consequência de estes se verem obrigados a deixar o território da União para acompanhar os seus pais. E, constatando que idêntica consequência tem a não atribuição de autorização de trabalho a esses progenitores, pois correm o risco de não disporem dos recursos necessários para sustentarem a si próprios e a sua família, concluiu que essas decisões colidiam com o art. $20 .^{\circ}$ do TFUE, tendo em conta que impossibilitavam os ditos filhos de exercer os direitos conferidos pelo seu estatuto de cidadãos da União ${ }^{36}$. Portanto, os direitos dos filhos do casal Zambrano, decorrentes do seu estatuto de cidadania europeia, foram suficientes para garantir o direito de residência dos seus pais.

Ante ao exposto, podemos dizer que a posição do TJUE na jurisprudência Zambrano marcou um passo a mais na trajetória constitucional de uma cidadania europeia de compleição federal, na medida em que ela acabou por eliminar a diferença de tratamento entre cidadãos dinâmicos e estáticos. Logo, a invocação das disposições da cidadania europeia (art. 20. ${ }^{\circ}$ do TFUE) não estaria subordinada ao exercício prévio do direito de livre circulação, podendo-se aceder através da cidadania europeia ao padrão de jusfundamentalidade europeu ${ }^{37}$.

Contudo, se por um lado, o acórdão Zambrano tem efeito vinculante e erga omnes, por outro lado, importa sublinhar que não é ainda jurisprudência consolidada do TJUE, o que significa dizer que está sujeita tanto a avanços, quanto a retrocessos ${ }^{38}$. Com base em suas decisões mais recentes, verificamos que o cenário tem sido mesmo de um retrocesso, principalmente em relação aos direitos à vida familiar ${ }^{39}$ e aos direitos à segurança social ${ }^{40}$ de cidadãos da União considerados inativos e estáticos.

No acórdão $M c$ Carthy ${ }^{41}$, proferido dois meses após o Zambrano, o TJUE

\footnotetext{
${ }^{36}$ Acórdão Zambrano..., considerando 45.

${ }^{37}$ Cfr. Maria Rosa Oliveira Tching, "O estatuto de cidadão europeu como instrumento da tutela dos direitos de cidadania e dos direitos fundamentais e como elemento de coesão entre os cidadãos da União", UNIO - EU Law Journal 0 (2014): 43.

${ }^{38}$ Cfr. Alessandra Silveira e Claudia McKenny Engström, "The emerging culture of EU citizenship as "citizenship of rights" and the legal nature of the EU polity", UNIO - EU Law Journal 2, 2 (2016): 147.

${ }^{39} \mathrm{Cfr}$. Spaventa, "Striving for equality", 2452.

${ }^{40}$ Cfr. Stefano Giubboni, "Free Movement of Persons and European Solidarity Revisited", Perspectives on Federalism 7, 3 (2015): 5.

${ }^{41}$ Acórdão McCarthy, 5 de maio de 2011, Processo C 434/09, EU:C:2014:2450.
} 
apresentou uma interpretação bem mais restritiva relativamente ao direito do gozo à vida familiar de uma cidadã da União estática e inativa.

Neste processo, S. McCarthy colocou-se numa determinada situação para que o Reino Unido não pudesse recusar, ao abrigo do direito da União, um visto de residência ao seu marido G. McCarthy, de nacionalidade jamaicana. Com este objetivo solicitou, depois do seu casamento, e pela primeira vez, um passaporte irlandês, o que lhe foi deferido devido ao fato de sua mãe ter nascido na Irlanda. $\mathrm{Na}$ posse deste passaporte e forjando uma situação transfronteiriça em razão da sua dupla nacionalidade (britânica e irlandesa), S. McCarthy requereu uma autorização de residência no Reino Unido para o seu marido, com fundamento na Diretiva 2004/38. No entanto, as autoridades inglesas indeferiram o pedido dizendo que S. McCarthy não era beneficiária da referida diretiva, uma que não era capaz de prover às suas necessidades, já que recebia prestações sociais. Consequentemente, o seu cônjuge também não era qualificável para atribuição de qualquer autorização de residência.

Em sede de reenvio prejudicial, foi colocado ao TJUE a questão de saber se a Diretiva 2004/38 podia ser aplicada a um cidadão europeu com dupla nacionalidade, que não era autossuficiente economicamente e que tinha toda a sua vida residido no mesmo Estado-Membro.

Em resposta à questão prejudicial, o TJUE entendeu que não obstante $\mathrm{S}$. McCarthy possuir dupla nacionalidade, isso não era suficiente para estabelecer uma conexão com a Diretiva 2004/38, já que esta somente seria à partida aplicável a cidadãos da União "que se desloquem ou residam num Estado-Membro que não aquele de que são nacionais, bem como aos membros das suas familias" ${ }^{42}$.

Na sequência, o TJUE cuidou de indagar a aplicabilidade do art. $21 .^{\circ}$ do TFUE no sentido de verificar se a medida nacional em causa tinha por efeito privar S. McCarthy do gozo efetivo dos direitos associados ao seu estatuto de cidadã da União. No âmbito desta análise, o TJUE entendeu que o fato de as autoridades do Reino Unido não tomarem em conta a nacionalidade irlandesa de S. McCarthy (a fim de reconhecer-lhe um direito de residência no Reino Unido ao abrigo do direito da

\footnotetext{
${ }^{42}$ Acórdão McCartby..., considerando 39.
} 
União) não a afetava no seu direito de circular e de residir livremente no território dos Estados Membros - nem, de resto, qualquer outro direito que lhe seja conferido pelo seu estatuto de cidadã da União ${ }^{43}$. Nesta medida, a situação de S. McCarthy não apresentava nenhuma conexão com o direito da União, sendo-lhe portanto inaplicável o art. $21^{\circ}$ do TFUE ${ }^{44}$.

Notamos, portanto, que o TJUE interpreta o direito de residência da forma mais restritiva possível, deixando de fora o direito que o cidadão da União tem de ser acompanhado pela sua família. Ao considerar que a recusa de uma autorização de residência a G. McCarthy em nada afetaria os direitos da sua mulher, o TJUE recusouse a reconhecer a natureza fundamental do direito à reunião familiar, consagrado no art. $7^{\circ}$ da CDFUE - que aliás poderia ter sido motivo suficiente para estabelecer uma conexão com o direito da União ${ }^{45}$. Entretanto, o único direito ao qual se atribuiu ao estatuto fundamental da cidadania europeia, neste caso, foi o direito de não ser forçado a deixar o território da União.

Do mesmo modo, no acórdão Dano ${ }^{46}$, verificamos um decisivo retrocesso na dinâmica constitucional empreendia pelo TJUE que, desde Martínez Sala, havia promovido o acesso dos cidadãos economicamente inativos aos sistemas de segurança social dos países de acolhimento, com base no princípio da igualdade de tratamento entre os nacionais dos Estados-Membros da União.

Neste caso, E. Dano, de nacionalidade romena, e seu filho Florin, nascido na Alemanha, viviam em Leipzig, no apartamento de uma irmã de E. Dano. Em 2011, foi atribuído à E. Dano uma autorização de residência, quando então passou a receber, pelo seu filho Florin, prestações por filho a cargo, pagas pela Caixa de Prestações Familiares de Leipzig por conta da Agência Federal para o Emprego. Além disso, o Serviço de assistência social para a juventude e infância de Leipzig pagava um adiantamento sobre a pensão de alimentos para o filho, cujo pai era

\footnotetext{
${ }^{43}$ Acórdão McCarthy..., considerando 49.

44: Acórdão McCarthy..., considerando 56.

${ }^{45}$ Cfr. Maria Rosa Oliveira Tching, "O papel dos tribunais na construção do padrão de jusfundamentalidade da União Europeia e do estatuto de cidadania europeia”, p. 130.

${ }^{46}$ Acórdão Dano, 11 de novembro de 2014, Processo C-333/13, EU:C:2014:2358.
} 
desconhecido. E. Dano havia frequentado a escola na Roménia por apenas 3 anos, não possuía qualquer qualificação profissional, nem havia exercido qualquer profissão, quer na Alemanha, quer anteriormente na Roménia. E nada indicava que procurava emprego.

E. Dano e o filho apresentaram dois pedidos de atribuição de prestações do seguro de base, tendo sido no entanto indeferidos pelo Jobcenter de Leipzig. Em sede de recurso interposto no segundo pedido apresentado pelos Dano, o Sozialgericht Leipzig submeteu ao TJUE uma questão prejudicial no sentido de saber, em suma, se deveriam ser consideradas abrangidas pelo âmbito de aplicação do direito da União as pessoas que pretendem beneficiar de uma prestação especial de caráter não contributivo, ou seja, a questão focava-se na igualdade de tratamento à luz do Regulamento n 883/2004 do Parlamento Europeu e do Conselho, de 29 de abril de 2004, dos Tratados, da Diretiva 2004/38, e dos arts. $1 .^{\circ}$ e 20. da CDFUE.

Neste contexto, o TJUE considerou que E. Dano não detinha nenhum direito de residência segundo o direito da União e, por isso mesmo, não podia invocar igual tratamento em relação a beneficiários da Diretiva 2004/38 $8^{47}$. Primeiramente, o TJUE referiu que as garantias de não-discriminação, presentes na legislação secundária como a invocada Diretiva 2004/38 e o Regulamento no 883/2004, tinham de ser interpretadas de acordo com o estipulado no direito primário, isto é, nos Tratados, nomeadamente o art. $^{\circ} 18 .^{\circ}$ do TFUE. De seguida, o TJUE mencionou que só pode reclamar uma igualdade de tratamento com os nacionais do Estado-Membro de acolhimento, relativamente ao acesso a prestações sociais, o cidadão que estiver no âmbito ratione materiae do direito da União. O que não acontecia com E. Dano, visto não deter nenhum direito de residência - já que não possuia um trabalho - e por não lhe ser aplicável o art. ${ }^{\circ} 1^{\circ}$ do TFUE. Por último, o TJUE entendeu que E. Dano não podia, ab initio, reivindicar qualquer direito de livre circulação ${ }^{48}$.

Diante ao exposto, o TJUE declara que apenas nos casos em que se verifique o preenchimento dos requisitos de autossuficiência económica (e de cobertura extensa

\footnotetext{
${ }^{47}$ Acórdão Dano..., considerando 66 e 81.

${ }^{48}$ Acórdão Dano..., considerando 69.
} 
de seguro saúde), imposta pela letra b), n. ${ }^{\circ} 1$, do art. 7. ${ }^{\circ}$ da Diretiva (CE) 2004/38, o cidadão inativo tem o direito de residir no Estado-Membro de acolhimento e, nesta medida, beneficiar-se da igualdade de tratamento no acesso a prestações de assistência social nesse território. A residência legal nos termos do art. $7 .^{\circ}$ da referida diretiva é, portanto, uma condição prévia, cujo incumprimento permite que um Estado-Membro possa excluir os cidadãos da União economicamente inativos do gozo de um benefício não contributivo especial que é reconhecido aos seus nacionais ${ }^{49}$.

A partir de então podemos afirmar que ressurgem "duas categorias de cidadania da União" ${ }^{50}$ caracterizadas por diferentes estatutos de proteção. A primeira categoria, abrangida pelo estatuto de proteção, está reservada àqueles que estão ativos no mercado interno (como os trabalhadores ou prestadores de serviços), e àqueles que, embora sejam economicamente inativos, podem comprovar a sua autossuficiência económica. E a segunda categoria, por sua vez, está reservada àqueles que não possuem qualquer estatuto de proteção transnacional em razão de não satisfazerem os requisitos previstos pela Diretiva 2004/38.

Com base neste cenário jurisprudencial desenhado pelo TJUE, que à partida mais confunde do que esclarece, importa ponderar se, afinal, a cidadania da União limita-se apenas a apoiar a liberdade de circulação dos cidadãos economicamente ativos, ou se seria um conjunto uniforme de direitos e obrigações em que o respeito pelos direitos fundamentais desempenham um papel fundamental ${ }^{51}$.

\section{Considerações finais}

Uma das questões mais discutidas e que precisam de uma urgente clarificação na seara da cidadania da União refere-se ao âmbito de aplicação dos direitos fundamentais

\footnotetext{
${ }^{49}$ Acórdão Dano...,considerando 84.

${ }^{50}$ Cfr. Herwig Verschueren, "Free Movement of EU Citizens: Including the Poor?”, Maastricht Journal of European and Comparative Law 1, 1 (2015): 10-34.

${ }^{51}$ Cfr. Conclusões da Advogada-Geral Eleanor Sharpston em Zambrano, 30 de setembro de 2010., Zambrano, Processo C-34/09.
} 
que decorrem do ordenamento jurídico europeu. Há quem defenda a necessidade de haver uma cidadania da União inclusiva, em que os direitos fundamentais se estendam a todos, independentemente de serem estáticos ou dinâmicos, ativos ou inativos. Isto porque uma cidadania de mercado não poderia continuar a ser incluída entre os desideratos do projeto de integração ${ }^{52}$. De resto, uma cidadania da União inclusiva poderia fazer frente ao crescente movimento antieuropeu, que desde as últimas eleições para o Parlamento Europeu vem alimentando a ideia de que a União Europeia não tem sido capaz de proporcionar vantagens palpáveis para os seus habitantes menos empreendedores ${ }^{53}$.

De acordo com a jurisprudência do TJUE, confirmada pelo art. $51 .^{\circ}$ da CDFUE, os direitos fundamentais protegidos pela ordem jurídica europeia podem ser invocados quando a medida em causa pertence ao campo de aplicação material do direito da União. E o campo de aplicação das normas europeias é o que deriva das suas competências, tal como indicado nos arts. $2 .^{\circ}$ ao $6 .^{\circ}$ do TFUE. Porém, a partir destas disposições, resulta uma diferença de tratamento entre os cidadãos dinâmicos (que, por exercerem as suas liberdades económicas, beneficiam do estatuto de proteção dos direitos fundamentais da União) e os cidadãos estáticos (que, por não exercerem liberdades económicas, não beneficiam do estatuto de direitos fundamentais da União ${ }^{54}$. Contudo, se o art. 20. ${ }^{\circ}$ do TFUE estabelece que "é cidadão da União qualquer pessoa que tenha a nacionalidade de um Estado-Membro", e o art. 18. do TFUE proíbe qualquer discriminação em razão da nacionalidade, logo não poderia existir nenhuma discriminação entre os cidadãos da União.

Além do mais, o n. ${ }^{\circ} 2$ do art. $20 .^{\circ}$ do TFUE prevê que "os cidadãos da União gozam dos direitos e estão sujeitos aos deveres previstos nos Tratados". Uma interpretação não restritiva sugere que a cidadania da União não só inclui os direitos tradicionalmente reservados a ela (como os direitos políticos), mas também inclui a proteção dos

\footnotetext{
${ }_{52}$ Cfr. Kochenov, "The Citizenship Paradigm", 30.

${ }^{53}$ Cfr. Spaventa, "Striving for equality", 2451.

${ }^{54}$ Cfr. Silveira e Engström, "The emerging culture of EU Citizenship as "citizenship of rights" and the legal nature of the EU polity", 145.
} 
direitos fundamentais ${ }^{55}$. Assim sendo, se o direito de sufrágio para o Parlamento Europeu, o direito de dirigir petições para o Parlamento Europeu e o direito de recorrer ao Provedor de Justiça Europeu não dependem de prévio exercício das liberdades económicas e de circulação para outro Estado-Membro, o estatuto de cidadania europeia deveria ser a ligação suficiente para que qualquer cidadão da União pudesse invocar a proteção dos direitos fundamentais da União, independentemente da condição de ser estático e/ou inativo não autossuficiente.

O TJUE, no entanto, tem hesitado em reconhecer o estatuto autónomo dos direitos fundamentais e da própria cidadania. Se inicialmente em sua jurisprudência pós-Maastricht houve um certo empenho no sentido de garantir o desaparecimento do elemento transfronteiriço e económico em determinados casos, eliminando a discriminação inversa e, consequentemente, ampliando a noção de cidadania europeia, de tal modo que pudesse ser compreendida como uma "cidadania de direitos", esta sua nova vaga de decisões - a partir de McCarthy - trouxe de volta o impasse em torno do que realmente corresponde o estatuto de cidadania da União.

Todavia, importa observar que, se por um lado, na ausência de um quadro normativo para além dos Tratados, o TJUE teve inicialmente uma grande margem de manobra para desenvolver sua própria visão de cidadania europeia, por outro lado, com a introdução de normas secundárias, nomeadamente a Diretiva (CE) 2004/38 entre outras, é evidente que o TJUE passou a ter uma capacidade de interpretação mais limitada ${ }^{56}$.

Ademais, a atual incerteza política quanto ao futuro do projeto de integração europeu - desencadeada principalmente pela crise económica nos países da zona Euro - tem chamado a atenção para os problemas relacionados com a solidariedade transfronteiriça. Como não existe uma europeização dos sistemas nacionais de proteção social, a dimensão da solidariedade transnacional é confrontada com uma tensão que inevitavelmente aparece quando uma liberdade de circulação, não exercida

\footnotetext{
${ }^{55}$ Cfr. Silveira e Engström, "The emerging culture of EU Citizenship as "citizenship of rights" and the legal nature of the EU polity", 142.

${ }^{56}$ Cfr. Spaventa, "Striving for equality", 2459-2460.
} 
conforme às necessidades do mercado interno, acaba por colidir com as finanças nacionais do Estado de bem-estar-social ${ }^{57}$ - eis inclusivamente um dos problemas que motivou a votação a favor do último referendo no Reino Unido, que ficou conhecido como Brexit.

O desenvolvimento de uma cidadania da União inclusiva encontra-se, portanto, em primeiro lugar, na dependência do aprofundamento das componentes federativas do processo de integração europeu, que compreende uma ampliação das competências da União em matérias como, por exemplo, a segurança social. Ampliando-se as competências da União, o âmbito de aplicação da CDFUE também se estenderia a um conjunto maior de situações, sem assim desrespeitar o constante no seu n..$^{\circ}$ do art. 51. ${ }^{\circ}$ Logo a CDFUE poderia passar a constar do essencial dos direitos conferidos pelo estatuto de cidadão europeu. Em segundo lugar, a cidadania europeia deveria passar a ser considerada como conexão hábil, a partir da qual seria possível invocar os direitos fundamentais decorrentes da ordem jurídica europeia, independentemente da condição de dinâmico/estático ou ativo/inativo. No entanto, enquanto a União Europeia não enveredar por um sistema constitucional maduro e abrangente, com um verdadeiro regime de proteção dos direitos fundamentais ${ }^{58}$, continuaremos a enfrentar o problema da discriminação inversa, que por fim afeta a substância genuína de uma cidadania de direitos.

\footnotetext{
${ }^{57}$ Cfr. Giubboni, "Free Movement of Persons and European Solidarity Revisited", 8-9.

${ }^{58}$ Cfr. Eleanor Spaventa, "Federalisation Versus Centralization: tensions in fundamental rights discourse in the EU", in 50 years of European Treaties: looking back and looking forward, ed. Michael Dougan e Samantha Currie (Oxford: Hart Publishing, 2009), 344.
} 



\title{
Tempo, vínculos e direitos: quando circular e permanecer não tende a ser o estatuto fundamental dos nacionais dos Estados-Membros
}

\author{
Fátima Pacheco*
}

RESUMO: A autora aborda o conteúdo e evolução dos direitos de cidadania a partir do entendimento de que a qualidade de cidadão europeu corresponde ao estatuto jurídico-político fundamental dos nacionais dos Estados-Membros da União Europeia. Após percorrer a jurisprudência mais impactante neste domínio, conclui que o princípio da não discriminação alargou o âmbito de aplicação daqueles direitos, expandiu as liberdades fundamentais para além do mercado, além de consubstanciar a cidadania como um fator de ligação ao direito da União Europeia e a sua vinculação aos direitos fundamentais. Assim, i) demonstrando que o TJUE proibiu as discriminações em função da nacionalidade e os obstáculos à livre circulação, conduzindo à atribuição de direitos de cidadania não só a cidadãos ativos e inativos mas também a estáticos e ii) aventando que as limitações temporais e económicas dos períodos de residência, permitidos pelo direito secundário, restringiram a liberdade fundamental de circular e de residir - e que o respeito pelas opcõoes politico-legislativas dos Estados-Membros conduziram à diferenciação entre cidadãos e à falta de solidariedade transnacional-, a autora vem propor que a aplicação do direito secundário não deve entrar em conflito com os direitos fundamentais protegidos pela ordem jurídica da União, sugerindo uma interpretação conforme ao direito primário e à luz dos preceitos da Carta de modo a não prejudicar o essencial dos direitos conferidos pelo estatuto de cidadão da União, sob pena de involução do projeto mais bumanizante e sinergético da Europa.

PALAVRAS-CHAVE: cidadania europeia - circulação - residência - direitos fundamentais - não discriminação solidariedade transnacional.

SUMMARY: Being the European citizen the fundamental legal-political status of the nationals of the Member States of the European Union, the author addresses the content and evolution of citizenship rights. After examining the most relevant case law in this area, it concludes that the principle of non-discrimination extended the scope of those rights;

\footnotetext{
* Professora Adjunta no ISCAP (Instituto Superior de Contabilidade e Administração do Porto Politécnico do Porto). Membro Doutorado do Centro de Estudos em Direito da União Europeia (CEDU), da Universidade do Minho.
} 
expanded fundamental freedoms beyond the market; and embodied citizenship as a factor linking European Union law and its link to fundamental rights. Demonstrating that the CJEU has banned discrimination on grounds of nationality and obstacles to free movement leading to the attribution of rights of citizenship not only to active and inactive but also to static citizens; arguing that the temporal and economic limitations of periods of residence allowed by secondary law restricted the fundamental freedom to move and reside and that respect for the political and legislative options of the Member States led to the differentiation between citizens and the lack of solidarity transnational; the author proposes that the application of secondary law should not conflict with fundamental rights protected by the legal order of the Union suggesting an interpretation consistent with primary law and in the light of the provisions of the Charter so as not to prejudice the 'Of the rights conferred by the status of citizen of the Union'; under penalty of involution of the most bumanizing and synergetic project in Europe.

KEY WORDS: European citizenship - circulation - residence - fundamental rights - non-discrimination transnational solidarity.

\section{Introdução: noção e conteúdo da cidadania europeia}

Com o processo de construção europeia nada permaneceu imutável. Dentro das fronteiras que dantes nos separavam nasceu uma nova "comunidade política" que nos uniu, pacificando a Europa. A então Comunidade Europeia, em 1992, criou um estatuto jurídico que aspirava gerar um laço indissolúvel entre os indivíduos e ela própria, dando corpo a um complexo de direitos desdobrável em múltiplas facetas. Os direitos de cidadania, ainda que alicerçados na nacionalidade eram - como o são ainda - algo que a transcende servindo de instrumento de legitimação democrática; condição de inclusão numa comunidade; e elemento aglutinador da integração política europeia.

Este estatuto de sobreposição materializa a nossa ligação a uma comunidade democrática de povos iguais entre si. Envolvendo uma dimensão política, cívica e social, a cidadania europeia - essencialmente por obra do TJUE ${ }^{1}$ - foi-se afirmando de forma dinâmica, apresentando-se hoje como uma realidade "pós-nacional" e supraestadual. A evolução destes direitos pode ser aprofundada pelo Conselho (art.

\footnotetext{
${ }^{1}$ A partir daqui a palavra "Tribunal" designa o Tribunal de Justiça da União Europeia que, nos termos do art. 19. ${ }^{\circ}$ do Tratado da União Europeia (TUE) «inclui o Tribunal de Justiça, o Tribunal Geral e os tribunais especializados».
} 
25. 'TFUE), mediante recurso a um processo legislativo especial, bem como pode constituir objeto de cooperação reforçada (art. 20. 'TUE). A atribuição deste estatuto aos seus beneficiários foi, contudo, desacompanhada da enunciação de deveres, o que contribuiu para a falta de solidariedade redistributiva transnacional e para a condicionalidade da liberdade de circulação.

Depois de o n. 1 do art. 20. ${ }^{\circ}$ TFUE definir como "cidadão da União qualquer pessoa que tenha a nacionalidade de um Estado-Membro", o n. 2 do mesmo dispositivo enuncia - ainda que não exaustivamente - os direitos fundamentais que lhe assistem. A sua previsão não se inclui nas disposições que versam sobre as competências exclusivas, partilhadas ou complementares da União. Trata-se, todavia, de uma competência partilhada ainda que a atribuição da nacionalidade - da qual depende geneticamente constitua um domínio reservado dos Estados relativamente ao qual todos os outros lhe devem reconhecimento. Nessa medida, é usual apontar-se-lhe a falta de igualdade nas condições de acesso.

Não podendo a União, por si só, criar um vínculo de nacionalidade, a cidadania europeia adquire-se indiretamente. Por força desta cidadania derivada reconhece-se a todos os cidadãos o direito de entrar, circular e de residir noutro Estado (ainda que cumprindo requisitos); procurar emprego, trabalhar e estabelecer-se ou prestar serviços em qualquer Estado-Membro; obter vantagens sociais e fiscais nos mesmos termos do que os nacionais dos Estados onde se encontrem (ainda que não incondicionalmente); participar nas eleições municipais e para o Parlamento Europeu; participar civicamente na vida da União (vertente interna); e usufruir de proteção diplomática e consular por parte de qualquer Estado-Membro sempre que se encontrem em Estados terceiros onde o seu Estado não tenha representação (vertente externa).

Onde quer que os cidadãos europeus residam, o exercício daqueles direitos não pode ser preterido pelos Estados-Membros. Esta certeza reforça a inclusão e a não discriminação dos indivíduos essencialmente em função da sua residência; esbate a ligação destes direitos à nacionalidade original; e demonstra o fundamento existencial da cidadania nos vínculos de pertença que se querem estabelecer relativamente ao local onde se encontrem. 
Sendo certo que o direito de livre circulação e de permanência (art. 21. ${ }^{\circ}$ TFUE) constitui o núcleo destes direitos e não obstante o seu cunho excludente distinguindo cidadãos europeus e nacionais de terceiros Estados - regista-se uma tendência do Tribunal no sentido de autonomizar e expandir a sua proteção jurídica a cidadãos inativos e a não cidadãos, ainda que por equiparação. Neste quadro, o leque dos direitos de cidadania devem agrupar-se conforme estão (ou não) reservados a cidadãos (direitos de participação política); ligados à sua residência (direitos de livre circulação de intensidade variável); ou atribuídos a todas as pessoas (direitos de boa administração).

Com efeito, analisando a jurisprudência neste domínio verificamos que não só os cidadãos migrantes são abrangidos pelo véu protetor que decorre deste estatuto fundamental dos nacionais dos Estados-membros². Partindo das liberdades fundamentais de mercado, o Tribunal dissociou o conceito de trabalhador e de cidadão, desvinculando-o da justificação económica das liberdades e da mobilidade transfronteiriça, assim esbatendo a inicial diferença entre indivíduos ativos e não ativos; estáticos ou dinâmicos; e incluindo na sua proteção os membros da sua família originária de Estados terceiros. Numa palavra, humanizou os trabalhadores, emancipando-os da sua inicial condição de elementos de produção, ainda que a existência de recursos económicos suficientes e o prévio exercício da circulação possa condicionar o pleno gozo destes direitos por parte de indivíduos não trabalhadores.

Aqui chegados, é hora de concretizar o objeto de trabalho. O problema que aqui trazemos parte de várias premissas, ilustradas pela jurisprudência que se vai apresentar (ainda que de forma breve) quais sejam: I) O princípio da não-discriminação alargou o alcance da cidadania e o seu âmbito pessoal e material; II) expandiu as liberdades para além do mercado; III) a própria cidadania é fonte de direitos fundamentais, também sociais, a que a nacionalidade dá serventia.

Partindo da tese que a irreversibilidade democrática - no seu sentido criador de extensão e densificação dos direitos sociais - implica um certo grau de solidariedade

\footnotetext{
${ }^{2}$ Conforme formulação do Tribunal no Acórdão Rudy Grzelcayyk, de 20 de setembro de 2001, Processo C-184/99, ECLI:EU:C:2001:458.
} 
transnacional, é nossa intenção descortinar se o argumento da sustentabilidade dos sistemas sociais nacionais esbate a estrutura e alcance destes direitos.

$\mathrm{Na}$ verdade, estando a solidariedade financeira entre cidadãos cativa das desigualdades estaduais, a articulação da proteção dos direitos sociais com a livre circulação questiona os parâmetros da justiça distributiva, a par da tendência para a sua secundarização. Ainda que a Carta não consinta a todos os direitos sociais a possibilidade da sua invocabilidade (direitos e princípios), cremos que o seu conteúdo ultrapassa o mínimo denominador comum aos Estados-membros. Nesse quadro, sendo certo que as restrições admissíveis ${ }^{3}$ aos direitos reconhecidos na Carta dos Direitos Fundamentais da União Europeia (CDFUE) não podem beliscar o seu conteúdo essencial (art. 52. ${ }^{\circ}$, n. ${ }^{\circ}$ 1), cabe questionar se o exercício dos direitos de cidadania conferidos pelo Tratado, e pelas disposições adoptadas em sua aplicação, o descaracteriza.

Postas estas considerações, e em jeito de assim as delimitar, propomo-nos refletir sobre se a vertente social da cidadania - enquanto expressão do princípio da solidariedade consagrado na Carta - constitui um desiderato europeu, ou se a luz daquele catálogo de direitos não susteve a sua involução. Por outras palavras: o receio de que o exercício dos direitos que assistem aos cidadãos possa esmorecer e que a sua plenitude se revele, a final, uma desoladora "concha vazia", leva-nos a acompanhar o percurso do Tribunal com vista a descortinar se aquela instituição não estará a involuir na proteção que confere a estes direitos tão essenciais à integração europeia.

\section{Processo genético da cidadania europeia: o passado, o presente e o presente do futuro}

A Europa dos cidadãos tem sido um percurso sem ruturas e sem acasos, mas marcado por hesitações. O seu processo genético ilustra tal constatação: nascendo no

\footnotetext{
${ }^{3}$ Os direitos de cidadania só podem ser restringidos mediante reserva de lei; por necessidade de proteção de interesses gerais da União ou direitos de terceiros; no respeito da proporcionalidade de tal restrição; e na salvaguarda do núcleo essencial desses direitos.
} 
Tratado de Maastricht ${ }^{4}$ para suavizar o seu economicismo e exaltar os valores comuns dos europeus, afirma-se - em Amesterdão - como uma qualidade complementar e não substitutiva da cidadania nacional, e vem com o Tratado de Lisboa assumir-se como adicional àquela (art. 9. 'TUE). Ademais, aspirando criar uma "união cada vez. mais estreita entre os povos da Europa" e erigir um espaço público europeu, as disposições relativas aos princípios democráticos, consagram o direito de representação dos cidadãos no Parlamento Europeu, atribuem-lhes o direito de participarem cívica e democraticamente na vida da União (arts. $10^{\circ}$, n. $^{\circ} 2$ e 3, e $11 .^{\circ}$, n. $^{\circ} 1$ TUE), e o direito de iniciativa legislativa (art.11. ${ }^{\circ}$, n. $\left.^{\circ} 4\right)$, conferindo mais substância à cidadania enquanto pilar democrático da União.

Por outro lado, a vinculatividade da CDFUE (art. 6. ${ }^{\circ}$, n. ${ }^{\circ}$ 1, TUE) permitiu revelar a mais recente base jurídica na qual a cidadania se sustenta, reforçando e enunciando os vários direitos fundamentais em que se decompõe, ainda que de forma não coincidente com os Tratados (arts. 39. ${ }^{\circ}$ a $46 .^{\circ}$ ). Estes incluem o direito à não discriminação (art. 18..$^{\circ}$ e $19 .^{\circ}$ TFUE) na Parte II que se dedica à Cidadania (art. 20. ${ }^{\circ}$ a 25. ${ }^{\circ}$ TFUE), pelo que tal direito - sendo inerente a ela - deve ser considerado como fundamental e conjugado com o princípio da igualdade de tratamento, consagrado no art. 9. ${ }^{\circ} \mathrm{TUE}$.

De referir, ainda, que estes direitos, bem como a jurisprudência que sobre eles incidiu, foram codificados na Diretiva (CE) 2004/38 do Parlamento e do Conselho, relativa à livre circulação e residência dos cidadãos e membros da sua família (que

\footnotetext{
${ }^{4}$ Sobre a evolução da cidadania, cfr. Ana Maria Guerra Martins, "A cidadania na União Europeia definição, conteúdo e contributo para a constitucionalização da União Europeia", in Estudos em Homenagem ao Prof. Doutor Paulo da Pitta e Cunha, Vol. I, (Coimbra: Almedina, 2010), 9-20; Alessandra Silveira, "Autonomia institucional/processual dos EM e efetividade do direito da União Europeia na jurisprudência do TJUE (ou do Baile de Pierre-Auguste Renoir)", in Estudos em Homenagem ao Prof. Doutor Jorge Miranda: Direito Constitucional e Justiça Constitucional (Coimbra: Coimbra Editora, 2012), 11-33; Denys Simon, "Les Droits du Citoyen de l'Union", in Revue Universelle des Droits de l'Homme, 12, (2000): 22-27; Francis G. Jacobs, "Citizenship of the European Union - a legal analysis", in European Law Journal, 13, 2007: 591-610; Sofia de Oliveira Pais, "Todos os cidadãos da União Europeia têm direito de circular e residir no território dos Estados-membros, mas uns têm mais direitos do que os outros", in Scientia Ivridica - Revista de Direito Comparado Português e Brasileiro, 323 (2010): 50-65; Rui Manuel Moura Ramos, "Maastricht e os direitos do cidadão europeu", in A União Europeia (Coimbra: Faculdade de Direito Curso de Estudos Europeus, 1994), 93-129.
} 
os acompanhem ou a eles se reúnam), sem prejuízo das limitações previstas no Tratado, Diretiva essa cujo objetivo principal consiste na simplificação e reforço dos direitos dos cidadãos ${ }^{5}$. Trabalhadores assalariados e autónomos, estudantes, familiares, prestadores ou destinatários de serviços e pessoas economicamente independentes integram o leque dos seus titulares ativos, sempre que se desloquem ou residam num Estado-Membro que não o da sua nacionalidade. Acresce que os direitos que lhe são atribuídos ${ }^{6}$ deverão ser exercidos em condições idênticas a qualquer cidadão do Estado de acolhimento onde se encontrem. De salientar que nos termos da referida Diretiva, a partir de três meses e até cinco anos de permanência, o direito de residência dos cidadãos ativos depende do exercício de uma atividade económica. Quanto aos cidadãos não ativos depende da posse de recursos suficientes e de um seguro de doença, para evitar que possam constituir um encargo para os sistemas nacionais de segurança social (art. . $^{\circ}$ ). Por outro lado, deve também referir-se que aqueles sistemas, desde 2004, se apresentam coordenados por força do Regulamento (CE) 883/2004, do Parlamento Europeu e do Conselho, permitindo aos trabalhadores gozar de benefícios sociais em função do lugar onde

\footnotetext{
${ }^{5}$ Cfr. Acórdão Metock, 25 de junho de 2008, Processo C-127/08, ECLI:EU:C:2008:449.

${ }^{6} \mathrm{O}$ direito de residência adquire-se para períodos de permanência até três meses, por mais de três meses, ou por terem residido legalmente durante cinco anos consecutivos. Todavia, nos domínios sociais o princípio da não discriminação sofre as derrogações previstas no seu n. ${ }^{\circ}$ 2, do seu art. $24 .^{\circ}$. Assim, os Estados podem não conceder prestações sociais durante os três primeiros meses de residência ou mesmo durante um período superior, durante o qual o cidadão procure trabalho, bem como as podem negar às pessoas que não exerçam atividades assalariadas ou autónomas antes de adquirem direito de residência permanente. A esta vicissitude deve acrescentar-se que, nos termos do art. $7 .^{\circ}$, n. ${ }^{\circ} 1$, al. b), da mesma Diretiva, o direito de residência depende - previamente - de recursos suficientes e de seguro de doença. Deve salientar-se que nada impede o Estado de acolhimento de atribuir aos cidadãos migrantes aquelas prestações ainda antes de adquirido o direito de residência permanente, sendo certo que depois dele são equiparados de pleno direito aos nacionais dos Estados de acolhimento, conforme dispõe o art. $24 .^{\circ}$, n. ${ }^{\circ} 1$ do diploma. O direito de residência não permanente até três meses é possível desde que os cidadãos não se transformem em encargo para a segurança social e possuam meios de subsistência, (sendo trabalhador ou se estiver à procura de trabalho pode não os ter, cfr. art. 14. ${ }^{\circ}$, n. ${ }^{\circ}$ ) ou por período superior a três meses se exercerem uma atividade económica. Caso assim não aconteça a sua liberdade fica condicionada para assim evitar o "turismo social", pelo que a Diretiva protege melhor o indivíduo enquanto agente económico do que enquanto cidadão. Estas restrições ao direito fundamental de circular e de permanecer devem ser interpretadas restritivamente pois implicam verdadeiras derrogações a ele.
} 
permanecem, o que também contribuiu para esbater a importância da nacionalidade na evolução destes direitos.

De âmbito mais estrito do que os Tratados, a CDFUE apresenta um Preâmbulo, onde se apresentam os fundamentos da União e a diversidade das suas fontes ${ }^{7}$. A Carta desenrola-se em cinquenta e quatro arts. - agrupando ao longo de 6 Títulos, direitos de primeira, segunda e terceira geração, estabelecidos em torno dos valores comuns que constituem os alicerces da União - e encerra-se com 4 disposições horizontais que são a chave da sua interpretação e aplicação ${ }^{8}$. De resto, a Carta incorpora as "Anotações" completadas pela Convenção Europeia de 2003 que preparou o texto da Constituição Europeia. Em nome do princípio da indivisibilidade os direitos estão sistematizados em plano de igualdade e, excepção feita para os direitos de cidadania (e os específicos), são atribuídos a indivíduos independentemente da sua nacionalidade 9 . Ainda que continue a residir no art. $6 .^{\circ}$ do TUE a estruturação do sistema de proteção de direitos fundamentais da União, aspirando à universalidade, os direitos reconhecidos na Carta permitem a incorporação da igualdade e possibilitam a irradiação da sua influência a terceiras pessoas, densificando o valor indivisível da dignidade humana. Ademais, a Carta goza dos predicados típicos do direito primário da União, de onde se destaca o primado e o efeito direto, ambos densificações do princípio geral da lealdade.

\footnotetext{
${ }^{7}$ A Carta refere os direitos que decorrem «das tradições constitucionais e das obrigações internacionais comuns aos Estados-membros, do Tratado da União Europeia e dos Tratados comunitários, da Convenção Europeia para a Proteção dos Direitos do Homem e das Liberdades Fundamentais, das Cartas sociais aprovadas pela Comunidade e pelo Conselho da Europa, bem como da jurisprudência do Tribunal de Justiça das Comunidades Europeias e do Tribunal Europeu dos Direitos do Homem». ${ }^{8} \mathrm{O}$ art. $51{ }^{\circ}$ refere-se ao âmbito de aplicação da Carta; o art. 52. ${ }^{\circ}$ ao âmbito e interpretação dos direitos e dos princípios; o art. $53 .^{\circ}$ ao nível de proteção e; finalmente, o art. $54 .^{\circ}$ proíbe o abuso de direito. Sobre a importância destas disposições, cfr. Alessandra Silveira e Mariana Canotilho coords., Carta de Direitos Fundamentais da União Europeia - Comentada (Coimbra: Almedina, 2012), 572-628; Cristina Atienza e José Luis Pérez, cood. La Europa de los Derechos - estudio sistemático de la Carta de los Derechos Fundamentales de la Unión Europea (Granada: Editorial Comares, 2012), 1302-1439; Koen Lenaerts, "Exploring limits of the EU Charter of Fundamental Rights", in European Constitutional Law Review, Vol. 8, Issue 3, (2012): 375403; Ricardo Alonso Garcia, "The General Provisions of the Charter of Fundamental Rights of the European Union", in European Law Journal, Vol. 8, 4, (2002): 492-514;

${ }^{9}$ Os cidadãos da União não são considerados estrangeiros para efeitos da $\mathrm{CEDH}$, pelo que as restrições especiais previstas no art. $16^{\circ}$ da $\mathrm{CEDH}$, para a atividade política dos estrangeiros não se lhes aplicam.
} 
Sendo um dado incontrovertível que a apresentação do percurso da jurisprudência do TJUE neste domínio seria uma tarefa hercúlea, veremos perfunctoriamente - algumas ilustrações da proteção dispensada a estes direitos por parte daquela instituição ao longo da evolução da integração europeia.

\subsection{Fase expansionista: a conjugação da cidadania com a igualdade e a não discriminação}

Foi em 1998 que o Tribunal desprendeu o estatuto da cidadania da necessidade prévia de exercício de uma atividade económica. Com efeito, no acórdão Martinez. Sala ${ }^{10}$ salienta-se a ligação intrínseca da cidadania e do princípio da igualdade e da não discriminação em razão da nacionalidade. Esta jurisprudência ampliou o espaço de proteção social conferido pelo direito da União, transvertendo o princípio da não discriminação em verdadeiro direito fundamental. Tratava-se de uma reivindicação

\footnotetext{
${ }^{10}$ Acórdão Martinez Sala, de 12 de maio de 1998, processo C-85/96, ECLI:EU:C:1998:217. Assinalando a tendência para o alargamento do campo dos beneficiários do princípio, aliando-os aos direitos de cidadania, destacando a não exigência de ligação a liberdades económicas e justificando o direito de circulação nos direitos de cidadania, cfr. Acórdão Bickel e Franz̧, de 24 de novembro de 1994, Processo C-274/96, ECLI:EU:C:1998:563. O Tribunal, no considerando 19, reafirmando o caráter de direito fundamental do art. 18. TFUE, diz que "(...) o direito conferido por uma regulamentação nacional, de faz̧er com que um processo penal decorra numa lingua diferente da lingua principal do Estado em causa, entra no campo de aplicação do Tratado (...)", assim associando o uso da língua e a livre circulação. O acórdão afirma que qualquer cidadão pode deslocar-se e circular livremente noutro Estado para aí receber serviços. Autonomizando o estatuto de cidadão (estudantes) e reconhecendo-lhe o direito ao mesmo tratamento (art. 18. ${ }^{\circ}$ TFUE) dos nacionais, que no caso se traduzia no recebimento de prestações sociais não contributivas, cfr. Acórdão Grzelcyk..... As suas orientações seriam prosseguidas no Acórdão Marie-Nathalie D' Hoop, de 11 de junho de 2002, Processo C- 224/98, ECLI:EU:C:2002:432, sobre o direito a subsídios de inserção e, muito particularmente, na afirmação do efeito direto do art. $21 .^{\circ}$ TFUE, enquanto fundamento da invocabilidade dos direitos de cidadania, em concreto da liberdade de circulação, contra o seu próprio Estado, por ter estudado fora dele. De forma ainda mais clarividente, o Acórdão Baumbast, de 17 de setembro de 2002, Processo C-413/99, ECLI:EU:C:2002:493, sobre atribuição de direitos de residência, esclarece a aplicação do estatuto de cidadania, sedimentando e ultrapassando a jurisprudência Martinez Sala, desligando em absoluto a cidadania de mercado, confirmando o efeito direto do art. 21. ${ }^{\circ}$ TFUE. No mesmo sentido, Acórdão Tas-Hagen Tas, de 26 de outubro de 2006, Processo C-192/05, ECLI:EU:C:2006:676. Sobre esta jurisprudência, cfr. Ana Maria Guerra Martins, Manual de Direito da União Europeia (Coimbra: Almedina, 2012), 238.
} 
de uma prestação familiar considerada "vantagem social,"11 no sentido do art. 7, n. 2, do Regulamento (CEE) n. ${ }^{\circ}$ 1612/68 (ponto 28), sem que a parte que a reivindicava fosse um "trabalhador" no sentido daquele instrumento jurídico, quando para os nacionais tal atribuição era automática. O Tribunal afirmou que a condição para beneficiar daquelas vantagens, qual fosse a exigência do cartão de residência, criava uma situação de desigualdade de tratamento (art. 12. ${ }^{\circ}$ TCE) que constituía uma discriminação (não justificada) em razão da nacionalidade dos beneficiários do subsídio.

Este aresto abriu um processo de autonomização do estatuto de cidadania, alargando a proteção social aos cidadãos passivos ou economicamente inativos e aos membros das suas famílias. O Tribunal afirmou que a situação da Senhora Martinez revelava diretamente do âmbito de aplicação ratione personae das disposições do Tratado que versavam sobre a cidadania. Segundo o Advogado-Geral Jacobs a não discriminação em razão da nacionalidade seria o "mais fundamental" dos direitos conferidos pelo Tratado e "factor de base" da cidadania, facultando a qualquer cidadão a invocação daquele princípio em todas as situações abrangidas pelo âmbito de aplicação ratione materiae do direito da União. O direito de residir em qualquer um dos Estados afirmava-se inseparável da cidadania e autónomo do direito de livre circulação contribuindo para erigir uma nova qualidade subjetiva aos particulares, determinada em função da sua residência! Não sendo assim, o Tribunal consentiria que um tratamento desigual constituísse um óbice à tão desejável mobilidade dos europeus.

Nesse caminho, em 2001, o Tribunal dá mais um passo no sentido da construção de um modelo social europeu no acórdão Grz̧elçy/k, afirmando que os

\footnotetext{
${ }^{11}$ A noção de "vantagem social" não coincide com as prestações sociais contributivas da segurança social. A sua definição está prevista no art. 70. do Regulamento (CE) 883/2004 do Parlamento Europeu e do Conselho, de 29 de abril de 2004, relativo à coordenação dos sistemas de segurança social, alterado pelo Regulamento (UE) n. ${ }^{\circ}$ 1244/2010 da Comissão, de 9 de dezembro de 2010. Nelas incluem-se as prestações sociais e fiscais ou de assistência social que os indivíduos que não disponham de recursos suficientes para fazer face às suas necessidades elementares têm expectativa de auferir, mesmo não sendo trabalhadores. Em nome do princípio da igualdade, e logo que cumpridos os requisitos temporais e substanciais fixados na Diretiva (CE) 2004/38, todos os cidadãos podem dela vir a beneficiar. A fixação das suas condições é, porém, de competência estadual.
} 
estudantes residentes noutro Estado-Membro tinham direito a beneficiar do subsídio do mínimo de subsistência (minimex) nas mesmas condições que os estudantes nacionais. O Tribunal - conjugando a cidadania e a não-discriminação; declarando a sua vocação para ser o estatuto fundamental dos nacionais dos Estados-Membros; e que tal estatuto permitia a invocação da igualdade de tratamento em todas as situações ratione materiae abrangidas pelos Tratados (exercício das liberdades de circular e residir) - afirmaria que as prestações sociais não contributivas não eram apenas devidas a trabalhadores, mas também a estudantes que se deslocassem para outro Estado. O Tribunal já exortava a necessidade de alguma solidariedade financeira para com os beneficiários do direito de residência, em especial se as dificuldades económicas fossem transitórias e não se revelassem uma sobrecarga injustificada ou não proporcional para as finanças do Estado de acolhimento, o que é dizer que todas as limitações (previstas no direito secundário) ao exercício destes direitos teriam de ser apropriadas e necessárias para atingir os fins previstos pelas mesmas!

Assim sendo, um cidadão de um Estado-Membro que estudasse noutro Estado poderia invocar a seu favor o direito, consagrado nos arts. $18{ }^{\circ} \mathrm{TFUE} \mathrm{e}$ 21. ${ }^{\circ}$ TFUE, de circular e permanecer livremente no território de residência sem sofrer discriminações, diretas ou indiretas, em razão da sua nacionalidade, inclusive no que concernia ao recebimento de vantagens sociais.

Em jurisprudência posterior o Tribunal foi exaltando a possibilidade de os Estados verificarem a existência de um vínculo ou ligação real ${ }^{12}$ entre o indivíduo e o Estado de permanência, vínculo esse que traduziria o tempo ${ }^{13}$ necessário à sua

\footnotetext{
${ }^{12}$ Cfr. acórdão D’Hoop, de 11 de julho de 2002, Processo C-224/98, ECLI:EU:C:2002:432, acórdão Collins, de 23 de março de 2004, Processo C-138/02, ECLI:EU:C:2004:172; acórdão Bidar, de 15 de março de 2005, Processo C- 209/03, ECLI:EU:C:2005:169; acórdão Vatsouras e Koupatantæ̌e, de 4 de junho de 2009, Processos C- 22/08 e C-23/08, ECLI:EU:C:2009:344. De salientar que esta jurisprudência não se fundamenta na cidadania enquanto estatuto fundamental dos europeus e na inerente necessidade de sedimentação do conceito de solidariedade financeira, mas põe o acento tónico na questão do nível de integração dos estudantes e do "vínculo real" com o mercado de trabalho quanto aos candidatos a emprego.

${ }^{13}$ Cfr. neste sentido acórdão Förster, de 18 de novembro de 2008, Processo C-158/07, ECLI:EU:C:2008:630, onde se estabelece que é legítimo que um Estado-Membro só conceda uma ajuda para cobrir despesas de subsistência aos estudantes que demonstrarem um certo grau de integração na sociedade desse Estado. A
} 
integração no local de residência. Nessa medida, a residência continuada sucedeu ao vínculo de nacionalidade e passou, paulatinamente, a critério de atribuição de direitos sociais no Estado de acolhimento, ainda que a sua origem se encontrasse no exercício de uma liberdade económica e ainda que o direito secundário enunciasse requisitos para a eles aceder. Desta forma, mesmo os cidadãos não ativos poderiam beneficiar de direitos de cidadania, derivados do art. 21. ' TFUE, ainda que o direito secundário estabelecesse - como veremos infra - requisitos económicos específicos e um período mínimo de residência para auferir vantagens sociais, sob pena da ruína dos sistemas nacionais e do incremento ao "turismo social"!

$\mathrm{Na}$ verdade, este era o tempo em que o direito de livre circulação poderia transformar a Europa: os cidadãos podiam residir onde pretendiam, mesmo sem exercerem uma atividade económica. Porém, a supressão de restrições à entrada e permanência dos cidadãos desembocou no problema da solidariedade transnacional dos nacionais dos Estados-Membros de acolhimento para com indivíduos não contribuintes. Esta decorrência provou que a cidadania era, com efeito, um instrumento de integração política apto a criar um nexo entre os povos da Europa constitutivo de uma verdadeira cultura e espaço comum! Todavia - como veremos a jurisprudência recente indica-nos que o Tribunal não pretende assumir (sozinho) a concretização de tal "quimera” em matéria social deixando aos Estados espaço para seguirem as próprias políticas de solidariedade financeira.

\subsubsection{Para lá do elemento transfronteiriço: a densificação dos direitos de cidadania e a sua instrumentalização à integração europeia}

De qualquer forma, a implementação dos direitos de cidadania humanizou os trabalhadores, densificando os seus direitos. Com efeito, para além de alargar o alcance do princípio da não discriminação e de expandir as liberdades para além

este propósito, a existência de um certo grau de integração demonstra-se quando se verificar que o estudante em causa residiu no Estado-Membro de acolhimento durante um determinado período., conforme se lê no considerando 58. 
do mercado, a cidadania acabou por ser fonte de direitos fundamentais a que a nacionalidade dava acesso. O acórdão Rottmann ${ }^{14}$ demonstra que o nexo necessário para invocar o direito da União foi sendo ampliado para justificar a aplicação do seu padrão de jusfundamentalidade, partindo direta e autonomamente do estatuto de cidadania. Este acórdão determinou que os direitos de cidadania não implicam que os indivíduos "circulem" para adquirir os direitos que dela advêm: tratava-se de um cidadão austríaco a quem se pretendia revogar a nacionalidade alemã, adquirida por naturalização, o que perigava os seus direitos futuros enquanto cidadão, impossibilitando-o do seu exercício. Nas palavras de Alessandra Silveira, "este acórdão abre portas a que o cidadão invoque o Direito da União, via estatuto de cidadania europeia, a

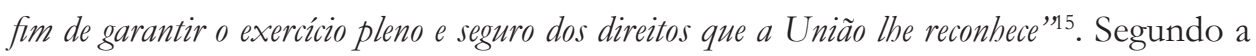
Professora, o acórdão destaca: por um lado, o poder autónomo dos Estados para determinar a aquisição e perda de nacionalidade, direito fundamental não regulado pelo direito da União e doravante submetido ao respeito pelos direitos decorrentes da cidadania. Por outro lado, desliga o gozo daqueles direitos, tal como referido no art. $20 .^{\circ}$ do TFUE, da necessidade prévia dos direitos de circulação, solidificando que eles se destinam também a cidadãos estáticos.

O acórdão Zambrano ${ }^{16}$ prossegue esta tendência dinâmica e optimista. Tratavase de uma situação de discriminação inversa ${ }^{17}$ : nacionais belgas menores privados do direito à reunificação familiar vêm levantar o problema do âmbito dos direitos fundamentais, e se os mesmos poderiam ser invocados sem nexo evidente com o direito da União. Discutia-se se lhes era reconhecido um direito de residência no próprio território de nacionalidade, independentemente de terem circulado.

\footnotetext{
${ }^{14}$ Acórdão Rottmann, de 2 de março de 2010, Processo C-135/08, ECLI:EU:C:2010:104.

15 Alessandra Silveira, "Implicações nos litígios entre particulares resultantes da horizontalidade dos princípios gerais de direito protegidos pela União Europeia", in Cadernos de Direito Privado, 32 (2010): 3-21. ${ }_{16}$ Acórdão Ruír Zambrano, de 8 de março de 2011, Processo C-34/09, ECLI:EU:C:2011:124.

${ }^{17}$ Nos termos do considerando 147 das Conclusões, de 30/9/2010, destaca-se uma situação integrável no art. 52. ${ }^{\circ}$, n. 3 da Carta: "Quando a discriminaşão inversa conduzisse a um resultado que fosse considerado uma violação de um direito protegido pelo Tribunal de Estrasburgo, seria, de igual modo, considerado uma violação de um direito protegido pelo nosso Tribunal de Justiça. Assim, o direito da UE assumiria a responsabilidade de remediar as consequências da discriminação inversa causada pela interação do direito da UE com o direito nacional somente nos casos em que essas consequências fossem incoerentes com os niveis de proteção minimos estabelecidos pela CEDH”.
} 
A concessão da autorização de residência aos pais, não europeus, determinaria a aplicabilidade dos direitos de cidadania a cidadãos estáticos, por via da proibição da discriminação em razão da nacionalidade, previsto no art. $180^{\circ}$ do TFUE, sustendo a discriminação inversa provocada pelo não exercício dos direitos previstos no art. 21. ${ }^{\circ}$ do TFUE: o direito de circular e o direito de permanecer, desligando o último da dependência do primeiro. Discutia-se, portanto, o direito de permanência dos ascendentes de cidadãos, por derivação do direito de seus filhos, apesar de estes não terem exercido uma liberdade económica. Cuidava-se de determinar se a cidadania - integrando uma competência material da União - poderia atribuir por si só direitos fundamentais (proteção da vida familiar e direitos da criança) advindos da sua dupla previsão (tratados e na Carta), por via da conjunção dos dispositivos indicados (18. ${ }^{\circ}$ e 20. ${ }^{\circ}$ TFUE) com os arts. $21 .^{\circ}, 24 .^{\circ}$ e $34 .^{\circ}$ da Carta. Com efeito, a expulsão dos pais privaria os filhos, cidadãos europeus, do gozo efetivo do conjunto de direitos que decorriam do seu estatuto, assim se ligando uma situação aparentemente interna ao direito da União. Neste histórico aresto, o Tribunal afirmaria que uma medida nacional que privasse os cidadãos do gozo genuíno da substância daqueles direitos ${ }^{18}$ não poderia ser uma situação puramente interna. Para a Advogada-Geral, tratava-se, igualmente de delimitar o âmbito de proteção do direito fundamental ao respeito pela vida familiar, consagrado no art. $7 .^{\circ}$ da CDFUE, cujo exercício resultaria violado pela ordem de afastamento.

Este acórdão revelou-se de uma enorme importância para a evolução da cidadania, pois ultrapassou a necessidade do exercício de atividade económica; permitiu aceder ao padrão de jusfundamentalidade europeia; e desconsiderou o elemento transfronteiriço. Ademais, na sua fundamentação, o Tribunal não referiu a Diretiva (CE) 2004/38, sustentando-se na força do direito primário e subtraindo ao Estado de acolhimento a aplicabilidade do seu direito de imigração.

\footnotetext{
${ }^{18}$ Zambrano..., considerando 42: “(...) o art. 20. ${ }^{\circ}$ TFUE obsta a medidas nacionais que tenham o efeito de privar os cidadãos do gozo efetivo do essencial dos direitos conferidos pelo seu estatuto de cidadão da União»"
} 


\subsection{Fase da auto-contenção: a relativização da incondicionalidade do direito de entrar, circular e permanecer}

O processo anterior daria origem a uma sequência de pedidos de decisão prejudicial sobre a interpretação do art. $200^{\circ}$ do TFUE, a propósito de um conjunto de pedidos de autorização de residência, sucessivos indeferimentos, e ordens de afastamento da Áustria. Formulados por membros da família de cidadãos da União que nunca tinham circulado, solicitando um direito de residência cuja recusa ocasionaria "uma privação do gozo efetivo do essencial dos direitos conferidos pelo estatuto de cidadão da União", a decisão do Tribunal no acórdão Murat Dereci ${ }^{19}$, e apensos, precisaria o alcance de Zambrano salientando a sua excepcionalidade.

$\mathrm{Na}$ verdade, doravante, o TJUE determinaria o alcance do critério que ele próprio formulara ao sublinhar a "essencialidade" dos direitos que assistiam aos cidadãos europeus. Com efeito, tratando-se de uma área politicamente sensível (controlo da imigração), neste acórdão o Tribunal assumiu uma postura de autocontenção declarando que lhe incumbia interpretar o direito da União no estrito respeito pelos limites das suas competências, estribando-se numa interpretação restrita do art. 51. ${ }^{\circ}$ da $\operatorname{Carta}^{20}$. Nesse quadro, afirmaria que apenas a necessidade de abandono de todo o território da União é que integraria o critério Zambrano! De resto, o Tribunal não incluiria na apreciação da privação do gozo efetivo do essencial dos direitos de cidadania as consequências da proteção da vida familiar, consagrada na Carta (art. . $^{\circ}$ ) como um direito de todos, nem assumiria o direito de residência como diretamente resultante do direito da União. A apreciação da recusa de emissão do título de residência teria, portanto, de resultar da apreciação a nível nacional e convencional (art. 8. ${ }^{\circ}$ da $\mathrm{CEDH}$ ), por não se ter demonstrado que a situação se integrava no âmbito de aplicação do direito da União. Inexistindo, no caso concreto, dependência económica e circulação dos cidadãos relativamente aos nacionais de Estados terceiros o Tribunal,

\footnotetext{
19 Acórdão Murat Dereci, de 15 de dezembro de 2011, Processo C-256/11, ECLI:EU:C:2011:734, considerando 33.

${ }^{20}$ Cfr. Acõrdão Fransson, de 26 de fevereiro de 2013, Processo C-617/10, ECLI:EU:C:2013:105.
} 
no considerando 74, decidiu que "(...) o direito da União, (...), deve ser interpretado no sentido de que não se opõe a que um Estado Membro recuse a um nacional de um Estado terceiro a residência no seu território, quando pretenda residir com um membro da sua família que é cidadão da União, residente neste Estado Membro, do qual tem a nacionalidade, e que nunca exerceu o seu direito de livre circulação, desde que tal recusa não comporte, para o cidadão da União em causa, a privação do gožo efetivo do essencial dos direitos conferidos pelo estatuto de cidadão da União, o que incumbe ao órgão jurisdicional de reenvio verificar".

O caso O.S..$^{21}$, de novo, questiona o alcance da decisão Zambrano, estreitando a sua expansividade. O Tribunal reiteraria que o critério Zambrano era excecional, exigindo uma situação de dependência económica que colocasse o cidadão na inevitabilidade de abandonar o território da União, anulando o efeito útil da cidadania. Atente-se que o Tribunal - ainda que coerente com o receio de vagas de "turismo social" - não deixou de exortar os Estado-Membros de que a aplicação da diretiva do reagrupamento familiar [Diretiva (CE) 2003/86] deveria ser feita de modo a respeitar os direitos fundamentais da União, onde se deveriam incluir os preceitos da Carta (art. 7. $^{\circ}$ e $24 .^{\circ}$, n. ${ }^{\circ} 2$ e 3). Ademais, sublinhou que o direito nacional deveria ser interpretado em conformidade com o direito da União, destacando que a diretiva não concedia margem de apreciação aos Estados-Membros, antes lhes impunha obrigações precisas. Na verdade, afirmou que os Estados-Membros podiam exigir a prova dos recursos, mas sublinhou que isso não devia impedir que o requerente pontualmente recorresse à assistência social. Neste quadro, quer-nos parecer que ainda aqui - invocando a verificação da proporcionalidade das medidas nacionais o Tribunal continuou a trilhar o caminho da humanização da cidadania.

$\mathrm{O}$ acórdão Alokpa $a^{22}$ analisava o pedido de residência de uma Togolesa (nos termos dos arts. $20 .^{\circ}$ e $21 .^{\circ}$ TFUE articulados com os $21 .^{\circ}, 24 .^{\circ}, 33 .^{\circ}$ e $34 .^{\circ}$ da Carta), ascendente de cidadãos menores, nacionais franceses, que nunca tinham circulado. A ascendente não se encontrava a cargo dos cidadãos - tal como exigia a Diretiva (CE)

\footnotetext{
${ }^{21}$ Acórdão O.S. c. Maahanmunttovirasto, de 6 de dezembro de 2011, Processos C-356/11 e C-357/11, ECLI:EU:C:2012:776.

${ }^{22}$ Acórdão Adzo Alopka, de 10 de outubro de/2013, Processo C-86/12, ECLI:EU:C:2013:645.
} 
2004/38 - e não havia vida familiar entre Alopka, seus filhos e o pai francês. Após ter recordado que o direito de residência de não cidadãos é "derivado" do exercício da livre circulação dos cidadãos, para assim não os dissuadir de circular, o Tribunal decidiu que não sendo os menores obrigados a abandonar o território da União no seu todo, e tendo, por isso, um direito incondicional de entrar e residir no território francês, Luxemburgo poderia recusar o pedido devido aos menores não satisfazerem o requisito fixado na Diretiva (CE) 2004/38. Não estava, portanto, em causa o abandono do território da União: um ascendente não dependente do cidadão menor, muito embora não abrangido pelo âmbito pessoal da diretiva, tem um direito de residência derivado da cidadania de seus filhos, por via autónoma do art. 21. ${ }^{\circ}$ TFUE, para lhe ser possível garantir os seus recursos futuros e concretizar a subsistência. Solução, aliás, já preconizada no acórdão $I_{i l a}^{23}$, que relaciona a jurisprudência Zambrano e Dereci, propondo uma interpretação da Diretiva (CE) 2004/38 à luz dos direitos fundamentais da União Europeia.

\subsection{O presente do futuro: crise e diferenciação, tempo e solidariedade transnacional - os sinais de uma involução?}

Mais recentemente - apesar de o Tribunal vir afirmando que os cidadãos são abrangidos pelo âmbito pessoal dos Tratados - temos de registar que aquela instituição se mostra temerosa em atribuir o direito de prestações de assistência social (destinadas a garantir o mínimo de subsistência) a cidadãos economicamente inativos ou que se encontrem a procurar trabalho.

Ao condicionar-se o direito de permanência até aos cinco anos ao cumprimento de requisitos temporais e económicos previstos na Diretiva (CE) 2004/38 pode obstaculizar-se a igualdade e não discriminação no que concerne à liberdade de circulação e permanência e à faceta social da cidadania, bem como introduzir uma diferenciação entre os cidadãos europeus. Vicissitude que leva a obliterar a automaticidade do direito de residência consagrado no direito primário, enquanto

${ }^{23}$ Acórdão Yoshikazu Iida, de 8 de novembro de 2012, Processo C- 40/11, ECLI:EU:C:2012:691. 
liberdade absoluta. Senão façamos um brevíssimo percurso da jurisprudência mais ilustrativa desta vicissitude: Elizabeta Dano ${ }^{24}$, romena e mãe de um filho menor, portadora de uma declaração de residência desde 2011 - não obstante invocar o princípio da não discriminação e o direito de permanência resultante do art. $20 .^{\circ}$ TFUE - viu negado o recebimento de prestações sociais asseguradas pela legislação alemã e, por consequência, o seu direito de aí residir. Dano não tinha formação escolar, não se exprimia em alemão, nunca tinha procurado emprego e vivia das prestações sociais de seu filho. Sendo certo que o art. 24. ${ }^{\circ}$, n. $^{\circ} 2$ da Diretiva (CE) 2004/38 concretiza uma derrogação ao princípio da igualdade de tratamento contemplado no art. 18. ${ }^{\circ}$ TFUE de que o n. ${ }^{\circ} 1$ do art. $24 .^{\circ}$ constitui concreta expressão; e que a Senhora Dano, residente há mais de três meses e menos de cinco anos na Alemanha, nunca tinha procurado emprego e que não se situava na previsão do art. . $^{\circ}$, n. $^{\circ} 1$, al. b) do mesmo dispositivo, o Tribunal decidiu que ela, não possuindo recursos suficientes e assistência médica, poderia tornar-se uma sobrecarga não razoável para a segurança social alemã, durante o período de permanência. Nesta medida, consentiu a exclusão de cidadãos carenciados do recebimento de prestações pecuniárias especiais de carácter não contributivo, atribuídas a nacionais em idêntica situação, quando não preenchessem os requisitos da residência legal, nos termos da referida diretiva ${ }^{25}$, com o intuito de precaver a sobrecarga do sistema de assistência social.

O Tribunal escudou a sua posição no n. ${ }^{\circ} 2$, do art. 20. ${ }^{\circ}$ TFUE, afirmando que os direitos de cidadania são «exercidos nas condições e limites definidos pelos tratados e pelas "medidas" adoptadas para a sua aplicação», e relembrou que o próprio art. 21. ', n. 1 TFUE, subordina a liberdade de circulação às "limitações e condições previstas no Tratado e nas disposições adoptadas em sua aplicação". Convicto que a cidadania não deve implicar a sua instrumentalização à captura de benefícios sociais, o Tribunal foi claro ao excluir a concessão de tais vantagens do âmbito de aplicação do direito da União (Carta incluída) e ao incluí-las no âmbito de apreciação do legislador nacional, frisando que apenas ele poderia estabelecer o alcance da cobertura social das prestações por si atribuídas.

\footnotetext{
${ }^{24}$ Acórdão Elisabete Dano, de 11 de novembro de 2014, Processo C-333/13, ECLI:EU:C:2014:2358.

${ }^{25}$ Ver supra a nossa nota 6 sobre a aplicabilidade da Diretiva (CE) 2004/38.
} 
Prosseguindo nesta posição, também em 2014, o Tribunal vem negar a mesma pretensão a Alimanovic ${ }^{26}$, de nacionalidade sueca e residente na Alemanha, que, depois de ter trabalhado menos de um ano, ainda lá se encontrava a procurar emprego, invocando que as prestações de assistência social, na aceção do art. 24. ${ }^{\circ}$, n. ${ }^{\circ} 2$ da Diretiva (CE) 2004/38, estavam excluídas para candidatos a emprego - ainda que não o estivessem para os nacionais alemães em idêntica situação - devido ao não preenchimento das condições de residência. No considerando 60, o Tribunal recordou que a Diretiva (CE) 2004/38, "estabelece um sistema gradual de manutenção do estatuto de trabalhador que visa perenizar o direito de residência e o acesso às prestações sociais, tomando em consideração diferentes fatores (...), designadamente, a duração do exercício de uma atividade económica". Assim, ainda que os Estados-Membros não possam afastar os que procuram emprego podem, no entanto, negar-lhes (automaticamente) a atribuição de benefícios sociais, quando os mesmos se revelem um encargo significativo para o sistema nacional de Segurança Social.

Este entendimento fundamentou idêntica recusa, ao companheiro e ao filho de Jovana García-Nieto ${ }^{27}$, de nacionalidade espanhola. Saliente-se, sem prejudicar, que o Advogado-Geral Wathlet alertou que o princípio da igualdade impunha que "as autoridades nacionais competentes" não excluíssem automaticamente um cidadão (requerente) de tais benefícios, mesmo durante os primeiros três meses, sem exaurirem as possibilidades de demonstração do vínculo real com o mercado de trabalho onde se encontrasse. Jovana trabalhava efetivamente na Alemanha (num restaurante) e o processo revelava a existência de laços de natureza familiar do requerente para com o restante agregado - ainda que o seu companheiro não fosse trabalhador e lá se encontrasse há menos de três meses. Ora, de acordo com a opinião do Advogado-Geral, os elementos resultantes do contexto pessoal e familiar do requerente deveriam integrar o conceito de "vínculo efetivo" a apreciar por parte das jurisdições nacionais, no respeito do princípio da proporcionalidade. $\mathrm{Na}$ verdade, este princípio - enquanto limite jurídico das ações do legislador - é um

\footnotetext{
${ }^{26}$ Acórdão Narifa Alimanovic, de 15 de setembro de 2015, Processo C-67/2014, ECLI:EU:C:2015:597.

${ }^{27}$ Acórdão Jovana García-Nieto, de 25 de fevereiro de 2016, Processo C- 299/14, ECLI:EU:C:2016:114.
} 
instrumento adequado à tutela do conteúdo normativo dos direitos fundamentais, permitindo ao juíz a densificação do fundamento dos direitos sociais na sua vertente garantística da dignidade humana, enquanto valor comum da União e dos Estados-Membros.

Todavia, o Tribunal - abrigando-se na Diretiva (CE) 2004/38 - demonstrou a sua vontade em não continuar a liderar o processo de construção da Europa social afirmando que as prestações não contributivas estão excluídas para os cidadãos residentes por um período até três meses, independentemente da ligação efetiva que possam ter com o Estado de acolhimento, e ainda que as mesmas se destinem a facilitar o acesso ao mercado de trabalho e que, por isso, devessem caber, tal como o Advogado-Geral sugeria, no âmbito de aplicação do art 45. ${ }^{\circ}$, n. ${ }^{\circ} 2$ TFUE. Afirmando que a interpretação dos arts. $18 .^{\circ}$ e $45 .^{\circ}, \mathrm{n} .^{\circ} 2$, TFUE, dos arts. $4 .^{\circ} \mathrm{e}$ 70. ${ }^{\circ}$ do Regulamento (CE) n. ${ }^{\circ} 883 / 2004$, de 29 de abril de 2004, (coordenação dos sistemas de segurança social), conjugada com n. ${ }^{\circ} 2$, do art. $24 .^{\circ}$, da Diretiva (CE) 2004/38, permite a não concessão de tais prestações a quem se encontre numa situação enquadrável na previsão do art. $6^{\circ}{ }^{\circ}$, n. ${ }^{\circ} 1$, daquela diretiva, o que era o caso do companheiro e do filho de Jovana, o Tribunal confirma a sua jurisprudência restritiva neste domínio.

\section{Juízo Conclusivo}

Num cenário de transição para o constitucionalismo multinível, o estatuto de cidadania revestiu um significado nuclear para a legitimidade e o avanço do processo de integração europeia. Com efeito, sem aderir a valores e princípios comuns não seria possível construir um "sentimento de inserção", na expressão de Gomes Canotilho. Nesse contexto, a autonomia que aquele estatuto fundamental foi adquirindo revelouse um excelente instrumento para a construção de uma identidade europeia, na via da edificação de uma Europa onde o "nós” e o "eles" sejam a luz e não a sombra do projeto mais humanizante e sinergético da Europa.

De entre os direitos de cidadania, o direito de residência permanente 
consubstancia a total integração de um cidadão nacional de um Estado-Membro no território de outro. Todavia, julgamos ter demonstrado que o domínio social da cidadania - em especial no que concerne ao direito a au ferir prestações não contributivas antes de adquirido o direito de residência permanente - tolera a diferenciação entre nacionais dos Estados-membros de acolhimento e cidadãos não nacionais deles. Tal diferenciação resulta da possibilidade de os Estados estabelecerem derrogações ao princípio da igualdade, na sua formulação do art. $18 .^{\circ}$ do TFUE e do art. $21 .^{\circ}$, n. $^{\circ} 2$ da CDFUE, concretizadas no art. 24. ${ }^{\circ}$, n. ${ }^{\circ} 2$ da Diretiva (CE) 2004/38.

O caráter inacabado da cidadania e a sustentabilidade dos sistemas sociais nacionais consentem limites negativos ao conteúdo de tais direitos a fixar positivamente por cada Estado-Membro, reiterando o respeito pelo espaço de autonomia legislativa estadual. Limitações temporais e económicas dos períodos de residência são - na prática - restrições à liberdade fundamental de circular e de residir que implicam que o TJUE reconheça espaço para as opções político-legislativas dos Estados-Membros no que concerne à utilização dos seus recursos públicos.

Nesta medida, aquela diferenciação espelha o alcance da cidadania consagrada no art. 20. ${ }^{\circ}$, n. ${ }^{\circ}$ 1: ainda que se assista a um desgaste do critério da nacionalidade e a uma expansão do critério de residência, no que respeita ao direito a auferir prestações sociais o fundamento para a sua concessão reside ainda na sua acoplagem à mobilidade. Esta vicissitude revela que, apesar de o Tribunal ter humanizado a cidadania, a integração económica preside ainda à socialidade e à comunitarização. Estamos em crer que as decisões do Tribunal estão em sintonia com o avanço (ou o recuo) da integração europeia ${ }^{28}$.

Nestes termos, não queríamos deixar de trazer à liça uma frase de Holderlin que afirma que "onde quer que o perigo cresça cresce também o que o salva". Por isso, não poderíamos deixar de nos referir à importância das Cartas de Direitos - nelas se encontrando a possibilidade da efetivação dos direitos fundamentais nelas contidos!

Ora, também a Europa tem a sua Carta, que introduziu os direitos sociais no

\footnotetext{
${ }^{28}$ Esta convicção justifica os gráficos que juntaremos posteriormente à conclusão, com a especial intenção de facilitar a visualização espacial deste nosso raciocínio.
} 
contexto da diferenciação entre direitos, princípios e objetivos. A consciencialização da igual importância da dimensão civil, política e social dos direitos fundamentais justificou a previsão dos direitos sociais no contexto daquela tríade. Por isso, sendo certo que tais direitos são um elemento fundamental para o exercício das liberdades, e mais certo ainda que sem eles não será possível a edificação de um código comum para os europeus, a sua positivação tem de implicar que resida na Carta o seu conteúdo normativo mínimo, imperativo e irreversível!

Tendo a Carta o mesmo valor jurídico dos Tratados, prevalece sobre os demais atos legislativos da União e impõe-se aos Estados-Membros enquanto elemento aglutinador de todos os direitos fundamentais que assistem aos cidadãos. Por conseguinte, o recurso aos instrumentos jurídicos que consentem tais diferenciações deve ser restrito e a sua interpretação e aplicação deve ser conforme aos objetivos da cidadania europeia. A não ser assim, perigar-se-á o efeito útil do estatuto fundamental dos europeus. Estamos em crer que apenas a aplicação de todas as virtualidades contidas na Carta, em especial a interpretação sistemática das suas disposições horizontais, poderá densificar uma cidadania verdadeiramente transversal e inclusiva. 
Fase da Sedimentação

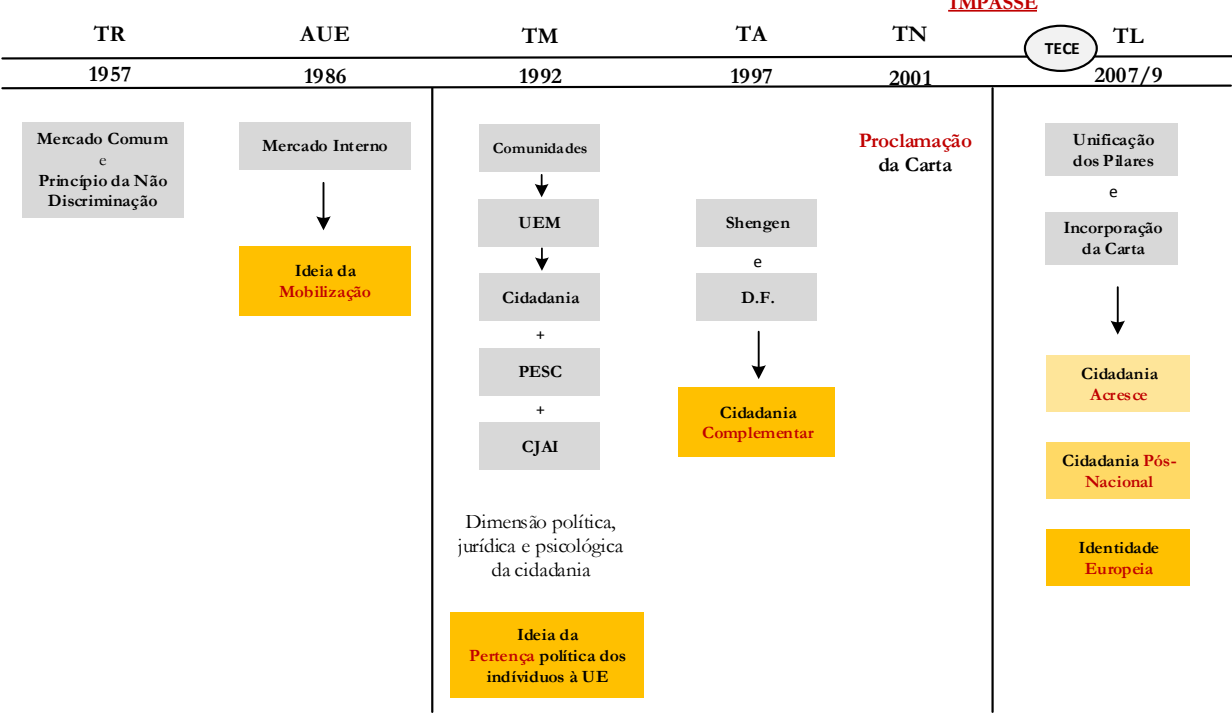

Fase da Autocontenção
Fase Expansionista
Fase Restritiva

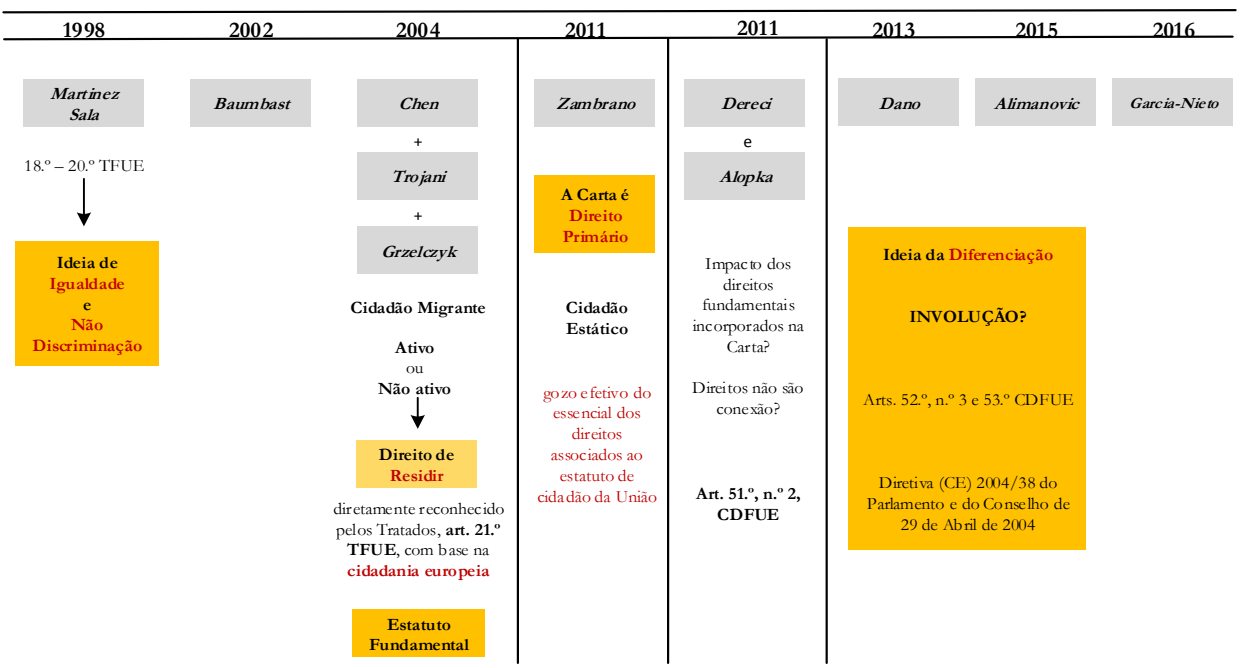





\title{
A cidadania municipal a partir da Carta Europeia de Autonomia Local e do princípio da subsidiariedade
}

\author{
Ricardo Hermany* \\ Guilherme Estima Giacobbo**
}

RESUMO: A democracia surgida na Grécia antiga pressupunha a participação dos cidadãos nos assuntos da Polis, os quais discutiam e deliberavam em uma ágora política. Com o surgimento dos Estados contemporâneos, após a segunda grande guerra, o modelo de democracia representativa foi adotado na grande maioria os Estados ocidentais, coadunandose às acep̧̣ões do liberalismo econômico vigente. Com o avanço do Welfare State, esse modelo representativo-liberal de democracia passa a dar sinais de exaurimento, colocando os Estados em um contexto de crise de legitimidade institucional. Tal crise, aliada a uma apatia dos atores sociais, vem suscitando a discussão de modelos democráticos mais permeáveis à participação política coletiva e não exclusiva de uma elite política incapaz de atender as complexas demandas sociais. Nesse contexto, a descentralização do poder estatal entre instâncias inferiores e a aplicação do princípio da subsidiariedade, consubstanciados no Tratado da União Europeia e consolidados na Carta Europeia de Autonomia Local, aparecem como instrumentos aptos a fomentar um novo paradigma de atuação da cidadania. Tal paradigma tem gênese no espaço local, integrando sociedade e poder público - por meio da subsidiariedade horizontal e privilegiando a esfera mais próxima dos cidadãos com o poder das decisão que estiveram ao seu alcance.

PALAVRAS-CHAVE: cidadania - descentralização - democracia - participação popular-subsidiariedade.

ABSTRACT: The democracy emerged in ancient Greece presupposed the participation of citizens in the affairs of the Polis, which discussed and deliberated in a political agora. With the emergence of modern states after the Second World War, the model of representative democracy was adopted in most Western states, aligned with the current understandings of economic liberalism. With the advancement of the welfare state, this liberal-representative model of democracy begins to show signs of exhaustion, putting the States in a context of institutional legitimacy crisis. This crisis, allied with an

\footnotetext{
* Doutor em Direito pela Universidade do Vale do Rio dos Sinos (2003) e Doutor em Doutorado sanduíche pela Universidade de Lisboa (2003); Pós-Doutor na Universidade de Lisboa (2011).

${ }^{* *}$ Mestre em Direito pela Universidade de Santa Cruz do Sul - UNISC; Mestre em Direito das Autarquias Locais pela Universidade do Minho em Portugal em regime de dupla titulação.
} 
apathy of social actors, leads the discussion of a model that allows a collective political participation, abandoning the exclusivity of some political elites, which are unable to respond to the existing complex social demands. In this context, the decentralization of State power between the political instances below and the application of the principle of subsidiarity, embodied in the Treaty on European Union and consolidated in the European Charter of Local Self-Government, appear as instruments capable of fostering a new paradigm of citizenship. Such a paradigm has a genesis in the local space, integrating society and public power - through horizontal subsidiarity, and privileging the sphere closest to the citizens with the power of the decisions that were within their reach.

KEYWORDS: citizenship - decentralization - democracy - popular participation - subsidiarity.

\section{Considerações iniciais: crise de legitimidade e a (re)democratização a partir do espaço local}

O processo de transnacionalização e de globalização dos mercados, bem como as rápidas transformações sociais e o aumento das demandas reivindicatórias de grupos sociais oprimidos acabaram por evidenciar a crise do Estado Contemporâneo, tendo em vista sua insuficiência em resolver satisfatoriamente os conflitos, garantir os direitos consubstanciados por Constituições vanguardistas com influência do modelo de Welfare State e, principalmente, por seu aparado jurisdicional não conseguir acompanhar a evolução social ocorridas no interior de suas fronteiras.

Dessa forma, a crise da jurisdição do modelo hegemônico do monismo jurídico, que serviu de base ao desenvolvimento da classe burguesa, nos últimos séculos, conferindo estabilidade e segurança jurídica à nova ordem econômica e política, é, na verdade, advinda da crise do próprio Estado Contemporâneo.

Uma das implicações dessa crise é o esvaziamento das funções estatais, especialmente na regulação do mercado econômico global, notadamente pela crescente desregulação e pelo uso da Lex Mercatoria, regulamentando de modo uniforme as relações comerciais instauradas no mercado mundial, desvencilhando-se do legislador ordinário e consubstanciando um regulamento autônomo.

O outro fator reside na necessária redemocratização do modelo político e administrativo, implicando, inclusive, no reconhecimento do pluralismo jurídico e 
da multiplicidade de fontes originárias do direito. O Direito oficial, hegemônico e exclusivamente produzido pelo processo legislativo oficial, desconexo de sua base social e aplicado pelo Estado, não é mais capaz de dar o tratamento adequado às demandas sociais de forma isolada e estanque.

Assim, este Estado contemporâneo se vê diante do desafio de estabelecer controles à atividade decisional que possam reaproximar o direito e a democracia. A democracia que se busca "como referência para tencionar com o modelo jurisdicional do sistema jurídico é uma democracia participativa, valorizadora dos espaços públicos, dos momentos coletivos, propulsora de emancipação social'.

Corroborando a tese da inexistência de neutralidade do direito, Santos ${ }^{2}$ afirma que "a posição eminentemente política do liberalismo de reduz̧ir o direito ao Estado foi a primeira condição da despolitização do direito". A apatia política gerada a partir dessa despolitização propicia e endossa os argumentos do tecnicismo jurídico, da competência e da racionalidade.

A mudança do paradigma jurisdicional se faz necessária no topo da estrutura político-normativa, devendo-se atentar também às bases do Estado, especialmente nas relações entre o cidadão e poder público no âmbito local, onde a participação social tem o condão de exercer influência significativa no sentido de (re)construção do espaço público, de modo compartilhado, para que esse possa ser permeado pela participação dos múltiplos atores sociais que compõem uma sociedade democrática.

É somente a partir das bases de um Estado, da intersecção entre a cidadania local e o poder público, que se conforma a viabilidade de realização da tarefa de democratização de um espaço público permeável às decisões coletivas, integrando uma gestão compartilhada, oriundo da manifestação democrática proveniente de um conjunto variado de atores - institucionais ou não - em um Estado Constitucional Democrático. Para tanto, é de fundamental importância a consolidação da autonomia local enquanto locus mais próximo da esfera de atuação dos cidadãos.

\footnotetext{
${ }^{1}$ Gabriela Maia Rebouças, Tramas entre subjetividades e direito: a constituição do sujeito em Michel Foucault e os sistemas de resolução de conflitos (Rio de Janeiro: Lumen Juris, 2012), 131.

${ }^{2}$ Boaventura de Souza Santos, Para uma revolução democrática da justiça (São Paulo, Cortez, 2008), 6.
} 


\section{A cidadania ativa como pressuposto da participação social}

No conceito de cidadania republicana, a relevância da participação política atribui um papel central à atuação do indivíduo na comunidade política. Uma das questões centrais acerca da cidadania versa em torno da possibilidade de existência de uma comunidade política compatível com os moldes da democracia moderna e o com o pluralismo jurídico-político.

No liberalismo clássico, a participação política e liberdade não se coadunam, eis que a liberdade individual só pode ser entendida de forma negativa, como ausência de coerção.

"A democracia nasceu de uma concepção individualista da sociedade, isto é, da concepção para a qual — contrariamente à concepção orgânica, dominante na idade antiga e na idade média, segundo a qual o todo precede as partes — a sociedade, qualquer forma de sociedade, e especialmente a sociedade politica, é um produto artificial da vontade dos individuos"3.

Essa incapacidade do modelo liberal nos governos democráticos de dominarem os conflitos de uma sociedade complexa é justificada como forma de evitar a sobrecarga dos estados democráticos com o excesso de demandas sociais que poderiam ser geradas em um contexto participativo de gestão, correndo o risco de gerar crises de governabilidade.

Esse entendimento é refutado por inúmeros autores que demonstram não haver incompatibilidade entre a conceção republicana clássica de cidadania e a democracia moderna, tendo em vista que a liberdade, ainda que negativa (no conceito contemporâneo), inclui a participação política e a virtude cívica, devendo, portanto, conciliar a liberdade individual e a participação política ${ }^{4}$.

A discussão fundamental para a realização da cidadania não passa, necessariamente, pela (re)significação de seu conceito, mas, sobretudo, necessita da reativação da esfera pública, espaço onde os indivíduos podem agir coletivamente e voltar esforços em torno de deliberações comuns os temas referentes a seu espaço local.

\footnotetext{
${ }^{3}$ Norberto Bobbio, Liberalismo e Democracia, trad. Marco Aurélio Nogueira (São Paulo: Brasiliense, 2006), 34.

${ }^{4}$ Liszt Vieira, Os Argonautas da Cidadania: a sociedade civil na globalização (Rio de Janeiro: Record, 2001),73.
} 
Nesse sentido, espaço público pode ser compreendido como um local onde se realiza a interação intersubjetiva de cidadãos conscientes, solidários e participativos. Baseia-se no princípio do discurso, não se filiando nem à visão liberal, nem à republicana. Habermas coloca em um plano secundário os interesses individuais, destacando os interesses coletivos. O espaço público permite a institucionalização das pluralidades nas sociedades civis modernas com a chance de alcançarem um consenso por meio de procedimentos comunicativos exercidos na esfera pública, que é uma instância geradora de decisões coletivas e legitimadora da democracia 5 .

É pressuposto inerente a prática da cidadania, também, a formação da identidade política baseada em valores de solidariedade, autonomia e reconhecimento da diferença. A cidadania participativa é essencial para atingir uma ação política efetiva, fundamental para a expansão da opinião política. Vieira ${ }^{6}$ refere que a democracia não é mais passageira e funcional, mas, permanente e em constante processo de ajuste entre a legalidade e a legitimidade, entre a moral e a lei, restando aberto espaço para os movimentos sociais e as associações da sociedade civil na compreensão do processo de democratização. Assim, é preciso sobremaneira superar os limites do modelo de democracia liberal "Enfatizando, entre outros pontos: a importância de se resgatar a ideia de soberania popular, no sentido de um reconhecimento de que cabe aos cidadãos decidir acerca das questões de interesse coletivo; a relevância do caráter dialógico dos espaços públicos como formadores do interesse público; o reconbecimento do pluralismo cultural, das desigualdades sociais e da complexidade social; o papel do Estado e dos partidos políticos na criação de esferas públicas deliberativas; e a implementação das decisões advindas de processos deliberativos"”.

Grande parte da absorção das iniciativas sociais difusas e democratizantes do espaço público tendem a vir das associações civis, de coletivos organizados, ensejando o confronto político e a discussão dos assuntos da vida local, ampliando o espectro político, inserindo novos temas na agenda política e desempenhando papel importante na construção de um espaço local redesenhado, permeado pela

\footnotetext{
${ }^{5}$ Vieira, Os Argonautas da Cidadania, 64-65.

${ }^{6}$ Vieira, Os Argonautas da Cidadania, 73.

${ }^{7}$ Lindijane de Souza Bento Almeida, "Gestão Pública e Democracia: Os Conselhos Gestores de Saúde da Região Metropolitana de Natal-RN”: Revista Democracia e Participação 1,1 (2004):59.
} 
coletividade e não restrito a uma elite política eleita sazonalmente mediante sufrágio.

"A democracia, nesse sentido, sempre implica ruptura com tradicões estabelecidas, e, portanto, a tentativa de instituição de novas determinações, novas normas e novas leis. É essa a indeterminação produzida pela gramática democrática, em vez apenas da indeterminação de não saber quem será o novo ocupante de uma posição de poder" $"$.

O fenômeno do controle democrático, difícil de ser obtido em populações marcadas pela pobreza política, encontra apoio também evolucionário, não apenas político. Por trás disso estaria a simples matemática de que as minorias subalternas são numericamente muito mais numerosas e, se souberem articular sua força coletiva, podem encurralar o prepotente. Enquanto o prepotente precisa disputar sempre a lealdade do oprimido, as maiorias disputam a "contralealdade" dos excluídos?.

Assim, o desafio que se torna premente hoje passa pelo processo de construção de uma nova democracia, onde o cidadão, articulado coletivamente mediante diversas formas de organização (associações de bairro, sociedade civil organizada), deverá ser o grande protagonista dessa mudança de paradigma e, para para tanto:

"Terá que construir um tipo de sistema político-social que rompa com os limites que o capitalismo internacional impõe aos países latino-americanos; terá que inventar uma nova democracia, de caráter social, que compatibilize desenvolvimento e integração social, que promova a extensão da democracia política a todos os rincões de nossa sociedade. Com democracia na propriedade da terra, na questão habitacional, nos serviços de saúde, de educação, de seguridade social, com uma cultura democrática que abarque todos os setores sociais, com democracia nos meios de comunicação, com direito das minorias politicas a decidir autonomamente seu destino" 10 .

Assim, ao contrário do que pensavam os iluministas, para mudar a sociedade não basta mudar o direito, esse pensamento muda com início da sociedade industrial na sociedade civil que passa a considerar o direito como instrumento de manutenção de poder. No entanto, a função promocional do direito, de caráter dirigista, tem o

\footnotetext{
${ }^{8}$ Boaventura de Sousa Santos e Leonardo Avritzer, "Introdução: para ampliar o Cânone Democrático”, in: Democratizar a Democracia: Os caminhos da democracia participativa, org. Boaventura de Sousa Santos (Porto: Afrontamento, 2003), 51-52

${ }^{9}$ Pedro Demo, Solidariedade como efeito de poder (São Paulo: Cortez; Instituto Paulo Freire, 2002), 141.

${ }^{10}$ Emir Sader, O Poder, Cadê o Poder? Ensaios para uma nova esquerda (São Paulo: Boitempo, 1997), 129.
} 
condão de, mediante incentivos e prêmios, incentivar condutas desejadas ao invés de, exclusivamente, reprimir condutas não-desejadas mediante sanções negativas. Assim, para que as ações políticas "transformem uma sociedade (diversificada ou complexa) de forma pacifica, épreciso que os atores politicos demonstrem capacidade não só para diagnosticar e analisar a realidade social, econômica e política em que vivem, mas também para interagir e negociar de forma democrática com os diferentes atores envolvidos no processo" 11 .

A sociedade participa e interage na construção do direito mediante apropriação do espaço público, redemocratizando as esferas de poder, esse direito funcional, pode "direcionar" uma determinada sociedade e, principalmente, decidir os tipos de comportamentos e condutas que devam ser incentivados e promovidos. Aproximandose de uma lógica de democracia administrativa, as ações políticas devem ser tomadas mediante articulação entre poder público e coletividade na construção de um direito mais dirigista e promocional, onde a própria sociedade enquanto partícipe ativa dos espaços públicos e das decisões políticas, ajuda a criar o direito e as ações políticas das quais serão destinatários.

\section{O princípio democrático no ordenamento jurídico português}

O princípio do Estado democrático de direito tem relevante papel entre os princípios fundamentais previstos na Constituição da República Portuguesa (CRP), de 1976. Esse princípio é referido no preâmbulo da CRP, sendo tratado especificamente ${ }^{12}$ no art. $2^{\circ}$ e o "respeito pelos princípios do Estado de direito democrático" constitui tarefa fundamental do Estado (CRP, art. 9. / b). Tem-se, portanto, que o Estado de direito “é um Estado constitucionalmente conformado. Pressupõe a existência de uma Constituição e a afirmação inequivoca do princípio da constitucionalidade"13.

\footnotetext{
${ }^{11}$ Marta M. A.Rodrigues, Políticas Públicas. (São Paulo: Publifolha, 2011), 25.

${ }^{12}$ CRP, art. 2..$^{\circ}$ " A República Portuguesa é um Estado de direito democrático, baseado na soberania popular, no pluralismo de expressão e organização política democráticas, no respeito e na garantia de efectivação dos direitos e liberdades fundamentais e na separação e interdependência de poderes, visando a realização da democracia económica, social e cultural 0 o aprofundamento da democracia participativa" (grifos nossos).

${ }^{13}$ José Joaquim Canotilho e Vital Moreira, Fundamentos da Constituição (Coimbra: Coimbra Editora, 1991).
} 
Nesse sentido, o Princípio democrático se desvela multidimensional, podendo ser reconhecidas ao menos quatro dimensões em sua perspetiva da organização do poder político. A primeira dimensão consubstancia-se no viés da forma representativa, pois "ela é a forma constitucionalmente estabelecida para a escolha de alguns dos mais importantes órgãos do poder político" 14 , dentre os quais a escolha da Presidência da República, Assembleia da República, assembleias regionais, assembleias das autarquias locais e câmaras municipais. Tal representação baseia-se no sufrágio universal, igual, direto, secreto e periódico, conforme preceituado no art. $10 .^{\circ}$ e no pluralismo partidário, segundo disposto no art. $51 .^{\circ}$.

A segunda dimensão do Princípio democrático na ordem constitucional portuguesa materializa-se na dimensão participativa, que reflete a assunção pela CRP de diversas formas de democracia participativa.

"Surgida num contexto interno marcado por intensa participação popular e num ambiente político-cultural internacional caracterizado pela exigência da democratização da democracia através da participação, a Lei Fundamental procurou responder ao problema nevrálgico da democracia, que é o da participação popular permanente no exercício do poder. Se o poder político pertence e é exercido pelo povo, então é necessário assegurar aos cidadãos uma possibilidade de participação directa e activa" ${ }^{15}$.

Disso decorre que a participação do povo enquanto governante não pode se subsumir a uma colaboração restrita ao sufrágio eleitoral, mas, sobretudo, pressupõe uma atuação permanente e incisiva que permita a perfectibilização de uma genuína democracia participativa ${ }^{16}$.

Portanto, o Princípio democrático apresenta-se como princípio normativo complexo, onde o engendramento dessas duas dimensões o subsume como

\footnotetext{
${ }^{14}$ Canotilho e Moreira, Fundamentos da Constituição, 193.

${ }^{15}$ Canotilho e Moreira, Fundamentos da Constituicão, 194.

${ }^{16}$ São numerosos os dispositivos constitucionais relacionados à efetivação da democracia participativa, dentre os quais se pode destacar os art. $263 .^{\circ}$ a $266 .^{\circ}$ (que trata da constituição de organizações de moradores); o art. $63 . \% / 2$ (que trata da participação das associações sindicais, de outras organizações representativas dos trabalhadores e de associações representativas dos demais beneficiários); e art 65. /5 (onde é garantida a participação dos interessados na elaboração dos instrumentos de planeamento urbanístico e de quaisquer outros instrumentos de planeamento físico do território).
} 
princípio multiforme, tendo em vista sua estrutura pluridimensional. Desse modo, a democracia figura como processo de democratização enquanto caminho de aprofundamento democrático de natureza política, socioeconômica e cultural. Posteriormente, tal princípio agrega as duas dimensões que, por muito tempo, foram consideradas antagônicas, onde em um dos polos figuram os elementos de democracia representativa, com órgãos representativos, eleições periódicas e separação de poderes, enquanto o outro polo passa a incorporar algumas demandas fundamentais da teoria participativa, dentre elas a ampliação do princípio democrático, em diferentes perspetivas da visão econômica e sociocultural com a incorporação da participação popular direta e o reconhecimento de associações e organizações como atores relevantes à concretização e dinamização democrática ${ }^{17}$.

O Direito, a partir do século XX, abandona seu caráter marcado pela exclusividade na produção de normas, admitindo e defendendo a existência de normas jurídicas provenientes de núcleos de produção não estatais. Daí é possível vislumbrar uma "pulverização do poder e das fontes de direito, irradiando-se a criação jurídica num sentido supraestadual (v.g., organizações internacionais, de entre as quais a União Europeia é o exemplo mais visivel)" ${ }^{\prime \prime}$.

Da mesma forma admite-se a criação de ordens jurídicas paraestatais, com as oriundas das ordens profissionais, entidades e organismos representativos de classe, bem como infraestatais, como aquelas provenientes das regiões, Autarquias e comunidades locais. Consubstancia-se definitivamente a existência de um pluralismo jurídico na ordem constitucional portuguesa e refuta-se a exclusividade estatal, superando-se o paradigma monista com forte característica tecnocrática e estandardizante ${ }^{19}$.

Isso implicou uma mudança de lógica do Estado Moderno que, apesar da preocupação inicial de generalização e obtenção de uma igualdade meramente formal,

\footnotetext{
${ }^{17}$ Canotilho e Moreira, Fundamentos da Constituicão, 195.

${ }^{18}$ Joaquim Freitas da Rocha, Direito financeiro local (finanças locais) (Braga: CEJUR, 2009), 10.

${ }^{19}$ Guilherme E. Giacobbo "Participação e controle social na gestão municipal no Brasil e em Portugal: uma análise à luz do Direito Social de Gurvitch” (Master's. diss., Universidade de Santa Cruz do Sul UNISC, 2014).
} 
passar a admitir, de maneira mais intensa, a proteção das minorias, pois a "verdadeira igualdade pressupõe sempre desigualdades, na medida em que surge constantemente a necessidade de dispensar um tratamento jurídico diferenciado" ${ }^{20}$, pois os sujeitos e os atores jurídicos encontram-se em situação de desigualdade.

A partir disso, advém a necessidade de resguardar o direito das comunidades locais, onde se pode identificar, preliminarmente, um movimento de "reativação das culturas locais ou de renascimento da referência local' que acaba dando origem a um movimento jurídico de criação de um conjunto de normas próprias, designado como "Direito das Autarquias Locais", decorrendo destes pressupostos de quebra da exclusividade estatal, deslegalização e referência da cultura local, o ambiente propício para a ocorrência dos fenômenos de descentralização, não apenas sob o viés sociopolítico, mas essencialmente do ponto de vista político ${ }^{21}$.

Tem-se então a vital importância das Autarquias Locais enquanto parte integrante da organização democrática do Estado, pois se desvelam em uma relação intrínseca com a democracia, na medida em que a efetiva participação da sociedade, bem como a articulação dos cidadãos no processo de tomada de decisões, perpassam, necessariamente, pelas Autarquias Locais.

\section{A subsidiariedade e a Carta Europeia de Autonomia Local}

Quando se menciona o princípio da subsidiariedade, deve-se ter em conta que o princípio implica que as decisões, ou seja, a atuação primária, deve ter gênese nas comunidades de menor dimensão, partindo dos indivíduos para, apenas em uma perspetiva subsidiária, invocar a atuação do poder público estatal. Ressaltese, no entanto, que a lógica subsidiária não deverá significar risco de retrocesso a propostas liberais clássicas, de notáveis lacunas em relação aos direitos sociais e, consequentemente, às garantias constitucionais fundamentais ${ }^{22}$.

\footnotetext{
${ }^{20}$ Rocha, Direito financeiro local (finanças locais), 10.

${ }^{21}$ Rocha, Direito financeiro local (finanças locais), 10.

${ }^{22}$ Ricardo Hermany, (Re)Discutindo o espaço local: uma abordagem a partir do direito social de Gurvitch (Santa Cruz do Sul: Edunisc, 2007), 12.
} 
Desse modo, a subsidiariedade proporciona elementos para o empoderamento e a soberania do indivíduo, de maneira que aproxima o diálogo e as decisões do cidadão, fomenta sua participação política e propicia o estabelecimento de diálogos pluralistas. Assim, ela reforça o papel das comunidades menores e do cidadão, e assegura um locus delimitado para a atuação do Estado, na medida em que só agirá para resguardar o necessário para a garantia dos avanços sociais, e quando a comunidade não puder, por seus próprios recursos e capacidades, deliberar e decidir sobre os assuntos públicos.

Se o princípio da subsidiariedade não significa exatamente proximidade, a Carta Europeia de Autonomia Local, ao adotar o critério de repartição de poderes, dá um sentido praticamente sinônimo ao estipular que os poderes devem ser exercidos e praticados pelas autoridades mais próximas dos cidadãos e que "só assim não deverá ser quando a amplitude e a natureza da tarefa a desempenhar, bem como exigências de eficácia e economia justifiquem a atribuição do poder a outra entidade menos próxima dos cidadãos"23.

"Estes são os pressupostos da aplicaşão do princípio da subsidiariedade que permite que o poder seja exercido ora por uma dada autoridade, a mais próxima do destinatário da decisão, ora por outra autoridade que embora mais longinqua, é aquela que está apta pela natureza e amplitude da tarefa, a realizá-la mais eficaz e economicamente. Isto significa que, consoante as características e a dimensão da tarefa a realizar e, em função dos efeitos que produz e dos recursos que envolve, assim o poder será distribuido pelos vários niveis de decisãa"24.

Os fundamentos de base da Autonomia Local estão consagrados em dois diplomas legais: A Constituição da República Portuguesa, de 1976, e a Carta Europeia de Autonomia Local, de 1985 representa o "primeiro instrumento jurídico multilateral que define e que garante os principios da autonomia local', perfazendo-se como um dos marcos da democracia em que o Conselho da Europa tem por objetivo defender e garantir seu desenvolvimento. Tal autonomia local tem conceção em uma base territorial, ensejando uma certa conjuntura de liberdade e iniciativa que se consubstancia como

\footnotetext{
${ }^{23}$ Margarida Salema D'Oliveira Martins, O princípio da subsidiariedade em perspectiva jurídico-politica (Coimbra: Coimbra Editora, 2003), 445.

${ }^{24}$ Martins, O princípio da subsidiariedade em perspectiva juridico-política, 445.
} 
"um elemento de diversidade inevitável” e que é, em grande medida, colidente com os princípios da uniformidade e igualdade, princípios estes característicos do Estado Moderno ${ }^{25}$.

"A autonomia local e regional implica uma concepção descentralizada do Estado e, em certo sentido, uma policracia ou pluralidade de centros de poder, configurando uma separação vertical de poderes, complementar da tradicional separação horizontal de poderes" ${ }^{26}$.

Dessa forma, a Carta Europeia de Autonomia Local destaca já em seu preâmbulo alguns preceitos fundamentais que se coadunam com a ideia de democracia local e participação social no âmbito local, afirmando que "as autarquias locais são um dos principais fundamentos de todo o regime democrático" e que "o direito dos cidadãos de participar na gestão dos assuntos públicos faz parte dos princípios democráticos comuns a todos os Estados membros do Conselho da Europa", destacando, ainda, que é no nível local que tal direito pode ser mais bem desenvolvido.

Já na Constituição portuguesa, a expressão “autonomia local” aparece uma única vez, denotando a preferência do texto constitucional pelo uso de outra expressão: "autonomia das autarquias locais". A autonomia local é elencada como um dos princípios fundamentais (art. $6^{\circ}, \mathrm{CRP}$ ), constituindo limite material em matéria de revisão constitucional, bem como tem seu conteúdo desenvolvido no Título VIII que trata do "Poder Local". As revisões constitucionais que sucederam a CRP não alteraram a estrutura fundamental no que se refere à autonomia dos autarquias locais, com exceção da revisão constitucional de 1982, que acabou por reforçar a autonomia local restringindo a atuação dos poderes do Governo em relação às autarquias locais no exercício de duas funções administrativas, limitando-se ao exercício da tutela e "eliminando assim a referência ao poder de superintendência que passou a caracterizar a relação do Governo com a administração indireta do Estado" 27.

No contexto constitucional português existem duas categorias de autarquias locais: os municípios (concelhos) e as freguesias, sendo a câmara municipal e a

\footnotetext{
${ }^{25}$ António Cândido de Oliveira, Direito das Autarquias Locais (2. ${ }^{a}$ ed. Coimbra: Editora Coimbra, 2013), 108-109.

${ }^{26}$ Canotilho e Moreira, Fundamentos da Constituição, 226.

${ }^{27}$ Oliveira, Direito das Autarquias Locais, 74.
} 
junta de freguesia os órgãos executivos e a assembleia municipal e a assembleia de freguesia os órgãos deliberativos que, com exceção da junta de freguesia, são eleitos por sufrágio universal direto. Desse modo, municípios e freguesias são elementos que compõem a democracia e a cidadania portuguesa.

Tanto em sede de mecanismos constitucionais, quanto na estrutura infraconstitucional, é possível se vislumbrar a preocupação em garantir a autonomia das autarquias locais, a efetivação do princípio da subsidiariedade e a intenção de criar uma gestão pública compartilhada. Portanto, é inequívoco o direcionamento de toda a estrutura política do Estado para a pessoa humana que é sua própria razão de existência, enquanto sujeito ativo da política.

Desse modo, garante um governo local autônomo, com margem para decidir e governar de acordo com o interesse local, podendo, com base no princípio da subsidiariedade, efetuar a descentralização em dimensão horizontal, propiciando a ampliação da democracia participativa e fomentando a concretização de uma gestão autônoma com base participativa e compartilhada.

\section{Considerações finais}

Somente com a superação do modelo liberal de democracia representativa, a qual restringe a participação política ao sufrágio universal periódico e interpreta a apatia do eleitorado como satisfação, é que se pode pensar na construção de uma cidadania para além da mera formalidade jurídica da capacidade de votar e ser votado. A transformação de uma sociedade passa, inevitavelmente, pela reconstrução do seu direito, e, é na sociedade contemporânea que o direito tem experimentado sua mudança mais profunda: supera a preocupação de como ele está estruturado e volta-se à compreensão de sua finalidade.

Pensar a democracia para além do modelo liberal representativo, onde as decisões são exclusivas de uma elite política e sob a guarda de poucos partidos políticos não conseguem responder às demandas de uma sociedade complexa. É fundamental para a construção de uma cidadania efetiva. À sociedade, 
articuladamente com o poder público, cabe deliberar e participar dos rumos da ação política. O cidadão deve abandonar a condição de mero espetador do "Olimpo político" que se criou e transformar o espaço público em uma espécie de ágora contemporânea, onde ele seja o protagonista de um direito no qual são criadores e destinatários; um direito cada vez mais promocional e que deve ser permeável ao pluralismo dos complexos estados contemorâneos.

A participação social, baseada no princípio democrático da constituição portuguesa e sua possibilidade de atuar nas decisões no espaço local, sob os pressupostos da descentralização e do princípio da subsidiariedade, corroboram com o novo viés do Estado Contemporâneo, de democracia coparticipativa e de abandono da rigidez formalista da tutela jurisdicional e do processo legislativo oficial.

A demanda pela democratização dos espaços públicos institucionais é ao mesmo tempo um reflexo da crise do Estado moderno e uma oportunidade de legitimação de processos de integração e aproximação entre sociedade e poder público. A democracia representativa, oriunda do modelo liberal econômico, parece-nos incapaz de atender adequadamente as múltiplas demandas de uma sociedade pluralista.

Parece-nos indissociável a relação entre a abertura democrática de um Estado, com aprofundamento dos instrumentos de participação social e abertura para uma gestão pública compartilhada, com o devido fortalecimento da autonomia local mediante aplicação do princípio da subsidiariedade vertical - com repartição de competência das instâncias maiores para as menores - e, horizontal - com repartição das decisões locais entre os atores sociais que compõe determinado espaço local.

O exercício democrático tem gênese justamente na esfera local, propiciando a deliberação e a participação da comunidade local junto ao poder público acerca dos rumos de sua autarquia ou município, utilizando-se dos instrumentos constitucionais participativos postos à disposição, ajudando a moldar a melhor interpretação desses dispositivos. Parece-nos que a Constituição Portuguesa logrou êxito em privilegiar 
certos espaços de participação social e a autonomia das autarquias locais, de modo a possibilitar que essa transformação paradigmática possa ter início em suas bases sociais. 



\title{
A tramitação prejudicial acelerada e urgente como resposta às exigências de celeridade e proteção jurisdicional efetiva no contencioso da União
}

\author{
Natacha Ribeiro*
}

RESUMO: O reenvio prejudicial tem vindo a converter-se numa alternativa de proteção jurisdicional dos particulares, no seio das vias de acesso à justiça da União Europeia. Apontado pela doutrina como um mecanismo ao serviço do princípio da tutela jurisdicional efetiva, a verdade é que o reenvio prejudicial não é isento de dificuldades de aplicação, nomeadamente, e para ao que ao presente texto interessa, de celeridade processual. Ocupar-nos-emos, assim, da problemática da dilação temporal, especialmente no âmbito dos processos que se enquadram no domínio do espaço europeu de liberdade, segurança e justiça, ou cujas circunstâncias factuais relevem de uma particular urgência. Numa tentativa de defrontar aquelas dificuldades, o legislador da União envidou esforços para uma revisão do funcionamento do reenvio prejudicial, criando mecanismos excecionais e derrogatórios da tramitação ordinária: a tramitação prejudicial acelerada e a tramitação prejudicial urgente. Numa União marcada pelo crescimento do contencioso naquelas matérias, é necessário analisar se a aplicação daquelas tramitações excecionais pelo TJUE protege suficientemente as garantias dos cidadãos.

PALAV RAS-CHAVE: tutela jurisdicional efetiva-tramitação prejudicial urgente-tramitação prejudicial acelerada - contencioso da União Europeia - espaço europeu de liberdade, segurança e justiça.

ABSTR ACT: The preliminary ruling has matured as an alternative of judicial protection of individuals, among the procedure instruments of the Union litigation. Pointed by the legal doctrine as a means at the service of the principal of effective judicial protection, the truth is that the preliminary ruling is not exempt of application difficulties, namely, and for the purpose of this study, in the field of procedural celerity. We will approach the issue of the temporal delay, especially in procedures whose questions arise from the European area of freedom, security and justice or whose factual circumstances embody a particular urgency. In an attempt to deal with these difficulties, the EU legislator made efforts to revise the preliminary ruling procedure, by creating exceptional and derogatory mechanisms of the ordinary ruling procedure: the expedited preliminary ruling procedure and the urgent preliminary ruling procedure. In a Union marked by the litigation

\footnotetext{
${ }^{*}$ Mestre em Direito da União Europeia, Universidade do Minho. Advogada e responsável pela assessoria jurídica de um grupo internacional.
} 
growth falling under those areas, it is necessary to analyze how the employment of those exceptional mechanisms by the CJUE protects adequately the guarantees of citizens.

KEYWORDS: effective judicial protection - urgent preliminary ruling procedure - expedited preliminary ruling procedure - Union litigation - European area of freedom, security and justice.

\section{A remodelação do reenvio prejudicial na busca de uma maior e melhor proteção jurisdicional efetiva dos interesses dos particulares}

Para uma efetiva proteção dos direitos fundamentais dos particulares é imprescindível a instituição de garantias processuais fundamentais, capazes de reforçar os mecanismos de salvaguarda daqueles direitos. Nesse sentido, a garantia de um processo equitativo apresenta-se como uma tarefa fundamental da preeminência do direito, ocupando um lugar essencial no seio da estrutura jurídica da União.

Por força do art. 19. ${ }^{\circ}$, n. ${ }^{\circ} 3$, al. b), do TUE e do art. 267. ${ }^{\circ}$ do TFUE, o TJUE é competente para decidir, a título prejudicial, sobre a interpretação do DUE e sobre a validade dos atos adotados pelas instituições, órgãos ou organismos da União. O processo prejudicial constitui, pois, o meio contencioso destinado a garantir a uniformidade ${ }^{1}$ na interpretação e na aplicação do $\mathrm{DUE}^{2}$.

Não raras vezes, o TJUE deve ser capaz de responder muito rapidamente a pedidos de decisões prejudiciais, designadamente no âmbito de processos judiciais nacionais urgentes ou quando estão em causa circunstâncias factuais que justificam uma especial celeridade.

É no âmbito do espaço de liberdade, segurança e justiça (art. 3. ${ }^{\circ}$ do TUE e 67. . do TFUE) ${ }^{3}$, inerente aos processos de reenvio com tramitação urgente, que têm

\footnotetext{
${ }^{1}$ Cfr. Maria José Rangel Mesquita, Introducão ao Contencioso da União Europeia (Coimbra: Almedina, 2013), 124.

${ }^{2}$ Cfr. Nota Informativa relativa à apresentação de pedidos de decisão prejudicial pelos órgãos jurisdicionais nacionais, JOUE (2009/C 297/01), pp. 1-6, \1: “[o] sistema de reenvio prejudicial é um mecanismo fundamental do direito da União Europeia, que tem por finalidade fornecer aos órgãos jurisdicionais nacionais o meio de assegurar uma interpretação e uma aplicação uniformes deste direito em todos os Estados Membros".

${ }^{3}$ Os Tratados constitutivos, na versão Lisboa, conferem uma grande importância à concretização de um espaço de liberdade, de segurança e de justiça e reparte as matérias relacionadas em quatro domínios: as políticas relativas ao controlo nas fronteiras, ao asilo e à imigração; a cooperação
} 
surgido aquelas questões prejudiciais que requerem uma maior celeridade processual. Nesse domínio, que se caracteriza pelo seu dinamismo ao nível social, incluem-se, designadamente, litígios sobre pedidos de asilo ou decisões de expulsão em matéria de direito de imigração, litígios sobre responsabilidades parentais ou execução de mandados de detenção europeus.

Frequentemente, ainda, os juízes nacionais são assaltados com as dificuldades que subjazem a um eventual reenvio no âmbito de um litígio judicial, na medida em que acarreta um incidente processual de suspensão da instância, prologando o processo nacional mais do que o desejado. E, como sabemos, os juízes nacionais têm vindo a sentir uma certa instância na célere conclusão dos processos que lhes são atribuídos, quer por via da própria legislação nacional processual, quer em termos de carreira. Reveste-se, portanto, de particular importância a faculdade processual de o reenvio prejudicial perante o TJ ser suscetível de correr os seus termos sob uma tramitação especialmente célere.

Em contrapartida, e sem prejuízo da abordada exigência de celeridade, importa não descurar a efetiva tutela dos direitos e interesses dos indivíduos, uma vez que não seria concebível uma tal simplificação da tramitação processual que originasse uma inaceitável compressão dos direitos dos particulares.

Ora, ao TJUE, enquanto instituição jurisdicional da União, aplicam-se princípios e regras jurídicas de natureza substantiva e processual, que se regem pelos tratados e por diversos diplomas legislativos avulsos que contemplam e desenvolvem a tramitação processual aplicável. No caso do TJ, aplica-se em específico, nomeadamente, o Regulamento de Processo do Tribunal de Justiça ${ }^{4}$, que constitui a sua principal fonte do regime processual. Este regulamento prevê tramitações diferenciadas ${ }^{5}$ no âmbito dos reenvios prejudiciais, as quais visam responder à necessidade de resposta célere por esta instituição: a tramitação prejudicial acelerada, ou TPA, e a tramitação prejudicial urgente, ou TPU.

judiciária em matéria civil; a cooperação judiciária em matéria penal e a cooperação policial.

${ }^{4}$ Cfr. JOUE (2012/L 265/1), pp. 1-42.

${ }^{5}$ Cfr. Maria José Rangel Mesquita, Introducão ao Contencioso da União Europeia, 189. 
A primeira tem por objetivo promover a progressão do reenvio prejudicial, reduzindo a média da duração dos processos em situações especiais. No entanto, a sua aplicação pelo TJ tem sido limitada, em razão da sua complexidade e consequências.

Quanto à segunda, com a sua entrada em vigor em 2008, procurou-se responder às insuficiências sentidas em domínios delicados como o asilo, imigração e cooperação judiciária em matéria civil, policial ou penal, incorporados pelo referido ELSJ.

\section{Da tramitação prejudicial urgente}

Atualmente, a TPU é regulada pelos arts. 23. ${ }^{\circ}-\mathrm{A}$ do Protocolo (n. ${ }^{\circ}$ 3) relativo ao ETJUE $^{6}$ e $107 .^{\circ}$ e ss. do RPTJ. A possibilidade do órgão jurisdicional nacional pedir, no âmbito de um reenvio prejudicial, a aplicação da TPU é cumulável com a possibilidade de pedir, subsidiariamente, a aplicação da TPA, nas condições previstas nos arts. 23..$^{\circ}$ A do Protocolo (n. ${ }^{\circ}$ 3) relativo ao ETJUE e $105 .^{\circ}$ do RPTJ, prática frequente pelos órgãos jurisdicionais de reenvio.

Note-se que, se é verdade que a TPU simplifica as diferentes etapas do processo de reenvio prejudicial no TJ, prevendo o seu regime medidas processuais simplificadas comparativamente com a tramitação ordinária, não menos verdade é que a sua aplicação impõe contingências processuais significativas ao Tribunal, às partes, e aos outros interessados que intervenham no processo, em particular aos Estados-Membros ${ }^{7 / 8}$.

\footnotetext{
${ }^{6}$ Cfr. JOUE (2012/C 326/201), p. 210.

${ }^{7}$ Esclarece o TJ que “[p]or conseguinte, só deve ser requerida em circunstâncias em que seja absolutamente necessário que o Tribunal profira uma decisão sobre o pedido de decisão prejudicial o mais rapidamente possivel. Não sendo possivel enumerar aqui essas situações de modo exaustivo, em virtude, designadamente, do carácter variado e evolutivo das normas da União que regulam o espaço de liberdade, segurança e justiça, um órgão jurisdicional nacional poderá apresentar um pedido de tramitação prejudicial urgente, por exemplo, nas situaçoes seguintes: no caso, previsto no art. 267.', quarto parágrafo, TFUE, de uma pessoa detida ou privada de liberdade, quando a resposta à questão colocada seja determinante para a apreciação da situação jurídica dessa pessoa ou, no caso de um litígio relativo ao poder parental ou à guarda de crianças, quando a competência do juiz chamado a julgar a causa nos termos do direito da União dependa da resposta à questão prejudicial', in Nota Informativa relativa à apresentação de pedidos de decisão prejudicial pelos órgãos jurisdicionais nacionais, $\ 36$.

${ }^{8}$ Cfr. Vassilios Skouris, "L'urgence dans la procédure applicable aux renvois préjudiciels", in Liber Amicorum en l'honneur de Bo Vesterdorf (Bruxelas: Bruylant,2007), 58-78.
} 


\subsection{Condições de acesso tramitação prejudicial urgente}

A TPU foi inicialmente consagrada para os domínios a que se reportam os art. 29. ${ }^{\circ}$ a $42 .^{\circ}$ do título VI do TUE e os art. $61 .^{\circ}$ a $69 .^{\circ}$ do título IV da terceira parte do TCE, no que respeita, respetivamente, à cooperação policial e judiciária em matéria penal e aos vistos, asilo, imigração e outras políticas ligadas à livre circulação das pessoas, incluindo a cooperação em matéria civil. Com a entrada em vigor do Tratado de Lisboa, tais matérias encontram-se reunidas no título $\mathrm{V}$ da terceira parte do TFUE. Trata-se de temáticas agrupadas sob a designação de espaço de liberdade, segurança e justiça, anteriormente denominado justiça e assuntos internos.

A primeira condição de acesso à TPU assenta precisamente no facto de as questões prejudiciais apresentadas ao juiz da União recaírem sobre o domínio do ELSJ. A segunda condição prende-se com a urgência que ressalta do processo principal, isto é, a necessidade fática de resposta urgente às questões prejudiciais. Assim, o art. 107. ${ }^{\circ}$, n. ${ }^{\circ}$ 2, do RPTJ exige que a jurisdição de reenvio exponha "as circunstâncias de facto e de direito comprovativas da urgência e que justificam a aplicação deste tipo de tramitação derrogatória".

\subsubsection{Determinação da condição do dominio do ELSJ}

Conforme tem vindo a ser destacado pela doutrina, a implementação da TPU no quadro jurídico da União está diretamente relacionada com a extensão das competências da UE, nomeadamente ao nível do ELSJ e, bem assim, à cada vez mais extensa jurisprudência nesse domínio?.

\footnotetext{
${ }^{9}$ Sobre esta matéria cfr. Laurent Coutron, “Urgence et renvoi préjudiciel” Revue des Affaires Européennes 2 (2012): 393; Bernard Chevalier, "Les nowveaux développements de la procédure préjudicielle dans le domaine de l'espace judiciaire européen : la procédure préjudicielle d'urgence et les réformes principales prévues par le traité de Lisbonne", ERA Forum 9 (2009) : 591-607; Allan Rosas, "Justice in haste, justice denied? The european Court of justice and the Area of Freedom, Security and Justice", in Cambridge Yearbook of European Legal Studies (Vol. 11, Oregon : Hart Publishing, 2008-2009) 1-13; Caroline Naômé, "La procédure accélérée et la procédure préjudicielle d'urgence devant la Court de justice des Communautés européennes", in Journal de Droit Européen, 162 (2009); Skouris, Vassilios, L'urgence dans la procédure applicable aux renvois préjudiciels, 58-78.
} 
Um reenvio prejudicial poderá, assim, ser submetido a esta tramitação excecional caso levante uma ou várias questões relativas àquele domínio, "em que seja assegurada a livre circulação de pessoas, em conjugação com medidas adequadas em matéria de controlos na fronteira externa, de asilo e imigração, bem como de prevenção da criminalidade e combate a este fenómeno" 10 . Englobando temáticas variadas, o ELSJ caracteriza-se ainda pela sua diversidade de procedimentos: política comum em matéria de asilo, imigração e controlo de fronteiras, medidas de prevenção da criminalidade, racismo e xenofobismo, coordenação e cooperação entre autoridades policiais e judiciais, reconhecimento mútuo de decisões judiciais em matéria penal, e, se necessário, aproximação das legislações em matéria penal, reconhecimento mútuo e execução das decisões judiciais civis.

Após a entrada em vigor do Tratado de Lisboa, este espaço tornou-se numa prioridade para a União, enquanto objetivo da UE, figurando no TUE imediatamente após a promoção da paz, dos seus valores e do bem-estar dos seus povos, e imediatamente antes da consagração de um mercado interno. Neste contexto, é esperado que a qualidade da justiça europeia no geral, e em especial nesta matéria, seja irrepreensível.

De facto, a criação de um espaço de liberdade, segurança e justiça reveste uma importância significativa no seio da União, particularmente na medida em que permite melhorar a eficácia e transparência do procedimento legislativo, e ainda porque coloca o cidadão no coração do debate, logrando uma inevitável e necessária aproximação da União dos seus cidadãos.

A celeridade processual torna-se cada vez mais necessária em função da urgência determinada por uma situação de vulnerabilidade na qual se encontrem os particulares, quer seja por se encontrarem em situação de pedido de asilo por ameaça de expulsão, ou por se tratar de uma situação de afastamento de crianças dos seus pais, ou ainda por estar em causa um particular privado da sua liberdade.

Às exigências de qualidade da justiça e celeridade processual, acresce a necessidade de preservar os interesses não só dos particulares, mas também dos Estados-

$\overline{{ }^{10} \text { Cfr. art. 3. }{ }^{\circ} \text {, n. }{ }^{\circ} 2 \text {, do TUE. }}$ 
Membros, na medida em que o ELSJ debruça-se sobre domínios particularmente sensíveis para os Estados-Membros ${ }^{11}$.

\subsubsection{Determinação da condição de urgência}

Quanto à condição de urgência que permite acionar a TPU, a sua definição legislativa permanece lacunar, conforme, aliás, assinala Antonio Tizzano, relembrando que os textos do Estatuto e do RPTJ não precisam o que é suscetível de consubstanciar a urgência e tão-pouco encerram elementos suficientes que permitam determinar o que entenderam os autores daqueles textos por urgente ${ }^{12}$.

Sem embargo, notemos que na Declaração do Conselho que acompanha a decisão que alterou o Protocolo (n. ${ }^{\circ}$ 3) relativo ao ETJUE ${ }^{13}$ foram apontadas as preocupações que esta tramitação procura solucionar, pelo que é possível encontrar nesse texto alguns elementos auxiliares da interpretação daquele conceito. Nessa declaração, o Conselho faz referência às situações em que a urgência resulta dos curtos prazos impostos pela legislação nacional ou no DUE, ou das implicações graves de uma elevada dilação temporal para as pessoas envolvidas. O Conselho convida ainda o Tribunal a aplicar a TPU em situações privativas de liberdade. Encoraja ainda o Tribunal no sentido de este, na nota informativa sobre a instauração de processos prejudiciais pelos órgãos jurisdicionais nacionais, oferecer a estes órgãos as indicações úteis no que respeita aos casos em que é conveniente requerer a aplicação da tramitação urgente ${ }^{14}$.

\footnotetext{
${ }^{11}$ Como o direito penal, historicamente ligado ao poder soberano do Estado, ou o direito dos visas e da imigração, através dos quais os Estados-Membros dirigem as suas políticas nacionais, ou ainda o direito da família.

${ }^{12}$ Cfr. Antonio Tizzano e Bruno Gencarelli, "La procédure préjudicielle d'urgence devant la Cour de Justice de l'Union Européenne”, in Il Diritto dell'Unione Europea 4 (2009): 929.

${ }^{13}$ Cfr. Declaração do Conselho que acompanha a decisão que alterou o Protocolo relativo ao Estatuto do Tribunal de Justiça, JOUE (2008/L 24/44), p. 44.

${ }^{14}$ Nesse seguimento, na sua recomendação, antiga nota informativa, o TJ alude aos litígios referentes às pessoas detidas ou privadas de liberdade, assim como àqueles que se reportam às responsabilidades parentais ou à guarda de crianças. Anteriormente, JOUE (2008/C 64/1), pp. 1-2, e JOUE (2011/C 160/1), p. 1-5. Atualmente, JOUE (2012/C 338/1), p. 1-6.
} 


\subsection{Prática jurisprudencial}

Constata-se, na prática, que os processos de reenvio prejudicial que foram submetidos a esta forma processual circunscrevem-se nas linhas traçadas pelos documentos e recomendações do Conselho e do próprio do TJ, tendo sido, ainda assim, jurisprudencialmente traçada uma interpretação restrita do conceito de urgência.

A aplicação desde 2008 da TPU consagra um enquadramento das questões prejudiciais suscetíveis de desencadear esta tramitação em três grandes grupos materiais:

a) Cooperação judiciária em matéria civil: prevista no art. $81 .^{\circ}$ do TFUE, esta matéria consiste numa política que procura aproximar e estabelecer novos meios de colaboração entre as autoridades judiciárias dos Estados-Membros, e que, nas explicações de Anabela Gonçalves, visa "garantir que as divergências entre os sistemas judiciários e as ordens jurídicas dos diferentes Estados-Membros não limitem o acesso à justiça e o exercício dos direitos. Este escopo está na base da construção do Espaço Europen de Liberdade, Segurança e Justiça, sendo a cooperação judiciária em matéria civil uma das suas políticas estruturantes (... ${ }^{p 15}$. Resulta da jurisprudência que a esmagadora maioria dos processos de reenvio submetidos ao TJ sobre esta matéria versa sobre o Regulamento (CE) n. ${ }^{\circ} 2201 / 2003^{16}$.

\footnotetext{
${ }^{15}$ Cfr. Anabela Susana de Sousa Gonçalves, "Cooperação Judiciária em Matéria Civil”, in Direito da União Europeia. Elementos de Direito e Políticas da União, coords. Alessandra Silveira, Mariana Canotilho e Pedro Madeira Froufe (Coimbra: Almedina, 2016) 339-391. Nos ensinamentos daquela autora, a política de cooperação judiciária em matéria civil é uma forma de concretização do ELSJ, e abrange a regulamentação de relações jurídicas de natureza civil e comercial cujos elementos estão em contacto com mais do que um Estado-Membro. Esta política procura aproximar e estabelecer meios de colaboração entre as autoridades judiciárias dos diferentes Estados-Membros e tem como propósito garantir que as divergências entre os sistemas judiciários e as ordens jurídicas dos diferentes Estados-Membros não limitem o acesso à justiça e o exercício dos direitos. Cfr. Anabela Susana de Sousa Gonçalves, "O caso Rinan e a deslocação ou retenção ilícitas de crianças", in UNIO EU Law Journal, 0 (2014): 126-127. Para maiores desenvolvimentos sobre o surgimento da política de cooperação judiciária em matéria civil, seus objetivos e desenvolvimentos, cfr. Ainda Anabela Susana de Sousa Gonçalves, Da Responsabilidade Extracontratual em Direito Internacional Privado, A Mudança de Paradigma (Coimbra: Almedina, 2013), 106127 e 212-226.

${ }^{16}$ Relativo à competência, ao reconhecimento e à execução de decisões em matéria matrimonial e em matéria de responsabilidade parental e que revoga o Regulamento (CE) n. ${ }^{\circ}$ 1347/2000, JOUE (2003/L 338/1), pp. 1-29. Aliás, a TPU foi inaugurada em 2008 com o acórdão Rinau, 11 de julho de 2008,
} 
b) Vistos, asilo e imigração: sobre esta matéria, cumpre mencionar que o ELSJ caracteriza-se primordialmente como um espaço sem controlos de pessoas na passagem das fronteiras comuns dos Estados-Membros, ou seja, as fronteiras internas da UE. Isto significa que, como explica Nuno Piçarra, circula-se no interior de um só Estado, pelo que deve o controlo de pessoas e a vigilância nas fronteiras externas ser suficientemente eficaz para que tal espaço se possa manter e desenvolver sem défices de segurança ${ }^{17}$. É no âmbito desta matéria que surgem, primordialmente, as detenções administrativas de cidadãos provenientes de Estados terceiros que entraram irregularmente no território de um Estado-Membro e que justificam a condição de urgência ${ }^{18}$.

c) Cooperação em matéria penal: por fim, esta matéria assenta no princípio do reconhecimento mútuo das sentenças e decisões judiciais e inclui a aproximação das disposições legislativas e regulamentares dos Estados-Membros nos domínios a que se referem o n. ${ }^{\circ} 2$ do art. $82 .^{\circ}$ e o art. 83. ${ }^{\circ}$ do TFUE $^{19}$. O mandado de detenção europeu ${ }^{20}$ foi adotado pela Decisão-Quadro 2002/584/JAI do Conselho, de 13 de junho de $2002^{21}$, relativa ao mandado de detenção europeu e aos processos de entrega entre os

Processo C-195/08 PPU, EU:C:2008:377 que teve como alicerce a interpretação daquele diploma. Cfr. Anabela Susana de Sousa Gonçalves, O caso Rinau e a deslocação ou retenção ilícitas de crianças, 124-125.

${ }^{17}$ Cfr. Nuno Piçarra, "Fronteiras, Vistos, Asilo e Imigração", in Direito da União Europeia. Elementos de Direito e Politicas da União, coords. Alessandra Silveira, Mariana Canotilho e Pedro Madeira Froufe, 245-337.

${ }^{18}$ Note-se que a natureza unicamente administrativa de um processo, sem qualquer relevância a título penal, não releva para a decisão de deferimento ou indeferimento da TPU.

${ }^{19}$ Para maiores desenvolvimentos, cfr. Mário Ferreira Monte e Joana Whyte, "Cooperação Judiciária e Policial em Matéria Penal”, in Direito da União Europeia. Elementos de Direito e Políticas da União, coords. Alessandra Silveira, Mariana Canotilho e Pedro Madeira Froufe, 393-447.

${ }^{20} \mathrm{O}$ mandado europeu é definido no n. ${ }^{\circ} 1$ do art. 1. ${ }^{\circ}$ da Decisão-Quadro 2002/584/JAI do Conselho, de 13 de junho de 2002, relativa ao mandado de detenção europeu e aos processos de entrega entre os Estados-Membros, (JO L 190) de 18 de julho de 2002, como sendo "uma decisão judiciária emitida por um Estado-Membro com vista à detenção e entrega por outro Estado-Membro duma pessoa procurada para efeitos de procedimento penal ou de cumprimento de uma pena ou medida de segurança privativas de liberdade".

${ }^{21}$ Cfr. JOUE (2002/L 190/1), pp. 1-20. Entrou em vigor no dia 7 de agosto de 2002, tendo sido alterada pela Decisão-Quadro 2009/299/JAI, do Conselho, de 26 de fevereiro de 2009, que alterou na mesma altura a Decisão-Quadro 2005/214/JAI, a Decisão-Quadro 2006/783/JAI, a DecisãoQuadro 2008/909/JAI, e a Decisão-Quadro 2008/947/JAI, visando reforçar os direitos processuais dos particulares e promover a aplicação do princípio do reconhecimento mútuo das decisões proferidas na ausência do arguido. 
Estados-Membros, que veio substituir o anterior sistema da extradição, procurando fomentar uma prática de diálogo diretamente entre as autoridades judiciárias dos Estados-Membros envolvidos. Tem por objetivo facilitar o reconhecimento do pedido de entrega de uma pessoa, através de determinados controlos, com vista a que aquela cumpra uma pena ou a fim de efetivar o procedimento criminal ${ }^{22}$.

\section{Implicações da condição do ELSJ: a posição dos particulares}

Como referimos, se o litígio não incidir sobre o ELSJ não será capaz de ser submetido à TPU, pelo que determinar o domínio a que pertence o caso em apreço, e consequentemente as questões prejudiciais a submeter ao TJ, constitui uma tarefa primordial do juiz nacional. De facto, verificando-se que o litígio não incide sobre o ELSJ, o pedido de tramitação urgente será liminarmente indeferido pelo TJ ${ }^{23}$.

Perante o indeferimento pelo TJ de aplicação da TPU, é legítimo questionarmos essa denegação num caso que não incida sobre o título V da parte III do TFUE, mas que revele tanta urgência quanto um caso que incida sobre o ELSJ. Esta limitação leva-nos a concluir que poderão existir litígios cujas questões prejudiciais sejam eventualmente menos sensíveis que as do ELSJ, mas cujo caso possa revelar mais urgência e não ser ainda assim submetido a uma tramitação urgente ou acelerada, sujeitando-se às consequências temporais que comporta o reenvio prejudicial ordinário.

\footnotetext{
${ }^{22}$ Conforme resulta do considerando 5 da Decisão-Quadro 2002/584/JAI, “[o] objetivo que a União fixou de se tornar um espaço de liberdade, de segurança e de justiça conduz à supressão da extradição entre os Estados-Membros e à substituição desta por um sistema de entrega entre autoridades judiciárias. Acresce que a instauração de um novo regime simplificado de entrega de pessoas condenadas ou suspeitas para efeitos de execução de sentenças ou de procedimento penal permite suprimir a complexidade e a eventual morosidade inerentes aos atuais procedimentos de extradição. As relações de cooperação clássicas que até ao momento prevaleceram entre Estados-Membros devem dar lugar a um sistema de livre circulação das decisões judiciais em matéria penal, tanto na fase pré-sentencial como transitadas em julgado, no espaço comum de liberdade, de segurança e de justiça".

${ }^{23} \mathrm{O}$ que se verificou, nomeadamente, no caso Pontini, cujo processo foi concluído em praticamente 26 meses. Cfr. acórdão Pontini, 24 de junho de 2010, Processo C-375/08, EU:C:2010:365.
} 


\subsection{A fragilidade da condição do ELSJ: o indeferimento da tramitação prejudicial urgente por exclusão do domínio do ELSJ}

$\mathrm{Na}$ hipótese de o processo principal não poder ser tramitado sob a forma urgente, poderá, então, seguir a forma ordinária, o que acarreta naturalmente inconvenientes significativos nos prazos de conclusão do processo. Em alternativa, poderá seguir a tramitação prejudicial acelerada, o que se verificou, nomeadamente, no caso Achugbbabian ${ }^{24}$, sobre matéria de regresso de nacionais de países terceiros em situação irregular, e mais recentemente no caso $G \cdot^{25}$, no qual se encontrava um indivíduo detido, cuja resposta à questão prejudicial poderia conduzir à sua libertação, sendo certo que as questões prejudiciais incidiam sobre matéria de livre circulação de mercadoria e, portanto, não se enquadravam no domínio do ELSJ. A decisão que veio a ser proferida pelo TJ neste processo, implicou que G. não poderia ser responsabilizado penalmente pelos factos que lhe eram imputados no caso principal, pelo que este último foi erradamente sido detido. A sua libertação dependeu, pois, diretamente da decisão do TJ, pelo que se impunha uma decisão prejudicial tão célere quanto possível.

Importa, nesta sede, analisarmos quais as consequências processuais quando uma privação de liberdade não é suscetível de desencadear a tramitação prejudicial urgente, por não estar enquadrada no título $\mathrm{V}$ da parte III do TFUE.

$\mathrm{O}$ art. 267. ${ }^{\circ}$ do TFUE prevê que sempre que uma questão sobre a interpretação dos Tratados, ou validade e interpretação dos atos adotados pelas instituições da União, seja suscitada em processo pendente perante um órgão jurisdicional nacional cujas decisões não sejam suscetíveis de recurso judicial previsto no direito interno, esse órgão é obrigado a submeter a questão ao Tribunal. Dispõe ainda que se uma questão desta natureza for suscitada em processo pendente perante um órgão jurisdicional nacional relativamente a uma pessoa que se encontre detida, o Tribunal deverá pronunciar-se com a maior brevidade possível.

\footnotetext{
${ }^{24}$ Cfr. acórdão Achughbabian, 6 de dezembro de 2011, Processo C-329/11, EU:C:2011:807.

${ }^{25}$ Cfr. acórdão G, 10 de julho de 2014, Processos apensos C-358/13 e C-181/14, EU:C:2014:2060.
} 
Desde logo, retiramos desta disposição normativa que nem todos os processos apresentados ao TJ poderão ser decididos com a maior brevidade possível. Para além disso, facilmente nos apercebemos que os autores dos tratados demonstraram uma preocupação adicional no tratamento de processos que envolvam a privação de liberdade de cidadãos, impondo que estes sejam decididos nos prazos mais curtos quanto possível.

A TPU é a tramitação mais célere prevista no Regulamento de Processo do TJ, a qual se aplica somente a questões que sejam levantadas no âmbito do ELSJ. Isto significa que sendo apresentado ao TJ um caso de privação da liberdade não relacionado com o ELSJ, não poderá ser tramitado pela TPU, sendo legítimo debater se tal desfecho é suscetível de constituir uma violação do art. $267 .^{\circ}$ n. ${ }^{\circ} 4$ do TFUE.

Antes de mais, estando-se perante um caso de privação de liberdade, e com vista ao cumprimento do art. $267 .^{\circ}$ n. ${ }^{\circ}$ 4, deverá ser excluída a tramitação normal. Não se preenchendo os requisitos previstos no art. 107. do RPTJ para a TPU, deverá então recorrer-se à TPA, ainda que a média de duração média destes processos seja superior.

Ora, a TPA não é a tramitação mais célere prevista no RPTJ, pelo que, nestas condições, poderemos deparar-nos, na prática, com uma incoerência legislativa nos art. 267. ${ }^{\circ}$ n. 4 do TFUE e $23 .^{\circ}$-A do Protocolo (n. ${ }^{\circ}$ 3) relativo ao ETJUE.

Defendemos ainda que o acesso à TPU para uns processos nos quais esteja em causa uma privação de liberdade e o recurso à tramitação ordinária ou acelerada noutros processos em que também se verifique uma privação de liberdade - mas que não releve do ELSJ - é suscetível de se concretizar num tratamento desigual de casos semelhantes.

Um entendimento diferente poderá defender que, se um caso releva do ELSJ e outro não, não poderão ser verdadeiramente semelhantes. Não obstante, o facto de estarmos perante uma privação de liberdade, e não fazendo o art. $267 .^{\circ}$ n. ${ }^{\circ} 4$ qualquer distinção entre as diferentes medidas privativas de liberdade dos particulares, deveria ser suficiente para aplicar a mesma forma processual. 
Ou será o enquadramento das questões prejudiciais no ELSJ suficiente para determinar o carácter urgente de um caso e justificar essa distinção?

Cremos que não.

Independentemente do facto de revelar ou não do ELSJ, a verdade é que pode ser premente em ambos os casos que o TJ se pronuncie nos prazos mais céleres, tendo a sua decisão influência sobre a eventual libertação da parte principal. Afigura-se-nos que um tal tratamento diferente poderá colidir com o princípio da não discriminação, que se encontra no coração da União Europeia, com valor de direito primário. De resto, este princípio, para além de se encontrar consagrado nos tratados ${ }^{26}$, resulta ainda dos princípios gerais de direito.

Nesta sede, atente-se aos termos da reforma do RPTJ ocorrida em 29 de setembro de 2012. Relativamente à TPA, o art. 62. ${ }^{\circ}$-A do Regulamento de Processo de 1991 dispunha que "[o] presidente pode excecionalmente, a pedido do demandante ou do demandado, sob proposta do juiz-relator, ouvidas as outras partes e o advogado-geral, decidir julgar um processo seguindo uma tramitação acelerada, afastando as disposições do presente regulamento, quando a especial urgência do processo exija que o Tribunal decida num prazo curto" 27 (destaque nosso). E no seu art. 104. ${ }^{\circ}-\mathrm{A}$, aplicável aos reenvios prejudiciais, era determinado que "a pedido do órgão jurisdicional nacional, o presidente pode, excecionalmente, sob proposta do juiz-relator, ouvido o advogado-geral, decidir submeter um reenvio prejudicial a tramitação acelerada, afastando a aplicação das disposições do presente regulamento, quando as circunstâncias invocadas justifiquem a urgência extraordinária em responder à questão submetida a titulo prejudicial' (destaque nosso).

No atual RPTJ, temos que no art. 133. ${ }^{\circ}$, sob a epígrafe "[d]ecisão relativa à tramitação acelerada" deixou de se fazer menção à "especial urgência do processo", e, no que toca aos reenvios prejudiciais, também no art. 105. ${ }^{\circ}$, sob a epígrafe "Tramitação acelerada", deixou de se fazer referência à "urgência extraordinária" das circunstâncias invocadas. Estes dois arts. dispõem atualmente que a tramitação acelerada pode ser aplicada quando "a natureza do processo exija o seu tratamento dentro de prazos curtos".

\footnotetext{
${ }^{26}$ Cfr. art. $18 .^{\circ}$ e $19 .^{\circ}$ do TFUE.

${ }^{27}$ Cfr. JOUE (1991/L 176/7), pp. 7-32.
} 
Deixou, assim, de se fazer qualquer referência à condição de "urgência", o que, a nosso ver, permite aplicar esta tramitação a um maior número de processos. Cremos ainda que esta reforma permitiu distinguir as condições de aplicação da tramitação prejudicial urgente e tramitação prejudicial acelerada.

\subsection{Alternativas à condição do ELSJ}

Face às aludidas dificuldades decorrentes das condições de acesso à TPU, poder-se-ia defender a eliminação tout court da condição do ELSJ, e, em respeito do

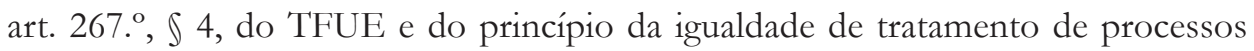
semelhantes, aplicar a tramitação prejudicial urgente a todos os processos nos quais estivesse em causa a aplicação a um indivíduo de uma medida privativa de liberdade e cuja decisão do TJ seja suscetível de alterar essa circunstância.

Teríamos, nessa hipótese, que o TJ poderia optar pela tramitação mais conveniente e adaptada ao caso concreto, independentemente do âmbito material da questão suscitada ao TJ. A consideração pelo TJ do grau de urgência do caso seria suscetível de permitir uma maior uniformização de jurisprudência com vista à aplicação da mesma tramitação a processos com circunstâncias semelhantes. Para processos menos urgentes mas cujo tratamento acelerado seja necessário, manterse-ia a aplicabilidade da tramitação acelerada.

Contudo, esta solução teria por desvantagem a limitação da aplicabilidade da TPU aos processos que envolvem uma medida privativa de liberdade. Nesta hipótese, todos os processos cujas questões prejudiciais integram atualmente o ELSJ, mas que não preenchessem aquela condição, seriam excluídos.

Não se nos afigura aceitável uma tal solução, desde logo porque a jurisprudência do TJ ensina-nos que a urgência do caso não está forçosamente relacionada com medidas privativas de liberdade, podendo, antes, prender-se com temas como a cooperação judiciária em matéria civil, designadamente a necessidade de salvaguardar os laços familiares entre progenitores e filhos menores.

Outra solução que tem vindo a ser reproduzida pela doutrina passa pela fusão 
da tramitação prejudicial urgente com a tramitação prejudicial acelerada. Neste sentido, defende Laure Clément-Wilz que a urgência do processo deve ser a única circunstância a atender para a determinação da tramitação que irá seguir ${ }^{28}$. Defende ainda esta doutrina que a interpretação do carácter urgente deveria continuar a ser realizada no sentido estrito, porquanto não podemos deixar de lembrar que se trata de uma forma processual excecional. Independentemente de o âmbito material das questões recair ou não sobre o ELSJ, estando em causa uma privação de liberdade aplicar-se-ia automaticamente a TPU, desde logo por estar bem nítido o cunho urgente, sem contudo limitar a tramitação em apreço a estes casos.

Segundo este entendimento, caberia ao TJ determinar antes de mais se as circunstâncias do caso em concreto revelam um carácter urgente que lhe permita aplicar-lhe uma tramitação mais célere, sendo certo que, em caso contrário, o processo seguiria os trâmites ordinários. Esta solução permitiria oferecer um tratamento igual a processos cujas circunstâncias casuísticas se assemelham.

Não obstante, não podemos olvidar que esta solução, embora mais justa que a anterior, tem a penosa consequência de desprovir a TPU de todo o seu enquadramento formal e condições de acesso, cujo regime é excecional, podendo abrir caminho para uma receada banalização da TPU. Cremos que é essa banalização que o legislador da União pretendeu evitar, antecipando que, caso tal sucedesse, certamente não seria possível ao TJ cumprir a expectativa de célere conclusão do processo de reenvio.

\section{Da tramitação prejudicial acelerada}

A TPA encontra-se, por seu turno, regulada pelos art. 23. ${ }^{\circ}-A$ do Protocolo (n. ${ }^{\circ}$ 3) relativo ao ETJUE e 105. ${ }^{\circ}$ e ss. do RPTJ. Como já referimos, o órgão jurisdicional de reenvio pode formular desde logo um pedido de TPA do processo de reenvio,

\footnotetext{
${ }^{28} \mathrm{Cfr}$. "La procédure préjudicielle d'urgence, nouveau théâtre du procès européen ?", Laure ClementWilz, acesso em janeiro 20, 2008, http://www.gdr-elsj.eu/wp-content/uploads/2012/10/Article_ PPU_extrait_LCW-1.pdf.
} 
assim como pode, alternativamente, formular aquele pedido subsidiariamente ao pedido de TPU, para o caso de este último ser indeferido, prática que os órgãos jurisdicionais nacionais de reenvio têm vindo a adotar ${ }^{29}$.

\subsection{Condições de acesso à tramitação prejudicial acelerada: dominios de aplicação}

Nos termos do art. $105 .^{\circ}$ do RPTJ, um reenvio prejudicial pode ser sujeito a TPA, em derrogação das disposições gerais deste regulamento, quando a natureza do processo exija o seu tratamento dentro de prazos curtos.

Diferentemente do que ocorre na TPU, não existe para a TPA um domínio material específico ao qual se encontre limitada a sua condição de acesso. A tramitação acelerada tem sido aplicada às mais diversas áreas do DUE, desde política externa e segurança comum, política económica e monetária, matéria de princípios, objetivos e missões dos tratados, entre outras. $\mathrm{Na}$ verdade, é às circunstâncias de facto e à suscetibilidade de um ou vários indivíduos serem prejudicados irreparavelmente nos seus direitos ou interesses que o presidente do TJ tem atendido no momento da decisão acerca da tramitação. Tal não obsta que sejam apreciados sobre esta forma processual processos cujas questões prejudiciais digam respeito a matéria enquadrada no ELSJ ${ }^{30}$.

\subsection{Situações de exclusão da tramitação prejudicial acelerada}

Uma vez que esta tramitação impõe condicionalismos importantes a todos os intervenientes no processo, designadamente ao conjunto dos Estados-Membros

\footnotetext{
${ }^{29}$ Estando-se perante um reenvio cujas questões prejudiciais não pertencem ao domínio do ELSJ, e sendo em consequência indeferido o pedido de tramitação urgente, sem que o órgão de reenvio tenha formulado um pedido subsidiário de tramitação acelerada, o TJ poderá, em cumprimento do princípio da cooperação com os Estados-Membros, entender que o pedido que o órgão de reenvio pretendeu, efetivamente, formular foi o de aplicação da TPA.

${ }^{30}$ Cfr. acórdão Kozlowski, 17 de julho 2008, Processo C-66/08, EU:C:2008:437; Acórdão Chatzi, 16 de setembro de 2010, Processo. C-149/10; EU:C:2010:534; Acórdão Purrucker, 9 de novembro de 2010, Processo C-296/10, EU:C:2010:665 e Acórdão Ivanova Gogova, 21 de outubro de 2015, Processo C-215/15, EU:C:2015:710.
} 
chamados a apresentar observações, escritas ou orais, em prazos bastante mais curtos do que os prazos ordinários, a sua aplicação só deve ser pedida em circunstâncias particulares que justifiquem que o Tribunal se pronuncie rapidamente sobre as questões submetidas.

Destacamos que, conforme resulta, nomeadamente, do caso Sánchez Morcillo e Abril García ${ }^{31}$ o número importante de pessoas ou de situações jurídicas potencialmente afetadas pela decisão que o órgão jurisdicional de reenvio deve proferir após ter submetido um pedido prejudicial ao Tribunal não constitui, enquanto tal, uma circunstância excecional suscetível de justificar o recurso à tramitação acelerada ${ }^{32}$.

Decorre ainda do entendimento do TJ que a exigência de tratamento de um processo, perante o órgão jurisdicional nacional, nos mais curtos prazos também não justifica, por si só, a aplicação da tramitação acelerada, ainda que o processo principal corra os seus termos sob uma tramitação urgente ${ }^{33}$.

Note-se, de resto, que deriva ainda de jurisprudência constante do TJ que a incerteza jurídica que afeta os particulares em causa no processo principal, relativamente ao seu desfecho, não é suscetível de justificar a aplicação da tramitação acelerada ${ }^{34}$.

\section{Notas finais}

O reenvio prejudicial encontra-se fortemente enquadrado num esquema próprio que permite dirigir-se ao juiz da União. Contudo, a eficácia do seu funcionamento

\footnotetext{
${ }^{31}$ Cfr. despacho do presidente do TJUE sobre o pedido de TPA de 5 de junho de 2014, proc. C-169/14, $\ 10$. ${ }^{32}$ Neste sentido, cfr. ainda os despachos do presidente do TJUE sobre o pedido de TPA Kögáz, 21 de setembro de 2006, Processos C-283/06 e C-312/06, S 9; Plantanol, 3 de julho de 2008, Processo C-201/08, S 10; Football Association Premier League e Murphy,3 de dezembro de 2008, Processos C-403/08 e C-429/08, \ 9; Lesoochranárske zoskupenie, 23 de outubro de 2009, Processo C-240/09, \11; Abdullabi, 5 de outubro de 2012, Processo C-394/12, \11; G., de 8 janeiro de 2013, Processo C-400/12, \14.

${ }^{33}$ Este entendimento resulta ainda do caso Rabal Cañas, referente a política social e no qual estava em causa no processo principal a impugnação de um despedimento, cujo processo, na jurisdição de reenvio, segue tramitação urgente. Cfr. despacho do presidente do TJ de 7 de outubro de 2013, Processo C-392/13. Neste sentido, cfr. ainda os despachos do presidente do TJ sobre o pedido de TPA: Jipa, 3 de abril de 2007, Processo C-33/07, \ 7, e ainda Miçsa, 31 de janeiro de 2011, Processo C-573/10, \11. ${ }^{34}$ Neste sentido, cfr. despachos do presidente do TJ sobre o pedido de TPA Abdullabi... \$ 14; I., 18 de julho de 2013, Processo C-255/13, \$15, e ainda Gielen, de 24 de outubro de 2013, Processo C-369/13, \ 14 .
} 
não se traduz forçosamente numa eficácia da proteção individual. Como vimos, o reenvio prejudicial foi particularizado em meios - a TPA e a TPU - que visam assegurar a proteção jurisdicional efetiva dos particulares, permitindo, mormente, que a jurisdição da União possa emitir as suas decisões em prazos razoáveis.

No que à TPU diz respeito, não sendo praticável elencar exaustiva e taxativamente as circunstâncias de facto que conduzem o TJ à sua aplicação - em virtude, designadamente, do carácter variado e evolutivo das normas da União que regulam o ELSJ -, podemos, não obstante, destacar que um órgão jurisdicional nacional poderá apresentar um pedido de TPU no caso aludido no art. 267. , \4, do TFUE. Prevê essa disposição normativa a circunstância de uma pessoa se encontrar detida ou privada de liberdade, e cuja resposta pelo TJ à questão prejudicial apresentada seja determinante para a apreciação da situação jurídica dessa pessoa. É ainda aplicável, em princípio, no caso de um litígio relativo às responsabilidades parentais ou à guarda de crianças, quando a competência do juiz chamado a julgar a causa nos termos do DUE dependa da resposta à questão prejudicial. Todas estas circunstâncias são suscetíveis de se enquadrarem no domínio do ELSJ.

Cremos que o campo de aplicação da TPU está destinado a evoluir em função da intensidade da atividade do legislador da União. Atualmente, todavia, a especialização verificada ao nível do âmbito material das questões prejudiciais que justificam aquela tramitação, relaciona-se com as exigências que subjazem à urgência de per si dos casos em concreto.

Relativamente à TPA, para além de esta tramitação não dispor de condições de aplicação concretamente definidas processualmente, o seu emprego pelo TJ acarreta a penosa consequência de lhe ser conferida prioridade sobre os restantes processos pendentes. Talvez por tal motivo, o TJ tem demonstrado uma tímida aplicação desta tramitação.

Sem prejuízo de poder funcionar como uma tramitação subsidiária da TPU nos casos que não cumprem com os requisitos da aplicação desta, solucionado, de certa forma, as dificuldades subjacentes às condições da TPU, importa destacar que a TPA fica aquém do esperado pelo legislador da União em matéria de dilação temporal. 
Por fim, o estudo jurisprudencial demonstra que o desvirtuamento do reenvio prejudicial no âmbito da TPU, receado pela doutrina aquando da sua criação legislativa, não se verifica na prática.

Não podemos deixar de apontar que o sucesso desta tramitação é suscetível de conduzir, num futuro próximo, a uma sobrecarga do serviço da secção designada. A fim de combater essa eventual sobrecarga, afigura-se-nos concebível que o TJ lance mão da decisão por despacho fundamentado com maior frequência, verificados os requisitos do art. 99. ${ }^{\circ}$ do RPTJ. Não descuramos ainda a possibilidade de o TJ fazer um uso mais reiterado da TPA, ou, ainda, de proceder a uma fusão desta com a TPU, sem todavia desprovir o atual enquadramento excecional e restrito da TPU das suas características processuais próprias, evitando a sua vulgarização. Importará, além do mais, que o mecanismo que possa resultar de uma tal solução não se faça sentir sob a forma de um aumento da dilação temporal nos processos de reenvio à luz do princípio da tutela jurisdicional efetiva. 



\title{
Qual a contribuição do direito penal contemporâneo em face da responsabilidade das pessoas jurídicas por atos de corrupção?*
}

\author{
Rogério Gesta Leal**
}

RESUMO: Pretendemos tratar neste texto do árduo tema da responsabilidade penal da pessoa jurídica por atos de corrupção, tendo em vista a utilização cada vez. maior destas figuras jurídicas para o cometimento de crimes altamente sofisticados e de profundo impacto social. Para tanto vamos revisar algumas posições da dogmática penal contemporãnea e apresentar em relação a elas críticas de superação.

PALAVRAS-CHAVES: responsabilidade penal da pessoa jurídica - corrupşão - crime organiżado.

ABSTRACT: We intend to deal in this text with the arduous issue of criminal liability of the legal person for acts of corruption, in view of the increasing use of these legal figures for the commission of highly sophisticated crimes with profound social impact. To do so, we will review some of the positions of contemporary dogmatics criminal perspectives and present some criticics of them.

KEYWORDS: criminal liability of the legal entity - corruption - organized crime.

\footnotetext{
* Este artigo é o resultado de pesquisas feitas junto ao Centro de Direitos Sociais e Políticas Públicas, do Programa de Doutorado e Mestrado da Universidade de Santa Cruz do Sul-UNISC, e vinculado ao Diretório de Grupo do CNPQ intitulado Estado, Administração Pública e Sociedade, coordenado pelo Prof. Titular Dr. Rogério Gesta Leal, bem como decorrência de projeto de pesquisa intitulado PATOLOGLAS CORRUPTIVAS NAS RELAÇÕES ENTRE ESTADO, ADMINSTRAÇ̃O PÚBLICA E SOCIEDADE: causas, conseqüências e tratamentos, e foi apresentado no Workshop sobre o tema Políticas Públicas e Criminalidade, que teve lugar no dia 17 de março de 2016, junto à Universidade do Minho, organizado pelo CEDU, sob a coordenação da Profa. Dra. Alessandra Aparecida Souza Silveira.

** Desembargador do Tribunal de Justiça do Estado do Rio Grande do Sul, Doutor em Direito. Professor da UNISC, da FMP e da UNOESC.
} 


\section{Notas introdutórias}

Em pesquisa do fórum econômico mundial sobre o tema da corrupção (em 2014) foi possível asseverar que ela tendo sido responsável por perdas de 2,6 trilhões de dólares por ano em todo o mundo, o que representa cerca de 5\% do PIB mundial. $\mathrm{Na}$ mesma pesquisa restou consolidado que em 71, de 148 países pesquisados pelo fórum, a corrupção foi detetada como um dos 3 principais problemas, representando em média cerca de $10 \%$ a $20 \%$ de custo adicional para fazer negócios. O banco mundial estima que cerca de $20 \%$ a $40 \%$ do dinheiro enviado a países pobres vai para a corrupção e é desviado ${ }^{1}$.

É de se ter presente que na ultima pesquisa da Transparência Internacional, o Uruguai, por exemplo, aparece na 19. ${ }^{a}$ posição, e o Chile, na 22. ${ }^{a}$ posição, no ranking de 177 países. O Brasil, por sua vez, está na 72. ${ }^{a}$ posição ${ }^{2}$.

Diante do histórico destes cenários, várias empresas multinacionais estão desenvolvendo códigos de condutas negociais entre fornecedores e consumidores, criando sistemas de denúncias anônimas de casos de corrupção ou falta de ética funcional, metas de redução de impacto ambiental e de engajamento com comunidades, sendo óbvio que isto tem se dado pelo fato de que a reputação das empresas passou a ser um fator de risco com maior impacto nas estratégias de negócios³.

Estes dados todos evidenciam a preocupação internacional de que todos se sintam responsáveis pela condução ética e moral de suas relações privadas e públicas, como imperativo civilizatório preocupado com as presentes e futuras gerações, o que impõe a revisão de comportamentos cotidianos voltados à efetivação daqueles compromissos, tarefa que demanda não só mudanças de hábitos de consumidores e fornecedores, mas

\footnotetext{
${ }^{1}$ Augusto Borges, "Um Mundo mais Ético", Revista Exame CEO, 20 de abril (2014): 18. A matéria aponta para o fato de que a crise de imagem enfrentada pelos bancos - que também é uma crise de confiança -, mais o colapso financeiro global, são apontados como principais motivos por trás do interesse das empresas por políticas de responsabilidade corporativa, associado ao alto grau de exposição que elas enfrentam praticado pelas redes sociais.

2 “Corruption Perceptions Index 2013", Transparency International, acesso em 6 de maio, 2014, http:// cpi.transparency.org/cpi2013/results/.

${ }^{3}$ Cfr. em especial o site do Institute of Business Ethics (http://www.ibe.org.uk/).
} 
de cidadãos, para que se ocupem mais dos interesses públicos efetivos em todos os sentidos. O problema é que, quando a mudança cultural e cívica é insuficiente, o Direito Penal é chamado a contribuir nesta tarefa, o que se tem percebido nestes últimos tempos.

Pretendo neste texto apresentar algumas considerações sobre os marcos conceituais estruturantes que estão hoje a operar o debate da migração da responsabilidade penal individual à empresarial, tanto em face do reconhecimento dos nefastos impactos que são cometidos por pessoas jurídicas em diversos âmbitos das relações sociais, mas em particular para que se ampliem as ferramentas jurídicas ao tratamento preventivo e curativo dos atos de corrupção praticados por elas.

\section{Preliminares contextuais e conceituais sobre a responsabilidade penal empresarial}

É interessante ter presente que em termos históricos, no Ocidente, o Direito romano não admitia a responsabilização penal da pessoa jurídica - SOCIETAS DELINQUERE NON POTEST, lembrando-se ainda que, como referia Montesquieu, a corrupção foi causa da queda do império romano, dizendo o autor que a grandeza do Estado fez a grandeza das fortunas privadas, e os que não foram corrompidos por sua riqueza o foram por sua pobreza ${ }^{4}$.

No final do século XVIII, com fundamento na Teoria da Fiç̧ão de Feuerbach e Friedrich Karl von Savigny, a pessoa jurídica é definida como criação artificial da lei e, como tal, não pode ser objeto de autêntica responsabilidade penal, que somente pode recair sobre os reais responsáveis pelo delito, os homens por trás das pessoas jurídicas 5 .

Entretanto, no início do século XX, tanto a Inglaterra como os EUA já tinham posições no sentido de buscar a responsabilização penal da pessoa jurídica em face

\footnotetext{
${ }^{4}$ Montesquieu, Consideracoões sobre as causas da grandeza dos romanos e de sua decadência (Rio de Janeiro: Ediouro, 1980), 31.

${ }^{5}$ Ver o excelente texto de João Marcello de Araújo, "Societas delinquere potest: revisão da legislação comparada e estado atual da doutrina", in Responsabilidade penal da pessoa jurídica e medidas provisórias e Direito Penal, coord.. Luiz Flávio Gomes (São Paulo. RT,1999) 91.
} 
de determinados delitos econômicos - como se pode ver nos casos New York Central and Hudson River Railroad Co. v. United States 212 US 481, em 1909, e Mousell Bros v. London and North Western Railway, em 1917. Lembra Elidiana que: "US courts follow the principle of respondent superior, which means that a corporation is liable for the wrongful acts of any of its employees, provided that such an employee commits the crime within the scope of his or her employment and with the intent to benefit the company".

É de se ter presente, em data mais contemporânea, que desde a década de 1990 o tema da responsabilidade penal da pessoa jurídica já estava na agenda das principais nações desenvolvidas (América do Norte e Europa Central), alarmadas com o contingente cada vez maior de fraudes econômicas, violações ambientais, propinas a agentes públicos, obstrução da justiça e crimes financeiros envolvendo corporações, resultando daí reações de organização normativa e jurisdicionais voltadas a combater as chamadas corporações transgressoras (corporate wrongdoing), tanto na perspetiva penal, como civil e administrativa ${ }^{7}$.

Os ingleses chegaram a criar a Doutrina do Alter Ego (ou Teoria da Identificação) para o tratamento da matéria, no sentido de que a responsabilidade penal de comportamentos ilícitos deve cair sobre as pessoas que dirigem e controlam as atividades da empresa, eis que os atos destas pessoas devem ser considerados como forma de realização da empresa. Assim, a conduta criminosa daquelas são consideradas como a longa manus da empresa, razão pela qual constitui a base de sua responsabilidade penal ${ }^{8}$.

\footnotetext{
${ }^{6}$ Elidiana Shkira, "Criminal Liability of Corporations: A Comparative Approach to Corporate Criminal Liability in Common Law and Civil Law Countries", acesso em 13 de maio, 2014, http://papers.ssrn. com/sol3/papers.cfm?abstract_id=2290878. Adverte a autora, todavia, que: "However, presently, this approach has been criticized as unduly restrictive and unrepresentative, as a result of the complexity that today's modern corporations have related to their horizontal or decentralized decision making structures".

${ }^{7}$ Lawrence Friedman, "In Defense of Corporate Criminal Liability", Harvard Journal of Law and Public Policy 23 (2000): 833-844.

${ }^{8}$ Cfr. os textos de John Clough e Carl Mulhern, The Prosecution of Corporations (Oxford: Oxford University Press, 2002) e de Bernard Hogan e James Smith, Criminal Law (London: Butterworths, 1988). Estes autores chegam a afirmar que na England, "the corporations are liable for almost any type of crimes with the exception of those crimes punished only by imprisonment" (p. 54).
} 
Nos EUA, a perceção de que as empresas são pessoas como qualquer outro indivíduo foi ainda mais enfatizada por decisão da Suprema Corte no caso Citizens United versus Federal Election Commission, que rejeitou o argumento de que o comportamento de empresas ou outras associações devem ser tratados de forma diferente em face da Primeira Emenda simplesmente porque elas não se configuram como pessoas singulares. Em outras decisões igualmente importantes, este Tribunal teve oportunidade de sustentar as teses de que: "(a) An agent's knowledge is imputed to the corporation where the agent is acting within the scope of his authority and where the knowledge relates to matters within the scope of that authority'; (b) bolding agent's culpability and knowledge may only be imputed to the corporation where agent was acting as authorized and motivated at least in part by an intent to benefit the corporation" 10 .

Não se pode perder de vista, de qualquer sorte, o fato de que o poder das corporações e pessoas jurídicas é muito maior do que o de seus membros isoladamente considerados, o que se evidencia pela força e influência do crime organizado que se utiliza de instituições públicas e privadas para alcançar seus desideratos ilícitos. Isto ainda é mais importante quando se sabe que as pessoas jurídicas podem se estruturar para evitar responsabilidades jurídicas, criando figuras fictícias de laranjas para responderem por atos contra a lei, escondendo-se por detrás deles ${ }^{11}$.

Basta verificar as denuncias - a maior parte delas reconhecidas pelas próprias empresas - que envolveram a Siemens e a Phizer, corporações de porte global que praticaram atos corruptivos para obterem contratos e vantagens econômicas, a saber: "German conglomerate Siemens A.G. admitted to paying approximately \$1.4 billion in bribes, over

\footnotetext{
${ }^{9}$ Hellenic, Inc., 252 F.3d 391, 395 (5th Cir. 2001).

${ }^{10}$ United States v. 7326 Highway 45 N., 965 F.2d 311, 316 (7th Cir. 1992). Ver também a decisão United States v. Cincotta, 689 F.2d 238, 241-42 (1 ${ }^{\text {st }}$ Cir. 1982). Ver também as decisões: United States v. Basic Construction Co., 711 F.2d 570, 573 (4th Cir. 1983) (" [A] corporation may be beld criminally responsible for antitrust violations committed by its employees. even if, as in Hilton Hotels and American Radiator, such acts were against corporate policy or express instructions.").

${ }^{11}$ Fisse Brent, "Restructuring Corporate Criminal Law: Deterrence, Retribution, Fault and Sanctions", California Law Review 56 (1983): 1141-1163. Acrescenta o autor ainda que: "recognizing that the corporate entity as a whole is criminally liable allows for more effective legal and moral sanctioning of wrongful corporate activity. As such, criminal liability of corporations through the recognition of legal personality directly encourages the adoption of better standards, more responsible corporate behavior and deterrence from future misconduct'.
} 
a six-year period, through subsidiaries in France, Turkey, and the Middle East to obtain contracts. Similarly, pharmaceutical giant Phizer paid \$2.3 billion, including a criminal fine of $\$ 1.195$ billion, to settle civil and criminal investigations for promoting 'off-label' uses of its drugs"'12.

O problema é que a responsabilidade penal da pessoa jurídica, a despeito de todos os dados que se tem sobre o crime organizado, a lavagem de dinheiro, o tráfico de drogas e pessoas, os crimes ambientais praticados por estes sujeitos coletivos, etc., ainda encontra controvérsias que buscam afastá-la ou reduzi-la drasticamente, fragilizando o argumento da mente criminosa da corporação (criminal mind corporation) ${ }^{13}$.

Em termos penais estes argumentos se travestem em outros dois, a saber, a "falta de capacidade de ação e de culpabilidade" da pessoa jurídica. A doutrina contrária à responsabilização penal desdobra estes argumentos apontando o "princípio da personalidade das penas", ou seja, somente é punível quem executou materialmente o ato criminoso; ou o "princípio da individualidade da responsabilidade criminal", para o qual a responsabilidade criminal recai exclusiva e individualmente sobre os autores das infrações, ou, ainda, o "princípio da intransmissibilidade da pena e da culpa", para o qual as penas não deverão ultrapassar, em nenhum caso, da pessoa que praticou a conduta, como barreiras insuperáveis para a criminalização dos entes coletivos ${ }^{14}$.

Na doutrina alemã, Hans-Heinrich Jescheck entende nesse sentido:

“(...) las personas jurídicas y las asociaciones sin personalidad unicamente pueden actuar a

\footnotetext{
${ }^{12}$ Cfr. em "Press Release", Martin Joint, in US Department of Justice, acesso em 12 de maio, 2014, https://www.justice.gov/archive/opa/pr/2008/December/08-crm-1105.html. Os casos Enron e WorldCom também foram emblemáticos para este debate nos EUA - ver a matéria em "The Real Scandal: America's capital markets are not the paragons they were cracked up to be", The Economist, 17 de julho, 2002, acesso em 26 de maio, 2014, http://www.economist.com/node/940091.

${ }^{13}$ Cfr. o texto de Eric Engle, "Extraterritorial Corporate Criminal Liability: A Remedy for Human Rights Violations?", St. John's Journal of Legal Commentary 20 (2006): 288. No texto o autor refere que: “The difficulty to consider corporations, as legal persons subject to criminal sanctions is partially due to the criminal law's focus on a guilty mind. Traditionally, corporations have been considered unable to form the requisite mental element to commit crimes Historically, a corporation could not be criminally liable in national law because the corporation was a legal fiction which possessed no independent Will." Ver igualmente o texto de Günter Heine, "New Developments in Corporate Criminal Law Liability in Europe: Can Europeans Learn from the American Experience-or Vice Versa?", Transatlantic Law Journal (1998): 173-176.

${ }^{14}$ Cfr. o texto de Luigi. Foffani, "La corrupción en el sector privado: iniciativas internacionales y derecho comparado", Revista Brasileira de Ciências Criminais 17, 81 (2009): 48-60.
} 
través de sus órganos, por lo que ellas mismas no pueden ser penadas. Además, respecto a ellas carece de sentido la desaprobación ético-social que subyace en la pena, pues sólo contra personas individuales responsables cabe formular un reproche de culpabilidad, y no contra los miembros del grupo no participantes, o contra una masa patrimonial'15.

Para Claus Roxin, "tampoco son acciones conforme al Derecho Penal alemán los actos de personas jurídicas, pues, dado que les falta una sustancia psíquico-espiritual, no pueden manifestarse a sí mismas. Sólo "órganos" bumanos pueden actuar con eficacia para ellas, pero entonces hay que penar a aquéllos y no a la persona jurídica"16.

Na doutrina italiana, Antonio Pagliaro sustenta que:

"Anziché parlare di condotta della persona giuridica basta considerare la condotta della persona fisica che funge da suo organo (es.: amministratore di societa). Ė sempre una persona fisica, anche se qualificata da uno certo rapporto com lénte, a porre la condotta illecita. In questo senso può dirsi che le persone giuridiche non sono idonee a compiere una condotta penalmente illecita"17.

Vai no mesmo sentido Moscarini, ao dizer que: "ad una responsabilizzazione in chiave penalistica della societas s'è obiettato che la persona giuridica è solo una finzione, mentre il diritto penale è fatto per l'uomo: solo il soggetto fisico dotato d'intelligenza e volontà sarebbe capace d'intendere il disvalore della sua condotta e di determinarsi conseguentemente, nonché di patire l'affittività della pena e d'intenderne la finalità rieducativa"18.

O tema é tão polêmico que nem todos os Estados norte-americanos adotam a responsabilidade penal da pessoa jurídica, assim como nem todos os países de sistemas legais codificados rejeitam a responsabilidade penal da pessoa jurídica, haja vista que a França instituiu a responsabilidade penal da pessoa jurídica em 1994 (arts.121-2, do Código Penal Francês) ${ }^{19}$, e o mesmo ocorreu na Áustria (2006), Bélgica (1999),

\footnotetext{
${ }^{15}$ Hans-Heinrich Jescheck, Tratado de Derecho Penal: Parte General, trad. José Luiz Manzanares Samaniego (Granada: Editorial Comares, 1993), 205.

${ }^{16}$ Claus Roxin, Derecho Penal: Parte General, trad. Diego-Manuel Luzón Peña et al. (Madrid: Editorial Civitas, 1999), 258-259.

${ }^{17}$ Antonio Pagliaro, Principi di Diritto Penale: Parte Generale (Milano: Giuffrè Editore, 2004), 161.

${ }^{18}$ Paolo Moscarini, "Contrasto della corruzione e procedimento penale de societate." Rivista de Proceso Penale e Giustizia 4. (2013): 5.

${ }^{19}$ Mesmo na França, centro neural do desenvolvimento da Responsabilidade Penal da Empresa, mister é que se conheça a posição do doutrinador René Garraud, ao sustentar que não se pode pensar em declarar as universitatis bonoum penalmente responsáveis, pois as pessoas morais são bem menos pessoas que
} 
Dinamarca (1996), Finlândia (1995), Holanda (1976), Noruega (1991), Espanha (2003), Suíça (2003), a despeito de que em alguns casos excecionais prevaleceu a posição de que as pessoas jurídicas não poderiam estar sujeitas à responsabilidade criminal, como na Alemanha, durante longo tempo ${ }^{20}$.

No modelo alemão mais recente, a responsabilidade criminal das pessoas jurídicas demanda que os delitos sejam cometidos por um órgão ou representação oficial das empresas, sendo que o Código Penal não impõe um limite ou lista exaustiva de situações delituosas que possam ser cometidas por aquelas, mas elas não podem ser responsabilizadas por delitos que, em face de sua natureza, podem ser somente cometidos por indivíduos. Como diz Elidiana Shkira: "The only condition is that the offenses have to be linked with the corporation's activities. However, it is not required that the offense be within the competences conceded to the corporation"21.

No Código Penal Espanhol foi criado o tipo penal de corrupção entre particulares, pelos termos do art. 286, bis, inserido no Título XIII, definindo que:

"1. Quem por si mesmo ou por interposta pessoa prometa, ofereça ou conceda a empresários, administradores, empregados ou colaboradores de uma empresa mercantil ou de uma sociedade, associação, fundação ou organização, um beneficio ou vantagem de qualquer natureza, sem

meios ou instrumentos de que se servem as pessoas verdadeiras; e, além disto, a responsabilidade penal ou coletiva do ser moral é uma ficção; o que é verdadeira é a responsabilidade individual de cada um dos seus membros. Mesmo assim, os arts. 121 e 122, do Código Penal Francês, determinam que as pessoas jurídicas são responsáveis penalmente quando a lei ou a regulação que as atinge expressamente prever tal penalidade. Cfr. o texto de René Garraud, Compêndio de Direito Criminal., trad. Ricardo Rodrigues Gama (Vol. I., Campinas/SP: LZN Editora, 2003).

${ }^{20}$ Cfr. o texto de Andrew Weissmann., "A new approach to Corporate Criminal Liability" American Criminal Law Review 44,4 (2007). Uma versão extendida deste artigo apareceu no Indiana Law Journal como "Rethinking Corporate Criminal Liability". Cristina De Maglie lembra que: "There are three systems of determining for which crimes the corporations can be held liable. Under the first system" - adotado por Inglaterra, Holanda e Bélgica -, "the general liability, the legal person's liability is similar to that of individuals, in which corporations are considered to be capable of committing any crime. The second system" - adotado em França, por exemplo - "requires that the legislator mentions for each crime whether corporate criminal liability is possible. While, the third system" - EUA - "consists of listing all the crimes for which collective entities can be held liable." Cristina De Maglie, "Models of Corporate Criminal Liability in Comparative Law", Washington University Global Studies Law Review 4 (2005): 547- 552.

21 "Criminal Liability of Corporations: A Comparative Approach to Corporate Criminal Liability in Common Law and Civil Law Countries”, Elidiana Shkira, 19. 
justificativa, para que seja favorecido a si mesmo ou a terceiro, perante outros, faltando com suas obrigações na aquisição ou venda de mercadorias ou na contratação de serviços profissionais, será castigado com a pena de prisão de seis meses a quatro anos, inabilitação especial para o exercício da indústria ou comércio por tempo de um a seis anos e multa até o triplo do valor do benefício ou vantagem. 2. Com as mesmas penas será castigado o empresário, administrador, empregado ou colaborador de uma empresa mercantil, ou de uma sociedade, associação, fundação ou organização que, por si mesmo ou por interposta pessoa, receba, solicite ou aceite um benefício ou vantagem de qualquer natureza, sem justificativa, com a finalidade de favorecer, perante terceiros, a quem lhe outorgou ou prometeu a vantagem ou benefício, faltando com suas obrigações na aquisição ou venda de mercadorias ou na contratação de serviços profissionais. (...)"22.

Parte da doutrina estrangeira também anda nesta direção, haja vista as posições de Bettiol, por exemplo, quando afirma que a pessoa jurídica poderia ser passível de medidas diversas da pena, de medidas de caráter administrativo (dissolução da sociedade, sanções pecuniárias, etc.), mas, em nenhum caso de penas verdadeiras ${ }^{23}$.

Igualmente a argentina, com Zaffaroni, asseverando que as leis que "sancionan a personas juridicas, (...) no hacen más que conceder facultades administrativas al juez. penal, o sea que las sanciones no son penas ni medidas de seguridad, sino consecuencias administrativas de las conductas de los órganos de las personas jurídicas" 24 . Já Muñoz Conde defende medidas civis ou administrativas que possam aplicar-se à pessoa jurídica como tal (dissolução, multa, proibição de exercer determinadas atividades, etc. $)^{25}$.

Mas de qualquer sorte, como lembra Renata Ferreira, a União Européia, em data de 22/12/1998, fundada no art. K.3, do Tratado da União Européia relativa ao combate da corrupção no setor privado, adotou a chamada Ação Comum (98/742/ JAI), bem como a Decisão Quadro 2003/568/GAI, do seu Conselho (de 22.07.2003, publicada no Jornal Oficial da União Européia, n. L 192, de 31.07.2003, p. 54-56) ${ }^{26}$.

\footnotetext{
${ }^{22}$ Cfr. o texto de Ortiz De Urbina Gimeno, Ínigo. Reforma Penal. Ley Orgánica 5/2010 (Madrid: Francis Lefebvre, 2012).

${ }^{23}$ Giuseppe Bettiol. Direito Penal. (Vol. I., São Paulo: Editora Revista dos Tribunais, 1966).

${ }^{24}$ Eugenio Raúl Zaffaroni, Tratado de Derecho Penal (Vol. III, Buenos Aires: EDIAR, 1981) 231.

${ }^{25}$ Francisco Muñoz Conde, Teoria Geral do Delito (Porto Alegre: Sergio Antonio Fabris Editor, 1988).

${ }^{26}$ Renata Rodrigues de Abreu Ferreira, "Corrupşão no setor privado: uma questão de bem jurídico" Revista Liberdades 15 (janeiro a abril de 2014).
} 
O primeiro documento operava com a lógica econômica restritiva de que a corrupção falseia a concorrência leal e compromete os princípios de abertura e liberdade dos mercados, nomeadamente o bom funcionamento do mercado interno, e é contrária à transparência e à abertura do comércio internacional, determinando a criminalização, por partes dos Estados-Membros, dos atos de corrupção particular, estando mais preocupado com os interesses dos empresários em face de condutas indevidas e ilícitas de seus funcionários.

Da mesma forma a Decisão Quadro 2003/568/GAI trabalhou com conceito de natureza mais econômica da corrupção, tendo-a como verdadeira ameaça a sociedade que poderia conduzir a distorções da concorrência em relação à aquisição de bens ou serviços comerciais e prejudicar o desenvolvimento econômico, fixando, todavia, a obrigatoriedade a todos os Estados-Membros de criminalizarem a corrupção privada, autorizando, no entanto, que cingissem sua seara de aplicação às práticas relacionadas com a aquisição de bens ou de serviços comerciais, que implicassem distorção da concorrência ${ }^{27}$.

Estes documentos permitem a compreensão, como lembra Regina Helena Fonseca Fortes Furtado ${ }^{28}$, de alguns modelos penais que se constituíram a partir destas discussões, a saber: a) o de que o injusto típico está na infração de deveres do funcionário corrupto frente ao empresário (França, Holanda e Reino Unido); b) o de que o conteúdo do injusto vem determinado pelo menoscabo oriundo da concorrência desleal (Alemanha e Suíça), havendo ainda modelos como o sueco, que iguala a corrupção no setor privado e público, e o italiano, que exige um resultado lesivo consistente em um dano patrimonial concreto.

\footnotetext{
${ }^{27}$ Como bem lembra o Osservatorio sull'Anticorruzione (http:/ /www.diritto24.ilsole24ore.com, acesso em 21/05/2014): "La "decisione quadro" - come la direttiva - non ha efficacia diretta (art. 34), ma presuppone la sua attuazione da parte dello Stato membro con un proprio provvedimento normativo di recepimento. Analogamente a quanto previsto per le direttive (art.249.3 del Trattato), la decisione quadro 'vincola' gli Stati membri quanto al risultato da ottenere, visto l'obbligo per i giudici nazionali di interpretare le norme dell'ordinamento interno anche alla luce della lettera e dello scopo della decisione quadro (cfr. CGCE, causa C-105/2003, Putino, 16/6/2005)” (sublinhado meu).

${ }^{28}$ Regina Helena Fonseca Fortes Furtado "O combate à corrupção no setor privado - o crime de corrupcão entre particulares do art. 286 bis do Código Penal Espanhol” Boletim do Instituto Brasileiro de Ciências Criminais 221(2011).
} 
Por certo que estes modelos são insuficientes para dar conta, de um lado, da complexidade que toma a corrupção nos dias atuais; de outro, da definição do bem jurídico penal tutelado na espécie, eis que vai além da preocupação com a concorrência desleal ou dos deveres do funcionário público, pois está em jogo e em regra é atingida a probidade administrativa e a moralidade e ética públicas, âncoras maiores da relação de confiança que as instituições públicas (maiores que os agentes que as operam) mantêm com a Sociedade.

O uso de elaboradas redes financeiras e técnicas de contabilidade para esconder transações ilegais tem se revelado comum também. Para além disto, estruturas corporativas complexas e altamente sofisticadas - sob o ponto de vista jurídico e empresarial -, somadas a negócios e operações globais e descentralizados, com múltiplos profissionais nelas atuando, torna mais difícil atribuir responsabilidades pelos ilícitos cometidos a pessoas físicas particulares.

Veja-se que, nos termos do art. VIII (que envolve o tema dos subornos internacionais), da Convenção Interamericana contra a Corrupção, de 1997; do art. 2. ${ }^{\circ}$ (versando sobre a responsabilidade das pessoas jurídicas), da Convenção de Combate ao Suborno de Funcionários Públicos Estrangeiros em Transações Negociais Internacionais, de 1999; e mesmo o art. 26. (tratando da responsabilidade das pessoas jurídicas), da Convenção contra a Corrupção das Nações Unidas, de 2003, já havia preocupações explícitas de tratamento desta matéria.

O estabelecimento de um efetivo regime de responsabilidade é fundamental na luta contra a corrupção, e a capacidade de se manter a responsabilidade das empresas por tais atos - e não somente a individual - consigna clara mensagem de que a corrupção não é algo ínsito à atividade comercial/negocial de mercado.

A convenção Interamericana contra a Corrupção, em seu art.VIII - acima referido - reforça a necessidade dos Estados-Partes deverem proibir e punir quem quer que esteja envolvido em ações de oferta, direta ou indireta, de subornos (em moeda ou de outra forma, com qualquer tipo de benefício - favores, presentes ou vantagens) à Administração Pública, sejam nacionais ou estrangeiros, caracterizando a troca ilícita de interesses. Vai mais longe a Convenção em exigir que os Estados-Partes 
firmatários deste documento que não tenham tipificado o suborno internacional em suas legislações domésticas, na medida em que suas legislações permitam, devem providenciar assistência e cooperação na investigação e punição dos atos corruptivos ora relacionados.

Já no documento internacional sobre o combate ao suborno de funcionários públicos em transações comerciais internacionais, mencionado anteriormente, seu art. 2. $^{\circ}$, que trata sobre a responsabilidade das pessoas jurídicas, deixa claro que cada Estado-Parte deve tomar todas as medidas necessárias, de acordo com sua legislação doméstica (regras e princípios jurídicos), para incorporar tal responsabilidade.

É curioso que no anexo da Convenção que trata do guia de boas práticas à implementação dos seus arts., há expressa referência ao disposto no art. $2^{\circ}$, da Convenção Anti-Suborno da OECD, estabelecendo, por outro lado, que a responsabilidade da pessoa jurídica não pode restringir a responsabilidade da pessoa física, eis que ambas podem estar configuradas no mesmo caso, evidenciando a complexidade destas questões na prática. Diz ainda o documento que é preciso ficar atento aos casos de subornos por intermediários (laranjas, pessoas jurídicas fictícias, etc.), prática muito usual nas relações comerciais ordinárias e de vulto ${ }^{29}$.

Vejamos como isto está posto na realidade Brasileira agora.

\section{A responsabilidade penal das empresas no Brasil}

Há algumas normas jurídicas infraconstitucionais no Brasil que autorizam o entendimento de que a responsabilidade penal de pessoa jurídica é uma realidade que não admite mais retrocesso, haja vista, por exemplo, os termos da Lei Federal n. ${ }^{\circ}$ 9.605/98, que define crimes contra o meio ambiente (o art. $24 .^{\circ}$ prevê, inclusive,

\footnotetext{
${ }^{29}$ Como diz o documento: "Member countries should ensure that, in accordance with Article 1 of the OECD Anti-Bribery Convention, and the principle of functional equivalence in Commentary 2 to the OECD Anti-Bribery Convention, a legal person cannot avoid responsibility by using intermediaries, including related legal persons, to offer, promise or give a bribe to a foreign public official on its behalf". "Corporate Liability for Corruption Offences in Latin America", Organization for Economic Co-Operation and Development, acesso em 10 de março, 2015, http://www.oas.org/juridico/PDFs/enc_compilation.pdf. 16. Ver também o site Track: On Track Against Corruption, http://www.track.unodc.org/LegalLibrary.
} 
a hipótese de liquidação forçada da pessoa jurídica constituída ou utilizada preponderantemente com o fim de permitir, facilitar ou ocultar a prática de crimes ambientais); da Lei Federal n. ${ }^{\circ}$ 9.613/98, e as alterações provocadas pela Lei Federal n. ${ }^{\circ} 12.683 / 2012$, que dispõe sobre os crimes de lavagem ou ocultação de bens, direitos e valores; a prevenção da utilização do sistema financeiro para os ilícitos previstos nesta Lei, estabelecendo sanções severas às pessoas jurídicas que descumprirem seus comandos (arts. 8. ${ }^{\circ}, 9^{\circ}, 10 .^{\circ}$ ), e ainda cria o Conselho de Controle de Atividades Financeiras - COAF; a Lei n. ${ }^{\circ}$ 12.846/2013, que dispõe sobre a responsabilização administrativa e civil de pessoas jurídicas pela prática de atos contra a administração pública, nacional ou estrangeira ${ }^{30}$.

Veja-se que a norma do art. 173. ${ }^{\circ}$, \5. ${ }^{\circ}$, da Constituição Brasileira de 1988, determina ao legislador ordinário instituir a responsabilidade da pessoa jurídica (sem prejuízo da responsabilidade individual de seus dirigentes) por atos contra a ordem econômica e financeira e contra a economia popular.

Alguns doutrinadores afirmam que onde a Constituição fala de responsabilidade neste âmbito, quer dizer, na verdade, responsabilidade penal da pessoa jurídica, por causa da referência sobre "punições compativeis com sua naturęa" ${ }^{31}$.

Por sua vez, outros afirmam que se a Constituição fala de responsabilidade, quer dizer simplesmente responsabilidade, sem adjetivos, porque a atribuição geral (responsabilidade) não implica atribuição especial (responsabilidade penal), e o conceito de "punições" não é exclusivo do direito penal, abrangendo, também, sanções administrativas, com fins retributivos e preventivos semelhantes às sanções penais e, às vezes - como no caso das multas administrativas da Lei 9.605/98 -, com poder aflitivo superior às penas criminais, substituídas por penas restritivas de direito, ou com início de execução em regime aberto $^{32}$.

\footnotetext{
${ }^{30}$ A Lei 9.605/98 instituiu a responsabilidade administrativa, civil e penal da pessoa jurídica, em infrações contra o meio ambiente cometidas por decisão de representantes legais ou contratuais, ou de órgãos colegiados, tomadas no interesse ou benefício da entidade. Ver texto de João Castro e Sousa, As pessoas colectivas em face do direito criminal e do chamado "direito de mera ordenação social" (Coimbra: Coimbra Editora, 1985). ${ }^{31}$ Cfr. Luiz Flávio Gomes, "Responsabilidade penal da pessoa jurídica e medidas provisórias e Direito Penal". ${ }^{32}$ Cfr. "A responsabilidade penal da pessoa jurídica", Juarez Cirino dos Santos, acesso em 22 de novembro, 2013, http://icpc.org.br/wp-content/uploads/2013/01/responsabilidade_penal_juridica.pdf.
} 
$\mathrm{Na}$ mesma linha se sustenta ainda a perspetiva de impossibilidade da responsabilidade penal da empresa uma vez que o princípio da legalidade se realiza no conceito de tipo injusto, como descrição legal da ação proibida. A "ação", como fundamento psicossomático do conceito de crime, ou substantivo qualificado pelos adjetivos da tipicidade, da antijuridicidade e da culpabilidade, é fenômeno exclusivamente humano, sendo que, para o modelo causal constituiria comportamento humano voluntário; para o modelo final, acontecimento dirigido pela vontade consciente do fim; para o modelo social, comportamento humano de relevância social; para o modelo pessoal, manifestação da personalidade, etc., ou seja, se a ação é fenômeno exclusivamente humano, então a pessoa jurídica é incapaz de ação e, por esse motivo, os atos das pessoas jurídicas são referidos como situações de ausência de ação.

A proposta mais aproximada do conceito de ação pessoal, formulada por partidários da criminalização da pessoa jurídica, parece ser o conceito de "ação institucional", produto daquela vontade coletiva sedimentada em reuniões, deliberações ou votos, que exprimiria uma vontade pragmática, no sentido sociológico, na linha de uma imaginária perspetiva dicotômica de dupla imputação para o direito penal ${ }^{33}$.

O problema é que, para os opositores desta responsabilidade, a vontade pragmática da ação institucional é incapaz de dolo, como vontade consciente de realizar um tipo de crime, em que a vontade é a energia psíquica produtora da ação típica e a consciência é a direção inteligente da energia psíquica individual, ambas inexistentes no vazio psíquico da vontade pragmática impessoal da ação institucional da pessoa jurídica ${ }^{34}$.

A irresponsabilidade penal da pessoa jurídica encontra outras vertentes doutrinárias que entendem ser necessária a criação intermediária entre a

\footnotetext{
${ }^{33}$ Ver texto de Luiz Regis Prado (coord.), Responsabilidade penal da pessoa jurídica: em defesa do princípio da imputação penal subjetiva. (São Paulo: Revista dos Tribunais, 2001).

${ }^{34}$ Ver o texto de Sara Sun Beale, "Is Corporate Criminal Liability Unique?", American Criminal Law Review 44,4 (2007):1503-1504. Diz a autora que, talvez, a crítica mais convincente contra a responsabilidade penal das empresas é que a única punição real disponível contra uma corporação é uma multa, que pode ser muito mais facilmente calibrada para corrigir qualquer dano através de um processo civil, sem necessitar de todos os cuidados geralmente exigidos em um processo criminal.
} 
responsabilidade civil e a responsabilidade penal, para neutralizar a periculosidade que determinadas pessoas jurídicas podem trazer para o sistema social. Neste sentido, defendem a adoção de medidas preventivas especiais integrantes de um: Direito de Intervenção, "que seria um meio-termo entre Direito Penal e Direito Administrativo, que não aplique as pesadas sanções de Direito Penal, especialmente a pena privativa de liberdade, mas que seja eficaz. e possa ter, ao mesmo tempo, garantias menores que as do Direito Penal tradicional, para combater a criminalidade coletiva (...)"35.

Se é certo que as medidas especiais, de caráter ordenatório, administrativo ou civil podem ser utilizadas para a prevenção dos ilícitos praticados pelas pessoas jurídicas, a doutrina favorável à responsabilidade penal das pessoas jurídicas insiste com a tese de que elas são insuficientes para responder à realidade criminal econômica e ambiental de nossos dias, devendo ser aplicadas juntamente com medidas de caráter penal, fazendo parte de um sistema jurídico-penal novo, apto a atuar de forma eficaz no combate à criminalidade contemporânea, à lavagem de dinheiro, à criminalidade organizada.

"Por fim, a responsabilidade civil ou administrativa não pode impedir a responsabilidade penal dos entes coletivos. Em primeiro lugar, porque esse tipo de responsabilidade possui, respectivamente, o escopo de reparar o dano causado ou meramente preventivo (no sentido de se impedirem maiores prejuízos à coletividade), enquanto a responsabilidade penal possui o de punir os atos que causam perturbação da ordem pública. Em segundo lugar, não se pode deixar de mencionar a possibilidade de decisões de cunho administrativo serem objeto de ingerências políticas, o que tem levado ao descrédito desse tipo de sanção"36.

A realidade social em relação à criminalidade vem forçando a superação dos dogmas clássicos, com a adequação do sistema penal para apresentar soluções em face da nova criminalidade econômica, ambiental e, enfim, social. Klaus Tiedemann sustenta isto ao dizer que:

"De una parte, la sociología nos enseña que la agrupación crea um ambiente, um clima que facilita a incita a los autores físicos (o materiales) a cometer delitos em beneficio de la agrupación. De abi

\footnotetext{
${ }^{35}$ Winfried Hassemer apud Cezar Roberto Bitencourt, "Reflexões sobre a responsabilidade penal da pessoa jurídica", in Responsabilidade penal da pessoa jurídica e medidas provisórias e Direito Penal, coord. Luiz Flávio Gomes (São Paulo: RT, 1999), 71. Ver também o texto Winfried. Hassemer, "Perspectivas de uma moderna politica criminal” Revista Brasileira de Ciências Criminais 8 (out./dez. 1994): 41.

${ }^{36}$ Fausto Martin de Sanctis, Responsabilidade penal da pessoa jurídica (São Paulo: Saraiva, 1999), 45.
} 
la idea de no sancionar solamente a estos autores materiales (que pueden cambiary ser reemplazados), sino también, y sobre todo, a la agrupación misma. De outra parte, nuevas formas de criminalidad como los delitos de los negocios, en los que quedan comprendidos aquéllos contra el consumidor, los atentados al medio ambiente y el crimen organizado, se instalan en sistemas y medios tradicionales del Derecho Penal ante dificultades tan grandes que una nueva aproximación parece indispensable" ${ }^{37}$.

Pode-se dizer que as correntes doutrinárias reconhecem a importância da pessoa jurídica na criminalidade dos dias atuais. Desde a efetuação do crime até a sua ocultação, como a lavagem de dinheiro proveniente do tráfico ilícito de entorpecentes, o que constitui, por si só, crime. As diferenças ocorrem quanto à forma de atuação do Direito em face desta realidade.

Neste sentido, David Baigún sugere o "sistema da dupla imputação" como uma das modificações necessárias ao Direito Penal para o enfrentamento da criminalidade empresarial: "Este sistema, que se cobija ya bajo el nombre de doble imputación, reside esencialmente en reconocer la coexistencia de dos vías de imputación cuando se produce un hecho delictivo protagonizado por el ente colectivo; de una parte, la que se dirige a la persona jurídica, como unidad independiente y, de la otra, la atribución tradicional a las personas físicas que integran la persona jurídica"38.

Este sistema de dupla imputação, na hipótese de delitos praticados pelas pessoas jurídicas, permitiria que em relação às pessoas físicas não ocorresse mudança, continuando o sistema penal tradicional com os conceitos e garantias individuais historicamente fixados.

Em relação às pessoas jurídicas, entretanto, poderia ser firmado um novo sistema, rápido e eficaz, conforme exige a realidade da criminalidade empresarial, isto porque a pessoa jurídica está apta a praticar ações independentes das ações das pessoas físicas que a integram; isso é reconhecido pelo Direito na atualidade, para a responsabilização civil e administrativa da pessoa jurídica ${ }^{39}$.

\footnotetext{
${ }^{37}$ Klaus Tiedemann, "Responsabilidad penal de personas jurídicas y empresas en el Derecho comparado”, in Responsabilidade penal da pessoa jurídica e medidas provisórias e Direito Penal, coord. Luiz Flávio Gomes (São Paulo. RT, 1999), 27.

${ }^{38}$ David Baigún, "Naturaleza de la acción institucional en el sistema de la doble imputación. Responsabilidad penal de las personas jurídicas", in De las penas, coord.. David Baigún et al. (Buenos Aires: Depalma, 1997), 25-59.

${ }^{39}$ Ver o texto de Sérgio Salomão Shecaira, Responsabilidade penal da pessoa jurídica (São Paulo: Revista dos
} 
No sistema da dupla imputação, a culpabilidade deve ser vista como a "culpabilidade do fato". Não há dúvidas quanto à individualidade da culpa para o Direito Penal, ou seja, cada indivíduo deve ser analisado de acordo com a sua situação pessoal, as suas circunstâncias pessoais, dentro das suas diferenças. Por outro lado, a "decisão institucional é um produto normativo" estipulado no estatuto social, de acordo com a legislação vigente em cada país, em que há divisão de funções internas, de administração, e externas, de representação, havendo fixação de atribuições e responsabilidades, ou seja, a decisão institucional deverá ser conforme os seus estatutos determinem.

Assim, se a "organização" está diretamente relacionada com a ordem normativa, ela se manifesta autonomamente, posto que engloba a coletividade humana que integra a empresa, bem como um sistema de comunicação institucionalizado, um sistema de poder e o conseqüente conflito interno, ou seja, o estabelecimento de um sistema de controle interno.

O "interesse econômico" está na gênese das empresas, ou seja, na própria razão da sua formação, constituindo ao mesmo tempo seu objetivo. O que se precisa demonstrar é a sua interação com os componentes normativos e organizacional para a produção da ação institucional ${ }^{40}$.

\section{Notas conclusivas}

Como já referi anteriormente, a responsabilização criminal da pessoa jurídica no que se refere aos crimes ambientais, por meio da Lei $n^{\circ} 9.605$, em seu art. 3. ${ }^{\circ}$, deixou explícita esta opção, eis que dispôs: “As pessoas jurídicas serão responsabilizadas administrativa, civil e penalmente conforme o disposto nesta Lei, nos casos em que a infração seja cometida por decisão de seu representante legal ou contratual, ou de seu órgão colegiado, no interesse ou benefício de sua entidade. Parágrafo único. A responsabilidade das pessoas jurídicas não exclui a das pessoas físicas, autoras, co-autoras ou partíipes do mesmo fato".

Tribunais, 1999). Ver também o texto de David Baigún, "Naturaleza de la acción institucional en el sistema de la doble imputación - resposabilidad penal de las personas jurídicas", 37-53.

${ }^{40}$ Ver o texto de João Marcello de Araújo "Societas delinquere potest: revisão da legislação comparada e estado atual da doutrina", 91. 
Em verdade, tem sido esta legislação especial protetiva do meio ambiente que mais tem oportunizado a reflexão - ao menos em termos de tempo histórico percorrido - desta responsabilidade penal da pessoa jurídica, razão pela qual merece abordagem mais pontual.

A Lei sob comento determinou para tal responsabilização dois requisitos: "(a) Que a decisão sobre a conduta seja cometida por seu representante legal ou contratual, ou de seu órgão colegiado". Ou seja, é preciso que a ação institucional se dê de acordo com a sua normatização interna e seu caráter organizacional; a decisão deve ser tomada por quem estatutariamente poderia fazê-lo em nome da empresa e seguindo sua determinação organizacional interna; "(b) Que a infração seja cometida no interesse ou benefício da pessoa jurídica”, exigindo-se o interesse econômico da empresa como finalidade da conduta infracional praticada.

Não se pode deixar de lembrar aqui a contribuição da denominada "teoria do domínio do fato", para a qual é tanto autor do crime a pessoa que executa materialmente as elementares do tipo penal como aquele que detém o domínio final da ação praticada, tendo o controle sobre a realização ou não da conduta delitiva e o modo de sua execução. A aplicação dessa teoria é importantíssima na configuração da autoria nos chamados crimes de mando, estabelecendo uma co-autoria entre o mandante e o mandatário da infração penal. Nesse sentido, a atuação do indivíduo na qualidade de integrante da pessoa jurídica que realize a vontade desta dirigida a um fim penalmente ilícito implica a responsabilização conjunta do ente coletivo e da pessoa física ${ }^{41}$.

Esta perspetiva ganha fôlego na medida em que se reconhece hoje a existência de uma complexidade organizacional no âmbito das relações econômicas e de

\footnotetext{
${ }^{41}$ Ver o texto já clássico de Claus Roxin, Autoria y Domínio del Hecho en Derecho Penal (Madrid: Marcial Pons, 2000). Lembrando Lawrence Friedman "In Defense of Corporate Criminal Liability", 37, é preciso sempre ter em conta "who is really the directing mind and will of the corporation, the very ego and centre of the personality of the corporation". Ganha força assim o argumento de Fernando Galvão Rocha, ao dizer que: "A possibilidade de construção de nova teoria do delito, no entanto, não foi consagrada [sic] pelo legislador. Prova disto é que todos os tipos penais descritos na Lei $n .9 .605 / 98$ se referem à conduta proibida e não à atividade. Ora, se a lei ambiental que prevê expressamente responsabilidade penal para a pessoa jurídica não trabalha tipos referidos à atividade, fica claro que a responsabilização do ente moral se sustenta em outra fundamentação dogmática. A referida lei também não indica deva ser construída nova teoria do delito para responsabilizar a pessoa jurídica." Fernando Antônio Nogueira Galvão da

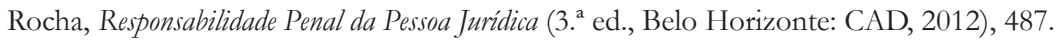


mercado, com a utilização de aparatos e tecnologias avançadas, com facilidades de movimentação e transações financeiras por questões de segundos de um canto ao outro do mundo, dificultando ou impossibilitando o seu rastreamento. Tais fatos evidenciam a ineficácia e a impotência de sistemas penais tradicionais, exigindo reformulações de conceitos, a criação de novos modelos de combate ao crime, de tal forma a atingir eficazmente tanto os delitos humanos como os corporativos, aliada à tentativa de se reduzir, no seio da população, o sentimento disseminado de impunidade.

A despeito de todos estes debates, os Tribunais Superiores têm entendido que é possível a responsabilização penal da pessoa jurídica na esfera ambiental, referindo o Superior Tribunal de Justiça - STJ que pessoa jurídica comete crime, podendo ser denunciada desde que juntamente com a pessoa física, sendo que o STF já referiu ser dispensável que pessoa física e jurídica tenham que ser denunciadas juntas ${ }^{42}$.

Assim, hoje, os que antes eram poucos e que passarão a ser vários autores de atos criminosos organizados, com comando e inteligência coordenativa, reclamam outra configuração de estruturas e operações jurídicas igualmente complexas, a serem geridas por políticas criminais eficientes para dar conta disto, o que sem dúvida traz desafios importantes às garantias penais e processuais que a Modernidade conquistou, tudo dentro do marco constitucional do Estado de Direito vigente ${ }^{43}$.

Por tais razões urge ampliar o debate que tem surgido em determinados campos doutrinários - referidos acima - para o fim de aceitar e desenvolver um sistema de responsabilidade penal das pessoas jurídicas que parta da própria atuação desta, ou seja, independentemente de ter que se localizar algum indivíduo que também fosse responsável (e se for factível fazê-lo, o sancionar-se-ia também).

\footnotetext{
${ }^{42}$ REsp 889.528/SC, relator o Min. Felix Fischer, DJU 18.06.2007)” (STJ, REsp 847476/SC, rel. Min. Paulo Galotti, DJU 05.05.2008, p. 1; RE 548181 AgR, Relator(a): Min. Rosa Weber, Primeira Turma, julgado em 14/05/2013, Acórdão Eletrônico DJe-117 Divulg 18-06-2013 Public 19-06-2013.

${ }^{43}$ Ver o texto de Germano Marques da Silva, Responsabilidade Penal das Sociedades e dos seus Administradores e Representantes (Lisboa: Verbo, 2009). Na mesma senda ver Bernd Schünemann, Delincuencia Empresarial: Cuestiones Dogmáticas y de Política Criminal (Buenos Aires: Fabian J. Di Plácido, 2004).
} 



\section{A recuperação de ativos na política de prevenção e repressão da criminalidade económico-financeira: linhas essenciais do modelo português no atual quadro de cooperação internacional}

\section{Flávia Noversa Loureiro*}

RESUMO: A necessidade de apostar seriamente na recuperação de ativos, especialmente em matéria de criminalidade económicofinanceira, tem vindo a ser assumida como uma prioridade político-criminal. Sobretudo impulsionado por instrumentos juridicos internacionais e europeus, o ordenamento jurídico português criou um gabinete de recuperação de ativos com competência para levar a cabo a investigação financeira e patrimonial em determinado tipo de crimes, visando impedir que a prática de crimes redunde num ganho económico suscetivel de alimentar o ciclo de criminalidade. Uma tal investigação não se apresenta, todavia, sem dificuldades e dúvidas, particularmente no que diz respeito à sua articulação com os direitos fundamentais dos cidadãos. Tentaremos, por isso, neste trabalho, fazer uma apresentação deste problema, explicar o surgimento do gabinete de recuperação de ativos português, analisar sinteticamente as suas competências e deixar algumas interrogaçōes e avisos.

PALAV RAS-CHAVE: recuperação de ativos - criminalidade económico-financeira - cooperação internacional gabinete de recuperação de ativos português.

\footnotetext{
* Professora Auxiliar na Escola de Direito da Universidade do Minho.

Este artigo foi desenvolvido, sobretudo, com base na intervenção oral que tivemos oportunidade de fazer no workshop "Políticas públicas e criminalidade", organizado pelo CEDU no dia 17 de março de 2016, na Escola de Direito da Universidade do Minho - agradecemos à Prof. Doutora Alessandra Silveira o gentil convite que nos endereçou para participar. O tema de há muito nos preocupa e tivemos mesmo a oportunidade de participar no grupo de trabalho constituído pelo Ministro da Justiça, através do despacho n. ${ }^{\circ}$ 11389/2010, publicado no Diário da República em 13 de julho de 2010, com o objetivo de "desenvolver as necessárias tarefas de análise, avaliação, organizaçãa do trabalbo, preparação do(s) anteprojeto(s) legislativo(s) que poderá(ão) dar execução cabal ao conjunto de obrigações internacionais aqui implicadas, bem como de opções politicamente determinadas e de estruturação de outros passos que se revelem pertinentes para uma cabal implementação de um Gabinete de Recuperação de Ativos (doravante Gabinete)", e que acabaria por dar origem a uma proposta de criação deste Gabinete. A matéria foi já alvo de outras reflexões nossas, quase sempre parcelares ou a propósito de distintos problemas, pelo que nos pareceu adequado dar agora corpo a algumas das considerações que sobre ela temos vindo a expender.
} 
ABSTRACT: The need to commit seriously in asset recovery, especially in the matter of economic and financial crime, has been assumed as a political-criminal priority. Driven, above all, by international and European legal instruments, the Portuguese legal system created an asset recovery office with the power to carry out financial and patrimonial investigation in certain types of crimes, in order to prevent its practice from producing an economic gain capable of sustaining the cycle of crime. Such an investigation does not, however, present itself without difficulties and doubts, particularly regarding its articulation with the fundamental rights of citizens. We will try, therefore, in this paper, to present the problem, to explain the emergence of the Portuguese asset recovery office, to analyse its competences synthetically and to raise some questions and warnings.

KEYWORDS: asset recovery - economic and financial crime - international cooperation - Portuguese asset recovery office.

\section{Apresentação do problema}

De há algumas décadas a esta parte se vem sublinhando, quer entre a doutrina, quer pela voz da prática judiciária, a importância fulcral de, em matéria de criminalidade económico-financeira e de criminalidade organizada, se apostar decisivamente na chamada recuperação de ativos ${ }^{1}$. Na verdade, se em qualquer formato de comportamento criminal importa, desde logo por razões de prevenção geral e especial, passar a mensagem clara de que «o crime não compensa», desestimulando a sua prática por via da intimidação ${ }^{2}$, o relevo desse aforismo é capital quando esteja em causa criminalidade economicamente motivada ou geradora de lucros elevados.

Nestas hipóteses, de facto, não basta aplicar a pena respetiva ao agente do crime (seja ela, entre nós, pena de prisão, ou tenha antes natureza pecuniária, como é o caso da multa), pois que o seu cumprimento pode não afetar o âmago do ato criminoso em causa: os lucros, os bens ou, globalmente, os ativos obtidos através da prática do crime. Por um lado, a sanção torna-se até, em certa medida, mais suportável para o

\footnotetext{
${ }^{1} \mathrm{Na}$ verdade, muito embora o confisco e a perda de bens sejam instrumentos de há muito conhecidos do direito penal, nos últimos anos temos assistido a uma sua valorização sem precedentes, em grande medida devido à influência norte americana. Ver, a este propósito, as considerações de João Conde Correia, Da Proibição do Confisco à Perda Alargada (Lisboa: INCM, 2012), 26 ss., e, mais recentemente, "A recuperação dos ativos dos crimes contra a economia e a saúde pública (Decreto-Lei n. ${ }^{\circ} 28 / 84$, de 20 de janeiro)", Revista do Ministério Público 146 (2016): 47-76.

${ }^{2}$ Cfr., por todos, Jorge de Figueiredo Dias, Direito Penal, Parte Geral, Tomo I: Questões Fundamentais. A Doutrina Geral do Crime (2. ${ }^{a}$ ed., Coimbra: Coimbra Editora, 2007), 78 e ss.
} 
agente, na medida em que este sabe que essas vantagens permanecem intocadas e que poderá usufruir delas (ainda que somente mais tarde, se, por exemplo, cumpre uma pena privativa de liberdade), o que naturalmente põe em causa o pretendido efeito de prevenção especial. Por outro, é cada vez mais comum, com se vem destacando ${ }^{3}$, que estes produtos ou vantagens originados na prática de crimes económico-financeiros (mas não só ${ }^{4}$ ) sirvam, a jusante, para o financiamento de nova criminalidade, da mesma ou de distinta natureza ${ }^{5}$, usualmente passando por um processo de branqueamento de capitais, de modo a ocultar a sua proveniência.

Há, pois, se quisermos começar por ordenar as principais razões que estão na origem do desenvolvimento do conceito de recuperação de ativos, um princípio fundamental da investigação de crimes económicos que tem vindo a sublinhar-se um pouco por todo o mundo: o "follow the money" tornou-se na matriz não apenas de toda a atividade investigatória como, igualmente, da generalidade dos modelos de reação à criminalidade económico-financeira, sobretudo organizada e de dimensão

\footnotetext{
${ }^{3}$ Diríamos já praticamente universal esta constatação. Para compreendermos a importância que a comunidade internacional tem dado à questão, veja-se, por exemplo, o art. 31. ${ }^{\circ}$ da Convenção das Nações Unidas contra a Corrupção (conhecida por Convenção de Mérida) - aprovada, entre nós, pela resolução da Assembleia da República n. ${ }^{\circ}$ 47/2007, de 21 de setembro -, especialmente dedicado ao congelamento, apreensão e perda de bens. Aí se estabelece não apenas a necessidade de prever as hipóteses de perda de produtos, bens ou instrumentos de crime, como igualmente a necessidade de desenvolver medidas para a identificação, apreensão e congelamento. Semelhantes indicações se deixam, igualmente, nos demais instrumentos internacionais respeitantes a este domínio: vejam-se, por exemplo, os arts. 13. ${ }^{\circ}$ e $23 .^{\circ}$ da Convenção Penal sobre a Corrupção, do Conselho da Europa (resolução da Assembleia da República n. ${ }^{\circ}$ 68/2001, de 26 de outubro), relativos ao branqueamento dos produtos resultantes de infrações de corrupção e àquilo a que chama "medidas que visem facilitar a recolha de provas e a perda dos produtos"; o art. XV da Convenção Interamericana contra a Corrupção (Caracas, 39 de maio de 1996); ou o art. 16. da Convenção da União Africana para prevenir e combater a Corrupção (Maputo, 11 de julho de 2003).

${ }^{4}$ Este movimento em defesa da necessidade de recuperação de ativos como faceta fundamental de uma política criminal adequada e eficaz não está somente relacionado com a criminalidade económicofinanceira, na verdade, mas antes com todas as práticas criminosas. Não cabendo aqui essa análise, a verdade é que é indesmentível a afirmação de que esse tem sido um aspeto cada vez mais importante da atuação dos Estados. Veja-se, a título de exemplo, o art. 12. ${ }^{\circ}$ da atual lei de política criminal (biénio 2015-2017) - lei n. ${ }^{\circ}$ 72/2015, de 20 de julho, que considera "prioritária a identificação, localização e apreensão de bens ou produtos relacionados com crimes, a desenvolver pelo Gabinete de Recuperação de Ativos".

${ }^{5}$ Não é, portanto, inocente a opção político-criminal que tem vindo a fazer-se na associação entre este tipo de criminalidade e o financiamento do terrorismo.
} 
transnacional ${ }^{6}$. Uma tal expansão corresponde, por outro lado, a uma acentuação das referidas finalidades de prevenção geral e especial, obtida através da demonstração de que o crime não gera benefícios ${ }^{7}$, a mesmo tempo que constitui um óbice à criação de um ciclo de criminalidade, com o investimento destes ganhos ilegalmente obtidos em outros crimes, perpetuando a atividade ilícita. Simultaneamente, o desapossamento de tais bens ou proventos permite, ao invés, apostar na prevenção da criminalidade, dotando as instâncias de controlo de adequados instrumentos e meios humanos, e na indemnização das vítimas dos crimes. Numa última perspetiva, deve ainda levar-se em linha de conta a possibilidade de estes lucros ilegalmente obtidos serem investidos em atividades económicas (lícitas em si próprias consideradas), o que poderá consubstanciar um ato de concorrência desleal, pondo em causa o necessário equilíbrio do mercado ${ }^{8}$.

\footnotetext{
${ }^{6}$ Se bem que possa falar-se, obviamente, em criminalidade económico-financeira simples (não organizada) e absolutamente nacional - pense-se, por exemplo, naquilo que pode suceder com um crime de corrupção (ativa e/ou passiva) ou de recebimento indevido de vantagem, onde pode continuar a fazer sentido equacionar a questão da recuperação de ativos -, a fenomenologia mais preocupante neste domínio é seguramente aquela que eleva estes crimes a uma dimensão transnacional (de que a cibercriminalidade é o exemplo mais paradigmático, mas está longe de ser o único), assente por regra em construções organizacionais complexas. Cfr., por todos, as considerações de Carlos Martínez-Bujan Pérez, "Los fenómenos de la expansión y de la reducción en el Derecho Penal Económico", in Infrações Económicas e Financeiras: Estudos de Criminologia e Direito (Coimbra: Coimbra Editora, 2013), 401-420; e Anabela Miranda Rodrigues, "Criminalidade Organizada - Que Política Criminal?", in Direito Penal Económico Europeu: Textos Doutrinários (vol. III, Coimbra: Coimbra Editora, 2009), 183-198.

${ }^{7}$ Nas palavras de Euclides Dâmaso Simões e José Luís F. Trindade, 'Recuperação de Activos: Da Perda Ampliada à Actio in Rem (Virtudes e Defeitos de Remédios Fortes para Patologias Graves)", Julgar Online (2009). Não deverá afirmar-se isto, todavia, sem equacionar as muitos questões que podem aqui ser suscitadas, nomeadamente no que respeita à natureza jurídica destes instrumentos (como o confisco, a perda ou a perda alargada, por exemplo) e sua relação com as finalidades das penas. $\mathrm{Na}$ verdade, se estes mecanismos não são verdadeiras penas - o que, como se sabe, é amplamente discutido pela doutrina, nacional e estrangeira - , temos de ter particular cuidado quando pretendemos assacar-lhes finalidades que o nosso ordenamento jurídico reconhece àqueles instrumentos. Cfr., a propósito da natureza destes institutos, Jorge de Figueiredo Dias, Direiro Penal Português. As Consequências Jurídicas do Crime (Coimbra: Coimbra Editora, 2005), 613 e ss.; e João Conde Correia, Da Proibição do Confisco à Perda Alargada (Lisboa: INCM, 2012), 77 e ss.

${ }^{8}$ Cfr. Anna Maria Maugeri, "Relazione Introduttiva. I Modelli di Sanzione Patrimoniale nel Diritto Comparato", in Le sanzioni patrimoniali come moderno strumento di lotta contro il crimine: reciproco reconoscimento e prospettive di armonizzazione (Milano: Giuffrè, 2008), 5-9.
} 
Ainda que se tenham por decisivos estes argumentos e, nessa medida, se aceite como boa a solução que passa por um mais decisivo empenho na recuperação dos ativos gerados pelo crime - o que, como veremos, não pode ser feito precipitada e acriticamente -, a realidade é que a sua implementação não se afigura fácil, quer por força dos modelos existentes em cada Estado e da necessidade de respeito e articulação com eles, quer devido à natureza diversificada e transnacional das condutas em causa, a exigir soluções conjuntas ou tão harmonizadas quanto possível.

\section{Dos instrumentos internacionais e europeus à criação do Gabinete de Recuperação de Ativos português}

Esta compreensão a respeito da importância da recuperação de ativos generalizou-se, em grande medida, por força da proliferação de instrumentos internacionais votados à matéria da criminalidade organizada e transnacional económico-financeira e outra -, que não só sublinharam a importância da recuperação de ativos no enfrentamento dos problemas colocados por estes ilícitos como criaram verdadeiras obrigações de atuação para os Estados ${ }^{9}$, forçando-os a adaptar os seus ordenamentos jurídicos internos. Tais convenções, acordos ou atos dizem sobretudo respeito ao tema de corrupção e infrações conexas, área onde mais se tem sublinhado a relevância desta recuperação, mas não se esgotam nele, como se pode verificar, logo, pela Convenção das Nações Unidas contra o Tráfico Ilícito de Estupefacientes e Substâncias Psicotrópicas (resolução da Assembleia da República n. ${ }^{\circ}$ 29/91, de 6 de setembro), onde se estabelecem regras especialmente vocacionadas para a perda, ocultação, dissimulação e utilização de bens, produtos e proventos destes crimes. Aí se estabelece, desde logo, que "as Partes adoptam as medidas que se mostrem necessárias para permitir a perda: a) de produtos provenientes de infrações estabelecidas de acordo com 0 n. 1 do

\footnotetext{
${ }^{9}$ Mesmo quando não se tratava de verdadeiras obrigações em sentido técnico-jurídico, nomeadamente por assumirem a forma de recomendações, a verdade é que as disposições destes instrumentos acabaram por forçar uma adequação dos regimes jurídicos nacionais, seja pela atenção que chamaram para o problema e que depois ecoou dentro de cada país, seja pela intrínseca necessidade de articulação e atuação global (ou tão global quanto possível) que estes fenómenos criminais reclamam.
} 
art. 3. ${ }^{\circ}$ ou de bens cujo valor corresponda ao valor desses produtos; b) de estupefacientes, substâncias psicotrópicas, materiais e equipamentos ou outros instrumentos utilizados ou destinados a serem utilizados, por qualquer forma, na prática das infrações estabelecidas de acordo com 0 n. ${ }^{\circ} 1$ do artigo 3. ${ }^{\circ}{ }^{\prime 10}$.

Semelhante relevo deve ser atribuído, igualmente, à Convenção das Nações Unidas contra a Criminalidade Organizada Transnacional (resolução da Assembleia da República n. ${ }^{o}$ 32/2004, de 2 de abril), conhecida por Convenção de Palermo, cujo art. 12. ', dedicado à perda e apreensão, fixa que "os Estados Partes adotarão, na medida em que o seu ordenamento jurídico interno o permita, as medidas necessárias para permitir a perda: a) do produto das infrações previstas na presente Convenção ou de bens cujo valor corresponda ao desse produto; b) dos bens, equipamentos e outros instrumentos utilizados ou destinados a ser utilizados na prática das infrações previstas na presente Convenção". Mais se estabelece aí a possibilidade da chamada "perda alargada", dizendo-se, nomeadamente, que "os

\footnotetext{
${ }^{10}$ Nos termos do n. ${ }^{\circ} 1$ do art. 5. ${ }^{\circ}$, epigrafado de "perda". Deve sublinhar-se igualmente que, nos elenco de crimes estabelecido no art. $3 .^{\circ}$, n. $^{\circ} 1$, desta Convenção, estão previstos não apenas os comportamentos de produção, o fabrico, a extração, a preparação, a oferta, a comercialização, a distribuição, a venda, a entrega em quaisquer condições, a corretagem, a expedição, a expedição em trânsito, o transporte, a importação ou a exportação de quaisquer estupefacientes e substâncias psicotrópicas, a cultura, a detenção ou a aquisição de estupefacientes ou de substâncias psicotrópicas, o fabrico, o transporte ou a distribuição de equipamentos, materiais ou substâncias, ou a organização, direção ou financiamento de qualquer destas infrações, mas igualmente, de acordo com a alínea b) daquele n. $^{\circ} 1$, os de i) conversão ou a transferência de bens, com o conhecimento de que os mesmos provêm de qualquer das infrações estabelecidas de acordo com a alínea a) do n. ${ }^{\circ} 1$ deste art., ou da participação nessa ou nessas infrações, com o objetivo de ocultar ou dissimular a origem ilícita desses bens ou de auxiliar a pessoa implicada na prática dessa ou dessas infrações a eximir-se às consequências jurídicas dos seus atos; e os de ii) ocultação ou dissimulação da verdadeira natureza, origem, localização, disposição, movimentação, propriedade ou outros direitos respeitantes aos bens, com o conhecimento de que eles provêm de uma das infrações estabelecidas de acordo com a alínea a) do n. ${ }^{\circ} 1$ deste art. ou de atos de participação nessa ou nessas infrações.

${ }^{11}$ Como se sabe, a "perda alargada" consiste num mecanismo que assenta na incongruência do património do arguido, prescindindo da demonstração de que a vantagem em causa decorre da prática do crime pelo qual aquele é condenado, como é exigido na perda tradicional, e colocando sobre o arguido o ónus de provar a origem lícita do património em causa. As questões suscitadas por um tal instrumento são muitíssimas, não podendo ser tratadas nesta sede. Assim, para as críticas e contracríticas, cfr. Euclides Dâmaso Simões e José Luís F. Trindade, "Recuperação de Activos: Da Perda Ampliada à Actio in Rem (Virtudes e Defeitos de Remédios Fortes para Patologias Graves)", Julgar Online (2009); Jorge Godinho, "Brandos costumes? O confisco penal com base na inversão do ónus da prova (Lei n. ${ }^{\circ}$ 5/2002, de 11 de janeiro, artigos $1 .^{\circ}$ e $7 .^{\circ}$ a $12 .^{\circ}$ )", in Liber Discipulorum para Jorge de Figueiredo Dias (Coimbra: Coimbra Editora, 2003), 1315-1363; José Manuel Damião da Cunha, "Perda de bens a favor do Estado", in Medidas de Combate à Criminalidade Organizada e Económico-Finaceira, (Coimbra: Coimbra Editora, 2004), 121-164;
} 
Estados Partes poderão considerar a possibilidade de exigir que o autor de uma infração demonstre a proveniência lícita do presumido produto do crime ou de outros bens que possam ser objeto de perda, na medida em que esta exigência esteja em conformidade com os princípios do seu direito interno e com a natureza do processo ou outros procedimentos judiciais" ${ }^{12}$.

Neste domínio, devem ainda pôr-se em evidência a Convenção do Conselho da Europa relativa ao Branqueamento, Deteção, Apreensão e Perda dos Produtos do Crime, assinada em Estrasburgo a 8 de novembro de 1990, aprovada pela resolução da Assembleia da República n. ${ }^{\circ}$ 70/97, de 13 de dezembro, e, mais tarde, a Convenção do Conselho da Europa relativa ao Branqueamento, Deteção, Apreensão e Perda dos Produtos do Crime e ao Financiamento do Terrorismo, adoptada em Varsóvia, em 16 de maio de 2005, e aprovada pela resolução da Assembleia da República n. ${ }^{\circ} 82 / 2009$, de 27 de agosto, nomeadamente os arts. $21 .^{\circ}$ a $27 .^{\circ 13}$, bem como, naturalmente, todos aqueles instrumentos que dizem respeito à prevenção e repressão da Corrupção. Para lá das já referidas Convenção de Mérida e Convenção Penal sobre a Corrupção, do Conselho da Europa ${ }^{14}$, destacamos ainda a resolução

João Conde Correia, Da Proibição do Confisco à Perda Alargada (Lisboa: INCM, 2012), 100, "Anotação ao Acórdão do Tribunal da Relação de Lisboa de 8 de outubro de 2014. O arresto preventivo dos instrumentos e dos produtos do crime", Julgar Online (2014), "Presunção de proveniência ilicita de bens para perda alargada: anotação aos acórdãos do Tribunal Constitucional n. ${ }^{\circ}$ 101, 392 e 476/2015 (Lei n. ${ }^{\circ}$ 5/2002, de 11 de janeiro-Confisco - Perda alargada - Presunção de inocência - Ónus de prova - Atividade criminosa)", Revista do Ministério Público 145 (2016): 207-221, e "A recuperação dos ativos dos crimes contra a economia e a saúde pública (Decreto-Lei n." 28/84, de 20 de janeiro)", Revista do Ministério Público 146 (2016): 47-76; e Pedro Caeiro, "Sentido e função do instituto da perda de vantagens relacionadas com o crime no confronto com outros meios de prevenção da criminalidade reditícia (em especial, os procedimentos de confisco in rem e a criminalização do enriquecimento "ilícito")", Revista Portuguesa de Ciência Criminal 21 (2011): 267-321.

${ }^{12}$ Nos termos do n. ${ }^{\circ} 7$ do preceito. Outras regras igualmente relevantes se fixam aí, como por exemplo a possibilidade de, se o produto do crime tiver sido convertido, total ou parcialmente, noutros bens, estes últimos poderem ser objeto das medidas previstas, em substituição do referido produto (n. ${ }^{\circ}$ ); de, se o produto do crime tiver sido misturado com bens adquiridos legalmente, estes bens poderem, sem prejuízo das competências de congelamento ou apreensão, ser declarados perdidos até ao valor calculado do produto com que foram misturados (n. $\left.{ }^{\circ} 4\right)$; de as receitas ou outros benefícios obtidos com o produto do crime, os bens nos quais o produto tenha sido transformado ou convertido ou os bens com que tenha sido misturado poderem ser objeto também das medidas previstas, da mesma forma e na mesma medida que o produto do crime (n. $\left.{ }^{\circ} 5\right)$.

${ }^{13}$ Estes arts. estabelecem regras quanto às medidas provisórias de apreensão e congelamento (arts. 21. ${ }^{\circ}$ e 22..$^{\circ}$ ), por um lado, e regras relativas à perda, propriamente dita (arts. $23^{\circ}{ }^{\circ}$ a $27 . .^{\circ}$ ), por outro.

${ }^{14}$ Cfr. supra nota 3 , onde referimos igualmente outras Convenções, que, muito embora, não vinculam o 
(97) 24 do Comité de Ministros do Conselho da Europa, adotada em 6 de novembro de 1997, sobre os princípios diretores da luta contra a corrupção ${ }^{15}$, a resolução (99) 5 do Comité de Ministros do Conselho da Europa, adotada em 1 de maio de 1999, que estabeleceu o grupo de Estados Contra a Corrupção (GRECO) ${ }^{16}$, no âmbito do Conselho da Europa, e, no espaço da União Europeia ${ }^{17}$, a decisão-quadro 2001/500/ JAI, de 26 de junho de 2001, relativa ao branqueamento de capitais, à identificação, deteção, congelamento, apreensão e perda dos instrumentos e produtos do crime ${ }^{18}$, a decisão-quadro 2003/577/JAI, de 22 de julho de 2003, relativa à execução na União Europeia das decisões de congelamento de bens ou de provas ${ }^{19}$, a decisão-quadro 2005/212/JAI, de 24 de setembro de 2005, relativa à perda de produtos, instrumentos e bens relacionados com o crime ${ }^{20}$, e a decisão 2007/845/JAI do Conselho, de 6 de dezembro de 2007, relativa à cooperação entre os gabinetes de recuperação de bens dos Estados-Membros no domínio da detecção e identificação de produtos ou outros bens relacionados com o crime ${ }^{21}$.

No que respeita, em particular, à criação do Gabinete de Recuperação de Ativos português, estes últimos instrumentos, sobretudo aqueles que foram aprovados pela União Europeia, desempenharam um papel crucial. $\mathrm{Na}$ verdade, de há muito a União vinha chamando a atenção para a necessidade de agir concertadamente em matéria de criminalidade económico-financeira organizada, nomeadamente através de um maior investimento em matéria de recuperação de ativos. As conclusões do Conselho Europeu de Viena, de dezembro de 2008, relativas ao plano de ação do

\footnotetext{
Estado português.

${ }^{15}$ Cfr. "Resolução (97) 24 do Comité de Ministros do Conselho da Europa", Conselho da Europa, acesso em 01/02/2017, https://search.coe.int/cm/Pages/result_details.aspx?ObjectID=0900001680534ea6

${ }^{16}$ Cfr. "Resolução (99) 5 do Comité de Ministros do Conselho da Europa", Conselho da Europa, acesso em 01/02/2017, http://www.coe.int/t/dghl/monitoring/greco/default_en.asp

${ }^{17}$ Muitos outros instrumentos de enfrentamento da corrupção tem vindo a ser desenvolvidos dentro da União Europeia. Chamamos aqui a atenção apenas para aqueles que mais diretamente estão relacionados com a matéria que nos ocupa, a recuperação de ativos.

${ }^{18}$ JO L 182, de 5 de julho de 2001, 1.

${ }^{19}$ JO L 196, de 2 de agosto de 2003, 45.

${ }^{20}$ JO L68, de 15 de março de 2005, 49.

${ }^{21}$ JO L 332, de 18 de dezembro de 2007, 103.
} 
Conselho e da Comissão sobre a melhor forma de aplicar as disposições do Tratado de Amesterdão relativas à criação de um espaço de liberdade, de segurança e de justiça ${ }^{22}$, salientavam já a relevância de uma abordagem integrada dentro do espaço europeu em matéria de criminalidade organizada ${ }^{23}$ e fixavam a necessidade de, no prazo de cinco anos após a entrada em vigor do Tratado, se "melhorar e aproximar, na medida do necessário, as disposições nacionais em matéria de apreensão e confiscação dos produtos do crime, tendo em conta os direitos dos terceiros de boa fe ${ }^{24}$. Nem um ano mais tarde, no ponto 51 das conclusões do Conselho Europeu de Tampere, de 15 e 16 de outubro de $1999^{25}$, salienta-se que o branqueamento de capitais é o cerne da criminalidade organizada, pelo que deverá ser erradicado onde quer que ocorra, afirmando-se e que o Conselho Europeu está decidido a garantir que sejam tomadas medidas concretas para detetar, congelar, apreender e declarar perdidos os produtos do crime, sendo que se apela também à aproximação do direito penal e dos procedimentos relativos à luta contra o branqueamento de capitais (designadamente, deteção, congelamento e perda de fundos) ${ }^{26}$.

Por outro lado, o plano de ação de 2000, intitulado "Prevenção e controlo da criminalidade organizada: estratégia da União Europeia para o início do novo milénio", aprovado pelo Conselho em 27 de março de $2000^{27}$, na sua recomendação n. ${ }^{\circ} 19$, estabeleceu que "deverá analisar-se a oportunidade de aprovar um instrumento que, tendo em conta as melhores práticas em vigor nos Estados-Membros e respeitando devidamente os princípios jurídicos fundamentais, preveja a possibilidade de, na legislação penal, civil ou fiscal, conforme o caso, tornar menos rigorosas as disposições em matéria de ónus da prova no que se refere à origem dos bens que

\footnotetext{
${ }^{22}$ JO C 19, de 23 de janeiro de 1999, 1.

${ }^{23}$ Nos termos do ponto 12 daquele plano "[a] resposta da União ao desafio da criminalidade organizada consta do plano de ação aprovado pelo Conselho Europeu de Amesterdão, que prevê uma abordagem integrada em cada fase, desde a prevenção e a repressão até aos procedimentos penais. Foram já realizados importantes progressos, tal como reconbecen o Conselho Europeu de Cardiff, mas as oportunidades oferecidas pelo Tratado de Amesterdão deverão o ser exploradas mesmo depois da plena execução do plano de ação".

${ }^{24}$ Nos termos da alínea b) do ponto 50.

${ }^{25}$ Cfr. "Conselho Europeu de Tampere 15 e 16 de outubro de 1999 Conclusões da Presidência", Parlamento Europeu, acesso em 01/02/2017, http://www.europarl.europa.eu/summits/tam_pt.htm

${ }^{26}$ Ponto 55.

${ }^{27}$ JO C 124, de 3 de maio de 2000, 1.
} 
se encontrem na posse de uma pessoa condenada por um crime relacionado com a criminalidade organizadd". No ano seguinte, tomando ainda em linha de conta que os Estados membros aderiram aos princípios da Convenção de 1990 do Conselho da Europa relativa ao branqueamento, deteção, apreensão e perda dos produtos do crime, foi adotada a decisão quadro 2001/500/JAI, do Conselho ${ }^{28}$, que veio estabelecer um conjunto de disposições relativas ao branqueamento de capitais, à identificação, deteção, congelamento, apreensão e perda dos instrumentos e produtos do crime, obrigando ainda os Estados membros a não formular nem a manter quaisquer reservas relativas às disposições da referida Convenção de 1990 relativas à perda, na medida em que a infração seja punível com pena privativa de liberdade ou com uma medida de segurança de duração máxima superior a um $\mathrm{ano}^{29}$.

Pouco tempo volvido, o Conselho entendeu, todavia, que os instrumentos existentes neste domínio não se vinham mostrando suficientes para induzir uma efetiva cooperação além fronteiras no que respeita à perda, na medida em que ainda existiam vários Estados membros não habilitados a declarar perdidos os produtos de todas as infrações puníveis com pena privativa de liberdade de duração superior a um $a_{n}{ }^{30}$, e, tendo em consideração que a principal motivação da criminalidade organizada transnacional é o lucro e, por isso, qualquer tentativa de prevenir e combater essa criminalidade deverá centrar-se na deteção, congelamento, apreensão e perda dos produtos do crime, se quiser ser eficaz ${ }^{31}$, adotou a decisão quadro 2005/212/JAI, do Conselho, de 24 de fevereiro de 2005, relativa à perda de produtos, instrumentos e bens relacionados com o crime ${ }^{32}$. O objetivo declarado deste instrumento era o de "assegurar que todos os Estados membros disponham de regras efetivas que regulem a perda dos produtos do crime, nomeadamente no que respeita ao ónus da prova relativamente à origem dos bens detidos por uma pessoa condenada pela prática de uma infração relacionada com a criminalidade

\footnotetext{
${ }^{28}$ JO L 182, de 5 de julho de 2001, 1.

${ }^{29}$ Nos termos do art. 1. ${ }^{\circ}$ da decisão quadro.

${ }^{30}$ Esta a justificação apontada no considerando 9 da decisão quadro 2005/212/JAI, do Conselho, de 24 de fevereiro de 2005 , relativa à perda de produtos, instrumentos e bens relacionados com o crime.

${ }^{31}$ Considerando 1.

${ }^{32}$ JO L 68, de 15 de março de 2005, 49.
} 
organizadd" ${ }^{33}$, com o intuito de avançar no caminho do reconhecimento mútuo, na União Europeia, de decisões relativas à perda dos produtos do crime e à partilha de bens perdidos ${ }^{34}$.

Dois anos mais tarde, aprofundando o caminho que vinha fazendo, o Conselho aprovou, então, a decisão n. ${ }^{0}$ 2007/845/JAI, de 6 de dezembro, relativa à cooperação entre os gabinetes de recuperação de bens dos Estados-Membros no domínio da deteção e identificação de produtos ou outros bens relacionados com o crime ${ }^{35}$. Sublinhando a necessidade de "estreita cooperação entre as autoridades competentes dos EstadosMembros a quem incumbe detetar os produtos e outros bens ilicitos susceptiveis de ser objeto de uma ordem de perda e tomar medidas que permitam a comunicação direta entre essas autoridades" 36 , e utilizando como modelo a Rede Camden Inter-serviços de Recuperação de Bens (CARIN), criada em Haia, a 22 e 23 de setembro de 2004, pela Áustria, Bélgica, Alemanha, Irlanda, Países Baixos e Reino Unido, esta decisão pretendeu fornecer uma base jurídica para o intercâmbio de informações entre os gabinetes de recuperação de bens de todos os Estados membros ${ }^{37}$. Para que um tal intercâmbio possa efetuarse, o art. 1. ${ }^{\circ}$ deste instrumento começa, por isso, por fixar que "cada Estado-Membro cria ou designa um gabinete nacional de recuperação de bens, para efeitos de facilitar a deteção $e$ identificação dos produtos e outros bens relacionados com o crime suscetiveis de serem objeto de uma ordem de congelamento, apreensão ou perda emitida por uma autoridade judiciária competente no decurso de um processo penal ou, tanto quanto possivel ao abrigo da legislação nacional do EstadoMembro em causa, durante um processo civil'. Estabelecem-se, depois, um conjunto de regras respeitantes à cooperação e intercâmbio de informações entre gabinetes de

\footnotetext{
${ }^{33}$ Conforme estabelecido no considerado 10 do instrumento.

${ }^{34}$ A decisão quadro em causa teve a sua origem num projeto apresentado pela Dinamarca, que simultaneamente apresentou dois outros: um relativo ao combate à corrupção do setor privado e outro respeitante à execução das decisões de confisco na União Europeia (JO C 184, de 2 de agosto de 2002, 3 , 5 e 8).

${ }^{35}$ JO L 332, de 18 de dezembro de 2007, 103.

${ }^{36}$ Considerando 3 da decisão.

${ }^{37}$ Que há de fazer-se, de acordo com o fixado no considerando 7, com base nos procedimentos e prazos previstos na decisão quadro 2006/960/JAI do Conselho, de 18 de dezembro de 2006, relativa à simplificação do intercâmbio de dados e informações entre as autoridades de aplicação da lei dos Estados-Membros da União Europeia.
} 
recuperação de ativos dos diversos $\operatorname{Estados}^{38}$.

Esta decisão constitui, assim, a alavanca última da legislação nacional neste domínio $^{39}$, uma vez que, à data, Portugal não possuía ainda um gabinete votado à recuperação de ativos e se viu pressionado a constitui-lo dentro dos parâmetros fixados. Acabou por fazê-lo através da lei n. ${ }^{\circ}$ 45/2011, de 24 de junho, dando um passo por muitos considerado decisivo na prevenção e repressão da criminalidade económico-financeira ${ }^{40}$, criando quer o Gabinete de Recuperação de Ativos (GRA), quer um Gabinete de Administração de Bens (GAB).

\section{O GRA, suas competências e funcionamento: algumas questões}

Feito este breve enquadramento histórico-legislativo, essencial para compreendermos o surgimento do Gabinete de Recuperação de Ativos, vamos agora ater-nos sinteticamente aos aspetos mais significativos do seu regime. De entre as diversas hipóteses - discutidas ${ }^{41}$-, a lei n. ${ }^{\circ}$ 45/2011 estabeleceu que o GRA funciona na dependência da Polícia Judiciária, com atribuições de investigação análogas às dos órgãos de polícia criminal ${ }^{42}$, cabendo-lhe proceder à identificação, localização

\footnotetext{
38 Não relevam aqui, neste momento, essas disposições, muito embora estabeleçam regras e procedimentos fundamentais em matéria de cooperação entre gabinetes e intercâmbio de informações. ${ }^{39} \mathrm{Na}$ verdade, já depois de instituído, em Portugal, o Gabinete de Recuperação de Ativos, o Parlamento Europeu e o Conselho aprovaram a Diretiva 2014/42/UE, de 3 de abril de 2014, sobre o congelamento e a perda dos instrumentos e produtos do crime na União Europeia, que pretendeu promover a confiança mútua e uma cooperação transfronteiriça mais eficaz através da adoção de regras mínimas, com vista a aproximar os regimes de congelamento e de perda dos Estados membros. JO L 127, de 29 de abril de 2014, 39 .

${ }^{40}$ Vejam-se, por exemplo, as reflexões de Euclides Dâmaso Simões, "A proposta de Lei sobre o Gabinete de Recuperação de Activos (Um passo no caminho certo)", Revista do CEJ 14 (2010): 183-192; Hélio Rigor Rodrigues e Carlos A. Reis Rodrigues, Recuperação de Activos na Criminalidade Económico-Financeira. Viagem pelas idiossincrasias de um regime de perda de bens em expansão., (Lisboa: SMMP, 2013), 14 e ss.

${ }^{41}$ Cfr., por exemplo, as considerações de Hélio Rigor Rodrigues, "Gabinete de Recuperação de Activos - O que é, para que serve e como actua", Revista do CEJ 1 (2013): 67-69, e de Hélio Rigor Rodrigues e Carlos A. Reis Rodrigues, Recuperação de Activos na Criminalidade Económico-Financeira. Viagem pelas idiossincrasias de um regime de perda de bens em expansão, (Lisboa: SMMP, 2013), 20-22, num e noutro lado, sobretudo aqui, considerando que o GRA deveria estar na dependência do Ministério Público.

${ }^{42}$ Nos termos do art. $2 .^{\circ}$ da lei n. ${ }^{\circ} 45 / 2011$, de 24 de junho.
} 
e apreensão de bens ou produtos relacionados com crimes, a nível interno e internacional, assegurar a cooperação com os gabinetes de recuperação de ativos criados por outros Estados e exercer as demais atribuições que lhe sejam legalmente atribuídas, competindo-lhe igualmente proceder à recolha, análise e tratamento de dados estatísticos sobre apreensão, perda e destinação de bens ou produtos relacionados com crimes ${ }^{43}$.

Sendo o inquérito dirigido pelo Ministério Público, nos termos estabelecidos no art. 263..$^{\circ}$ do Código de Processo Penal, e competindo-lhe igualmente, de acordo com o art. 8. ${ }^{\circ}$ da lei n. ${ }^{\circ}$ 5/2002, de 11 de janeiro, a liquidação do património incongruente no âmbito da perda alargada, o GRA há de levar a cabo a referida investigação patrimonial e financeira por determinação daquela autoridade judiciária ${ }^{44}$. Tal não sucederá, todavia, em todos os casos, mas apenas naqueles que, pela sua gravidade ou relevância, justifiquem o recurso a este Gabinete especializado. Assim, o art. 4. ${ }^{\circ}$ da referida lei diz-nos que esta intervenção ocorrerá quando se trate de instrumentos, bens ou produtos relacionados com crimes puníveis com pena de prisão igual ou superior a 3 anos e o valor estimado dos mesmos seja superior a 1000 unidades de conta $^{45 / 46}$. Para lá destas hipóteses-regra, o GRA pode ainda realizar a investigação financeira ou patrimonial, mediante prévia autorização do Procurador-Geral da República ou, por delegação, dos procuradores-gerais distritais ${ }^{47}$, em casos em que

\footnotetext{
${ }^{43}$ De acordo com o estabelecido no art. $3 .^{\circ}$, n. ${ }^{\circ} 1$ e n. ${ }^{\circ} 2$.

${ }^{44}$ Ao GRA cabe ainda, obviamente sem necessidade de intervenção legitimadora do MP, proceder ao intercâmbio de informações, de dados e de boas práticas com os gabinetes de recuperação de ativos criados por outros Estados e coadjuvar os tribunais na realização dos atos de cooperação judiciária pertinentes, nos termos do art. 9. ${ }^{\circ}$ da lei n. $.^{\circ} 45 / 2011$.

${ }^{45}$ Quando ultrapasse, portanto, os 102000 euros, uma vez que a unidade de conta é atualmente 102 euros, nos termos do art. 5..$^{\circ}$ do decreto-lei n. $.^{\circ} 34 / 2008$, de 26 de fevereiro (que estabelece o regulamento das custas processuais) do art. $73^{\circ}$ da lei n. ${ }^{\circ} 7-\mathrm{A} / 2016$, de 30 de março (lei que aprovou o orçamento do Estado para 2016).

46 Como bem salienta Hélio Rigor Rodrigues, "Gabinete de Recuperação de Activos", 72-74, se o preenchimento da alínea a) do preceito não suscita dúvidas de relevo, dependendo apenas de uma operação de subsunção jurídica (ainda assim, acrescentaríamos, necessariamente baseada em elementos indiciários e, por isso, suscetíveis de se verem não verificados - o que sempre pode dar azo a algumas questões), já a concretização da alínea b) do preceito exige a difícil tarefa de estimar o valor dos bens ou produtos relacionados com o crime (ou crimes) em causa.

${ }^{47}$ Delegação de competências que foi efetuada através do despacho n. ${ }^{\circ}$ 6922/2013 (DR II Série de 28 de maio).
} 
o estimado valor económico, científico, artístico ou histórico dos bens a recuperar e a complexidade da investigação o justifiquem. Nos termos do n. ${ }^{\circ} 6$ do art. $4 .^{\circ}$, a investigação financeira ou patrimonial pode igualmente realizar-se, para efeitos do n. ${ }^{\circ}$ 2 do art. 8. ${ }^{\circ}$ da lei n. ${ }^{\circ}$ 5/2002, de 11 de janeiro, depois de encerrado o inquérito, ou seja, para liquidação do montante que deva ser perdido a favor do Estado, se este não tiver sido apurado no momento da acusação. No que respeita à apreensão de bens realizada pelo GRA, que aqui nos interessa em particular, dispõe o n. 3 do art. $4 .^{\circ}$ da lei n. ${ }^{\circ}$ 45/2011 que esta tem de ser feita nos termos do Código de Processo Penal, podendo o titular dos bens ou direitos requerer ao juiz de instrução, no prazo de 10 dias após a notificação, a modificação ou a revogação da medida ${ }^{48}$.

No que respeita à composição do GRA e respetiva coordenação, o legislador remeteu para portaria conjunta dos membros do Governo responsáveis pelas áreas das finanças e da justiça, fixando, todavia, a necessidade de dele fazerem parte elementos que integram a Polícia Judiciária, o Instituto dos Registos e do Notariado, I. P., a Direção-Geral dos Impostos e a Direção-Geral das Alfândegas e dos Impostos Especiais sobre o Consumo. A portaria em causa - portaria n. ${ }^{\circ}$ 269/2012, de 3 de setembro - veio, então, estabelecer que compete ao Diretor Nacional da Polícia Judiciária (ou, mediante delegação, ao Diretor Nacional-Adjunto) determinar, de acordo com as necessidades de investigação, o número de elementos que compõem o GRA, não podendo o número de elementos da Polícia Judiciária ser inferior ao total dos membros originários das outras entidades. No caso do Instituto dos Registos e Notariado, I. P., estes poderão ser, no máximo, dois, e no da Autoridade Tributária e Aduaneira, sete elementos, a definir após consulta prévia aos dirigentes máximos das respetivas entidades ${ }^{49}$. Deve ainda sublinhar-se que, muito embora o GRA tenha sede em Lisboa, integra três delegações, cuja competência territorial coincide com a das diretorias da Polícia Judiciária em que estão sediadas e dos departamentos de investigação criminal delas dependentes: a Delegação do Norte, situada no Porto; a

\footnotetext{
${ }^{48}$ Disposição que, como notam Hélio Rigor Rodrigues e Carlos A. Reis Rodrigues, Recuperação de Activos na Criminalidade Económico-Financeira, 29-36, não está isenta de críticas, tendo porventura uma elasticidade menor do que aquela que seria desejável.

${ }^{49}$ Nos termos do n. ${ }^{\circ} 1$ e do n. ${ }^{\circ} 2$ do art. $2 .^{\circ}$ da portaria n. ${ }^{\circ}$ 269/2012, d e 3 de setembro.
} 
Delegação do Centro, situada em Coimbra; e a Delegação do Sul, situada em Faro ${ }^{50}$. Na cabendo aqui uma análise detalhada da atuação do GRA - que justificaria, só por si, um outro trabalho autónomo -, parece-nos essencial tecermos a este propósito algumas considerações. Em primeiro lugar, para tentarmos alcançar mais claramente o que seja a investigação patrimonial e financeira. Começámos por dizer, de facto, que ao lado da aplicação de uma pena a um agente responsável por um crime económicofinanceiro tem vindo a considerar-se igualmente significativa - senão mesmo mais importante ${ }^{51}$ - a perda dos produtos ou vantagens resultantes do ilícito em causa ${ }^{52}$. Para que uma tal desiderato seja cumprido, impõe-se ao Ministério Público, porém, uma dúplice tarefa: por um lado, terá de conduzir a investigação criminal, tendente a verificar se houve crime e quem foi o seu agente e a recolher a prova que possa sustentar, em julgamento, a aplicação de uma pena ${ }^{53}$; por outro, e concomitantemente, há de levar a cabo a investigação patrimonial e financeir $a^{54}$ correspondente, destinada

\footnotetext{
${ }^{50}$ Conforme estabelece o art. $7 .^{\circ}$ da lei n. ${ }^{\circ} 45 / 2011$, no sentido de agilizar a investigação patrimonial e financeira e de a fazer coincidir, tanto quanto possível, com a investigação da matéria criminal, propriamente dita.

${ }^{51}$ Vejam-se, v.g., as considerações de Euclides Dâmaso Simões, "A proposta de Lei sobre o Gabinete de Recuperação de Activos (Um passo no caminho certo)", Revista do CEJ 14 (2010): 183: "a repressão dessa criminalidade [crimes socialmente mais danosos que têm como objetivo o lucro] não ultrapassará a fase platónica se não se voltar para a recuperação de activos, isto é, dos instrumentos com que foi cometida a infração (quando tenham significado económico relvante) e para os bens e produtos por ele gerados. As intenções ético-retributiva e preventiva que tradicionalmente presidem ao direito penal só lograrão plena satisfação se, a par do sancionamento com as penas adequadas, os agentes do crime sofrerem o abalo económico resultante da perda em favor do Estado ou das vítimas dos bens ou produtos que hajam obtido". Não aceitando nós com as finalidades ético-retributivas referidas, não podemos deixar de salientar a importância da recuperação de ativos, que o Autor sublinha.

${ }_{52}$ A recuperação do ativo correspondente. Como assinalam Hélio Rigor Rodrigues e Carlos A. Reis Rodrigues, Recuperação de Activos na Criminalidade Económico-Financeira, 14, "o conceito de 'recuperação' espelha uma certa função credíticia assumida pela actividade do Estado na formulação da perda de bens resultantes das vantagens do crime. Tal expressão [recuperação de ativos] possui a virtualidade de anunciar que os bens que integram o incremento patrimonial resultante da actividade criminosa pertencem à sociedade, não são do criminoso, uma vez que o facto que lhes deu origem produziu uma importante lesão nos interesses do Estado. Os bens são 'recuperados' porque a titularidade legitima apenas é restabelecida com a declaração de perda". Não se concordando inteiramente com a construção apresentada, não pode todavia negar-se que a escolha da expressão vise, de facto, passar a mensagem que é sublinhada pelos Autores.

${ }^{53}$ Nos termos, nomeadamente, do art. $10^{\circ}$ da Lei de Organização da Investigação Criminal (lei n. ${ }^{\circ}$ 49/2008, de 27 de agosto) e do n. ${ }^{\circ} 1$ do art. $262 .^{\circ}$ do CPP.

${ }^{54}$ Conceito que não encontra definição legal, mas ao qual se consegue aceder por força, desde logo, quer das disposições da lei n. ${ }^{\circ}$ 5/2002, de 11 de janeiro, quer das normas atinentes ao GRA, constantes da
} 
a proceder à identificação e localização dos ativos passíveis de virem a ser declarados perdidos e à adoção das medidas necessárias para a respetiva recuperação. Muito embora "umbilicalmente ligadas" diferenciadas, com caraterísticas próprias e finalidades específicas.

Dúvidas podem suscitar-se a respeito dos instrumentos, dos meios, de que pode o GRA lançar mão para proceder à identificação e localização dos ativos. Sendo que a lei equipara o Gabinete aos órgãos de investigação criminal no que respeita às suas atribuições de investigação, parece implicar-se aí que todos os meios de obtenção de prova disponíveis no nosso ordenamento jurídico para a investigação criminal poderão igualmente ser utilizados na investigação patrimonial e financeira, desde que, naturalmente, estejam preenchidos os requisitos legais a que cada um deles obedeça ${ }^{56}$. Esta opção, todavia, não se apresenta isenta de dificuldades. Primeiro, porque esta equiparação de atribuições, feita pela lei, não afasta a natureza intrinsecamente distinta que tem sido reconhecida a uma e outra investigação. E, se assim é, se a investigação patrimonial e financeira é realidade autónoma e essencialmente diversa da investigação criminal propriamente dita, reticências podem ser colocadas à utilização por esta dos meios, particularmente intrusivos, que o legislador entendeu dedicar à atividade de averiguação de factos criminosos e dos seus agentes. Sobretudo quando, como acontece atualmente, temos uma definição de perda cada vez mais ampla, que passou já da perda tradicional ou clássica ${ }^{57}$ para a chamada perda ampliada ou alargada ${ }^{58}$ e que

lei n. ${ }^{\circ}$ 45/2011, de 24 de junho.

${ }^{55}$ Nas palavras de João Conde Correia, Da Proibição do Confisco à Perda Alargada, (Lisboa: INCM, 2012), 193, que nos diz que "[d]e acordo com a Lei, uma coisa será a investigação criminal, realizada no inquérito, segundo os cânones e com as finalidades tradicionais, e outra bem diferente, a investigação financeira e patrimonial documentada num apenso (art. $4 .^{\circ} n .^{\circ} 5$ da Lei n. ${ }^{\circ} 45 / 2011$, de 24 de junbo) e com objectivos especificos. Ainda que contemporâneas ou sobrepostas (umbilicalmente ligadas), as duas investigações são distintas".

${ }^{56}$ Neste sentido, por exemplo, Hélio Rigor Rodrigues, "Gabinete de Recuperação de Activos", 76-77, muito embora admitindo o Autor que esta leitura possa suscitar algumas interrogações.

${ }^{57}$ Globalmente correspondente àquela que está consagrada nos arts. 109. e ss. do Código Penal português.

${ }^{58}$ Entre nós vertida na lei n. ${ }^{\circ}$ 5/2002, de 11 de janeiro, cujo art. $7 .^{\circ}$ dispõe lapidarmente no seu n. ${ }^{\circ}$ 1: " $[e] m$ caso de condenação pela prática de crime referido no artigo 1.", e para efeitos de perda de bens a favor do Estado, presume-se constituir vantagem de atividade criminosa a diferença entre o valor do património do arguido e aquele que seja congruente com o seu rendimento lícito". Como dissemos já, esta modalidade de perda prescinde 
pode mesmo avançar - agudizando muitíssimo os problemas que estamos a apontar - para o chamado sistema civil de recuperação de ativos ${ }^{59}$. Depois, porque ainda que se entenda superada esta dificuldade (ou não significativa), a verdade é que outros obstáculos concretos podem suscitar-se, como é o caso de saber se poderão ser utilizados na investigação patrimonial e financeira os meios de obtenção de prova que expressamente exigem a demonstração da sua indispensabilidade para a descoberta da verdade material ${ }^{60 / 61}$.

Em segundo lugar, impõe-se igualmente uma referência ao art. $8 .^{\circ}$ da lei n. 45/2011, de 24 de junho, que dispõe o seguinte: " [c]om vista à realização da investigação financeira ou patrimonial referida no presente capitulo, o GRA pode aceder a informação detida por organismos nacionais ou internacionais, nos mesmos termos dos órgãos de polícia encarregados da investigação criminal' (n. ${ }^{\circ}$ ), clarificando em seguida que GRA pode aceder, nomeadamente, às bases de dados do Instituto dos Registos e do Notariado, I. P.; da Direção-Geral dos Impostos e da Direção-Geral das Alfândegas e dos Impostos Especiais sobre o Consumo; da Segurança Social; do Instituto de Seguros de Portugal; da Comissão do Mercado de Valores Mobiliários; e do Banco de Portugal. Importantíssima, como se compreende, esta faculdade de acesso à informação, que o legislador sentiu necessidade de sublinhar no texto do diploma. Na verdade, tal como é comummente reconhecido, o acesso à informação (em particular, aos dados dos

da conexão direta ao ato criminoso em causa e baseia-se, antes, na incongruência do património do arguido, presumindo a sua ilicitude e invertendo o ónus da prova.

${ }^{59}$ A non-conviction based asset forfeiture é a perda de bens não dependente de uma condenação do arguido em processo crime que, sendo própria do modelo anglo-saxónico, tem vindo a ser referida em sucessivos instrumentos internacionais. Cfr., a este propósito, Euclides Dâmaso Simões e José Luís F. Trindade, 'Recuperação de Activos: Da Perda Ampliada à Actio in Rem (Virtudes e Defeitos de Remédios Fortes para Patologias Graves)" Julgar Online (2009) e "Recuperação de Activos - Confisco sem ação penal - A "actio in rem" na jurisprudência do Tribunal Europeu dos Direitos Humanos" Julgar Online (2016); Hélio Rigor Rodrigues e Carlos A. Reis Rodrigues, Recuperação de Activos na Criminalidade Económico-Financeira, 267 e ss.; e Karla Padilha Rebelo Marques, "O sistema civil de recuperação de ativos como instrumento de efetividade da realização do direito (e sua conformidade com os princípios inspiradores do processo civil e com os primados constitucionais)", Julgar Online (2014).

${ }^{60}$ É, por exemplo, o caso das escutas telefónicas, nos termos do n. ${ }^{\circ} 1$ do art. $187 .{ }^{\circ}$ do CPP.

${ }^{61}$ Levantando este problema, e não o considerando intransponível, Hélio Rigor Rodrigues, "Gabinete de Recuperação de Activos", 76-77. 
cidadãos a diversos níveis) é hoje realidade incontornável do investigação financeira e patrimonial - mais ainda, porventura, do que da investigação criminal propriamente dita -, que depende em larguíssima medida da capacidade de obter conhecimento atempado a respeito dos dados bancários e da propriedade de bens móveis e imóveis.

Dúvidas poderão suscitar-se, uma vez mais, em torno desta faculdade concedida ao GRA, pois que ela corresponde a um enorme poder de intromissão na reserva da vida privada dos indivíduos. Sempre terá de sublinhar-se, todavia, que, por um lado, uma eficaz investigação financeira e patrimonial tendente à efetiva recuperação de ativos não pode fazer-se sem que se concedam os instrumentos necessários para o efeito - dependendo, pois, do legislador, em verdadeira opção político-criminal, saber que modelo pretende implementar a este nível -, e que, por outro, o texto da lei teve o cuidado, uma vez mais, de equiparar a atuação do Gabinete neste âmbito à dos órgãos de polícia encarregados da investigação criminal, ficando pois sujeita às mesmas regras, pressupostos e limitações, nomeadamente no que respeita à exigência de autorização, como aliás resulta do n. ${ }^{0} 3$ do preceito $^{62}$. Não se permite, pois, aqui, coisa distinta daquela que o ordenamento jurídico prevê já para a (restante) investigação criminal.

\section{Conclusão e reflexão prospetiva}

Assim apresentados, de modo necessariamente perfunctório, os traços essenciais do Gabinete de Recuperação de Ativos português, impõe-se agora uma reflexão simultaneamente conclusiva e prospetiva. Por um lado, será inegável reconhecer que a lei n. ${ }^{\circ}$ 45/2011, de 24 de junho, colocou Portugal ao nível dos seus pares internacionais, sobretudo europeus, no que à matéria da recuperação de ativos respeita, adequando o ordenamento jurídico interno às obrigações assumidas pelo

\footnotetext{
${ }^{62}$ Cfr., a este propósito, as reflexões de Hélio Rigor Rodrigues e Carlos A. Reis Rodrigues, Recuperação de Activos na Criminalidade Económico-Financeira, 36-37, chamando a atenção para a parcial incongruência entre o disposto no n. ${ }^{\circ} 4$ deste art. $8 .^{\circ}$ e o que vai fixado no n. 3 do art. $79 .^{\circ}$ da lei n. ${ }^{\circ} 36 / 2010$, de 2 de setembro, que criou a base de contas bancárias junto do Banco de Portugal.
} 
Estado português. E, nessa medida, como já era defendido ${ }^{63}$ e foi imediatamente reconhecido ${ }^{64}$, a implementação do GRA representou um significativo avanço alguns dirão, o verdadeiro arranque - da investigação financeira e patrimonial em Portugal.

A receção de um modelo como este, assente na ideia de que é essencial perseguir o dinheiro, de modo a atingir não apenas o facto criminoso passado e sob investigação mas igualmente a evitar que os ativos dele decorrentes possam financiar o cometimento de novos atos ilícitos ou entrar na atividade económica regular, distorcendo a concorrência, não está, todavia, isenta de críticas.

De uma primeira perspetiva, sempre se poderá questionar quer a importância reconhecida aos instrumentos, produtos e vantagens decorrentes do crime, quer o seu peso relativo face à investigação criminal propriamente dita. Ou, se se preferir, estando o direito penal pensado para a proteção de bens jurídicos, até que ponto faz sentido autonomizar a investigação financeira e patrimonial, autorizando-lhe a utilização do instrumentário próprio do direito criminal, particularmente limitador de direitos, liberdades e garantias? Se é certo que não nos parece constituir esta questão um óbice suficientemente relevante para pôr em causa o modelo existente em Portugal, a verdade é que devemos permanecer atentos, sobretudo à expansão do arquétipo em causa e alargamento dos poderes correspondentes. $\mathrm{Na}$ verdade (muito embora esta não seja uma questão necessariamente ligada apenas ao GRA), quer o regime da perda ampliada, quer, sobretudo, a hipótese de um mecanismo de perda civil, suscitam já problemas de monta, a exigir uma reflexão detida e aprofundada ${ }^{65}$, pois que parecem caminhar cada vez para mais longe do direito penal e dos seus cânones humanistas e garantistas.

\footnotetext{
${ }^{63}$ Atente-se, a este propósito, nas conclusões do Projeto Fénix, coordenado pela Procuradoria-Geral da República, em Recuperação de Activos - Projecto Fénix (Lisboa: Procuradoria-Geral da República, 2012), maxime, no caso, 401 e ss.

${ }^{64}$ Ver as considerações de Euclides Dâmaso Simões, "A proposta de Lei sobre o Gabinete de Recuperação de Activos (Um passo no caminho certo)", Revista do CEJ 14 (2010), 192; e Hélio Rigor Rodrigues, "Gabinete de Recuperação de Activos", 63-64.

${ }^{65}$ Que, naturalmente, não cabe nem no escopo nem do espaço deste trabalho. Ver, a propósito de um e outro instrumento, as referências bibliográficas que fomos indicando.
} 
De um outro enfoque, o próprio regime criado em 2011 e consubstanciado na criação do GRA contém alguns aspetos que podem ser discutíveis. Desde logo, como é óbvio, os critérios eleitos para a atribuição da competência de investigação ao Gabinete. Claramente pensado para fazer face à criminalidade económica mais grave e séria, poderá afirmar-se que esse juízo deixa de fora da alçada do GRA um conjunto muito significativo de criminalidade, que será tratado de forma forçosamente distinta. Uma vez mais, afigura-se-nos que uma tal opção se encontra ainda justificada, pois que está aqui em causa não a investigação criminal propriamente dita mas apenas a investigação patrimonial, a exigir, nas hipóteses em apreço, meios específicos e fortalecidos, mas que não põem em questão a possibilidade de levar a cabo uma tal investigação também nos demais casos. Vários outros aspetos poderiam ser sublinhados - para alguns deles, aliás, já fomos chamando a atenção ao longo deste texto - , mas pretendemos deixar somente uma última palavra para a necessidade de um especial cuidado na administração dos ativos alvo de apreensão ou recuperação por força da intervenção do Gabinete. Também sobre este aspeto se debruça a lei n. ${ }^{\circ}$ 45/2011, de 24 de junho ${ }^{66}$, dedicando os arts. $100^{\circ}$ e ss. ao Gabinete de Administração de Bens (GAB), que também criou, reconhecendo a exigência de que tais bens sejam administrados, "no estrito respeito pelo princípio da transparência, visando a gestão racional e eficiente dos bens administrados e, se possivel, o seu incremento patrimonial' ${ }^{67}$. Efetivamente, se o objetivo de proteger, conservar e gerir os bens recuperados ou à guarda do Estado ${ }^{68}$ parece incontroverso, já a hipótese de determinar a venda, a afectação ao serviço público ou a destruição dos bens mencionados na alínea anterior, desde que salvaguardado o cumprimento da regulamentação europeia aplicável ${ }^{69}$, não será seguramente tão pacífico. Também aqui, se bem vemos, será preciso manter uma observação atenta e crítica, de modo a evitar a subversão do modelo gizado.

\footnotetext{
${ }^{66}$ Também aqui com críticas, naturalmente.

${ }^{67}$ Conforme estabelece o n. ${ }^{\circ} 4$ do art. 10. ${ }^{\circ}$ do diploma.

${ }^{68}$ Nos termos da alína a) do n. ${ }^{\circ} 3$ do art. $10 .^{\circ}$ referido.

${ }^{69}$ Alínea b) do mesmo preceito.
} 


\section{La búsqueda de la homogeneidad en las atribuciones de los Miembros Nacionales de Eurojust y su papel en la lucha contra la delincuencia transnacional: ¿misión cumplida?}

\section{Gemma Pérez Souto*}

RESUMEN: Eurojust es la Unidad de Cooperación Judicial de la Unión Europea creada en el año 2002 con la finalidad de cumplir sus objetivos en la lucha contra la delincuencia transnacional grave. Tras su refuerzo mediante la Decisión 2009, en la actualidad se encuentra pendiente de ser aprobada la propuesta de Reglamento que debería concluir en la Agencia Europea de Cooperación en materia de Justicia Penal. En su iter jurídico ba sido común denominador el intento de procurar la homogeneidad en las atribuciones del estatuto de sus Miembros Nacionales capaz de ser conjugada con los respectivos ordenamientos jurídicos de los Estados Miembros y la eficacia en las funciones de Eurojust. El objetivo de este trabajo se centra en determinar si ha sido posible alcanzar tal homogeneidad y si ello contribuiría a un mejor funcionamiento de Eurojust en su lucha contra la delincuencia transnacional. Para ello se analizará la evolución de sus distintos instrumentos jurídicos, partiendo de la Decisión 2002 de creación de Eurojust hasta la actual propuesta de Reglamento 2013 aún en fase de discusión.

PALABRAS CLAVE: dedlincuencia transnacional - cooperación judicial en materia penal - Eurojust - asimetría de las competencias de los Miembros Nacionales.

ABSTRACT: Eurojust is the European Union's Judicial Cooperation Unit set up in 2002 with the main objective of supporting the national authorities of the Member States in the cooperation and coordination of transnational investigations and prosecutions against cross-border crime. Council Decision 2009/426/JHA on the strengthening of Eurojust amended the Unit's legal framework and on 17 July 2013 the Commission presented the proposal for a regulation of the European Parliament and of the Council on the European Union Agency for Criminal Justice Cooperation (Eurojust). From the very beginning it was felt that Eurojust National Members should be granted with a minimum common denominator of equivalent individual powers according to their Member States and corresponding

\footnotetext{
* Miembro Doutorado del Centro de Estudos em Direito da União Europeia (CEDU), Universidade do Minho.
} 
legal systems and, at the same time, able to perform the coordination and cooperation task of the Unit. This article aims to show if such minimum status was finally achieved and thus if contributes to the effectiveness of Eurojust in fighting against cross-border crime, analyzing this question through its different legal instruments till the proposal 2013 currently under discussion.

KEYWORDS: cross-border crime - judicial cooperation in criminal matters - Eurojust - National Members variable-geometry powers.

\section{Introducción}

Eurojust se convertiría en el año 2002 a través de su Decisión de creación ${ }^{1}$, en el primer órgano con personalidad jurídica propia instituido para la cooperación judicial permanente en el marco de la Unión Europea. Su objetivo principal es contribuir a una mayor eficacia de las autoridades nacionales encargadas de la instrucción e investigación, intensificando la cooperación judicial y la coordinación, con el fin de luchar más diligentemente contra los casos de delincuencia transnacional grave en los cuales se vean involucrados dos o más Estados ${ }^{2}$. En el momento actual asistimos

\footnotetext{
${ }^{1}$ Decisión (2002/187/JAI) del Consejo de 28 de febrero de 2002 por la que se crea Eurojust para reforzar la lucha contra las formas graves de delincuencia (DO L 63/1, 6.3.2002).

${ }^{2}$ La originaria Decisión de creación de Eurojust,contemplaba asimismo en su redacción del artículo 3 en sus apartados 2 y 3, la posibilidad de que para dar cumplimiento a los objetivos de Eurojust, fuese posible también prestar apoyo en sus tareas de coordinación y cooperación a investigaciones y actuaciones que afectasen a un solo Estado miembro de la Unión (si así lo solicitaba su autoridad competente) y a un tercer estado si se hubiese celebrado con ese país un acuerdo de cooperación. Asimismo, el artículo 3 contenía la posibilidad de que a petición de una autoridad de Estado miembro o de la Comisión, Eurojust podría prestar asistencia a investigaciones y actuaciones que afectasen a un solo Estado miembro y a la Unión Europea. El último texto de la orientación general de 27 de febrero de 2015 (6643/15) de la Propuesta de Reglamento de Eurojust que se encuentra en fase de desarrollo, también recoge la posibilidad de que Eurojust intervenga en los casos que contemplen formas graves de delincuencia y para los que sea competente, cuando afecte a un solo Estado miembro, o a un solo Estado miembro y a un tercer Estado con el que se haya celebrado un acuerdo de cooperación, o a un Estado miembro y la Unión, pero que deben perseguirse de acuerdo a criterios comunes (considerandos 9 y 9 bis). Asimismo, recoge la posibilidad de que a petición de la autoridad competente de un Estado miembro o de la Comisión, Eurojust podrá prestar su apoyo a investigaciones de un solo Estado miembro pero que tengan "repercusiones a escala de la Unión”, considerándose estos casos como aquellos que afectan a una institución, órgano u organismo de la Unión, o a un número significativo de los
} 
a un nuevo período de evolución de Eurojust hacia la "Agencia Europea de Cooperación en materia de Justicia Penal', en tanto en cuanto aún se encuentra en fase de discusión y desarrollo, la propuesta de Reglamento $2013^{3}$ de Eurojust traída a escena al mismo tiempo que la respectiva propuesta de la creación de la futura Fiscalía Europea ${ }^{4}$

Para proceder al establecimiento de la Unidad de Cooperación Judicial de la Unión Europea se optaría por la Decisión ${ }^{5}$, pero es necesario que recordar que la misma Decisión ${ }^{6} 2002$ de creación de Eurojust en su artículo 42 venía a confirmar que no existía ningún método que se pudiese aplicar de manera común a todos los Estados Miembros $^{7}$ para llevar a cabo su transposición limitándose a señalar que

Estados miembros y que puedan requerir una respuesta europea coordinada.

${ }^{3}$ Comisión Europea, Propuesta de Reglamento del Parlamento europeo y del Consejo sobre la Agencia Europea de Cooperación en materia de Justicia Penal (Eurojust), COM (2013) 535 final, Bruselas, (17.7.2013). Para un seguimiento de su iter legislativo al que haremos referencia en este trabajo, consultar: http://www. europarl.europa.eu/oeil/popups/ficheprocedure.do?reference=2013/0256(COD)\&l=en.

${ }^{4}$ Comisión Europea, Propuesta de Reglamento del Consejo relativo a la creación de la Fiscalía Europea, COM (2013) 534 final, 2013/0255 (APP), Bruselas, (17.7.2013). Para un seguimiento de su iter legislativo al que haremos referencia en este trabajo, consultar: http://www.europarl.europa.eu/oeil/popups/ ficheprocedure.do? reference $=2013 / 0255$ (APP) \&l $=E N \#$ documentGateway.

${ }^{5}$ Suominen opinaba que la creación de Eurojust "a través de una Decisión del Consejo y no mediante una Convención, supuso que se dejara abierta la crítica tanto porque suponía el resultado de una decisión supranacional en un área tan cercana a la soberanía nacional, como también por la relativa facilidad con que el instrumento jurídico de la Decision podia ser modificado", Vid., Annika Suominen, "The past, the present and the future of Eurojust", Maastricht Journal of European and Comparative Law 15 (2008):219. Por otro lado, en una interesante reflexión, la Comisión de Asuntos Jurídicos del Parlamento Europeo afirmaría que la naturaleza jurídica de las decisiones "parece infringir el principio fundamental de la seguridad jurídica y el derecho fundamental a un control efectivo", Vid., Parlamento Europeo, Opinión de la Comisión de Asuntos Jurídicos y Mercado Interior para la Comisión de Libertades y Derechos de los Ciudadanos, Justicia y Asuntos Interiores sobre la Iniciativa de República de Finlandia, con vistas a la aprobación de la Decisión del Consejo relativa a las disposiciones de cooperación entre las unidades de información financiera de los Estados miembros para el intercambio de información, , 11636/1999, C50330/1999-1999/0824 CNS, Bruselas, (28.3.2000), p.4

${ }^{6}$ Como es conocido, las Decisiones eran obligatorias para todos los Estados Miembros; esto suponía que su contenido en sí mismo creaba obligaciones jurídicas para aquéllos, pero al mismo tiempo dejaba a los países la toma de medidas necesarias para la puesta en marcha de tales decisiones unas "medidas complementarias indispensables" que hiciesen posible la aplicación efectiva de sus previsiones, Vid., Sentencia del TJCE de 10 de septiembre de 1996, as. C-277/94, caso Z. Taflan Met.

${ }^{7}$ Asimismo, el informe de la Comisión Europea sobre la transposición a los ordenamientos jurídicos de los Estados Miembros de la Decisión Eurojust, recordaba entonces que "en sí misma, la Decisión Eurojust no contempla una aproximación de las legislaciones nacionales, contrariamente a una decisión marco que se adoptara de conformidad con lo dispuesto en la letra b) del apartado 2 del artículo 34 del Tratado de la Unión Europea", Vid.,Comisión Europea, Informe de la Comisión sobre la transposición a los ordenamientos jurídicos nacionales de la 
deberían adaptar su derecho nacional "a la mayor brevedad" y "en cualquier caso a más tardar el 6 de septiembre de 2003", plazo que no sería cumplido ${ }^{8}$ por la mayoría de los Estados.

El Consejo ya haría notar ${ }^{9}$ entonces un aspecto esencial que en la actualidad se continúa intentar equilibrar, y que se resume en que la heterogeneidad en el estatus de los distintos Miembros Nacionales de Eurojust no obstaculice en la práctica su trabajo operativo contra la delincuencia transnacional grave. Esta heterogeneidad supone que en el transcurso de determinadas operaciones de cooperación o coordinación no todos los Miembros Nacionales posean iguales competencias entre sí, por ejemplo, a la hora de practicar o solicitar que se practique determinada identificación de las diligencias o en sus condiciones de acceso a la información en su país de los asuntos competencia de Eurojust (bases de datos de interés o registros de $\mathrm{ADN}$, por citar las más habituales $)^{10}$, cuestión que se explica en definitiva, por

Decisión del Consejo de 28 de febrero de 2002 por la que se crea Eurojust para reforzar la lucha contra las formas graves de delincuencia, COM (2004) 457 final, (6.7.2004), p. 1.

8 A excepción hecha de Portugal que sí cumplió en el tiempo establecido, el plazo dado para la transposición de la Decisión Eurojust no fue respetado por la mayoría de los Estados miembros, siendo objeto de sucesivas llamadas de atención por parte de la propia Eurojust que se reflejarían en sus respectivos informes anuales: En este sentido, el Informe anual de Eurojust del año 2003, p. 6, mencionaba que: "existe aún un número de Estados que no han adaptado su legislación, y por tanto, han incumplido el plaz̧o señalado por la Decisión. Tenemos la seguridad de que esto ha influido negativamente en el trabajo de Eurojust sobre casos concretos. En particular, es necesario que todos los Miembros nacionales tengan acceso a la información que precisen para el ejercicio de sus funciones. Algunos de los Miembros nacionales reciben muy pocos casos de sus autoridades nacionales competentes; entendemos que ello pueda deberse a menudo a la ausencia de legislación interna de desarrollo". Asimismo, el Informe anual de 2004, pág. 5, señalaba: "varios Estados miembros, no sólo los que se incorporaron a la Unión Europea en mayo de 2004, aún no han adoptado normas internas de transposición, incumpliendo así el plazo señalado por la Decisión". Los informes anuales de Eurojust pueden encontrarse en su web oficial, www.eurojust.europa.eu.

${ }^{9}$ A propósito de la observación de este asunto, el Consejo emitiría una nota en la que orientaba acerca de las competencias básicas que debían atribuirse a cada Miembro nacional con el fin de que para la buena marcha de Eurojust y la cooperación judicial, todos los Miembros Nacionales dispusiesen de un estatuto y competencias comparables, Vid., Consejo de la Unión Europea, Nota a las Delegaciones sobre la adaptación del Derecho nacional de los Estados miembros a la Decisión por la que se crea Eurojust, 9404/02, EUROJUST 16, Bruselas, (14.6.2002).

${ }^{10}$ La doctrina señalaría en este sentido que: "Uno de los puntos débiles de Eurojust es el hecho de que los poderes de los Miembros Nacionales difieren de manera considerable, creando una situación insostenible. Por ejemplo, la cooperación judicial es retrasada debido al hecho de que no todos los Miembros Nacionales tienen la misma capacidad para acceder a sus respectivas bases de datos nacionales", Vid., Suominen, "The past, the present and the future of Eurojust", 226. Vid., también, Nadine Thwaites, "Eurojust: autre brique dans l'édifice de la coopération judiciaire en matière pénale 
los diferentes ordenamientos jurídicos nacionales ${ }^{11}$. Con base en estas premisas que acabamos de señalar se establece el objeto de nuestro estudio, para determinar cómo ha sido tratada la heterogeneidad en el estatus y, por tanto, en las atribuciones de los Miembros Nacionales de Eurojust a través de la evolución de sus distintos instrumentos jurídicos. Para ello, se partirá desde los inicios de la Unidad desde la Decisión 2002 de creación, realizando un recorrido en su iter legislativo hasta la -aún en discusión- actual Propuesta de Reglamento 2013 sobre la Agencia Europea de Cooperación en materia de Justicia Penal que, a pesar de su propio carácter de Propuesta ( $\mathrm{y}$ no de texto definitivo), presenta un valor indicativo de tendencias presentes y futuras en la materia que nos ocupa.

\section{La Decisión de creación 2002 de Eurojust y las competencias de los Miembros Nacionales: del consenso en el establecimiento de la Unidad a las consecuencias de la heterogeneidad de sus estatutos en la misión de Eurojust contra la delincuencia transnacional}

La cuestión del estatus del Miembro Nacional y sus competencias en Eurojust, se plantearía mucho antes de su definitiva creación en el año 2002, con la puesta en funcionamiento de la Unidad provisional Pro Eurojust ${ }^{12}$. Los trabajos para crear una Unidad de Cooperación Judicial en la Unión Europea fueron largos y complicados y hubieron de explorarse diferentes escenarios de actuación ante las

\footnotetext{
ou solide mortier?", Revue de science criminelle et de droit penal comparé 1 (2003): 51-52.

${ }^{11}$ Cobran entonces actualidad, en nuestra opinión más que nunca, las palabras de Edgard Morin: "Europa necesita una política de seguridad coordinada en un momento bistórico en el que las amenazas para la paz. no se limitan a la forma tradicional del ataque externo, sino que se extienden por nuestras sociedades con el terrorismo y con las guerras informáticas", Vid., Edgard Morin \& Mauro Ceruti, La nostra Europa, (Milano: Raffaello Cortina Editore, 2013), 62.

12 Antes de la definitiva creación de Eurojust, entraría en funcionamiento la Unidad Provisional ProEurojust, que serviría de laboratorio de pruebas para el futuro de la cooperación judicial en materia penal. Pro-Eurojust se establecería mediante la Decisión del Consejo de 14 de diciembre de 2000 por la que se crea una Unidad provisional de Cooperación Judicial, (DO L 324, 21.12.2000).
} 
futuras atribuciones de los Miembros Nacionales ${ }^{13}$ que concluyesen en el diseño de un dispositivo eficaz en el ámbito de la cooperación judicial penal para luchar contra la delincuencia transnacional grave.

De acuerdo a la Decisión de creación 2002, Eurojust debía estar compuesta por un Miembro Nacional por cada Estado de la Unión "conforme a su sistema jurídico" con la condición de fiscal, juez o funcionario de policía ${ }^{15}$ con competencias equivalentes". " Las competencias iniciales conferidas a los Miembros Nacionales en la primigenia Decisión pronto se mostrarían asimétricas debido a la acordada dependencia de aquéllos de sus respectivos Estado Miembros, así que ante el ejercicio desigual de sus facultades, el Consejo ${ }^{17}$ - en aras de identificar dicha problemática y proponer soluciones- terminaría identificando esta asimetría clasificando las competencias en diferentes niveles de intensidad: "reducida", "media" y "elevada".

En la de "intensidad reducida", el Miembro Nacional podía solicitar a la autoridad competente de su país la práctica de diligencias de determinadas pruebas o también que varias autoridades competentes se coordinasen en el ejercicio de actuaciones penales sin que ello tuviese un carácter vinculante. El Miembro Nacional con competencias de "intensidad media", poseía el derecho de ordenar a la autoridad de su Estado la práctica de diligencias de obtención de información o de pruebas e incluso

\footnotetext{
${ }^{13}$ Una muestra de dichos trabajos la constituye el documento del Consejo denominado Reflexiones sobre Eurojust que contemplaba las distintas opciones de actuación de Eurojust una vez que ésta se pusiese en funcionamiento y entre la que se encontraba la espinosa cuestión de las competencias de los futuros Miembros Nacional que se planteaba de la siguiente manera en este documento de trabajo para ser discutido por los Estados Miembros: "¿Estaría dispuesto a conferir poderes nacionales (en todo el territorio de su pais) a su representante ante Eurojust?; ¿Convendría prever una flexibilidad en la determinación de los poderes de Eurojust, de manera que las competencias de los representantes nacionales ante Eurojust variaran en función de la legislación nacional (poder de decisión o simplemente de coordinación y de facilitación)?', Vid., Consejo de la Unión Europea, Nota de la Presidencia. Reflexiones sobre Eurojust, 5700/1/00 REV 1, CATS 7, (22.2.2000).

${ }^{14}$ Lo cual, como hemos venido señalando, preveía la posibilidad de que se produjese una gran asimetría entre las competencias de los diferentes Miembros Nacionales como así efectivamente sucedió, viniendo a dar la razón al Consejo en su percepción de dicha problemática y contemplación de escenarios posibles, Vid., aún, Consejo de la Unión Europea, Nota a las Delegaciones...

${ }^{15}$ Sin embargo, es una tendencia en Eurojust que continúa en la actualidad que la mayoría de los Miembros Nacionales y los adjuntos a los mismos procedan de la carrera fiscal.

${ }^{16}$ Artículo 2 de la Decisión 2002/187/JAI del Consejo...

${ }^{17}$ Consejo de la Unión Europea, Nota a las Delegaciones...,punto 2.2.2.
} 
la capacidad de realizarlas él mismo de acuerdo a su ordenamiento jurídico nacional. Finalmente, en las competencias de "intensidad elevada" el Miembro Nacional podría ejercer por sí mismo la acción pública y realizar las diligencias necesarias a tal efecto, además de solicitar la intervención de la policía en relación a los delitos competencia de Eurojust.

En esta misma línea, la doctrina continuó poniendo de manifiesto como la divergencia en las atribuciones de los Miembros Nacionales podía suponer en la práctica un importante obstáculo a la cooperación judicial ${ }^{18}$. Así, Alonso Moreda

\footnotetext{
${ }^{18}$ Esta cuestión ya fue abordada por la Comisión en el momento primigenio en el que se discutía acerca de la creación de Eurojust tras la eficaz puesta en marcha de la Unidad provisional Pro Eurojust. La Comisión señalaba cómo el otorgar un mínimo de atribuciones homogéneas a los Miembros Nacionales (al principio denominados "delegados") favorecería su trabajo en la Unidad, de la misma manera que una excesiva divergencia en su respectivo estatus podría perjudicarlo: "Es también deseable que los Estados miembros se pongan de acuerdo por lo menos sobre un mínimo común denominador de los poderes individuales equivalentes conferidos a sus delegados nacionales con vistas a su posible conjunción operativa. En caso de que fuera necesaria una acción urgente por ejemplo para una congelación de activos, sería muy útil que todos los delegados en Eurojust estuvieran autorizados al menos por su Estado miembro a ordenar la medida o a solicitarla al juez, nacional competente para abarcar todos los territorios nacionales pertinentes. Por otra parte, si los poderes de los delegados nacionales individuales divergieran considerablemente, podría afectar negativamente o influir artificialmente sobre el funcionamiento de la coordinación en algunos casos", Vid., Comisión Europea, Comunicación de la Comisión sobre la creación de Eurojust, COM (2000) 746 final, Bruselas (22.11.2000), p.6-7. La doctrina ha venido sosteniendo esta teoría de manera mayoritaria sobre todo en lo que se refiere a un acuerdo -al menos- en la homogeneidad de unas mínimas atribuciones a los diferentes Miembros Nacionales que facilitasen el trabajo operativo de Eurojust y, por ende, la cooperación y coordinación en los fines que le son propios. Vid., Hans G. Nilsson and Maylis Labayle, "The Role and Organisation of Eurojust: Added Value for Judicial Cooperation in Criminal Matters", in The institutional dimension of the European Union's area of freedom, security and justice, ed. Jörg Monar , (Bruxelles: Peter Lang, 2010), 195-215; Steve Peers, "Revising the Eurojust Decision: Effectiveness versus Accountability”, Journal of European Criminal Law 2 (2008-2009): 5-18; Jiri Vlastník, "Eurojust -A cornerstone of the federal criminal justice system in the EU?" in Security versus Justice? Police and Judicial Cooperation in the European Union, ed. Elspeth Guild and Florian Geyer (Aldershot: Ashgate Publishing, 2008), 35-49. Otros autores sostienen que, de hecho, -y a pesar de los intentos de homogeneizar las atribuciones y el estatus de los Miembros Nacionales de Eurojust con la modificación de la Decisión en 2009-, en la práctica persisten las limitaciones. Vid., también en este sentido, Anne Weyembergh, "The Development of Eurojust: Potential and Limitations of Article 85 of the TFEU", New Journal of European Criminal Law 1 (2011):75-99. Téngase en cuenta que la propia Decisión 2009 en su artículo 9 sexies establece lo siguiente, con las consiguientes limitaciones: "Solicitudes de los miembros nacionales en caso de que no puedan ejercerse las competencias. 1. El miembro nacional, en su condición de autoridad nacional competente, será competente como minimo para presentar una propuesta a la autoridad competente para que se ejerzan las competencias contempladas en los articulos 9 quater y 9 quinquies cuando conferir dichas competencias al miembro nacional sea contrario a:a) normas constitucionales; b) aspectos fundamentales del sistema judicial penal: i) sobre el reparto de competencias entre la policía, fiscales y jueces, ii) sobre la división de funciones entre autoridades fiscales, o iii) sobre la estructura federal
} 
hacía notar "las dificultades que provoca la insuficiente regulación originaria, que se ha traducido en una grave falta de uniformidad en los estatutos jurídicos de los diferentes Miembros Nacionales, lo que constituye una de las principales debilidades de la regulación de Eurojust"'19. Xanthaki señalaba, asimismo, que "las discrepancias acerca del estatus de los Miembros Nacionales son inevitables en circunstancias en las cuales no existe uniformidad en el derecho penal sustantivo o en el derecho procesal. Sin embargo, un cierto grado de armonización en las competencias concedidas a los Miembros Nacionales permitiría a la Unidad funcionar coherentemente y sin discriminación alguna basada en la nacionalidad"20.

Con el establecimiento de Eurojust se entraba de lleno en un asunto que constituía un paso esencial en la cooperación judicial: esto es, la puesta en marcha de la comunicación directa entre las autoridades judiciales evitando el canal de las autoridades centrales para así agilizar las actuaciones precisas frente al fenómeno de la delincuencia transnacional grave. No obstante las limitaciones del contexto jurídico de entonces, Eurojust - por su propia misión eminentemente práctica -, buscaría vías de entendimiento ${ }^{21}$ entre las autoridades nacionales para superar los obstáculos

del Estado miembro de que se trate. 2. Los Estados miembros garantizarán que en los casos a los que hace referencia el apartado 1, la solicitud expedida por el miembro nacional sea tramitada sin demora injustificada por la autoridad nacional competente". Finalmente, en fechas más recientes, la doctrina continua poniendo de manifiesto que esta falta de acuerdo en el estatus de los Miembros Nacionales deriva de la propia naturaleza de Eurojust que continúa influida por el "espiritu interestatal del antiguo tercer pilar", Vid. Anne Weyembergh et. al., The inter-agency cooperation and future architecture of the EU criminal justice and law enforcement área (Bruselas: European Parliament, 2014), 13.

${ }^{19}$ Vid., Nicolás Alonso Moreda, La dimensión institucional de la cooperación judicial en materia penal en la Unión Europea: magistrados de enlace, Red Judicial Europea y Eurojust (Bilbao:Servicio Editorial de la Universidad del País Vasco, 2010), 157.

${ }^{20}$ Vid., Helen Xanthaki, “Eurojust: Fullfilled or Empty Promises in EU Criminal Law”, European Journal of Law Reform 2 (2007): 186.

${ }^{21}$ El Consejo en su nota de reflexión acerca de la Adaptación del Derecho Nacional de los Estados Miembros de la Decisión 2002 de Eurojust, hizo especial énfasis en la cuestión del estatuto de los Miembros Nacionales y señalaba que: "Si la calidad y la experiencia profesional de las personas que componen el Colegio son absolutamente fundamentales, su estatuto no lo es menos. A este respecto, conviene que los Miembros Nacionales tengan un estatuto que les permita entablar una relación de confianza con los colegas de su Estado de origen, independiente de su nivel jerárquico". Además, a causa de la disparidad en los poderes de los Miembros Nacionales, el Consejo reconocía el valor añadido de Eurojust frente a la delincuencia transnacional y su capacidad de intervenir más allá de los cauces competenciales establecidos, debido a las relaciones de trabajo que se establecen entre los Estados a través de la tarea llevada a cabo por su Miembro Nacional. El Consejo lo remarca de esta manera, señalando que aquella relación de confianza con las autoridades de su Estado de origen tiene "aún mayor importancia para los Miembros Nacionales que no gocen de amplias 
legales fruto de la asimetría en los estatutos de los Miembros Nacionales que, sin embargo, no era posible subsanar en tanto en cuanto dicho marco jurídico no fuese modificado.

Ahondando en este argumento, se trae a colación otro aspecto de la Decisión de creación que de manera transversal debilitaba el ejercicio efectivo de las competencias de los Miembros Nacionales. Así, el artículo 9 de la Decisión 2002, establecía que era al Estado miembro de origen al cual le correspondía determinar la duración del mandato de los Miembros Nacionales y, en consecuencia, tal escenario podía interrumpir el adecuado desempeño de las funciones de la respectiva delegación destacada en La Haya, debido al hecho de que es necesario un término mínimo del mandato y al menos de una duración suficiente, para que los Miembros Nacionales puedan desarrollar y consolidar sus líneas estratégicas en Eurojust en la lucha contra la delincuencia nacional.

\section{De la Decisión 2002 a la Decisión 2009 de refuerzo Eurojust: el proceso} de toma de conciencia de los Miembros Nacionales hacia la necesaria revisión de sus atribuciones en busca del incremento de la eficacia de la Unidad.

El proceso de cambio y evolución en las competencias de los Miembros Nacionales que impulsaría el siguiente escalón hacia la Decisión 2009 de refuerzo de Eurojust, ${ }^{22}$ se construiría a través de la propia toma de conciencia de aquéllos ${ }^{23}$,

\footnotetext{
competencias judiciales: de ello dependerá su capacidad de persuasión y de acceso a la información", Vid., Consejo de la Unión Europea, Nota a las Delegaciones sobre la adaptación del Derecho nacional..., punto 3.

${ }^{22}$ Consejo de la Unión Europea, Decisión 2009/426/JAI del Consejo de 16 de diciembre de 2008 por la que se refuerza Eurojusty se modifica la Decisión 2002/187/JAI por la que se crea Eurojust para reforzar la lucha contra las formas graves de delincuencia, (DO L 138/14, 4.6.2009).

${ }^{23}$ Así se recordaba, señalando que era "importante que entre los miembros del Ministerio Fiscal a cargo de los procedimientos y el Miembro Nacional de Eurojust por un lado, y entre los Miembros Nacionales de Eurojust de los respectivos Estados Miembros por otro, se establez̧ca una relación desburocratizada y asentada en la confianza mutua así como en contactos directos e informales, orientada hacia el proceso en concreto, que incluya activamente a todas las entidades implicadas y más concretamente a la policia, al Ministerio Público y otras instituciones competentes de los Estados
} 
especialmente entre los que contaban con más experiencia en el campo de la cooperación judicial en la Unión Europea, ${ }^{24}$ señalando que era necesaria una profunda revisión de sus atribuciones así como de su estatuto, que impulsase a su vez el papel de Eurojust para evitar que sus capacidades se vieran progresivamente reducidas con el tiempo.

La homogeneidad en las atribuciones de los Miembros Nacionales y su acceso a la información debía ir pareja, por tanto, a la modificación del artículo 13 de la Decisión 2002. Así, en la antigua redacción de artículo 13 se establecía el carácter potestativo del intercambio de información con los Estados de la Unión y entre Miembros Nacionales: "Las autoridades competentes de los Estados Miembros podrán intercambiar ${ }^{25}$ con Eurojust cualquier información necesaria con miras al cumplimiento de las funciones de esta última de conformidad con lo dispuesto en el artículo 5". En cambio, la nueva redacción del artículo 13 de la Decisión 2009 señalaba que el intercambio de información sería obligatorio: "Las autoridades competentes de los Estados Miembros intercambiarán ${ }^{26}$ con Eurojust cualquier información necesaria ...", lo que suponía, por

\footnotetext{
Miembros (...) Estos aspectos son de gran importancia para mejorar la situación existente cuyas deficiencias son conocidas, de manera que se potencie una dimensión europea de la acción de la justicia para asi dar respuesta a los problemas de la cooperación en el ámbito de la criminalidad transnacional", Vid., José Luís Lopes da Mota, "O Ministério Público e a construçâo europeia: os caminhos da justiça penal e a Eurojust" in O Ministério Público e os novos desafíos da justiça. Actas do VI Congresso do Ministério Público de Evora, 21-24 de novembro de 2002, ed. Sindicato dos Magistrados do Ministério Público (Lisboa: Sindicato dos Magistrados do Ministério Público, 2007), 70. ${ }^{24}$ El Consejo de Ministros de Justicia e Interior reunido el 2 de diciembre de 2004, invitaría a Eurojust a evaluar desde su propia experiencia los poderes judiciales de sus miembros nacionales en naturaleza y alcance, y a darle cuenta del resultado para mediados del año 2005. Aunque de la evaluación llevada a cabo por Eurojust en aquel momento, se desprendía que el número de Miembros Nacionales afectados por los problemas graves de insuficiencia de competencias judiciales específicas ya sean propias o de compañeros, sucedía con cierta frecuencia pero no era tan amplio, no obstante, cuando estas disfunciones aparecían de manera práctica en una operación de coordinación de la Unidad, afectaban verdaderamente al alcance y al éxito de la misma. Uno de estos ejemplos lo encontramos en el curso de una investigación que fue coordinada por Eurojust, en la cual uno de los Miembros nacionales de los países concernidos por dicha operación estaba autorizado a solicitar la intervención de comunicaciones de los sospechosos, mientras que otro de los Miembros Nacionales parte de la misma operación, manifestó que difícilmente podría incluso recomendar la adopción de una medida de la misma naturaleza en su país, Vid., Michèle Coninsx, "Strengthening Interstate Cooperation: the Eurojust Experience", in Ana María Salina de Frías et al., Counter-terrorism: international law and practice, (Oxford, Oxford University Press, 2012), 967.

${ }^{25}$ Cursiva de la autora.

${ }^{26}$ Cursiva de la autora.
} 
tanto, la necesidad de establecer en los Estados una oficina nacional de coordinación que gestionase adecuadamente el envío de información a Eurojust.

Además, entre las competencias comunes mínimas que el Colegio de Eurojust entendía que todos los Miembros Nacionales debían poseer, se proponían las de presentar y tramitar solicitudes de asistencia judicial, ejercer como interlocutores principales de las autoridades judiciales extranjeras, recomendar y definir modalidades de asistencia, investigaciones y actuaciones judiciales y finalmente, determinar y autorizar entregas controladas en casos urgentes y definir otro tipo de actuaciones en tales casos (como la intervención de telecomunicaciones y operaciones encubiertas) ${ }^{27}$

A consecuencia de estos trabajos desarrollados en el seno de la propia Eurojust, se concluiría en una amplia revisión del artículo 9. En primer lugar, se introducirían los artículos 9 bis a 9 sexies para garantizar una duración mínima de los mandatos de los Miembros Nacionales así como una cláusula de salvaguarda ${ }^{28}$ en su imparcialidad ante posible el cese extemporáneo por parte de sus autoridades nacionales. En segundo lugar, se otorgaría a los Miembros Nacionales unas competencias de carácter mínimo y uniformes en todos los Estados Miembros, manteniéndose la vinculación con sus respectivas autoridades de origen pero reforzando la capacidad de Eurojust mediante los ajustes necesarios en las competencias de los Miembros Nacionales para que fuesen "autoridades nacionales competentes" en sí mismos en su ámbito de actuación ${ }^{29}$.

\footnotetext{
${ }^{27}$ Vid., Eurojust, Informe anual 2005, (La Haya, 2005), p. 25-26. Disponible en la web de Eurojust: www. eurojust.europa.eu

${ }^{28}$ La Decisión 2009 de refuerzo de Eurojust corregiría esta divergencia estableciendo una duración mínima de cuatro años con posibilidad de ser renovado por igual período. Además, se establecía que el Miembro Nacional no podrá ser separado del cargo antes del final de su mandato "sin que se informe previamente al Consejo y se le comuniquen los motivos", (artículo 9.1 de la Decisión 2009). La propuesta de Reglamento de Eurojust 2013 establece en el texto actual de su artículo 10.2 que: "El mandato de los miembros y de sus suplentes será de cuatro años como minimo, renovable una vez".

${ }^{29}$ El nuevo artículo 9 ter de la Decisión 2009/426/JAI establece que "1. Los Miembros Nacionales, en su condición de autoridades nacionales competentes, estarán facultados para recibir, transmitir, proporcionar, dar curso y aportar información complementaria en relación con la ejecución de las solicitudes y resoluciones en materia de cooperación judicial, incluidos los instrumentos que dan efecto al principio de reconocimiento mutuo. Cuando se ejerzan las competencias contempladas en el presente apartado, se informará sin demora a la autoridad nacional competente". El apartado 2 del citado artículo otorga al Miembro Nacional la facultad, en caso de ejecución parcial o inadecuada de una
} 
En tercer lugar, el Estado Miembro de origen debía al menos conferir una relación de competencias ejercidas "de acuerdo con" 30 la autoridad competente (artículo 9 quater) y otras que ejercerá únicamente en caso de urgencia (artículo 9 quinquies). La Decisión 2009 incluye además la capacidad del acceso a la información de los registros de su Estado31 "al menos equivalente al que tendría en su función de fiscal, juez.o funcionario de policía" y que como hemos visto, constituía uno de los "caballos de batalla" importantes de la anterior Decisión 2002.

Otro aspecto relevante en relación a la misión de Eurojust en su doble aspecto de cooperar y coordinar, lo constituye el hecho de que puede llevar a cabo sus funciones ejerciendo sus competencias por un lado a través del Colegio y por otro, a través de sus Miembros Nacionales. La Decisión 2009 mantendría los casos en los cuales las funciones de Eurojust se realizan a través de sus Miembros Nacionales ${ }^{32}$

cooperación judicial, de solicitar a la autoridad competente que su Estado Miembro que ordene medidas complementarias, a fin de dar cabal ejecución a la solicitud.

${ }^{30}$ Cursiva de la autora.

${ }^{31}$ En concreto, el artículo 9.3 de la Decisión 2009, señala los siguientes tipos de registros como aquellos a los que el Miembro Nacional de Eurojust deberá tener acceso: a) el registro de antecedentes penales; b) los libros-registro de detenidos; c) los registros de investigaciones; los registros de ADN y finalmente, otros registros de su Estado Miembro, cuando estime que estos contienen información que necesite para el ejercicio de sus funciones.

${ }^{32}$ El artículo 6, tras la modificación de la Decisión 2009, que establece las funciones de Eurojust a través de sus Miembros Nacionales, señala que: "1. Cuando actúe a través de los Miembros Nacionales correspondientes, Eurojust: a) podrá solicitar a las autoridades competentes de los Estados Miembros afectados, motivando su solicitud que: i) lleven a cabo una investigación o unas actuaciones judiciales sobre bechos concretos, ii) reconozcan que una de ellas puede estar en mejores condiciones para llevar a cabo una investigación o unas actuaciones judiciales sobre hechos concretos, iii) realicen una coordinación entre las autoridades competentes de los Estados Miembros afectados, iv) creen un equipo conjunto de investigación, de conformidad con los instrumentos de cooperación pertinentes, v) faciliten cuanta información sea necesaria para que Eurojust desempeñe sus funciones, vi) tomen medidas especiales de investigación, vii) tomen cualquier otra medida que esté justificada en relación con la investigación o las actuaciones judiciales; b) garantizará que las autoridades competentes de los Estados Miembros afectados se informan mutuamente sobre las investigaciones y actuaciones judiciales de que Eurojust tenga conocimiento; c) ayudará a las autoridades competentes de los Estados Miembros, a petición de éstas, a garantizar la mejor coordinación posible de las investigaciones y actuaciones judiciales; d) colaborará para mejorar la cooperación entre las autoridades competentes de los Estados Miembros; e) cooperará y consultará con la Red Judicial Europea, entre otros medios utilizando su base de datos documental y ayudando a mejorarla; f) aportará en los casos contemplados en los apartados 2 y 3 del articulo 3 y con acuerdo del Colegio, su apoyo a investigaciones y actuaciones judiciales que afecten a las autoridades competentes de un único Estado Miembro. 2. Los Estados Miembros garantizarán que las autoridades nacionales competentes respondan sin demora indebida a las solicitudes que se les hagan al amparo del presente artículo". 
(provenientes de la originaria Decisión de creación 2002), pero introduciría varios incisos que reafirmaban su voluntad dotar de más capacidad a aquéllos mediante la posibilidad de que pudieran solicitar motivadamente a las autoridades competentes de sus respectivos Estados Miembros, "medidas especiales de investigación” y "cualquier otra medida que esté justificada en relación con la investigación o las actuaciones judiciales" 33 .

Pues bien, la reforma que se concretó en la Decisión de refuerzo 2009 no obstante suponer importantes avances en la homogeneidad de las competencias de los Miembros Nacionales, seguiría sin mostrarse completamente satisfactoria. Primeramente, debido a su tardía y desigual transposición ${ }^{34}$ que retrasaría el ajuste necesario que debía de hacerse en la equiparación de sus atribuciones a fin de aproximar las diferencias existentes. La segunda razón de esta eficacia únicamente parcial, la encontramos en que cada Estado Miembro continua ostentando el control de la naturaleza y alcance de las competencias de sus Miembros Nacionales en lo que respecta a la cooperación judicial ${ }^{35}$, ya que en este marco jurídico se mantiene el respeto a la iniciativa y ámbito de decisión de los Estados miembros a la hora de organizar su sistema judicial, así como sus procedimientos administrativos para designar al Miembro Nacional.

\footnotetext{
${ }^{33}$ Se establece en el modificado artículo 6 de la Decisión 2009, apartado 1, letra a), números vi) y vii).

${ }^{34}$ La fecha límite para la adaptación al derecho interno de la Decisión 2009 de refuerzo de Eurojust, estaba fijada a más tardar el 4 de junio de 2011. Como muestra de esa tardía transposición - por otra parte bastante mayoritaria entre los Estados Miembros - hay que señalar que por ejemplo España no ha procedido a realizar tal adaptación hasta julio de 2015, mediante la Ley 16/2015, de 7 de julio, "por la que se regula el estatuto del Miembro Nacional de España en Eurojust, los conflictos de jurisdicción, las redes judiciales de cooperación internacional y el personal dependiente del Ministerio de Justicia en el Exterior" (BOE, núm. 162, 8.7.2015), Disponible en la web: www.boe.es. En otro sentido, para un interesante punto de vista práctico-jurídico acerca de cómo se ha conciliado la implementación de la Decisión 2009 en Alemania, en relación a su propia federación y los Länder germanos, Vid., Council of the European Union, Note from the German delegation on Mutual Evaluation report on the sith round of Mutual Evaluations "The practical implementation and operation of the Council Decision 2002/187/JHA of 28 February 2002 setting up Eurojust with a view to reinforcing the fight against serious crime and of the Council Decision 2008/976/JHA on the European Judicial Network in criminal matters", 13421/15, GENVAL 51, EUROJUST 184, Brussels, (28.10.2015). ${ }^{35}$ Vid., art. 9 bis, párrafo 2 de la Decisión 2009.
} 


\section{La Propuesta de Reglamento 2013 de Eurojust y los interrogantes del futuro en la arquitectura institucional de las competencias de los Miembros Nacionales}

Primeramente recordemos que a día de hoy y mientras no sea aprobado el Reglamento sobre Eurojust, continua vigente la Decisión 2009. Esta situación de transición no ha alterado significativamente la perspectiva del trabajo operativo de los Miembros Nacionales en lo que se refiere a la coordinación de las investigaciones transfronterizas en las competencias de Eurojust, ya que su estatuto permanece bajo el paraguas de la Decisión 2009 a expensas de una eficaz adaptación legislativa a sus correspondientes ordenamientos jurídicos nacionales. No obstante, merced a la disposición de los actos jurídicos ${ }^{36}$ adoptados bajo el Tratado de Funcionamiento de la Unión Europea (TFUE) y conforme a su artículo $85^{37}$, se prevé que Eurojust se rija conforme al Reglamento que sea adoptado con arreglo al procedimiento legislativo ordinario. En consecuencia, la futura adopción y entrada en vigor del Reglamento Eurojust supondría la aplicación directa de todas sus previsiones -incluidas las referentes a las competencias y estatuto de los Miembros Nacionales- de manera automática, uniforme y simultánea en cada uno de los Estados de la Unión Europea, excluyendo a su vez la posibilidad de aplicar normas nacionales incompatibles con las cláusulas materiales que contiene el propio Reglamento.

En efecto, la nueva propuesta de Reglamento quiere asegurarse de que Eurojust pueda respaldar y coordinar correctamente las investigaciones transfronterizas siendo necesario que "todos los Miembros Nacionales tengan las mismas competencias operativas con respecto a sus Estados miembros de origen para cooperar con mayor eficacia tanto entre si como con las

\footnotetext{
${ }^{36}$ Los actos jurídicos de la Unión se enumeran en el artículo 288 del TFUE (el reglamento, la directiva, la decisión, la recomendación y el dictamen)

${ }^{37}$ Artículo 85. "1. La función de Eurojust es apoyar y reforzar la coordinación y la cooperación entre las autoridades nacionales encargadas de investigar y perseguir la delincuencia grave que afecte a dos o más Estados miembros o que deba perseguirse según criterios comunes, basándose en las operaciones efectuadas y en la información proporcionada por las autoridades de los Estados miembros y por Europol. A tal fin, el Parlamento Europeo y el Consejo determinarán, mediante reglamentos adoptados con arreglo al procedimiento legislativo ordinario, la estructura, el funcionamiento, el ámbito de actuación y las competencias de Eurojust (...)".
} 
autoridades nacionales"38. Tal y como puso de manifiesto el Miembro Nacional español en su memoria anual del año $2012^{39}$, argumento que continua vigente en 2016, la asimetría se mantiene en determinados aspectos en el día a día del trabajo de Eurojust y son escasos los Miembros Nacionales que tienen competencias de investigación directa sin necesidad de realizar solicitud a sus respectivas autoridades nacionales y, aquellos que poseen el más alto techo competencial (Suecia o Estonia, por ejemplo) no hacen uso de tal atribución en la práctica. Además, no hay que perder de vista que la propuesta de Reglamento de Eurojust se trae a colación por parte de la Comisión para conseguir su transformación en línea con las correspondientes disposiciones del TFUE y, en consecuencia, su "lisbonización" mediante la reorganización de su estructura interna para transformarla en una Agencia más eficaz y efectiva ${ }^{40}$.

Por otro lado, y en relación al estatutos de los Miembros Nacionales, siendo ciertos los esfuerzos reflejados en la actual propuesta 2013 para conseguir un tratamiento más homogeneizado de sus atribuciones y servir a una mejor coordinación en la lucha contra la delincuencia organizada transfronteriza, en el momento actual

\footnotetext{
${ }^{38}$ Considerando 11 del texto de la orientación general de 27 de febrero de 2015 (6643/15) de la Propuesta de Reglamento de Eurojust...El estado y las atribuciones de los Miembros Nacionales en la Propuesta de Reglamento, fue uno de los aspectos acerca de los cuales el Colegio de Eurojust dirigió su aportación al Grupo de Trabajo del Consejo sobre cooperación en materia penal (COPEN) en abril de 2014, Vid., Annual Report 2014, (The Hague, 2014), 68.

39 Vid., Miembro Nacional de España en Eurojust, Memoria anual del Miembro Nacional de Eurojust correspondiente al año 2012, (La Haya, 5 de abril de 2013).

${ }^{40}$ Esto se observa más claramente, en el ámbito del intercambio de información, cuando se acude a comparar el texto de la Decisión 2009 con el de la propuesta 2013 de Eurojust. En efecto, el refuerzo de la eficacia de Eurojust que persigue la nueva propuesta, por ejemplo en aquel ámbito particular, prevé que la información se proporcione por parte de los Estados Miembros de manera mucho más rápida y eficazmente en tiempo, así como en línea con el espíritu y disposiciones del TFUE. Así, si observamos el aún vigente artículo 13.6 de la Decisión 2009 en relación al intercambio de información, vemos que se establece: "Los Estados miembros garantizarán que su miembro nacional sea informado sin demora injustificada de cualquier caso que afecte directamente al menos a tres Estados miembros y para los cuales se hayan transmitido al menos a dos Estados miembros solicitudes o decisiones de cooperación judicial, incluidas las referentes a instrumentos que den efecto al principio de reconocimiento mutuo" (cursiva del autor). En el texto de la propuesta 2013 de Eurojust, en cambio, se señala que: "Las autoridades nacionales competentes informarán sin demora injustificada a los miembros nacionales de cualquier caso relacionado con delitos que competan a Eurojust y que afecten al menos a tres Estados miembros y para los cuales se hayan transmitido al menos a dos Estados miembros solicitudes o decisiones de cooperación judicial, incluidas las basadas en instrumentos que den efecto al principio de reconocimiento mutuo" (cursiva del autor).
} 
de discusión del texto aún se observan ciertos aspectos que no concluyen con una total homogeneidad, además de que mostrar que Eurojust continua influenciado por el "espiritu interestatal del antigno tercer pilar"41. En este sentido, por ejemplo, puede observarse que en el texto de la última orientación general del 27 de febrero de $2015^{42}$, se establece la posibilidad de que cada Estado Miembro pueda otorgar al Miembro Nacional "atribuciones adicionales", pero siempre "de conformidad con la legislación nacional"43.

Finalmente, es cierto que bien podría argumentarse que, esta línea de evolución de la propuesta en lo que atañe a las competencias de los Miembros Nacionales de Eurojust respondería a la propia dinámica actual de la Unión. Esto es, que en los últimos tiempos se ha dado prioridad política al desarrollo de una futura Fiscalía europea ${ }^{44}$ - aunque las

\footnotetext{
${ }^{41} \mathrm{Vid}$., en este sentido, el comentario de Anne Weyembergh en la nota al pié núm. 23 del presente trabajo. ${ }^{42}$ A día se hoy, el último texto consensuado de la orientación general sobre la propuesta de Reglamento de Eurojust, continúa siendo el de fecha 27 de febrero de 2015.

${ }^{43}$ Artículo 8. 1 bis del texto de la orientación general de 27 de febrero de 2015 (6643/15) de la Propuesta de Reglamento de Eurojust...

${ }^{44}$ Tal y como recordaba la presidenta de Eurojust, Michèle Coninsx, en su comparecencia en el año 2014 ante la Cámara de los Lores británica con estas palabras: "It is a choice made by the legislators. There was a choice whether to opt for an improvement of Eurojust on the basis of Article 85, empowering Eurojust more, stepping up the fight, the co-ordination and cooperation role, giving new powers to Eurojust and enabling Eurojust to prevent and solve conflicts of jurisdiction. A decision was made by the legislators not to opt for that but to go for a vertical set-up - an additional entity based on Article 86", Vid., House of Lords, EPPO: The impact on non-participating Member States, Evidence given by Michèle Coninsx, President of Eurojust, Evidence Session no 4 , The Select Committee on the European Union, Justice, Institutions and Consumer Protection (Sub-Committee E), London, (7.5.2014), available at www.parliament.uk. Por otro lado, una parte de la doctrina ha señalado - en nuestra opinión de manera acertada - que la propuesta de la Fiscalía Europea, tal y como se encuentra en el estadio actual, supone un "escenario incierto" que "ha suscitado numerosas cuestiones, muchas de las cuales continúan sin resolverse", las cuales se extienden a su "impacto en las relaciones con las otras agencias e instituciones de la Unión Europea" entre las que se encuentra Eurojust, Vid., Weyembergh, The inter-agency cooperation, 43-44. Para una reflexión sobre los interrogantes acerca de la competencia material de la futura Fiscalía Europea y otros, Vid., Katalin Ligeti, "Approximation of substantive criminal law and the European Public Prosecutor's Office", in Approximation of substantive criminal law in the EU. The way forward, ed. Francesca Galli and Anne Weyemberg (Bruxelles: Eds. De l’Université de Bruxelles, 2013), 73-ff; José Luís Lopes da Mota, "A propósito da Procuradoria Europeia”, Revista do Ministério Público 138 (2014): 285-298; J.J.E Schutte, "Establishing enhaced cooperation under 86 TFEU” in The European Public Prosecutor's Office - an extended arm or a two-headed dragon?, ed. L.H. Erkelens, et al., (The Hague, Springer, 2015), 195-ff.; Rosaria Sicurella, "Setting up a European Criminal Policy for the Protection of EU Financial Interests: Guidelines for a Coherent Definition of the Material Scope of the European Public Prosecutor's Office" in Toward a Prosecutor for the European Union, A Comparative Analysis, ed. Katalin Ligeti, (Oxford: Hart Publishing, 2013): 870-904; John A. E. Vervaele, "The material scope of competence of the European Public Prosecutor's Office: Lex uncerta and unpraevia?", ERA Forum 15 (2014):
} 
negociaciones avancen muy lentamente y sin concreciones prácticas -, en detrimento de otras opciones para Eurojust descritas en el artículo 85.1 del TFUE que por el momento no han sido contempladas. Recordemos que este artículo establecía la posibilidad de que mediante reglamento adoptado con arreglo al procedimiento legislativo ordinario se determinasen, entre otras, las competencias de Eurojust, que "podrán incluir: a) el inicio de diligencias de investigación penal, así como la propuesta de incoación de procedimientos penales por las autoridades nacionales competentes, en particular los relativos a infracciones que perjudiquen a los intereses financieros de la Unión ...”. Sin embargo, tal y como ya había sido vislumbrado por Vervaele, la opción ha sido bien distinta y: "está claro que los Estados Miembros no han querido que Eurojust se convierta en un órgano supranacional con competencia operativa en un espacio común"45.

En su lugar, y tal y como se encuentra recogido en el texto a día de hoy, lo que se pretende es reforzar su rol actual con la finalidad de que ejerza una función más anticipatoria en la coordinación de casos, y continúe con su decisiva tarea de apoyo a las autoridades nacionales en sus investigaciones y actuaciones judiciales contra la delincuencia transnacional con una base esencial en el intercambio de información. La posibilidad contemplada en el artículo 85.1 a) TFUE de que entre las competencias de Eurojust se pudieran incluir el inicio de diligencias de investigación penal, se descarta de momento para Eurojust. A cambio, la propuesta 2013 (artículo 4.2) contempla un refuerzo del rol de la futura Agencia en este asunto, pero siempre actuando en dependencia de los Estados Miembros, al establecer que: "En el ejercicio de sus funciones, Eurojust podrá, motivando su solicitud, pedir a las autoridades competentes de los Estados miembros ${ }^{46}$ afectados que: a) Ileven a cabo investigaciones o incoen procedimientos penales sobre hechos concretos".

85-99. Una versión "actualizada" de este artículo de John Vervaele del año (2015) bajo el título, "The material scope of competence of the European Public Prosecutor's office: a harmonised national patchwork?", editada por el Centro Studi di Diritto Penale Europeo, se encuentra disponible en, http:// dirittopenaleeuropeo. it/wp-content/uploads/2015/10/Vervaele-2014-15.pdf.

${ }^{45}$ Vid., John Vervaele, "De Eurojust a la Fiscalía Europea en el espacio judicial europeo: ¿el inicio de un derecho procesal europeo?" in La futura Fiscalía Europea, ed. Rosa Ana Morán y Jorge Espina (Madrid, Fiscalía General del Estado, 2009), 164. Para una visión reciente de la relación entre la Fiscalía Europea y Eurojust, Vid., Catherine Deboyser, "European Public Prosecutor's Office and Eurojust: love match or arranged marriage? in The European Public Prosecutor's Office - an extended arm or a two-headed dragon?, ed. L.H. Erkelens et al., (The Hague, Springer, 2015):84-ff.

${ }^{46}$ Cursiva del autor. 


\section{Conclusiones}

Las competencias de los Miembros Nacionales de Eurojust y su progresivo recorrido en la búsqueda de la homogeneidad de sus facultades para un adecuado cumplimiento de los fines de Eurojust en su misión contra la delincuencia transnacional grave, han ido parejas a la construcción de la arquitectura institucional del espacio de libertad, seguridad y justicia en la Unión Europea y, en consecuencia, al iter jurídico de la propia Unidad creada mediante la Decisión del Consejo 2002, posteriormente reforzada con la Decisión 2009, y en el momento actual con la propuesta de Reglamento del año 2013 de Eurojust en el horizonte aún en fase de discusión y desarrollo. Es posible afirmar, por tanto, que el refuerzo de Eurojust y la amplia modificación del artículo 9, tuvo su razón de ser en el impulso de los propios Miembros Nacionales ante la constatación de las limitaciones en sus competencias así como de la asimetríade sus estatutos y que concluían con obstáculos prácticos a las operaciones de coordinación y cooperación de la Unidad en su misión contra la delincuencia transnacional grave.

Dichas barreras al cumplimiento de los fines de Eurojust, se observaban por ejemplo en la imposibilidad de todos los Miembros Nacionales de poseer el mismo nivel de acceso a las bases de datos y registros relacionados con los fines de Eurojust o las solicitudes a la autoridad nacional competente de eventuales intervenciones de comunicaciones. Podría decirse que, en cuanto a la voluntad de poner en marcha la modificación y refuerzo de la Decisión Eurojust, los Estados Miembros alcanzaron entonces un amplio nivel de consenso que hay que destacar por lo inusual en este ámbito. Hay que recordar, sin embargo, que los Estados Miembros continúan poseyendo el control en lo referente a las atribuciones y el estatus de sus Miembros Nacionales, ya que se mantiene el respecto al ámbito de decisión de aquéllos en la organización de su sistema judicial y en sus respectivos procedimientos nacionales establecidos para nombrar a su Miembro Nacional.

Como hemos venido sosteniendo en este trabajo, estimamos que un acuerdo en torno unos mínimos acerca de las atribuciones de los Miembros Nacionales de 
Eurojust - y en una situación más favorable, en un sentido lo más amplio posible -y el avance hacia la búsqueda de la homogeneidad en su estatuto, incrementa la mejora en la eficacia de la misión de Eurojust. Las eventuales barreras al cumplimiento de los fines de Eurojust que al inicio señalamos, se verían entonces traspasadas pudiendo llevarse a cabo acciones operativas coordinadas sin obstáculos para, por ejemplo, realizar entradas y registros en los distintos países de la operación correspondiente o garantizar la simultánea observación de las comunicaciones en una eventual conversación entre las personas investigadas localizadas en países distantes en kilómetros de la Unión, evitando de esta manera que los miembros de un grupo criminal organizado pudieran ponerse a cubierto evitando la acción de la justicia.

Para resolver las asimetrías en las atribuciones de los Miembros Nacionales coincidimos con la reflexión que ha sido sugerida por el servicio jurídico de Eurojust en varias ocasiones. Esta indicación concluye que lo más adecuado habría sido desvincular las competencias del Miembro Nacional del estatuto original que hubieran mantenido según su carrera de origen, dotándole con poderes comunes o uniformes - con independencia de su capacidad funcional originaria - que podrían ejercer en su condición de Miembros Nacionales de Eurojust y no como autoridad nacional. No parece, sin embargo, que esta vaya a ser la solución, teniendo en cuenta como se está reflejando a día de hoy la evolución de esta cuestión en el texto de la propuesta de Reglamento de Eurojust que mantiene, por ejemplo, que "los miembros nacionales podrán conservar con arreglo a su legislación nacional, las competencias derivadas de su capacidad como autoridades nacionales" ${ }^{37}$.

Habrá que atender pues a la futura evolución de la propuesta de la futura Fiscalía Europea que no olvidemos va pareja a la de Eurojust ${ }^{48}$ y que al tener que estructurarse según el artículo 86 del TFUE “a partir de Eurojust” (cuya articulación se

\footnotetext{
${ }^{47}$ Considerando 11 del texto de la orientación general de 27 de febrero de 2015 (6643/15) de la Propuesta de Reglamento de Eurojust...

${ }^{48}$ En lo que se refiere a las relaciones de la futura Fiscalía Europea con Eurojust, el texto más reciente de 19 de septiembre de 2016 (referencia del documento del Consejo número ST 123422016 INIT), aún no se encuentra accesible de manera pública.
} 
encuentra aún en discusión y no completamente explorada), vendrá a influir sin duda en el futuro desarrollo de la futura Agencia y, por ende, en sus Miembros Nacionales. Finalmente, no puede olvidarse en definitiva que las Agencias de la Unión Europea están a llamadas a representar un papel fundamental en Europa en la arquitectura de la Unión, en especial ante las amenazas a la seguridad que se revelan en el momento actual. Sin embargo para el cumplimiento de un rol que sea verdaderamente efectivo ante la delincuencia transfronteriza, tal y como recuerda la Unión en su Agenda Europea de Seguridad 2015-2020, habrá de realizarse un esfuerzo efectivo en el abordaje intersectorial e interinstitucional por parte de dichas Agencias - entre las que se encuentra Eurojust,- a través, entre otras acciones, del apoyo tanto a las iniciativas de cooperación operativa como a las acciones transnacionales conjuntas. 


\title{
La agenda "Mujeres, paz y seguridad" como una política internacional de criminalización de la violencia sexual en los conflictos armados: la contribución de la Unión Europea
}

\author{
Isabel Lirola Delgado*
}

RESUMEN: Desde la aprobación de la Resolución 1325 (2000), el Consejo de Seguridad de las Naciones Unidas ha configurado progresivamente una política internacional de criminalización de la violencia sexual en los conflictos armados a través del desarrollo de la agenda "Mujeres, pazy seguridad" (MPS). La Unión Europea constituye uno de los principales actores regionales de referencia en la aplicación y ejecución de dicha política mediante sus instrumentos de acción exterior y la promoción y apoyo a la implementación de la agenda MPS por sus Estados miembros vía planes nacionales. A pesar de los avances alcanzados, la acción de la Unión Europea en este ámbito necesita de un nuevo impulso y una actualización tanto en el plano interno como en el externo.

PALABRAS CLAVE: mujeres - pazy seguridad - crimenes internacionales - violencia sexual - Unión Europea.

ABSTRACT: Since the adoption of resolution 1325 (2000), the United Nations Security Council has progressively set up an international policy criminalizing sexual violence in armed conflicts through the development of the "Women, peace and security" (WPS) agenda. The European Union constitutes one of the main regional actors in the application of this policy by means of its external action instruments and the support for the implementation of the MPS agenda by its Members States via national plans. In spite of the significant advances achieved, the European Union action in this area requires a new impetus and updating both at internal and external level.

KEYWORDS: women - peace and security - international crimes - sexual violence - European Union.

\footnotetext{
* Profesora Titular de Derecho Internacional Público y Relaciones Internacionales (Acreditada a Catedrática de Universidad). Departamento de Derecho Público y Teoría del Estado. Universidade de Santiago de Compostela.
} 


\section{Introducción}

La utilización masiva y sistemática de la violencia sexual constituye uno de los elementos característicos de las "nuevas guerras". En la calificada "pedagogía de la crueldad', el cuerpo humano, femenino o feminizado, ocupa una posición central en la escena de los conflictos armados actuales, hasta el punto de convertirse en el verdadero campo de batalla. En esta tipología de conflictos, propios de un contexto internacional a caballo entre la globalidad y el localismo, la violencia sexual se utiliza como una estrategia o táctica bélica con una doble dimensión, individual de sometimiento de la víctima y colectiva de humillación de toda la comunidad enemiga. De esta manera, la violencia sexual sirve como instrumento de los objetivos estratégicos, la ideología y la financiación de los grupos parte en el conflicto. Así, su empleo responde a imperativos tácticos, como el reclutamiento, el acatamiento de órdenes o el desplazamiento de determinadas comunidades étnicas o religiosas de zonas estratégicas. Se utiliza como "arma biológica" para alterar la demografía y destruir los lazos sociales y familiares. Y sirve para financiar el conflicto a través de la explotación, el tráfico y el secuestro de mujeres y niñas para la venta, prostitución, esclavitud sexual y el matrimonio forzoso ${ }^{1}$.

El Derecho Internacional y la Sociedad Internacional institucionalizada no han permanecido ajenos a esta lacra que, cuando tiene un carácter generalizado y sistemático, supone una amenaza a la paz y seguridad internacionales. Partiendo de la acción desarrollada desde la segunda mitad del siglo XX, la respuesta internacional en los dos últimos decenios se ha articulado a un doble nivel.

Primeramente, se ha operado un proceso de criminalización de la violencia sexual en los conflictos en el plano normativo, cuyo punto álgido se sitúa en la adopción del Estatuto de Roma de la Corte Penal Internacional en 1998. En segundo lugar y desde la aprobación de la Resolución 1325 (2000), se ha ido configurando una política internacional de criminalización de la violencia sexual en los conflictos

\footnotetext{
1"La violencia sexual relacionada con los conflictos", Informe del Secretario General Doc. S/2015/203 (23 de enero de 2015): párr.83.
} 
a través de la agenda "Mujeres, pazy seguridad" (MPS) del Consejo de Seguridad de las Naciones Unidas.

Como tal política internacional, su ejecución involucra a una multiplicidad de actores en distintos ámbitos y a través del recurso a diferentes instrumentos y mecanismos. Así, en primer término, su implementación se lleva a cabo a través del sistema de Naciones Unidas, bajo el liderazgo del Consejo de Seguridad, apoyado por una serie de órganos, entidades y mecanismos específicos, como la "Iniciativa de las Naciones Unidas para detener la violencia sexual en las situaciones de conflicto". En un segundo nivel, se sitúa la acción de los Estados, mediante los llamados planes nacionales. Ambos niveles de actuación se completan con la implementación que llevan a cabo las Organizaciones regionales, que refuerzan la acción de Naciones Unidas y la acción de los Estados con sus propios planes y estrategias de aplicación. Es precisamente en este plano en el que se sitúa la contribución de la Unión Europea, que claramente comprometida en la protección de los derechos fundamentales en el plano interno y en el de su acción exterior, constituye uno de los actores de referencia en la aplicación de la política internacional de criminalización de la violencia sexual que representa la agenda MPS.

En función de estas ideas iniciales, comenzamos refiriéndonos al proceso de criminalización internacional de la violencia sexual en los conflictos (2), poniendo de manifiesto que se trata de uno de los supuestos más claros y efectivos de fertilización mutua entre ámbitos sectoriales del Derecho Internacional que se ocupan de la protección de la persona humana. A continuación, abordamos la configuración de una política internacional de criminalización de la violencia sexual en los conflictos armados a través del desarrollo de la agenda "MPS" por el Consejo de Seguridad (3), centrándonos en las sucesivas resoluciones a través de las que, partiendo de la Resolución 1325, se ha concretado dicha agenda. Finalmente haremos algunas reflexiones críticas sobre la contribución de la Unión Europea a la ejecución de la agenda "MPS" (4), para rematar con unas breves conclusiones (5) ${ }^{2}$.

\footnotetext{
${ }^{2}$ Para un desarrollo en extenso de las ideas de esta contribución, vid. I. Lirola Delgado y M. Martín Martinez, Crimenes internacionales de violencia sexual y conflictos armados (Pamplona: Thomson Reuters-Aranzadi, 2016).
} 


\section{La criminalización internacional de la violencia sexual en los conflictos}

Desde la perspectiva normativa, la criminalización internacional de la violencia sexual en los conflictos es el resultado de un proceso de fertilización y mutua interacción en el que confluyen e interactúan normas e instrumentos jurídicos elaborados en diferentes momentos y procedentes de tres ámbitos sectoriales del Derecho Internacional: el Derecho Internacional Humanitario, el Derecho Internacional Penal y el Derecho Internacional de los Derechos Humanos.

De esta manera, es posible identificar un núcleo inicial de regulación constituido por un conjunto de normas convencionales de Derecho Internacional Humanitario que, hoy en día, son reconocidas en su mayoría como normas consuetudinarias. Son las disposiciones de los Convenios de Ginebra de 1949 y sus Protocolos Adicionales que están destinadas específicamente a proteger a las mujeres en situaciones de conflicto armado contra "todo atentado a su honor y, en particular, contra la violación, contra el forzamiento a la prostitución y contra todo atentado a su pudor" (art. 27 del IV Convenio de Ginebra y art. 76, p.1 del Protocolo Adicional I). A estas disposiciones se suman las que protegen con carácter general la dignidad de todas las personas frente a "los atentados a la integridad corporal" (art. 3 común), la tortura, y "los tratos bumillantes y degradantes, la prostitución forzada y cualquier atentando contra el pudor" (art. 75, p. 2 del Protocolo Adicional I y art. 4, p. 2, e del Protocolo Adicional II).

A este primer bloque normativo se añaden un conjunto de normas e instrumentos de Derecho Internacional Penal a través de los que se incrimina la violencia sexual como crímenes de guerra, crímenes de lesa humanidad y genocidio. Este conjunto normativo que se identifica primordialmente con los Estatutos y la jurisprudencia de los órganos jurisdiccionales del llamado "Sistema de justicia penal internacional", se construye a partir de la creación de los Tribunales Penales Internacional para la ExYugoslavia y Ruanda y la adopción del Estatuto de Roma de la Corte Penal Internacional. Este Instrumento establece una categoría específica de crímenes de violencia sexual que aparecen explícitamente incorporados dentro de las categorías más amplias de crímenes de lesa humanidad (art. 7) y crímenes de guerra (art. 8) y que 
incluyen "la violación, esclavitud sexual, prostitución forzada, embarazo forzado, esterilización forzada o cualquier otra forma de violencia sexual de gravedad comparada".

En tercer lugar, hay que sumar las normas e instrumentos procedentes del Derecho Internacional de los Derechos Humanos de ámbito universal y regional que protegen frente a la violencia sexual, bien de manera explícita o a través de una interpretación dinámica e integradora de sus disposiciones. Además de por los principales instrumentos de protección de los derechos humanos de ámbito universal, incluida la Convención sobre la eliminación de todas las formas de discriminación contra la mujer (CEDAW), en este bloque normativo hay que tener en cuenta una serie de instrumentos regionales de particular significado: la Convención Interamericana para Prevenir, Sancionar y Erradicar la Violencia contra la Mujer, de 9 de junio de 1994; el Protocolo a la Carta africana de Derechos Humanos y de los pueblos sobre los derechos de las mujeres en África, de 11 de julio de 2003 (conocido como Protocolo de Maputo) y el Convenio del Consejo de Europa sobre prevención y lucha contra la violencia contra las mujeres y la violencia doméstica, de 11 de mayo de 2011.

El resultado de todo este proceso normativo es el establecimiento de la prohibición absoluta de toda violencia sexual en cualquier situación relacionada con un conflicto armado, cuya protección se extiende a todas las personas sin ningún tipo de distinción ${ }^{3}$. Esta prohibición tendría en su conjunto el carácter de norma de Derecho Consuetudinario e incluso de norma de ius cogens, al menos por lo que respecta al crimen de violación y en todo caso a los actos de violencia sexual como actos de tortura o de esclavitud ${ }^{4}$.

\footnotetext{
${ }^{3}$ G. Gaggioli., "Sexual Violence in Armed Conflicts: A Violation of International Humanitarian Law and Human Rights Law”, International Review of the Red Cross, 96,884 (2014): 503-538, en 537. En opinion más matizada, H. Tigrouda, "L'interdiction absolue des violences sexuelles en droit international bumanitaire et en droit international des droits de l'homme" Vulnerabilities in Armed Conflicts: Selected Issues, 14th Bruges Colloquium, Collegium (2014): 73-81 en 69.

${ }^{4}$ Cf. M. Ayat, "Quelques apports des Tribunaux pénaux internationaux, ad hoc et notamment le TPIR, à la lute contre les violences sexuelles subies par les femmes durant les génocides et les conflits armés", International Criminal Law Review 10,5 (2010): 787-827, en 811 y M. Eriksson, Defining Rape: Emerging Obligations for States Under International Law (Leiden: Brill-Nijhoff, 2011), 334-336.
} 
3. El diseño de una política internacional de criminalización de la violencia sexual en los conflictos armados: la agenda "Mujeres, paz y seguridad"

El Consejo de Seguridad se ha ocupado de la violencia sexual en situaciones de conflicto armado en el marco de sus competencias en materia de mantenimiento de la paz y seguridad internacionales a través de la Agenda "Mujeres, paz y seguridad". Dicha agenda se inicia con la Resolución $1325(2000)^{5}$, adoptada tras una década de dramáticos fracasos en el mantenimiento de la paz en Ruanda, Somalia y la Ex-Yugoslavia, todos ellos conflictos en los que las mujeres fueron objeto de una violencia sexual sistemática.

Esta Resolución pionera aúna dos elementos novedosos que son característicos del desarrollo de la agenda MPS. En primer lugar, por lo que se refiere a su génesis, su aprobación a través de la llamada "fórmula Arría" fue fruto de la movilización de una coalición de Organizaciones no gubernamentales de mujeres, apoyadas por un grupo de "Estados amigos". Esta forma de operar, involucrando a los Estados y las redes transnacionales de ONGs de mujeres y sumando el impulso político y la actuación de la Secretaria General de Naciones Unidas y sus instancias encargadas de las cuestiones relativas al mantenimiento de la paz y seguridad internacionales, se ha mantenido a lo largo de todo el proceso de configuración de la Agenda MPS.

El segundo elemento novedoso de la Resolución 1325 se refiere a la incorporación de la dimensión de género en el modelo de seguridad internacional de la Carta de las Naciones Unidas a través del reconocimiento del impacto específico de los conflictos armados sobre las mujeres y las niñas. Por esta razón, la Resolución 1325 exige que

\footnotetext{
${ }^{5}$ S/RES/1325 (2000), 31 de octubre de 2000.

${ }^{6}$ En relación con la génesis de la Resolución 1325, vid., entre otros, los trabajos ampliamente documentados de I. Rodríguez Manzano, "Más que víctimas?: una lectura teórico-discursiva de la Resolución 1325, relativa a las mujeres, la paz y la seguridad" in El arreglo pacifico de las controversias internacionales, coord. E. A. Vázquez Gómez, M. D Adam Muñoz Y N. Cornago Prieto (Valencia:Tirant lo Blanch, 2013), 1041-1054 en 1042-1045 y M. Carrillo Robles, "Mujer, paz y seguridad en la ONU”, in Género, conflictos armados y seguridad. La asesoría de género en operaciones (Granada: Universidad de Granada, 2012), 135-186 en 155.
} 
en cualquier conflicto armado las partes protejan a las mujeres y niñas ante cualquier forma de violencia, particularmente la violencia por razón de género, subrayando la responsabilidad de los Estados en la lucha contra la impunidad y el enjuiciamiento de los crímenes de lesa humanidad y crímenes de guerra que incluyan violencia sexual contra las mujeres y niñas.

Ahora bien, como esta exigencia no venía acompañada de procedimientos de verificación ni de medidas en caso de incumplimiento, hubo de ser objeto de desarrollo a través de una batería de resoluciones posteriores interrelacionadas en las que se va a continuar perfilando la política internacional de criminalización de la violencia sexual iniciada por la Resolución $1325^{7}$.

Destaca, en primer lugar, la Resolución 1820 (2008) ${ }^{8}$, cuyos catalizadores fueron la jurisprudencia sobre crímenes internacionales del TPIY y el TPIR, junto con los informes sobre la utilización sistemática de la violencia sexual en la República Democrática del Congo. El centro de gravedad de esta resolución gira alrededor de la obligación de protección, que se extiende a todas las partes enfrentadas en un conflicto armado, a las que exige que pongan fin a la utilización de todas las formas de violencia sexual y que adopten con celeridad medidas para proteger a los civiles, en particular a las mujeres y las niñas. En esta línea, destaca que el propio Consejo de Seguridad considerará, a la hora de imponer o renovar sanciones contra un Estado, si procede aplicar medidas selectivas y graduales contra las partes en el conflicto que usen la violencia sexual. Esta obligación se extiende también a otros organismos y asociaciones dentro y fuera del marco de la $\mathrm{ONU}$, a los que se pide su participación en la elaboración de mecanismos eficaces de protección, instándose además a aquellos países que participan en las misiones de mantenimiento de la paz a que aumenten el nivel de formación de sus contingentes para poder dar una respuesta adecuada a esta particular forma de violencia. Además, en la medida en que la violación y otras formas de violencia sexual "pueden" constituir genocidio, crímenes de guerra

\footnotetext{
7 T. Tryggestad, "Trick or Treat? The UN and Implementation of Security Council Resolution 1325 on Women, Peace and Security”, Global Governance, 15,4 (2009):.550.

${ }^{8}$ S/RES/1820 (2008), 19 de junio de 2008.
} 
o crímenes de lesa humanidad, se subraya la necesidad de que estos actos queden excluidos de los acuerdos de amnistía en los procesos de paz. De esta manera, en esta segunda resolución se amplía el alcance de los crímenes internacionales de violencia sexual más allá de lo regulado en los Convenios de Ginebra, aproximándolos a la definición establecida en el Estatuto de Roma?.

La tercera Resolución, la $1888(2009)^{10}$, fue adoptada un año más tarde a instancias de H. Clinton, la entonces Secretaria de Estado de los Estados Unidos de Norteamérica, coincidiendo con un desesperanzador informe sobre el seguimiento y la ineficacia de las medidas previamente adoptadas. Para paliar esta situación, además de reafirmar las obligaciones ya establecidas, se establece una estrategia para reforzar la protección de las mujeres y los niños y prevenir la violencia sexual en los conflictos armados a través de una serie de nuevas medidas, entre las que destacan dos: el nombramiento de un Representante Especial del Secretario General que liderase la acción de la ONU en la materia y el mandato al Secretario General para que designase un equipo de expertos para colaborar con la presencia de Naciones Unidas sobre el terreno, ayudando a las autoridades nacionales. Asimismo, se insta a los Estados a emprender reformas legislativas y judiciales para enjuiciar sin demora a los responsables de dichos actos, asegurando que las víctimas supérstites de dichos actos sean, sin distinción por razón de sexo, protegidas y debidamente resarcidas por sus sufrimientos.

La cuarta de esta miríada de Resoluciones es la 1889 (2009) ${ }^{11}$ que, aunque también condena los actos de violencia sexual cometidas contra las mujeres y las niñas en situaciones de conflicto armado y posteriores, se centra en los aspectos de la participación de la mujer en la prevención y solución de los conflictos y en su representación en todas las etapas de los procesos de paz.

La siguiente Resolución, la 1960 (2010) ${ }^{12}$, se focaliza de nuevo en la protección contra la violencia sexual. El Consejo de Seguridad constata que, pese a su repetida

\footnotetext{
${ }^{9}$ Cf. R. Manjoo, "Women, Peace and Security - Negotiating in Women's Best Interests", Global Policy 7,2 (2016): 268.

${ }^{10} \mathrm{~S} / \mathrm{RES} / 1888$ (2009), 30 de septiembre de 2009.

${ }^{11} \mathrm{~S} / \mathrm{RES} / 1889$ (2009), 5 de octubre de 2009.

${ }^{12}$ S/RES/1960 (2010), 16 de diciembre de 2010.
} 
condena de la violencia contra las mujeres y los niños, tales actos siguen ocurriendo, por lo que reitera la prohibición de todas las formas de violencia sexual, recordando la responsabilidad que incumbe a los Estados para poner fin a la impunidad, y refiriéndose a los mecanismos de justicia transicional como instrumento para promover no sólo la rendición de cuentas individual respecto de los crímenes graves, sino también la paz, la reconciliación y los derechos de las víctimas. Además, profundiza en las medidas de implementación, exhortando a las partes en conflictos armados a asumir y cumplir compromisos concretos con plazos definidos para combatir la violencia sexual. A tal fin, solicita al Secretario General que establezca disposiciones de seguimiento, análisis y presentación de informes sobre la violencia sexual relacionada con los conflictos, así como la inclusión en su informe anual de información detallada y de una lista de las partes y los autores, con nombres y apellidos, sospechosos de perpetrar tales crímenes.

La intensificación de la acción internacional a un nivel político y mediático inédito, que dio lugar a la "Declaración sobre la prevención de la violencia sexual en los conflictos", aprobada por el G-8 en Londres, promovió la aprobación de la Resolución $2106(2013)^{13}$. En la misma, al afirmar que la violencia sexual puede utilizarse no sólo como táctica sino también como método bélico, se amplían varios aspectos de la agenda MPS. Por lo que se refiere a las víctimas, aunque se observa que la violencia sexual afecta "en forma desproporcionada a las mujeres y las niñas", destacando el reconocimiento expreso de la vulnerabilidad de las mujeres que han sido secuestradas por la fuerza para incorporarlas a grupos armados, se incluye también en esta categoría a otros grupos vulnerables como son los hombres y los niños, y las personas traumatizadas indirectamente por ser testigos forzados de actos de violencia sexual contra familiares. También se formula una mención expresa a la asistencia integral a las víctimas, incluyendo su salud sexual y reproductiva, así como la mención al nexo existente entre la violencia sexual en situaciones de conflicto armado y posteriores y la infección del VIH.

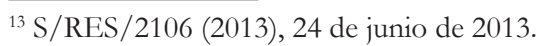


El empoderamiento y la participación de las mujeres y de las niñas es el aspecto principal de la siguiente Resolución, la $2122(2013)^{14}$, en la que se utiliza por primera vez la expresión "ejecución de la agenda relativa a las mijeres, la pazy la seguridad”. Destaca el carácter transversal con que se plantea dicha ejecución, reflejada en el hecho de que el Consejo de Seguridad exprese su intención de prestar mayor atención a las cuestiones relativas a las mujeres, la paz y la seguridad en todas las esferas de las que se ocupa, mencionando en particular la protección de los civiles en los conflictos armados, la consolidación de la paz después de los conflictos, la promoción y el fortalecimiento del estado de derecho en el mantenimiento de la paz y la seguridad internacionales, la paz y seguridad en África, las amenazas a la paz y seguridad internacionales causadas por actos terroristas, y el mantenimiento de la paz y seguridad internacionales. En el plano de la responsabilidad y la rendición de cuentas, además de exhortar a los Estados miembros al cumplimiento de sus obligaciones pertinentes para poner fin a la impunidad de los crímenes internacionales cometidos contra las mujeres y las niñas, se recuerdan específicamente la aplicabilidad de aquellas disposiciones internacionales relativas al derecho a reparaciones de las víctimas de vulneraciones de derechos individuales. La Resolución 2122 concluye con una referencia a la intención de convocar un examen de alto nivel en 2015 para evaluar el progreso a escala mundial, regional y nacional en la aplicación de la resolución 1325.

Dicho examen se llevó a cabo a partir del informe conocido como "Estudio mundial' ${ }^{15}$, cuyas recomendaciones sentaron las bases para la adopción de una nueva resolución, la $2242(2015)^{16}$. Esta Resolución, que se planteó como una revisión de la agenda MPS a los quince años de la Resolución 1325, tenía dos objetivos principales. El primero era la introducción de mecanismos destinados a mejorar la implementación de la agenda. Para ello, se propuso la creación de un Grupo Informal de Expertos MPS en el seno del Consejo de Seguridad (Grupo 2242), que ayudara a

\footnotetext{
${ }^{14}$ S/RES/2122 (2013), 18 de octubre de 2013.

${ }^{15}$ Entidad de las Naciones Unidas para la Igualdad de Género y el Empoderamiento de las Mujeres (ONU Mujeres), Prevenir los conflictos, transformar la justicia, garantizar la paz- Estudio mundial sobre la aplicación de la resolución 1325 del Consejo de Seguridad de las Naciones Unidas (12 Octubre 2015).

${ }^{16}$ S/RES/2242 (2015), 13 de octubre de 2015.
} 
lograr un enfoque sistemático de las cuestiones sobre las mujeres, la paz y la seguridad abordadas por el Consejo y posibilitara una mayor supervisión y coordinación de las actividades de implementación.

El segundo objetivo de la Resolución 2242 fue incorporar cuestiones nuevas a la agenda MPS, tales como la integración de la perspectiva de género en la lucha contra el extremismo violento y el terrorismo. Reconociendo que los actos de violencia sexual y por razón de género son parte de los objetivos estratégicos y la ideología de ciertos grupos terroristas y su utilización como táctica de terrorismo y como instrumento para aumentar su poder, la resolución pide a los Estados miembros y las Naciones Unidas que aumenten la integración ente sus agendas MPS y la agenda relativa a la lucha contra el terrorismo y el extremismo violento.

En suma, a la vista de lo establecido en las Resoluciones a través de las cuales el Consejo de Seguridad ha ido configurando la agenda MPS como una política de criminalización de la violencia sexual en los conflictos, se pone de manifiesto que tal política tiene su fundamento en las obligaciones jurídico-internacionales de las partes en un conflicto armado en relación con la prohibición expresa y absoluta de cualquier tipo de violencia sexual, cuyo incumplimiento puede dar lugar a la responsabilidad internacional del Estado y/o a la responsabilidad penal internacional de los individuos. En este sentido, al reiterar que los actos de violencia sexual pueden dar lugar a un crimen de guerra, un crimen de lesa humanidad o un acto constitutivo en relación al genocidio, la agenda MPS confirma su condición inequívoca de crímenes internacionales. Por consiguiente, la agenda MPS refuerza la obligación de los Estados de enjuiciar a las personas responsables de tales crímenes, excluyéndolos de las disposiciones de amnistía, así como la obligación de garantizar los derechos de todas las víctimas, incluyendo el derecho a la igualdad en el acceso a la justicia.

Esta política tiene además una clara dimensión de género, ya que, aunque las consecuencias de los conflictos armados sobre los hombres y los niños, y en concreto su condición de víctimas de la violencia sexual, solo se reconoce en algunas de sus resoluciones, la agenda MPS no puede entenderse únicamente como una 
agenda sobre las mujeres. Al contrario, se configura progresivamente como una agenda de género, en la medida en que en las sucesivas resoluciones hay cada vez mayor consenso acerca de que el orden binario hombre/mujer no es suficiente para abarcar la variedad de vulnerabilidades a la violencia sexual en situaciones de conflicto que se derivan de la orientación sexual de una persona, conjuntamente con otros factores como la identidad étnica o religiosa y/o la condición económica o social $^{17}$.

Se trata además de una política con vocación de transversalidad, ya que la agenda MPS forma parte de una serie de cuestiones temáticas interrelacionadas que conforman la labor del Consejo de Seguridad desde finales de la década de los 90, entre las que destacan las relativas a "los niños y los conflictos armados", "la protección de los civiles" o la llamada "responsabilidad de proteger". Por tanto, la transversalidad está ligada a un enfoque global e integrado de la agenda MPS, que busca la coherencia entre todas las acciones que se llevan a cabo en los ámbitos de la política, la seguridad, el desarrollo, los derechos humanos, incluida la igualdad de los géneros, y el Estado de derecho y la justicia ${ }^{18}$. A este respecto, hay que tener en cuenta que la revisión de la Agenda MPS ha coincidido en el tiempo con la revisión de otras cuestiones en el seno del Consejo de Seguridad, como por ejemplo la Comisión de consolidación de la paz y sobre las operaciones de paz, así como con la aprobación por la Asamblea General de la nueva Agenda 2030 de Desarrollo Sostenible ${ }^{19}$.

\footnotetext{
${ }^{17}$ Vid. P. Kirby.Y L. J. Shepherd, “Reintroducing women, peace and security” International Affairs 92, 2 (2016): 252. ${ }^{18}$ M. Villelas Ariño, Mujeres, pazy seguridad:15 años de la resolución 1325. Una evaluación de la agenda sobre mijeres, pazy seguridad, (Institut Català internacional per la pau, Informes 12/201621), 21 y M. SOLANAS, “Mujeres, pazy seguridad: lejos de las aspiraciones de la Resolución 1325" ARI 44 (2015): 1-9 en 5.

${ }^{19}$ Como señala Mesa, dentro de los 17 nuevos objetivos de desarrollo sostenible (ODS) que se incluyen en la nueva agenda 2030, aparece el ODS 5 sobre la igualdad de género y el ODS 16 que, por primera vez, incorpora metas de erradicación de la violencia en todas sus formas y manifestaciones, con referencia expresa a la violencia sexual que sufren las mujeres en los conflictos armados, y a otras formas de violencia de género contra mujeres y niñas ("El Objetivo n $n^{\circ} 16$ de Desarrollo Sostenible: paz, seguridady gobernanza", Temas para el debate 254-255 (enero-febrero 2016): 37-40.
} 


\section{La contribución de la Unión Europea a la ejecución de la agenda MPS}

Por lo que se refiere a la Unión Europea, la cuestión de la violencia contra mujeres y niñas, y en especial la violencia sexual, también se ha articulado a partir de la acción de Naciones Unidas, plasmándose en la Resolución 2005/2215 del Parlamento Europeo sobre la situación de las mujeres en los conflictos armados y su función en relación con la reconstrucción y en el proceso democrático en los países en situación de pos-conflicto y el subsiguiente Informe de 3 de mayo de 2006, en el que se asume una visión holística y dinámica de la mujer en los conflictos, distinguiendo entre las mujeres como víctimas de la guerra, como vectores de paz y como vectores de guerra.

Partiendo de este acervo, además de las medidas adoptadas en favor de la igualdad, la incorporación de una perspectiva de género, la lucha contra la violencia y la protección de las víctimas en el marco de las distintas políticas de la UE, con posterioridad se adoptaron un conjunto de normas de soft-law destinadas a articular de manera más concreta el desarrollo de la agenda MPS por la UE. Incluyen un instrumento de alcance general, las "Directrices sobre la violencia contra las mujeres y la lucha contra todas las formas de discriminación contra ellas", aprobadas el 8 de diciembre de 2008 y que recogen el compromiso político a largo plazo de la UE en relación con los derechos de las mujeres y la lucha contra la violencia de género. Ese mismo día se adoptaron dos documentos más específicos para su aplicación en la dimensión externa: el "Comprehensive approach to the EU implementation of the United Nations Security Council Resolutions 1325 and 1820 on women, peace and security", completado por la creación de una TaskForce sobre MPS desde 2009 y por unos indicadores desde 2010, y el "Implementation of UNSCR 1325 as reinforced by 1820 in the context of ESDP"20.

Cualquier valoración de la acción de la Unión Europea destinada a la aplicación

\footnotetext{
20 "Comprehensive approach to the EU implementation of the United Nations Security Council Resolutions 1325 and 1820 on women, peace and security" (Consejo de la Unión Europea, Doc 15671/1/08 REV 1, de 1.12.2008) e "Indicators for the Comprehensive approach to the EU implementation of the United Nations Security Council Resolutions 1325 and 1820 on women, peace and security" (Consejo de la Unión Europea, Doc. 11948/10, de 14.07.2010).
} 
de la agenda MPS ha de partir de un dato incuestionable y positivo: en el ámbito europeo es donde más Planes Nacionales de Acción se han adoptado ${ }^{21}$. De hecho, de los actuales 28 Estados miembros, 18 cuentan con un plan nacional propio, a los que se añaden los adoptados por Noruega, Suiza y los terceros Estados destinatarios de las políticas de preadhesión y vecindad ${ }^{22}$. Se evidencia así el compromiso inequívoco de la UE en la promoción y el apoyo de la implementación de la agenda MPS en el plano nacional, con independencia de la efectividad de dichos planes en función de su dotación, objetivos o mecanismos de verificación de cumplimiento, e incluso de que tal promoción pueda estar perdiendo intensidad en los últimos años ${ }^{23}$. En el plano externo, destaca la contribución de la UE para que la agenda MPS siga estando presente en la agenda global mundial, también el que la haya incorporado, proyectado y aplicado en las políticas de preadhesión, de vecindad y en las misiones PESD, así como la coordinación e interacción con la acción desarrollada en otros ámbitos regionales, caso de la UA, el ECOWAS o el ASEAN.

Ahora bien, desde una perspectiva crítica hay que aclarar que el contenido de los instrumentos específicos hasta ahora adoptados por la Unión Europea no ha sido realmente novedoso, tal como evidencia su fecha de adopción y que se limiten a recopilar buenas prácticas y acciones ya existentes. Además, resulta evidente su desfase temporal respecto a una parte muy importante del conjunto de las resoluciones que

\footnotetext{
${ }^{21}$ Para un examen de acción de la UE en desarrollo de la agenda MPS, vid. entre otros, E. Barbé, "Supporting practices inspired by solidarist ideas: The EU in the UNSC Open Debates on Women, Peace and Security"in EU Policy Responses to a Shifting Multilateral System, ed. E. Barbé, O. Costa y R Kissack (London: Palgrave, 2016); M. A Caracuel Raya, "La Aplicación de la Resolución 1325 en las Organizaciones de Seguridad y Defensa Europeas", Security and Defense Studies Review Fall-Winter Issue (2010): 65-80; M. Martinelli, "Resolution 1325 fifteen years on", European Union Institute for Security Studies Brief Issue,29 (Septiembre 2015).

22 Por orden de adopción, Dinamarca (2005), Reino Unido y Suecia (2006), España y Austria (2007), Países Bajos, Irlanda y Finlandia (2008), Portugal y Bélgica (2009), Eslovenia, Italia, Francia, Estonia (2010) Irlanda y Croacia (2011), Alemania (2103); Noruega (2006) y Suiza (2007); Serbia y BosniaHerzegovina (2010), Macedonia (2013) y Kosovo (2014); Georgia (2012) y Ucrania (2016). Datos de agosto 2016, disponible en http://www.peacewomen.org/member-states.

${ }^{23}$ Para un seguimiento de los PAN en el ámbito de la UE, vid los informes presentados por EPLO (EuropeanPeaceBuildingLiason Office), consultado el 15 de septiembre de 2016, http://eplo.org/ activities/policy-work/gender-peace-security/implementation-unscr-1325-europe/.
} 
integran la agenda MPS, lo que pone de manifiesto la necesidad de su actualización ${ }^{24}$. En concreto y en relación con la prohibición del uso de la violencia sexual como arma de guerra, es destacable que no contemplen, siguiendo lo previsto en las resoluciones posteriores a la 1820, la extensión de dicha protección a todas las víctimas y no sólo a las mujeres, ni su utilización en nuevos contextos como el terrorista o el de los extremismos violentos.

Desde el punto de vista institucional, cabe señalar que el Servicio Europeo de Acción Exterior (SEAE) ha centrado sus esfuerzos en afianzar su papel y misión en la arquitectura institucional de la UE, razón por la cual no ha asumido el liderazgo que cabría esperar en el desarrollo integral de la agenda MPS ${ }^{25}$. Es por ello que resulta paradójico que se ponga de manifiesto la relativa escasez de medios personales y de recursos de los que dispone para el desarrollo de la agenda MPS, en especial teniendo en cuenta que su escasa actividad se ha encaminado más a los procesos que a la obtención de resultados efectivos que cambien la situación sobre el terreno. En este mismo sentido, llama también la atención que el SEAE cuente con un asesor en materia de género y no con un representante especial de la agenda MPS, figura que, por su mayor conocimiento del terreno, en teoría sería más adecuada para propiciar soluciones de carácter local. Las críticas apuntan también que la implicación personal de individuos concretos es insuficiente, sino va acompañada de un compromiso político y de un apoyo institucional a largo plazo $^{26}$. De ahí la importancia de que se formulen manifestaciones institucionales que reafirmen el compromiso de la Unión Europea contra cualquier tipo de violencia sexual en los conflictos, como el "Joint Statement on the International Day for the Elimination of Sexual Violence in Conflict" en el que se dice expresamente que "the European Union reaffirms its strongest support for zero tolerance to any form of sexual violence" $\mathrm{y}$ "We want to see practical steps to tackle impunity for the

\footnotetext{
${ }^{24}$ Durante el debate abierto previo a la adopción de la Resolución 2242, la Unión Europea se comprometió a actualizar los indicadores del "Comprehensive Approach" con el objetivo de adoptar un enfoque global en aplicación de la agenda MPS a fin de medir más eficazmente los efectos de sus actividades.

${ }^{25}$ Vid. R. Guerrina y K. Wright, "Gendering normative power Europe: lessons of the Women, Peace and Security agenda", International Affairs 92, 2 (2016): 293-312 en 303.

${ }^{26}$ Guerrina y Wright, "Gendering normative power Europe”, 303.
} 
use of rape as a weapon of war and to begin to change global attitudes to these crimes" 27 .

Finalmente, hay que hacer referencia al importante papel desempeñado por los Estados de la UE que forman parte del Consejo de Seguridad, en especial los miembros permanentes, en la adopción de sanciones y la remisión de asuntos a los órganos del sistema de justicia internacional en casos de uso sistemático de la violencia sexual en situaciones de conflicto. En este sentido, queremos apuntar que el Brexit podría tener una incidencia negativa en la materia puesto que Gran Bretaña, además de la función ya señalada de penholder de la agenda MPS en el Consejo de Seguridad, ha sido uno de los Estados miembros más activos en el desarrollo de la agenda MPS, incluso a través de su participación en nuevas formas de respuesta internacional.

\section{Conclusiones}

La agenda MPS puede entenderse como una política internacional de criminalización de la violencia sexual en los conflictos, cuyo fundamento se encuentra en la obligación de los Estados de poner fin a la impunidad de los actos de violencia sexual llevados a cabo en el contexto de un conflicto armado. Dicha obligación se concreta a su vez en la obligación de emprender las reformas legislativas y judiciales necesarias para enjuiciar a los responsables de dichos actos, asegurando que las víctimas supérstites sean, sin distinción alguna, protegidas y debidamente resarcidas por sus sufrimientos, y por tanto garantizado en el plano interno la aplicabilidad de las disposiciones internacionales relativas al derecho a reparaciones de las víctimas de vulneraciones de derechos individuales.

La Unión Europea constituye uno de los principales actores regionales implicados en el desarrollo de la agenda MPS, cuyo compromiso resulta claro a la vista de que en el ámbito europeo es donde más planes nacionales se han adoptado y que la Unión Europea no sólo ha promovido la incorporación de una perspectiva de

\footnotetext{
27 Vid "Joint Statement on the International Day for the Elimination of Sexual Violence in Conflict" de 19.06. 2016, consultado el 15 de septiembre 2016, europa.eu/rapid/press-release_ STATEMENT-16-2243_en.htm.
} 
género en sus políticas en el plano interno y externo, sino que también se ha dotado de instrumentos específicos de desarrollo de la agenda MPS. Sin embargo, el impulso inicial parece estar un poco parado, por lo que resulta necesaria una renovación de los instrumentos existentes, sobre todo aquellos que marcan la ejecución por parte de la Unión Europea de la agenda MPS en la acción exterior. También resulta necesario seguir avanzando en la aplicación de todas las normas de Derecho procesal penal adoptadas en el marco del espacio de libertad, seguridad y justicia para permitir cumplir de manera efectiva las obligaciones asumidas por la UE y sus Estados miembros en el marco de la agenda MPS. 



\title{
Las nuevas formas de creatividad literaria digital y los límites del derecho de autor: especial referencia a las fanfiction
}

\author{
Isabel Espín Alba*
}

RESUMEN: Las últimas iniciativas comunitarias sobre derecho de autor en el mercado único digital Eeuropeo revelan, por un lado, la voluntad de implantación y crecimiento de industrias culturales en el entorno digital, y por otra parte, paradójicamente, pretende fomentar el acceso a la cultura y la reducción de trabas y costes para los consumidores europeos. Con ese trasfondo, este trabajo está dedicado a la creación literaria, para responder a la cuestión de si los textos literarios que circulan en el entorno digital no serían los viejos contenidos dentro de nuevas expresiones formales. La diseminación de las tecnologias de la información y de la comunicación y la popularización de herramientas y plataformas de producción y difusión de audiovisuales ha favorecido una explosión de creaciones realizadas por los usuarios. Para ilustrar esta cuestión se analiza la fanfiction, una formas de producción literaria muy popular en el ámbito digital, pero que conserva elementos clásicos de la creación literaria analógica.

PALABRAS CLAVE: derecho de autor-mercado único digital europeo - creación literaria - fanfiction.

ABSTRACT: The latest Community initiatives on copyright in the European digital single market reveal, on the one band, the will to establish and grow cultural industries in the digital environment, and on the other hand, paradoxically, it aims to promote access to culture and the reduction of barriers and costs for European consumers. With this background, this work is dedicated to literary creation, in order to answer the question of whether literary texts circulating in the digital environment would not be old content within new formal expressions. The dissemination of information and communication technologies and the improvement of audiovisual production and diffusion tools and platforms has favored an explosion of creations made by users. To illustrate this issue we analyze fanfiction, a form of literary production very popular in the digital field, but wich retains classic elements of analogical literary creation.

KEYWORDS: copyright - European digital single market - literary creation - fanfiction.

\footnotetext{
* Profesora Titular de Derecho Civil, Universidad de Santiago de Compostela.
} 


\section{I - Cuestiones Previas}

\section{Creatividad digital y derecho de autor: tensiones}

Los últimos avances tecnológicos generan formas innovadoras de creación y también de puesta a disposición de contenidos. La mera referencia, por ejemplo, a la tecnología de la impresión 3D abre un universo de posibilidades creativas; y si nos centramos en las plataformas de difusión, las redes sociales, entre otras, ya no son un mero lugar de encuentro y divulgación de contenidos, sino que permiten nuevos modelos de creación colectiva que proporcionan a los ciudadanos, no necesariamente profesionales de la creación, canales más sencillos y económicos de expresión artística y/o literaria.

Por supuesto que la utilización de estas herramientas verdaderamente inéditas, genera un volumen exponencial de obras literarias, artísticas o científicas, muchas ellas de autoría múltiple, divulgadas instantáneamente y con una elevada capacidad de puesta a disposición del público. Al mismo tiempo, es un reclamo de amplios sectores de la sociedad que el acceso a dichos contenidos sea libre en muchos casos, y en otros con costes sensiblemente reducidos.

¿Cómo responde el derecho de autor a estos desafíos?

Un estudio de las últimas iniciativas comunitarias, en especial aquellas referidas al mercado único digital europeo ${ }^{1}$, revela la paradoja de favorecer la implantación y crecimiento de industrias culturales en el entorno digital, por un lado, e por otra parte, fomentar el acceso a la cultura y la reducción de trabas y costes para los consumidores europeos ${ }^{2}$.

La multiplicación de agentes económicos implicados -autores, titulares de derechos, usuarios, prestadores de servicios, proveedores de acceso, entre otros-, hace todavía más compleja la búsqueda del equilibrio entre la propiedad intelectual y los diversos actores implicados ${ }^{3}$.

\footnotetext{
${ }^{1}$ El fundamento de tales iniciativas está ubicado en el artículo 4, apartado 2, letra a), y artículos 26, 27, 114 y 115 del Tratado de Funcionamiento de la Unión Europea.

${ }^{2}$ Vid. el trabajo de Rodrigo Bercovitz Rodríguez-Cano, "El mercado único digital y la propiedad intelectual”, Revista Doctrinal Aranzadi Civil-Mercantil 2 (2016): 1-3. Consultado en BIB 2016 258.

${ }^{3}$ Vid. las reflexiones de Pedro Alberto de Miguel Asensio, Derecho Privado de Internet (Cizur Menor:
} 
En ese debate sobre el futuro de la regulación de la propiedad intelectual existe un sector de académicos y profesionales, principalmente vinculados al estudio de los géneros literarios, muy reacio a cualquier modificación esencial en los paradigmas clásicos del derecho de autor diseñados en los convenios internacionales de finales del siglo XIX y primera mitad del siglo $\mathrm{XX}^{4}$.

La premisa de su argumentación es clara. La base de las vigentes normas de copyright han surgido precisamente de una importante revolución tecnológica, la invención de la imprenta, y en medio de fuertes tensiones entre intereses públicos y privados, y a partir de entonces, en cada evolución tecnológica el derecho de autor ha demostrado un alto grado de resiliencia, adaptándose a las nuevas demandas, sin perder la conexión con sus principios rectores básicos. En consecuencia no sería necesaria una reforma muy profunda, sino una puesta al punto de los mecanismos ya existentes.

Cada momento en la evolución de los derechos de los creadores literarios, artísticos y científicos fueron propiciando nuevas formas de creación y de acceso a los contenidos creados, sin que ello significase la desaparición de la autoría o que la misma no diese lugar a derechos para sus autores ${ }^{5}$. Al fin y al cabo, el derecho de autor protege la expresión de la creación literaria y no la idea en sí misma.

La pregunta aquí formulada se dirige a indagar sobre si en el caso del universo digital y de las nuevas tecnologías de la sociedad de la información esa demostrada ductilidad del derecho de autor es suficiente para enfrentarse a muchos de los desafíos de los usos transformativos no autorizados. De hecho, desde el punto de vista de

Aranzadi, 2015) (consultado en BIB 2015 \7, 1-2).

${ }^{4}$ Sobre la confrontación de argumentos puede reflexionar en el trabajo Isabel Espín Alba, "Nuevas forma de producción y de acceso al conocimiento: políticas legislativas. Sobre la necesidad de volver sobre los principios rectores del derecho de autor", en Propiedad intelectual en el siglo XXI: nuevos continentes y su incidencia en el derecho de autor, ed. Isabel Espín Alba (Madrid: Reus, 2014), 9-40.

${ }^{5}$ Así considera Miguel Lacruz Mantecón cuándo manifiesta que las nuevas máquinas no crean un nuevo derecho de autor, porque la obra en sí no es realmente nueva, y ubica el debate en la forma, con la interesante conclusión de que "las máquinas de entretener han producido, además de entretenimiento", Derecho. Miguel Lacruz Mantecón, "Las máquinas de entretener o cómo de hace el derecho de autor", en Propiedad Intelectual, Derecho Fundamentales y Propiedad Industrial, ed. César Iglesias Rebolo (Madrid: Reus, 2005), 131-133. 
las relaciones de mercado y la propiedad intelectual, el mayor problema no parece ser tanto la adaptación a las nuevas tecnología de la creación, sino su convivencia con el acceso a copias y puesta a disposición incontrolados ${ }^{6}$, así como su posterior reutilización sin consentimiento de los titulares de derechos.

En suma, ¿es en realidad una cuestión únicamente de viejos contenidos en nuevos continentes?

Para avanzar en algunas de las claves del debate, es preciso acercarse a la cuestión diferenciando los géneros de la creatividad digital. Tal vez los ámbitos que estén sufriendo más las tensiones sean el musical, con sus nuevas modalidades de usos transformativos y canales ilimitados de comunicación pública, o incluso el sector de las obras visuales, en el que la tecnología de la impresión 3D abre posibilidades infinitas de reproducción.

La creación literaria, a la que se dedicarán estas líneas de reflexión, se mueve más próxima al argumento indicado de que en realidad estamos en un juego clásico de viejos contenidos, ahora en nuevas expresiones formales. Con todo, ello no significa, en mi opinión, que no sea necesaria una profunda reforma de ciertos elementos básicos en la configuración del derecho de autor. Por un lado, los límites al derecho de exclusiva deben adecuarse a las nuevas demandas de acceso por parte de los usuarios, y por otra parte, es obligada la adaptación de la regulación de las facultades de explotación, muy especialmente del derecho de transformación, con el fin de estimular la creatividad y generar nuevas formas de explotación de las obras ${ }^{7}$.

\section{Derecho de autory derechos fundamentales desde la perspectiva comunitaria}

Los nuevos retos de la sociedad de la información relacionados con la creación y difusión de contenidos digitales reavivan debates clásicos en la literatura dedicada al derecho de autor y afines, como es el caso de la colisión entre los derechos de autor y

\footnotetext{
'Preocupación manifestada por Lacruz Mantecón, “Las máquinas”, 133.

${ }^{7}$ Por supuesto, muchos otros temas están en la agenda de una profunda reforma del derecho de autor, como la cuestión de los plazos o la extensión de las fronteras del dominio público.
} 


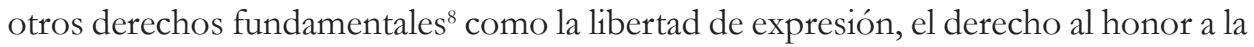
intimidad o a la propia imagen, u otros más discutidos como el acceso a la educación y a la cultura?.

En esta ocasión, una mayor versatilidad en los formatos y la facilidad de difusión y acceso alimenta el discurso de la propiedad intelectual como obstáculo para el libre ejercicio de muchos derechos fundamentales, una verdadera traba para la creación y propagación del conocimiento. Es el caso, por ejemplo, de la pretendida violación de derechos como la libertad de expresión o incluso de la libertad de creación - en este caso, de los nuevos autores que crean a partir de obras que están o estuvieron circulando en el mercado, cuando se imponen medidas restritivas de la circulación de contenidos protegidos.

En este trabajo únicamente se quiere dejar constancia de algunas claves básicas, que sirvan de herramienta para enriquecer el argumentario, a veces plagado de lugares comunes y datos indiscutiblemente falsos. Las conclusiones quedan, como no podría ser de otra manera, para estudios más profundos y detallados.

Bajo estas premisas, en primer lugar no se puede soslayar la propia configuración del derecho de autor como derecho fundamental, así como de la existencia de límites intrínsecos a su conformación, más allá de las cláusulas generales de buena fe y de prohibición del abuso del derecho.

El tema de la ubicación constitucional de los derechos de autor ${ }^{10}$ soporta una fuerte carga filosófica, pues está en la base de la discusión sobre su propio fundamento ${ }^{11}$.

\footnotetext{
${ }^{8}$ Vid. Carmen Buganza "La gestión del derecho de autor y las licencias Creative Commons", en Derecho y Nuevas Tecnologías 3, (Bilbao: Universidad de Deusto, 2011), 1-3.

${ }^{9}$ Vid. el trabajo de Luis Anguita Villanueva, "Derechos fundamentales y propiedad intelectual: el acceso a la cultura", en Propiedad Intelectual, Derecho Fundamentales y Propiedad Industrial, ed. César Iglesias Rebolo (Madrid: Reus, 2005), 49-87.

${ }^{10}$ De modo monográfico vid. los trabajos en la obra VVAA, Constitución y Propiedad Intelectual, ed. Luis Anguita Villanueva (Madrid: Reus, 2014), 1-143.

${ }^{11}$ En el derecho español, el artículo 20.1.b) CE constitucionaliza el derecho a la producción y creación literaria, artística, científica y técnica, mientras el artículo $33 \mathrm{CE}$ sirve de fundamento a la propiedad intelectual. En el caso de la Constitución portuguesa, su artículo 42, bajo el epígrafe de "Liberdade de criação cultural" determina que: 1 . É livre a criação intelectual, artística e científica. 2. Esta liberdade
} 
En efecto, la historia de la convivencia del derecho de autor con otros derechos subjetivos es una historia de ponderación, incluso intrínseca, pues en la propia formulación normativa el capítulo de los límites o excepciones tiene un papel protagonista $^{12}$.

El derecho comunitario da una respuesta que coloca la cuestión en la La Carta de los Derechos Fundamentales de la Unión Europea que dedica su artículo 17 al derecho de propiedad, reseñando en su párrafo primero "Toda persona tiene derecho a disfrutar de la propiedad de sus bienes adquiridos legalmente, a usarlos, a disponer de ellos y a legarlos. Nadie puede ser privado de su propiedad más que por causa de utilidad pública, en los casos y condiciones previstos en la ley y a cambio, en un tiempo razonable, de una justa indemnización por su pérdida. El uso de los bienes podrá regularse por ley en la medida que resulte necesario para el interés general', y en el párrafo segundo sin ninguna limitación o matización dice que "se protege la propiedad intelectual".

Esa protección de la propiedad intelectual es uno de los principios inspiradores de la política de armonización de los mercados, una vez que existe el consenso sobre la idea de que la armonización de las normativas de los Estados miembros sobre los derechos de autor y derechos afines a los derechos de autor contribuye a la realización de los objetivos de creación de un mercado interior y a la instauración de un sistema que garantice que la competencia dentro de ese mercado interior no sea falseada.

En esa línea el considerando 9 de la Directiva (CE) 2001/29, de 22 de mayo, de armonización de determinados aspectos de los derechos de autor y derechos afines a los derechos de autor en la sociedad de la información (DDASI) establece que "Toda armonización de los derechos de autor y derechos afines a los derechos de autor debe basarse en un elevado nivel de protección, dado que tales derechos son primordiales para la creación intelectual. Su protección contribuye a preservary desarrollar la creatividad en interés de los autores, los intérpretes, los productores, los consumidores, la cultura, la industria y el público en general. Por lo tanto, la propiedad intelectual ha sido reconocida como una parte integrante del derecho de propiedad"13.

compreende o direito à invenção, produção e divulgação da obra científica, literária ou artística, incluindo a protecção legal dos direitos de autor."

${ }^{12}$ En el caso del sistema norteamericano, la doctrina del fair use ha posibilitado un amplio margen para limitar el ejercicio del derecho de copia.

${ }^{13}$ Respecto de su consideración como un tipo de propiedad especial, no se puede perder de vista la 
La primera Directiva que de una manera más o menos directa quiere conforntar el derecho de autor con la libre circulación del conocimiento es la Directiva 2012/28/ UE, de 25 de octubre, sobre ciertos usos autorizados de las obras huérfanas $(\mathrm{DOH})^{14}$, que sin utilizar en su parte expositiva términos como obstáculo o traba, se propone a imponer un límite al derecho de autor en todos los Estados miembros. Es importante que, a diferencia de la DDASI, no deja margen a los Estados miembros a implemenar o no el límite, ya que lo impone.

En su Considerando 5 reconoce la importancia de la protección de la propiedad intelectual, pues "los derechos de autor constituyen el fundamento económico de la industria creativa, ya que estimulan la innovación, la creación, la inversión y la producción. Por consiguiente, la digitalización y divulgación a gran escala de las obras es una forma de proteger el patrimonio cultural europeo. Los derechos de autor son un instrumento importante para garantizar que el sector creativo sea recompensado por su trabajo"; sin embargo, justifica la imposición del límite en la existencia de importantes procesos de digitalización llevados a cabo por las bibliotecas, los centros de enseñanza y los museos, accesibles al público, así como los archivos, los organismos de conservación del patrimonio cinematográfico o sonoro y los organismos públicos de radiodifusión establecidos en los Estados miembros, y la consecuente necesidad de conservar y difundir el patrimonio cultural europeo, así como de destacar el valor para la investigación de las colecciones de las bibliotecas.

Así las cosas, la necesidad de impulsar la libre circulación del conocimiento y de la innovación en el mercado interior ocupa un lugar importante en la estrategia Europa 2020. Todo ello en la línea marcada por la Comunicación de la Comisión titulada "Europa 2020: Una estrategia para un crecimiento inteligente, sostenible e integrador"15, base para el desarrollo de una Agenda Digital para Europa. En dicha Comunicación se colocaban como objetivos de trabajo de la Comisión, tanto una adecuada protección y remuneración de los propietarios de derechos y como el apoyo activo a la digitalización del rico patrimonio cultural europeo.

cuestión recurrente de la función social del derecho de autor André R. Bertrand, Droit d'Auteur (París: Dalloz, 2010) 55.

${ }^{14}$ DOUE de 27 de octubre de 2012.

${ }^{15}$ COM (2010) 2020 final, de 3 de marzo de 2010. 
La Resolución de 1 de marzo de $2010^{16}$, que acoge favorablmente la Comunicación de la Comisión, de 11 de septiembre de 2009, titulada "Mejorar el respeto de los derechos de propiedad intelectual en el mercado interior" de proteger los derechos de propiedad intelectual, que son fundamentales para fomentar la cultura y la diversidad, y aprovechar plenamente la investigación, la innovación y la actividad creativa de las empresas europeas, en especial las pequeñas y medianas empresas, con objeto de respaldar el crecimiento y el empleo en la Unión Europea y que Europa sea más competitiva en el mundo". De hecho, en la referida Comunicación se colocó como punto de partida de cualquier política de armonización comunitaria la puesta en valor de la propiedad intelectual en el seno de la Unión, principalmente desde un punto de vista económico. Afirma que el crecimiento del valor de los derechos de propiedad intelectual es un indicador de éxito y que "en la actual sociedad del conocimiento, tales derechos son activos empresariales de vital trascendencia, ya que al asegurar un rendimiento justo de la inversión fomentan la innovación y la creatividad"18.

Por último, es preciso tener en cuenta la ya mencionada Estrategia para el Mercado Único Digital, presentada el 6 mayo de 2015. Aquí están previstos una serie de pasos que incluyen la mejora en la protección de los derechos de propiedad intelectual, a la vez que reclaman un acceso más sencillo por parte de los usuarios a los contenidos protegidos. Interesa especialmente el anuncio de acometer modificaciones en el campo de los límites o excepciones a la propiedad intelectual, pues es una oportunidad de mejorar los resultados armonizadores e incluso de añadir alguna nueva excepción relacionada con el acceso a la los contenidos. Todo ello se

\footnotetext{
${ }^{16}$ DOC de 6 de marzo de 2010.

${ }^{17}$ COM (2009) 467 final, de 11 de septiembre de 2009.

${ }^{18}$ En lo relativo a los derechos conexos a la propiedad intelectual, el legislador comunitario puso de manifiesto la preocupación por una protección más acorde con el papel económico, social y cultural que esos titulares de derechos - principalmente los artistas e intérpretes ejecutantes - desempeñan en la construcción de un mercado cultural europeo. Así, el considerando 4 de la Directiva (UE) 2011/77 proclama que "la importancia que socialmente se atribuye a la contribución creativa de los artistas intérpretes o ejecutantes debe reflejarse en un nivel de protección que reconozca esa contribución creativa y artística"(Directiva (UE) 2011/77, del Parlamento Europeo y del Consejo, de 27 de septiembre de 2011, por la que se modifica la Directiva (CE) 2006/116 relativa al plazo de protección del derecho de autor y de determinados derechos afines, DOUE de 11 de octubre de 2011).
} 
puede ver en la Comunicación de la Comisión al Parlamento Europeo, al Consejo, al Comité Económico y Social Europeo y al Comité de las Regiones "Promover una economía europea fundada en los derechos de autor justa, eficiente y competitiva en el mercado único digital', de 14 de septiembre de $2016^{19}$ que incide, y muy especialmente en la Propuesta de Directiva del Parlamento Europeo y del Consejo sobre los derechos de autor en el mercado único digital de 14 de septiembre de $2016^{20}$.

\section{II - Creatividad Literaria Y Nuevas Tecnologías}

\section{Nuevas formas de expresión literaria}

En los últimos años, la extensión de las tecnologías de la información y de la comunicación y la popularización de herramientas y plataformas de producción y difusión de audiovisuales ha favorecido una auténtica explosión de creaciones realizadas por los usuarios. Este tipo de producciones suelen ser realizadas con pocos medios, impulsadas por individuos y colectivos no siempre ‘profesionales' y que utilizan habitualmente internet como campo base de operaciones. Estos procesos de producción, circulación y consumo de productos culturales en los medios digitales apuntan hacia nuevas formas participativas donde se da la aparición de un nuevo agente mediático, el propio consumidor, ciudadano o usuario, y contempla desde la incorporación de los públicos en el proceso productivo hasta la redefinición del propio modelo de producción y consumo cultural ${ }^{21}$.

\footnotetext{
${ }^{19} \mathrm{COM}(2016) 592$ final.

${ }^{20} \mathrm{COM}(2016) 593$ final.

${ }^{21}$ Las interrelaciones entre la cultura digital y la creación literaria ha sido objeto de diferentes estudios por filólogos y semióticos. Para un acercamiento a estos temas, Covadonga López Alonso, "La hiperficción, entre tecnología y literatura", Lorenzo Hervás, Documentos de trabajo de Lingüistica teórica y general, 20 (2011): 247-269.

http://e-archivo.uc3m.es/bitstream/10016/11530/1/20_10_lopez_alonso.pdf Fecha de consulta 29/07/16.
} 


\section{El caso de las fanfiction}

Para ilustrar el relato sobre nuevas formas de producción literaria se toma como referencia un fenómeno creativo muy popular en el ámbito digital, pero que conserva elementos clásicos de la creación literaria.

La fanfiction, también conocida como fanfic, es una creación elaborada por seguidores (en algunas ocasiones, detractores) de una obra preexistente, y divulgada para el público que conoce de antemano la obra matriz, generando una dinámica colaborativa. De ese modo, la fanfic toma de la obra originaria sus personajes, elementos de la trama, de la ambientación, y los transforman, en algunas ocasiones cambiando el género, en otras haciendo secuelas o precuelas, y siempre manipulando el texto, sin esconder su procedencia.

La obra original objeto de transformación, es la fandomain (fandom) y puede pertenecer a cualquier género: literarias, audiovisuales, videojuegos, comics (especialmente el manga). En todo caso, a pesar del origen variado de obras fandom, lo cierto es que las fanfic son en su inmensa mayoría, narrativas ${ }^{22}$.

Lo primero que se puede decir es que la fanfic no es una herramienta novedosa. Los estudiosos del fenómeno suelen indicar que el término surgió para describir la comunidad promovida por los fans de Star Treck que creaban sus propios fanzines, una serie de textos e ilustraciones basadas en sus personajes, editados bajo la forma de unos cuadernillos de producción artesanal y con una distribución muy reducida, personalmente en reuniones entre amigos o por correo postal con suscripción ${ }^{23}$.

En la actualidad es objeto de estudios en distintos ámbitos de investigación, debido al crecimiento exponencial del fenómeno en internet, a través de foros, blogs, o redes sociales que invitan a participar de una forma activa en la creación y divulgación de nuevas obras.

\footnotetext{
${ }^{22}$ La mayor parte están escritas en inglés, y muchas páginas ponen a disposición de los fans creadores beta readers para la traducción al inglés o la corrección de textos ya traducidos.

${ }^{23}$ Sobre el fenómeno Star Treck, vid. Jane M.Becker, "Stories Around the Digital Campfire: Fan Fiction and Copyright Law in the Age of the Internet”, Connecticut Public Interest Law Journal 1/ 14 (2014): 134-136.
} 
Los canales de divulgación más activos suelen ser páginas web de fanfiction en general o bien páginas web sobre una fandomain en particular ${ }^{24}$.

El salto para la red se ha visto por algunos especialistas en semiótica como un salto de continentes, preservando los contenidos básicos de la creación literaria. Mientras la historieta basada en un superhéroe podía ser leída por un número muy reducido de suscriptores, incluso pasando de mano en mano, las posibilidades de comunicación han alcanzado dimensiones infinitas ${ }^{25}$.

Pasamos de aquellos folletos distribuidos entre amigos, fotocopiados, con ilustraciones de poca calidad, calificados como contracultura alejada de los estándares clásicos de la literatura, a un movimiento de creación colaborativa con capacidad de competencia con canales tradicionales de edición. Ahora el underground se estandariza y puede poner en el mercado productos de calidad técnica que compitan directamente con los originales o lo superen, por entrar en nuevos géneros ${ }^{26}$. Si bien la vida de un fanfic pueda ser efímera, no en pocos casos ha alcanzado un éxito, superando las expectativas comerciales del original. Baste con citar el ejemplo de las "Cincuenta sombras de Grey", que tuvo su origen en una fanfiction de la saga "Crepúsculo".

Con todo, por lo que a la producción literaria se refiere, el nuevo vehículo de difusión no destruye los elementos tradicionales de la clásica edición impresa: atribución de autoría única o en colaboración perfectamente delimitadas, la utilización de un nombre, en su mayoría pseudónimos (nicknames), y la fijación de un espacio (el foro, el blog, el grupo en la red social).

En consecuencia, por lo que al derecho de autor se refiere, no se presentan demasiados cambios respecto de las relaciones entre los titulares de derechos exclusivos y los usuarios de los contenidos protegidos. El único elemento analógico que la técnica de la fanfiction parece pulverizar es el derecho exclusivo de

\footnotetext{
${ }^{24}$ Por ejemplo www.library of moria o www.tolkienfanfiction.com/ íntegramente dedicadas a las fanfic de la obra de Tolkien; aunque también son frecuentes los blogs personales que disponen de foros temáticos.

${ }^{25}$ Carmen Morán Rodríguez, "Li(nk)teratura de kiosko cibernético: Fanfictions en la red", Cuadernos de Literatura, Bogotá-Colombia, 12/23 (2007): 27-53.

${ }^{26}$ Morán Rodríguez, “Li(nk)teratura”, 39-40.
} 
transformación - al que se puede añadir el derecho moral a la integridad de la obra -, pues el resultado creativo de la fanfic, sin excluir esta posibilidad, dista bastante de la parodia, único límite del derecho de transformación.

Ahora bien, a pesar de la plena vigencia de los derechos de propiedad intelectual en esos universos fanfiction, lo cierto es que los autores, productores y distribuidores son muy permisivos con tales prácticas - algunos incluso las fomentan ${ }^{27}$ - claramente infractoras de los derechos de propiedad intelectual. Ello es así, en gran medida, porque son una poderosa forma de publicidad que mantiene en el tiempo la actualidad del producto cultural y genera expectativas de mercados sobre nuevos capítulos de una serie o la publicación de otro libro sobre la saga, aumenta la demanda de merchandasing de personajes ${ }^{28}$, etc.

Es previsible que pronto empiecen a surgir conflictos en los tribunales, en la medida en que las fanfic vayan saliendo del circuito de los fans, pues ya son varios los ejemplos en los que estas producciones independientes han captado la atención de la industria, convirtiéndose en historias de éxito integradas en los medios "tradicionales" de edición ${ }^{29}$.

Asimismo, es preciso señalar la curiosa la contradicción que refleja este universo que parece aspirar a ser libre de derechos de autor, pero al mismo tiempo presenta como regla de participación en los foros, la eliminación de archivos o listas tras descubrirse que han copiado sin autorización otras fanfic. Es decir, la violación de los derechos de explotación está en la esencia de la creación de una fanfiction, pero después e exige el respeto del derecho de autor para el resultado de la creación derivada de la transformación no consentida.

\footnotetext{
${ }^{27}$ Es el caso de J.K. Rowling (Harry Potter) y de Stephanie Meyer (Crepúsculo). Vid. W. Michael Schuster, "Fair use and licensing of derivative fiction:a discussion of possible latent effects of the commercialization of fan fiction", South Texas Law Review 55 (2013-2014): 533.

${ }^{28}$ Sobre la protección de los personajes de la obra originaria y de la obra derivada (fanfiction), Vid. Stephen Richard Donnelly, The Legal Protection of Fictional Characters in Intellectual Property: Protecting Creativity, Property Rights or a Monopoly?, King's Inns Student Law Review (2012):21-48.

${ }^{29}$ Hace un interesante análisis Schuster, "Fair use", 529-552.
} 


\section{III - ¿Derecho De Autor Versus Creatividad Literaria?}

\section{El discurso del obstáculo}

Uno de los tópicos que aparece con más frecuencia en el discurso de la confrontación entre los derechos de los autores y el acceso al conocimiento por los usuarios es la idea de que el vigente sistema de protección de los derechos de propiedad intelectual se encuentra obsoleto y no responde a las necesidades de la sociedad de la información que reclama una inmediatez en el consumo de los contenidos y una flexibilidad en las relaciones comerciales. Se llega a decir que el derecho de autor viene actuando como un freno al desarrollo de la cultura ${ }^{30}$.

Las dificultades y demora en la búsqueda de soluciones para la ausencia de autorización para el acceso y la explotación de obras derivadas de producciones fuera del circuito comercial (huérfanas o no) estuvo alimentado ese relato del derecho de autor como una traba a la propagación del conocimiento. Se habla de barreras arbitrarias creadas por el derecho de autor, levantadas sobre la base de monopolios sobre el conocimiento ${ }^{31}$.

Esa argumentación que en muchos casos pretende expoliar los derechos de los autores sin ningún tipo de contraprestación y/o reconocimiento por su trabajo necesita una revisión, pues como reconoce la Comunicación UE 32 "Un mercado único de los derechos de propiedad intelectual: Estimular la creatividad y la innovación para generar crecimiento económico, empleos de calidad y productos y servicios de excelencia en Europa", de 24 de mayo de 2011, estamos en presencia de un sector estratégico para la Unión Europea $^{33}$.

\footnotetext{
${ }^{30}$ Vid. Maximiliano Marzetti, Propuestas para ampliar el acceso a los bienes públicos en Argentina. Estableciendo el necesario balance entre derechos de propiedad intelectual y dominio público (Buenos Aires: Clacso, 2013), en especial su primer capítulo que lleva por título "La excesiva protección de los derechos de autor va en detrimento de la sociedad", 11-39.

${ }^{31}$ Vid. por todos Lawrence Lessig, Free Culture (New York: The Penguin Press, 2004).

${ }^{32}$ COM (2011) 287 final.

${ }^{33}$ Esta Comunicación del año 2011 parte de un impacto del 3,3 \% del PIB de la Unión. En concreto, dice "Las industrias creativas basadas en los derechos de autor (que comprenden la producción de programas informáticos y bases de datos8, la edición de libros y periódicos9, la música10 y las películas cinematográficas11) aportan una contribución del 3,3\% al PIB de la UE (2006)".
} 
Urge, en todo caso, una reforma no parcheada del sistema de límites contenidos esencialmente en la DDASI, pues si el derecho de autor quiere conservar su fortaleza debe redefinir las fronteras de los usos autorizados, y dar más seguridad jurídica a los agentes económicos y usuarios implicados en la industria cultural.

\section{El problema de los usos transformativos}

En esa pretendida reforma de los límites, a tenor de las acciones implementadas en el marco del Mercado Único Digital, no parece existir una voluntad inmediata de afrontar los distintos problemas de los usos transformativos no autorizados por parte de usuarios de contenidos protegidos por derechos de autor.

La jurisprudencia norteamericana cuenta con una herramienta más flexible por medio de la aplicación del el fair use $e^{34}$, pero en un sistema de límites o excepciones al derecho de autor, parece que el margen es más reducido, ya que tradicionalmente están ceñidos a la parodia (artículo 39 LPI $^{35}$ ).

Por ello es creciente el debate comunitario, y en el caso del derecho español, sobre la necesidad de un auténtico estatuto de la obra derivada, que en la actualidad cuenta con la regulación del artículo 11 LPI, según el cual:

Artículo 11. Obras derivadas

Sin perjuicio de los derechos de autor sobre la obra original, también son objeto de propiedad intelectual:

1. ${ }^{\circ}$ Las traducciones y adaptaciones.

2. ${ }^{\circ}$ Las revisiones, actualizaciones y anotaciones.

\footnotetext{
34 Sobre el tema del alcance de la doctrina del fair use, Jacqueline D. Lipton, "Copyright and the commercialization of fanfiction", Houston Law Review, 52 (2014-2015): 445-453, M. Lantagne, Sherlock Holmes and the Case of the Lucrative Fandom: Recognizing the Economic Power of Fanworks and Reimagining Fair Use in Copyright, Mich. Telecomm. \& Tech. L. Rev. 21 (2015): 285-303; Christina Chung, "Holy fandom, Batman! Commercial fan works, fair use, and the economics of complements and market failure", B. U.J Sci. \& Tech. L., 19 (2013): 380-385.

${ }^{35}$ La vigente LPI española es el Real Decreto Legislativo 1/1996, de 12 abril, que aprueba el Texto Refundido de la Ley de Propiedad Intelectual; y su última modificación corresponde a la Ley 21/2014, de noviembre.
} 
3. ${ }^{\circ}$ Los compendios, resúmenes y extractos.

4. ' Los arreglos musicales.

5. ${ }^{\circ}$ Cualesquiera transformaciones de una obra literaria, artística o científica.

Obra derivada que nuestro legislador entiende como compuesta ex artículo 9. $1 \mathrm{LPI}$ " "Se considerará obra compuesta la obra nueva que incorpore una obra preexistente sin la colaboración del autor de esta última, sin perjuicio de los derechos que a éste correspondan y de su necesaria autorización."

Esa mera descripción ya revela lagunas importantes para cubrir diferentes prácticas creativas presentes en la cultura digital, en las que predominan técnicas colaborativas y transformadoras.

\section{Los limites del derecho de autor y los usos transformativos}

Cuando la DDASI, en su Considerando 14, indica como objetivo "fomentar el aprendizaje y la cultura mediante la protección de las obras y prestaciones, permitiendo al mismo tiempo excepciones o limitaciones en interés generalpara fines educativos y docentes", a continuación presenta una serie de límites y excepciones que proporcionan un espacio para el uso libre de los derechos de autor. Excepciones como la cita, la parodia, la ilustración, etc. Todas ellas permiten la circulación del conocimiento y el refuerzo del contenido de las enseñanzas.

Pero esa preocupación con el acceso presente en la Propuesta de Directiva sobre los derechos de autor en el mercado único digital de 14 de septiembre de 2016, contrasta con el escaso margen que existe para la licitud de usos transformativos sin autorización del autor.

Cada vez es más amplio el abanico de excepciones con base en el derecho de acceso a la cultura y educación, así como en el interés público de preservación del patrimonio cultural, que permiten a los usuarios acercarse lícitamente a un vasto conjunto de obras protegidas; sin embargo, ello no significa que las obras puedan, a partir de ese acceso lícito, ser objeto de futuras explotaciones, y muy concretamente de transformación, sin autorización del autor. 


\subsection{Limites relacionados con el acceso a la cultura y a la educación}

El acceso a la cultura y a la educación están en el sustrato de los límites y excepciones del derecho de autor, el principal expediente técnico para alcanzar el equilibrio entre los intereses en juego.

Son varias las excepciones que están relacionadas de una manera más o menos directa con la actividad didáctica de enseñanza así como con la investigación, y que responden a las exigencias de garantizar los derechos contenidos en los artículos 27 CE (derecho fundamental a la educación) y 40 CE (principios rectores de acceso a la cultura y de promoción de la ciencia y la investigación científica y técnica). Además de la que específicamente de refiere a la ilustración de la enseñanza, no cabe la menor duda que otras excepciones facilitan el acceso legal y libre a contenidos didácticos, en algunos de los supuestos con licencias remuneradas y en otros no. Es el caso del denominado derecho de cita (de los que muchos entienden que la ilustración para la enseñanza es una especie), la copia privada, limitaciones y excepciones en favor de las bibliotecas y archivos, más recientemente las obras huérfanas, límites que favorezcan el accesoa personas con discapacidad visual ${ }^{36}$, etc.

Ese entramado de posibilidades de utilización de las obras favorecen la flexibilidad del derecho de autor, y funcionan como garantía de acceso legal a la cultura y al conocimiento a través de contenidos protegidos por el derecho de autor $^{37}$, sin necesidad de la autorización de sus titulares.

La protección del interés público en esos casos bascula entre diferentes grados de acceso. El acceso ilimitado a contenidos es visto como una herramienta básica

\footnotetext{
${ }^{36}$ En esta línea la Propuesta de "Reglamento sobre el intercambio transfronterizo entre la Unión y terceros países de ejemplares en formato accesible de determinadas obras y otras prestaciones protegidas por derechos de autory derechos afines a los derechos de autor en beneficio de las personas ciegas, con discapacidad visual o con otras dificultades para acceder al texto impreso", de 14 de septiembre de 2016 [COM (2016) 595 final].

${ }^{37}$ En efecto, cuando la DDASI, en su Considerando 14, subraya como objetivo "fomentar el aprendizaje y la cultura mediante la protección de las obras y prestaciones, permitiendo al mismo tiempo excepciones o limitaciones en interés general para fines educativos y docentes", a continuación presenta una serie de límites y excepciones que proporcionan un espacio para el uso libre de los derechos de autor. Excepciones como la cita, la parodia, la ilustración, etc. Todas ellas permiten la circulación del conocimiento y el refuerzo del contenido de las enseñanzas.
} 
para la diseminación del conocimiento y como fuente para la creación de nuevos contenidos, a partir, principalmente, de un repertorio de obras intelectuales - en dominio púbico o de uso libre - más robusto ${ }^{38}$.

De ese modo, en esta materia el sistema de límite o excepciones es una herramienta en el avance de la sociedad de la información, abandonando el lugar periférico en la configuración del sistema internacional del copyright para ganar un papel más central en las medidas propuestas para el desarrollo económico, especialmente de los denominados países en vía de desarrollo ${ }^{39}$; y cuya mayor dificultad de articulación normativa es encontrar mecanismos que no supongan una traba a los procesos formativos, al acceso a una educación de calidad, y al mismo tiempo no representen una carga excesiva a los titulares de derechos, que vacíe de contenido las facultades inherentes a la propiedad intelectual.

La citada Propuesta de Directiva sobre los derechos de autor en el mercado digital de 14 de septiembre de 2016 avanza en la excepciones relacionadas con fines educativos y de investigación y perfila límites en tres ámbitos de intervención: usos digitales y transfronterizos en la educación; minería de textos y datos en el campo de la investigación científica; y conservación del patrimonio cultural.

\subsection{Limites relacionados con el derecho de transformación: la parodia}

El artículo 5.3.k DDASI dice que los Estados podrán establecer límites “cuando el uso se realice a efectos de caricatura, parodia o pastiche". En el caso español, el LPI no presenta una definición de parodia, pero la reconoce con límite del derecho de transformación, y por lo tanto lícita, siempre que cumpla tres requisitos ${ }^{40}$, que son reseñados a continuación.

\footnotetext{
${ }^{38}$ Vid. estas apreciaciones en Ruth L. Okediji, The international copyright system: Limitations, Exceptions and Public Interest Considerations for Developing Countries (Ginebra: Ed. UNCTAD - ICTSD, 2006), ix-xii.

${ }^{39}$ Okediji, The international copyright system, xii.

${ }^{40}$ Tuve la oportunidad de analizarlos en Isabel Espín Alba, "La parodia de obras divulgadas", en Los limites del derecho de autor, ed. Carlos Rogel Vide (Madrid: Reus, 2006), 284.
} 


\subsubsection{Transformación de una obra divulgada protegida por el derecho de autor}

La parodia es una técnica intertextual, puesto que efectúa una superposición de obras - una que parodia y otra que es parodiada - que permite al público reconocer en el resultado satírico, la obra original que le ha servido de inspiración.

Debe referirse a una obra ya divulgada en consonancia con el respeto al derecho de inédito de los autores, entendido como el derecho a decidir si su obra ha de ser divulgada y en qué forma ex artículo 14.1 LPI.

Una discusión tradicional en este punto es aquella relativa a si la parodia debe referirse a la obra original (target parody) o si por el contrario puede ser un mero instrumento para la crítica ajena al contenido y naturaleza de la obra parodiada, que en este caso es mero instrumento (weapon parody).

La mayor parte de la doctrina española ${ }^{41}$, en contradicción con algunas decisiones judiciales ${ }^{42}$, mantuvo que para ser considerada lícita, la parodia debería dirigirse a una obra divulgada y a su autor, y no a elementos exógenos a la misma. Con todo, el TJUE fulminó esa distinción en la Sentencia de 3 de septiembre de 2014, más adelante comentada, de modo que se puede afirmar que la libertad de expresión ampara cualquiera de las dos formas de creación de parodia, y será en cada caso concreto cuándo se determine si en el ejercicio de su libertad de creación el autor de la parodia infringió o no algún derecho de terceros.

\subsubsection{Ausencia de confusión}

En segundo lugar, se exige la ausencia de confusión. Es fundamental que se evoque el modelo previo, provocando el efecto de burla, de tal forma que el público detecte dos discursos creativos: el originario, y el derivado que es una imitación

\footnotetext{
${ }^{41}$ Por todos Miguel Ángel Bouza López, "¿Parodia nacional o individual? Nota a la sentencia de la Audiencia Provincial de Madrid (Sección 13a) de 2 de febrero de 2000", Revista General de Derecho, 675 (2000): 15133.

${ }^{42}$ Sentencias de la Audiencia Provincial de Madrid de 2 de febrero de 2000 y de 30 de noviembre de 1998, y Sentencias de la Audiencia Provincial de Barcelona de 24 de abril de 2002 y 10 de octubre de 2003.
} 
burlesca del primero. En caso contrario, esa copia casi literal de la obra original entraría en el ámbito del plagio u de otras prácticas parasitarias ilícitas.

\subsubsection{Ausencia de un daño a la obra original o a su autor}

Por último, la ausencia de un daño, requisito que mantiene la esencia de la prohibición de utilizaciones no autorizadas y que cierra el paso a usos transformativos que no estén ceñidos a la parodia. En esa línea, la Sentencia de la Audiencia Provincial de Barcelona de 22 de julio de 2003 sobre una demanda entablada por la empresa creadora del personaje Lara Croft, protagonista del popular videojuego Tom Raider, contra la sociedad editora de la revista Interviú, desestimó la alegación de la demandada de que la publicación de un reportaje con imágenes modificadas de la referida heroína digital sin el consentimiento de los titulares de derechos fuese una parodia. El Tribunal entendió que las imágenes modificadas, acompañadas además de una serie de fotografías de una modelo humana, no presentaban los elementos esenciales del género y que, por lo tanto, indicaban una infracción tanto de los derechos patrimoniales como morales de los titulares de derechos de propiedad intelectual.

\subsection{Comentario a la Sentencia del Tribunal de Justicia de la Unión Europea de 3 de} septiembre de 2014. Caso Deckmyn y Vrijheidsfonds ${ }^{43}$

El Caso Johan Deckmyn y Vrijheidsfonds VZW contra Helena Vandersteen y Otros, contiene un claro ejemplo de confrontación entre libertad de expresión y derechos de autor, y ha significado una decisiva delimitación del concepto y alcance de la parodia en el derecho comunitario. Por consiguiente, esta decisión del TJUE tiene una doble importancia para el tema aquí tratado. Por un lado, obvia la cuestión de la diferencia entre weapon parody y target parody en la delimitación del concepto comunitario de parodia; y por otra parte, reflexiona sobre la ponderación entre derechos de autor

\footnotetext{
${ }^{43}$ Sentencia de 3 septiembre 2014, Johan Deckmyn y Vrijheidsfonds VZW contra Helena Vandersteen y Otros, asunto C-201/13, ECLI:EU:C:2014:2132.
} 
y libertad de expresión, para los casos en que los titulares de derechos no quieren vincular su obra con determinadas ideas expresadas por el creador de la parodia.

La petición de decisión prejudicial versa sobre la interpretación del artículo 5. 3. K) DDASI, y se planteó en el marco de un litigio entre, por un lado, el Sr. Deckmyn y el Vrijheidsfonds VZW, asociación sin ánimo de lucro, y, por otro lado, varios herederos del Sr. Vandersteen, autor de los tebeos Suske en Wiske, y los titulares de los derechos asociados a estas obras, en relación con la distribución por el Sr. Deckmyn de un calendario en el que se reproducía un dibujo parecido a otro que figuraba en la portada de un álbum de Suske en Wiske.

El supuesto de hecho se refiere a que el Sr. Deckmyn, político vinculado a un partido de extrema derecha (Vlaams Belang), en una recepción celebrada en la ciudad de Gante con motivo del Año Nuevo de 2011, distribuyó una serie de calendarios en los que figuraba como editor responsable. La cubierta de los calendarios contenía un dibujo que evocaba la portada del álbum cómic titulado "El benefactor compulsivo" (De Wilde Weldoener), creado en 1961 por el Sr. Vandersteen.

En la tira original, se puede observar como un personaje, ataviado con una túnica blanca y volando ayudado de una hélice, deja caer monedas y diversas personas intentan hacerse con ella, bajo la atenta mirada de unos sorprendidos niños, mientras la parodia contenida en el calendario reproduce la misma imagen, pero el personaje que lanzaba las monedas era el alcalde socialista de la ciudad y las personas que recogen las monedas pertenecen a diferentes grupos étnicos, raciales y religiosos.

El conflicto que trasciende de la demanda se refiere al rechazo por parte de los titulares de derechos de autor a que su obra sea utilizada con fines de caricatura política que pueda tener connotaciones racistas, y que en todo caso, son contrarias a las convicciones políticas o ideológicas del autor. Es un supuesto claro de weapon parody, pues se está utilizando una obra para hacer una crítica social completamente ajena al contenido de la obra misma.

En respuesta a las cuestiones prejudiciales planteadas ${ }^{44}$, la Sentencia fija el

\footnotetext{
${ }^{44}$ Son tres cuestiones que pivotan sobre la delimitación del concepto del parodia: "1) ¿Es el concepto de 'parodia' un concepto autónomo del Derecho de la Unión? 2) En caso de respuesta afirmativa, ¿debe la parodia cumplir los requisitos siguientes o poseer las características siguientes: acreditar un carácter original propio (originalidad); - acreditar tal carácter de forma que la parodia no pueda atribuirse razonablemente al autor de la obra original; - estar
} 
concepto de parodia como un concepto autónomo del Derecho comunitario que exige una interpretación uniforme para todos los Estados miembros. En ausencia de una definición de la parodia en la legislación europea, entiende que debe interpretarse según el lenguaje común, es decir, una manifestación humorística que evoca una obra existente, de la que se diferencia inequívocamente.

De igual modo, establece que es necesario un justo equilibrio entre la libertad de expresión del creador de la parodia y los intereses de los titulares de derecho y de los usuarios de las obras y prestaciones protegidas. En el caso concreto, manifiesta que los demandantes tienen un interés legítimo en que no se asocie la obra original con un mensaje discriminatorio transmitido por la parodia.

Así las cosas, el órgano jurisdiccional nacional deberá considerar si el calendario litigioso evoca una obra anterior con un espíritu humorístico o burlesco ${ }^{45}$, y asimismo analizar si hubo un mensaje discriminatorio que manifieste un perjuicio a los intereses del autor de la obra original.

\section{IV - Breves Reflexiones Finales}

La apuesta de la UE por un mercado único digital y por el crecimiento y consolidación de las industrias culturales requiere marcos jurídicos más estables que garanticen una circulación de productos absolutamente respetuosa con la propiedad intelectual.

En un contexto de inminentes modificaciones normativas en sede de derechos de autor, la tarea más acuciante es acometer una reforma del sistema de límites, con el fin de proporcionar un marco más estable para la creación y puesta a disposición de obras literarias, artísticas y científicas en el mercado.

Parece evidente, como señala el Informe Lescure, que las excepciones que

dirigida a hacer bumor o burla, con independencia de si la crítica eventualmente realizada afecta a la obra original o bien a algo o a otra persona; - indicar la fuente de la obra parodiada? 3) ¿Debe una obra cumplir otros requisitos o poseer otras características para tener la consideración de parodia?".

${ }^{45}$ El límite de la parodia está previsto en el derecho belga, de tal manera que el artículo 22.1. de la Ley de 30 de junio de 1994, relativa a los derechos de autor y a los derechos afines a los derechos de autor, impide al autor, cuando la obra es hecha pública de forma lícita, oponerse a " 6 " las caricaturas, parodias o pastiches, realizados en observancia de las buenas costumbres". 
protegen la libertad de creación de los usuarios no permiten asegurar correctamente las prácticas de creación transformativa ${ }^{46}$, de modo que para sortear esta dificultad, un sector doctrinal defiende la necesidad de tomar elementos de flexibilización de las excepciones previstas a través de la aplicación de la doctrina del fair use. El carácter dúctil de las fórmulas de uso leal guarda en esa aparente inseguridad su principal virtud, una vez que hace la noma excepcional más dinámica para atender a los desafíos de la era digital ${ }^{47}$. En todo caso, ello nunca deberá amparar prácticas parasitarias, como algunas de aquellas descritas en la praxis de las fanfiction.

Asimismo, es preciso construir un nuevo paradigma para las obras derivadas que permita compaginar el fomento a la creatividad, la libertad de expresión y el derecho de acceso a la cultura con los derechos de autor de un modo más equilibrado y que - unidos a una adaptación de la normativa de los límites, ya que la parodia no se ha mostrado idónea para este fin - reste protagonismo al discurso del obstáculo.

\footnotetext{
${ }^{46}$ Informe Lescure, t.1 (París, 2013), 36. Ese Informe publicado en mayo de 2013 es resultado de un estudio encargado por el gobierno francés y elaborado por Pierre Lescure sobre los desafíos de las industrias culturales en el universo digital. Se puede consultar en http://institutoautor.org/userfiles/Rapport \% 20 Lescure\%20498(1).pdf Fecha de consulta 29/07/16.

${ }^{47}$ Así aparece reflejado en el Estudio elaborado por Giuseppe Mazziotti para el CEPS sobre el derecho de autor en el mercado único europeo, que entiende que las nuevas formas de creación transformativa obligan a que se vuelva al debate sobre la eventual flexibilización del sistema de límites, para acoger técnicas más próximas al fair use, pero también señala que es poco probable que se alcance el consenso necesario para una auténtica armonización en esta materia (Giuseppe Mazziotti, Copyright in the EU Digital Single Market Report of the Ceps Digital Forum (Bruselas: CEPS, 2013), 73. Disponible en http:// www.ceps.eu.).
} 


\title{
Estatuto e competências da Entidade Reguladora da Saúde - em especial em matéria de defesa da concorrência
}

\author{
Isa António*
}

RESUMO: O presente artigo reflete a preocupação com os imperativos constitucionais de universalidade, igualdade e equidade no acesso à saúde (art. $64 .{ }^{\circ} \mathrm{CRP}$ ), bem como com o nível de qualidade e de segurança na prestação do serviço de saúde em Portugal. Estes valores e desideratos somente serão alcançados perante um setor ("mercado") da saúde em que exista efetiva concorrência na atuação dos respetivos agentes económicos (v.g. estabelecimentos prestadores de serviços de saúde do setor público, privado e do "terceiro setor"). Após indicarmos as especificidades do "mercado da saúde" e de referirmos os principais "perigos" para o doente, "consumidor" de serviços de saúde (v.g. discriminação, seleç̧ão adversa, assimetria da informação, falta de qualidade e de segurança), procedemos à caracterização jurídica da Entidade Reguladora da Saúde (ERS). Em Portugal, a ERS é a instituição independente dotada da vocação estatutária de proteger a saúde, enquanto direito e valor, e igualmente com a missão de salvaguardar e zelar pelo bom funcionamento do "mercado da saúde". Por conseguinte, analisamos de modo desenvolvido os seus deveres e competências especiais na senda da leal e sã concorrência entre os inúmeros prestadores. Preconizamos, por último, a posição que impõe a regulação rigorosa, permanente e eficaz levada a cabo pela ERS como o mecanismo sine qua non para a existência de concorrência na saúde.

PALAVRAS-CHAVE: Entidade Reguladora da Saúde-estatuto e competências-concorrência-mercado da saúde.

ABSTR ACT: This article reflects the concern with the constitutional imperatives of universality, equality and equity in access to health (article $64 \mathrm{CRP}$ ), as well as the level of quality and safety in the provision of health services in Portugal. These values and objectives will only be achieved in a bealth sector ("market") where there is effective competition in the performance of its economic agents (v.g health service providers from the public, private and third sectors). After indicating the specificities of the "bealth market" and referring the main "risks" to the patient, "consumer" of bealth services (v.g discrimination, adverse selection, asymmetric information, lack of quality and safety), we proceed to legal characterization of the Regulatory Authority of Health (RAH). In Portugal, RAH is the independent institution with the statutory

\footnotetext{
* Doutorada em Direito Administrativo/Contratação Pública. Docente no Instituto Politécnico do Porto e no Instituto Politécnico de Coimbra. Membro Doutorado do Centro de Estudos em Direito da União Europeia (CEDU), Universidade do Minho.
} 
vocation to protect health as a right and value, and also with the mission of safeguarding and ensuring the proper functioning of the "bealth market". Consequently, we have profoundly analyzed its special duties and competences in the mission of fair and efective competition among the many providers. In conclusion, we advocate the position that requires strict, permanent and effective regulation by the $\mathrm{RAH}$ as the sine qua non mechanism for the existence of competition in bealth.

KEYWORDS: Regulatory Authority of Health - statute and powers - competition - bealth market.

\section{A Entidade Reguladora da Saúde: caracterização jurídica}

A Entidade Reguladora da Saúde (ERS) ${ }^{1}$ é juridicamente qualificada como uma Pessoa Coletiva Pública, mais precisamente, um instituto público sui generis, porque ao contrário dos demais institutos públicos inseridos organicamente na denominada "Administração Pública Indireta", não se submete aos típicos poderes exercidos pelo Governo. Neste caso em concreto - setor da saúde - é independente do Ministério da Saúde.

É matriz estruturante da independência da ERS o seu "eixo orgânico", no âmbito do qual os seus órgãos não são de livre nomeação e destituição pelo Governo (independência orgânica) e nem se sujeitam às diversas formas de controlo deste, designadamente através da «superintendência»e da «tutela», pois estes poderes eliminariam qualquer atuação independente por parte de uma entidade que se quer rigorosa, imparcial e objetiva (independência funcional). Possui, pois, uma verdadeira independência orgânica relativamente ao poder executivo (Governo), através do mandato fixo, da irremovibilidade dos seus membros e de um forte regime de incompatibilidades de funções. A fundamentação para este tratamento diferenciado reconhecido pela lei consubstancia-se no facto de a ERS consistir numa

\footnotetext{
${ }^{1}$ A ERS foi criada pelo Decreto-Lei n. ${ }^{\circ}$ 309/2003, de 10 de dezembro de 2003, na sequência de uma reforma no setor da saúde, sobretudo no que concerne ao Serviço Nacional de Saúde, tendo sido regulamentada pela Portaria n. ${ }^{\circ}$ 418/2005, de 14 de abril. Entretanto, foi aprovada a Lei-Quadro das Entidades Reguladoras Independentes (Lei no 67/2013, de 28 de agosto), de que a ERS é paradigma, o que obrigou a uma sua reconformação legislativa por meio do Decreto-Lei n. ${ }^{\circ}$ 126/2014, de 22 de agosto.
} 
entidade administrativa independente ${ }^{2}$. No ordenamento jurídico português, as entidades reguladoras independentes assumem a natureza de "entidades administrativas independentes" consagradas constitucionalmente no art. $267 .{ }^{\circ}$, n. $^{\circ} 3^{3}$, ora tendo

\begin{abstract}
${ }^{2}$ Porém, esta independência não equivale a uma atuação desenvolvida "à margem" ou "à revelia" do Estado, ao qual não deixa de pertencer, sob pena de se tratar de uma entidade "fora da le?" cuja atividade seria, ela própria, ilegal e inconstitucional. O que a Lei Fundamental e as leis ordinárias pretendem com a consagração expressa da independência da ERS é assegurar a existência de uma verdadeira entidade reguladora, de supervisão e de fiscalização efetiva debruçada sobre o setor da saúde, à semelhança do que sucede com as entidades reguladoras dedicadas a outros setores de atividade, como a Autoridade Nacional de Comunicações (ANACOM), Entidade Reguladora para a Comunicação Social (ERC), Entidade Reguladora da Energia (ERSE), etc.
\end{abstract}

${ }^{3}$ A ERS é, por excelência, guardiã do SNS. A preservação do SNS nos termos prescritos pela Constituição é o alfa e ómega da atuação da ERS. Em primeiro lugar, o direito de acesso à prestação de cuidados de saúde e o princípio da universalidade relativo a esse acesso têm diversos corolários ou implicações, do qual ressalta a obrigatoriedade de ser assegurado o acesso à saúde a todos os utentes, em condições de igualdade, designadamente no que ao "preço" se refere. Para tanto, é imperiosa a eficácia de uma "regulação económica no acesso aos serviços", através do estabelecimento de preços ou taxas em função do serviço público prestado que deverá ter em consideração a exigência constitucional de "tendencial gratuitidade". Com efeito, na senda da Constituição da República Portuguesa, o direito de proteção à saúde é concretizado mediante um serviço universal e geral, tendencialmente gratuito. Mas importa salientar que "tendencial gratuitidade" não equivale à isenção absoluta de pagamento relativo às prestações usufruídas pelo utente. Aliás, a doutrina dominante na esteira do Tribunal Constitucional, já chamado a pronunciar-se sobre esta questão, afirma ser compaginável com "tendencial gratuitidade" o pagamento de "taxas moderadoras" ou a fixação de tabelas de preços por atos clínicos. Até porque existe uma franja de utentes que beneficiam da isenção do pagamento de taxas moderadoras, após demonstração dos seus parcos rendimentos, pelo que é assegurado aos cidadãos mais pobres proteção no acesso à saúde. Em segundo lugar, de acordo com o princípio de igualdade do acesso à saúde, a "saúde" deverá ser proporcionada, em perfeitas condições de igualdade, ao utente-beneficiário, sendo absolutamente vedada a possibilidade de se adotar condutas discriminatórias, ou sob qualquer forma cerceadoras da liberdade de acesso à saúde, como a «recusa ilegítima» em prestar esse serviço. Numa terceira vertente, em conformidade com o princípio da equidade no acesso à prestação de cuidados de saúde é estabelecida uma prioridade no acesso aos cuidados de saúde, mediante o preenchimento de certos pressupostos ou fatores, designadamente fatores de natureza médica ou técnico-científica, mas também a idade e o trabalho. Uma eventual discriminação positiva pode ser igualmente um mecanismo a ser utilizado no esforço de concretização da "equidade". Exemplo ilustrativo, a este propósito, é a existência de zonas do país menos favorecidas dotadas de serviços de saúde que podem vir a ser beneficiadas com mais recursos humanos, económicos e técnicos. Neste sentido, veja-se a alínea d), da Base XXIV, constante da Lei de Bases da Saúde, segundo a qual "o SNS caracteriza-se por garantir a equidade no acesso para utentes, com o objetivo de atenuar os efeitos das desigualdades económicas, geográficas e quaisquer outras no acesso aos cuidados". Numa quarta vertente, a qualidade e a segurança na prestação de cuidados de saúde, características do direito de acesso aos cuidados de saúde [art. 10. ${ }^{\circ}$, alíneas b), c) d), do DL n. ${ }^{\circ}$ 126/2014, de 22 de agosto], versarão sobre diversas facetas, designadamente na física, na técnica, na profissional e na humana. E, neste aspeto, um mecanismo de incontornável relevância é a "acreditação" sobre esse 
funções de regulação económica, ora funções de garantia de determinados direitos fundamentais, como a liberdade de expressão (Alta Autoridade para a Comunicação Social - AACS, com previsão no art. 39. ${ }^{\circ} \mathrm{CRP}$ ) ou o direito à proteção da vida privada (Comissão Nacional de Proteção de Dados Pessoais - CNPD, consagrada na Lei n. ${ }^{\circ}$ 43/2004, de 18 de agosto). Na verdade, seria uma construção falaciosa a criação de uma qualquer entidade de regulação que não visse ser legalmente consagrada a sua independência e que devesse subordinação hierárquica às entidades para cuja fiscalização ela própria havia sido criada.

Mas existem outros eixos basilares desta independência. Senão vejamos.

A ERS apresenta igualmente independência de tipo funcional, o que significa que no exercício das funções reguladoras as suas decisões não podem vir a ser objeto de modificação por parte do Governo, encontrando-se apenas sujeitas a uma apreciação jurisdicional, nos termos gerais da judicial review da atividade administrativa.

Outro elemento imprescindível à independência de uma entidade reguladora prende-se com a sua autonomia financeira, consubstanciada na dotação de recursos financeiros próprios distintos e independentes do orçamento do Estado. Acresce por isso, necessariamente, um leque de poderes regulamentares e sancionatórios ao “normal' conjunto de poderes próprios de autoridade administrativa.

Os titulares do órgão regulador são inamovíveis durante o mandato temporal, não podendo o Governo destituí-los salvo em caso de ilegalidade ou de infração grave aos deveres legais e após inquérito realizado por autoridade independente, sendo que esta imposição legal constitui uma das efetivas garantias de independência orgânica. Acresce que não pode ser sancionada pelo modo como exercita as suas competências de regulação, nem se submete ao ciclo eleitoral, ou seja, à maioria governamental de cada legislatura.

grau de qualidade e de segurança. Igualmente, o princípio da continuidade dos serviços prestados e de permanente adaptação e atualização física, técnica, científica e humana, encerra em si mesmo uma outra vertente estrutural do Serviço Nacional de Saúde que deverá ser assegurada com maior acuidade, neste especial momento em que a empresarialização no setor da saúde se encontra em voga. Veja-se, a este respeito, a «Carta dos Direitos de Acesso aos Cuidados de Saúde pelos Utentes do Serviço Nacional de Saúde» consagrada na Lei n. ${ }^{\circ} 41 / 2007$, de 24 de agosto. 
Podemos em termos sintéticos qualificar a ERS como uma entidade administrativa independente vocacionada à supervisão e regulação económica e social do setor da saúde, para cuja missão possui um leque concreto de poderes específicos face aos poderes dos demais institutos públicos. De uma perspetiva orgânica, é composta por, pelo menos, dois órgãos, um órgão de governo colegial e um órgão de fiscalização da gestão (administrativa e financeira), que em Portugal tem natureza singular (fiscal único) e sem participação direta na função regulatória ${ }^{4}$.

\section{Competências e poderes específicos: tipologias}

Podemos enunciar três grandes tipologias de competências ou poderes que se desdobram noutros sub-poderes, pertencentes à Entidade Reguladora da Saúde necessários ao exercício da sua missão, como designadamente, os poderes normativos (ou poderes normativos de natureza regulamentar), os poderes administrativos (ou poderes de autoridade administrativa) e os poderes parajurisdicionais (v.g. poderes de supervisão e poderes sancionatórios). Dentro dos poderes normativos de natureza regulamentar [art. 15. ${ }^{\circ}$, o qual deve ser lido conjuntamente com o art. $10 .^{\circ}$, alínea e)], encontramos o poder de emitir recomendações ou orientações e diretrizes [arts. 11. ${ }^{\circ}$, alínea a), $15^{\circ}{ }^{\circ}$ e $17 .^{\circ}$ ] e o poder de aprovar os instrumentos de auto-regulação dos prestadores ou operadores [art. 14. ${ }^{\circ}$, alínea d)]. Encontram-se inseridos nos poderes de supervisão (arts. $19 .^{\circ}$ e $21 .^{\circ}$ ) os poderes que permitem ordenar inspeções e auditorias, solicitar informações periódicas sobre o funcionamento dos serviços de saúde, sobre os resultados atingidos, os relatórios de contas, etc. Acerca da garantia de livre e leal concorrência, a ERS possui nesta matéria competências decisivas, previstas no art. 16. .

De entre os poderes de autoridade administrativa constam o poder de emitir injunções e de ordenar medidas provisórias. Os poderes sancionatórios ou punitivos

\footnotetext{
${ }^{4}$ Em termos gerais, a reforma institucional no âmbito da saúde operada em 2003 e reforçada com o novo DL n. ${ }^{\circ}$ 126/2014, de 22 de agosto, trouxe consigo inovações muito relevantes da perspetiva da emergência de uma regulação no setor da saúde.
} 
(arts. 22..$^{\circ}$ e $23 .^{\circ}$, concretizados pelos arts. $61 .^{\circ}$ a $66 .^{\circ}$ ) abrangem a capacidade de impor a aplicação de coimas (sanções pecuniárias), sanções pecuniárias compulsórias e sanções acessórias (suspensão ou encerramento de serviços e estabelecimentos, inibição de funções de gestão, etc.).

A estes poderes acrescem os poderes arbitrais (arts. $28 .^{\circ}$ e $29 .^{\circ}$ ) que conferem à entidade reguladora a capacidade para dirimir conflitos entre operadores e entre estes e os utentes-consumidores, assim como os poderes de apreciação de queixas dos utentes contra os prestadores do serviço de cuidados de saúde (art. 30. ${ }^{\circ}$ ). Com efeito, veja-se, a este respeito, o art. 67. ${ }^{\circ}$ segundo o qual a atividade de natureza administrativa da ERS fica sujeita a controlo do tribunal administrativo (art. 67. ${ }^{\circ}$, n. $\left.{ }^{0} 11\right)$, ao passo que as sanções aplicadas em virtude de infrações de mera contraordenação ou as decisões de natureza arbitral são objeto de recurso para o tribunal judicial (comum).

Ora, esta solução permite presumir que as decisões tomadas pela ERS, quando esta intervém na resolução de conflitos entre operadores privados, possuem natureza materialmente arbitral (e não de ato administrativo), consistindo numa decisão arbitral com força de caso julgado e munida de força executiva de primeira instância, passível de recurso para o tribunal comum, nos termos prescritos pela Lei de Arbitragem. Quanto à arbitragem de litígios entre prestadores e/ou entre estes e utentes, encontram-se previstos no art. 29. ${ }^{\circ}$ os poderes da ERS.

No que respeita às decisões em que tenha sido fixada pela ERS uma coima ou uma sanção acessória, é competente o «Tribunal da Concorrência, Regulação e Supervisão», podendo modificar aquela decisão, reduzindo ou aumentando a coima ou alterar a sanção acessória aplicada (n. ${ }^{\circ}$, do art. $67^{\circ}$ ).

A ERS enquanto guardiã do setor da saúde tem como principais missões a fiscalização e a supervisão da atividade e funcionamento dos estabelecimentos prestadores de cuidados de saúde. Com este propósito tem a competência de zelar pelo cumprimento dos pressupostos de exercício da atividade e de funcionamento, à garantia dos direitos relativos ao acesso aos cuidados de saúde e dos demais direitos dos utentes, à legalidade e transparência das relações económicas entre os 
diversos operadores, entidades financiadoras e utentes. Compete, nesta senda, à ERS: (a) exercer controlo sobre o funcionamento dos estabelecimentos, zelando pelo cumprimento dos requisitos do exercício da atividade dos estabelecimentos prestadores de cuidados de saúde; (b) assegurar a garantia de acesso aos cuidados de saúde e defesa dos direitos dos utentes, assegurando o respeito pelos critérios de acesso aos cuidados de saúde e pelos direitos constitucionalmente consagrados dos utentes; (c) proceder à regulação económica (art. 15. ${ }^{\circ}$ ), velando pela legalidade e transparência das relações económicas estabelecidas pelos vários players do mercado; (d) defender a concorrência (art. 16. ${ }^{\circ}$ ) nos setores abertos ao mercado, colaborando com a Autoridade da Concorrência na prossecução das suas atribuições.

No que especificamente respeita à garantia de acesso aos cuidados de saúde e defesa dos direitos dos utentes, em conformidade com os arts. $12 .^{\circ}$ a $14 .^{\circ}$, compete à ERS, entre outras funções: i) assegurar o direito de acesso universal e equitativo aos serviços públicos de saúde ou publicamente financiados, nos termos do art. 12. ${ }^{\circ}$, alínea a) e art. $10 .^{\circ}$, alíneas b) e c); ii) prevenir e punir as práticas de rejeição discriminatória ou infundada de pacientes nos estabelecimentos públicos de saúde ou publicamente financiados (ex. seleção adversa, em que o doente com necessidades de tratamento mais caras são "excluídos"), segundo o art. 12. ${ }^{\circ}$, alínea b); iii) prevenir e punir as práticas de indução artificial da procura de cuidados de saúde [art. 12. alínea c)]; iv) zelar pelo respeito da liberdade de escolha nos estabelecimentos privados de saúde; v) rececionar e processar as queixas e reclamações dos utentes, nos termos do art. $13 .^{\circ}$, alínea a) e art. $30 .^{\circ}$; vi) promover um sistema de classificação dos estabelecimentos de saúde quanto à sua qualidade global, segundo critérios objetivos e mensuráveis; vii) verificar o (não) cumprimento da "Carta dos Direitos dos Utentes", em conformidade com o art. 13. ${ }^{\circ}$, alínea b), articulado com o art. 12. ${ }^{\circ}$; art. $14{ }^{\circ}$, alínea c); viii) analisar o cumprimento das obrigações legais e regulamentares relativas à acreditação, certificação e licenciamento dos estabelecimentos de saúde [art. 11. ${ }^{\circ}$, alíneas a), b) c)]; ix) assegurar e promover a leal e sã concorrência, mediante imposições de conduta transparente e objetiva, nos termos do art. $10 .^{\circ}$, alínea e), art. 15..$^{\circ}$ alínea a), art. $16 .^{\circ}$, art. $20 .^{\circ}$, art. $21 .^{\circ}$, n. $^{\circ} 1$. 


\subsection{Em particular, a salvaguarda da livre, leal e sá concorrência no "setor/ mercado da saúde"}

Atualmente o setor da saúde - ou, melhor dito, o mercado da saúde - apresenta uma estrutura organizacional uniforme, sendo, pelo contrário, multifacetada e rica na diversidade de agentes, operadores, regimes jurídicos e figurinos ou modelos de gestão existentes no âmbito dos cuidados de saúde primários, diferenciados e continuados 5 .

$\mathrm{Na}$ verdade, ao lado do setor público e do setor social, encontra-se um setor privado em franca expansão, investindo avultados capitais na prestação de cuidados de saúde, cujo arco de atuação vai desde o primeiro contacto do doente com a instituição (consulta com o clínico geral), passando por consultas de especialidade até ao contacto diferenciado, ou seja, as cirurgias e o internamento hospitalar. Pelo contrário, os cuidados paliativos ou continuados continuam sem causar interesse nos agentes privados, em virtude dos respetivos elevados custos proporcionalmente inversos à obtenção de receita.

O objetivo primacial do setor privado é o lucro ${ }^{6}$, sendo que a prestação dos cuidados de saúde ao utente-consumidor em termos de elevada qualidade não deixa de ser a prioridade. Mas, evidentemente, apenas como um meio natural de captar "clientela" e obter o lucro.

O direito à saúde na ótica de um direito humano de assento constitucional não é, por isso, a perspetiva com que o setor privado encara a prestação de cuidados de saúde. É, ao invés, um negócio apelativo, em que o privado vê uma hipótese de ganhar quota de mercado ao setor público, agastado com as crescentes solicitações

\footnotetext{
${ }^{5}$ Está absolutamente ultrapassada a ideia de um setor público exclusivo a operar na prestação de cuidados de saúde, fortemente apoiado pelo «setor da solidariedade» (terceiro setor) constituído pela vasta rede de Misericórdias, Lares e demais Instituições Particulares de Solidariedade Social.

${ }^{6}$ Acerca da dimensão da despesa com hospitais privados em comparação com a despesa dos hospitais públicos, bem como, sobre a análise rigorosa da estrutura do financiamento do setor privado de saúde, vide o artigo exemplar de Pedro Pita Barros. Cfr. http://momentoseconomicos.wordpress. com/2014/10/02/o-mercado-de-cuidados-hospitalares-privados/ (acesso em 5 de outubro de 2014).
} 
da população, mais consciente dos seus direitos, e refém das margens de restrição orçamental. Por conseguinte, não são raras as situações em que o doente "caro" corre o sério risco de ser "enjeitado" por este setor. Por outro lado, vislumbram-se atualmente "movimentos" de tentativa de aquisição de grandes grupos de saúde, por parte de empresas privadas multinacionais nacionais e estrangeiras, incluindo grupos de seguradoras, o que é suscetível de constituir um "perigo" para uma real e efetiva concorrência no mercado da saúde.

Naturalmente, o zelo e a proteção pelo desiderato de livre, leal e sã concorrência no mercado da saúde competirá a um binómio institucional, a Autoridade da Concorrência e a Entidade Reguladora da Saúde. Eventualmente, a Comissão de Mercado de Valores Mobiliários (CMVM) também terá uma palavra a dizer sobre eventuais fenómenos empresariais aptos de conduzir a um constrangimento significativo da concorrência, mediante Ofertas de Aquisição Públicas, em Bolsa. Mas, neste estudo, o âmbito de atuação e competências destas duas entidades ficarão de fora, debruçando-nos somente sobre a ERS.

Sublinhamos pelo ora exposto a independência da ERS enquanto condição determinante para a livre concorrência no setor da saúde, porquanto constitui uma garantia da proteção dos interesses dos utentes-consumidores perante os operadores (públicos e privados), fazendo com que tenham uma livre e real escolha no acesso aos serviços de saúde e que estes sejam dotados da qualidade e celeridade adequados.

Em termos finalísticos, a Entidade Reguladora da Saúde tem por escopo regular e supervisionar (arts. 19..$^{\circ}$ e $21 .^{\circ}$, conjugados com os arts. $5 .^{\circ}$ e $10 .^{\circ}$ ) os operadores, públicos (v.g. Estado), privados e cooperativos ou sociais que desenvolvem a seu cargo a prestação de cuidados de saúde, de modo a assegurar o cumprimento escrupuloso das regras de qualidade e de segurança, das obrigações resultantes dos instrumentos jurídicos, regulamentares e contratuais lhes respeitantes (v.g. contratos de concessão, contratos de gestão, convenções, títulos de licenciamentos, etc.).

Apenas deste modo é assegurada uma eficaz atuação conforme às regras de mercado e da concorrência por parte de todos os players envolvidos, garantindo 
que os direitos dos utentes-consumidores do serviço de saúde sejam plenamente realizados.

No que a este respeito concerne, o antigo art. 8. ${ }^{\circ}$, do Estatuto da ERS, é claro ao alargar o "espectro de jurisdição" da ERS a todo o sistema de saúde, não se restringindo somente ao SNS ou sobretudo às Parcerias Público-Privadas, como inicialmente se poderia supor em virtude dos problemas regulatórios que, pela complexa natureza destas, se revelam potencialmente mais prováveis.

Não faria qualquer sentido condicionar a regulação no setor da saúde somente a um aspeto circunscrito, num contexto de profícua empresarialização dos hospitais públicos inseridos no Serviço Nacional de Saúde, os quais passaram a ser remunerados pelos cuidados prestados, tornando-se eles próprios suscetíveis de provocar problemas graves, como a desnatação e a seleção adversa e, desse modo, colocando em risco os princípios constitucionais de universalidade e de igualdade no acesso à saúde pelos utentes com doenças mais complexas e porventura mais onerosas ${ }^{7}$.

Quando se trata de atividades liberais ou licenciadas sujeitas a regras do mercado, a regulação terá por finalidades principais assegurar a transparência do mercado e a proteção dos utentes-consumidores, acautelar o respeito pelo cumprimento das condições de licenciamento e demais normas legais respeitantes à qualidade e segurança da atividade, sendo igualmente relevante garantir a separação efetiva entre a competência da entidade reguladora e as atribuições e poderes das corporações profissionais com poderes públicos de auto-regulação com a tarefa de supervisão deontológica das profissões (Ordem dos Médicos, Ordem dos Enfermeiros, Ordem dos Farmacêuticos).

Por último, podemos referir que as atribuições da ERS, no seu conjunto, quando

\footnotetext{
${ }^{7}$ No fundo, as mesmas questões que se colocam nos hospitais e nos restantes estabelecimentos de saúde públicos são idênticas às levantadas nos hospitais privados e, deste modo, fará todo o sentido estenderse a abrangência das competências da Entidade Reguladora às unidades de saúde públicas. De facto, tratando-se de uma entidade reguladora setorial, esta terá de exercitar eficazmente a sua jurisdição sobre todos os setores da saúde, sem exceção. Contudo, o modo como a regulação será exercitada irá variar, consoante estejamos perante o Serviço Nacional de Saúde ou não.
} 
são exercidas eficazmente contribuem para a garantia da livre, leal e sã concorrência no setor da saúde.

São as atribuições previstas no antigo art. $6 .^{\circ}$ e arts. $12 .^{\circ}, 13 .^{\circ}$ e $15 .^{\circ}$, constantes no Decreto-Lei n. ${ }^{\circ}$ 126/2014, as quais são suscetíveis de suscitar algumas questões de diversa natureza, a vários níveis, designadamente: a) nível da regulação do mercado e obrigações de serviço público, b) exclusão do controlo do acesso à atividade, c) exclusão da regulação dos preços e tarifas, d) registo de operadores e demais intervenientes no setor, e) cumprimento das obrigações legais e contratuais a que se encontram submetidos os operadores, f) qualidade, g) obrigações de serviço público, nomeadamente a igualdade de acesso aos serviços de saúde, h) direitos dos utentes, i) acreditação, avaliação e licenciamento [arts. 10. ${ }^{\circ}$, alínea a); $11 .^{\circ}$, alíneas a), b), c); $14 .^{\circ}$, alínea b)].

Cabe, pois, com especial atinência, à ERS assegurar a efetividade do direito de acesso e da igualdade de acesso à proteção na saúde e em termos de qualidade, de assento constitucional, sobretudo no concreto contexto mercantilista, de um verdadeiro «mercado de saúde», caracterizado pela empresarialização de hospitais públicos e marcado por uma vaga de Parcerias Público-Privadas que têm como grande desiderato o lucro, em detrimento daqueles valores. Esta missão da ERS encontra-se contemplada no art. $12 .^{\circ}$, sob a epígrafe «garantia de acesso aos cuidados de saúde, o qual deverá ser lido conjuntamente com o art. 10. ${ }^{\circ}$, alíneas a), b), c); art. $14^{\circ}$, alíneas a) e c) e com o art. 5. ${ }^{\circ}$, alínea b).

Perante um cenário ou sistema de saúde misto e de privatização de muitas unidades de cuidados de saúde, outrora pertencentes ao setor público, com os riscos já enunciados, de rejeição de doentes e de discriminações no acesso a um direito constitucionalmente pensado para todos os cidadãos, cabe à Entidade Reguladora da Saúde a missão de velar pelo cumprimento da própria Constituição, fiscalizando e sancionando qualquer comportamento positivo ou negativo suscetível de violar o direito de acesso universal de todos à saúde (art. 10. ${ }^{\circ}$, alínea b), c) e alínea e); art. 20. ${ }^{\circ}, \mathrm{n}^{\circ} 1$, alínea c); art. $13 .^{\circ}$, alínea b) e art. $12 .^{\circ}$, alínea a)].

Nesta senda, numa primeira linha de ação, a Entidade Reguladora da Saúde tem 
a competência para definir e estabelecer as regras, estribar os limites de atuação das entidades prestadoras de serviços de saúde, com vista a impedir futuras violações do art. 64. ${ }^{\circ}$ da Constituição.

A posteriori, numa segunda linha de ação, a Entidade Reguladora da Saúde surge munida do direito de iniciativa ou de ação, que se traduz no poder de instaurar verdadeiros "inquéritos" ou investigações, isto é, fiscalizar ou supervisionar de moto próprio ou por impulso (via queixa ou denúncia) de utentes-consumidores a prestação de serviços de saúde das entidades privadas, públicas, sejam do setor social, seja do setor cooperativo.

Compete-lhe, igualmente, o poder punitivo ou sancionatório, que permite adotar as providências necessárias ao restabelecimento da legalidade e impor medidas desvantajosas, com maior ou menor grau de severidade, aos operadores incumpridores.

Com vista ao alcance do desiderato de defesa dos direitos e interesses dos utentes-consumidores (arts. $10 .^{\circ}$ a $14 .^{\circ}$ ), todos os estabelecimentos e subsetores de saúde têm a obrigação legal de se submeterem a procedimentos de avaliação periódica e de acreditação pelos competentes organismos certificados para o efeito (arts. 11. ${ }^{\circ}$, 19. ${ }^{\circ}, 20 .^{\circ}, 21 .^{\circ}, 26 .^{\circ}$ e $\left.27 .^{\circ}\right)$. A instrução e a decisão sobre o "licenciamento" [art. 11. ${ }^{\circ}$, alínea b)] pertencem à autoridade reguladora, cabendo, em particular: i) estabelecer os parâmetros e requisitos dos procedimentos de acreditação, avaliação periódica e licenciamento [art. 11. ${ }^{\circ}$, alínea a)]; ii) proceder à verificação da observância dessas obrigações de acreditação, de avaliação e licenciamento [art. 11. ${ }^{\circ}$, alíneas b), c), $1^{\text {a }}$ parte]; iii) determinação das medidas de correção que resultem desses procedimentos; iv) sancionar o incumprimento tanto da obrigação de acreditação, avaliação e licenciamento, como das determinações impostas pela autoridade [art. 11. ${ }^{\circ}$, alínea c), in fine].

Podemos destacar como sendo principais riscos que atualmente se colocam no âmbito do setor de saúde português, os seguintes: i) possibilidade de deterioração do nível de qualidade dos cuidados e de segurança dos utentes em favorecimento da regra de redução de custos sem se atender a critérios de rigor e de legis artis ad 
hoc medicinae (boas práticas de medicina e de ética); ii) surgimento de fenómenos de "desnatação" e de "seleção adversa" em virtude da pressão para maximizar o lucro; iii) possibilidade de cessação de fornecimento por parte das entidades privadas encarregadas da gestão de estabelecimentos do Serviço Nacional de Saúde ou a estes associadas, em caso de dificuldades económicas, colocando em causa o "princípio da continuidade e manutenção do serviço público"; iv) o eventual surgimento de "assimetrias de informação" entre prestadores-operadores dos cuidados de saúde e os respetivos utentes-consumidores, em virtude da nova panóplia de prestadores de serviços de saúde ao dispor dos utentes-consumidores, sem que se haja previamente procedido a delimitação de reservas territoriais; v) a nova concorrência entre a miríade de prestadores privados e públicos associados à coexistência de subsistemas de saúde e de seguros torna urgente uma regulação séria e rigorosa num setor tão sensível como o setor da saúde.

No que respeita à prestação de "serviços públicos", a regulação assume, no seu núcleo duro, a prossecução de uma dupla finalidade.

Em primeiro lugar, colmatar as "falhas de mercado" ("market failures") traduzidas no surgimento de monopólios naturais e em assimetrias de informação. Em segundo lugar, assegurar a efetividade das "obrigações de serviço público", como a universalidade e igualdade de acesso à saúde, a continuidade do serviço, a qualidade e a segurança nos serviços de cuidados de saúde prestados aos utentes-consumidores.

A primacial função da autoridade de regulação no setor da saúde é, seguramente, supervisionar a atividade dos respetivos operadores, de modo a garantir o escrupuloso cumprimento das "obrigações de serviço público".

Essas funções competiam ora ao Ministério da Saúde, ora às Administrações Regionais de Saúde, conforme as situações. Atualmente, com o novo Estatuto já cabe na esfera de atribuições da ERS a tarefa de controlar o próprio acesso à atividade, organizando e outorgando as concessões e emitindo as licenças, no caso de atividades licenciadas, à semelhança do que sucede com as unidades privadas de saúde.

A propósito da questão sobre se a matéria concernente à fixação de preços e de tarifas relativos aos cuidados de saúde prestados no seio do setor público, a ser 
cobrados pelas unidades prestadoras ao Estado ou aos subsistemas, quando não existe lei, contrato, acordo ou convenção que responda a esta situação, deve competir à ERS, a resposta é negativa. A ERS possui, a este respeito, os poderes constantes na alínea e), do art. 15.': "pronunciar-se sobre (...) e zelar pelo seu cumprimento", o que significa que não possui um poder impositivo unilateral ou, vinculativo, que estabeleça seja que montante for. Trata-se de um poder de recomendação e de controlo.

Este é um aspeto que se encontra excluído do leque de atribuições da ERS, por considerar-se que continuando o Serviço Nacional de Saúde a ser predominantemente gratuito, a questão dos preços e tarifas apenas teria pertinência para efeitos das relações entre o Estado fornecedor/prestador e o Estado financiador e para efeitos das relações entre o Estado e as entidades privadas intervenientes, sobretudo no caso das Parcerias Público-Privadas.

Outra das suas missões é "zelar pelo respeito dos preços administrativamente fixados ou convencionados no SNS", competindo-lhe, assim, a tarefa de fiscalizar os preços estipulados por lei ou por outro instrumento contratual (v.g. concessões) por parte das entidades prestadoras [art. 13. ${ }^{\circ}$, alínea e)].

Dentro do quadro de atribuições da Entidade Reguladora da Saúde existe a obrigação de manter o registo oficial de certas categorias de operadores de serviços de saúde e demais intervenientes do setor (art. 27. ${ }^{\circ}$ ), como as unidades de prestação de cuidados de saúde privadas, do setor social e corporativo e as entidades convencionadas. No que respeita ao cumprimento das obrigações legais e contratuais a que os operadores da prestação de saúde se encontram sujeitos, cumpre-nos dizer que o controlo desse cumprimento consiste numa outra tarefa da ERS.

Também no domínio da "qualidade" do serviço de saúde prestada ao utente compete especialmente à autoridade reguladora do setor de saúde avaliar os padrões vinculativos de qualidade, fiscalizar o seu cumprimento e sancionar as respetivas infrações, assim como monitorizar o respeito pelas obrigações de acreditação dos estabelecimentos e demais serviços de prestação de cuidados de saúde, de acordo com o disposto nos atuais arts. $10 .^{\circ}$ e $11 .^{\circ}$ (antigo art. $25^{\circ}$ ). 
Perante este novo sistema de saúde, em que avulta o fator "lucro" em detrimento de outros "valores-farol" - que no setor da saúde deveriam imperar e presidir a qualquer decisão ou ato de gestão, como a ética, a qualidade ou a componente humana inerentes à nova lógica da prestação de cuidados de saúde - é natural que advenham certos riscos e, nessa medida, é mister a emergência de um Estado Social de Regulação que se revele apto e munido dos poderes e mecanismos adequados a eliminar esses perigos.

\section{O mercado da saúde}

A situação de um grupo privado "forte" com muitas ramificações em Portugal adquirir outro grupo que, por si próprio, já possui dimensões elevadas com uma quota de mercado é, a nosso ver, apto para "esmagar" a concorrência, com as inerentes consequências daí resultantes, da perspetiva da livre escolha e qualidade do serviço de saúde.

Dando-se um exemplo prático. Em Portugal, os três principais intervenientes privados - Espírito Santo Saúde, José de Mello e HPP Saúde (antigo negócio hospitalar da CGD) - detêm conjuntamente uma quota agregada de 11,7\% $\%^{8 / 9}$, levantando-se a questão sobre se estaremos na presença de um oligopólio.

No que respeita a outras formas imperfeitas de mercado, a que o mercado da

\footnotetext{
${ }^{8}$ Importa, a este respeito, cfr. a Lei n. ${ }^{\circ}$ 19/2012, de 8 de maio (Lei da Concorrência). De primordial pertinência acerca das implicações práticas e contornos jurídicos da violação da concorrência (concorrência desleal) a doutrina de Luís Manuel Couto Gonçalves, Manual de Direito Industrial. Propriedade Industrial e Concorrência Desleal, $5^{a}$ ed., (Coimbra: Almedina, 2014). Vide ainda, Miguel Gorjão-Henriques, Direito da União, 6a edição, (Coimbra: Almedina, 2010), pp.655 e ss, bem como, João Mota de Campos e João Luiz Mota de Campos, Manual de Direito Europeu, 6a ed., (Coimbra: Coimbra Editora, 2010), 611 e ss. Também é muito relevante a Comunicação da Comissão Europeia 97/C 372/03, publicado no Jornal Oficial $n^{\circ}$ C 372 de 09/12/1997, pp.0005-0013. Do teor desta Comunicação podemos ler: "O objetivo de definir um mercado tanto em função do seu produto como em função da sua dimensão geográfica é o de identificar os concorrentes efetivo das empresas em causa suscetiveis de restringir o seu comportamento e de impedi-las de atuar independentemente de uma pressão concorrencial efetiva. É nesta ótica que a definição de mercado permite subsequentemente calcular as quotas de mercado (....)".

${ }^{9}$ Vide, a este respeito, José Engrácia Antunes, Os Grupos de Sociedades, $2^{\mathrm{a}}$ ed., (Coimbra: Almedina, 2002) e ainda cfr. http://momentoseconomicos.wordpress.com/2014/10/01/continua-a-corrida-pela-espiritosanto-saude/ - artigo de Pedro Pita Barros (informação consultada em 5 de outubro de 2014)
} 
saúde não é de todo alheio, existem os oligopólios, com ou sem acordo entre os prestadores oligopolistas.

Nesta situação, temos poucos prestadores, que acordam entre si a «repartição» das quotas do mercado (cartel ${ }^{10}$ ou, pelo contrário, competem entre si, aliciando o doente com agressivas estratégias de marketing, não só ao nível do preço praticado, mas também ao nível de "ofertas" de cartões de desconto, análises ou exames grátis, etc.

Podem apenas existir dois grandes prestadores de serviços de saúde (duopólio) a disputar os "clusters" de mercado de serviços de saúde, quando pela sua enorme dimensão e posição numa determinada localidade ou região, são os que mais serviços de saúde proporcionam, em termos de diversidade e volume, tanto nos cuidados primários, como nos diferenciados, a preços mais atrativos.

Pese embora, o cartel (acordo concertado entre duas ou mais empresas; no nosso caso, hospitais ou outro tipo de estabelecimentos de saúde privados) seja a estrutura de mercado nociva para os outros prestadores de saúde (concorrentes pequenos), é-o ainda mais para o doente, pelos mesmos motivos imputáveis ao monopólio.

O mercado monopolístico ${ }^{11}$ caracteriza-se pela existência de um único produtor, que controla, por si só, todos os aspetos relativos à produção. Domina, nessa medida, sozinho o lado da oferta, ditando as "regras" sem interferências dos seus concorrentes. Pode aplicar o preço que contribuir para a maximização do lucro sem ter de, em contrapartida, aumentar a qualidade dos serviços prestados. Exemplo de monopólio no mercado da saúde seria a existência de urgências especializadas numa área geográfica do interior de Portugal onde não existem serviços de saúde.

Naturalmente, não configura a melhor solução do ponto de vista do utente/ consumidor de serviços de cuidados de saúde, porquanto ver-se-á o utente forçado a pagar um preço demasiado alto para o ato clínico prestado, em termos de volume, diversidade e qualidade. Existe, por outro lado, uma tendência “natural", por parte do prestador, para o abuso da sua posição dominante que poderá manifestar-

\footnotetext{
${ }^{10}$ Sobre o cartel, seus aspetos positivos e negativos, vide João Mota de Campos e João Luiz Mota de Campos, Manual de Direito Europeu. O sistema institucional, a ordem jurídica e o ordenamento económico da União Europeia (6a ed., Coimbra: Coimbra Editora, 2010), 626 e 627.

${ }^{11}$ Vide João César das Neves, Introdução à Economia (9. ${ }^{2}$ ed., Lisboa: Verbo, 2011), 219 e ss.
} 
se em fenómenos negativos, como a seleção adversa (rejeição do doente com problemas pouco dispendiosos), a indução da procura (conduzir a um acréscimo de exames médicos, de diagnóstico e outros, análises clínicas, tratamentos e cirurgias desnecessárias à concreta situação do doente, com vista a aumento da receita), entre outros.

A concorrência desleal aparece como em efeito natural neste tipo de estruturas imperfeitas de mercado, por oposição ao da concorrência perfeita, caracterizada pela existência de uma multiplicidade rica de prestadores de serviços de saúde, que atuam livremente, praticam preços (quase) idênticos e, por isso, (mais) justos face ao serviço praticado, pois existe o sério risco de fuga dos seus clientes/doentes para o concorrente mais próximo. Deste modo, são impelidos a desenvolver o esforço de constante aperfeiçoamento e de melhoria da qualidade do serviço prestado, com enormes mais-valias para o doente em particular e para o mercado da saúde em geral.

Trata-se, pois, da situação em que o mercado funciona em pleno, sem interferências suscetíveis de alterar o preço, atingindo o seu «ponto ótimo» denominado na linguagem económica como "Ótimo de Pareto" ". Esta expressão traduz, em economia, uma situação de real e efetiva eficiência, "em que não é possível melhorar num sentido sem piorar no outro". Leia-se "lado da oferta" e "lado da procura", entendendo-se o "ponto de equilíbrio", como sendo o ponto em que os produtores não pretendem produzir mais e os consumidores não querem adquirir mais, estando de acordo quanto ao preço fixado.

De acordo com César das Neves, "a situação de concorrência perfeita define-se pela ausência de poder de mercado por parte de todos os agentes envolvidos"13.

A grande virtude que decorre da concorrência perfeita reconduz-se ao facto de nenhum dos produtores possuir a capacidade de, por si só, influenciar o mercado ou manipular preços, o que gera ganhos para o consumidor (no nosso caso, simultaneamente, utente/doente) em termos de binómio qualidade-quantidade do bem ou serviço.

\footnotetext{
${ }^{12}$ Assim, cfr. João César das Neves, Introdução à Economia, 214.

${ }^{13}$ Neste sentido, cfr. João César das Neves, Introdução à Economia, 207 e ss.
} 
O equilíbrio do mercado da saúde compete à ERS, Autoridade da Concorrência com funções mais amplas da perspetiva do direito concorrencial e à CMVM, num aspeto especial que se prende com aquisição, fusão e venda de participações sociais de empresas, etc.

\section{Breve conclusão}

A regulação social e económica é essencial no mercado da saúde, ou seja, à sua viabilidade enquanto "sistema".

De acordo com a posição firmada por António Correia de Campos, "num sistema totalmente público, sem liberdade de escolha, não fazia sentido qualquer regulação. Mas, tal sistema não existe em lado algum e o português tem imperfeiçōes, riscos e insuficiências" ${ }^{\prime \prime}$. Por seu turno, nesta senda, Pedro Costa Gonçalves define a regulação do seguinte modo: “(...) a regulação, entendida como um sistema de orientação, de acompanhamento e de controlo de processos económicos e sociais, surge como conceito central e verdadeiro elemento chave (... ${ }^{p 15}$ que é levada a cabo por meio da criação legislativa (atos legislativos e regulamentos da Administração Pública reguladora), de produção de atos típicos da função administrativa (decisões administrativas, contratos, atos materiais de fiscalização e vigilância), assim como através da prática de atos informais, como recomendações e advertências, sem deixar de considerar as suas "ferramentas de eficácia", como as funções de punição dos infratores da lei de concorrência. No tocante à regulação na área da saúde, esta foi até ao presente momento desenvolvida por meio da função legislativa e mediante as estruturas centrais do Ministério da Saúde ou outras deste dependentes, como a Direção-Geral da Saúde e Inspeção-Geral das Atividades em Saúde ou, ainda, ao nível da Administração Pública Regional (Administrações Regionais de Saúde, I.P.), sem esquecer o papel desempenhado por uma diversidade de institutos públicos de atuação setorial específica (Instituto Nacional da Farmácia e do Medicamento

\footnotetext{
${ }^{14}$ Neste sentido, cfr. António Correia de Campos, "Imperfeições e Assimetrias”, in Revista Economia Pura. Tendências e Mercados, sob o tema de "Os Remédios para a Saúde", V, 51, (2002): 40.

${ }^{15}$ Assim, cfr. Pedro Costa Gonçalves, "Estado de Garantia e Mercado", in Revista da Faculdade de Direito do Porto, VII especial, (2010): 61 e ss.
} 
ou "INFARMED"). Pese embora reputemos como sendo de incontornável relevância o papel desempenhado por estas entidades no que se prende com as funções desempenhadas no âmbito da supervisão e fiscalização sobre a atividade desenvolvida no setor da saúde, assistimos nos últimos tempos a um seu desajustamento e ineficácia face ao fenómeno de "empresarialização" e às crescentes mutações no domínio da saúde. Daí o imprescindível papel da ERS neste contexto atual tão dinâmico e de "áreas cinzentas".

O mercado de saúde, privado e público, deverá ter como bússola valores como a universalidade, igualdade de todos os cidadãos utentes-consumidores no acesso à saúde e aos adequados tratamentos, primários e diferenciados, com o mais elevado nível de qualidade e grau de continuidade. A independência da ERS confere-lhe a necessária e adequada liberdade de atuação, supervisão e de fiscalização aptas à prossecução da sua missão e ao alcance do seu escopo. Mas uma maior liberdade far-se-á acompanhar sempre da correspetiva responsabilidade e aqueles princípios enunciados são corolários lógicos deste princípio estruturante do direito. Apenas deste modo é que a atuação livre e responsabilizante proporcionada pelo modelo adotado - assim como qualquer decisão adotada pela entidade reguladora - imporse-á naturalmente à sociedade e será comummente aceite pelos operadores públicos e privados. A legitimidade da entidade reguladora resulta, pois, não da sua liberdade de conformação e de atuação, mas da sua responsabilidade perante os outros e, acima de tudo, perante si mesma.

É curial afirmar que os imperativos legais de livre, leal e sã concorrência (e competitividade) assumem-se como um verdadeiro mecanismo para o acesso à saúde e à efetiva qualidade dos serviços de saúde. Neste contexto, é interessante constatar que o cabal respeito pelo Direito da Concorrência é, por isso, conditio sine qua non para a concretização efetiva dos direitos humanos à "saúde" e, no limite, à própria "vida”. 



\title{
As competências reguladoras e decisórias europeias e nacionais no negócio TAP - reflexões
}

\author{
José Ricardo Sousa*
}

RESUMO: O presente artigo focaliza o importante contributo das entidades reguladoras nacionais tanto no combate a práticas concorrenciais ilícitas quanto na garantia de uma oferta de qualidade e segurança aos consumidores a partir dos exigentes padrões de qualidade europeus. O presente artigo tem especialmente em conta a operação de concentração entre a Parpública e Atlantic Gateway com a TAP e pretende demonstrar a imprescindibilidade de entendimento entre as entidades reguladoras dos Estados-Membros e a própria Comissão Europeia, além de escrutinar os critérios que definem as competências de ambas, tendo em conta o Regulamento (CE) 139/2004 e a lei 19/2012 (Lei da Concorrência).

PALAVRAS-CHAVE: operação de concentração - entidade reguladora - Comissão Europeia - Autoridade da Concorrência-ANAC.

ABSTRACT: This paper intends to demonstrate the important contributions that national regulatory authorities have made over the last decades in both the fight against illicit competitive practices and to ensure an offer of quality and safety for European consumers, following the demanding European quality standards. The focus of this paper is merger between Parpublica and Atlantic Gateway with TAP and the author intends to demonstrate the essential understanding between the regulatory authorities of the Member States and the Commission, and the criteria defining the competences of both agencies, taking into account Regulation (EC) No 139/2004 and Law 19/2012 (Competition Law).

KEY WORDS: Concentration - Regulatory Entity - European Commission - Competition Authority - ANAC.

\footnotetext{
* Mestrando em Direito da União Europeia na Escola de Direito da Universidade do Minho. Colaborador de UNIO - The Official Blog: Thinking \& Debating Europe.
} 


\section{Introdução}

O presente artigo científico pretende demonstrar o importante contributo que as entidades reguladoras nacionais têm vindo a realizar ao longo destas últimas décadas, tanto no combate a práticas concorrenciais ilícitas quanto na garantia de uma oferta de qualidade e segurança para os consumidores, a partir dos exigentes padrões de qualidade europeus. Tanto as entidades reguladoras nacionais como as agências europeias são peças fundamentais num mercado concorrencial e em expansão em alguns países que não têm grande expressão comercial. Assim, estas entidades funcionam de acordo com os princípios e normas europeias, regulando e fiscalizando a área para o qual foram criadas. Neste momento existem várias entidades reguladoras nacionais que zelam pela segurança e qualidade dos respetivos produtos e serviços nos mercados e algumas delas velam pela competitividade do sector económico a que se dedicam.

Neste ensaio abordo o trabalho realizado por duas entidades reguladoras nacionais, a Autoridade da Concorrência (AdC) e a Autoridade Nacional de Aviação Civil (ANAC), na operação de concentração ${ }^{1}$ da empresa pública Transportes Aéreos de Portugal (TAP) por parte da Atlantic Gateway, um consórcio composto por um grupo português (HPGB) e uma sociedade de direito norte-americana (DGN)².

\footnotetext{
${ }^{1}$ Segundo o art. 3. ${ }^{\circ}$ do Regulamento (CE) 139/2004, de 20 de janeiro de 2004, entende-se por operação de concentração "1. ... quando uma mudança de controlo duradoura resulta da:

a) Fusão de duas ou mais empresas ou partes de empresas anteriormente independentes; ou

b) Aquisição por uma ou mais pessoas, que já detêm o controlo de pelo menos uma empresa, ou por uma ou mais empresas por compra de partes de capital ou de elementos do activo, por via contratual ou por qualquer outro meio, do controlo directo ou indirecto do conjunto ou de partes de uma ou de várias outras empresas.

2. O controlo decorre dos direitos, contratos ou outros meios que conferem, isoladamente ou em conjunto, e tendo em conta as circunstâncias de facto e de direito, a possibilidade de exercer uma influência determinante sobre uma empresa e, nomeadamente:

a) Direitos de propriedade ou de uso ou de fruição sobre a totalidade ou parte dos activos de uma empresa;

b) Direitos ou contratos que conferem uma influência determinante na composição, nas deliberações ou nas decisões dos órgãos de uma empresa."

${ }^{2}$ Ccent 41/2015, Atlantic Gateway/TAP, 1/10/2015, Autoridade da Concorrência, acesso em setembro 20, 2015, 2-3, http://www.concorrencia.pt/FILES_TMP/2015_41_final_net.pdf.
} 
Sem surpresas, a operação de concentração da empresa TAP por parte da Atlantic Gateway tem sido tudo menos pacífica no que diz respeito à avaliação do negócio. Para além de se tratar de uma empresa pública com um elevado estatuto no seio da economia portuguesa (o que significa que acarreta consigo factores extra como a componente política, lobbistas e até mesmo a pressão da opinião pública), tem-se observado certos "volte-faces" técnicos e jurídicos ao longo do negócio.

Não obstante a constante pressão com que as entidades reguladoras nacionais supra mencionadas têm trabalhado na avaliação da concentração de empresas, a verdade é que pouco ou nada se tem falado entre a opinião pública e os académicos acerca do contributo destas entidades reguladoras para o normal funcionamento de um mercado global e competitivo. Deste modo, este artigo científico pretende não só evidenciar o trabalho realizado pelas entidades reguladoras no passado e no presente, mas também pretende refletir sobre o papel que as mesmas podem ter na construção de um mercado único europeu mais justo, eficiente e concorrencialista sem depender de terceiros para atingir os fins que lhes são propostos.

Posto isto pretendo desenvolver dois aspetos que, no meu entender, devem ser analisados e estudados para perceber o verdadeiro contributo das entidades reguladoras nacionais na defesa da concorrência: o primeiro aspeto tem que ver com o modus operandi da Comissão Europeia nas operações de concentração e a posição que a mesma tomou relativamente a este negócio; o segundo aspeto incide na avaliação deste negócio não só pela Autoridade da Concorrência, mas também pela Autoridade Nacional de Aviação Civil e de que forma estas duas entidades condicionaram uma primeira tentativa de concentração entre empresas que se revelara ilícita perante o direito da União Europeia.

\section{A avaliação das operações de concentração de empresas pela Comissão Europeia: Regulamento (CE) 139/2004}

Desde os finais do século XX (quando começaram a proliferar as primeiras entidades reguladoras europeias nos respetivos Estados-Membro) que as entidades 
reguladoras têm dado um contributo importante para a harmonização e controlo de qualidade do mercado único europeu nas suas respetivas áreas de intervenção. De facto, não podemos falar de entidades reguladoras sem antes mencionar uma reforma europeia lançada por Romano Prodi ${ }^{3}$ com o objetivo de dar mais credibilidade a um órgão europeu que começava a evidenciar algum desgaste devido à excessiva carga de trabalhos técnicos que pendia sobre a mesmo graças, em parte, à transferência de competências dos Estados-Membro para a Comissão Europeia (sobretudo após a ratificação do Tratado de Maastricht) e a crescente exigência dos cidadãos por uma Comunidade Europeia que apresentasse uma diminuição do défice democrático que tinha apresentado até então ${ }^{4}$.

Por conseguinte, é apresentada uma nova orientação da Comissão Europeia a que os políticos e académicos intitularam de "New Mode of Governance". Este novo método de governança (se assim se pode dizer) ${ }^{5}$ visa o afastamento das práticas antigas de regulação da Comissão Europeia, que desta forma opta por políticas de regulação mais suaves, com métodos mais eficazes e reflexivos, com a implementação de uma aproximação consciente do novo método de coordenação ${ }^{6}$. "Open method of coordination" é o termo adequado para definir esta delegação de competências por parte da Comissão Europeia para as várias agências europeias e entidades reguladoras que foram criadas após esta reforma. Como referi supra, a grande vantagem desta orientação política está na redução da crescente carga de trabalho técnico e especializado de vários setores económicos cuja avaliação estava até então acometida à Comissão. Assim, esta delegação dos poderes reguladores e fiscalizadores a entidades nacionais aliviam a Comissão Europeia de processos que

\footnotetext{
${ }^{3}$ Presidente da Comissão Europeia entre 1999 e 2004.

${ }^{4}$ Ellen Vos, "European Administrative Reform and Agencies", Robert Schuman Centre for Advanced Studies (2000): 3 .

${ }^{5} \mathrm{Na}$ língua portuguesa não existe um termo apropriado para desginar a palavra "Governance".

${ }^{6}$ Govin Permanand e Ellen Vos, "EU regulatory agencies and health protection", in Health Systems Governance in Europe: The Role of European Union Law and Policy, ed. Elias Mossialos (Cambridge: Cambridge University Press, 2010), 135. Tradução nossa do seguinte excerto: "The NMG debate focuses on the shift away from the traditional 'Community method' of regulation to embrace softer, more responsive and reflexive modes, with the incremental and consensus-generating approach of the open method of coordination (OMC) best conforming to this ideal."
} 
não revelam ter uma dimensão relevante para o mercado único europeu ${ }^{7}$. Porém, vários académicos apontam outra vantagem para a Comissão Europeia e para os governos dos restantes Estados-Membros: as agências europeias e as entidades reguladoras podem servir de escudo perante algumas decisões mais complexas e atenuar o desgaste da sua imagem e da dos políticos perante os media nacionais ${ }^{8} /{ }^{9} /{ }^{10}$.

O novo método de coordenação entre a Comissão, as entidades reguladoras e os próprios Estados-Membros torna-se o paradigma europeu para a estruturação normativa de regulamentos ou diretivas que visam o funcionamento das respetivas entidades reguladoras ou instituições. Mais precisamente, o Regulamento (CE) 139/2004 ${ }^{11}$ é um dos vários atos normativos de direito derivado onde se verifica esta partilha de competências entre a instituição e as agências supra mencionadas.

Destarte, o Regulamento (CE) 139/2004 solidifica a posição da Comissão Europeia em querer trabalhar em conjunto com outras entidades reguladoras para que, num espírito de cooperação, seja possível cumprir os objetivos integracionalistas do mercado da União Europeia sem "acarretar a um prejuízo duradouro para a concorrência"12, à luz de princípios basilares da União Europeia como são os princípios da subisidiariedade, proporcionalidade e o princípio de uma economia de mercado aberto e de livre concorrência ${ }^{13}$. Desta forma, a Comissão Europeia e as respetivas autoridades da concorrência e demais entidades reguladoras setoriais formam uma "rede de autoridades públicas"14 no sentido de aplicar os atos normativos de direito derivado à luz do direito originário. Para além da promoção da cooperação entre

\footnotetext{
${ }^{7}$ Permanand e Vos, "EU regulatory agencies and health protection", 138.

${ }^{8}$ Segundo, Martin Lodge, "delegation to regulatory agencies has also been interpreted as a method of shifting blame away from politicians and toward defenceless regulators as well regulated companies".

9 João Luís Mendonça Gonçalves, Da independência das autoridades reguladoras indenpendentes, (Repositório da Universidade Católica Portuguesa, 2014), 13.

${ }^{10}$ Alec Stone Sweet e Mark Thatcher, "Theory and Practice of Delegation to Non-Majoritarian Institutions", Yale Law School Faculty Scholarship (2002): 9.

${ }^{11}$ Regulamento (CE) 139/2004 do Conselho relativo ao controlo das concentrações de empresas, Jornal Oficial da União Europeia, 20 de janeiro de 2004.

${ }^{12}$ Regulamento (CE) 139/2004, considerando 5.

${ }^{13}$ Regulamento (CE) 139/2004, considerando 6.

${ }^{14}$ Regulamento (CE) 139/2004, considerando 14.
} 
os dois lados, o Regulamento (CE) 139/2004 também tem o objetivo de tornar a avaliação de operações de concentrações mais eficiente de forma a evitar notificações múltiplas e garantir que o caso "é tratado pela autoridade mais adequada"15.

É através dos princípios da subsidiariedade e da proporcionalidade que a noção de "dimensão comunitária" se transfigura no principal critério do regulamento para determinar se a Comissão Europeia é ou não competente para apreciar uma operação de concentração de empresas. Este critério revela-se como um critério meramente quantitativo $^{16}$. Por sua vez, a noção de concentração de dimensão comunitária é entendida, num sentido lato, "quando o volume de negócios total das empresas em causa ultrapassa determinados limiares" ${ }^{17}$.

Apesar de o Conselho Europeu ter redigido um conceito demasiado abstrato no preâmbulo do regulamento em causa, este é complementado pelo art. $1 .^{\circ}$ do respetivo Regulamento. Como já tive oportunidade de referir, o principal critério para definir se uma operação de concentração tem dimensão comunitária, é quantitativo e incide no valor total do volume de negócios das empresas. Contudo, este valor não é um valor fixo e pode ser modificado caso o Conselho Europeu assim o entenda. Para que isso aconteça, segundo o art. 1. ${ }^{\circ}$, n. ${ }^{\circ} 5$ do Regulamento 139/2004, a Comissão Europeia tem de enviar uma proposta ao Conselho Europeu para "rever os limiares e os critérios" ${ }^{18}$ que determinam esta dimensão comunitária, a que posteriormente sucederá a respetiva avaliação do Conselho Europeu que decidirá por maioria qualificada o destino dessa respetiva proposta ${ }^{19}$.

Segundo o art. $1 .^{\circ}$ n. ${ }^{\circ}$, uma operação de "concentração de empresas tem dimensão Comunitária quando: a) O volume de negócios total realizado à escala mundial pelo conjunto das empresas em causa for superior a 5000 milhões de euros; e b) O volume de negócios total realizado individualmente na Comunidade por pelo menos duas das empresas em causa for superior a 250 milhões de euros; a menos que cada uma das empresas em causa realize mais

\footnotetext{
${ }^{15}$ Regulamento (CE) 139/2004, considerando 14.

${ }^{16}$ Regulamento (CE) 139/2004, considerando 9.

${ }^{17}$ Regulamento (CE) 139/2004, considerando 10.

18 Tendo em conta os dados estatísticos fornecidos pelos Estados-Membros.

${ }^{19}$ Art. $1^{\circ}$, no5 do Regulamento (CE) 139/2004.
} 
de dois terços do seu volume de negócios total na Comunidade num único Estado-Membro." No entanto, o n. ${ }^{\text {o }} 3$ do mesmo artigo refere outras situações que podem ser consideradas como tendo dimensão comunitária apesar de não figurarem no número anterior. Assim sendo, "Uma concentração que não atinja os limiares estabelecidos no n. 2 tem dimensão comunitária quando: a) O volume de negócios total realizado à escala mundial pelo conjunto das empresas em causa for superior a 2500 milhões de euros; b) Em cada um de pelo menos três Estados-Membros, o volume de negócios total realizado pelo conjunto das empresas em causa for superior a 100 milhões de euros; c) Em cada um de pelo menos três Estados-Membros considerados para efeitos do disposto na alínea b), o volume de negócios total realizado individualmente por pelo menos duas das empresas em causa for superior a 25 milhões de euros; $e$ d) $O$ volume de negócios total realizado individualmente na Comunidade por pelo menos duas das empresas em causa for superior a 100 milhões de euros, a menos que cada uma das empresas em causa realize mais de dois terços do seu volume de negócios total na Comunidade num único Estado-Membro."

Após esta breve exposição do que o Conselho Europeu entende por dimensão comunitária torna-se possível analisar o negócio TAP no sentido de verificar se a Comissão Europeia seria a entidade competente para avaliar a operação. Apesar de não ser conhecido o valor exato do volume de negócios disponibilizado pelas duas empresas à Autoridade da Concorrência portuguesa - por ser confidencial devido a segredos de negócio -, o grupo HPGB tem um volume maior que 100 milhões de euros em Portugal20 ${ }^{20}$, porém o mesmo já não acontece quando se verifica o volume de negócios total da empresa DGN que apresenta um volume de negócios total inferior a 5 milhões de euros ${ }^{21}$. Ou seja, o negócio TAP não adquire os requisitos necessários para ser considerado como um negócio de dimensão comunitária. Apesar do grupo HPGB conseguir cumprir com o critério quantitativo definido no art. $1 .^{\circ}$, n..$^{\circ} 3$, alínea d), acontece que para ser considerada a apreciação pela Comissão Europeia seria necessário que a empresa DGN auferisse um valor no mínimo semelhante ao que o grupo HPGB auferiu nesses últimos três anos. De facto, o grupo atingiu a meta dos 100 milhões de euros no Espaço Económico Europeu, contudo este não é o

\footnotetext{
${ }^{20}$ Ccent 41/2015, Atlantic Gateway/TAP, 1/10/2015, 3.

${ }^{21}$ Ccent 41/2015, Atlantic Gateway/TAP, 1/10/2015, 3.
} 
critério essencial para definir se um negócio tem ou não uma dimensão comunitária. Em Portugal o grupo DGN ficou-se apenas por uma quantia inferior a 5 milhões de euros, um valor muito aquém daquilo que é exigido no Regulamento.

Assim, a única hipótese que esta operação de concentração tinha de ser avaliada pela Comissão Europeia deixa de ser possível graças à escassa quantia que o grupo DGN apresentou à Autoridade da Concorrência. Desta forma, o novo método de coordenação entre a Comissão Europeia e as entidades reguladoras competentes é colocado em prova e as entidades reguladoras nacionais ficam desde logo incumbidas de apreciar os termos da operação da concentração da Atlantic Gateway e da TAP22 - o que vai ao desencontro do que a Associação "Peço a Palavra" pretendia ${ }^{23}$. Num comunicado emitido pela mesma Associação esta manifestou o entendimento de que a Comissão Europeia deveria analisar a operação de concentração por se tratar de uma "empresa estratégica" e "que poderia vir a ter repercussões sociais e económicas de enorme gravidade para o nosso país"24.

De facto, a Comissão Europeia pode ainda ter uma palavra a dizer em negócios que não tenham dimensão comunitária. Existem duas exceções presentes no Regulamento (CE) 139/2004 que dão hipótese à Comissão Europeia de apreciar concentrações que estejam fora dos limiares definidos pelo Conselho Europeu. A primeira exceção dá a possibilidade às próprias empresas de pedirem à Comissão Europeia que faça essa mesma avaliação, contudo é necessário que comuniquem essa intenção à Comissão antes de notificarem a operação de concentração às autoridades nacionais. De acordo com o art. $4 .^{\circ}$, n. 5 do presente Regulamento, "no caso de uma concentração tal como definida no art. 3. ${ }^{\circ}$ que não tenha dimensão comunitária na acepção do art. 1. ${ }^{\circ}$ e que pode ser apreciada no âmbito da legislação nacional de concorrência de, pelo menos, três Estados-Membros, as pessoas ou empresas referidas no n. ${ }^{\circ} 2$ podem, antes de uma eventual notificação

\footnotetext{
${ }^{22}$ Regulamento (CE) 139/2004, considerando 8.

${ }^{23}$ A Associação "Peço a Palavra" "é uma associação sem fins lucrativos, que promove a dinamização de uma cidadania activa relativamente aos interesses nacionais, ajudando todos os cidadãos a ter uma maior participação democrática.”.

${ }^{24}$ Comunicado de Imprensa realizado pela Associação "Peço a Palavra", Associação Peço a Palavra, acesso em setembro 20, 2015, http://www.associacaopecoapalavra.org.pt/index.php/press-release/142reuniao-em-bruxelas.
} 
às autoridades competentes, informar a Comissão, através de um memorando fundamentado, que a concentração deve ser examinada pela Comissão".

A outra possibilidade é aquela que está prevista no o artigo $22^{\circ}$ do respetivo regulamento. Este artigo explicita que: "Um ou mais Estados-Membros podem solicitar à Comissão que examine qualquer concentração, tal como definida no art. 3. ${ }^{25}$, que não tenha dimensão comunitária na acepção do art. 1. , mas que afecte o comércio entre Estados-Membros $e$ ameace afectar significativamente a concorrência no território do Estado-Membro ou EstadosMembros que apresentam o pedido".

Tendo em conta o explicitado supra pelos arts. $4 .^{\circ}$, n. $^{\circ} 5$ e art. $22 .^{\circ}$, n. ${ }^{\circ} 1$, seria possível que a Comissão Europeia pudesse analisar a operação de concentração da TAP, contudo não poderia ser a Associação "Peço a Palavra" a entidade com legitimidade para apresentar esse pedido à Comissão Europeia. O exposto no art. 22. ${ }^{\circ}$, n. ${ }^{\circ} 1$ do Regulamento 139/2004 é claro: só os Estados-Membros podem solicitar à Comissão Europeia que examine uma concentração de empresas que possa afetar o mercado relevante daquele Estado-Membro ou entre um Estado-Membro e os demais Estados-Membros que pertencem à União Europeia. O art. 4. ${ }^{\circ}$, n. 5 do regulamento prevê um aumento do número de intervenientes que podem solicitar à Comissão o exame de uma operação de concentração via memorando devidamente fundamentado sobre as razões pelas quais a operação de concentração deve ser analisada pela Comissão Europeia.

\footnotetext{
${ }^{25} \mathrm{O}$ art. 3. ${ }^{\circ}$ do Regulamento (CE) 139/2004 corresponde à definição do que o Conselho Europeu entende por concentração de empresas. O Tribunal de Geral da União Europeia já teve oportunidade de manifestar a sua posição relativamente a este conceito no acórdão Aer Lingus vs Comissão, 6 de julho de 2010, Processo T-411/07, T-411/07.

Assim, o Tribunal Geral entende expõe o sentido da norma da seguinte forma: "Nos termos do referido artigo $3 .{ }^{\circ}, n .^{\circ} 1$, considera-se que uma concentração está realiz̧ada quando bá uma mudança duradoura do controlo, que resulta, por exemplo, da fusão de duas empresas ou da aquisição por uma empresa do controlo de outra empresa. $O$ artigo $3 .^{\circ}, n .^{\circ} 2$, precisa que o dito controlo decorre dos direitos, contratos ou outros meios que conferem a possibilidade de exercer uma influência dominante sobre a actividade da empresa visada." E prossegue o raciocinio concluindo que: "qualquer operação ou conjunto de operações que realize «uma mudança do controlo duradoura», conferindo «a possibilidade de exercer uma influência dominante sobre [a] empresa» visada, é considerada uma concentração realizada na acepşão do regulamento das concentrações. A característica comum a essas concentrações é a seguinte: onde existiam duas empresas distintas antes da operação para uma determinada actividade económica passa a só existir uma após essa operação.".
} 
Assim, a conclusão que podemos retirar é que somente os intervenientes principais da operação de concentração e o próprio governo tinham legitimidade para pedir à Comissão que apreciasse a respetiva operação. De certa forma, a posição tomada pelo Conselho Europeu não é de todo descabida. A principal motivação que levou o Conselho Europeu a criar as entidades reguladoras do setor da concorrência foi a apreciação em casos de dimensão muito residual para o contexto do mercado único da União Europeia que não valia a pena serem analisados pela Comissão. A Comissão Europeia fez com que as entidades reguladoras sejam uma espécie de estrutura hierárquica inferior (algumas para regular, ficalizar e outras somente para fiscalizar) ${ }^{26}$ que a podem auxiliar Europeia em assuntos de relevo nacional e esperar que estas entidades continuem a zelar pelo cumprimento de estados, empresas e cidadãos do direito originário e também do direito derivado evidenciando assim uma forma de descentralização de poderes de Bruxelas para os restantes Estados-Membros. Assim, não faz sentido que alguma entidade derrotada ou algum assistente numa operação de concentração sem uma dimensão europeia exija que a Comissão Europeia atue nesses casos. No caso português e mais precisamente no negócio da TAP, a Autoridade da Concorrência é a autoridade mais adequada para registar e julgar as prováveis ilegalidades que possam existir na operação de concentração.

\section{A articulação das entidades reguladoras}

A Comissão Europeia, no seu comunicado referente à estruturação das entidades reguladoras, enuncia a criação de dois tipos de agências reguladoras: as entidades executivas e as entidades reguladoras ${ }^{27}$. Por entidades executivas a Comissão entende

\footnotetext{
${ }^{26}$ Colin Scott, "Agencies for European Regulatory Governance: A Regimes Approach", in Regulation through Agencies in the EU: A new paradigm in European Governance, ed. Damian Geradin, Nicolas Petit e Rodolphe Muñoz (Massachusetts: Edward Elgar Publishing Limited, 2005), 75: "The legal framework makes provision for member state governments to put in place national regulatory authorities (NRAs) which carry the main burden of monitoring the conduct of the key actors in the sector for compliance with the rules and enforcement to realign behaviour. The Commission has been very active in encouraging NRAs to use their powers in the cause of creating a single market in communications, and speaks to firms directly through soft law instruments.".

${ }^{27}$ Communication from the Comission: the operating framework for the European Regulatory Agencies,
} 
todas aquelas que são responsáveis por todas as tarefas administrativas, assistindo a Comissão Europeia na implementação de fundos financeiros e são sujeitos a uma estrita supervisão pela mesma ${ }^{28}$. Por outro lado, as entidades reguladoras são entendidas como entidades que estão envolvidas ativamente nas funções executivas pela promulgação de instrumentos que auxiliam na regulação de um setor específico e a fazer com que a regulação seja mais consistente e efetiva ${ }^{29}$.

Tom Christensen define as entidades reguladoras como organizações que pertencem ao direito público mas cujas funções estão desagregadas dos ministérios dos seus setores económicos ${ }^{30}$. Por sua vez, Mark Thatcher entende que uma entidade reguladora é um corpo com os seus próprios poderes e responsabilidades conferidos sob o direito público e separado em termos organizacionais dos ministérios e que não são diretamente eleitos ou geridos por oficiais eleitos ${ }^{31}$. Já no nosso ordenamento jurídico e tendo em conta o art. 3. ${ }^{\circ}$ n. 1 da lei-quadro $67 / 2013$, as entidades reguladoras tratam-se de "...pessoas coletivas de direito público, com a natureza de entidades administrativas independentes, com atribuições em matéria de regulação da atividade económica, de defesa dos serviços de interesse geral, de proteção dos direitos e interesses dos consumidores e de promoção e defesa da concorrência dos setores privado, público, cooperativo e social' 32 .

Tom Christensen prossegue referindo que as entidades reguladoras são agências com um cariz especial uma vez que é mais fácil expor as suas semelhanças do que

11/12/2002 COM (2002) 718 final.

${ }^{28}$ Communication from the Comission: the operating framework for the European Regulatory Agencies, 11/12/2002 COM (2002) 718 final 3.

${ }^{29}$ Communication from the Comission: the operating framework for the European Regulatory Agencies, 11/12/2002 COM (2002) 718 final. 4. No original: "regulatory agencies are required to be actively involved in the executive function by enacting instruments which help to regulate a specific sector. The majority of them are intended to make such regulation more consistent and effective by combining and networking at Community level activities which are initially a matter for the Member States".

${ }^{30}$ Tom Christensen e Per Lægreid, "Regulatory Agencies-The Challenges of Balancing Agency Autonomy and Political Control', Governance 20, 3 (2007): 505.

${ }^{31}$ Sugestão: Mark Thatcher, "Regulation after delegation: independent regulatory agencies in Europe", Journal of European Public Policy 9, 6 (2002), 956.

${ }^{32}$ Lei no 67/2013 de 28 de agosto relativo à lei-quadro das entidades administrativas independentes com funções de regulação da atividade económica dos sectores privado, público e cooperativo. 
as diferenças existentes entre elas ${ }^{33}$. A afirmação proferida por Christensen ganha ainda mais ênfase quando se verifica que a maior parte das entidades reguladoras têm especificidades de acordo com o seu setor económico.

Centrando a atenção no ordenamento jurídico português, a lei-quadro 67/2013 34 das entidades reguladoras independentes, o art. $1^{\circ}{ }^{\circ}$ n n. 1 refere que a presente lei "estabelece os princípios e as normas por que se regem as entidades administrativas independentes com funções de regulação, de promoção e defesa da concorrência respeitantes às atividades económicas dos setores privado, público, cooperativo e social, doravante e para efeitos da presente lei-quadro designadas por entidades reguladoras". Curiosamente, esta lei-quadro fez parte do Memorando de Entendimento sobre as Condicionalidades de Política Económica que foi subscrito pelo Governo Português, pela Comissão Económica, Banco Central Europeu e Fundo Monetário Internacional, e foi a primeira vez que se legislou esta matéria que já havia sido estudada em 2002 mas que foi inconsequente na época ${ }^{35}$. O maior contributo que esta lei-quadro trouxe para o nosso ordenamento jurídico foi a aproximação dos estatutos das entidades reguladoras e maior independência (art. 45. ${ }^{\circ}$ ), responsabilidade (art. 46. ${ }^{\circ}$ ), transparência (art. 48..$^{\circ}$ ) com a obrigatoriedade da inclusão de um Conselho de Administração (art. 17. ${ }^{\circ}$ ), com um regime orçamental (art. 33..$^{\circ}$ ) e competências para poder cobrar taxas e tarifas (art. 34. ${ }^{\circ}$ ).

No exposto do art. 3..$^{\circ}$, n. ${ }^{\circ} 1$ da lei-quadro mencionada supra, estão expostas as entidades reguladoras existentes e que estavam ao abrigo da respetiva lei. Entre elas encontra-se a Autoridade da Concorrência [alínea c)], ao passo que a Autoridade Nacional de Aviação Civil estava em processo de redenominação (art. 4. ${ }^{\circ}$ ). Contudo, esta lei-quadro também abrangia as entidades que se encontravam em processo de reestruturação ou redenominação, segundo o art. $4^{\circ}{ }^{\circ}$, n. ${ }^{\circ}$ 4. A primeira alínea do n. 1 do art. 40. 'da lei 67/2013 explicita que as entidades reguladoras devem "Fazer cumprir as

\footnotetext{
33 Tom Christensen e Per Lægreid, "Regulatory Agencies", 505 e 6. No original: "Regulatory agencies are a special type of agency, but it is easier to describe their similarities to other agencies than their differences since regulatory functions are often integrated into or related to other functions, even in those regulatory bodies said to have a mainly regulatory role".

${ }^{34}$ Lei no 67/2013 de 28 de agosto relativo à lei-quadro das entidades administrativas independentes com funções de regulação da atividade económica dos sectores privado, público e cooperativo.

35 João Luís Mendonça Gonçalves, Da independência das autoridades reguladoras indenpendentes, 29.
} 
leis, os regulamentos e os atos de direito da União Europeia aplicáveis". Como podemos verificar, as entidades reguladoras em questão são as competentes para apreciar a operação de concentração ${ }^{36}$ da Atlantic Gateway/TAP em detrimento da Comissão Europeia. Por conseguinte, é interessante compreender o porquê das duas entidades reguladoras estarem obrigadas a apreciar o negócio e não apenas a Autoridade da Concorrência.

A principal legislação portuguesa que trata de assuntos relacionados com a concorrência é a lei 19/2012 ${ }^{37}$ e a autoridade competente pela aplicação da presente lei é a Autoridade da Concorrência. Segundo o art. 2. ${ }^{\circ}$, n. $^{\circ} 2$ da respetiva lei “...é aplicável à promoção e defesa da concorrência, nomeadamente às práticas restritivas e às operações de concentração de empresas que ocorram em território nacional ou que neste tenham ou possam ter efeitos." Posteriormente, a lei 19/2012 refere que a Autoridade da Concorrência “... dispõe dos poderes sancionatórios, de supervisão e de regulamentação estabelecidos na presente lei e nos seus estatutos" (art. 5. ${ }^{\circ}$, n. ${ }^{\circ}$ ) e que "No desempenho das suas atribuições legais, a Autoridade da Concorrência é orientada pelo critério do interesse público de promoção e defesa da concorrência, podendo, com base nesse critério, atribuir graus de prioridade diferentes no tratamento das questões que é chamada a analisar" (art. 7. ', n. '1). A lei 19/2012 designa também, mais detalhadamente, qual deve ser a apreciação das operações de concentração (art. $41 .^{\circ}$ ) e os procedimentos de controlo de concentrações (art. $42 .^{\circ}$ ao art. 57. $\left.{ }^{\circ}\right)^{38}$.

Por outro lado, a Autoridade Nacional de Aviação Civil “. .. é a autoridade nacional em matéria de aviação civil, pessoa coletiva de direito público, com a natureza de entidade administrativa independente, dotada de autonomia administrativa, financeira e de gestão..." (art. 1. ${ }^{\circ}$, n. ${ }^{\circ}$ 1) e exerce “... funções de regulação, fiscalização e supervisão do setor da aviação civil e rege-se de acordo com o disposto no direito internacional e europeu, na lei-quadro das entidades reguladoras, nos presentes

\footnotetext{
${ }^{36}$ Nos termos da lei, a operação de concentração da Atlantic Gateway/TAP caracteriza-se como uma "... aquisição, direta ou indireta, do controlo da totalidade ou de partes do capital social ou de elementos do ativo de uma ou de várias outras empresas, por uma ou mais empresas ou por uma ou mais pessoas que já detenham o controlo de, pelo menos, uma empresa.".

${ }^{37}$ Lei 19/2012 de 8 de maio que aprova o novo regime jurídico da concorrência, revogando as Leis n. ${ }^{\circ s} 18 / 2003$, de 11 de junho, e 39/2006, de 25 de agosto, e procede à segunda alteração à Lei n. ${ }^{\circ}$ 2/99, de 13 de janeiro.

${ }^{38} \mathrm{O}$ art. $42^{\circ}$ da lei 19/2012 indica que para além da presente lei, o Código do Procedimento Administrativo também pode ser invocado.
} 
estatutos e na demais legislação setorial aplicávep' (art. 1. ${ }^{\circ}$, n. ${ }^{\circ}$ 2) ${ }^{39}$. Neste momento, é na ANAC que se centram as atenções uma vez que esta entidade reguladora também terá uma palavra a dizer no desfecho desta operação de concentração, pois um dos objetivos consagrados neste decreto-lei é, segundo o art. 4. ${ }^{\circ}$, n. ${ }^{\circ} 1$, alínea h): "Promover e defender a concorrência no setor da aviação civil, em estreita cooperação com a Autoridade da Concorrência, nos termos dos estatutos desta autoridade." Mais do que uma entidade reguladora, a ANAC é uma entidade fiscalizadora e que, acima de tudo, contribui com regulamentos em busca de uma maior qualidade para o sector da aviação civil.

Relativamente à articulação entre as entidades reguladoras setoriais no âmbito do controlo de operações de concentração, o art. 55. ${ }^{\circ}$, n. ${ }^{o} 1$ refere que: "Sempre que uma concentração de empresas tenha incidência num mercado que seja objeto de regulação setorial, a Autoridade da Concorrência, antes de tomar uma decisão que ponha fim ao procedimento, solicita que a respetiva autoridade reguladora emita parecer sobre a operação notificada, fixando um prazo razoável para esse efeito.", suspendendo desta forma o prazo que a Autoridade da Concorrência tem para publicar uma decisão (art. 55. ${ }^{\circ}$, n. ${ }^{\circ}$ 2). Por outras palavras, a Autoridade de Concorrência tem obrigatoriamente de pedir um parecer à ANAC sobre esta operação de concentração uma vez que este negócio interfere também na esfera de atuação desta entidade reguladora.

Ainda no decreto-lei 40/2015 são apontados alguns deveres à entidade reguladora como é o caso dos deveres de cooperação, transparência e proteção de passageiros. Precisamente nos deveres de cooperação existem dois artigos distintos. $\mathrm{O}$ art. 42 . $^{\circ}$ revela a cooperação com as demais entidades reguladoras onde elas devem estabelecer “... formas de cooperação ou associação atinentes ao desempenho das suas atribuiç̃es com outras entidades de direito público ou privado, nacionais e internacionais, nomeadamente com entidades reguladoras afins, a nivel internacional, europeu e nacional, quando tal se mostre necessário ou conveniente para a prossecução das respetivas atribuições.". Nos termos deste artigo., a parceria entre a ANAC e a Autoridade da Concorrência é merecedora de uma norma única o que releva a

\footnotetext{
${ }^{39}$ Decreto-Lei no 40/2015, Aprova os estatutos da Autoridade Nacional da Aviação Civil, anteriormente designado Instituto Nacional de Aviação Civil, I. P., em conformidade com o regime estabelecido na Lei n. ${ }^{\circ}$ 67/2013, de 28 de agosto, que aprova a lei-quadro das entidades administrativas independentes.
} 
importância que a cooperação entre entidades reguladoras tem para a resolução de problemas.

O número 1 do art. 43. ${ }^{\circ}$ da presente lei refere que " $A A N A C$ deve, no âmbito das suas atribuições de promoção e defesa da concorrência, colaborar com a Autoridade da Concorrênciā" e, em particular, proceder "à identificação dos comportamentos suscetíveis de infringir o disposto na lei de defesa da concorrência em matéria de práticas proibidas, bem como na organização e instrução dos respetivos processos e na verificação e cumprimento das decisões neles proferidas." Para além desta referência, também encontramos na lei da concorrência um artigo exclusivo para a cooperação da Autoridade da Concorrência com as restantes entidades.

Neste caso específico a Autoridade da Concorrência terá pedido parecer à ANAC que o terá dado no sentido favorável à concentração. A Autoridade da Concorrência já emitiu a declaração de não oposição ao consórcio, no entanto está consagrado no art. 55. ${ }^{\circ}$, n. ${ }^{\circ} 4$ da lei 19/2012 que "A não emissão de parecer vinculativo dentro do pražo estabelecido no n. ${ }^{\circ} 1$ do presente art. não impede a Autoridade da Concorrência de tomar uma decisão que ponha fim ao procedimento". Ou seja, caso o prazo que a entidade reguladora setorial tem para tomar uma posição tenha expirado, a Autoridade da Concorrência pode tomar uma decisão final sem o parecer dessa mesma entidade.

Na declaração de não oposição da Autoridade da Concorrência, o Agrupamento SAGEF (um dos interessados na compra da TAP) apontou uma irregularidade à luz do direito da União Europeia. Com efeito, segundo os próprios existe uma infração à alínea f) do art. 4. ${ }^{\circ}$ do Regulamento (CE) 1008/2008 ${ }^{40}{ }^{41}$. A Autoridade da Concorrência retorquiu que não é da sua competência analisar o Regulamento n. ${ }^{\circ}$ 1008/2008. Para além da Lei da Concorrência, a entidade reguladora ainda acrescenta o decreto-lei n. ${ }^{\circ}$ 125/2014 como outro instrumento normativo que esta tem em conta para analisar estes $\operatorname{casos}^{42}$.

A entidade reguladora que tem competências para fiscalizar e utilizar este

\footnotetext{
${ }^{40}$ Regulamento n. ${ }^{\circ}$ 1008/2008, relativo a regras comuns de exploração dos serviços aéreos na Comunidade.

${ }^{41}$ Ccent 41/2015, Atlantic Gateway/TAP, 1/10/2015, 18.

${ }^{42}$ Ccent 41/2015, Atlantic Gateway/TAP, 1/10/2015, 19.
} 
instrumento normativo para avaliar a legalidade da empresa é a Autoridade Nacional de Aviação Civil, mais propriamente o Conselho de Administração. Segundo a alínea a) do número 2 do art. 32. ${ }^{\circ}$, estão sujeitos a licenciamento da ANAC "as atividades de transporte aéreo, de trabalho aéreo, de exploração aeroportuária e de assistência em escala e quaisquer outras que envolvam a exploração de meios aéreos ou conexos."

Prosseguindo com a análise, segundo as alíneas d) e r) do art. 16. ${ }^{\circ}$ do Regulamento (CE) 1008/2008 é o Conselho de Administração da ANAC que tem competências para "Exercer os poderes de licenciamento (...) bem como quaisquer outros poderes públicos compreendidos nas atribuições da ANAC, enquanto entidade reguladora setorial e autoridade nacional da aviação civil, designadamente emitindo os titulos representativos das licenças, autoriz̧ações e certificações concedidas e os demais documentos oficiais da $A N A C$ " e, se for o caso, para "Suspender ou cancelar as licenças, certificados e certificações, homologações, autoriz̧ações, aprovações, credenciações e reconhecimentos concedidos, nos termos estabelecidos nos respetivos regimes".

O principal objetivo do Regulamento (CE) 1008/2008 é “regular a concessão de licenças às transportadoras aéreas comunitárias, o direito de as transportadoras aéreas comunitárias explorarem serviços aéreos intracomunitários..." (art. 1. ${ }^{\circ}$ ). No n. ${ }^{\circ} 1$ do art. 3. ${ }^{\circ}$ verificamos que "Só estão autorizadas a efetuar o transporte aéreo de passageiros, de correio el ou de carga mediante remuneração e/ ou em execução de um contrato de fretamento as empresas estabelecidas na Comunidade que sejam titulares de uma licença de exploração adequada" e o artigo prossegue referindo que "As empresas que satisfaçam as condições estabelecidas no presente capitulo têm direito à licença de exploração." Por empresas o regulamento apresenta um conceito indeterminado e bastante abrangente: "entende-se qualquer pessoa singular ou colectiva, quer desenvolva ou não uma actividade lucrativa, ou qualquer organismo oficial, com ou sem personalidade jurídica própria” (art. 2. ${ }^{\circ}$, n. $\left.^{\circ} 3\right)$.

Entre as várias condições estabelecidas no art. 4. ${ }^{\circ}$ (obrigatoriedade do estabelecimento principal se situar nesse Estado-Membro; preencher as condições financeiras do art. 5. ${ }^{\circ}$; dispor de uma ou mais aeronaves de que seja proprietária ou em regime de locação, etc) a alínea f) do art. $4 .^{\circ}$ revelou-se como um impedimento para a operação de concentração da primeira tentativa ainda no anterior governo. Pelo que se pode ler na declaração de não oposição, a Autoridade da Concorrência tinha sérias 
dúvidas acerca de quem seria o verdadeiro detentor da TAP após a finalização da concentração, ${ }^{43}$ porém a Autoridade refere que os instrumentos jurídicos que utiliza não são destinados a fiscalizar esta matéria, remetendo a decisão final para a ANAC. Esta última entidade reguladora comprova os argumentos expostos pela SAGEF e aponta que a operação de concentração é incompatível com o disposto na alínea f) do art. $4{ }^{\circ}$ segundo o qual: "Mais de $50 \%$ da empresa pertencer e for efectivamente controlada por Estados-Membros e/ ou nacionais de Estados-Membros, directa ou indirectamente através de uma ou várias empresas intermediárias, excepto conforme previsto num acordo com um país terceiro no qual a Comunidade seja Parte". Em suma, o facto de a operação de concentração ter sido aprovada pela Autoridade da Concorrência não significa que a mesma esteja apta para entrar em vigor uma vez que a ANAC também tem que apreciar se o consórcio se encontra compatível com os instrumentos normativos que existem em vigor no seu setor económico, sob pena de retirar as licenças para poder voar livremente pelo espaço aéreo europeu à TAP.

\section{Conclusão}

Ao longo desta exposição verificamos que tanto a Comissão Europeia como as entidades reguladoras de cada Estado-Membro (neste caso específico a AdC e a ANAC) estão a ganhar cada vez mais importância no sistema económico e comercial da União Europeia. O "New Mode of Governance" criado no início deste século veio trazer maior eficiência ao sistema regulador europeu que confia as suas competências a entidades reguladoras nacionais que se querem especializadas, independentes, confiáveis, disponíveis para cooperar e cumpridoras dos objetivos pelos quais estas foram criadas pelo Conselho Europeu.

Segundo Ellen Vos, existem vários fatores favoráveis que provieram das entidades reguladoras nacionais. Para além do aumento da eficiência e da maior celeridade de processos, as entidades reguladoras trouxeram também maior consistência na

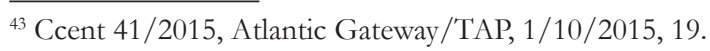


implementação de políticas e são essenciais para a uniformização de normas europeias de segurança ou de qualidade de um determinado setor económico. Para além disso, as entidades reguladoras promovem o diálogo com a sociedade e dão a liberdade a quem estiver interessado em seguir os processos que as entidades reguladoras estejam a trabalhar ${ }^{44}$.

$\mathrm{Na}$ operação de concentração da TAP verifica-se que as entidades reguladoras demonstraram a razão pela qual a Comissão Europeia delegou os seus poderes de apreciação a outras entidades em concentrações que não atinjam a dimensão comunitária especificada no Regulamento (CE) 139/2004. A qualidade e a especialidade evidenciada pelas entidades reguladoras ao longo do processo conseguiu impedir uma concentração que ia contra os princípios e contra as normas europeias.

Destarte, o trabalho das entidades reguladoras nacionais nesta operação de concentração assemelha-se a uma regra usada em várias empresas para conferir a qualidade dos produtos e que é designada por "regra dos quatro olhos". A regra dos quatro olhos é utilizada quando uma coisa (pode ser um produto ou um serviço) passa pela supervisão de duas ou mais pessoas para garantir a qualidade da mesma. Se tivermos em conta esta definição verificamos que a Autoridade da Concorrência foi a primeira entidade reguladora a pronunciar-se sobre a concentração seguindo os princípios e as normas concorrenciais plasmadas no ordenamento interno português, e simultaneamente ia pedindo pareceres à entidade reguladora setorial acerca do mesmo. Posteriormente, foi a vez da Autoridade Nacional de Aviação Civil fiscalizar a concentração seguindo os princípios e as normas nacionais e europeias. No ramo da aviação civil, de nada vale a uma ou várias empresas conseguir ter uma declaração de não oposição a uma concentração (como foi o caso da primeira tentativa) pela Autoridade da Concorrência e ver a sua entrada neste setor económico vetada por não cumprir os padrões ou os requisitos necessários para conseguir que as licenças lhe sejam concedidas ${ }^{45 / 46}$.

\footnotetext{
${ }^{44}$ Ellen Vos, "European Administrative Reform and Agencies", 22.

${ }^{45}$ Ccent 31/2016 Atlantic Gateway/TAP, Autoridade da Concorrência, acesso em setembro 20, 2016, http://www.concorrencia.pt/vPT/Controlo_de_concentracoes/Decisoes/Paginas/pesquisa. aspx?pNumb $=31 \&$ yearNot $=2016 \& p a g=1 \&$ doc $=$ False.

46“Concorrência dá luz verde à operação que deixa o Estado com metade da TAP”, Diário de Notícias,
} 
Em suma, apesar de ainda existirem algumas dúvidas em relação a um possível auxílio estatal pelas garantias expressas no contrato aquando da venda da empresa, o trabalho das entidades reguladoras tem sido satisfatório neste processo. Esta operação de concentração pode ser considerado um exemplo e demonstram que a confiança depositada pela Comissão Europeia nas entidades reguladoras para se assumirem elas próprias como uma extensão da própria Comissão nos seus respetivos EstadosMembros, exigindo os requisitos mínimos necessários às empresas, implementando padrões europeus de elevada qualidade nos seus sectores económicos e demonstrando elevadas competências fiscalizadoras e sancionatórias contra empresas que estejam a atuar de uma forma desconforme ao direito nacional ou da União Europeia é uma mais-valia para o mercado único europeu.

acesso em setembro 20, 2016, http://www.dn.pt/dinheiro/interior/concorrencia-da-luz-verde-aoperacao-que-deixa-o-estado-com-metade-da-tap-5363021.html. 



\title{
O Regulamento n. ${ }^{\circ}$ 655/2014 que estabelece um procedimento de decisão europeia de arresto de contas: direitos à ação e de defesa em tensão reflexiva no contexto de uma integração judiciária em matéria civil - uma precoce antevisão
}

\author{
Joana Covelo de Abreu*
}

RESUMO: Poucos dias depois da entrada em vigor do Regulamento n. $655 / 2014$, que estabelece um procedimento de decisão europeia de arresto de contas bancárias, torna-se fundamental antecipar de que modo este instrumento terá cabimento no contexto económico da União Europeia. Assim, cabe precisar metodologicamente, esbatendo dúvidas teleológicas, que este ato normativo cria um procedimento cautelar especificado de arresto, mais amplo do que o estabelecimento de um sistema de penhora, circunscrito ao funcionamento de um processo executivo. E o seu surgimento vem na senda de a União Europeia ainda não se encontrar dotada de um mecanismo executivo transfronteiriço. Num exercício de prognose, cabe analisar como o funcionamento deste instituto se relacionará com demandas de tutela jurisdicional efetiva, tendo por referência duas das suas dimensões: o direito à ação e os direitos de defesa. Na realidade, a grande novidade que lhe é associada passa pelo facto de este se desenrolar sem a audição prévia do devedor - configurando-se como um processo ex parte - o que pede uma reflexão quanto às soluções aventadas de modo a perceber se a posição processual do devedor está acautelada e, bem assim, se este mecanismo se configura como um fator determinante no adensamento da integraşão judiciária europeia em matéria civil.

PALAVRAS-CHAVE: Regulamento n. ${ }^{\circ}$ 655/2014 - decisão europeia de arresto de contas - direito à ação direitos de defesa - processo ex parte - integração judiciária em matéria civil - tutela jurisdicional efetiva.

ABSTRACT: Regulation nr. 655/2014 entered into force a few days ago, establishing a European Account Preservation Order and showing how fundamental it is to anticipate how this instrument will fit in the European Union's economic context. Therefore, it is due to methodologically establish, setting aside teleological doubts, this normative act creates typical precautionary proceedings of bank accounts' seizure, wider than the institution of an attachment system, circumscribed to enforcement proceedings' functioning. And its appearance comes from the fact the European Union is not

\footnotetext{
* Professora da Escola de Direito da Universidade do Minho. Membro Doutorado do Centro de Estudos em Direito da União Europeia (CEDU) da Universidade do Minho.
} 
yet equipped with a cross-border enforcement mechanism. In a prognosis exercise, it is due to analyse how the functioning of this institute will connect itself with effective judicial protection's demands, having as reference two of its dimensions: right to action and defence rights. In fact, the great novelty associated to it is that it evolves without previously listening to the debtor - as an ex parte procedure - which claims a reflexion concerning stipulated solutions and if this mechanism is a determining factor in judicial integration in civil matters' densification.

KEYWORDS: Regulation nr. 655/2014 - European Account Preservation Order - Right to action - Defence rights - Exparte procedure - Judicial integration in civil matters - Effective judicial protection.

\section{O procedimento de decisão europeia de arresto de contas bancárias: precisões teleológicas tendentes à compreensão do status quo ante do Regulamento n. ${ }^{\circ}$ 655/2014}

O Regulamento n. ${ }^{\circ}$ 655/2014 ${ }^{1}$ estabelece um procedimento de decisão europeia de arresto de contas bancárias para facilitar a cobrança transfronteiriça de créditos em matéria civil e comercial.

Atentas as finalidades que lhe são inerentes, este ato normativo tem em vista manter e desenvolver um espaço de liberdade, segurança e justiça onde a livre circulação de pessoas seja assegurada na medida em que ao bom funcionamento do mercado interno é essencial à cobrança transfronteiriça de créditos (considerando 1).

Assim, como o título executivo europeu ${ }^{2}$, o procedimento de injunção ${ }^{3}$ e as ações de pequeno montante ${ }^{4}$, o arresto de contas bancárias tem em vista facilitar a cobrança rápida e eficaz de créditos não liquidados, assegurando, ao credor, que o património do devedor não é dissipado por este ou outrem, a seu mando (considerando 7).

A par da injunção europeia e das ações de pequeno montante, o arresto de

\footnotetext{
${ }^{1}$ Regulamento (UE) n. ${ }^{\circ}$ 655/2014, do Parlamento Europeu e do Conselho, de 15 de maio de 2014, que estabelece um procedimento de decisão europeia de arresto de contas para facilitar a cobrança transfronteiriça de créditos em matéria civil e comercial, disponível em www.eur-lex.europa.eu.

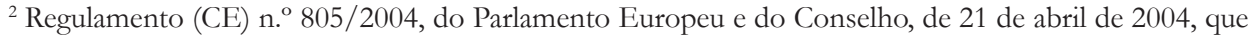
cria o título executivo europeu para créditos não contestados, disponível em www.eur-lex.europa.eu.

${ }^{3}$ Regulamento (CE) n. ${ }^{\circ}$ 1896/2006, do Parlamento Europeu e do Conselho, de 12 de dezembro de 2006, que cria um procedimento europeu de injunção de pagamento, disponível em www.eur-lex.europa.eu.

${ }^{4}$ Regulamento (CE) n. ${ }^{8} 861 / 2007$, do Parlamento Europeu e do Conselho, de 11 de julho de 2007, que estabelece um processo europeu para ações de pequeno montante, disponível em www.eur-lex.europa.eu.
} 
contas bancárias configura-se como um processo europeu uniforme que pode ser usado pelos litigantes como alternativo aos meios previstos no direito nacional ${ }^{5}-$ considerando 6 e art. $1 .^{\circ}$, n. $^{\circ} 2$ do Regulamento.

Com o surgimento destes mecanismos processuais - facilitadores / garantidores da cobrança transfronteiriça de créditos - e com a refundação do Regulamento n. ${ }^{\circ}$ 44/2001 pelo Regulamento n. ${ }^{\circ} 1215 / 2012^{6}$ e consequente supressão do exequatur, tornou-se cada vez mais tangível a cobrança de créditos no âmbito de outro ordenamento jurídico. No entanto, o processo executivo - porque sabemos que o Regulamento n. ${ }^{\circ} 805 / 2004$, relativo ao título executivo europeu, apenas acarreta uma certificação de uma decisão, transação judicial ou documento autêntico e não um verdadeiro processo executivo europeu transfronteiriço - continua a tramitar à luz do direito interno do Estado-Membro do foro. Ora, uma grande maioria dos EstadosMembros comumente recorre a mecanismos internos de penhora de contas bancárias [conforme disposto, na legislação portuguesa, no art. $780 .^{\circ}$ do Código de Processo Civil (CPC), atentas as limitações decorrentes dos arts. $735^{\circ}$, n. ${ }^{\circ} 3$ e $738 .^{\circ}$, n..$^{\circ} 4$ e 5 do $\mathrm{CPC}$ ] ou de arresto de bens (arts. 391. ${ }^{\circ}$ e seguintes do CPC). Ora, se o processo apenas tivesse em vista perseguir contas bancárias domiciliadas no Estado-Membro do foro, o problema não se colocaria. No entanto, sempre que o credor queira agir simultaneamente sobre contas bancárias do devedor domiciliadas em vários EstadosMembros, o facto de ter de usar diversos procedimentos nacionais acabava por ser complexo e dispendioso.

Na realidade, a Comissão começou a mostrar, desde muito cedo, uma preocupação com a verdadeira viabilidade e teleologia dos processos executivos. De acordo com o Livro Verde publicado por esta instituição "[a] legislação em matéria de execução é frequentemente considerada o «alcanhar de Aquiles» do espaço judiciário civil europeù" na medida

\footnotetext{
${ }^{5}$ Cfr., para maiores desenvolvimentos, Joana Covelo de Abreu, "O impacto do Regulamento n. 2015/2421, de 16 de dezembro no funcionamento das ações de pequeno montante - compreensões quanto à justiça eletrónica europeia”, in Livro em Homenagem ao Professor Doutor António Cândido de Oliveira, Braga, Escola de Direito da Universidade do Minho, 2017, (no prelo).

${ }^{6}$ Regulamento (UE) n. ${ }^{\circ}$ 1215/2012, do Parlamento Europeu e do Conselho, de 12 de dezembro de 2012, relativo à competência judiciária, ao reconhecimento e à execução de decisões em matéria civil e comercial (reformulação), disponível em www.eur-lex.europa.eu.
} 
em que, apesar de suprimido o exequatur e adotados mecanismos como o previsto no Regulamento n. ${ }^{\circ}$ 1215/2012 ou a certificação como título executivo europeu, a realidade é que "a execução de uma decisão judicial declarada executória noutro Estado-Membro continua a ser regulada exclusivamente pelo direito nacional' '7. Tal demanda, dos operadores judiciários nacionais, competentes para tramitar o processo executivo, um escrutínio destas soluções jurídico-processuais nacionais à luz dos testes da equivalência e da efetividade no âmbito da total operatividade do princípio da autonomia processual dos Estados-Membros ${ }^{8}$. Mas tal pode revelar-se problemático... Senão vejamos as dificuldades já auscultadas em aplicar o direito interno português à luz do art. 43. ${ }^{\circ}$ do Regulamento n. ${ }^{\circ}$ 1215/2012:

- O CPC português foi introduzido no ordenamento jurídico interno pela Lei n. ${ }^{\circ} 41 / 2013$, de 26 de junho que operou alterações também no âmbito do processo executivo, passando a tramitar sob duas formas: a ordinária e a sumária (art. 550. n. ${ }^{\circ} 1$ do CPC). Tal figurou, para a doutrina, como uma "contra-reforma", sobretudo quando comparada com as alterações introduzidas em 2008 (enquanto culminar da reforma iniciada em 2003) ${ }^{10}$.

Nesta circunstância, o processo executivo para pagamento de quantia certa irá

\footnotetext{
Cfr. Livro Verde sobre uma maior eficácia na execução de decisões judiciais na União Europeia: penhora de contas bancárias", da Comissão Europeia, Bruxelas, 24 de outubro de 2006, COM(2006)618 final, disponível em http://eur-lex.europa.eu/legal-content/PT/TXT/ PDF/?uri=CELEX:52006DC0618\&from=EN (acedido a 23 de janeiro de 2017), p. 2.

${ }^{8}$ Para mais desenvolvimentos, cfr. Joana Covelo de Abreu, "Regulation EU 1215/2012, exequatur's suppression and the optimization of executive proceedings based on other Member-States' decisions: executed person's service and refusal of judgement's recognition and enforcement in Portugal", in PoLaR - Portuguese Law Review, 0 (inaugural), (2016): 6. Na realidade, diz a autora " [...] we have to remember the principle of procedural autonomy of Member States, [...]. This principle is enshrined in article $19 .{ }^{\circ}, n{ }^{\circ} 1,2^{\text {nd }}$ paragraph of the Treaty of the European Union (TEU), where we can read that "Member States shall provide remedies sufficient to ensure effective legal protection in the fields covered by Union law". With this EU primary law disposition, European legislator wanted to determine that it is up to Member States to set procedural ways to protect rights given by EU legal order. However, this ability, given to Member States, is not unlimited and their procedural autonomy is tested under two principles: of equivalence (national procedural solutions cannot promote a less favourable treatment to litigations where EU law is applicable than that given to purely internal ones, of similar nature) and of effectiveness (internal rules cannot make impossible or excessively difficult, in practice, the exercise of rights given by EU legal order)".

9 Cfr. Elizabeth Fernandez, Um novo Código de Processo Civil? Em busca das diferenças (Porto: Vida Económica, 2014), 153.

${ }^{10}$ Cfr., entre outros, Elizabeth Fernandez, Um novo Código de Processo Civil?, 153.
} 
tramitar sob a forma ordinária, existindo emanação de despacho liminar (art. 726. n. 1 do CPC), o que pressupõe que a citação do executado precederá a penhora (art. 726. ${ }^{\circ}$, n. ${ }^{\circ}$ s 6 e 8 do CPC). "Contudo, o exequente pode requerer [...] que a penhora seja efetuada sem a citação prévia do executado, desde que alegue factos que justifiquem o receio de perda da garantia patrimonial do seu crédito e ofereça, de imediato, os meios de prova (art. 727. ${ }^{\circ}$ do CPC)" 11 . Por sua vez, a forma sumária caracteriza-se por não haver despacho liminar e a penhora preceder a citação - art. $855^{\circ}$, n. ${ }^{\circ} 3$ do CPC. Esta tramitação é mais simples e aplicase aos processos baseados em títulos executivos que congregam maior segurança jurídica como a decisão judicial ${ }^{12}$ (art. 550. ${ }^{\circ}$, n. ${ }^{\circ} 2$ do CPC). Nos termos do art. 626. ${ }^{\circ}$, n. 2 do CPC, as ações executivas baseadas em sentenças correrão sob a forma de processo sumário. No entanto, quando a execução se funda em sentença estrangeira, temos de ler esta disposição em conjugação com as regras relativas à competência internacional. Assim, dispõe o art. 90. ${ }^{\circ}$ do CPC que será competente para executar uma decisão emanada noutro Estado-Membro o tribunal que conheceria a execução se esta se fundasse em decisão proferida por tribunal superior, ou seja, será competente o tribunal do lugar do domicílio do executado. No caso, a ação executiva, em Portugal, baseada em decisão emanada noutro Estado-Membro e cujo exequatur tenha sido dispensado por conta da aplicação do Regulamento n. ${ }^{\circ}$ 1215/2012, tramitará sob a forma sumária, onde a penhora precederá a citação do executado. Sucede, contudo, que o art. 43. ${ }^{\circ}$, n. ${ }^{\circ} 1$ do Regulamento n. ${ }^{\circ}$ 1215/2012 "parece determinar que sempre [...] se opere a citação do executado antes de quaisquer outros atos inerentes ao processo executivo" 13 . Assim, cabe ao juiz assegurar que antes de qualquer diligência executiva se realize a citação do futuro executado. No entanto, tal poderá vir a frustrar o sistema interno de a penhora preceder a citação como mecanismo de acautelamento do credor, evitando que o devedor possa dispersar o seu património. Daqui talvez resulte que a legislação interna deste Estado-Membro se possa entender estar avant la lettre, numa ótica do exequente, relativamente ao determinado no Regulamento n. ${ }^{\circ}$ 1215/2012

\footnotetext{
${ }^{11}$ Cfr. Joana Covelo de Abreu, "Regulation EU 1215/2012, exequatur's suppression”, 7.

12 “[...] nos casos em que esta não deva ser executada no próprio processo." - artigo 550. , n..$^{\circ}$ 2, a) in fine do CPC.

${ }^{13}$ Cfr. Joana Covelo de Abreu, “Regulation EU 1215/2012, exequatur's suppression...”, 8.
} 
- afinal, o efeito surpresa é mais apetecível a quem pretende obter pagamento para os seus créditos. No entanto, entendemos que o legislador da União terá pretendido introduzir o justo equilíbrio entre o direito à ação (no caso, executiva) e os direitos de defesa do executado - justo equilíbrio esse que dá mote a esta nossa reflexão científica.

Daqui resulta a ainda total atualidade das palavras da Comissão: a "fragmentação das regulamentações nacionais em matéria de execução impede uma cobrança transfronteiriça de créditos eficaz" já que os credores "são confrontados com diferentes regimes jurídicos e múltiplas exigências processuais e barreiras linguísticas que implicam custos suplementares e atrasos a nivel do procedimento de execução" ${ }^{14}$. Neste contexto, cabe, no entanto, proceder ao enquadramento em que o Livro Verde foi desenvolvido: falava em "penhora de contas bancárias" (ênfase nosso), ainda que por referência a um procedimento cautelar, por oposição à opção legislativa literal realizada de adotar um processo cautelar especificado, no contexto europeu, relativo ao arresto de contas bancárias e a designá-lo enquanto tal.

Assim, apesar de, no direito interno - que acaba por influenciar os desenvolvimentos jurídicos no contexto europeu - "arresto" e "penhora" assumirem noções distintas, ainda que confluentes ou teleologicamente coincidentes, há que ter em conta que, como em tudo o que caracteriza a União Europeia, as aproximações terminológicas não podem ser realizadas sob a lente do direito interno já que esta não serve para explicar as realidades desenvolvidas nesta sede.

Ora, apesar de quer o arresto, quer a penhora determinarem uma apreensão judicial de bens com carácter provisório, o papel processual de um e de outra é diferente - um emerge de um processo de natureza cautelar e que pode ser decretado previamente à propositura de um processo executivo (quer no âmbito de uma ação declarativa, quer antes da apresentação desta ação em juízo); a outra surge como uma medida provisória no âmbito de um processo executivo. Apesar de operante no contexto em que emerge, a penhora acaba por ter um papel mais limitado - contextualmente, entenda-se - do que o arresto, na medida em que aquela se cinge a um encadeado de atos processuais especificados (os do processo de execução) enquanto o arresto se

${ }^{14}$ Cfr. Livro Verde sobre uma maior eficácia na execução de decisões..., p. 2. 
pode operacionalizar paralelamente em circunstâncias mais latas.

Atenta esta realidade, e porque o caminho para a criação de um processadotipo no domínio executivo ainda se está a sedimentar, o legislador da União pensou num mecanismo provisório que, aprioristicamente, poderá ser capaz de facilitar a cobrança transfronteiriça de créditos (que se lhe seguirá) e que visa não comprometer o equilíbrio hercúleo entre o direito à ação e os direitos de defesa ${ }^{15}$, ambos dimensões da tutela jurisdicional efetiva ${ }^{16}$, tal como ela é protegida e promovida no contexto alargado da União.

Posto isto, cabe-nos fazer aproximações breves a generalidades quanto ao âmbito de aplicação do Regulamento e, seguidamente, entender se a tramitação associada a este processo estabelece uma ponte estabilizadora entre as dimensões da tutela jurisdicional efetiva refletidas no título.

\section{A decisão de arresto de contas bancárias: generalidades}

O procedimento europeu de arresto de contas bancárias foi aprovado a 15 de maio de 2014 e entrou em vigor no dia 18 de janeiro de 2017.

O Regulamento n. ${ }^{\circ}$ 655/2014 vincula todos os Estados-Membros à exceção da Dinamarca e do Reino Unido ${ }^{17}$. Da definição deste âmbito territorial de aplicação resulta que os credores domiciliados na Dinamarca ou no Reino Unido (ou em Estado terceiro) não podem deitar mão ao procedimento aqui propugnado ainda que o tribunal competente seja o de um Estado-Membro vinculado ou quando as contas bancárias que se pretendia arrestar se encontrem domiciliadas num Estado-Membro

\footnotetext{
${ }^{15}$ Para maior precisão e desenvolvimento, cfr. Joana Rita Covelo de Abreu, "Effective judicial protection in judicial cooperation in civil matters and the Court of Justice of the European Union case law: the public policy clause and the absolute default of appearance as denial causes of judgments' recognition and enforcement in EU context', in UNIO - EU Law Journal, 0 (inaugural edition) (2014): 147-161.

${ }^{16}$ Para maiores desenvolvimentos, cfr. Joana Rita de Sousa Covelo de Abreu, "Tribunais nacionais e tutela jurisdicional efetiva: da cooperação à integração judiciária no Contencioso da União Europeia" (tese de doutoramento, Universidade do Minho, 2015).

${ }^{17}$ Cfr. considerandos 49 a 51 do Regulamento e Protocolos n. ${ }^{\circ}$ s 21 e 22, relativos à posição do Reino Unido, Irlanda e Dinamarca, anexos aos Tratado da União Europeia (TUE) e Tratado sobre o Funcionamento da União Europeia (TFUE).
} 
que se sujeitou à aplicação do Regulamento - art. $4 .^{\circ}$, n. ${ }^{\circ}$ 6. Da mesma forma, uma decisão de arresto obtida mediante a aplicação do Regulamento em análise também só produzirá os seus efeitos sobre contas bancárias mantidas em um ou mais EstadoMembros sujeitos à aplicação deste ato normativo - arts. $1 .^{\circ}$, n. $^{\circ} 1$ e $4 .^{\circ}$, n. $^{\circ} 4$ do Regulamento.

Mas o âmbito territorial de aplicação acarretou uma construção animadora: a decisão de arresto produzirá todos os seus efeitos sobre contas bancárias mantidas num Estado-Membro vinculado ainda que o banco em que as contas se encontram não tenha sede social na União Europeia, bastando, para o efeito, que aí tenha sucursal, agência ou filial - art. $4 .^{\circ}$, n. ${ }^{\circ} 2$ do Regulamento.

No que diz respeito à definição do âmbito material de aplicação da decisão de arresto, há alguma complexidade associada já que chama à colação o preenchimento de alguns pressupostos: a existência de i) uma conexão transfronteiriça e ii) de um crédito de natureza pecuniária, em matéria civil e comercial.

Nos termos do art. 3. ${ }^{\circ}$ do Regulamento, considerar-se-á existir um caso transfronteiriço quando a conta objeto da decisão se encontra 1) num Estado-Membro diferente daquele em que o pedido é submetido ou 2) daquele em que o credor tem o seu domicílio. Concretizando, o credor poderá deitar mão ao procedimento cautelar de arresto de contas bancárias se:

o tribunal em que o procedimento cautelar de arresto europeu é proposto se situar num Estado-Membro E a conta bancária a arrestar se localizar noutro EstadoMembro; OU

o credor tiver domicílio num Estado-Membro E quer o tribunal competente, quer a conta a arrestar se localizarem noutro Estado-Membro.

Do exposto resulta que, quando tais elementos de conexão se encontram todos localizados no mesmo Estado-Membro, não poderá o credor usar o procedimento de arresto aqui em análise, ainda que pretendesse, cumulativamente, arrestar contas domiciliadas noutro Estado-Membro. Nesta circunstância, ao credor resta usar um procedimento cautelar interno para as contas domiciliadas no mesmo EstadoMembro da residência do credor e do tribunal competente e, simultaneamente, o 
procedimento europeu para as contas que se encontrem noutro Estado-Membro.

$\mathrm{Na}$ senda das críticas que temos vindo a veicular à manutenção de uma noção de caráter transfronteiriço ${ }^{18}$, há que manifestar a nossa convicção de que esta noção é muito limitativa ${ }^{19}$; sobretudo neste contexto e quando há jurisprudência consolidada do Tribunal de Justiça na matéria (mais propriamente, o acórdão Denilauler ${ }^{20}$, acolhido no novo Regulamento n. ${ }^{\circ}$ 1215/2012) que veio confinar o âmbito de operatividade dos pedidos de decretação de medidas cautelares e provisórias ${ }^{21}$. Este Regulamento ganha, assim, importância reforçada pelo que somos de opinião que a exigência do carácter transfronteiriço apenas acaba por comprometer a efetividade do mecanismo antes mesmo de este ser apresentado em juízo.

Por sua vez, estaremos perante um crédito pecuniário em matéria civil e comercial, nos termos do art. $2 .^{\circ}$, n. $^{\circ} 1$ do Regulamento, desde que o crédito não tenha resultado, nos termos do art. $2{ }^{\circ}$, n. $^{\circ} 2$ do Regulamento: i) de regimes matrimoniais ou das relações equiparáveis ao casamento; ii) de testamentos e sucessões; iii) de créditos sobre devedores contra os quais foram iniciados processos de insolvência e outros análogos; iv) de matérias atinentes à Segurança Social; e v) de créditos decorrentes da arbitragem.

Ainda neste contexto, por força do art. 2. ${ }^{\circ}$, n. ${ }^{\circ}$ s 3 e 4 do Regulamento, também se encontram excluídas do seu âmbito de aplicação as contas bancárias impenhoráveis nos termos da legislação do Estado-Membro do foro e as contas bancárias detidas por bancos centrais ou em que estes ajam na qualidade de autoridades monetárias.

O procedimento pode ser utilizado pelo credor quer antes, quer durante, quer depois de obter decisão declarativa que titule o seu crédito (art. 5. ${ }^{\circ}$ do Regulamento).

\footnotetext{
${ }^{18}$ Cfr., para maiores desenvolvimentos, Joana Covelo de Abreu, "O impacto do Regulamento n. $2421 / 2015$, de 16 de dezembro no funcionamento das ações de pequeno montante - compreensões quanto à justiça eletrónica europeia”.

${ }^{19}$ Cfr., para maiores desenvolvimentos, Joana Rita de Sousa Covelo de Abreu, "Tribunais nacionais e tutela jurisdicional efetiva...".

${ }^{20}$ Cfr. Acórdão TJ Denilauler, de 21 de maio de 1980, Processo n. ${ }^{\circ}$ 125/79, ECLI:EU:C:1980:130., considerando 6.

${ }^{21}$ Cfr. Maria Cecília Paglietti, "Il Regolamento n. 655 del 2014 sull'ordinanza di sequestro conservativo dei conti bancari: effettività della tutela e convergenza tra sistemi di giustizia", Rivista Trimestrale di diritto e procedura civile, Anno LXIX, n. ${ }^{\circ}$ 4, Dicimbre (2015): 1298, nota de rodapé n. ${ }^{\circ} 43$.
} 
Pode ainda ser utilizado para fazer cumprir uma obrigação expressa num documento autêntico ou numa transação judicial, tal como estas expressões se encontram definidas no art. $4 .^{\circ}$, n. ${ }^{\circ}$ s 9 e 10 do Regulamento.

Serão competentes os tribunais do lugar onde a ação principal irá tramitar (a ser proposta em 30 dias) ou onde tramitou - art. 6. ${ }^{\circ}$, n. ${ }^{\circ}$ s 1 e 3 do Regulamento. Por conta da prossecução da proteção da parte mais fraca, se o devedor for um consumidor, só serão competentes para proferir a decisão de arresto os tribunais do lugar onde o devedor tem o seu domićlíio - art. $6 .^{\circ}$, n. $^{\circ} 2$ do Regulamento. Estando o crédito titulado por documento autêntico, serão competentes os tribunais do lugar onde o mesmo tenha sido exarado - art. $6 .^{\circ}$, n. ${ }^{\circ} 4$ do Regulamento.

Quanto à representação em juízo, e na senda do hábito instituído no âmbito dos procedimentos facilitadores da cobrança transfronteiriça de créditos, não é obrigatória a constituição de mandatário para a instauração do pedido de arresto no Estado-Membro de origem e, bem assim, para representar o devedor - art. 41. ${ }^{\circ}, 1$. $^{\text {a }}$ parte do Regulamento. Assim, em regra, as partes poderão encontrar-se, processualmente, desacompanhadas de mandatário judicial, ainda que em fase de recurso (arts. 33. ${ }^{\circ}$ e seguintes) a menos que a legislação do Estado-Membro do foro determine a obrigatoriedade de representação em sede de recurso (art. 41. ${ }^{\circ}$, 2. $^{a}$ parte do Regulamento).

Nos termos do art. 53. ${ }^{\circ}$ do Regulamento, a Comissão irá apresentar, até 18 de janeiro de 2022, um relatório sobre a aplicação do Regulamento, onde avaliará se deverão ser incluídos instrumentos financeiros no âmbito de aplicação deste normativo (art. 53. ${ }^{\circ}$, n. ${ }^{\circ} 1$, a) do Regulamento) e se os montantes creditados nas contas dos devedores depois da aplicação da decisão de arresto também poderão ser arrestados ao abrigo da mesma decisão (art. 53. ${ }^{\circ}$, n. ${ }^{\circ}$ 1, b) do Regulamento).

Retrospetivamente, os Estados-Membros tinham de comunicar, à Comissão, até ao dia 18 de julho de 2016, quais seriam os tribunais competentes para decretar o arresto, a possibilidade de penhorabilidade de contas conjuntas e os montantes impenhoráveis à luz do direito interno.

Nesta perspetiva, o sítio da internet do Portal Europeu de Justiça ${ }^{22}$ em matéria civil

${ }^{22}$ Cfr. sítio da internet do Portal Europeu de Justiça (acedido no dia 3 de fevereiro de 2017) https://e- 
e comercial foi atualizado no dia 17 de janeiro de 2017 para dar conta das informações facultadas pelos diversos Estados-Membros, nomeadamente o português ${ }^{23}$. Assim, Portugal prestou as informações, à Comissão, conforme obrigação que para si resultava do disposto no art. 50. ${ }^{\circ}$ do Regulamento n. ${ }^{\circ}$ 655/2014.

Serão competentes para emitir uma decisão de arresto de contas bancárias as Seções de Instância Central de Competência Especializada Cível, em ações de valor superior a 50.000,00€ $€^{24}$, e as Seções de Instância Local Cível / Seções de Competência Genérica, em ações de valor igual ou inferior a 50.000,00€ $€^{25}$ - dando cumprimento ao art. $50 .^{\circ}$, n. ${ }^{\circ} 1$, a) do Regulamento. Para efeitos de recurso da recusa de emissão de decisão de arresto, Portugal indicou como competentes os Tribunais da Relação (art. 50. ${ }^{\circ}$, n. ${ }^{\circ}$ 1, d) do Regulamento). Por sua vez, a Ordem dos Solicitadores e dos Agentes de Execução (OSAE) será competente para obter informações sobre contas bancárias (art. 50. ${ }^{\circ},{ }^{\circ}{ }^{\circ}$, b) do Regulamento) e para executar a decisão de arresto (art. 50. ${ }^{\circ},{ }^{\circ}{ }^{\circ}$, f) do Regulamento).

Já no que diz respeito aos métodos para obter informações sobre contas bancárias - dando cumprimento ao art. $14 .^{\circ}$, n. ${ }^{\circ}$ 5, a) e b) do Regulamento por força do disposto no art. 50. ${ }^{\circ}$, n. ${ }^{\circ}$ 1, c) - a legislação interna prevê a imposição da obrigação, a todos os bancos de Portugal, de divulgarem se o devedor é titular de uma conta e confere, à entidade competente para congregar tais informações, o direito a aceder a dados detidos por instituições públicas nos seus registos (ou equivalentes) - art. 749. ${ }^{\circ}$ do CPC e art. $17 .^{\circ}$ da Portaria n. ${ }^{\circ} 282 / 2013$, de 29 de agosto ${ }^{26}$.

Quanto à possibilidade de penhorabilidade de contas conjuntas (art. 50. ${ }^{\circ}$, n. $^{\circ} 1$,

justice.europa.eu $/$ home.do? action=home\&plang=pt.

${ }^{23}$ Para mais informações (e para eventuais alterações posteriores à redação do presente artigo), consultar o seguinte sítio da internet (acedido no dia 28 de janeiro de 2017) https:/ / e-justice.europa.eu/content_ european_account_preservation_order-379-pt-pt.do?member=1.

${ }^{24}$ Montante que inclui o capital, os juros e demais penalizações contabilizadas à data da propositura do pedido de arresto.

${ }^{25}$ Montante que inclui o capital, os juros e demais penalizações contabilizadas à data da propositura do pedido de arresto.

${ }^{26} \mathrm{Na}$ versão atualizada, que lhe foi dada pela Portaria n. ${ }^{\circ}$ 349/2015, de 13 de outubro, disponível no sítio da internet (acedido no dia 28 de janeiro de 2017): http:/ /www.pgdlisboa.pt/leis/lei_mostra_articulado. php?nid $=1968 \&$ tabela $=$ leis\&ficha $=1 \&$ pagina $=1 \&$ so_miolo $=\&$. 
g) do Regulamento), Portugal deu conta que, por força da presunção legal dos arts. 513..$^{\circ}$ e 516..$^{\circ}$ do Código Civil (CC), se entende que, em caso de contas conjuntas, há uma comparticipação em partes iguais no crédito - "presume-se enquanto se não fizerprova em contrário, que cada um dos depositantes é titular de metade da conta" ${ }^{27}$. Isto significa que, à partida, o arresto incidirá sobre a quota-parte do devedor na conta comum, ou seja, em metade (art. 780. ${ }^{\circ}$, n. 5 do CPC). Trata-se, no entanto, de uma presunção ilidível, mediante produção de prova em sentido contrário - quer demonstrando que as verbas apenas pertencem a um dos titulares ou que a distribuição das quotas é diferente, quer ainda que as verbas pertencem a um terceiro. Do mesmo modo, tratando-se de arresto peticionado contra um dos cônjuges e, à falta de bens suficientes próprios do devedor, sendo arrestada conta bancária conjunta, tem de ser citado o outro cônjuge para requerer a separação de bens ou para declarar que aceita a comunicabilidade da dívida. Incidindo o arresto em conta própria de um dos cônjuges, pode este alegar que a dívida é comum, caso em que se poderá proceder ao arresto de conta conjunta, caso exista (arts. 740. ${ }^{\circ}, 741 .^{\circ}$ e $742 .^{\circ}$ do CPC). Quando o dinheiro detido na conta conjunta pertença a terceiro, este pode deduzir "embargos de terceiro", nos termos e para os efeitos do disposto no art. $342 .^{\circ}$, n. ${ }^{\circ} 1$ do CPC.

No que se refere aos montantes impenhoráveis à luz do direito interno (arts. 2. ${ }^{\circ}$, n. ${ }^{\circ} 3$ e $50 .^{\circ}$, n. ${ }^{\circ} 1$, h) do Regulamento), Portugal deu conta que serão aplicáveis, ao arresto, as regras relativas ao regime da penhora - art. 391. ${ }^{\circ}$, n. 2 do CPC. Assim, por força do disposto no art. $735^{\circ}$, n. ${ }^{\circ} 3$ do CPC, o arresto deverá limitar-se aos bens necessários ao pagamento do crédito, sendo impenhoráveis dois terços da parte líquida dos vencimentos, salários, prestações periódicas (etc.) que assegurem a subsistência do executado (art. 738. ${ }^{\circ}$ do CPC), correspondendo o limite mínimo impenhorável ao montante equivalente a um salário mínimo nacional (se o devedor não tiver qualquer outro meio de subsistência) e o limite máximo ao montante equivalente a três salários mínimos nacionais. Sempre que o arresto incida sobre saldo bancário, é

\footnotetext{
${ }^{27}$ Cfr. sítio da internet da Rede Judiciária Europeia em matéria civil e comercial, acedido no dia 28 de janeiro de 2017, https://e-justice.europa.eu/content_european_account_preservation_order-379-ptpt.do?member $=1$.
} 
impenhorável o montante correspondente a um salário mínimo nacional (art. 738. ${ }^{\circ}$, n. 5 ex vi art. $780 .^{\circ}$, n. 2 in fine por força do art. 739. ${ }^{\circ}$ do CPC). No entanto, o devedor poderá peticionar, excecionalmente, que o valor não suscetível de arresto se cifre em montante superior, atentas as suas necessidades e do seu agregado familiar.

Dito isto, cabe-nos entender de que modo o processo tramitará, dando conta dos requisitos essenciais à obtenção de decisão de arresto.

\section{Obtenção da decisão de arresto - um processo ex parte e o justo equilíbrio entre as dimensões da tutela jurisdicional efectiva}

Chegados aqui, vemo-nos na contingência de explanar que este texto não tem a pretensão de aprofundadamente tratar o funcionamento do processo tendente à emanação da decisão de arresto de contas bancárias. Na realidade, tendo em conta a sua novidade, a principal preocupação prende-se em testar em que medida um processo pensado para proteger o credor, o poderá fazer sem comprometer a posição processual do devedor e, bem assim, a sua tutela jurisdicional. Por sua vez, desde cedo que se defende que os desafios ao entendimento da tutela jurisdicional efetiva são mais profundos e reais no seio dos instrumentos aventados no âmbito da cooperação judiciária em matéria civil e comercial, já que é aqui que, em primeira linha, mais tensões se colocam entre as várias dimensões da tutela e há um papel constante de acomodação das demandas que cada uma delas apresenta. "[F]oi no seio dos mecanismos jurídicoprocessuais desenvolvidos no âmbito da cooperação judiciária em matéria civil que as diversas dimensões da tutela jurisdicional efetiva são invocadas e surgem - não raras vezes - em sede de conflitos de direitos fundamentais, demandando o consequente dirimir desses conflitos" ${ }^{28}$. Assim, estarão em discussão, fundamentalmente, duas dimensões da tutela jurisdicional efetiva: o direito à ação [cuja consagração, no contexto jusfundamental da União Europeia, resulta claro no art. 47. ${ }^{\circ}$, 1. $^{\circ}$ parágrafo da Carta dos Direitos Fundamentais (CDFUE)] e os direitos de defesa (cuja expressão literal decorre da segunda parte do art. 47. ${ }^{\circ}$, 2. $^{\circ}$ parágrafo da CDFUE).

\footnotetext{
${ }^{28}$ Cfr. Joana Rita de Sousa Covelo de Abreu, “Tribunais nacionais e tutela jurisdicional efetiva ..., cit, 1.
} 
Para efeitos da presente análise, entende-se como direito à ação "o direito a um recurso jurisdicional efetivo em caso de violação" ${ }^{29}$ do direito da União. Tal construção foi primeiramente abordada, na jurisprudência do Tribunal de Justiça, no acórdão Johnston ${ }^{30}$, significando "o direito à ação a suscetibilidade de os particulares, a quem o direito da União conferiu direitos, poderem acioná-los judicialmente sempre que os mesmos sejam violados" 31 e sendo, neste aresto, sido designado como "controlo jurisdicional" 32 . Nesta circunstância, e na senda da jurisprudência Heylens ${ }^{33}$, o direito à ação demanda que sejam dadas todas as condições a que o indivíduo possa cabalmente comparecer perante um tribunal.

Por sua vez, os direitos de defesa têm sido entendidos e reputados como essenciais pelo Tribunal de Justiça e na sua jurisprudência constante ${ }^{34}$. Aliás, entende este tribunal que "qualquer processo que possa ter um desfecho desfavorável para qualquer pessoa singular ou coletiva deve pautar-se pela observância dos seus direitos de defesa, mesmo no caso de falta de regulamentação específica" 35 .

Como afirmámos, dos acórdãos mais esclarecedores da dinâmica necessária à compatibilização destas dimensões foi emanado no âmbito de um reenvio prejudicial que pedia a interpretação de disposições do Regulamento n. ${ }^{\circ}$ 805/2004, relativo ao título executivo europeu, e da sua leitura à luz do antigo Regulamento n. ${ }^{\circ}$ 44/2001 portanto, no seio da cooperação judiciária em matéria civil. No acórdão G. vs. Visser ${ }^{36}$, o Tribunal de Justiça recorda que, apesar da necessidade de assegurar os direitos de defesa do demandado, "tal não pode entravar a efetivação do direito que o Demandante tem de aceder às vias recursórias disponiveis para fazer valer os seus direitos" pondo em evidência as tensões entre estas duas dimensões da tutela ${ }^{37}$.

\footnotetext{
${ }^{29}$ Cfr., a propósito, as versões oficiais da CDFUE em inglês ("right to an effective remedy") e em francês (“droit à un recours effectif").

${ }^{30}$ Cfr. Acórdão TJ Johnston, de 15 de maio de 1986, Processo n. ${ }^{\circ}$ 222/84, ECLI:EU:C:1986:206.

${ }^{31}$ Cfr. Joana Rita de Sousa Covelo de Abreu, "Tribunais nacionais e tutela jurisdicional efetiva...", 30.

${ }^{32}$ Cfr. Acórdão TJ Johnston..., considerando 18.

${ }^{33}$ Cfr. Acórdão TJ Heylens, de 15 de outubro de 1987, Processo n. ${ }^{\circ}$ 222/86, ECLI:EU:C:1987:442.

${ }^{34}$ Para maiores desenvolvimentos, cfr. Acórdão TJ Alemanha vs. Comissão, de 5 de outubro de 2000, processo n. ${ }^{\circ}$ C-288/96, ECLI:EU:C:2000:537, considerando 99.

${ }^{35}$ Cfr. Joana Rita de Sousa Covelo de Abreu, "Tribunais nacionais e tutela jurisdicional efetiva...", 33.

${ }^{36}$ Cfr. Acórdão TJ G vs. Visser, de 15 de março de 2012, Processo n. ${ }^{\circ}$ C-292/10, ECLI:EU:C:2012:142.

${ }^{37}$ Cfr. Joana Rita de Sousa Covelo de Abreu, “Tribunais nacionais e tutela jurisdicional efetiva...”, 35.
} 
Como iremos perspetivar, apesar de o processo ter como tónica conferir operatividade ao direito à ação do credor - e ter, como referimos anteriormente, a teleologia de promover uma eficaz garantia à cobrança posterior de créditos transfronteiriços -, o legislador europeu usou de particular cuidado em esquematizar até onde tal proteção do credor poderia ir sem comprometer os direitos de defesa do devedor ou, ainda mais premente, do pretenso devedor. Assim, apesar de se tratar de um processo em que a decisão é emanada inaudita altera parte, o devedor não vê a sua posição processual diminuída, tendo o legislador, aliás, contemplado algumas "válvulas de escape" a fim de acautelar prejuízos sofridos pelo devedor / pretenso devedor: a constituição de garantia ficar na dependência de um teste de proporcionalidade realizado pelo juiz; a menção à responsabilidade do credor no art. $13 .^{\circ}$ do Regulamento; o estabelecimento de prazos razoáveis ao exercício do contraditório; a determinação de vias recursórias adequadas e previsíveis.

Como avançado supra, a obtenção de decisão de arresto prevista neste Regulamento ocorre, na sua plenitude, sem que o devedor tome conhecimento do processo (inaudita altera parte). Afinal, resulta do disposto no art. $11 .^{\circ}$ do Regulamento que "[o] devedor não é notificado do pedido de uma decisão de arresto nem ouvido antes de esta ser proferida", configurando-se aquilo que o legislador da União designou como um processo exparte. Para o efeito, o tribunal competente decidirá com base nos elementos de prova e nas alegações escritas apresentadas pelo credor no requerimento inicial art. 9. ${ }^{\circ}$, n. ${ }^{\circ} 1$ do Regulamento. Ao tribunal cabe o poder de determinar a audição do credor, de peritos e de testemunhas, podendo auxiliar-se das tecnologias associadas à vídeo e à teleconferência (art. 9. ${ }^{\circ}$, n. $^{\circ}$ 2).

Neste momento, cabe ao credor apresentar elementos probatórios suficientes que criem, no tribunal, a convicção de bom direito (fumus boni iuris), onde consiga reproduzir a urgência do acautelamento judicial procurado por se verificar um perigo real de que a execução do seu crédito seja impedida ou dificultada caso o arresto não seja decretado (periculum in mora) - art. $7^{\circ}$, n. 1.

A fim de sedimentar a convicção de bom direito, o art. $7 .^{\circ}$, n. $^{\circ} 2$ estabelece 
um adensamento ao critério do fumus boni iuris para os casos em que o arresto seja peticionado antes de ser decidida a ação principal: nesta circunstância, o credor tem de ser capaz de demonstrar, no tribunal competente para emanar a decisão de arresto, a probabilidade elevada que tem em obter ganho de causa no processo declarativo. Neste contexto, a Comissão Europeia explica que elementos deverão ter-se em consideração para o preenchimento do critério da urgência: "o facto de a situação financeira do devedor ser precária ou se esteja a deteriorar não deve constituir, por si só, motivo suficiente para o arresto" (ênfase nosso) embora possa o tribunal competente ter também estes fatores em consideração na "avaliação geral da existência do risco"38.

Esta construção acaba por assegurar, previamente ao exercício do contraditório pelo devedor, que os seus direitos de defesa não fiquem irremediavelmente comprimidos, confirmando que os prejuízos que se poderão causar na sua esfera patrimonial serão justificados.

Acresce ainda, numa perspetiva de acautelamento de um reduto essencial à tutela jurisdicional efetiva do pretenso devedor, que o art. 12. ${ }^{\circ}$ do Regulamento prevê a constituição de uma garantia pelo credor sempre que este não haja obtido decisão judicial, transação judicial ou instrumento autêntico. A garantia deverá ser prestada "num montante suficiente para prevenir a utilização abusiva do procedimento [...] e para assegurar a eventual indemnização do devedor por quaisquer prejuízos por este sofridos em resultado da decisão de arresto, na medida em que o credor seja responsável por tais danos" - art. 12. ${ }^{\circ}$, n. ${ }^{\circ} 1,1^{\circ}$ parágrafo do Regulamento. No entanto, ao juiz é reservado, pelo legislador da União, a faculdade de dispensar a constituição desta garantia sempre que excecionalmente considerar que, face às circunstâncias do caso, tal não é adequado - art. 12. ${ }^{\circ}$, n. ${ }^{\circ}$ 1, 2. ${ }^{\circ}$ parágrafo.

Do mesmo modo, havendo decisão judicial, transação judicial ou instrumento autêntico, o tribunal poderá exigir a constituição de garantia quando considere adequado às condições do caso - art. 12. ${ }^{\circ}$, n. ${ }^{\circ} 2$ do Regulamento. Auxiliando-nos

\footnotetext{
${ }^{38}$ Cfr. Guia Prático para os profissionais da justiça - cooperação judiciária em matéria civil na União Europeia, Comissão Europeia - Direção Geral da Justiça, Rede judiciária europeia em matéria civil e comercial, Serviço das Publicações, União Europeia, Bélgica, 2014, pp. 105 e 106 (versão portuguesa).
} 
do argumento literal, deste número 2 resulta que a regra será a não constituição de garantia, podendo esta ser ordenada excecionalmente.

A fim de evitar que haja alguma imprevisibilidade quanto às modalidades da garantia a constituir, o legislador da União determinou que, quando o tribunal competente ordena a prestação de garantia, terá de informar o credor: i) do montante exigido; ii) das formas de garantia aceitáveis no direito interno do Estado-Membro do foro; e c) que, logo que se efetive a constituição da garantia, a decisão de arresto é emanada. Tal promove a cooperação do tribunal com as partes o que, num contexto transfronteiriço, assume particular relevância de modo a evitar que o credor sobretudo porque pode pleitear isoladamente - se perca a tentar aferir que modalidade de garantia é permitida pela legislação do Estado-Membro do foro competente.

A sensibilidade à compatibilização das dimensões da tutela jurisdicional efetiva continua na definição dos prazos impostos ao tribunal para emanar a decisão de arresto. Assim, dispondo o credor de decisão ou transação judicial ou instrumento autêntico, o tribunal deverá decidir até ao final do décimo dia útil após a apresentação do requerimento; não dispondo o credor de um daqueles títulos, o tribunal deverá decidir até ao termo do quinto dia útil após a apresentação do pedido - art. $18 .^{\circ}$ do Regulamento. No caso de ser realizada audiência de julgamento, impõe-se ao tribunal decidir no prazo mais curto, na medida em que o período de tempo decorrido desde a propositura do pedido foi maior. Por sua vez, tendo o credor prestado garantia, a decisão deve ser imediatamente emanada, já que se presume que o acautelamento dos direitos de defesa e, bem assim, dos hipotéticos prejuízos a sofrer pelo devedor ficaram salvaguardados.

Fazendo ainda a mediação entre estas dimensões, torna-se vital a análise do regime de acesso às informações bancárias do devedor. $\mathrm{Na}$ realidade, dispõe o art. 8. ${ }^{\circ}$, n. ${ }^{\circ}$ 2, d) do Regulamento que cabe ao credor, no requerimento inicial, identificar, entre outros elementos, "um número que permita identificar o banco, como o IBAN ou BIC e / ou o nome e o endereço do banco no qual o devedor detém uma ou mais contas a arrestar" e, nos termos a alínea d), identificar "se disponível, o número da conta ou das contas a arrestar e, nesse caso, a indicação de que devem ser eventualmente arrestadas quaisquer outras contas detidas 
pelo devedor no mesmo banco". No entanto, a alínea f) vem desonerar o credor de tais conhecimentos, refletindo que "caso não possa ser prestada nenhuma das informações exigidas na alínea d), uma declaração de que foi apresentado um pedido de obtenção de informações sobre a conta ou contas nos termos do art. 14. "' (se tal pedido for possível) "e uma indicação das razões pelas quais o credor acredita que o devedor detém uma ou mais contas num banco de determinado Estado-Membro".

Ora, o art. 14. ${ }^{\circ}$ estabelece como se processará e quais as condições do pedido de acesso a informações sobre contas bancárias do devedor. Nesta circunstância, este pedido será apresentado ao tribunal competente para tramitar o processo atinente à obtenção da decisão de arresto com o próprio requerimento inicial de arresto - art. 14. ${ }^{\circ}$, n. ${ }^{\circ} 2$ do Regulamento.

No entanto, resulta da leitura do art. $14 .^{\circ}$, n. $.^{\circ} 1,1^{\circ}$ parágrafo que este acesso às informações apenas se poderá realizar quando o credor seja detentor de uma decisão judicial, transação judicial ou instrumento autêntico e que o mesmo já se configure título executivo. O Regulamento apenas prevê um regime de exceção: quando o credor, detendo um daqueles instrumentos, ainda não tenha adquirido carácter executório. Para o efeito, há que preencher, cumulativamente, as seguintes premissas: i) o crédito ser de valor avultado, tendo em conta as circunstâncias pertinentes; E ii) apresentar elementos de prova suficientes da urgência de tais informações sob pena de "deterioração substancial da situação financeira do credor" - art. 14. ${ }^{\circ}$, n. ${ }^{\circ}$ 1, 2. parágrafo do Regulamento.

$\mathrm{O}$ pedido de acesso às informações tem de ser fundamentado de modo evitar inquéritos prospetivos - art. $14 .^{\circ}$, n. $^{\circ} 2,2^{a}$ parte do Regulamento.

Verificamos, pois, que foi incluído um instrumento para consolidar a efetividade do arresto de contas bancárias, a fim de evitar que credores que desconhecessem o banco do devedor esmorecessem as suas pretensões em usar este mecanismo, mas pensado de modo a não sujeitar a esfera privada do devedor a incursões despropositadas de agentes que poderão, em última análise, nem sequer ser seus efetivos credores. Para o efeito, o legislador da União determinou que apenas aqueles que tenham um título executivo já sedimentado ou em fase de consolidação possam 
solicitar e aceder a tais informações e, mesmo assim, deverão sempre observar o dever de fundamentação do seu pedido.

Emanada a decisão de arresto, abrem-se as portas ao exercício do contraditório pelo devedor. Neste contexto, o Regulamento concede um conjunto de vias recursórias que servem para o devedor reagir à decisão de arresto ou à sua execução (arts. $33 .^{\circ}$ a $39 .^{\circ}$ do Regulamento).

Assim, ao devedor é aberta a possibilidade de solicitar a revisão da decisão de arresto ou a sua revogação, nos termos do art. $33 .^{\circ}$, n. ${ }^{\circ} 1$, devendo este seu pedido ser dirigido ao tribunal competente do Estado-Membro de origem.

Já o art. 34. ${ }^{\circ}$ estabelece as reações disponíveis perante a própria execução da decisão de arresto, onde é possível invocar:

- a limitação do arresto com base na impenhorabilidade de certos montantes que foram arrestados - art. $\left.34 .^{\circ},{ }^{\circ}{ }^{\circ} 1, a\right)$;

- a cessação do arresto com base 1) no facto de a conta estar fora do âmbito de aplicação do Regulamento OU 2) no facto de a execução do título executivo ter sido recusada no Estado-Membro de origem OU 3) a execução ter sido suspensa no Estado-Membro de origem - art. $34 .^{\circ}$, n. $^{\circ} 1, \mathrm{~b}$ );

- a execução do arresto ser manifestamente contrária à ordem pública do EstadoMembro de execução - art. $34 .^{\circ}$, n. $^{\circ} 2$.

$\mathrm{O}$ art. $35 .^{\circ}$, n. $^{\circ} 1$ prevê a possibilidade de recurso quer para o devedor, quer para o credor, nomeadamente para obter a alteração / revogação do arresto com base na modificação das circunstâncias que fundamentaram a decisão. $\mathrm{O}$ n. ${ }^{\circ} 2$ do mesmo art. estatui a faculdade de o tribunal do Estado-Membro de origem, oficiosamente, alterar ou revogar a sua decisão quando tome ciência que a conjuntura que fundamentou a sua decisão mudou, quando tal não seja contrário à legislação desse Estado-Membro.

Do mesmo modo, o art. 38. ${ }^{\circ}$ do Regulamento prevê que é lícito, ao devedor, requerer a libertação dos fundos arrestados mediante a prestação, ao tribunal de origem, de uma caução ou garantia suficiente nos termos da legislação nacional do seu Estado-Membro. Por sua vez, sempre que sejam arrestados valores superiores ao que foi peticionado no arresto, cabe ao credor - e não ao devedor - requerer 
a libertação dos fundos ${ }^{39}$ - art. 27..$^{\circ}$ do Regulamento. Tal instrumento promove necessariamente a boa conduta processual do credor e evita que o mesmo tente usar este mecanismo de forma irresponsável. Na realidade, deste art. resulta uma obrigação para a esfera jurídica do credor, com a qual ele se conforma aquando da apresentação do requerimento inicial e que, não sendo cumprida, pode gerar a emergência da sua responsabilidade perante o devedor.

Por último, cabe elencar a possibilidade de imputar, ao credor, a responsabilidade pelos prejuízos causados ao pretenso devedor. Afinal, dispõe o art. $13 .^{\circ}$, n. ${ }^{\circ} 1,1 .{ }^{a}$ parte que "o credor é responsável por todo e qualquer dano causado ao devedor pela decisão de arresto devido a uma falta do credor" (ênfase nosso), cabendo, em princípio, ao devedor o ónus da prova dessa "falta do credor" - art. 13. ${ }^{\circ}$, n. ${ }^{\circ} 1$ in fine. No entanto, o legislador da União introduz no n. ${ }^{\circ} 2$ um conjunto de presunções ilidíveis integrativas do conceito indeterminado "falta do credor". Ora, com estas presunções opera-se uma inversão do ónus da prova, cabendo ao credor uma prova na negativa. Assim, presume-se que a falta é do credor quando:

- a decisão de arresto é revogada pela falta de instauração da ação principal, salvo se tal falha se dever ao pagamento pelo devedor ou ao estabelecimento de qualquer outro compromisso entre eles;

- o credor não tiver requerido a liberação dos montantes arrestados em excesso;

- a concessão da decisão não era adequada ou apenas era adequada para um montante inferior, por não ter cumprido a sua obrigação de não mover processos paralelos, com o mesmo objeto e entre as mesmas partes, nos termos do art. $16 .^{\circ}$;

- a decisão é revogada / não executada por falha do credor no que diz respeito à notificação ou tradução de documentos.

Daqui se depreende que o credor deverá ter em mente as obrigações processuais que assume quando apresenta um pedido de arresto, sob pena de poder vir a ser responsabilizado perante o devedor.

\footnotetext{
${ }^{39}$ Se a decisão abranger várias contas no mesmo Estado-Membro ou em diferentes Estados-Membros ou se a decisão tiver sido proferida após a aplicação de uma ou mais decisões nacionais equivalentes contra o mesmo devedor com vista a garantir o mesmo crédito - art. $27 .{ }^{\circ}$, n. ${ }^{\circ} 1$, a) e b) do Regulamento.
} 
Muitas eram ainda as realidades que mereceriam a particular atenção. No entanto, são estes os elementos que saltam à vista na perspetiva de acomodação da tutela jurisdicional efetiva e que melhor patenteiam o esforço legislativo da União em patentear uma compatibilização harmoniosa entre o direito à ação do credor e os direitos de defesa do devedor.

\section{Notas conclusivas}

O Regulamento em análise configura-se como o primeiro instrumento europeu inteiramente vocacionado à criação de um mecanismo de execução forçada de carácter transfronteiriço ${ }^{40}$, ainda que de carácter provisório, já que se verificou que as soluções decorrentes do direito internacional privado não eram as mais eficazes. Por sua vez, e apesar de não colocar em questão o funcionamento da certificação como título executivo europeu, também se constatou que esta ficou aquém das expectativas que se geraram em seu redor.

Como acabamos de verificar, a União Europeia acabou por se dotar de um mecanismo provisório mas que permite ao credor chegar ao processo executivo - independentemente de nele ter de dar ciência ao Executado antes de qualquer diligência processual - com uma garantia patrimonial assegurada através do arresto das contas bancárias do devedor. A opção legislativa europeia acabou por se configurar mais ampla e mais consentânea com a realidade vivenciada porque, ao proclamar um procedimento cautelar especificado para efeitos de apreensão judicial de contas bancárias, deu ao credor um meio mais eficaz para assegurar os seus créditos na plenitude, em contexto transfronteiriço. Afinal, apesar das dificuldades ainda auscultadas ao nível das execuções com incidência transfronteiriça, este mecanismo permite ao credor assegurar o seu crédito enquanto corre uma ação declarativa ou mesmo antes de propor essa ação. Se o legislador europeu tivesse optado por um mecanismo de penhora transfronteiriça, este poderia ser pensado

${ }^{40}$ Em sentido confluente, cfr. Maria Cecília Paglietti, "Il Regolamento n. 655 del 2014 sull'ordinanza di”, 1301 e 1302. 
apenas para operar no âmbito de um processo executivo já iniciado, acabando por determinar que se postergasse no tempo a apreensão judicial de bens do devedor - o que, irremediavelmente concederia a tal devedor um hiato temporal mais alargado para dispersar o seu património.

Posto isto, a opção pela ausência de contraditório a priori determinou que o legislador da União se tivesse visto na contingência de contemplar um conjunto de mecanismos variados que visassem reestabelecer a igualdade das partes, sendo estes de natureza patrimonial, compensatória, processual e informativa ${ }^{41}$. Da nossa análise (que apelidamos de precoce, já que a entrada em vigor do instrumento ainda é recente), parece-nos que o legislador da União conseguiu manter um tendencial equilíbrio entre o direito à ação (inerente ao próprio escopo da decisão de arresto) e os direitos de defesa.

Nesta perspetiva, é nossa convicção (de uma leitura não empírica do Regulamento) que a posição processual do devedor não sai beliscada, ainda que o processo seja ex parte. Afinal, consideramos que, ao devedor foram conferidos direitos intrínsecos à sua própria condição, ou seja, inerentes à sua posição processual - como é o caso dos recursos jurisdicionais de que dispõe; mas também outros, de natureza extrínseca, que operam, em primeira linha e em caso de desproteção do devedor, na esfera jurídica do credor (como é o caso da prestação de garantia / caução e da possibilidade de emergência de uma responsabilidade imputável ao credor). Na nossa ótica, resultam ainda algumas "válvulas de segurança" com estatuto de tertium genus: são aquelas que, assegurando a igualdade de armas entre as partes, garantem um mínimo denominador comum, proclamando o princípio da segurança jurídica, só podendo ser acionadas em condições muito particulares. Neste campo intermédio referimo-nos, como não poderia deixar de ser, ao acesso às informações bancárias do devedor, que apenas poderá ser pedido se o credor tiver um título executivo já existente ou em potencial.

Do que ficou exposto, resulta perfeitamente claro que o caminho que

${ }^{41}$ Cfr. Maria Cecília Paglietti, "Il Regolamento n. 655 del 2014 sull'ordinanza di.”, 1305 e 1306. 
a União Europeia se encontra a desbravar passa por uma consolidação da integração judiciária, confiando que os tribunais nacionais, enquanto tribunais funcionalmente europeus, possam assegurar a operatividade de um processotipo desenhado, de início a fim, num ato normativo europeu. $O$ facto de o processo se encontrar assim contemplado num Regulamento, do qual apenas resultam devoluções pontuais para o ordenamento jurídico do Estado-Membro do foro (devidamente dadas a conhecer pelos Estados-Membros, à Comissão, e atempadamente publicitadas no Portal de Justiça Europeia) exponencia " $a$ previsibilidade de como o processo se desenrolarâ" 42 . E a nossa preocupação também é esta, numa perspetiva de igualdade de armas: que os credores e devedores possam saber, com maior segurança, como o processo decorre e se desenvolve. E parece que esta sensibilidade começa, paulatinamente, a ser absorvida.

Na realidade, como já temos vindo a defender ${ }^{43}$, cada vez se torna mais claro que o caminho passa pela proclamação de uma efetiva integração judiciária em matéria civil e comercial, já que apenas esta nomenclatura é suficientemente consentânea com o estádio evolutivo que se vivencia. O próprio instrumento que nos cativou a atenção já não pode ser explicado numa ótica intergovernamental para a qual o vocábulo "cooperação" ainda parece dirigir-nos. Do mesmo modo, recusam-se os esquemas ataviados a construções puramente internas que usam a expressão "direito processual civil europeu" ou "processo civil da União Europeia" 44 para explicar tais fenómenos.

O aprofundamento da integração judiciária surge como um resultado lógico que deriva da dinâmica da tutela jurisdicional efetiva aplicada a processos tipo, de carácter europeu, mas que tramitam perante os tribunais nacionais, como o de obtenção da

\footnotetext{
42 Para maiores desenvolvimentos, cfr. Joana Covelo de Abreu, "O impacto do Regulamento n. 2015/2421, de 16 de dezembro no funcionamento das ações de pequeno montante...”.

${ }^{43}$ Para maiores desenvolvimentos, cfr. Joana Rita de Sousa Covelo de Abreu, "Tribunais nacionais e tutela jurisdicional efetiva...".

${ }^{44}$ Cfr., a propósito, Paolo Biavati, "L'avenir du droit judiciaire privé d'origine européenne. De l'harmonisation des règles à l'harmonisation des effects", RTDeur - Revue trimestrielle de droit européen, 46, 3, (2010): 565; G. Tarzia, "L'ordine europeo del processo civile", Rivista de diritto processualle, 56, (2001): 902; e Luiz Gómez Amigo, El proceso monitório europeo (Navarra: Editorial Aranzadi, 2008), 29.
} 
decisão europeia de arresto. Afinal, sem comprometer o princípio fundamental da autonomia processual dos Estados-Membros, acaba por adensar a tutela jurisdicional efetiva pela capaz tensão reflexiva que extrai da acomodação entre o direito à ação e os direitos de defesa. 


\title{
O private enforcement em matéria de antitrust e o regime de clemência: uma nota sobre a articulação possível
}

\author{
Ana Margarida Pereira*
}

RESUMO: A Diretiva 2014/104/UE do Parlamento Europeu e do Conselho de 26 de novembro de 2014, relativa a certas regras que regem as ações de indemnização no âmbito do direito nacional por infração às disposições do direito da concorrência dos Estados-Membros e da União Europeia pretendia ser um instrumento fundamental no incremento das acções de indemnização por violação do Direito da Concorrência. No entanto, a Comissão Europeia, numa tomada de posição deveras atípica, optou por excluir da lista de documentos a fornecer pelas Autoridades da Concorrência Nacionais os documentos relativos ao regime de clemência. Esta tomada de posição afasta-se da orientação dada pelo Tribunal de Justiça nos Acórdãos Pleiderer e Donau, segundo a qual o acesso a documentos relativos ao regime de clemência não pode ser recusado sem uma prévia análise dos contornos de cada caso concreto. Este artigo visa, assim, apresentar os interesses em causa nesta matéria, bem como suscitar uma série de problemas que a Diretiva 2014/104/UE levanta.

PALAVRAS-CHAVE: direito da União Europeia - direito da concorrência- private enforcement - regime de clemência.

ABSTRACT: Directive 2014/104 / EU on certain rules governing actions for damages under national law for infringements of the competition law provisions of the Member States and of the European Union was intended to be a fundamental instrument in the increase of effective private enforcement actions under civil law. However, the European Commission, in a rather atypical move, decided to exclude the documents regarding the leniency regime from the list of documents to be provided by the National Competition Authorities on such actions. A different position was adopted by the Court of Justice in the Pleiderer and Donau judgments, according to which access to documents relating the leniency system can not be refused without first examining the contours of each individual case presented. The purpose of this article is to expose the interests in this area and to comment on a number of problems that Directive 2014/104 / EU raises.

KEYWORDS: European Union law - competition law - private enforcement - leniency.

${ }^{*}$ Mestre em Direito da União Europeia pela Universidade do Minho. 


\section{Nota prévia}

O presente artigo reproduz as inquietações partilhadas pela Autora com os participantes no workshop "Mercado interno, concorrência e regulação" organizado pelo Centro de Estudos em Direito da União Europeia (CEDU) da Universidade do Minho e não pretende ser um estudo exaustivo do antitrust private enforcement, nem do regime de clemência. Aquilo que nos propomos abordar é, unicamente, a forma como o legislador europeu encarou a necessária compatibilização entre a faculdade cedida a terceiros lesados por comportamentos anticoncorrenciais através de ações de indemnização e o regime da clemência. Procuraremos, assim, determinar de que forma o legislador europeu articulou o private enforcement com o public enforcement neste aspeto concreto e, por esta razão, começaremos por recordar a jurisprudência do TJUE relevante na matéria. A seleção deste tema prende-se com a atual importância que assume o private enforcement no contexto europeu, importância esta que foi reforçada com a adoção da Diretiva 2014/104 do Parlamento Europeu e do Conselho de 26 de novembro de 2014, relativa a certas regras que regem as ações de indemnização no âmbito do direito nacional por infração às disposições do direito da concorrência dos Estados-Membros e da União Europeia.

\section{2. $\mathrm{O}$ acórdão Pfleiderer $^{1}$}

O processo principal que está na base do acórdão Pfleiderer opunha a Pfeiderer AG à Autoridade da Concorrência Alemã - e o reenvio prejudicial tinha por objeto a interpretação do art. 11. ${ }^{\circ}$ e $12 .^{\circ}$ do Regulamento $1 / 2003^{2}$. A Pfeiderer solicitou à Autoridade da Concorrência Alemã o acesso completo aos autos de um processo relativo a um cartel da qual fazia parte uma empresa da qual era cliente. O objetivo

\footnotetext{
${ }^{1}$ Acórdão Pfleiderer, de 14 de junho de 2011, Processo C-360/09., EU:C:2011:389.

${ }^{2}$ Regulamento $1 / 2003$, de 16 de dezembro de 2002, relativo à execução das regras de concorrência estabelecidas nos atuais arts. $1010^{\circ}$ e $102 .^{\circ}$ do Tratado sobre o Funcionamento da União Europeia (TFUE).
} 
era preparar uma ação cível de indemnização e, para tal, foram solicitados todos os documentos do processo. Foi cedida a documentação pedida com exceção de documentos relativos a segredo de negócio, documentos internos, documentos abrangidos pelo regime de clemência, bem como documentos relativos a meios de prova confidenciais. Face à recusa de ceder os autos na totalidade, a Pfeiderer acorreu aos tribunais nacionais. Foi então solicitado ao Tribunal de Justiça da União Europeia (TJUE), em sede de reenvio prejudicial, que avaliasse se o acesso à informação solicitada poderia prejudicar a aplicação efetiva do direito da concorrência da União Europeia ou o sistema de cooperação e de intercâmbio de informação entre a Comissão e as autoridades dos Estados-Membros responsáveis em matéria de concorrência. Face a esta questão o TJUE começou por considerar que os programas de clemência são instrumentos preciosos para detetar e pôr cobro às violações das regras de concorrência e que a sua eficácia poderia ser afetada pela comunicação dos documentos relativos a um procedimento de clemência às pessoas que pretendam intentar uma ação de indemnização. Todavia, continuou o TJUE, qualquer pessoa tem o direito de reclamar reparação do prejuízo que the tenha sido causado por um comportamento violador da concorrência. Portanto, sempre que seja solicitado o acesso a documentos relativos a um programa de clemência apresentado por uma pessoa que procura obter uma indemnização, é necessário que as regras nacionais aplicáveis não sejam menos favoráveis do que as referentes às reclamações análogas de natureza interna (teste da equivalência) e não sejam estabelecidas de modo a tornar impossível ou excessivamente difícil a obtenção de tal reparação (teste da efetividade). O TJUE conclui no sentido de que existe uma necessidade de ponderar os interesses que justificam a comunicação das informações relativas a um procedido de clemência. Esta ponderação terá de ter uma base casuística, tendo o tribunal nacional de avaliar todos os elementos pertinentes do caso podendo, em momento posterior a esta análise, determinar se é ou não oportuna a cedência de tais informações. 


\section{O acórdão $D_{o n a u^{3}}$}

O processo principal que está na base do acórdão Donau opunha uma união de empresas (VDMT) à autoridade federal da concorrência austríaca (AFC) - e o reenvio prejudicial tinha por objeto a interpretação dos princípios da efetividade e da equivalência relativamente às normas austríacas em causa. A VDMT formulou um pedido à AFC tendente a aceder aos autos relativos ao processo intentado contra a Donau e outras empresas que as condenou ao pagamento de uma coima por terem participado num cartel contrário ao art. $101 .^{\circ}$ do TFUE. O objetivo da VDMT era examinar a natureza e o montante do prejuízo eventualmente sofrido pelos seus membros em razão das infrações cometidas pela Donau, assim como apreciar da oportunidade de propositura de uma ação de indemnização neste contexto. Sucede que tal acesso dependia, no sistema austríaco, do acordo e da autorização das partes envolvidas, sendo excluída ao juiz a possibilidade de ponderar o acesso face aos interesses em causa, tendo de o recusar quando não existisse acordo. Colocou-se a questão de saber se um quadro legislativo desta natureza seria compatível com o direito da União Europeia e, concretamente, com os princípios cuja interpretação era solicitada ao TJUE em sede de reenvio. O TJUE considerou que a competência para estabelecer regras relativamente ao direito de acesso das pessoas lesadas por um cartel aos documentos relativos ao último pertence aos Estados-Membros; não obstante, era necessário permitir às autoridades judiciais nacionais a ponderação dos interesses em causa que pudessem justificar o acesso à informação. Caso contrário, o exercício ao direito à reparação tornar-se-ia praticamente impossível. Assim, à semelhança do que já havia decidido no acórdão Pfeiderer, o TJUE determinou que aos tribunais nacionais seja concedida a faculdade de avaliar, caso a caso, da oportunidade de ceder documentos relativos a processos de clemência. Uma legislação que impeça tal avaliação é contrária ao princípio da efetividade e ao princípio da equivalência.

Esta breve referência ao acórdão Pfleiderer e ao acórdão Donau permite-nos inferir uma primeira conclusão: a de que no entendimento do TJUE, e ainda que

\footnotetext{
${ }^{3}$ Acórdão Donau, de 6 de junho de 2013, Processo C-536/11, EU:C:2013:366.
} 
se reconheça a importância de manter o regime de clemência atrativo às empresas, não se pode recusar, sem mais, o acesso a documentos relativos àquele regime. Isto não significa que deva existir um acesso livre a tais documentos; significa sim que o TJUE reconhece a importância de ser feita uma análise caso a caso quando tal acesso é solicitado. Afigura-se-nos claro que o TJUE procurou conciliar, da forma mais abrangente possível, o private enforcement (enquanto manifestação do direito à reparação dos danos que assiste a terceiro lesado e enquanto instrumento de proteção do direito da concorrência) e o regime da clemência (que se apresenta atualmente como um instrumento fundamental para as autoridades nacionais da concorrência e para a Comissão Europeia).

\section{A Diretiva $2014 / 104^{4}$}

A Diretiva 2014/104 tem por objetivo harmonizar aspetos relativos à compensação, além de eliminar dificuldades no acesso ao direito à reparação. A adoção desta diretiva traduziu-se num passo significativo no sentido de uma "maior coerência e segurança jurídica" ", atenta a referida necessidade de articular-se o acesso à indemnização com o regime da clemência.

Dos considerandos da diretiva decorre a ideia de que é fundamental assegurar que o terceiro lesado tenha acesso a meios de prova que lhe permitam intentar uma ação de reparação e que cumpre aos tribunais nacionais ordenar tal divulgação. Todavia, e no intuito de que esta cedência não comprometa a efetividade da aplicação das normas da concorrência pelas autoridades nacionais, o legislador europeu entendeu que a proteção deste direito à reparação não acarreta a necessária divulgação de todos os documentos relacionados com o processo em causa. Esta primeira ressalva salienta a importância dos programas de clemência enquanto instrumentos de luta contra

\footnotetext{
${ }^{4}$ Diretiva 2014/104, de 26 de novembro de 2014, relativa a certas regras que regem as ações de indemnização no âmbito do direito nacional por infração às disposições do direito da concorrência dos Estados-Membros e da União Europeia.

${ }^{5}$ Neste sentido cfr. Sólon Emanuel Salgado Moura, "Os acordos de colusão: o direito à informação nas acções de indemnização” (Master's diss., Universidade de Coimbra, 2014), 52.
} 
infrações ao direito da concorrência e procura transmitir a ideia de que é fundamental assegurar que este regime continue a mostrar-se atrativo para as empresas que dele beneficiam. A divulgação de documentos relativos a este programa implicaria expor os seus intervenientes - o que resultaria, inevitavelmente, numa diminuição do grau de cooperação das empresas.

É precisamente pelas razões que acabámos de enunciar que a diretiva determina que os documentos relativos a declarações de clemência ficam excluídos da lista de documentos a divulgar. $\mathrm{O}$ art. $6^{\circ}{ }^{\circ}$, n. ${ }^{\circ}$ 6, da diretiva determina, de forma expressa e inequívoca, que aos tribunais nacionais é vedado ordenar a divulgação de declarações de clemência ${ }^{6}$. O art. $6^{\circ}{ }^{\circ}$, n. ${ }^{\circ} 7$ permite, no entanto, que se solicite saber se determinada categoria de elementos de prova cabe no conceito de declaração de clemência previsto no art. 2. ${ }^{\circ}$, n. ${ }^{o} 16 .^{78}$ Contudo, mesmo neste aspeto o legislador europeu foi circunscrito, permitindo que o tribunal nacional possa contar, na sua avaliação, apenas com o apoio da Autoridade Nacional da Concorrência e com os autores dos elementos de prova.

Desta forma procurou-se impedir que o acesso a elementos de prova como as declarações de clemência tivesse impacto negativo na deteção e prevenção de práticas anticoncorrenciais, ou seja, procurou-se garantir segurança às empresas que decidam cooperar com as entidades nacionais da concorrência e com as instituições europeias.

\footnotetext{
6 "Os Estados-Membros asseguram que, para efeitos de ações de indemnização, os tribunais nacionais não possam em nenbum momento ordenar a uma parte ou a um terceiro a divulgação das seguintes categorias de informação:

a) As declarações de clemência".

${ }^{7}$ Segundo o art. $2^{\circ}$, n. ${ }^{\circ} 16$, da Diretiva 2014/104, uma declaração de clemência será “qualquer comunicaşão oral ou escrita apresentada voluntariamente por uma empresa ou uma pessoa singular, ou em seu nome, a uma autoridade da concorrência, ou um registo dessa comunicaşão, que descreve as informações de que essa empresa ou pessoa singular tem conhecimento sobre um cartel e o papel que a mesma nele desempenha, elaborada especificamente para apresentação à autoridade da concorrência a fim de obter dispensa ou redução da coima ao abrigo de um programa de clemência, excluindo as informacões preexistentes".

${ }^{8}$ Determina o art. 6. ${ }^{\circ}, \mathrm{n} .{ }^{\circ}$ 7, da Diretiva 2014/104 que "o demandante pode apresentar um pedido fundamentado de acesso do tribunal nacional aos elementos de prova referidos no $n .{ }^{\circ} 6$, alinea a) ou b), para o efeito exclusivo de assegurar que o conteúdo de tais elementos é conforme com as definições estabelecidas no art. 2.", pontos 16 e 18 . Nessa avaliação, os tribunais nacionais só podem pedir assistência à autoridade da concorrência competente. Os autores dos elementos de prova em causa também podem ser ouvidos. O tribunal nacional não pode em nenbuma circunstancia permitir o acesso de outras partes ou de terceiros a esses elementos de prova.".
} 


\section{Considerações conclusivas}

Os programas de clemência e as ações de indemnização são instrumentos fundamentais para fornecer uma resposta eficaz à prática de comportamentos anticoncorrenciais por parte dos agentes económicos?. A discussão relativa à proteção dos documentos de clemência tem estado no centro do debate sobre o direito à reparação de terceiros. Como vimos, e ainda que partilhem de um objetivo comum, a Diretiva 2014/104 proíbe a divulgação das declarações de clemência. Esta disposição parece encontrar a sua justificação no desejo, por parte das instâncias europeias, de proteger as empresas cooperantes da exposição inerente a uma ação de indemnização ${ }^{10}$.

É importante manter sempre em mente os interesses em causa nesta discussão. Se, por um lado, o fornecimento de informações sobre pedidos de clemência permitiria ao lesado provar mais facilmente os danos que surgiram em virtude deste comportamento, por outro lado, tal acesso poderia levar a que as empresas se eximissem de colaborar, pois ainda que o regime de clemência possa reduzir, ou mesmo eliminar, a coima a aplicar, nada poderia garantir que a ação de indemnização do terceiro lesado não iria culminar na condenação ao pagamento de uma quantia por parte das empresas cooperantes.

Da análise que levámos a cabo é possível concluir que este último interesse sobressaiu, já que a diretiva, contrariando o estabelecido na jurisprudência do TJUE, ditou que aos tribunais nacionais ficasse vedada a possibilidade de autorizar a divulgação de elementos de prova relacionados com as declarações de clemência. É precisamente este ponto que nos suscita mais questões, pois não nos resulta claro o porquê deste afastamento da posição assumida pelo TJUE. A nosso ver o mérito da

\footnotetext{
${ }^{9}$ Neste sentido cfr. Luiza Andrade Machado, "Programas de leniência e responsabilidade civil concorrencial: o conflito entre a preservação dos interesses da leniência e o direito à indemnização", Revista de defesa da concorrência 3,2 (novembro de 2015): 115.

${ }^{10}$ Para um maior aprofundamento sobre o tema cfr. Mariana Tavares, “A proteção dos documentos de leniência no âmbito de ações de indenização por violação das regras de concorrência na União Europeia", Revista de defesa da concorrência 1, 2 (novembro de 2013).
} 
solução apresentada pelo TJUE é inquestionável, já que apenas uma análise casuística permite ao julgador nacional determinar a pertinência das informações solicitadas para o ressarcimento dos danos causados a terceiro lesado por comportamentos anticoncorrenciais.

Na sua essência o private enforcement deveria garantir que os lesados obtenham uma compensação total pelos danos causados por comportamentos anticoncorrenciais. Ao consagrar esta proibição absoluta de divulgação do acesso às declarações de clemência a diretiva restringe este objetivo. É certo que o regime de clemência permite que, como contrapartida da cooperação com as autoridades nacionais da concorrência, seja concedida a empresas participantes de um cartel a redução, ou isenção, das coimas que de outra forma pagariam. É certo também que este sistema é fundamental na deteção e prevenção de cartéis e que é a existência deste regime que assegura que se consigam provas que de outra forma estariam fora do alcance das autoridades da concorrência. Dada a importância das provas facultadas no âmbito de um processo de clemência é natural que as instâncias europeias tenham procurado manter a atratividade deste regime. Todavia, também é certo que existem dúvidas doutrinárias relativamente à oportunidade e sentido da exclusão das declarações de clemência do elenco de documentos que podem ser divulgados no âmbito de um processo de indemnização ${ }^{11}$.

A diretiva que prometia ser um instrumento de harmonização e de sedimentação deste direito à reparação ficou, neste aspecto, aquém das expectativas. Poderá aceitarse uma restrição do direito à ação fundada na defesa do regime da clemência? Não podemos, ainda, fornecer uma resposta objetiva a esta questão. Não obstante, aquilo que parece claro é que a intenção de proteger e favorecer os terceiros lesados parece ter ficado por concretizar. A nosso ver, aquilo que se conseguiu foi aumentar o fosso entre o private enforcement e o public enforcement.

\footnotetext{
${ }^{11}$ De facto, é até questionável se esta exclusão não será contraproducente na medida em que poderá funcionar como um elemento desincentivador para aqueles que procuremm judicialmente, ser ressarcidos por comportamentos anti-concorrênciais . Neste sentido cfr. "Leniency and Damages", Paolo Buccirossi, Catarina Moura Pinto Marvão e Giancarlo Spagnolo, acesso em julho 1, 2016, http:/ / papers.ssrn.com/sol3/papers.cfm?abstract_id $=2566774$.
} 
Ao impedir o acesso às declarações de clemência numa ação de indemnização o legislador europeu acaba por consagrar uma limitação ao direito de reparação, sob o argumento de que estará em causa a manutenção da atratividade do regime de clemência. A nosso ver, esta solução não se afigura como a mais condizente com o espírito inerente à União Europeia e com os princípios que a fundaram. Mais sentido existira se o legislador europeu tivesse seguido a orientação propugnada pelo TJUE, ou seja, fazer depender este acesso de uma análise casuística, levada acabo pelos tribunais nacionais competentes.

Assim, acreditamos que a solução adotada pelo TJUE no acórdão Pfleiderer e no acórdão Donau se apresenta como a melhor solução na medida em que não estaríamos perante uma proibição completamente desligada dos contornos reais de cada caso. Poderíamos encontrar, naturalmente, situações de recusa de acesso, mas esta estaria fundamentada na natureza do processo em causa e não assente apenas na ideia de proteção de empresas cooperantes. A solução do TJUE permitiria um efetivo equilíbrio entre as duas figuras e seria, acima de tudo, uma solução mais concordante com o objetivo inicial da Comissão Europeia. 



\title{
A nova diretiva sobre proteção do segredo comercial: contributo para um sistema coordenado do mercado interno
}

\author{
Ana Filipa Afonseca* \\ RESUMO: A partir da novíssima diretiva sobre a proteção do segredo comercial na União Europeia, o presente texto \\ pretende partir para a sua análise, debatendo opcões do legislador europeu e tendo em conta a sua importância para o \\ desenvolvimento de um sistema coordenado no mercado interno \\ PALAVRAS-CHAVE: mercado interno - proteção do segredo comercial - coordenação - regulação. \\ ABSTRACT: Through the new directive about the protection of the know-how and business information (trade secrets) \\ in the European Union, the present text pretend analyze and debate the European lawmaker options without losing in \\ consideration the importance of that contribute to the development of an internal market coordinated system
}

KEYWORDS: internal market - know-how and business information protection - trade secrets-cordination regultation.

Mestranda em Direito da União Europeia na Escola de Direito da Universidade do Minho. Colaboradora de UNIO - The Official Blog: Thinking \& Debating Europe. 
A 8 de junho de 2016 surgiu a diretiva sobre os segredos comerciais, três anos após a proposta ter sido lançada pela Comissão Europeia. Apesar de várias vozes defenderem que a intervenção legislativa muito pouco de novo iria aditar às legislações nacionais, Jorge Novais Gonçalves, da Comissão Europeia, veio responder que, de facto, apesar de existir a figura da proteção do segredo comercial na maioria dos Estados-Membros (e não na totalidade, realçou), em alguns casos, as diferenças do regime influenciavam a tradução concreta dessa proteção, pelo que urgia a necessidade de estabelecer critérios comuns e transversais aos Estados Membros, que favorecessem a livre circulação e incentivassem o investimento privado ${ }^{1}$. Aliás, neste sentido, a própria Diretiva reconhece o chamado know-how como uma "moeda de economia do conbecimento" indispensável para a formação de um mercado interno complexo que mais do que construir uma economia mundialmente forte busca captar a inovação e o desenvolvimento da sociedade europeia.

Assim surgiria este texto. E se escreveu Karl Marx que " na análise das formas económicas nãopodem servirnem o microscópio nem reagentes quimicos. A faculdade de abstrair deve substituir ambas's, pois, é também dessa faculdade que partem estas linhas, através do seguinte exercício: partir da letra da Diretiva e deambular pelas suas entrelinhas, que mediarão, certamente, algum debate na ordem jurídica europeia com o aparecimento de casos concretos.

\section{A relação do know-how empresarial com a livre circulação e a concorrência leal.}

O Mercado interno concretizou-se. E o puzzle de Direitos de propriedade intelectual tem sido montado pela União Europeia. Até então, os Direitos de propriedade intelectual regulavam e repartiam a economia através de direitos de uso

\footnotetext{
${ }^{1}$ Conferencia que tivemos oportunidade de assistir a 30 de junho de 2016 na Universidade Católica do Porto, com o título "A proteção dos segredos comerciais e a nova directiva da União Europeia" também com a presença como orador do Professor Nuno Sousa e Silva.

${ }^{2}$ Diretiva (UE) 2016/943 do Parlamento Europeu e do Conselho de 8 de junho de 2016, Considerando 1.

${ }^{3}$ Karl Marx, O Capital (Lisboa: Editorial Avante, reimpressão de 1990), 129.
} 
exclusivo, pelo que assistíamos a momentos perigosos para o mercado interno: os Direitos de propriedade intelectual eram utilizados para restringir o Mercado interno, uma vez que o titular do direito exclusivo podia impedir a importação da mercadoria, criando um entrave ao princípio da livre circulação de mercadorias.

A "difícil" relação entre a livre circulação de mercadorias e os Direitos de propriedade intelectual resultam do art. 36. ${ }^{\circ}$ do TFUE, que permite que os Direitos de propriedade intelectual sejam uma exceção, conforme dispõe o art. 28. ${ }^{\circ}$. Contudo, a exceção à exceção ${ }^{4}$ revela-se de extrema importância para o instituto, uma vez que pró́be a restrição discriminatória do comércio entre os Estados Membros, justificada pela mesma Propriedade intelectual. Não tardou a surgir o acórdão Grunding $5^{5}$ a demandar uma urgente explicação do "intérprete máximo dos Tratados", sobre a convivência entre os Direitos de propriedade Intelectual e o princípio da livre circulação de mercadorias. Em género de fotografia polaróide do caso, o fabricante alemão Grundig garantiu à empresa Conten, um distribuidor exclusivo em França, proteção territorial absoluta através de uma cláusula de proibição de importações paralelas. O acórdão acabou por servir de lançamento aos Direitos de Propriedade intelectual, já que o Tribunal de Justiça decidiu que os Direitos de propriedade intelectual não podiam viver à margem do Direito da União, e criou a célebre (e não menos criticável) dicotomia ${ }^{6}$ : os Direitos de propriedade intelectual estariam quanto à sua existência imunes à aplicação das regras da União, contudo, o seu exercício ficaria sujeito a essas regras. No entanto, em 1971, com o acórdão Deutsche Grammophon-Metro o Tribunal consagraria o "principio do esgotamento", vetor incontornável dos Direitos de propriedade Intelectual. Em suma, enuncia o “princípio do esgotamento" que o titular do direito fixa as condições de comercialização da primeira venda, mas a partir do momento em que o produto é colocado no mercado, licitamente por si ou com o seu consentimento, não será permitida

\footnotetext{
${ }^{4}$ Luís Couto Gonçalves et al., "Propriedade Intelectual", in Direito da União Europeia: Elementos de Direito e Políticas da União, ed. Alessandra Silveira et al. (Coimbra: Almedina, 2016), 649.

${ }^{5}$ Acórdão Consten e Grundig, 13 de julho de 1966, Processo 56/64, EU:C:1966:41.

${ }^{6}$ Acórdão Consten e Grundig...., considerando 59 a 64.

${ }^{7}$ Acórdão Deutsche Grammophon-Metro, 8 de junho de 1971, Processo 78/70, EU:C:1971:59.
} 
nenhuma restrição à livre circulação do produto com invocação da proteção de propriedade intelectual ${ }^{8}$.

Em matéria de propriedade industrial, mais tarde, surgiria o acórdão Centrapharm/ Winthrop, em que o Tribunal de Justiça deixou claro que seria inaceitável se o uso exclusivo do direito de marca permitisse que o seu titular impedisse a livre circulação do produto depois de o ter colocado à venda?

Aos poucos chegávamos a um sistema complexo de normas e respetiva interpretação, reguladoras quer de Direitos de autor e direitos conexos, que protegem as criações intelectuais dos domínios literários e artísticos, quer da Propriedade industrial como protetora de "bens incorpóreos, mais diretamente ligados a interesses da atividade económica" agrupados, por sua vez, em duas espécies: "as criações industriais $e$ os sinais distintivos" ${ }^{10}$ As primeiras referem-se às patentes, modelos de utilidade, topografias de produtos semicondutores, origens vegetais, desenhos ou modelos, os segundos abrangem as marcas, os logótipos, as denominações de origem e indicações geográficas.

Assim, atualmente, proliferam diplomas legislativos sobre as marcas, patentes, desenhos ou modelos, denominações de origem, espécies vegetais, direitos de autor e direitos conexos, o direito sui generis das bases de dados... contudo, este crescimento de regras não podia ficar por aqui, sob pena de um desenvolvimento dúctil do mercado interno, e a União Europeia avançou, incrementando a liberdade de circulação e a concorrência leal com proteções "viz̧inhas" destes Direitos de propriedade intelectual, como é exemplo a Diretiva (UE) 2016/943 do Parlamento Europeu e do Conselho de 8 de junho de 2016 relativa à proteção de know-how e de informações comerciais confidenciais (segredos comerciais) contra a sua aquisição, utilização e divulgação ilegais, em análise.

\footnotetext{
${ }^{8}$ Pedro Sousa e Silva, Direito Comunitário e Propriedade Industrial: o principio do esgotamento dos direitos (Coimbra: Coimbra Editora, 1996).

${ }^{9}$ Acórdão Centrapharm/Winthrop, 31 de outubro de 1974, Processo 16/74, EU:C:1974:115.

${ }^{10}$ Luís Couto Gonçalves et al., "Propriedade Intelectual", 648.

${ }^{11}$ A expressão "viz̨inha" é utilizada no sentido em que a diretiva é próxima dos DPI mas não coincidente, claro está que em rigor, poderíamos considerá-la complementar ou sobreposta aos DPI, como defendem alguns autores.
} 
Desta forma, perspetivamos esta intervenção legislativa de proteção do segredo empresarial como uma sequência da lógica da integração económica, já que a liberalização do segredo comercial no território da União Europeia está intimamente ligada aos dois pilares fundamentais da construção do mercado interno, os princípios da livre circulação e a proibição da concorrência desleal.

Em primeiro lugar, e em retrospetiva, afirmamos que esta diretiva veio incrementar o desenvolvimento do Mercado interno, pertencendo a um amplo espectro de "sistemas de coordenação" do mercado único, já que até então as empresas, que cada vez mais se difundem pelo território da União Europeia, em virtude do princípio de livre circulação, não saberiam o que fazer no caso de revelação do seu segredo empresarial em território não nacional.

Por hipótese, se a receita da cerveja belga Duvel, guardada pelos monges trapistas, fosse adquirida, revelada e utilizada num local onde não existisse tão-pouco protecção do segredo empresarial, como poderia o produtor reagir? Apesar de existirem vários institutos de defesa, entre os quais, a concorrência leal, inclusivamente, conceito redimensionado pela União Europeia, ou até alguma protecção derivada dos Direitos de propriedade intelectual, a apropriação da receita secreta, per se, não estaria protegida por regras comuns aos Estados Membros, ficando essa protecção à mercê do direito nacional em causa, o que geraria incerteza e insegurança jurídica. O problema permaneceria inultrapassável e incoerente, já que a União Europeia possibilitaria o livre estabelecimento e a livre circulação de bens, mas não preveria nenhum instrumento jurídico europeu que regulasse a protecção dessa informação, que muitas vezes é nada mais do que "a alma do negócio"12.

Assim, em prol de uma livre circulação plena das empresas, esta Diretiva é um passo importante para um sistema coordenado de mercado livre. Mas não só, a protecção do segredo surge como um axioma da própria concorrência leal, a qual pressupõe uma plena liberdade empresarial, controlado apenas pelo jogo do mercado - ainda assim um jogo que se quer desenvolvido de forma leal - sendo esta Diretiva também a prova de um desenvolvimento de uma cultura concorrencial

\footnotetext{
${ }^{12}$ Apelo ao brocardo português que diz "o segredo é a alma do negócio".
} 
sofisticada na União Europeia, uma vez que ensina (ou pretende ensinar através da declaração da ilegalidade) que essa tal concorrência se desenvolva de forma justa e sem a apropriação de segredos comerciais.

Por isso concluímos, se a construção do mercado interno parece ser o ponto de não retorno da União Europeia, e se a integração económica é o trampolim para a integração política e social, parece-nos inevitável apontar a grande tensão da directiva: a proteção da identidade empresarial na União Europeia.

\section{A Diretiva 2016/943 do Parlamento Europeue do Conselho: uma análise substantiva à lupa}

\subsection{O que é o segredo comercial?}

"O segredo é o que somos"13, responde o escritor à pergunta "o que é um segredo?" Como densificar juridicamente este conceito? Era esta a primeira pergunta a ser respondida pela diretiva.

Assim, o art. 2. ${ }^{\circ}$, alínea 1, da Diretiva elenca um conjunto de definições, desde logo, harmoniza o conceito de segredo comercial: "Para efeitos da presente diretiva, entende-se por: 1) "Segredo comercial», as informações que cumprem cumulativamente os requisitos seguintes: a) serem secretas, no sentido de, na sua globalidade ou na configuração e ligação exactas dos seus elementos constitutivos, não serem geralmente conbecidas pelas pessoas dos círculos que lidam normalmente com o tipo de informações em questão, ou não serem facilmente acessiveis a essas pessoas; b) terem valor comercial pelo facto de serem secretas; c) terem sido objecto de diligências razoáveis, atendendo às circunstâncias, para serem mantidas secretas pela pessoa que exerce legalmente o seu controlo".

Em suma, a Diretiva caracteriza o segredo comercial como um segredo que surge dentro de um contexto empresarial que vem valorizar comercialmente algo, de tal forma, que não é acessível ao círculo de pessoas circunscritas ao espaço comercial e do qual se denota por parte do titular do segredo um esforço para manter esse segredo ${ }^{14}$.

\footnotetext{
${ }^{13}$ José Luís Peixoto, Dentro do Segredo, Uma viagem à Coreia do Norte (Lisboa: Quetzal, 2012).

${ }^{14}$ Nuno Sousa e Silva, Quando o segredo é a "alma do negócio" - definição de um conceito, (Porto:
} 
Esta definição não é particularmente inovadora, já que se trata de uma reprodução fiel da definição aposta no art. 39. ${ }^{\circ}$ do Acordo TRIPS. Em Portugal, o legislador que por sua vez plasmou esta definição do Acordo TRIPS no Código de Propriedade industrial, no art. 31 . $^{\circ}$, não terá grandes intervenções legislativas a fazer, pelo menos nesta definição não caberão mais ou menos casos do que até então.

Sublinhamos que a definição no acordo TRIPS nos parece juridicamente adequada ad inicio, contudo, não deixamos de sublinhar que a manutenção da exigência do segredo "ter valor comercial" coincidirá com o facto de o segredo "ter valor económico". É certo que se o segredo não tiver valor económico, à partida não interessará a sua aquisição ou divulgação, pois, pressupõe a diretiva que lhe falta o elemento "precioso" e "apetecivel" aos olhos de terceiro. Contudo, julgamos que o legislador europeu poderia ter ido mais além na definição, sendo original (isto é, no sentido de ter sido a origem de uma modificação legislativa do conceito) nesse ponto, já que em inúmeros casos esse valor comercial ou económico depende da aceitação do público do produto final, e não do valor efetivo e real do segredo, o legislador poderia ter suprido esta falta de proteção nesses casos, ao acrescentar a expressão "suscetivel de ter valor comercial".

Contudo, ficaremos atentos à interpretação do Tribunal de Justiça sobre a definição de segredo comercial, já que apesar da sua redação clara e inequívoca, o confronto com o real sempre trará nuances não espetáveis pelo legislador europeu.

\subsection{Do sinal verde ao sinal vermelho da diretiva}

$\mathrm{O}$ art. 3. ${ }^{\circ}$ oferece-nos uma lista de práticas legais, onde o legislador tendo em mente que "o segredo é segredo até alguém o descobrir" exibiu o sinal verde a um conjunto de práticas.

Os casos de coincidência criativa, a descoberta do segredo através de processos de desmontagem de um produto que seja de acesso público, também chamado de reverse engeneering no domínio do software, a descoberta do segredo através do normal exercício do trabalho ou outra prática comercial honesta são hipóteses isentas de

Dissertação de Mestrado, Universidade Católica Portuguesa, 2012). 
ilegalidade. No entanto, o disposto na Diretiva não oferece particular novidade, pese embora o conceito de "prática comercial honesta" possa ser de difícil prova nos casos concretos. Contudo, a racio legis inspira-se precisamente na prática comercial, uma vez que cada vez mais a inovação parte da observação do que já foi criado, demonstrando esta opção o carácter vincado da tutela da inovação como um objetivo a prosseguir pela Diretiva. Claro está que, em algumas indústrias, esta opção poderá ser particularmente problemática, já que o desenvolvimento da ciência quase nos permite o desmontar de um "sabor, cheiro e cor".

Mas, por isso mesmo, é importante refletir que tal artigo não se traduz numa desproteção total do objeto comercial, pois o artigo apresentado não obsta à possibilidade de proteção por via dos Direitos de Propriedade intelectual, através do Direitos de Autor e o direito de patente...encontramos aqui algumas possibilidades de complementaridade e comunicabilidade dos institutos. Por exemplo, a Diretiva 2009/2, relativa à proteção jurídica dos programas de computador, prevê a obrigatoriedade da autorização do Autor quando "a) A reprodução permanente ou transitória de um programa de computador, seja por que meio for, e independentemente da forma de que se revestir, no todo ou em parte. Se operações como o carregamento, visualização, execução, transmissão ou armaz̧enamento de um programa de computador carecerem dessa reprodução, essas operações devem ser submetidas a autorização do titular do direito;" ou quando “b) A tradução, adaptação, ajustamentos on outras modificações do programa e a reprodução dos respetivos resultados" 15 , pelo que, ainda que o segredo seja licitamente descoberto, não poderá ser usado para copiar a invenção.

$\mathrm{O}$ art. $3 .^{\circ}$, n. $^{\circ}$, por sua vez, constitui o epicentro da diretiva já que elenca a lista

\footnotetext{
${ }^{15}$ Art. $4 .^{\circ}$, n. ${ }^{\circ} 1$ da Directiva 2009/2, relativa à protecção jurídica dos programas de computador com a seguinte redacção "Sem prejuizo do disposto nos arts. $5 .^{\circ}$ e $6{ }^{\circ}$, os direitos exclusivos do titular, na acep̧̧ão do art. 2." devem incluir o direito de efectuar ou autorizar: a) A reprodução permanente ou transitória de um programa de computador, seja por que meio for, e independentemente da forma de que se revestir, no todo ou em parte. Se operaçoes como o carregamento, visualização, execução, transmissão ou armazenamento de um programa de computador carecerem dessa reprodução, essas operações devem ser submetidas a autoriz̧ação do titular do direito; b) A tradução, adaptação, ajustamentos ou outras modificações do programa e a reprodução dos respectivos resultados, sem prejuíro dos direitos de autor da pessoa que altere o programa; c) Qualquer forma de distribuição ao público, incluindo a locação, do original ou de cópias de um programa de computador. 2. A primeira comercialização na Comunidade de uma cópia de um programa efectuada pelo titular dos direitos ou realizada com o seu consentimento extinguirá o direito de distribuição na Comunidade dessa mesma cópia, com excepção do direito de controlar a locação ulterior do programa ou de uma sua cópia".
} 
de práticas ilegais: portanto, "(2) é ilegal a aquisição de um segredo comercial adquirido através de a) acesso, apropriação, ou cópia não autorizados de documentos, objetos, materiais, substancias ou ficheiros eletrónicos, legalmente sobre o controlo do titular comercial, que contenham o segredo comercial ou a partir dos quais seja deduzivel o segredo comercial ou b) outras condutas que nas circunstancias especificas sejam consideradas desonestas, é ilegal ainda, (3) a utilização ou divulgação um segredo a) adquirido ilegalmente, b) que viole um acordo de confidencialidade ou qualquer outro dever de não divulgação, c) que viole um dever contratual ou qualquer outro dever de limitação da utilização do segredo."

Apesar de tecermos vários elogios à opção legislativa, por conferir um amplo raio de proteção do segredo das empresas, a diretiva parece indicar que não só a aquisição dolosa desse segredo é ilegal. Não fazendo menção ou tão só distinguindo o dolo e a negligência na aquisição deduz-se que os dois devem ter a mesma consequência, isto é, será ilegal o comportamento descrito em (2) a) independentemente do animus, ou seja, ainda que, negligentemente um funcionário da empresa aceda ao segredo comercial, sem qualquer vontade ou intenção de se apropriar dele essa conduta é ilegal.

Desta forma, realçamos que já na alínea (2) b) a letra da lei indica precisamente esse requisito do dolo, camuflado através característica de desonestidade na prática, pelo que julgamos que não restará muita margem interpretativa do preceito legal anterior, uma vez que a opção legislativa revela a intenção de apartar as situações, punindo também a prática negligente.

Neste ponto, a diferença em relação à ordem jurídica portuguesa irá trazer alterações legislativas, contudo, por exemplo, a ordem jurídica espanhola já previa a punibilidade desta "prática negligente". Considerar se esta opção é melhor ou pior da que previa o regime português, mais uma vez, a prática o revelará, contudo não podemos deixar de levantar a dúvida sobre a tensão da certeza e da justiça, onde o legislador europeu premiou uma regra mais certa, mas talvez menos justa.

A grande novidade da diretiva reside no facto de ser considerado também ilegal a aquisição, divulgação e a utilização de um segredo que deriva já de uma aquisição, divulgação e utilização ilegal, numa espécie de ilegalidade dominó, já que a primeira 
aquisição ilegal mina a aquisição, divulgação e utilização seguintes, por um terceiro, o que não estará isento de criticas se pensarmos na figura do terceiro de boa fé, que, segundo o art. $3 .^{\circ}$, n. ${ }^{\circ}$, culminará também na sua responsabilidade.

$\mathrm{O}$ art. 5. ${ }^{\circ}$ surge como uma válvula de escape do regime, isto porque tutela as exceções às condutas proibidas, as exceções visam garantir essencialmente Direitos Fundamentais, quer quando se trata de um direito de liberdade de expressão e de informação, quando o interesse público se sobrepõe dado que o segredo esconde condutas ilegais e, ainda, quando o segredo é revelado por trabalhadores no exercício das funções representativas dos representantes do segredo, e, por fim, o segredo poderá ser divulgado com a motivação da proteção de um interesse legítimo reconhecido pela União ou lei nacional. Apesar de a norma estar recheada de conceitos indeterminados e de difícil delimitação já que os limites imanentes dos direitos que ela tutela são de difícil circunscrição, não podemos deixar de atender à contextualização da norma, provavelmente motivada por casos como o escândalo da Volkswagen. A empresa alemã terá falsificado um total de 11 milhões de veículos em todo o mundo para que os motores parecessem menos poluentes do que eram na realidade, o segredo foi divulgado por um dos funcionários da empresa. Neste caso, a conduta do funcionário não será punível, já que está em causa um interesse público - a proteção do meio ambiente - bem como um interesse legítimo protegido pela lei da União, que nestes casos impõe limites à emissão de dióxido de carbono. Contudo, se este caso nos parece uma ilustração simples e facilmente percetível da intenção legislativa, a tensão em relação a outros direitos fundamentais poderá ser mais difícil de concretizar, pelo que nos restará esperar por alguma delimitação dos direitos em causa, feita pelo Tribunal de Justiça.

\section{O que mudará?}

\subsection{Regras verdadeiramente processuais?}

O capítulo seguinte da diretiva, sob a epígrafe "Medidas, procedimento e vias de reparação", introduz regras de caris processual, apesar do Direito da União Europeia 
se reger pelo princípio geral da autonomia processual dos Estados Membros. Assim, a diretiva parece alinhavar um "caminho processual a seguir", contudo não nos coibimos de afirmar que alguma doutrina, à qual se deve prestar atenção e que talvez melhor se contextualize em casos como este capitulo III, defendem que a norma processual é apimentada de alguma substancialidade, pelo que esconde por vezes verdadeiras regras substantivas, será esse o caso?

Atentemos a alguns exemplos.

Em primeiro lugar, no art. 7. $^{\circ}$, n. ${ }^{\circ} 2,2^{a}$ parte, a diretiva prevê a possibilidade da condenação pela prática ilícita seguir em processo separado em relação ao pedido de indemnização sendo que na ordem jurídica portuguesa, por exemplo, prevê a regra de cumulação de pedidos no art. 555. ${ }^{\circ}$ do Código de Processo Civil sempre que "não se verifiquem circunstâncias que impeçam a coligação", contudo, não será este o primeiro caso de excepção a integrar as normas de processo civil português.

Por outro lado, a diretiva prevê um prazo de prescrição não superior a seis $\operatorname{anos}^{16}$, o que poderá ser particularmente conflituante com as regras estabelecidas nas ordens jurídicas nacionais, quer porque já tinham previsto esse prazo e ele seja maior, quer porque pode gerar uma regra especial em relação aos prazos de prescrição gerais, contudo essa mudança dependerá da opção de cada Estado Membro.

Por fim, e talvez mais interessante do nosso ponto de vista, o art. 9. ${ }^{\circ}$, n. ${ }^{\circ}$ 2, b) da diretiva prevê a possibilidade de, no decurso das ações judiciais, ser possível limitar o acesso a audiências judiciais, contrariamente às regras processuais da maioria dos Estados Membros que são orientadas por um princípio de publicidade, tal como escreve o Código Processual Civil português "o processo civil é público"17.

A regra prevista pela diretiva - e uma vez que o código processual civil também prevê a possibilidade de existirem restrições à regra - parecem-nos juridicamente compreensível. Por questões de praticabilidade, as empresas dificilmente proporiam ações sobre a revelação do seu segredo comercial para que estes viessem a ser divulgadas e discutidos num processo em Tribunal. Seria ilógico que a defesa da divulgação do

\footnotetext{
${ }^{16}$ Art. 8. ${ }^{\circ}$, n. ${ }^{\circ} 2$.

${ }^{17}$ Art. 163. ${ }^{\circ}$ do Código de Processo Civil português.
} 
segredo tivesse que passar, precisamente, pela sua divulgação. Contudo, esta opção processual poderá não fazer sentido na forma como processo está orientado nas ordens jurídicas nacionais, podendo, no limite, a intenção da diretiva vir a cair por terra, de tal forma, seja de difícil a adaptação ou haja uma certa resistência (ou velha teimosia!) na aplicação dessa regra nos Tribunais nacionais. No entanto, entre nós, julgamos que esta mudança deverá ser um desafio e, mais do que isso, são mudanças essenciais na construção do mercado integrado.

Por fim, o art. 12. ${ }^{\circ}$ estabelece um conjunto de medidas inibitórias e corretivas, entre as quais a cessação da utilização e proibição da divulgação, a proibição de produzir, oferecer, colocar no mercado, a adopção de medidas corretivas e, a destruição "da totalidade ou da parte de um documento, objeto, material, substancia ou ficheiro eletrónico que contenha ou constitua o segredo comercial, ou se for caso disso, a entrega da totalidade (...) desses objetos ao requerente", o que significa que no caso da criação de um novo objeto (portanto, um objecto inovador, suponhamos) que tenha por base um segredo ilícito, ou que pressuponha o conhecimento desse segredo adquirido ou revelado ilicitamente, deverá ser destruído. Assim, cumpre-nos afirmar que a inovação terá limites e esse limite será a manutenção de um mercado construído sob a base da concorrência leal. Depressa concluímos que, neste braço de ferro com a inovação, a concorrência leal vencerá.

\section{$2.2 O$ caso português: no segredo dos deuses}

$\mathrm{Na}$ União Europeia, apesar da maior parte dos regimes prever esta proteção como nos revela o relatório da Comissão Europeia, a sua genética era bastante confusa. Basta pensarmos na ordem jurídica portuguesa, em que existem vários meios de proteção de um segredo, mas nenhum constitui "o meio" de proteção ideal.

Em Portugal, o lesado poderá sempre invocar o enriquecimento sem causa, o direito dos contratos, os direitos de propriedade intelectual e mesmo a figura da

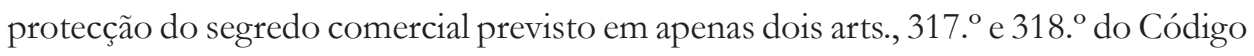
de Propriedade Industrial. No entanto, estes dois artigos pareciam ficar aquém das 
expetativas, uma vez que esta proteção se baseava, essencialmente, na proteção do segredo por apelo à tutela da concorrência desleal. A transposição deverá ser feita até 9 de junho de 2018, pelo que veremos como irá o legislador português transpor a diretiva, mais ambiciosa do que a tutela aposta nos simples arts. mencionados. Quanto a nós, julgamos que talvez fosse esta a oportunidade de rever ou reformular o Código de Propriedade Industrial de 2003, já que muitas regras têm sido trazidas nessa matéria pela União Europeia ${ }^{18}$.

\section{Considerações finais}

A Diretiva que analisamos é de harmonização mínima, isto é, propõe standards minimus. Mas a sua existência não deixa de ser muito importante no paradigma atual, em primeiro lugar porque o segredo empresarial é a maior riqueza das empresas, logo, não faria muito sentido esta disparidade de proteções no espaço da União Europeia e de um mercado consolidado, mas julgamos nós que, simbolicamente, podemos entender que esta Diretiva parte de uma importante constatação da União: a economia por si só não gera inovação, a inovação é gerada pela estimulação.

\footnotetext{
${ }^{18}$ Defendeu tal solução o Professor Nuno Sousa e Silva, na conferência já referida, que tivemos oportunidade de assistir a 30 de junho de 2016 na Universidade Católica do Porto, com o título "A protecção dos segredos comerciais e a nova Directiva da União Europeia”.
} 



\title{
O insustentável peso democrático do populismo: deambulações em torno da União Europeia, de olhos postos em Donald Trump
}

\author{
Pedro Madeira Froufe*
}

RESUMO: O populismo tem-se manifestado frequentemente na politica europeia e norte-americana. O populismo anda associado a uma defesa do nacionalismo e do isolacionismo que não só vai ao arrepio das liberdades (nomeadamente económica e de circulação), adotando políticas protecionistas, como também põe em causa a democracia, numa perspetiva material, afetando direitos fundamentais, nomeadamente de certas minorias. Recusa a integração europeia e, por paradoxal que pareça, é um fenómeno tendencialmente anti-democrático, gerado nas democracias e pelas democracias. Tem a sua origem seguramente numa pluralidade de causas que, em dado tempo e lugar, se encontram. Muitas delas (de caráter sociológico) surgirão por reação a uma certa cultura relativista, sem referências (niilista) e egocêntrica que, à falta de causas e de valores de referência, adere à imagem do anti-heroi, do politico genuíno. Trump desempenhou, também, esse papel, no universo norte-americano. O futuro e a reação da União Europeia deverão passar pelo aprofundamento da integração, ainda que tal possa ser feito a várias velocidades.

Palavras-chave: democracia - populismo - crise de identidade europeia - futuro da União Europeia.

ABSTR ACT: Populism is manifesting frequently itself in American and European politics. Populism is associated with the defence of nationalism and isolationism, it negates liberties (specifically economic liberties and freedom of movement), due to the adoption of protectionist policies, furthermore it endangers democracy, in a material perspective by threatening fundamental rights, namely of certain minorities. It refuses European integration and, even if it seems paradoxical, is a phenomenon with anti-democratic tendencies generated in democracies and by democracies. It traces its origin to numerous causes found in a certain time at a certain place. Many of them (sociological causes) appear to be a reaction to a certain relativistic culture, without references (nibilistic) and egocentric that, orphan of appropriate causes

* Diretor do Departamento de Ciências Jurídicas Públicas - Escola de Direito da Universidade do Minho. Membro Doutorado do Centro de Estudos em Direito da União Europeia (CEDU) da Universidade do Minho. 
and values, adheres in lieu to the figure of the anti-hero, to the figure of the genuine politician. Trump played that role in the American universe. The future and the reaction of the European Union shall consist in the deepening of its integration, even if its achieved at different speeds.

Keywords: democracy - populism - European identity crisis - future of the European Union.

Bret Easton Ellis é um escritor norte-americano representativo da denominada “Geração X”. Ellis é o autor de romances que, no final do século XX, marcaram a literatura e fascinaram (chocando) a sociedade norte americana, como, por exemplo, "Menos que zero" (1985) e o "Psicopata Americano" (1991). Bret Easton Ellis autoconsiderase "moralista", pese embora ser muito frequentemente qualificado como niilista. É interessante o método deste autoproclamado escritor moralista: ele consegue criar enredos e personagens tão "menos que zero", tão espantosamente indiferentes a qualquer tipo de referência valorativa-moral, tão relativistas e, por conseguinte, impressivamente inumanos que envolve o leitor, de facto e ilustrativamente, num mundo absolutamente amoral. Gente vã, reconhecendo a sua própria vacuidade mas, por egoísmo e prazer, indiferença ou fraqueza, escolhendo-a e cultivando-a, tornando-a quase naturalmente humana, inevitável. O bem e o mal são, no universo criado por Ellis, relativos - como, de resto, tudo na vida e a própria vida. Os seus enredos descrevem cidades e locais distópicos do mundo e do imaginário norteamericano, como certos meios sociais de Nova Iorque (yuppies dos anos 1980-1990) e de Los Angeles.

Em 1989 apareceu no mundo televisivo Homer Jay Simpson. Ele e a sua família, os Simpsons, rapidamente se instituíram como a família mais conhecida do universo televisivo norte-americano. As suas aventuras e desventuras quotidianas, as suas inquietações, habitualmente básicas e prosaicas, a sua linguagem e as suas aspirações, satirizam aspetos da cultura e da sociedade norte-americana e expõe-nos alguns lados menos agradáveis, mas reais e recorrentes, da condição humana. Patrick Bateman (o psicopata americano) e Homer Simpson têm muito em comum, desde logo, a enorme adesão e popularidade que granjearam nos Estados Unidos e um pouco por todo o mundo. E a cultura e o imaginário norte-americano foram aderindo de forma 
entusiasmada, mas também fácil e recorrentemente, a vários tipos de personagem literárias e televisivas que, tal como Patrick Bateman e Homer Simpson, não se interessam por grande coisa para além de si próprios. Personagens que nos expõem desassombradamente as suas fraquezas. São genuinamente anti-heróis; anti-heróis assumidos e descomplexados, mostrando-se como tal. Personagens que nos são familiares, que reconhecemos nos outros e, quiçá, também em nós próprios. Têm, por vezes, assomos de grandeza e de solidariedade, também percorrem, a espaços, caminhos que os aproximam de padrões de vida e de sentimentos que humanamente valorizamos. Mas não é por isso que se tornaram populares. Não são personagens e tipos sociais normais, antes têm por função evidenciar (satirizando) e sublinhar aquilo que consideramos mau, porém, de um modo sincero, genuíno. Talvez resida aí a respetiva atratividade. Poderíamos continuar a desfiar outras criações do imaginário literário, televisivo e cinematográfico norte-americano que fascinaram, primeiramente, a América, mas também e em certa medida, todo o mundo e a Europa (fruto da globalização e do enorme poder de divulgação que a cultura norteamericana tem hoje em dia). Ainda recentemente a série televisiva House of Cards e o casal Underwood (com uma vaga e relativa similitude com o casal Clinton), com a sua desmesurada ambição de poder e total relativismo moral e valorativo, encantou americanos e europeus.

Seria interessante, se tal fosse possível, ouvir a reação de Rousseau e confrontá-lo com o seu homem naturalmente bom, depois de ler ou de visualizar as peripécias dos Simpsons e de Bateman, por exemplo. E, sobretudo, depois de observado o grande fascínio e simpatia que geraram entre grande parte da população (nomeadamente, norte-americana, mas também europeia).

Situando-nos, agora, nos tempos que correm, o mundo - e a Europa, em particular - observa, atenta e desconfortavelmente, os primeiros dias da nova administração norte-americana. Depois de confrontado com a insólita e impossível eleição democrática de Trump - por muito que se estranhe, Trump foi efetivamente eleito democraticamente! - é tempo de atentar nas primeiras declarações e atos do novo Presidente em funções. 
Duas notas soltas e prévias, neste ponto: realmente, esquecemo-nos sistematicamente que o impossível só o é até acontecer e Trump, enquanto 45. Presidente norte-americano, segue o mesmo estilo e metodologia da sua campanha ou seja, tudo o que já começou a fazer é excessivo, publicamente estridente, insólito e (aparentemente) impulsivo. É genuíno, espontâneo; poderá ser mau, poderá ser muito perigoso, mas é genuíno! Um modo de fazer política norteado por uma proclamada adesão ao senso comum (ainda que distorcido), sem elaboração da razão. Um modo de governar transparente, no sentido em que não será necessário pensar para o compreender; ele percebe-se agindo e deixando-se observar. Um Presidente popular porque, aparentemente, tão claro, como inquietantemente linear.

Ora, a eleição de Donald Trump, após uma campanha ostensivamente agressiva e com uma linguagem, estilo e (poucas) mensagens persistentemente diretas e redutoras, desafiantes de alguns cânones ou limites de contenção habitualmente seguidos em campanha e na retórica política e eleitoral, ao invés do que uma maioria dominante de analistas, comentadores e outros atores políticos (inclusivamente, a generalidade da imprensa) considerava, não culminou numa derrota mais ou menos impressiva, numa rejeição popular imediata ou num descrédito e num ponto terminal de um percurso político (numa espécie de nado-morto político que, para memória futura, ficaria recordado como um episódio extremista e/ou simultaneamente caricato). Não, ao contrário e perante o espanto e a aflição de muitos, Donald Trump ganhou mesmo as eleições. E desfizeram-se algumas construções e "regras" que têm dominado o mainstream da ação política norte-americana. Por exemplo e ainda que não exaustivamente: é frequente ouvir-se dizer que, em termos políticos, ninguém sai incólume de acusações de sexismo (ainda que o conceito seja muitas vezes utilizado de um modo bastante plástico e suscetível de atrair manipulações); ora, Trump, durante a campanha, foi qualificado de sexista boçal e, avaliando o resultado final da eleição (ou seja, a sua vitória), isso não terá incomodado grandemente a maioria dos seus eleitores e eleitoras. Esses ataques deram-lhe inclusivamente o ensejo para contra-atacar a sua oponente. 
Generalizadamente, Trump foi (e é) considerado populista. A discussão e mesmo a reflexão em torno do que é o populismo e o seu impacto na decisão política - e, por conseguinte, no estado da democracia - voltou a estar (agora com premência) na ordem do dia.

Para a integração europeia, para a União assente na lógica e nos valores de uma "União de Direito", o ano de 2016 e este princípio de 2017 foram traumatizantes. Precisamente porque confrontamo-nos com a consequência política do populismo. O "Brexit" e a sua anatomia permitem-nos - penso eu que com propriedade chegar a essa conclusão. Para além disso, avizinham-se as eleições em França e uma candidata forte (avaliando as sondagens), tem pautado a sua ação e a sua narrativa política, nos últimos anos, precisamente por uma linha claramente populista (para além de assumidamente anti-imigração e intolerante com grupos étnicos e culturais diversos e minoritários). Marine Le Pen anunciou já, como resposta a todos os males que atormentam os franceses, a saída da União ("Francexil"), num processo de desresponsabilização muito facilmente utilizado por certos interesses e políticos internos, nacionais e que conta sempre com o pseudo-argumento fácil e precipitado de que a Europa - essa entidade colocada longinquamente para além de nós e dos nossos Estados e governos nacionais - é a causa de todos os nossos erros e infelicidades. Podemos dizer que, atualmente, a Europa e o processo de integração confrontamse com populismos internos (bem visíveis na campanha em curso em França, para não falar de outros fenómenos, epifenómenos e atores políticos que passam pela Hungria, pela Polónia, pela Áustria, pela Dinamarca, pela Itália e até mesmo por Espanha).

Além disso, na frente externa, a nova administração de Trump, com o seu lema "a América primeiro" e as suas alianças e/ou ligações a movimentos nacionalistas e anti-integração como o UKIP de Nigel Farage em Inglaterra, acaba por colocar em risco alguns pressupostos saídos indiretamente de Bretton Woods e da (nova) ordem internacional e com os quais se construiu e solidificou a posição internacional da União Europeia, nomeadamente, sob o ponto de vista geoestratégico e no âmbito comercial. Internamente - note-se, ainda - os movimentos e fenómenos de cariz 
nacionalista e populista referidos que proliferaram e se reforçaram cada vez mais no pós-2008, pelo seu lado, sentem-se, também, com um ânimo reforçado pela eleição de Donald Trump. Em síntese, vivemos, em termos de integração europeia, com uma pressão populista que se alia frequentemente a uma pulsão nacionalista. Sendo certo que tais populismos e nacionalismos, portadores (ou, pelo menos, indiciadores) de uma cosmovisão imediatista e profundamente anti-democrática sob o ponto de vista material, ganharam força e chegaram ao poder, precisamente, através dos meios e do exercício da democracia formal. São fenómenos potencialmente ameaçadores da democracia, gerados em democracia e através do exercício da democracia e utilizando direitos fundamentais que (também) a definem, como, por exemplo, a liberdade de associação e de expressão.

Em resumo, a estrutura constitucional democrática que é uma marca existencial da Europa integrada, gerou e desenvolveu pressões internas populistas e nacionalistas (com tudo o que de antidemocrático tais fenómenos têm), de um modo geral, manifestamente desintegradores - tendo tais pressões reforçado o respetivo alento, com o exemplo vindo dos Estados Unidos.

Duas grandes questões podem ser, na nossa perspetiva, suscitadas interligadamente: quais as causas para este estado de coisas e como perspetivar o futuro da União Europeia?

$\mathrm{Na}$ realidade, identificando-se as causas, os caminhos a trilhar a curto prazo pela integração europeia terão necessariamente que refletir a tentativa de ultrapassagem de tais causas.

Começando pelas causas, já muito se escreveu e disse sobre o que motiva esta disfunção entre, no fundo, o exercício da democracia e os resultados de risco democrático que esse mesmo exercício, por vezes, impressivamente, gera. O facto de serem muitas e variadas as causas apontadas, significa que, provavelmente, nenhuma delas pode ser identificada como sendo a causa determinante. O mais certo é existir uma interação, quer de fatores circunstanciais, quer estruturais e perenes, justificativos dessas erupções de risco para a democracia e, portanto, para a integração europeia. Até mesmo porque, como referimos, uma grande parte de tais fenómenos políticos 
têm como objetivo imediato apagar a História e acabar com a União. E isto, sob a bandeira de um ilusório nacionalismo primário e atávico (causa dos males - leia-se, guerras - da Europa do século XX), impossível, de resto, em tempo de globalização.

Damos por assente que as bolsas de pobreza, acentuadas pela crise financeira iniciada nos Estados-Unidos em 2008, geram manifestamente um descontentamento crescente relativamente aos poderes instituídos e vigentes, desde logo, na justa medida em que estes se revelam incapazes de criar respostas satisfatórias para as populações que integram tais bolsas. Em certas comunidades e, em especial, entre os mais jovens e os mais velhos, essas bolsas são cada vez maiores. A pobreza e a desigualdade, o aparecimento de novos desfavorecidos em resultado do processo de globalização excessivamente tecnocrática e imbuída de uma lógica capitalista a outrance (oitocentista) são fatores de aniquilação da esperança e, portanto, catalisadores de uma reação angustiada e impulsiva (naturalmente impulsiva) contra o estado de coisas e, portanto, contra a ordem e os poderes instituídos. A Europa não pode continuar a ser terreno fértil para o crescimento de tais fatores - ainda que operativamente e de facto, não tenha competências e atribuições para se substituir aos governos nacionais no que a este particular diz respeito. Note-se, esse mal-estar sócio-económico foi, também e seguramente, uma das causas justificativas do "fenómeno Trump". Também nos Estados-Unidos existem comunidades dilaceradas pelos fenómenos da "nova pobreza", nomeadamente, em cidades que viram as suas indústrias deslocalizarem-se para o exterior, em busca de maior rentabilidade, provocando desemprego interno.

Também consideramos - sem, por agora, a debatermos - a questão do aparente e alegado "défice democrático” da União Europeia. Entendemos que há um (inevitável?) afastamento entre a perceção comum do que é a ação da União (e de como funciona a integração) e o cidadão. Não é assunto para se encaixar nos poucos minutos ou segundos que a imprensa disponibiliza sobre as questões europeias; a própria construção e arquitetura de poder (institucional) da União não facilita uma perceção imediata e fácil do seu esquema de funcionamento e da sua representatividade (em rigor, da sua base de legitimidade que reside, também, nos próprios cidadãos dos Estados-Membros). Só há pouco - poderemos dizê-lo, no contexto dos cerca de 
66 anos de integração percorridos - é que a cidadania europeia (como cidadania de direitos) começou a fazer, pelo menos de um modo claro, o seu caminho. Além disso, as historicamente recorrentes dificuldades políticas em se empreender uma tão profunda, quanto necessária, reforma institucional, provam isso mesmo, ou seja, essa dificuldade em envolver, impulsionando a sua participação democrática, o cidadão eleitor (de resto, apenas chamado a eleger, diretamente no areópago europeu, os seus deputados para o Parlamento Europeu). A própria construção e, sobretudo, "vivificação" generalizada do conceito de democracia europeia, supranacional, assente numa materialidade de princípios e valores, de consensos e de representatividades difusas e indiretas, não é facilmente apreensível, exigindo um esforço comunicacional político redobrado e, sobretudo, eficiente. Essa eficiência comunicacional, no fundo, dependerá sempre da eficácia com que a resolução de problemas de vida das comunidades e dos cidadãos seja empreendida pela União - ou, pelo menos, sejam atribuídas à União e à dinâmica de integração, as respetivas quotas-parte de sucesso na resolução de tais problemas. Nem sempre isso será fácil, nem tão pouco será do interesse dos próprios governos e poderes locais-nacionais.

Mas, de todo o modo, existirão ainda causas que, sem que se negligenciem aquelas que habitualmente têm vindo a ser apontadas (nomeadamente, as atrás referidas), contribuirão, também, para este inquietante estado de coisas. Pensamos que são causas determinantes destas pulsões antidemocráticas e, concomitantemente, anti-integração, sendo certo que muito pouco terão a ver com a estrutura jurídica e constitucional existente (e isto, sem olvidar o facto de esta estrutura merecer, também e prementemente, mudanças e aperfeiçoamentos). Causas de caráter mais amplo, mais sociológico e, até certo ponto, resultantes do tempo que vivemos (de um certo "caldo cultural" que foi sendo aprimorado com a intensificação da sociedade técnica da informação, do consumismo e do imediatismo que nos envolvem e, por vezes, oprimem, hoje em dia). Até certo ponto, poderá, também, esse conjunto de causas (digamos, por facilidade de expressão, sociológicas) ser resultante de um certo nível de bem-estar (e dos seus padrões de vida), alcançado pelas sociedades de consumo (apesar das desigualdades assinaladas, refletindo problemas de redistribuição). 
Referimo-nos a um certo relativismo, senão mesmo, niilismo, que marca os padrões de socialização que vamos seguindo atualmente e que acaba por resvalar, inevitavelmente, numa cultura e numa sensibilidade da indiferença e, até certo ponto, da desresponsabilização. Há, por vezes e a coberto de uma má valoração do princípio da igualdade, um relativismo existencial que gera uma ausência de opções valorativas e normativas, uma demissão social generalizada, em relação a escolhas e a causas. Dificilmente, numa hipotética situação-limite, poderá assumir-se, por exemplo, uma verdadeira opção constitucional (qualquer que seja o seu conteúdo) porque as possibilidades e sentidos de ordenação da vida em comunidade, os valores (assim como a ausência deles) e todos os padrões de comportamento, equivalem-se. Logo, serão insuscetíveis de valoração. Será inviável procurar determinar um "mínimo ético fundamental" que sirva de argamassa à comunidade e permita organizá-la politicamente. Talvez o único valor reconhecido seja, precisamente, a autenticidade ou a genuinidade. Mensagens políticas assertivas, num contexto de relativismo e indiferença dominantes, parecendo genuínas, serão fácil e imediatamente atrativas. Mais valerá uma má causa, do que a ausência de causas: talvez seja também esta (ainda que não exclusivamente) a chave do populismo atual.

Cremos, de todo o modo, que esta hipótese de justificação das causas de um estado de risco potencial para a democracia (sucesso do populismo), poderá ser especialmente viável no caso norte-americano. Será um contributo, por exemplo, a ter em conta, também e até certo ponto, para a compreensão da eleição de Donald Trump e para o fascínio que, inegavelmente, ele suscitou numa parte da sociedade norte-americana (que o elegeu democraticamente). Um fascínio similar àquele que algumas das personagens literárias e televisivas que começamos por mencionar, também provocaram - e isso, independentemente do conteúdo, significado e comportamentos que (tais personagens) expõem de forma, precisamente, assertiva e genuína! ${ }^{1}$

\footnotetext{
${ }^{1}$ Neste sentido e com outros exemplos e ilustrações da realidade cultural (sobretudo, mediática) norteamericana, David Ernst, "Donald Trump is the first Presidente to turn PostModernism Against Itself", The Federalist (Philosophy), janeiro 23, 2017, https://thefederalist.com/2017/01/23/donald-trump-firstpresident-turn-postmodernism/.
} 
No que diz respeito agora mais particularmente à integração europeia, revemonos na inquietação que Miguel Poiares Maduro expressou numa entrevista publicada no Jornal de Negócios (10 de fevereiro de 2017) e que está refletida no seguinte excerto:

Questão: A União Europeia (UE) vai sobreviver à atual crise de identidade?

Resposta: Sobreviver, vai. De que forma é que o vai fazer? Essa é a questão. (...). A UE deixou de oferecer um espaço político que permita reconciliar as preferências, muito diferentes, dos seus Estados-Membros e respetivas populações. Isso acontece relativamente à questão dos refugiados, entre o Leste e o Oeste da Europa, e em relação ao euro, entre o Norte e o Sul. O problema não é a União não saber o que os cidadãos pretendem. O problema é que aquilo que os cidadãos pretendem nos diversos Estados da UE é substancialmente diferente e, muitas vezes, irreconciliável. Isso cria um círculo vicioso muito negativo que gera uma perceção de incapacidade da UE, algo que é manipulado politicamente ao nível interno. Uma manipulação que torna, por sua vez, ainda mais difícil reconciliar essas preferências ao nível europeu. É muito difícil sair daqui ${ }^{2}$.

Ora, como sair deste "círculo vicioso" negativo e que cria uma perceção de incapacidade da União Europeia? Como encontrar uma plataforma comum de entendimento entre as várias posições divergentes dos atores políticos e das populações? Como conciliar aquilo que entre si e de forma antagónica os cidadãos pretendem? Enfim, como "sair daqui"?

Como deixamos antever, referindo-nos a causas (que denominamos) "sociológicas", talvez exista um problema de base que, podendo não ser primeiramente de caráter jurídico-constitucional, acaba, de todo o modo, por condicioná-lo. O mal-estar dos cidadãos, a cosmovisão e a cultura relativista, o desencanto e as desigualdades, o sentimento de exclusão que uma parte da população (e do eleitorado) sente relativamente à ausência de ações de apoio social da parte da própria União, enfim, os

\footnotetext{
${ }^{2}$ David Santiago, "Entrevista a Miguel Poiares Maduro", Jornal de Negócios, fevereiro 10, 2017, http:// www.jornaldenegocios.pt/weekend/detalhe/miguel-poiares-maduro-antonio-costa-tentara-anteciparuma-crise-politica.
} 
resquícios e as consequências da crise das dívidas soberanas, acentuam o sentimento de exclusão e de indiferença política, no que respeita à integração europeia. Existe também um problema de comunicação política que cria e reforça permanentemente (até mesmo porque é uma crítica fácil) de falta de transparência do funcionamento das Instituições da União Europeia.

Com isto não pretendemos afirmar que a estrutura jurídica e institucional da União não careça de uma profunda reforma, nomeadamente, no sentido de garantir vias de transparência acrescida e de simplificação nos processos de decisão. Isso facilitaria uma melhor perceção de como funciona quotidianamente a União, como se processa a dinâmica da integração e, desse modo, parcialmente, tal crítica (de falta de transparência) poderia ser atenuada. Responder-se-ia ao alegado afastamento dos cidadãos relativamente à União Europeia? Não cremos, na medida em que os cidadãos europeus, para se sentirem como tal e cultivarem uma proximidade interessada na integração, têm que sentir a ação das Instituições diretamente na resolução dos seus anseios e problemas. Um reforço dos meios de tutela jurisdicional efetiva poderia auxiliar nesse propósito. A este respeito, uma reforma do sistema de contencioso da União, facilitando-se o contato/acesso directo (por exemplo, no domínio da tutela de direitos fundamentais) dos cidadãos ao Tribunal de Justiça, poderia ser um elemento contributivo desse reforço.

Mas decisivo e inultrapassável para o futuro da União Europeia será o aprofundamento da integração, ainda que, porventura, este aprofundamento se realize a diferentes velocidades e com diferentes graus de intensidade, entre os vários Estados-Membros. O problema/crise das dívidas soberanas e a intervenção ousada e decisiva do BCE evidenciaram a necessidade de, sem peias resultantes de interesses tributários de visões soberanísticas, avançar-se nesse sentido. Talvez seja isso que, de um modo consequente, possa contribuir para uma definitiva ultrapassagem da alegada crise de identidade (até mesmo sociológica) da União e para um rejuvenescimento do ideal da integração europeia. 



\title{
A “commonlização" do direito positivo, o ativismo judicial e a crise do Estado*
}

\author{
Paulo Márcio Cruz ${ }^{* *}$ \\ Zenildo Bodnar ${ }^{* * *}$
}

RESUMO: O presente artigo trata de analisar e discutir a crise de algumas das teorias modernas sobre o Direito e o Estado, principalmente a tripartição clássica de poderes e o protagonismo atual do Poder Judiciário, o que permite estabelecer relaçães teóricas sobre a aproximação el ou a colaboração entre as famílias jurídicas denominadas de Common Law e o Civil Law a partir do Ativismo Judicial.

PALAVRAS CHAVE: direito - Estado - ativismo judicial - sustentabilidade.

ABSTRACT: This article analyzes and discusses the crisis of some of the modern theories of Law and the State, especially the classic tripartition of powers and the current role of the Judiciary, which allows theoretical relationships to be established in the approach to and/or collaboration between legal families called Common Law and Civil Law based on Judicial Activism.

KEYWORDS: law - State - judicial activism - sustainability.

\footnotetext{
* Este texto foi também publicado na revista Novos Estudos Jurídicos (UNIVALI) 21 (2016): 1332.

${ }^{* *}$ Pós-Doutor em Direito do Estado pela Universidade de Alicante, Espanha. Coordenador e professor do Programa de Pós-Graduação Stricto Sensu em Ciência Jurídica da UNIVALI (cursos de Doutorado e Mestrado).

${ }^{* * *}$ Doutor em Direito pela Universidade Federal de Santa Catarina, Brasil. Professor no Programa de Pós-Graduação Stricto Sensu em Ciência Jurídica da UNIVALI (cursos de Doutorado e Mestrado).
} 


\section{Nota introdutória}

A necessidade de uma urgente reforma do Estado é inequívoca. A maioria dos estados forjados a partir das estruturas teóricas modernas carece de uma profunda reforma. São teorias, algumas delas, de antes da invenção da máquina a vapor. Não é possível continuar convivendo com essa conceção arcaica de organização estatal.

A maioria dos estados em nossa área ocidental de influência, os latino-americanos inclusive, seguem esse mesmo figurino de organização das suas estruturas públicas. E que perderam, se é que algum dia tiveram, a noção e a dimensão republicanas.

E o pior: quase todos, durante a segunda metade do século XX, copiaram ou tentaram copiar os modelos de constituições programáticas adotadas nos estados de bem estar europeus após a segunda guerra mundial. O mundo dividido entre o liberalismo capitaneado pela Inglaterra e pelos Estados Unidos e o socialismo igualitário liderado pela extinta União Soviético, numa disputa épica entre igualdade e liberdade.

As constituições europeias do pós-segunda guerra mundial, inspiradas na de Weimar, mas também produzidas pela ótica do keneysianismo ${ }^{1}$ e pela necessidade de passar às suas sociedades a ideia clara que seria possível viver com âmbitos adequados de igualdade, porém sem abrir mão da liberdade, que afinal de contas é o paradigma moderno.

Pois bem, a disputa oeste-leste terminou com o fim da União Soviética e os valores modernos representados pela liberdade retomaram com força seu protagonismo. E o capitalismo tornou-se hegemônico, inclusive com esse grande paradoxo sem qualquer tipo de submissão ao interesse geral da humanidade que se chama China.

\footnotetext{
${ }^{1}$ John Maynard Keynes, nobre e economista inglês, nascido em Cambridge em 1883 e morto em Sussex em 1946, foi conselheiro do Tesouro britânico durante a Primeira Guerra Mundial. Após a guerra, publicou o estudo Consequências Econômicas da Paz. (1919). Autor de Um Tratado sobre a moeda (1930) e, depois, de uma Teoria geral do emprego, do juro e da moeda (1936), Keynes atacou o problema do subemprego que existia na Inglaterra depois de 1930. Ele enxergou, nesta situação, um estado de subequilíbrio permanente que nenhum mecanismo automático de mercado corrigiria. Keynes pregou, em conseqüência, um crescimento do consumo, uma baixa taxa de juros, o crescimento dos investimentos públicos, medidas que implicavam a intervenção do Estado. Ele teve um papel muito importante na conferência de Bretton Woods, em 1944.
} 
Com o fim da guerra fria e com o triunfo do capitalismo já não existe lugar para algo absoluto. Apesar do importante papel que desempenham a China, a União Europeia, os Tigres Asiáticos e os Estados Unidos, o mundo atual vive de autoridades múltiplas e difusas, com a consciência da necessidade da sustentabilidade sendo talvez a única guia existente atualmente ${ }^{2}$.

Hoje estamos diante de sociedades hipercomplexas nas quais, apesar das evidentes assimetrias ${ }^{3}$ que existem num mundo no qual convivem sociedades muito avançadas e outras que sequer alcançaram a modernidade), as fronteiras já são relativas, assim como o conceito de soberania, cidadania e até de nacionalidade ${ }^{4}$. Há toda uma geração que nasceu e se desenvolveu nesse ambiente digital e que interage empaticamente desconsiderando boa parte das construções teóricas modernas.

Sob essa perspetiva, os estados não conseguem acompanhar esse mundo novo pós-moderno. O direito é uma ciência anacrônica em sua base teórica, seus métodos, seus procedimentos, seus processos e, principalmente, em se tratando da produção e aplicação.

Os estados, latu sensu, uns mais outros menos, são estruturas que perderam seus objetivos originais, os quais justificavam sua existência como tal. Em diversas partes do mundo o estado funciona como um gigolô da sociedade, promovendo um processo autofágico e gerador de privilégios, castas de funcionários públicos com regalias que ofendem a dignidade do trabalhador privado, incompetente para dar respostas às demandas sociais e, muitas vezes, atrapalha o desenvolvimento social por ser um antro de corrupção, incompetência e inapetência.

Por outro lado, temos o avanço dos grandes conglomerados empresariais privados estimulados pela hegemonia capitalista que já comentamos anteriormente. Mesmo que as empresas transnacionais não tenham assumido completamente

\footnotetext{
${ }^{2}$ Susan Strange, La retirada del estado: quien gobierna el mundo, trans. Josep Ibáñez. (Cambridge: Cambridge University Press, Icária Editorial/Intermón Oxfam, 2001), 101.

${ }^{3}$ Paulo Márcio Cruz e Gabriel Real Ferrer, "Los nuevos escenarios transnacionales y la democracia asimétrica" E-Lex Revista 5 (2010): 16.

${ }^{4}$ Paulo Márcio Cruz e Gabriel Real Ferrer, "Direito, Sustentabilidade e a Premissa Tecnológica como Ampliação de seus Fundamentos". Sequência 71 (2015): 239-278.
} 
contornos de "governos de estados de economia", sem dúvidas já ocupam parcelas significativas de seu poder. É cada vez maior a autoridade que exercem paralelamente aos governos, principalmente na definição da localização das principais regiões de produção, investimentos públicos e privados. Orientam a inovação tecnológica, dão o tom das relações trabalhistas e praticamente definem as políticas fiscais ${ }^{5}$.

Mais ou menos, os estados estão falidos e praticamente inviabilizados. Existem para prestar parcos serviços de baixíssima qualidade, com as exceções de praxe.

Estudos indicam que, caso os estados não promovam as adequações necessárias, não conseguirão chegar até a década de 40 do corrente século com desempenho minimante razoável de suas atribuições históricas ${ }^{6}$.

O mundo vem mudando com velocidades extraordinárias. E os estados - e o direito - insistem em viver a partir de padrões teóricos dos séculos XVII, XVIII e XIX. A impressão que dá é que tudo de mais genial com relação à teoria do estado e do direito foi produzido na modernidade e que nós estamos condenados a ficarmos dando voltas, tentando saber como as interpretações da constituição programática vão resolver nossos problemas.

Além disso, o mundo jurídico pouco se dá conta de que a ciência do direito está sendo atropelada pelas outras ciências, que possuem seus "tempos" muito mais desenvolvidos e adequados à atual realidade da sociedade hipercomplexa. É como pretender cruzar hoje o oceano comandando um jato de última geração tendo como instrumentos de navegação aqueles disponíveis no século XVII ou XVIII. Até seria possível, teoricamente, mas o risco de um desastre seria incrivelmente alto.

Apesar de estarmos vivendo uma crise gravíssima, é importante anotar que normalmente é das crises que surgem as condições para que os passos adiante sejam dados. É preciso que todos se conscientizem que a modernidade está chegando ao fim, arrastando com ela todo o seu arsenal teórico que a sustentou.

\footnotetext{
${ }^{5}$ Strange, La retirada del estado, 275.

${ }^{6}$ Conforme relatório da OCDE (Organização para a Cooperação e Desenvolvimento Econômico), divulgado em 08 de março de 2016.
} 
Principalmente sua principal característica, ou seja, a justificação de profundas e desumanas desigualdades em nome do liberalismo capitalista.

O que não é possível é ficar negando o óbvio. O capitalismo atual não é sustentável. Nada cresce ao infinito. A economia não pode crescer indefinidamente. Rawls defende que a existência do liberalismo político é plausível a partir de demonstração da possibilidade de um consenso sobreposto numa sociedade com uma tradição democrática caracterizada pelo fato do pluralismo razoável ${ }^{7}$. Ou seja, é possível supor que há um pluralismo não razoável. O pluralismo transnacional atual por certo não seria razoável na visão Rawls.

Já na metade do século XX eram iniciados os debates sobre desenvolvimento sustentável e, depois, sobre sustentabilidade. Durante as décadas seguintes essas duas categorias acabaram por se fundir. Uma de suas bases foi o importante documento da Comissão do Meio Ambiente das Nações Unidas, organizado por Gro Harlem Drundtland $^{8}$, na época presidente da Comissão Mundial do Meio Ambiente e Desenvolvimento, intitulado "Nosso Futuro Comum" e mais conhecido como "Relatório Brundtland". Esse documento marcou o ponto de inflexão no processo de institucionalização do conceito de desenvolvimento sustentável, que até então era apenas uma mera discussão acadêmica e partir desse momento passou a fazer parte das principais pautas mundiais.

Além disso, o "Relatório Brundtland" trouxe a definição mais difundida do termo desenvolvimento sustentável, como sendo aquele desenvolvimento que satisfaz as necessidades da atual geração sem comprometer a capacidade das gerações futuras para satisfazer suas próprias necessidades?.

Desde então o que começou como desenvolvimento sustentável passou a evoluir rapidamente para a consolidação da sustentabilidade como valor geral fundante e que cada vez mais ganha força como paradigma balizador de todas as ciências.

\footnotetext{
7 John Rawls, O liberalismo politico, trans. Dinah de Abreu Azevedo, (São Paulo: Ática, 2000), 219.

${ }^{8}$ Gro Harlem Brundtland, diplomata e médica norueguesa e líder internacional em desenvolvimento sustentável e saúde pública. Foi membro do Partido dos Trabalhadores da Noruega.

9 Itziar Aguado Moralejo, Carmen Echebarria Miguel e José M $\mathrm{M}^{\mathrm{a}}$ Barrutia Legarreta, "El desarrollo sostenible a lo largo de la historia del pensamiento económico" Revista de Economía Mundial 21 (2009): 87-110.
} 
A liberdade como meta valor está em acelerado processo de reconfiguração à condição de um valor civilizatório importante, porém não mais aquele destinado a matizar todas as atividades científicas. Assim como o direito, as demais ciências estão absolutamente envolvidas nessa transição paradigmática. É sempre fundamental notar que o direito produzido com base no paradigma da sustentabilidade será, evidentemente, muito diferente do direito que foi produzido quando a liberdade o matizava.

Aliás, é muito clara a convivência de paradigmas, atualmente. O paradigma moderno, a liberdade, vai demonstrando sua insuficiência para matizar as concepções científicas. E o possível paradigma pós-moderno chega mostrando sua capacidade de orientar a criação de bases teórico-científicas suficientes para transformar os movimentos da sociedade hipercomplexa em elementos para a criação de alternativas teóricas para as diversas ciências. O direito e o estado incluídos.

\section{A origem do Estado Democrático de Direito e a pós-modernidade}

Há um equívoco recorrente quando se começa a tratar de Estado Democrático de Direito que diz respeito a uma espécie de corte indevido da linha teórica que instruiu, em toda modernidade, a formação do próprio Estado e do Direito.

A maioria das sociedades ocidentais, e de outras partes do mundo também, optou pela república como princípio reitor de todos seus ordenamentos jurídicos.

Ser uma república significa a opção clara pela construção do estado e do ordenamento jurídico a partir do interesse geral ou interesse da maioria. O princípio democrático, aplicado também para viabilizar os instrumentos de democracia representativa, teoricamente permite à sociedade auscultar os cidadãos eleitores, a cada quatro anos, e estabelecer o interesse geral ou interesse da maioria, representado pela opção ideológica - esquerda, centro ou direita e suas variações - majoritária. Essa opção também, teoricamente, irá orientar a criação do direito e a formatação do estado. 
E está-se falando de interesse geral ou da maioria, não do Direito. As minorias terem direitos é também uma condição republicana. Maiorias num determinado momento poderão deixa-lo de ser e assim a existir como minoria no momento seguinte. Esse tem sido o figurino ideológico moderno básico.

O princípio republicano nas constituições ocidentais permite a transição entre os mundos político e jurídico. O princípio republicano opera, inclusive, nas chamadas monarquias constitucionais. A Espanha, por exemplo, apesar de formalmente ser uma monarquia, adota in totum o princípio republicano como base axiológica para formação de seu ordenamento jurídico.

O problema dos nossos tempos é o aumento da complexidade de maneira exponencial e a existência de sociedades extremamente heterogêneas, sincréticas, mundializadas e conectadas on line ao mundo digital. Isso faz com que o instrumento idealizado pelos modernos para promover a oitiva à sociedade a cada eleição parlamentar não traduza de forma eficiente as tendências da sociedade naquele determinado momento. Sair de casa para votar em um representante já não é o suficiente para a formação do interesse geral ou da maioria ${ }^{10}$. Principalmente nas sociedades heterogêneas e complexas.

É importante entender o mecanismo geral de criação do direito e do estado modernos relatado acima e verificar que, ao ser cotejado com as atuais características das sociedades contemporâneas, apenas naquelas com alto grau de homogeneidade, como eram os burgueses dos séculos XVII a XIX, os instrumentos de democracia representativa podem funcionar com um mínimo de eficiência. Nos países da Escandinávia, por exemplo, com alto grau de homogeneidade, apesar de serem sociedades hipercomplexas, as democracias representativas modernas ainda são capazes de servir como instrumento formador do Direito e conformador do Estado.

O problema está, exatamente, nas sociedades heterogêneas e assimétricas. Basta pensar sobre qual percentual de cidadão, num país subdesenvolvido ou dito emergente, sabe que, ao participar das eleições, estará fazendo a opção por uma

\footnotetext{
${ }^{10}$ Paulo Márcio Cruz. "Sobre el Princípio Republicano”. Juridicas, 06 (2009): 15-32.
} 
matriz ideológica, que poderá ser majoritária, que produzirá um direito típico daquela orientação política e que, por isso, também influenciará decisivamente a sua própria criação e aplicação.

\section{A modernidade ultrapassada}

Melhor então analisar como o direito e o estado chegaram até aqui a partir dos preceitos modernos. Alguns autores trabalham com a existência de duas modernidades. A primeira, representada pelo estado absoluto, e uma segunda, que passa a existir após as revoluções burguesas. Com todo respeito, mas não é essa a conceção que nos parece a mais adequada. A modernidade, stricto sensu, começa com o fim do antigo regime e com a implantação gradativa dos estados constitucionais. E junto com eles os instrumentos de liberalismo econômico e de liberalismo político.

As sociedades burguesas da Europa continental passaram a adotar esse figurino político-ideológico que lhes interessava e a organizar o estado e a construir seus ordenamentos jurídicos com base nos princípios liberais consagrados. São exemplos a inexistência de crime sem lei que o preveja, o direito de propriedade como um de seus fundamentos mais importantes, os limites ao poder de tributar do estado, entre tantos outros.

Nunca é demais registrar a consolidação do direito público como uma das principais características da modernidade. O direito público, que muitas vezes é equivocadamente confundido com direito do estado, na verdade é um grande sistema protetivo proposto pelos modernos com relação ao estado.

E vale ressaltar o protagonismo da Inglaterra nesse sentido. E porque a os ingleses desempenharam papeis tão vanguardistas na formação do que chamamos de teoria política moderna, que redundou no direito e no estado moderno? Seguramente por sua história e por seus costumes e também, em menor grau, por sua geografia que permitiu algum isolamento que serviu como uma espécie de membrana seletiva. Costuma-se chamar o processo de formação do direito inglês como de "trato sucessivo", o que possibilitou a sua construção ao longo dos séculos, desde a magna 
carta, passando por suas duas importantes revoluções sem uma rutura como as que aconteceram no continente.

Pode-se dizer que a modernidade chegou um século antes à Inglaterra e que o Direito Inglês (da Inglaterra e do País de Gales) adquiriu sua forma atual por conta desses fatos. Com os costumes e os precedentes ocupando lugar de destaque nas fontes primárias do direito daqueles países.

É possível dizer que esses traços específicos da formação do ordenamento jurídico e do estado inglês permitiram que o "tempo" do direito consuetudinário (e da produção de teorias políticas que o embasaram) inglês historicamente fosse mais ajustado aos tempos das demais ciências e da sociedade como um todo.

Sem a separação rígida entre direito público e direito privado, tão presente do direito europeu continental moderno, e com um parlamento muito mais voltado para o debate político e para a aprovação de regras gerais, com uma constituição formada por documentos aprovados ao longo da história (é incorreto dizer que a Inglaterra não tem constituição escrita, pois o que não possui é uma constituição organizada em um só documento, mas os documentos que a compõem são escrito, sim!). A maior parte do ordenamento jurídico formado por precedentes jurisprudenciais criados a partir dos costumes, a Inglaterra - e o direito inglês - podem proporcionar excelentes elementos para reflexão sobre o direito - e o estado - que temos e o direito - e o estado - que provavelmente teremos.

\section{O processo de "commonlização" do direito moderno e o ativismo judicial}

É muito difícil defender, atualmente, que as teorias modernas formadoras do direito e do estado são suficientes para o enfretamento dos desafios dessa nova era que está começando e que torna as sociedades complexas e hipercomplexas ${ }^{11}$.

Quando a União Soviética entrou em colapso já havia uma clara sinalização em

${ }^{11}$ Conforme Orlando Zanon Junior, Teoria complexa do direito (Florianópolis: Academia Judicial, Centro de Estudos Jurídicos, 2013). 
direção a um processo muito rápido de globalização, alavancado principalmente por três motivos: a evolução geométrica das comunicações por satélites, a popularização dos personal computers num primeiro momento e dos smart phones e tablets num segundo momento e o acesso cada vez maior às redes de internet. Isso começou a mudar o mundo em que vivemos.

As telecomunicações diminuíram a capacidade de controle dos estados e seus governos, que já não possuem o monopólio dessa atividade. Mas são os grandes usuários das tecnologias mais avançadas, as grandes corporações transnacionais, os que desequilibram sensivelmente as relações de força entre as sociedades civis e os grandes produtores da riqueza mundial.

Com o ingresso da China no grande cassino mundial capitalista as mudanças globais ficaram ainda mais rápidas e intensas. A preocupação com as mudanças climáticas ficou imensamente maior com o avanço desenfreado das atividades potencialmente mais poluentes a partir do início do processo de globalização com os Estados Unidos e a China como seus atores principais.

As fronteiras nacionais passaram a ser cada vez mais parecidas com peças de ficção e uma gigantesca comunidade global foi se formando com boa parte da população do planeta acompanhando tudo em tempo real. A chamada primavera árabe foi produzida tendo as mídias sociais como um de seus principais instrumentos.

Aquilo que era a grande meta a ser alcançada quando a modernidade foi teorizada, ou seja, âmbitos cada vez mais amplos de liberdade deixaram de ser prioridade.

Com a velocidade imposta pela comunicação digital via internet, o que Rifkin ${ }^{12}$ chama de civilização empática foi e vai se formando. A base do raciocínio moderno perde força gradualmente e vai dando lugar a valores superlativos, muito deferentes de liberdade, liberalismo, capitalismo, direito de propriedade, entre tantos outros. Começam a surgir discussões muito sérias em torno de temas até então negligenciados pelos axiomas modernos.

Com isso, o "tempo" do direito de estado torna-se cada vez mais anacrônico e,

\footnotetext{
${ }^{12}$ Jeremy Rifkin, La civilización empática: la carrera hacia una conciencia global en un mundo en crisis (Barcelona: Paidós, 2010).
} 
por isso, incapaz de dar respostas minimamente eficientes às sociedades globalizadas conectadas.

É nesse ambiente que surgiu, na última década do século XX, o que convencionou chamar de ativismo judicial, que começou a transformar o processo de produção do direito, tradicionalmente realizado a partir da produção legislativa, com a lei como fonte primária.

O ativismo judicial é a atitude dos membros do poder judiciário de, através de interpretações estendidas, alargarem os limites jurisdicionais estabelecidos para o exercício de seus poderes.

O ativismo judicial, portanto, significa a judicialização de funções até então tidas como típicas dos outros dois poderes do estado. Como já sugerido acimo, uma série de fatores concorreram para este fenômeno, mas o principal deles, de fato, decorre da incapacidade dos poderes legislativo e executivo em acompanhar o "tempo" da sociedade hipercomplexa, fazendo com que o princípio da separação dos poderes tal como foi concebida originalmente sofra significativa relativização ${ }^{13}$. Daí a transferência dos poderes decisórios de outros poderes ao poder judiciário.

Este fenômeno vem, paulatinamente, dando um intenso protagonismo ao poder judiciário e fazendo com que o Civil Law se aproxime do Common Law (não exatamente como o sistema inglês) com um evidente processo gradativo de emparelhamento de fontes primárias do direito entre a lei posta e as decisões judiciais.

A democracia representativa, instrumento fundamental do estado democrático de direito e a função governativa são incapazes, como concebidas a partir das teorias modernas, de fazer frente às demandas desse mundo novo. $\mathrm{E}$ nessa esteira foi que o ativismo judicial evoluiu, ganhou importância e angariou protagonismo.

Em alguns países está-se diante de uma espécie de "estado judiciário" e com as funções mais relevantes da república controladas por magistrados cuja legitimidade democrática é indireta. Porém parece prevalecer o critério da capacidade técnica sobre a capacidade política, o que a sociedade vem entendendo como legítimo e adequado.

\footnotetext{
${ }^{13}$ Sobre isso ver Mauro Cappelletti, Juizes Legisladores? , trans. Carlos Alberto Alvaro de Oliveira. (Porto Alegre: Sérgio Antônio Fabris, 1999).
} 
Em artigos anteriores já se assinalou os claros sinais de insuficiência dos critérios modernos de ordenação jurídica e de organização do estado.

Este novo cenário da globalização patrocinada pelo capitalismo transnacional neoliberal deve ser motivo de muita preocupação, como destaca Noam Chomsky, um dos maiores críticos à pós-modernidade impulsionada por este e sem capacidade para criar a necessária base teórica para a pós-modernidade. Esse sim, na opinião desse autor, o grande problema a ser enfrentado ${ }^{14}$.

\section{O século XXI e a coabitação de paradigmas: a era da sustentabilidade}

Existem novos poderes transnacionais desterritorializados que estão absolutamente sem nenhum tipo de controle ou limite que os faça estar submetidos ao interesse geral ou interesse da maioria.

É possível perceber a aproximação de uma grande revolução relativa ao paradigma da ciência ocidental. Morin acrescenta que, de modo correlato, também na perspetiva da metafísica, que ora é seu negativo, ora seu complemento ${ }^{15}$. Ao longo da história moderna o desenvolvimento econômico foi uma constante nas metas e objetivos das sociedades ocidentais. Mas a partir da segunda metade do século XX, após a segunda grande guerra, o desenvolvimento passa a contar com uma perspetiva multidisciplinar: o conceito de desenvolvimento sustentável passa a ocupar o centro dos debates ${ }^{16}$.

O surgimento desse intenso movimento começou a abalar definitivamente o paradigma moderno como pedra angular de todo um sistema de pensamento, afetou ao mesmo tempo a ontologia, a metodologia, a epistemologia, a lógica e, por consequência, a prática, a sociedade e a política.

E foi possível antever-se, portanto, a radicalidade e amplitude da reforma paradigmática. É toda a estrutura do sistema de pensamento que ficou abalada,

${ }^{14}$ Noam Chomsky, Estados fallidos - el abuso de poder y el ataque a la democracia. Trans. Gabriel Dols. (Barcelona: Ediciones B, 2007), 201.

${ }^{15}$ Edgar Morin, Introdução ao pensamento complexo, trans. Eliane Lisboa, (4 ed., Porto Alegre: Sulina, 2005), 54.

${ }^{16}$ Aguado Moralejo; Echebarria Miguel e Barrutia Legarreta, "El desarrollo sostenible a lo largo", 87-110. 
transformada com esse mundo novo e desterritorializado atual. É toda uma superestrutura de ideias que está desabando e outra que está se formando. É para isso que a humanidade precisa se preparar, escreve Morin ${ }^{17}$.

Caso se queira estar apto a uma nova compreensão do direito, a qual possa fornecer uma resposta ao novo conjunto de demandas ligadas aos novos cenários transnacionais ${ }^{18}$, é preciso superar a construção teórica da modernidade liberal, apesar de se saber que o período que está vindo conviverá com o atual.

O direito que advirá desse ambiente político-jurídico transnacional será forjado, muito provavelmente, com base em princípios de inclusão social, direitos humanos e proteção ao meio ambiente ${ }^{19}$. A sustentabilidade, em sua aceção mais ampla, muito provavelmente, passará ser, se já não o é, o principal item do debate político-jurídico e, portanto, possivelmente o novo paradigma indutor do direito.

A preservação e recuperação do ambiente e sua utilização racional sugere a reinvenção da tensão entre direito e liberalismo capitalista, o que poderá gerar a necessária sustentabilidade. Isso para que uma nova conceção de direito possa contribuir para que o mundo seja cada vez menos confortável para o capitalismo predatório e que um dia se possa ter uma alternativa ou, ao menos, um capitalismo sustentável.

Sabe-se perfeitamente das assimetrias existentes entre as regiões do planeta e entre os países que as formam. Isso indica a necessidade de coabitação entre o paradigma moderno e o pós-moderno do direito, entre a busca por âmbitos cada vez mais amplos de liberdade e a limitação desta mesma liberdade em função de se promover a sustentabilidade. É, mutatis mutandis, o que chamamos de "republicanização da globalização" ${ }^{20}$, com uma efetiva busca pela distribuição da riqueza e reequilíbrio ambiental. O grande desafio do ser humano será provar que conseguirá evoluir do

\footnotetext{
${ }^{17}$ Morin. Introdução ao pensamento complexo, 55.

${ }^{18}$ Paulo Márcio Cruz e Gabriel Real Ferrer. "Los nuevos escenarios transnacionales y la democracia asimétrica", E-Lex Revista 5(2010): 12-24.

${ }^{19}$ Rifkin. La civilización empática:; p. 29.

${ }^{20}$ Zenildo Bodnar e Paulo Márcio Cruz. "A possibilidade da justiça transnacional na globalização democrática”, Revista Novos Estudos Jurídicos 15(2010): 380.
} 
individualismo liberal, passando pelas experiências de igualdade relativa dos estados de bem estar, e alcançar a sustentabilidade. Provar que não é um elemento estranho e inadaptável ao planeta Terra, mas que pode não só conviver em harmonia como melhorar as condições gerais de vida.

Essa perspetiva sugere também, principalmente a partir do novo ritmo civilizacional a que estamos submetidos, que instâncias de governança institucional, a exemplo do Poder Judiciário, amoldem-se a esta nova realidade.

Isso porque a sociedade hipercomplexa apresenta importantes desafios para a jurisdição, principalmente por demandar uma nova racionalidade jurídica, já que denuncia as limitações da dogmática tradicional e do saber isolado ou pertencente a um único campo do conhecimento humano.

Pode-se ser enfático ao afirmar que os senhores invisíveis da globalização sabem que, para conservar seu poder, têm de construir a torre do pensamento único, globalizar ideias que não admitem a diversidade, o que seria a última versão do universalismo, a nova forma de assegurar a continuidade da razão abstrata ${ }^{21}$. Essa homogeneidade destrutiva é a igualdade como um modelo artificial, o que impede qualquer tipo de sensibilidade ou empatia global que torne a convivência humana mais civilizada ${ }^{22}$.

$\mathrm{Na}$ via da globalização, a política foi claramente ultrapassada pelos outros sistemas sociais, como escreve Teubner $^{23}$. A razão decisiva para que atualmente a produção normativa esteja se distanciando cada vez mais da política reside no fato de que o acoplamento do sistema político e do sistema jurídico por meio de constituições não conta com uma instância correspondente no plano da sociedade mundial.

A economia produz a riqueza e a política trata de distribuí-la. Sem uma política transnacional, será impossível distribuir a riqueza transnacional, torná-la

\footnotetext{
${ }^{21}$ Paulo Márcio Cruz e Zenildo Bodnar, “As dimensões materiais da efetividade da jurisdição ambiental” Revista de Estudos Constitucionais, Hermenêutica e Teoria do Direito (RECHTD) 6 (2014): 155-166.

${ }^{22}$ Cruz and Bodnar, "As dimensões materiais", 155-166.

${ }^{23}$ Gunther Teubner, "A Bukowina global: sobre a emergência de um pluralismo jurídico transnacional”, Impulso: Revista de Ciências Sociais e Humanas 14 (2003): 13.
} 
instrumento de desenvolvimento social efetivo em sintonia com a sustentabilidade em suas diversas dimensões.

A ideia historicamente consolidada de um direito baseado na completude, coerência e não contradição, já não é mais suficiente para o enfrentamento dos desafios da sociedade de risco. A crise contemporânea do Estado de direito e da justiça requer também a reformulação do pensamento jurídico com a superação dialética do paradigma moderno ${ }^{24}$. E deve-se anotar que não pode haver, a partir do novo paradigma pós-moderno, espaços para a miséria e a pobreza consentidas ou impostas.

Nesse contexto, incumbe ao direito e, por consequência, à jurisdição a tarefa de qualificar axiologicamente o agir humano não apenas na perspetiva do comportamento responsável intersubjetivo e comunitário, mas também enquanto um compromisso ético alargado, exercido em longo prazo, tanto em benefício e atenção das futuras gerações como também de toda a comunidade de vida.

O campo de atuação da hermenêutica judiciária sustentável caracteriza-se não apenas pela intensidade das colisões, mas pela quantidade de direitos fundamentais implicados, circunstâncias estas que também exigem especialização, ou seja, o desenvolvimento de uma hermenêutica própria. Na perspetiva ou dimensão material, a construção da justiça para o caso concreto exigirá critérios de ponderação abrangentes, ancoragem constitucional e nos critérios de sustentabilidade e sensibilidade para os bens com ampla repercussão planetária e de suporte da vida. Todas as variáveis intervenientes devem ser criteriosamente sopesadas e avaliadas; o instrumental técnico do Direito não pode prescindir do aporte de outros campos do saber e nem do forte substrato ético subjacente aos litígios.

Esse amplo repertório de variáveis a serem consideradas, demonstra que a produção judicial do direito, não se adstringe a um juízo meramente subsuntivo do fato à norma, sendo, portanto, inevitável conviver com âmbitos de ativismo judicial necessário.

\footnotetext{
${ }^{24}$ André-Jean Arnaud, Entre modernité et mondialisation: leçons d'bistoire de la phisosophie du droit et de l'État. (2. ed., Paris: L.G.D.J, 2004), 238 e ss.
} 
É consabido que existem muitos doutrinadores importantes, como Lênio Streck ${ }^{25}$, que são críticos ao ativismo judicial e, por via de consequência, a esse alargamento da atuação do Poder Judiciário. Esse momento de transição talvez justifique as intervenções dos magistrados em âmbitos tradicionalmente de competência dos poderes legislativo e executivo. Porém, com todo respeito aos posicionamentos contrários, o aspecto subjetivo, ou seja, a quantidade de interessados e as consequências de longo prazo de qualquer atividade interpretativa exigem especial consideração do julgador. Não se trata de não levar a sério o indivíduo, como reivindica Alexy ${ }^{26}$, mas sim de não esquecer a sociedade no seu conjunto, as futuras gerações e, por consequência, garantir ao próprio indivíduo as melhores condições de vida presente e futura. Um dos direitos fundamentais de feição predominantemente individualista que mais entra em rota de colisão com a sustentabilidade é o direito de propriedade. $\mathrm{Na}$ colisão entre o direito de propriedade e o ambiente, é importante o julgador fazer opções conscientes, responsáveis e criativas que, sem aniquilar o núcleo essencial da propriedade, preservem a intangibilidade do ambiente. Não se trata de estabelecer uma tirania apriorística de valores em prol ambiente, mas de uma opção consciente que deve necessariamente prestigiar um bem de toda a comunidade de vida atual e futura.

A realização substancial da justiça, na perspetiva também preventiva e com propósitos de uma justiça que transcenda o caso concreto, deve objetivar exatamente a melhora contínua do comportamento humano em relação à natureza numa perspetiva de futuro e não apenas numa focalização da análise dos danos já consumados e muitas vezes irreversíveis, ou seja, deve-se julgar com os olhos voltados para o futuro e não apenas para o histórico de fracasso do passado. Esse

\footnotetext{
${ }^{25}$ Sim, há ativismo em excesso. Ao contrário do que diz o novo ministro e ao contrário do que sustenta Thamy Progrenischi (que, aliás, no seu livro critica Barroso, que, paradoxalmente, parece, agora, concordar com a crítica que lhe foi feita), há, sim, excesso de ativismo. E quando digo excesso, não estou admitindo um "ativismo adequado ou necessário". Permito-me dizer: ativismo é vulgata da judicialização. Não há bom ou mau ativismo. "O ativismo judicial existe ou é imaginação de alguns?”, Lênio Streck, acesso em 12 janeiro, 2017, https://oobservadorconstitucional.com/2014/02/17/ ativismo-judicial-ou-papel-representativo-do-stf.

${ }^{26}$ Robert Alexy. El concepto y la validez del derecho (2.. ${ }^{a}$ ed. Barcelona: Gedisa, 1997), 211.
} 
enfoque, mais uma vez põe em destaque a dimensão temporal, como justificante da intervenção criativa da jurisdição.

A importante missão de completar e reconhecer novos direitos, ampliando os espaços de cidadania, caracteriza o fenômeno da judicialização da vida social ${ }^{27}$. O Poder Judiciário, enquanto poder político desempenha um papel proeminente na salvaguarda de direitos e garantias fundamentais e de socorro aos mais fragilizados.

São inúmeras as omissões dos poderes executivo e legislativo que acontecem nas mais diversas políticas públicas, políticas estas que deveriam ser implementadas para a garantia da sustentabilidade, enquanto utopia mobilizadora. Este quadro contribui decisivamente com as crises generalizadas por que passam as sociedades humanas e exige essa intervenção alargada e eficiente por parte do Poder Judiciário.

Um protagonismo mais ativo por parte do Poder Judiciário, não representa risco a secularizada teoria da tripartição, ao contrário traduz-se na sua plena afirmação. Afinal, esta é uma precondição para o exercício de poderes que são exercidos de maneira concorrente. Ademais, conforme destacam Neal, C. Tate e Torbjörn Vallinder o fenômeno é até mais profícuo nas situações em que há a concorrência e competição entre os poderes ${ }^{28}$.

\footnotetext{
${ }^{27}$ G. Cittadino, "Judicialização da política, constitucionalismo democrático e separação de poderes". in A democracia e os três poderes no Brasil, org. L.W. Vianna (Belo Horizonte/Rio de Janeiro, UFMG/ IUPERJ/FAPERJ, 2002), 17-42.

${ }^{28}$ Neal C. Tate e Torbjörn Vallinder. "The Global Expansion of Judicial Power: The judicialization of politics". in The Global Expansion of Judicial Power, org. Neal C. Tate and Torbjörn Vallinder (New York: New York University Press, 1995), 02 e ss.
} 



\title{
Brexit e o princípio federativo da lealdade europeia: considerações sobre o artigo $50 .^{\circ}$ do Tratado da União Europeia
}

\begin{abstract}
Alessandra Silveira*
RESUMO: $O$ art. 50. ${ }^{\circ}$ do TUE é omisso quanto a várias questões relacionadas com a retirada de um Estado-Membro da União Europeia - e por isso as dúvidas suscitadas terão de ser resolvidas à luz da principiologia do direito da União, máxime do princípio da lealdade europeia (art. $4 .{ }^{\circ}, n^{\circ} 3$ do TUE). Segundo este princípio de conduta amistosa, inerente a todos os sistemas federativos conhecidos, a União Europeia e os Estados-Membros respeitam-se e assistem-se mutuamente no cumprimento das missões decorrentes dos Tratados. Daqui decorre que os Estados-Membros facilitam à União o cumprimento da sua missão e abstêm-se de qualquer medida suscetivel de pôr em perigo a realização dos objetivos da União Europeia - enquanto a União, por sua vez, respeita a igualdade dos Estados-Membros perante os Tratados, bem como a respetiva a identidade nacional refletida nas suas estruturas políticas e constitucionais, além das funcões essenciais do Estado. A Autora identifica as principais perplexidades em torno do art. 50. ${ }^{\circ}$ do TUE e procura esclarecer em que medida o princípio da lealdade europeia deve orientar o procedimento de secessão do Reino Unido, por forma a garantir uma saida que minimize os danos da rutura, sobretudo quando o que se descortina no borizonte é a modalidade "bard Brexit".
\end{abstract}

PALAVRAS-CHAVE: Brexit-art. 50. ${ }^{\circ}$ do TUE-princípio da lealdade europeia-sistemas federativos - secessão.

ABSTRACT: Article 50 of the TEU is silent on several issues concerning the withdrawal of a Member State from the European Union. Therefore, the doubts raised by Article 50 of the TEU must be solved in accordance with the principles of the EU law, in special the principle of loyalty [Article 4(3) of the TEU]. According to this principle of friendly conduct, inherent to all known federative systems, the EU and the Member States respect and assist each other mutually in the fulfilment of the missions resulting from the Treaties. Thus, the Member States shall assist the Union in the fulfilment of its mission and shall not implement any measure that may compromise the EU's objectives. In turn, the Union must treat the Member States in equal terms as enshrined in the treaties, it must respect the national identity of the Member States reflected in their political and constitutional structures, and the core functions of the State. In this paper, the author identifies the main doubts regarding the Article 50 of the TEU and explains how the principle of loyalty must

* Titular da Cátedra Jean Monnet em Direito da União Europeia e Diretora do CEDU. 
be followed with diligence in the secession of the United Kingdom to mitigate the damage from the split, particularly when facing the probable scenario of a "bard Brexit".

KEYWORDS: Brexit - Article 50 of the TEU - principle of European loyalty - federative systems - secession.

\section{A possibilidade de secessão e o seu preço}

Desde que Abraham Lincoln enfrentou a maior crise constitucional dos EUA (Guerra de Secessão, 1861-1865), a moderna teoria jurídica dos sistemas federativos tinha por adquirido que a hipótese de secessão estaria afastada. Assim foi até que a Suprema Corte canadiana reequacionou os dados. No Canadá, em 1995, foi realizado um referendo sobre a declaração unilateral da secessão do Quebec. A proposta de secessão foi rejeitada por pequena margem - 50.58\% dos votos - tendo participado 94\% dos eleitores. Na sequência do referendo o Governo federal recorreu à Suprema Corte com o intuito de saber se uma secessão unilateral, referendada em uma consulta popular não aprovada pelas demais Províncias, violaria a Constituição. A Suprema Corte decidiu que sim: uma secessão unilateral nestes termos violaria a Constituição. Todavia, se em outro referendo, em resposta a uma "pergunta clara", a "maioria clara" dos quebequenses manifestasse a inequívoca vontade de não mais integrar o Canadá, então as demais Províncias e o Governo federal estariam obrigados a negociar com o Quebec as condições da sua saída, porque princípios constitucionais não escritos assim o determinavam ${ }^{1}$. O Governo federal fez então aprovar no Parlamento canadiano regras "claras" tendentes a regular e calcular o "preço" da saída, sobretudo para salvaguardar os legítimos interesses das restantes Províncias e suas populações - e em resultado disso, como sabemos, o Quebec ainda integra a federação. Moral da história: num sistema federativo não há almoços nem saídas grátis.

$\mathrm{Na}$ União Europeia este "preço" ainda não foi calculado - previu-se apenas a possibilidade de retirada - e, até lá, tudo está em aberto ${ }^{2}$. Com a entrada em vigor do

\footnotetext{
${ }^{1}$ Cfr. Reference re Secession of Quebec, [1998] 2 S.C.R. 217.

${ }^{2} \mathrm{Cfr}$. "Out is out (including in relation to the Mediterranean diet...). On the Article 50 of the European Union Treaty in the light of the federative principle of European loyalty", Alessandra Silveira, acesso
} 
Tratado de Lisboa foi introduzida no art. 50. ${ }^{\circ}$ do Tratado da União Europeia (TUE) uma exit clause, ${ }^{3}$ sobretudo para atender à vontade dos novos Estados-Membros da Europa de leste, traumatizados pela ausência de semelhante regra no sistema soviético ao qual pertenceram. Mas o que se prevê é um acordo de saída e não uma decisão unilateral de um Estado-Membro, tendo em conta a complexa rede de vínculos resultantes da pertença à União Europeia, em cuja continuidade os restantes EstadosMembros e suas populações legitimamente confiavam. O que resulta previsto no art. 50. ${ }^{\circ}$ do TUE é significativamente distinto da denúncia unilateral prevista no direito internacional dos tratados, basicamente porque a União Europeia desde sempre funcionou como um sistema federativo. O processo de saída previsto no art. 50. ${ }^{\circ}$ do TUE assenta no consenso entre a União e o Estado-Membro que manifeste a intenção de sair - e não entre este e os demais Estados Contratantes, como dispõe o art. 54. ${ }^{\circ}$ da Convenção de Viena sobre o Direito dos Tratados. Tal saída consensual não depende da concordância de todos os Estados-Membros da União Europeia, bastando a aprovação do acordo pelo Parlamento Europeu e pela maioria qualificada dos membros do Conselho (art. ${ }^{\circ} 50 .^{\circ}$, n. ${ }^{\circ} 2$ do TUE), ou seja, $72 \%$ dos membros do Conselho que correspondam a $65 \%$ da população dos Estados-Membros (sem contar com o Estado que esteja de saída) [art. 238. ${ }^{\circ}$, n. ${ }^{\circ}$ 3, alínea b) do Tratado sobre o Funcionamento da União Europeia (TFUE)].

$\mathrm{O}$ art. 50. ${ }^{\circ}$ do TUE prevê que o Estado-Membro notifique o Conselho Europeu da sua decisão de retirada "em conformidade com as respectivas normas constitucionais". A disposição procura evitar que o Governo de um Estado-Membro acione a possibilidade de saída arbitrariamente, ou seja, em desconsideração

em janeiro 23, 2017, https://officialblogofunio.com/2016/07/07/out-is-out-including-in-relation-tothe-mediterranean-diet-on-the-article-50-of-the-european-union-treaty-in-the-light-of-the-federativeprinciple-of-european-loyalty.

${ }^{3}$ Sobre o art. 50. ${ }^{\circ}$ do TUE cfr. Afonso Patrão, "Comentário ao artigo 50.", in Tratado de Lisboa Anotado e Comentado, coords. Manuel Lopes Porto e Gonçalo Anastácio, (Coimbra: Almedina, 2012); Carlo Curti Gialdino (coord.), Codice dell'Unione Europea operativo (Napoli: Gruppo Editoriale Simone, 2012); Fausto Pocar e Maria Caterina Baruffi, Commentario breve ai Tratatti dell'Unione Europea (Padova: CEDAM, 2014); Eva-Maria Poptcheva, Article 50 TEU: withdrawal of a Member State from the EU (EPRS - European Parliamentary Research Service, February, 2016). 
dos competentes órgãos de soberania ou sem respaldo jurídico-constitucional, eventualmente impulsionado por disputas ou retaliações internas. No caso concreto do Reino Unido, tal conformidade jurídico-constitucional porventura exija que os cerca de $2 / 3$ dos parlamentares que não apoiaram o Brexit acolham a decisão manifestada em referendo, algo que cumpre aos tribunais decidirem (ver infra o tópico 3). Há quem defenda que o facto de o Governo do Estado-Membro de saída estar ou não a respeitar as suas normas constitucionais não deveria ser um problema da União Europeia ${ }^{4}$. Não afinamos por este diapasão porque o princípio da lealdade europeia obriga a União a respeitar as estruturas políticas e constitucionais dos Estados-Membros (art. 4. ${ }^{\circ}$, n. ${ }^{\circ} 2$ do TUE), donde decorre que a União Europeia está impedida de compactuar com uma retirada ilegitimamente acionada. De qualquer forma, tendo sido acolhida nos Tratados, a conformidade jurídico-constitucional da notificação passa a ser um problema da União Europeia.

Na sequência da notificação, o Conselho Europeu decide que tipo de acordo deve ser oferecido ao Estado-Membro que pretende sair, tendente a estabelecer as condições da saída e do seu futuro relacionamento com a União Europeia (art. 50. ${ }^{\circ}$, n. 2 do TUE). Isto significa que o Tratado não permite uma saída parcial da União Europeia - ou seja, obriga à saída integral -, eis a razão da expressão adotada pelo Presidente da Comissão Europeia, Jean-Claude Juncker, na sequência do referendo britânico: out is out. Os detalhes do acordo de saída serão então negociados entre a União e o EstadoMembro durante dois anos (contados a partir do momento da notificação), salvo se o Conselho Europeu decidir, por unanimidade, prorrogar este prazo. $\mathrm{O}$ art. $50 .^{\circ}$, n. $^{\circ} 2$ do TUE prevê que o acordo é negociado nos termos do art. $218 .^{\circ}$, n. $^{\circ} 3$ do TFUE (que regula o processo de celebração de acordos entre a União Europeia e países terceiros ou organizações internacionais), devendo tal acordo estabelecer os direitos e obrigações da União, dos Estados-Membros e do Estado que pretenda retirar-se.

Os Tratados deixam de ser aplicáveis ao Estado que pretenda deixar a União

\footnotetext{
${ }^{4}$ Cfr. "The Article 50 litigation and the Court of Justice: why the Supreme Court must refer", Richard Lang, acesso em janeiro 20, 2017, http://verfassungsblog.de/the-article-50-litigation-and-the-courtof-justice-why-the-supreme-court-must-refer.
} 
Europeia a partir da data de entrada em vigor do acordo de saída ou, na falta deste, dois anos após a notificação (art. $50 .^{\circ}$, n. $^{\circ} 3$ do TUE). Isto significa que, embora a União Europeia suspenda por dois anos os efeitos da saída na tentativa de encontrar uma solução consensual, se ela não for possível o Estado em causa corre o risco de ter de retirar-se em condições não consensuais e porventura muitíssimo desfavoráveis. De qualquer forma, para os efeitos da celebração do acordo de saída, o Estado que pretende abandonar a União Europeia não participa nas deliberações nem nas decisões do Conselho Europeu e do Conselho que lhe digam respeito (art. 50. ${ }^{\circ}$, n. ${ }^{\circ}$ 4 do TUE). E finalmente, em conformidade com o art. 50. ${ }^{\circ}$, n. 5 do TUE, se um Estado que se tenha retirado da União Europeia voltar a pedir a adesão, é aplicável a esse pedido o processo referido no art. 49. ${ }^{\circ}$ do TUE, sem qualquer privilégio por ter um dia ter pertencido ao grupo, mediante acordo celebrado entre o Estado peticionário e os Estados Contratantes, o que reforça a ideia de que out is out.

\section{As dúvidas quanto ao procedimento de retirada}

$\mathrm{O}$ art. $50 .^{\circ}$ do TUE não regula expressamente várias questões que terão de ser resolvidas à luz da principiologia do direito da União, máxime do princípio da lealdade europeia (art. 4. ${ }^{\circ}$, n. $^{\circ} 3$ do TUE). Não se prevê, por exemplo, um prazo para que o Estado-Membro notifique a sua intenção de saída à União Europeia na sequência de um referendo. Ora, a demora da notificação provoca instabilidade nos mercados financeiros, nos operadores económicos, na atuação das instituições europeias, nos restantes Estados-Membros que aplicam o direito da União e, sobretudo, na vida dos cidadãos europeus em geral, especialmente os que exerceram as suas liberdades de circulação tendo como origem ou destino o Reino Unido. Por isso, na sequência do Brexit, o Parlamento Europeu aprovou uma resolução apelando à invocação imediata do art. 50. ${ }^{\circ}$ do TUE por parte do Reino Unido, a fim de evitar uma situação de incerteza perniciosa para todos e proteger a integridade da União (os eurodeputados esperavam que o então Primeiro-Ministro David Cameron notificasse o resultado do referendo ao Conselho Europeu de 28-29 de 
junho de 2016, logo a seguir ao referendo que decidiu pelo Brexit, algo que não se concretizou).

$\mathrm{O}$ art. $500^{\circ}$ do TUE também não dispõe (expressamente) sobre a hipótese de revogabilidade da notificação da intenção de saída, porventura para evitar que, diante da certeza da revogabilidade, os Estados-Membros tivessem a tentação de influenciar os destinos da União Europeia através de uma falsa ameaça de saída. Nesta perspetiva, o interesse geral da União, dos seus cidadãos e dos EstadosMembros que a integram poderiam conduzir ao reconhecimento da notificação de secessão como uma espécie de nuclear button ${ }^{5}$ ou de caminho sem volta. Contudo, nada indica que a notificação não seja revogável - ao contrário, o espírito do art. 50. ${ }^{\circ}$ indica que o ponto de não retorno seria aquele que marca o final dos dois anos de negociação subsequentes à notificação. A doutrina divide-se quanto à admissibilidade da hipótese de "retirada da retirada". Paul Craig defende que a notificação é revogável - e o faz à luz de princípios de direito internacional público, com fundamento no art. 68. ${ }^{\circ}$ da Convenção de Viena sobre o Direito dos Tratados, segundo o qual uma notificação de retirada pode ser revogada em qualquer momento, antes da produção dos seus efeitos ${ }^{6}$. Daniel Sarmiento afina pelo mesmo diapasão da revogabilidade, mas com fundamento em argumentos democráticos, pois seria absurdo que uma retirada tivesse de ser negociada por um parlamento eleito na sequência da notificação, se porventura se opusesse maioritariamente a ela 7 . O problema, como demos conta supra, reside no facto de a secessão prevista no art. $50 .^{\circ}$ do TUE ser significativamente distinta da denúncia unilateral prevista no direito internacional dos tratados. Por isso a revogabilidade da notificação, a ser admitida, deve fundar-se no direito da União.

\footnotetext{
${ }^{5}$ Neste sentido cfr. "R (Miller) v. The Secretary of State for Exiting the European Union [2016] EWHC 2768 (Admin): realpolitik and the revocation of an Article 50 TEU notification to withdraw", John Cotter, acesso em janeiro 19, 2017, https://officialblogofunio.com/tag/article-50/.

${ }^{6}$ Cfr. "Miller: winning battles and losing wars", Paul Craig, acesso em janeiro 19, 2017, http://ohrh.law. ox.ac.uk/miller-winning-battles-and-losing-wars.

${ }^{7}$ Cfr. "Miller, Brexit and the (maybe not to so evil) Court of Justice", Daniel Sarmiento, , acesso em janeiro 19, 2017, http://verfassungsblog.de/miller-brexit-and-the-maybe-not-to-so-evil-court-ofjustice.
} 
Outra questão não integralmente resolvida pelo TUE reside na extensão das competências do Estado-Membro que esteja de saída. Em princípio, porque nada é disposto em sentido contrário, os representantes daquele Estado mantêm-se em funções em todas as instituições europeias e em todas as matérias, pois até a sua retirada o Estado-Membro continua vinculado ao direito da União, correspondendo aos compromissos assumidos e participando na adoção das regras que o vinculam. $\mathrm{E}$ aqui o princípio da lealdade europeia impõe-se na sua plenitude (ver último tópico deste texto), sobretudo quando se sabe que um soft Brexit não seria uma opção ${ }^{8}$. O problema é que o Estado-Membro que está de saída continuaria a intervir nos debates e votar a aprovação de normas que nunca aplicará - uma solução de legitimidade democrática duvidosa, porquanto exigir-lhe-ia uma conduta orientada à prossecução do interesse europeu em detrimento do interesse nacional. Não foi por outra razão que, na sequência do referendo Brexit, o Parlamento Europeu instou o Conselho a alterar o calendário das presidências rotativas da União Europeia, de modo a que a britânica, prevista para o segundo semestre de 2017, fosse cancelada, a fim de evitar que o processo de retirada comprometesse a gestão corrente da União.

$\mathrm{O}$ art. $50 .^{\circ}$ do TUE também não dispõe sobre a proteção dos direitos dos cidadãos europeus nacionais do Estado-Membro de saída ou dos cidadãos europeus nele residentes. Estudos recentes revelam que a retirada do Reino Unido da União Europeia representará uma das mais radicais perdas da história recente quanto ao valor atribuído a uma nacionalidade, além de uma dramática redução de direitos?

\footnotetext{
${ }^{8}$ Cfr. "Soft Brexit is not an option", Stefano Micossi, acesso em janeiro 23, 2017, https:/ /www.ceps.eu/ publications $/ \% \mathrm{E} 2 \% 80 \% 98$ soft-brexit $\% \mathrm{E} 2 \% 80 \% 99$-not-option. Por soft Brexit entenda-se uma solução que permitisse ao Reino Unido restringir a livre circulação de trabalhadores europeus e simultaneamente manter o acesso ao mercado interno da União Europeia - especialmente quanto aos serviços, mais ou menos nos termos das normas atuais -, mimetizando arranjos já existentes no âmbito do Espaço Económico Europeu (EEE). O discurso de Theresa May em 17 de março de 2017 esclareceu a intenção de saída do mercado interno e afastou qualquer esperança (caso ainda houvesse) numa espécie de soft Brexit, ciente de que as instituições europeias e Estados-Membros nunca o aceitariam.

${ }^{9}$ Cfr. "Brexit and the Argentinisation of the British citizenship: taking care not to overstay your 90 days in Rome, Amsterdam or Paris", Dimitry Kochenov, acesso em janeiro 21, 2017, http://verfassungsblog. de/brexit-and-the-argentinisation-of-british-citizenship-taking-care-not-to-overstay-your-90-days-inrome-amsterdam-or-paris.
} 
Por isso o eurodeputado Guy Verhofstadt, responsável pela negociação do Brexit em nome do Parlamento Europeu, aventou a possibilidade de que os britânicos (que assim o desejarem) continuem a ser tratados como cidadãos da União, a fim de evitar a privação do gozo efetivo dos direitos que lhe são reconhecidos pela ordem jurídica europeia. Seria uma forma de "cidadania associativa", tendente a mitigar os danos dos nacionais britânicos que não concorreram para o Brexit, atendendo sobretudo ao apelo dos eurodeputados escoceses no sentido de que a União Europeia não os abandone. Todavia a solução não é pacífica, pois nada indica que a recíproca seja verdadeira para os nacionais dos Estados-Membros da União nas suas relações com o Reino Unido pós-Brexit. De resto, o mote da retirada reside precisamente na resistência da opinião pública britânica ao reconhecimento de direitos aos nacionais de outros Estados-Membros residentes no Reino Unido, o que levou alguns apoiantes do Brexit a equacionarem a hipótese de acesso ao mercado interno sem livre circulação de pessoas, uma solução ao estilo "melhor de dois mundos" inadmissível à luz dos Tratados.

E finalmente, ainda que o Tratado não disponha sobre o tema, é defensável que a remissão para o art. $218 .^{\circ}$ do TFUE, no que tange à negociação do acordo, abra a possibilidade de que o Tribunal de Justiça da União Europeia (TJUE) seja chamado a emitir parecer sobre a compatibilidade do projeto de acordo com os Tratados, a pedido de qualquer Estado-Membro, do Parlamento Europeu, do Conselho e da Comissão (art. 218. ${ }^{\circ}$, n. ${ }^{\circ} 11$ do TFUE), não podendo o acordo entrar em vigor em caso de parecer negativo do Tribunal, salvo alteração do acordo ou revisão dos Tratados. Ademais, a decisão do Conselho que conclui o acordo pode ser submetida à apreciação do TJUE através de um recurso de anulação (art. 263. ${ }^{\circ}$ do TFUE). E além disso, os tribunais nacionais dos Estados-Membros que continuam na União Europeia podem submeter questões prejudiciais ao TJUE relacionadas com o acordo de retirada (art. 267. ${ }^{\circ}$ do TFUE) ${ }^{10}$.

\footnotetext{
${ }^{10}$ De resto, já foram iniciadas movimentações neste sentido junto dos tribunais irlandeses, cfr. "Is Article 50 reversible? A primer on the Dublin case", Jolyon Maugham, acesso em janeiro 28, 2017, https://waitingfortax.com/2017/01/17/is-article-50-reversible-a-primer-on-the-dublin-case.
} 


\section{O imbróglio jurídico-constitucional britânico sobre a notificação}

Como referimos supra, o art. 50. ${ }^{\circ}$ do TUE prevê que o Estado-Membro notifique o Conselho Europeu da sua decisão de retirar-se da União "em conformidade com as respectivas normas constitucionais". E aqui reside o pomo da discórdia constitucional que se instalou no Reino Unido. Como do European Communities Act $1972^{11}$ (e suas sucessivas atualizações) e do European Union Referendum Act 2015 não resulta qualquer autorização do Parlamento ao Governo britânico para proceder à notificação de retirada da União Europeia nos termos do art. 50. ${ }^{\circ}$ do TUE, pôsse então à High Court of England and Wales a questão de saber se o Governo de Theresa May seria competente para proceder àquela notificação (a partir dos Royal prerogative powers, ou seja, da autoridade executiva do Governo) ou se esta seria uma matéria constitucional da exclusiva competência do Parlamento ${ }^{12}$. Ou seja, estava em causa saber se o Governo poderia acionar o art. 50. ${ }^{\circ}$ do TUE sem uma autorização expressa do Parlamento, na medida em que a notificação de saída teria implicações no European Communities Act 1972, diminuindo ou revogando direitos dos particulares dele decorrentes ${ }^{13}$.

A High Court considerou que, enquanto a condução das relações internacionais

\footnotetext{
${ }^{11} \mathrm{O}$ European Communities Act 1972 dá efetividade interna à pertença do Reino Unido à União Europeia, ou seja, às obrigações assumidas pelo Reino Unido no âmbito dos Tratados então em vigor, autorizando um processo dinâmico através do qual o direito da União Europeia torna-se uma fonte do direito do Reino Unido e adquire precedência aplicativa (primado) sobre todas as fontes do direito interno.

${ }^{12} \mathrm{R}$ (Miller) v. The Secretary of State for Exiting the European Union [2016] EWHC 2768

http://www.bailii.org/ew/cases/EWHC/Admin/2016/2768.html (última consulta: 20 de janeiro de 2017).

${ }^{13}$ Os considerandos 57 a 61 do acórdão reproduz o argumento do requerente segundo o qual do European Communities Act 1972 resultariam três categorias de direitos que seriam afetados caso o Reino Unido notifique a sua retirada da União Europeia: i) direitos suscetíveis de replicação na lei interna do Reino Unido, onde seriam integráveis as disposições que transpuseram diretivas europeias, caso não sejam repelidas pelo legislador; ii) direitos exercidos em outros Estados-Membros da União Europeia, onde estariam contemplados os direitos resultantes do exercício de liberdades de circulação; iii) direitos que não poderiam ser replicados na lei interna do Reino Unido, onde seriam integráveis alguns direitos resultantes da cidadania europeia como o direito de eleger e ser eleito ao Parlamento Europeu ou o direito de queixa à Comissão Europeia tendente a investigar uma violação do direito da União Europeia pelas autoridades britânicas e garantir um remédio em relação a isso.
} 
e a negociação de tratados internacionais são competências geralmente exercidas pelo executivo em nome da Coroa, se a retirada de um tratado tiver implicações na legislação interna, com a consequente privação de direitos previamente garantidos, então tal retirada não poderia ser realizada sem o consentimento do Parlamento. Tal conclusão - que atende aos anseios daqueles que defendem uma tomada de posição do Parlamento sobre a retirada, pois do Referendum Act 2015 não resulta a vinculatividade do referendo - parte da premissa de que a notificação de retirada seria irrevogável, ou seja, uma vez acionado o art. 50. ${ }^{\circ}$ do TUE pelo Reino Unido, o retorno ao estádio anterior seria impossível, e a consequente perda de direitos para os cidadãos britânicos seria inevitável. No considerando 10 do acórdão, a High Court aderiu à interpretação do art. 50. ${ }^{\circ}$ do TUE que lhe parecia consensual entre as partes: i) a notificação nos termos do art. $50 .^{\circ}$, n. ${ }^{\circ} 2$ do TUE não pode ser revogada, uma vez acionada; ii) o art. $50 .^{\circ}$ do TUE não permite uma notificação condicionada, ou seja, uma notificação cujos efeitos dependeriam da aprovação parlamentar do acordo resultante das negociações contempladas no art. 50. ${ }^{\circ}$, n. ${ }^{\circ} 2$ do TUE $^{14}$.

Ocorre que a premissa da irrevogabilidade da notificação na qual a High Court baseou o seu raciocínio é duvidosa à luz do direito da União Europeia. Primeiro porque não é razoável que, uma vez deflagrado o processo, um Estado-Membro tenha de deixar, custe o que custar, a União Europeia. Segundo porque, como demos conta, os Tratados deixam de ser aplicáveis ao Estado que pretenda deixar a União Europeia a partir da data de entrada em vigor do acordo de saída ou, na falta deste, dois anos após a notificação (art. 50. ${ }^{\circ}$, n. 3 do TUE). Até lá, o Estado que está de saída continua a ser obrigado a cumprir o direito da União e a respeitar os compromissos assumidos com os seus parceiros de integração. Não há, pois, perda de direitos para os cidadãos britânicos a partir da notificação da intenção de retirada, pois o European Communities Act 1972 não será automaticamente repelido ${ }^{15}$. Assim,

\footnotetext{
${ }^{14}$ No original: "Important matters in respect of Article 50 were common ground between the parties: (1) a notice under Article 50(2) cannot be withdrawn, once it is given; and (2). Article 50 does not allow for a conditional notice to be given: a notice cannot be qualified by, for example, saying that it will only take effect if Parliament approves any agreement made in the course of the negotiations contemplated by Article 50(2)".

${ }^{15}$ Neste sentido, cfr. Daniel Sarmiento, "Miller, Brexit".
} 
admitir a irrevogabilidade da notificação e impelir o Parlamento do Reino Unido a dar a sua aprovação num estádio inicial do procedimento de secessão pode comprometer a possibilidade de recuo num momento posterior - quando porventura fizesse falta! - e, por isso, aquilo que parecia, à partida, uma derrota do Governo britânico, pode acabar por favorecer a sua posição.

$\mathrm{Na}$ sequência da decisão da High Court houve recurso para a Supreme Court e instalou-se um aceso debate no Reino Unido sobre se deveria ou não haver reenvio prejudicial para o TJUE ${ }^{16}$. O problema a deslindar pela Supreme Court seria o de saber se o Governo de Theresa May tinha poderes para notificar a União Europeia da sua intenção de retirada nos termos do art. 50. ${ }^{\circ}$ do TUE sem uma autorização do Parlamento britânico neste sentido. Há quem defenda a inadmissibilidade do reenvio prejudicial por entender que a "conformidade com as respectivas normas constitucionais", nos termos do art. 50. ${ }^{\circ}$, n. 1 do TUE, não seria uma matéria de interpretação dos Tratados na aceção do art. 267..$^{\circ}$ do TFUE. Ocorre que a decisão recorrida, segundo a qual uma autorização do Parlamento é necessária, baseia-se na premissa de que a notificação da intenção de retirada é irrevogável - e, como vimos, à luz do espírito do art. 50. ${ }^{\circ}$ do TUE nada indica que assim seja. Acresce que, como sabemos, o único "pressuposto" para a admissibilidade de um reenvio prejudicial é precisamente que ele sirva para a correta solução do caso sub judice. O problema reside, portanto, em saber se um reenvio prejudicial da Supreme Court, tendente a deslindar se a notificação de retirada é ou não revogável, seria necessário à correta solução do caso.

Ora, se a High Court não tivesse baseado a sua decisão na premissa da irrevogabilidade da notificação, provavelmente o problema de direito da União Europeia não se colocaria (tão evidentemente) à Supreme Court. Mas o certo é que a High Court o fez, e por isso a solução do caso sub judice dependeria da apreciação

\footnotetext{
${ }^{16}$ Em defesa do reenvio prejudicial, cfr. Daniel Sarmiento, "Miller, Brexit"; Richard Lang, "The Article 50 litigation". Contra o reenvio prejudicial cfr. "The Article 50 litigation and the Court of Justice: why the Supreme Court must NOT refer”, Mike Wienbracke,, acesso em janeiro 20, 2017, http:// verfassungsblog.de/ the-article-50-litigation-and-the-court-of-justice-why-the-supreme-court-must-notrefer; "Could the Article 50 litigation result in a reference to the European Court of Justice?", George Peretz, acesso em janeiro 20, 2017, https://www.monckton.com/article-50-litigation-result-referenceeuropean-court-justice.
} 
daquela premissa que determinou a conclusão. É que se a notificação for considerada revogável, então não há privação de direitos até que o procedimento de retirada esteja concluído. Em resultado, seria admissível que o Governo notificasse a retirada porque não estaria a comprometer automaticamente os direitos decorrentes do European Communities Act 1972. Há quem defenda que a High Court teria engendrado tal solução precisamente no intuito de provocar um reenvio prejudicial por parte da Supreme Court $^{17}$. Ao fazê-lo, converte a solução numa questão de interpretação do direito da União Europeia a ser proferida por um tribunal de última instância - que por força do art. $267 .^{\circ}, 3^{\circ}$ parágrafo do TFUE estaria obrigado a reenviar para garantir a uniformidade de aplicação do direito da União Europeia, sem que pudesse invocar, para eximir-se da sua obrigação, a suposta a clareza do ato ${ }^{18}$.

Todavia, e apesar dos apelos neste sentido, a Supreme Court optou por não dialogar com o TJUE, quando o que parecia estar em causa era, antes de mais, decidir se a notificação de retirada é ou não revogável à luz do art. 50. ${ }^{\circ}$ do TUE - algo que deveria ser o TJUE, enquanto intérprete máximo dos Tratados, a decidir (art. 19. ${ }^{\circ}$, n. $^{\circ} 1$ do TUE), tendo em conta as implicações jurisdicionais do princípio da lealdade europeia amplamente reconhecidas pela jurisprudência do TJUE. A Supreme Court inclusivamente poderia ter requerido a tramitação prejudicial acelerada (art. 105. ${ }^{\circ}$ do TFUE), de resto concedida no processo Pringle, ${ }^{19}$ resolvido em quatro meses contando com as férias de agosto. De qualquer forma, não sendo aquela notificação irrevogável, como entendemos, nada impedia que a Supreme Court concluísse pela imprescindibilidade da autorização do Parlamento para proceder-se à notificação, na medida em que o Parlamento não autorizou o Governo a fazê-lo. O que não faria sentido era deduzir a necessidade de autorização parlamentar a partir de uma suposta irrevogabilidade da notificação, obrigando o Parlamento britânico a tomar uma posição inicial sobre a retirada da União Europeia em função de a notificação ser interpretada como inalterável.

\footnotetext{
${ }^{17}$ Neste sentido cfr. Daniel Sarmiento, "Miller, Brexit".

${ }^{18}$ Neste sentido cfr. Daniel Sarmiento, "Miller, Brexit" e Richard Lang, "The Article 50 litigation”, que inclusivamente equaciona a hipótese de uma ação por incumprimento movida pela Comissão.

${ }^{19}$ Acórdão Pringle, de 27 de novembro de 2012, Processo C-370/12, ECLI:EU:C:2012:756.
} 
Em 24 de janeiro de 2017 a Supreme Court proferiu a sua esperada decisão ${ }^{20}$. Provavelmente para justificar a ausência de reenvio prejudicial, o Tribunal ressalta que a “conformidade constitucional" em causa é uma matéria de direito interno que deve ser determinada pelos juízes do Reino Unido. E destacou que as questões sub judice nada tinham a ver com a apreciação política sobre o mérito da decisão de retirada, a calendarização e os termos da sua execução, ou os detalhes de uma futura relação entre o Reino Unido e a União Europeia. Dito isto, decidiu que as disposições do European Communities Act 1972 (que dão efetividade à pertença do Reino Unido à União Europeia) são incompatíveis com o exercício de qualquer poder de retirada pelo Governo sem uma prévia autorização do Parlamento. A Supreme Court confirma, portanto, a decisão recorrida mas a reconstrói a partir de outra premissa que não a irreversibilidade da notificação, não se pronunciando sobre a questão da "retirada da retirada" 21 .

No entendimento da Supreme Court, enquanto a section 2 do European Communities Act 1972 permanecer em vigor (General Implementation of Treaties), ${ }^{22}$ o seu efeito é constituir o direito da União Europeia como uma fonte independente e prevalecente sobre o direito interno do Reino Unido. Tais disposições operam uma transferência de competências legislativas do Parlamento para as instituições europeias, a menos que o Parlamento decida de outra forma. É certo que o direito interno vai mudar em resultado de o Reino Unido deixar de integrar a União Europeia e os direitos dos particulares residentes no Reino Unido garantidos pelo direito da União serão afetados. Mas da leitura do acórdão não deriva que a Supreme Court reconheça uma

\footnotetext{
${ }^{20} \mathrm{R}$ (on the application of Miller and another) v Secretary of State for Exiting the European Union [2017] UKSC 5. On appeals from: [2016] EWHC 2768 (Admin) and [2016] NIQB 85 https://www. supremecourt.uk/news/article-50-brexit-appeal.html .

${ }^{21}$ Cfr. "Brexit, the Supreme Court (UK) and the principle of loyalty: on the question of irrevocability of a withdrawal notice", Alessandra Silveira, acesso em janeiro 28, 2017, https://officialblogofunio. $\mathrm{com} / 2017 / 01 / 26 /$ brexit-the-supreme-court-uk-and-the-principle-of-loyalty-on-the-question-ofirrevocability-of-a-withdrawal-notice/\#more-1694).

${ }^{22}$ Section 2(1) dispõe: "All such rights, powers, liabilities, obligations and restrictions from time to time created or arising by or under the Treaties, and all such remedies and procedures from time to time provided for by or under the Treaties, as in accordance with the Treaties are without further enactment to be given legal effect or used in the United Kingdom shall be recognised and available in law, and be enforced, allowed and followed accordingly ...".
} 
automaticidade entre a notificação de retirada e a vigência do European Communities Act 1972 - que continua em produzir os seus efeitos até que o Parlamento do Reino Unido o afaste. A Supreme Court reconhece, isto sim, que a notificação de retirada provoca uma alteração fundamental no arranjo constitucional do Reino Unido por romper com a fonte de direito da União Europeia - e por isso a Constituição do Reino Unido exige que tal alteração seja efetuada pela lei do Parlamento. O Parlamento poderia ter autorizado os ministros do Governo a notificarem a retirada da União Europeia, mas tal exigia uma manifestação expressa neste sentido - que pura e simplesmente não existe. Assim, mesmo sem reenviar para o TJUE, a Supreme Court procura encontrar uma solução que não afronte a lealdade europeia, desconstruindo uma argumentação baseada na irreversibilidade da notificação, por tratar-se de uma matéria cuja interpretação reconhecidamente competiria ao TJUE. Em resultado disso, ficamos sem saber o que decidiria o TJUE sobre esta importante questão.

De qualquer forma, a decisão da Supreme Court não encerra a polémica jurídicoconstitucional em torno do Brexit, pois os britânicos, a seu tempo, ainda terão de enfrentar o problema da necessidade de outro referendo sobre um acordo final de retirada. Por ironia do destino, a fim de evitar que a União Europeia facilmente estendesse ou adquirisse novos poderes e competências, o European Union Act 2011 exige que qualquer alteração nos Tratados seja sujeita a referendo. Como explica Damian Chalmers, isto não seria problemático no âmbito do Brexit se a exigência apenas se aplicasse à extensão de poderes e competências europeias sobre o Reino Unido. Contudo, uma singela disposição - section 4(1)(i) - prevê que um referendo é necessário sempre que a alteração dos Tratados confira poderes às instituições europeias para impor uma obrigação ao Reino Unido. Ora, não é difícil equacionar soluções que demandariam um novo referendo. Como condição de uma qualquer forma de acesso ao mercado interno pós-Brexit, por exemplo, a União Europeia poderia exigir alguma modalidade de supervisão tendente a garantir que o Reino Unido observa as normas europeias aplicáveis. É certo que a norma que o exige, section 4(1)(i), pode sempre ser revista. Mas seria irónico que um processo justificado pela necessidade de dar voz aos cidadãos britânicos relativamente às questões 
europeias resultasse na eliminação de uma norma que lhes garantia o direito a serem ouvidos $^{23}$.

\section{A secessão e a lealdade}

Todo e qualquer sistema federativo assenta num compromisso constitucional de cooperação que orienta a condução dos interesses interdependentes. Este compromisso implica a proibição da omissão de auxílio, a moderação recíproca, e mesmo a abstenção do exercício de competências quando tal comprometa a prossecução dos objetivos sistémicos. E ainda que a Constituição de um sistema federativo não o refira expressamente, o compromisso cooperativo é sempre deduzível da teleologia da regulação constitucional, porque para que o sistema funcione devidamente os entes governativos devem abster-se de adotar qualquer medida suscetível de pôr em causa os objetivos constitucionalmente acordados - ou seja, não podem perturbar nem furtar-se a ajudar.

E é por isso que todos os sistemas federativos são orientados por um princípio de lealdade (ou cooperação leal) tendente a corrigir os descompassos da distribuição de competências e otimizar a partilha de responsabilidades - que no caso da União Europeia esteve desde sempre patente nos Tratados. Este vínculo de lealdade, que deriva do compromisso constitucional de cooperação, se estabelece i) entre os Estados-Membros, ii) dos Estados-Membros para com a União, e iii) da União para com os Estados-Membros. Tal princípio impõe uma obrigação de fidelidade ao conjunto, a partir da complementaridade entre vários níveis que se suportam e apoiam mutuamente. Esta complementaridade implica deveres jurídicos concretos, sobretudo o dever de consideração recíproca - que conduz à abstenção de iniciativas que acarretem prejuízo aos interesses do conjunto -, assim como o dever de promoção de tais interesses. E cumpre ao princípio da lealdade reintroduzir o equilíbrio sempre que uma das componentes sistémicas impõe-se ilegitimamente às

\footnotetext{
${ }^{23}$ Cfr. "Article 50 - five big legal questions", Damian Chalmers, acesso em janeiro, 19, 2017, http:// ukandeu.ac.uk/article-50-five-big-legal-questions.
} 
outras por desconsideração do interesse geral, ameaçando romper o delicado sistema de contrapesos.

Ora, sendo um princípio orientador do relacionamento entre níveis de poder nos sistemas federativos, o principal âmbito de atuação da lealdade será aquele do exercício de competências - é aqui onde o princípio da lealdade produz os seus efeitos mais visíveis. A lealdade entra em cena para garantir a funcionalidade sistémica, sobretudo naqueles casos em que a distribuição de competências apresenta zonas de contato ou interferência recíproca, impondo a consideração das competências e interesses alheios com os quais se esteja a interagir. Por isso se diz que o juízo da lealdade seria o juízo da ponderação de interesses aplicado ao conflito de competências - mas sobretudo aos conflitos de competência marcados não pela ilegítima invasão das competências alheias mas sim por alguma forma de interferência. Assim, a lealdade opera como um limite ao exercício de competências (e à discricionariedade que lhe corresponde) sempre que o exercício de competências legítimas prejudique os interesses de outrem ou de todos em detrimento dos objetivos constitucionalmente acordados.

Assim, no limite, a lealdade vai impor a abstenção (e, neste caso, afeta a discricionariedade de atuação de quem seja competente) ou, no mínimo, vai exigir a adoção da solução que acarrete menos sacrifícios aos interesses em concurso (e aqui a lealdade afeta a discricionariedade de conformação de quem seja competente). Portanto, a lealdade produz o efeito jurídico de obrigar os distintos níveis de poder, no exercício das suas competências, à consideração i) do interesse geral do sistema federativo, e ii) dos interesses concretos dos restantes entes periféricos, sob pena de comprometer o funcionamento e a própria existência da ordem constitucional federativa. Por isso Konrad Hesse defendia que a inobservância dos deveres e restrições decorrentes da lealdade, seja por um ato do poder central ou do poder periférico, acarreta a ilegitimidade do ato nos sistemas federativos, pois a lealdade funciona como um limite de legitimidade ao exercício de competências $^{24}$.

${ }^{24}$ Cfr. Konrad Hesse, Elementos de direito constitucional da República Federal da Alemanha (Porto Alegre: Sérgio Fabris Editora, 1998), 213. 
É por isso que o processo de secessão está sujeito ao cumprimento das obrigações decorrentes da lealdade europeia - pois o Estado que manifesta a sua intenção de saída continua, até ao final do prazo previsto no art. $500^{\circ}$ do TUE, a ser membro de pleno direito da União Europeia. Alguns doutrinadores sugerem mesmo que o art. 50. ${ }^{\circ}$ do TUE o refira expressamente, a fim de que um Estado-Membro que pretenda sair tenha presente as implicações da sua escolha ${ }^{25}$. Seria porventura desejável, mas não imprescindível, pois qualquer atuação das autoridades europeias ou nacionais está vinculada à lealdade. É compreensível que no período que antecedeu a notificação os ânimos estivessem mais exaltados pela expetativa e incerteza - o que porventura explique algum excesso de ambas as partes envolvidas. Mas a partir do momento em que foi acionado o art. 50. ${ }^{\circ}$ do TUE, cumpre às autoridades europeias e às autoridades britânicas acautelarem-se de que respeitam as obrigações que decorrem da lealdade com particular esmero, sob pena de o processo resultar viciado e o TJUE ser chamado a atuar em conformidade ${ }^{26}$.

\footnotetext{
${ }^{25}$ Cfr. Dora Kostakopoulou, "Brexit, voice and loyalty: reflections on Article 50 TEU", European Law Review, 41, 4, (2016), onde se lê: "In the light of the British referendum on EU membership, I wish to suggest the insertion of a new sentence into paragraph 50(1) TEU. The latter would read as follows: 'Any Member State may decide to withdraw from the Union in accordance with its own constitutional requirements. In so doing, it shall respect the Union's institutional framework and the principle of sincere co-operation under Article 4(3) TEU".

${ }^{26}$ Cfr. "Guide to the Brexit negotiations", Steve Peers, acesso em abril 5, 2017, http://eulawanalysis. blogspot.pt/2017/04/guide-to-brexit-negotiations.html, publicado em 4 de abril de 2017, onde o Autor reproduz e comenta (em itálico) as orientações de negociação sobre o Brexit propostas pelo Conselho Europeu:
}

"V. Principle of sincere cooperation:

23. Until it leaves the Union, the United Kingdom remains a full Member of the European Union, subject to all rights and obligations set out in the Treaties and under EU law, including the principle of sincere cooperation.

This reflects the UK's continued position that it will apply EU law until Brexit Day. Point 5 of the EP draft resolution matches it.

24. The European Council recognises the need, in the international context, to take into account the specificities of the United Kingdom as a withdrawing Member State, provided it remains loyal to the Union's interests while still a Member. Similarly the Union expects the United Kingdom to recognise the need of the 27 Member States to meet and discuss matters related to the situation after the withdrawal of the United Kingdom. 
The first sentence is ambiguous about a key issue: can the UK already discuss trade deals with non-EU countries? It can't conclude them without violating EU law (para 23); normally it could not negotiate them either, but does this sentence accept the argument that discussions on a post-Brexit deal would be acceptable, as a consequence of the UK's position as a withdrawing Member State? The second sentence asserts the remaining EU's right to meet without the UK, presumably going beyond the talks relating to Brexit without the UK present as referred to in Article 50. However, such meetings must remain informal, as the next paragraph confirms.

Compare to point 6 of the draft EP resolution, which more explicitly argues that the UK cannot negotiate with non-EU countries before Brexit, and argues that the UK should be excluded from EU trade talks with non-EU countries if it does. Such an exclusion would not be legal; the remedy in such cases of alleged breach of EU law is for the Commission or another Member State to bring the UK to the ECJ.

25. While the United Kingdom is still a member, all ongoing EU business must continue to proceed as smoothly as possible at 28 . The European Council remains committed to drive forward with ambition the priorities the Union has set itself. Negotiations with the United Kingdom will be kept separate from ongoing Union business, and shall not interfere with its progress.

The UK retains its formal position as a Member State until Brexit Day, although obviously it will have declining influence as there will be little interest in addressing its concerns and the other Member States merely have to wait out any veto or participation in a blocking minority vote by the UK." 

